ISBN - 978-1-64945-865-0

DOI- 10.46299/ISG.2020.MONO.ECON.III

Econamic strategies for the development of saciety

Gollective monograph

$\mathscr{B}$ ston 2020 


\section{ECONOMIC STRATEGIES FOR THE DEVELOPMENT OF SOCIETY}

Library of Congress Cataloging-in-Publication Data

ISBN - 978-1-64945-865-0

DOI- 10.46299/ISG.2020.MONO.ECON.III

Authors - Illiashenko K., Bezverkhnia Y., Melnyk N., Burdenyuk T., Petryshyn L., Zhydovska N., Рябенко В.В., Рябенко Л.M., Shegda A., Magomedova A., Mykytiuk O., Onysenko T., Petrenko K., Denysenko M., Breus S., Denysenko M., Breus S., Denysenko M., Mohylevska O., Opanasuk V., Filipovsky A., Vysochan O., Vysochan O., Lytvynenko N., Vysochan Ol., Мельник А., Мельник Н.В., Габчак Н.Ф., Срко I.В., Шевченко I., Лапоног Д.., Prokopets L., Voronetska I., Kravchuk O., Petrychenko I., Sprynchuk N., Voronetska Iryna, Маліновська О., Вовк B., Sitak I., Ivakhnenko А., Ізюмцева Н.B., Гринько O.O., Abraham Y., Федунов М.В., Черниш I.В., Бакало Н.В., Маховка В.М., Чичкало-Кондрацька I.Б., Новицька I.B., Чичкало-Кондрацька I., Sotnyk M., Sotnyk I., Bilovus T., Kharabara V., Greshko R., Tretyakova O., Kushnir L., Hrymak O., Kushnir L, Makohon V., Adamenko I., Квасницька P., Рубай O., Шкодіна I.В., Кондратенко Н.Д., Трофименко А.О., Шкодіна I.B., Fesenko N., Rubashka V., Martynenko A., Prygara O., Smyrnov I., Lyubitseva O., Кот Л., Довгаль О., Довгаль Г., Олійник О., Морозова Г., Панасенко Н., Громоздова Л.В., Тюхтій М.П., Писаренко Н.В., Аблова О.К., Маляревський В.M., Альрашді А., Vakulyk I., Литвиненко А., Литвиненко О., Рибак Г., Kushnir L., Hryniuk Н., Булат Г., Markovych I., Tkachenko V., Klymchuk M., Illina T., Vasylieva N., Voytsekhovska Y.

\section{REVIEWER}

Kvasnytska Raisa Doctor of Economics, Professor of Finance, Banking and Insurance, Khmelnytsky National University

Dovgal Olena Dr.Sc. of Economics, Professor (Full), Professor of the Department of International Economic Relations of V.N.Karazin Kharkiv National University.

Breus Svitlana Doctor of Economic Sciences, Associate Professor, Professor of the Department of Management and Public Administration, Kyiv National University of Technologies and Design. 


\section{ECONOMIC STRATEGIES FOR THE DEVELOPMENT OF SOCIETY}

Published by Primedia eLaunch

\section{https://primediaelaunch.com/}

Text Copyright (C) 2020 by the International Science Group(isg-konf.com) and authors.

Illustrations $(\mathcal{C} 2020$ by the International Science Group and authors.

Cover design: International Science Group(isg-konf.com). (C)

Cover art: International Science Group(isg-konf.com). C)

All rights reserved. Printed in the United States of America. No part of this publication may be reproduced, distributed, or transmitted, in any form or by any means, or stored in a data base or retrieval system, without the prior written permission of the publisher. The content and reliability of the articles are the responsibility of the authors. When using and borrowing materials reference to the publication is required.

Collection of scientific articles published is the scientific and practical publication, which contains scientific articles of students, graduate students, Candidates and Doctors of Sciences, research workers and practitioners from Europe and Ukraine. The articles contain the study, reflecting the processes and changes in the structure of modern science.

The recommended citation for this publication is:

Economic strategies for the development of society: collective monograph / Illiashenko K., Bezverkhnia Y., - etc. - International Science Group. - Boston : Primedia eLaunch, 2020. 409 p. Available at : DOI- 10.46299/ISG.2020.MONO.ECON.III 
ECONOMIC STRATEGIES FOR THE DEVELOPMENT OF SOCIETY

TABLE OF CONTENTS

\begin{tabular}{|c|c|c|}
\hline 1 & ACCOUNTING AND AUDIT & 10 \\
\hline 1.1 & $\begin{array}{l}\text { Illiashenko K., Bezverkhnia Y. } \\
\text { INFORMATION, ANALYTICAL AND ACCOUNTING } \\
\text { SUPPORT FOR MANAGEMENT DECISION-MAKING }\end{array}$ & 10 \\
\hline 1.2 & $\begin{array}{l}\text { Melnyk N., Burdenyuk T. } \\
\text { POSITIVE AND NORMATIVE ACCOUNTING THEORY } \\
\text { IN THE MODERN WORLD }\end{array}$ & 16 \\
\hline 1.3 & $\begin{array}{l}\text { Petryshyn L., Zhydovska N. } \\
\text { OUTLINE OF HISTORICAL CONCEPTS AND STAGES OF } \\
\text { CAPITAL FORMATION AS AN ECONOMIC CATEGORY }\end{array}$ & 21 \\
\hline 2 & ADMINISTRATIVE REGION AND BUDGET & 31 \\
\hline 2.1 & $\begin{array}{llr}\text { Рябенко В.В., РябенКо Л.М. } & & \\
\text { ОБЛІКОВО-АНАЛІТИЧНЕ } & \text { ЗАБЕЗПЕЧЕННЯ } \\
\text { УПРАВЛІННЯ ПІДПРИСМСТВОМ } & \text { НА } & \text { ОСНОВІ } \\
\text { ЗБАЛАНСОВАНОЇ СИСТЕМИ ПОКАЗНИКІВ } & \end{array}$ & 30 \\
\hline 3 & DEMOGRAPHY, ECONOMY, SOCIAL POLICY & 36 \\
\hline 3.1 & $\begin{array}{l}\text { Shegda A., Magomedova A., Mykytiuk O., Onysenko T., } \\
\text { Petrenko K. } \\
\text { ADULT EDUCATION IN UKRAINE: POST-QUARANTINE } \\
\text { CHALLENGES }\end{array}$ & 35 \\
\hline 4 & $\begin{array}{l}\text { ECONOMICS AND MANAGEMENT OF THE NATIONAL } \\
\text { ECONOMY }\end{array}$ & 46 \\
\hline 4.1 & $\begin{array}{l}\text { Denysenko M., Breus S. } \\
\text { THE IMPACT OF TOURISM }\end{array}$ & 45 \\
\hline 4.2 & $\begin{array}{l}\text { Denysenko M., Breus S. } \\
\text { HOTEL BUSINESS MANAGEMENT IN MODERN } \\
\text { BUSINESS CONDITIONS }\end{array}$ & 52 \\
\hline 5 & ECONOMICS OF INDUSTRIES & 59 \\
\hline 5.1 & $\begin{array}{l}\text { Mohylevska O., Opanasuk V., Filipovsky A. } \\
\text { SUSTAINABLE DEVELOPMENT OF INDUSTRIAL } \\
\text { ENTERPRISES IN THE CONDITIONS OF STATE- } \\
\text { PRIVATE PARTNERSHIP }\end{array}$ & 58 \\
\hline 5.2 & $\begin{array}{l}\text { Vysochan O., Vysochan O., Lytvynenko N. } \\
\text { MAIN AREAS, LEGISLATIVE AND REGULATORY } \\
\text { CONTROL OF ACTIVITY OF NON-BUDGETARY NON- } \\
\text { PROFIT ORGANIZATIONS IN UKRAINE }\end{array}$ & 62 \\
\hline
\end{tabular}


ECONOMIC STRATEGIES FOR THE DEVELOPMENT OF SOCIETY

\begin{tabular}{|c|c|c|}
\hline 5.3 & $\begin{array}{l}\text { Мельник А.В., Мельник Н.В., Габчак Н.Ф., Єрко І.В } \\
\text { КОНКУРЕНТОСПРОМОЖНІСТЬ ЕКВАДОРУ } \\
\text { СВІТОВОМУ РИНКУ ТУРИСТИЧНИХ ПОСЛУГ }\end{array}$ & 71 \\
\hline 5.4 & 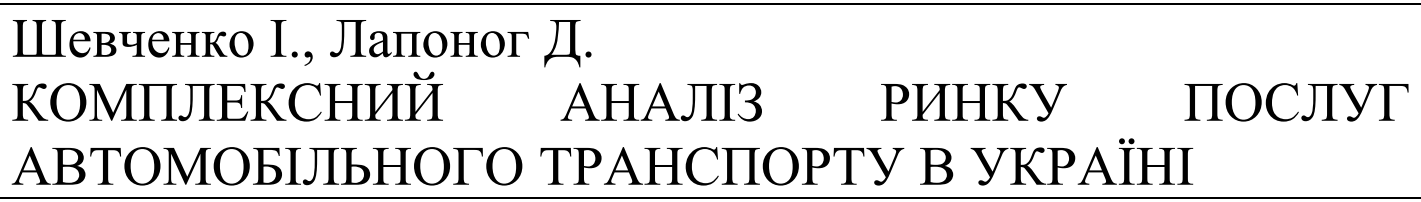 & 77 \\
\hline 6 & $\begin{array}{l}\text { ECONOMY AND MANAGEMENT OF STATE } \\
\text { GRATITUDE }\end{array}$ & 83 \\
\hline 6.1 & $\begin{array}{l}\text { Oleynik O. } \\
\text { INTERDEPENDENCE BETWEEN LEVEL OF TRUST AND } \\
\text { ECONOMIC GROWTH. MANIFESTATION OF TRUST } \\
\text { THROUGH ECONOMIC INDICES }\end{array}$ & 82 \\
\hline 6.2 & $\begin{array}{l}\text { Prokopets L. } \\
\text { THE ESSENCE OF PERSONNEL MANAGEMENT AND } \\
\text { ITS MAIN TASKS }\end{array}$ & 86 \\
\hline 6.3 & $\begin{array}{l}\text { Voronetska I., Kravchuk O., Petrychenko I., Sprynchuk N. } \\
\text { MARKETING ASPECTS OF FEED MARKET } \\
\text { DEVELOPMENT }\end{array}$ & 95 \\
\hline 6.4 & $\begin{array}{l}\text { Маліновська О., ВовК В. } \\
\text { ПРОЦЕСИ ЦЕНТРАЛІЗАЦЇ̈ ТА ДЕЦЕНТРАЛІЗАЦІЇ В } \\
\text { УКРАЇНІ }\end{array}$ & 105 \\
\hline 7 & $\begin{array}{c}\text { ECONOMY OF MANAGEMENT AND } \\
\text { ADMINISTRATION OF RADIO TECHNOLOGY }\end{array}$ & 112 \\
\hline 7.1 & $\begin{array}{l}\text { Sitak I., Ivakhnenko A. } \\
\text { CURRENT STATE OF MECHANICAL ENGINEERING OF } \\
\text { UKRAINE, INNOVATIONS AND PROSPECTS OF ITS } \\
\text { DEVELOPMENT }\end{array}$ & 111 \\
\hline 7.2 & $\begin{array}{ll}\text { Ізюмцева Н.В., Гринько О.О., Ізюмцева Н.В. } \\
\text { ШЛЯХИ } & \text { ПІДВИЩЕННЯ } \\
\text { КОНКУРЕНТОСПРОМОЖНОСТІ } & \text { ВІТЧИЗНЯНИХ } \\
\text { ПІДПРИЄМСТВ } & \end{array}$ & 117 \\
\hline 7.3 & $\begin{array}{l}\text { Abraham Y. } \\
\text { INTERNATIONAL PROJECT MANAGEMENT METHODS } \\
\text { AS A FACTOR IN IMPROVING THE EFFICIENCY OF } \\
\text { MODERN DOMESTIC MANAGEMENT }\end{array}$ & 125 \\
\hline 7.4 & $\begin{array}{l}\text { Федунов М.В. } \\
\text { РИЗИКИ ЗОВНІШНЬОЕКОНОМІЧНОЇ } \\
\text { АГРОПРОМИСЛОВИХ ПІДПРИЕМСТВ }\end{array}$ & 130 \\
\hline
\end{tabular}


ECONOMIC STRATEGIES FOR THE DEVELOPMENT OF SOCIETY

\begin{tabular}{|c|c|c|}
\hline 7.5 & $\begin{array}{l}\text { Черниш І.В., Бакало Н.В., Маховка В.М., } \\
\text { ФОРМУВАННЯ КОРПОРАТИВНОЇ КУЛЬТУРИ ЯК } \\
\text { ФАКТОРУ } \\
\begin{array}{ll}\text { ПІДПРИЕМСТВ СФЕРИ ТУРИЗМУ }\end{array}\end{array}$ & 141 \\
\hline 7.6 & $\begin{array}{l}\text { Чичкало-Кондрацька І.Б., Новицька І.В. } \\
\text { ТЕХНОЛОГІЯ БЛОКЧЕЙНУ ЯК НОВИЙ ПІДХІД } \\
\text { ПРОСУВАННЯ ОРГАНІЧНОЇ ПРОДУКЦІЇ НА РИНОК }\end{array}$ & 146 \\
\hline 8 & ECONOMY PROTECT THE MIDDLE OF THE MIDDLE & 152 \\
\hline 8.1 & $\begin{array}{l}\text { Sotnyk M., Sotnyk I. } \\
\text { THE WORLD EXPERIENCE AND MECHANISMS OF } \\
\text { "GREENING" UNIVERSITY CAMPUSES }\end{array}$ & 151 \\
\hline 9 & FINANCE, PENNILESS AND CREDIT & 159 \\
\hline 9.1 & $\begin{array}{l}\text { Bilovus T. } \\
\text { PROBLEM ASPECTS OF REGULATORY REGULATION } \\
\text { OF MARKET ACTIVITIES SECURITIES IN UKRAINE }\end{array}$ & 158 \\
\hline 9.2 & $\begin{array}{l}\text { Kharabara V., Greshko R., Tretyakova O. } \\
\text { THE STOCK MARKET: THE ENTITY AND THE } \\
\text { DEFINITION }\end{array}$ & 165 \\
\hline 9.3 & $\begin{array}{l}\text { Kushnir L., Hrymak O. } \\
\text { MODERN MECHANISMS OF BANK LENDING TO } \\
\text { AGRICULTURAL ENTERPRISES }\end{array}$ & 171 \\
\hline 9.4 & $\begin{array}{l}\text { Makohon V., Adamenko I. } \\
\text { BUDGET STRATEGY AS A TOOL FOR THE } \\
\text { DEVELOPMENT OF THE INNOVATION ENVIRONMENT } \\
\text { IN THE CONDITIONS OF TRANSFORMATIONAL } \\
\text { CHANGES IN THE ECONOMICS }\end{array}$ & 176 \\
\hline 9.5 & $\begin{array}{l}\text { Квасницька Р. } \\
\text { СУЧАСНІ РЕАЛІЇ РОЗВИТКУ IНВЕСТИЦІЙНИХ } \\
\text { ПРОЦЕСІВ НА РИНКУ ЦІННИХ ПАПЕРІВ УКРАЇНИ }\end{array}$ & 185 \\
\hline 9.6 & $\begin{array}{l}\text { РУбай О. } \\
\text { ШЛЯХИ }\end{array}$ & 191 \\
\hline 9.7 & $\begin{array}{lcr}\text { Шкодіна І.В., Кондратенко Н.Д., Трофименко А.О. } \\
\text { ІНСТИТУЦЙНІ } & \text { ФАКТОРИ } & \text { КОРПОРАТИВНОГО } \\
\text { ШАХРАЙСТВА } & \text { НА } & \text { ПІДПРИЄМСТВАХ } \\
\text { МІЖНАРОДНОГО БІЗНЕСУ } & \end{array}$ & 196 \\
\hline
\end{tabular}


ECONOMIC STRATEGIES FOR THE DEVELOPMENT OF SOCIETY

\begin{tabular}{|c|c|c|}
\hline 10 & INNOVATIVE ECONOMY & 202 \\
\hline 10.1 & $\begin{array}{l}\text { Fesenko N., Rubashka V. } \\
\text { ІННОВАЦІЙНА ДІЯЛЬНІСТЬ ТА ІНТЕЛЕКТУАЛЬНА } \\
\text { ВЛАСНІСТЬ ЯК ОСНОВА РОЗВИТКУ ДЕРЖАВИ }\end{array}$ & 201 \\
\hline 10.2 & $\begin{array}{l}\text { Martynenko A. } \\
\text { THE IMPACT OF ECONOMIC CYCLES ON THE } \\
\text { ACTIVITIES OF ENTERPRISES }\end{array}$ & 207 \\
\hline 10.3 & $\begin{array}{l}\text { Prygara O. } \\
\text { INNOVATION NETWORKS OF AN ENTERPRISE }\end{array}$ & 212 \\
\hline 10.4 & $\begin{array}{l}\text { Smyrnov I., Lyubitseva O. } \\
\text { MILITARY TOURISM DEVELOPMENT IN UKRAINE: } \\
\text { ACTUAL PROBLEMS IN MODERN CONDITIONS (ON } \\
\text { EXAMPLE OF KAMYANETS-PODILSKYI, ARPAD LINE } \\
\text { AND MOLOTOV LINE) }\end{array}$ & 218 \\
\hline 10.5 & $\begin{array}{lrl}\text { КОТ Л.Л. } & \\
\text { СОЦІАЛЬНЕ } & \text { ПІДПРИСМНИЦТВО: } & \text { ТРЕНД } \\
\text { СУЧАСНОГО ЕКОНОМІЧНОГО РОЗВИТКУ } & \\
\end{array}$ & 236 \\
\hline 10.6 & $\begin{array}{l}\text { Довгаль О., Довгаль Г. } \\
\text { ЛОГІКА, ФОРМИ ТА ІНСТРУМЕНТИ ГЛОБАЛЬНОЇ } \\
\text { ІННОВАЦІЙНОЇ ІНТЕГРАЦІЇ }\end{array}$ & 243 \\
\hline 10.7 & $\begin{array}{l}\text { ОЛіЙНик О.В., МорозОВа Г.С. } \\
\text { ФІНАНСОВЕ } \\
\text { РАБЕЗПЕЧЕННЯ IННОВАЦІЙНОСТІ } \\
\text { РОЗВИТКУ } \\
\text { СЕКТОРА }\end{array}$ & 252 \\
\hline 10.8 & $\begin{array}{l}\text { Панасенко Н. } \\
\text { ФОРМУВАННЯ } \quad \text { МЕТОДИЧНОГО ПІДХОДУ } \\
\text { ОЦІНЮВАННЯ РОЗВИТКУ ЕКОЛОГО-ІННОВАЦІЙНӦ̈ } \\
\text { ДІЯЛЬНОСТІ }\end{array}$ & 261 \\
\hline 11 & INSURANCE & \\
\hline 11.1 & $\begin{array}{llr}\text { Громоздова Л.В., Тюхтій М.П., Писаренко Н.В., Аблова } \\
\text { О.К., Маляревський В.М. } & & \\
\text { УПРАВЛІНЯ } \quad \text { ПРОЦЕСАМИ } & \text { СТРАХУВАННЯ } \\
\text { СІЛЬСЬКОГОСПОДАРСЬКИХ } & \text { КУЛЬТУР } & \text { ТА } \\
\text { ОРГАНІЗАЦІЙНО-ЕКОНОМІЧН } & \text { ОСНОВИ } & \text { ЙОГО } \\
\text { ПРОВЕДЕННЯ } & & \end{array}$ & 269 \\
\hline
\end{tabular}


ECONOMIC STRATEGIES FOR THE DEVELOPMENT OF SOCIETY

\begin{tabular}{|c|c|c|}
\hline 12 & INTERNATIONAL ECONOMIC NEWS & 286 \\
\hline 12.1 & $\begin{array}{l}\text { АЛЬрашді А. } \\
\text { ІНТЕГРАЦЙНА МІСІЯ ФІНАНСОВИХ ІНСТИТУТІВ У } \\
\text { ФОРМУВАННІ ГЛОБАЛЬНОЇ ТА РЕГІОНАЛЬНИХ } \\
\text { ФІНАНСОВИХ СИСТЕМ }\end{array}$ & 285 \\
\hline 12.2 & $\begin{array}{l}\text { Vakulyk I. } \\
\text { KEY TRENDS IN THE DEVELOPMENT OF IT IN THE } \\
\text { WORLD }\end{array}$ & 292 \\
\hline 12.3 & $\begin{array}{l}\text { Литвиненко А., Литвиненко О. } \\
\text { ФОРМУВАННЯ } \\
\text { КОНКУРЕНТОСПРОМОЖНОЇ } \\
\text { ПІДПРИСМСТВА }\end{array}$ & 312 \\
\hline 12.4 & $\begin{array}{l}\text { Рибак Г.І. } \\
\text { ГЛОБАЛЬНІ РИЗИКИ ТА } \\
\text { УКРАЇНИ }\end{array}$ & 332 \\
\hline 13 & $\begin{array}{l}\text { LOCATION OF PRODUCTIVE FORCES, REGIONAL } \\
\text { ECONOMY }\end{array}$ & 339 \\
\hline 13.1 & $\begin{array}{l}\text { Kushnir L., Hryniuk H. } \\
\text { THE ANALYSIS OF THE CURRENT STATE AND } \\
\text { DEVELOPMENT OF SKI TOURISM IN THE UKRAINIAN } \\
\text { CARPATHIANS }\end{array}$ & 338 \\
\hline 13.2 & $\begin{array}{lcr}\text { БУЛаТ Г. В. } & \\
\text { МЕТОДИКА } & \text { ВИЗНАЧЕННЯ } & \text { АУДИТОРСЬКОГО } \\
\text { РИЗИКУ } & \text { ЗА } & \text { УМОВИ } \\
\text { АВТОМАТИЗОВАНОГО АУДИТУ } & \\
\end{array}$ & 343 \\
\hline 14 & MECHANISMS OF REGULATION OF THE ECONOMY & 349 \\
\hline 14.1 & $\begin{array}{llll}\text { Markovych I. } & & & \\
\text { CONCEPTS AND DIMENSIONS } & \text { OF } & \text { CULTURAL } \\
\text { DISTANCE AS A TOOL OF INTERNATIONAL } \\
\text { ECONOMIC REGULATION }\end{array}$ & 348 \\
\hline 15 & MICRO AND MACRO ECONOMY & 353 \\
\hline 15.1 & $\begin{array}{l}\text { Tkachenko V., Klymchuk M., Illina T. } \\
\text { THE FORMATION OF THE ENERGY SAVING } \\
\text { MANAGEMENT MECHANISM OF REGIONAL SYSTEM } \\
\text { BASED ON THE EXPERIENCE OF EUROPEAN UNION } \\
\text { COUNTRIES }\end{array}$ & 352 \\
\hline
\end{tabular}


ECONOMIC STRATEGIES FOR THE DEVELOPMENT OF SOCIETY

\begin{tabular}{|c|l|c|}
\hline 16 & \multicolumn{1}{|c|}{ QUANTITATIVE METHODS IN ECONOMICS } & 357 \\
\hline 16.1 & $\begin{array}{l}\text { Vasylieva N. } \\
\text { ECONOMETRIC ANALYSIS OF REGIONAL GRAIN } \\
\text { PRODUCTION IN UKRAINE }\end{array}$ & 356 \\
\hline 16.2 & $\begin{array}{l}\text { Voytsekhovsk Y. } \\
\text { THE MODELING OF THE GROWTH RATE OF FIXED }\end{array}$ & 363 \\
& $\begin{array}{l}\text { ASSETS IN THE PROCESS OF INNOVATIVE } \\
\text { PRODUCTION DEVELOPMENT }\end{array}$ & 368 \\
\hline & REFERENCES & 3 \\
\hline
\end{tabular}




\section{ECONOMIC STRATEGIES FOR THE DEVELOPMENT OF SOCIETY \\ SECTION 1. ACCOUNTING AND AUDIT}

\subsection{Information, analytical and accounting support for management decision- making}

The activity of any enterprise and its success in the market depends on many environmental factors. That is why each organization in the framework of management implements the planning function, collecting and analyzing information about the conditions of doing business. Planning helps the organization make decisions that prevent the occurrence and development of problem situations, without compromising the achievement of organizational goals.

In the process of making any decision, including a managerial one, information is used. The accuracy and completeness of the information ensures that the decisions made will take into account the greatest possible number of factors.

Providing access to information necessary for effective management decisionmaking is called information and analytical support.

Information and analytical support for management decisions can be provided by specialized divisions of the enterprise or separately hired third-party companies (or experts) providing consulting services. The collection, processing and preparation of information can also be a function of any Departments of the company. The department may collect and analyze information related to its activities.

The purpose of information and analytical support of management decisions is to provide timely information of proper quality to decision makers.

It should be noted that the essence of information and analytical support is that the company's management or other decision makers must receive the information they need in full in time, while it must be reliable, which will give an idea of the external and internal situation in the organization.

An integrated approach to management decision support combines the method of calculating an integral indicator, methods of expert assessments, cluster analysis, and methods of artificial neural networks. For example, when using cluster analysis, the 


\section{ECONOMIC STRATEGIES FOR THE DEVELOPMENT OF SOCIETY}

person making a management decision understands what level the enterprise has in the aggregate of other analyzed enterprises [1].

To achieve the goal of information and analytical support of management decisions, it is necessary to implement a number of tasks:

- collection, processing and analysis of information about the market situation;

- forecasting of market trends;

- study of the competitive situation, methods of competition and goals of competitors;

- research of partners and clients, their goals and characteristics;

- monitoring of all divisions and systems of the organization;

- audit and security of the company's internal information;

- development of recommendations and analytical reports for the company's management and other decision makers [2].

Information and analytical support of solutions in the field of organization management should be based on a scientific approach to assessing the events and situations under study outside and within the company. At the same time, the information received must be up-to-date and reliable. The company must ensure the continuity of information collection and create a system for informing interested parties about significant events and emerging problems.

In order for the system of information and analytical support for management decisions to work effectively, it is necessary to clearly define the purpose and range of interests of decision makers, which will ensure the relevance and usefulness of information.

The process of conducting work on information and analytical support of management decisions is based on the following principles::

- the principle of goal setting - the presence of a clear specific goal allows you to determine the scale and methods of work on collecting and analyzing information;

- the principle of unambiguity - determining the exact content of terms used in information flows; 


\section{ECONOMIC STRATEGIES FOR THE DEVELOPMENT OF SOCIETY}

- the principle of multiple sources is the use of different sources of information to ensure its reliability and completeness.

Management decisions in modern conditions can be completely different in form, direction, time of development, adoption, and implementation. Some decisions are made quickly by the subject of management, based on existing experience, others after careful mathematical processing and justification.

In such circumstances, ordering and classifying management decisions becomes extremely necessary. Classification of management decisions allows us to distinguish classes and types of decisions that require a different approach to the organization of the management process.

Accounting serves the interests of meeting the social needs of the company's employees, increasing the volume of production of competitive products in the domestic and foreign markets, and efficient management using new advanced technologies. It is carried out directly on the basis of documentation of all economic processes and contributes to the control over the rational use of monetary and material resources, preventing unproductive expenses, preventing the occurrence of penalties for violation of contractual discipline, etc. [3].

Traditionally, the main supplier of financial information about an enterprise is the accounting department. Based on accounting data, that is, information that management collects during the company's activities, it makes management decisions to increase the efficiency and effectiveness of the company's indicators.

In turn, the information provided by the accounting system, and which corresponds to an interrelated set of tasks, is an information flow.

Based on the essence of accounting, the information flow formed within the framework of this system is a set of internal (within the accounting system) or external (between this system and the external environment) circulation of data that is necessary for managing and controlling the economic processes of an economic entity. Information in the enterprise is used as a basis for decision-making, as well as for performing and monitoring daily operations. It can even be argued that neither physical nor cash flows are possible without information flows [4]. 


\section{ECONOMIC STRATEGIES FOR THE DEVELOPMENT OF SOCIETY}

The analysis of economic information has become much more efficient due to the automation of accounting. The software can help you make a management decision thanks to the following algorithm shown in Fig. 1.

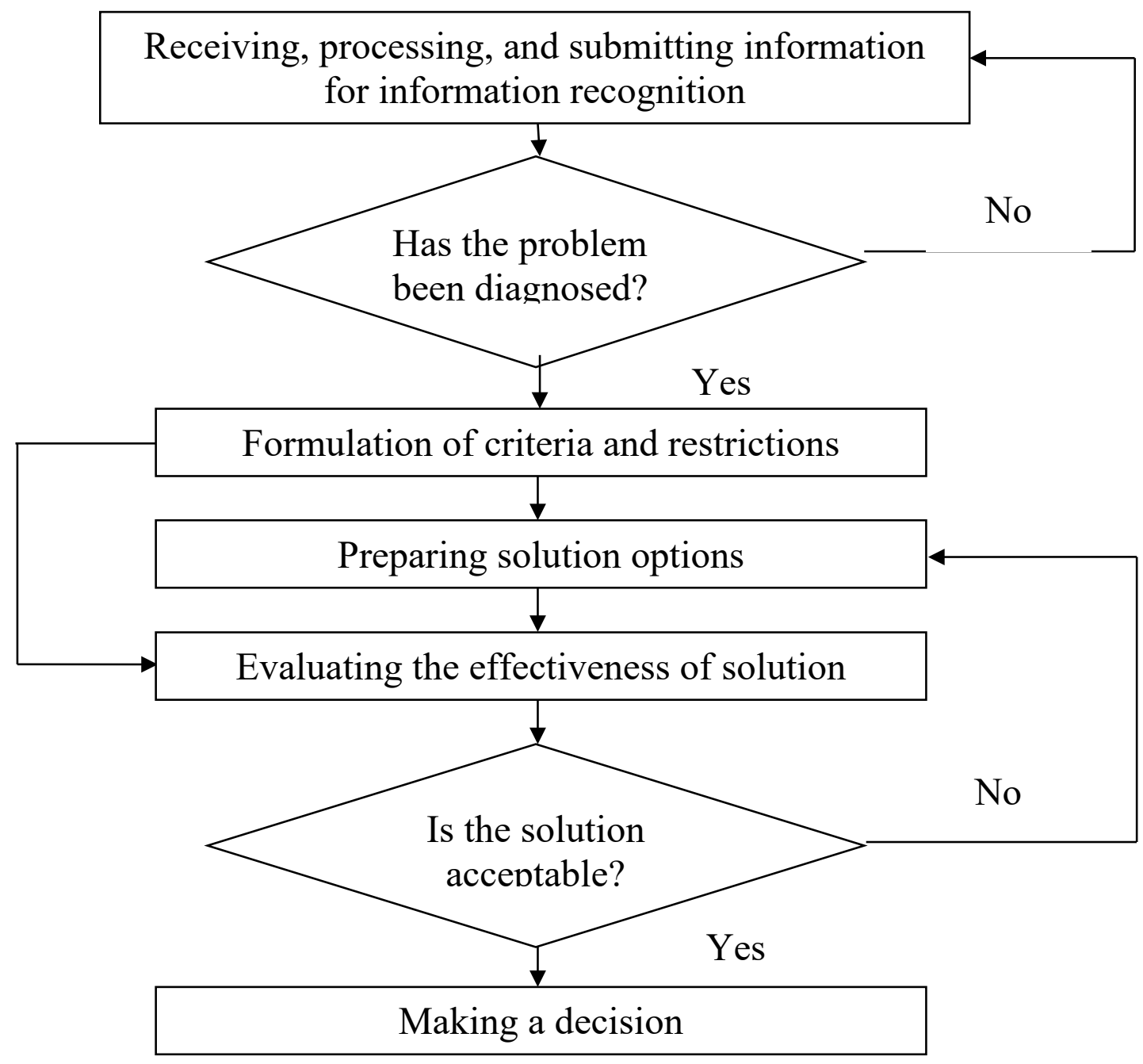

Figure 1. Algorithm for making managerial decisions

The most important feature of the management process is its informational nature. The organization of implementation of decisions made is carried out through a system of methods of influencing employees using information on the progress of implementation of decisions made (feedback). The more accurate and objective the information at the disposal of the management system, the more fully it reflects the actual state and relationships in the object of management, the more reasonable are the goals set and real measures aimed at achieving them. Since the manager in his work relies on information about the state of the object and creates new command information as a result of his activities in order to transfer the managed object from the 


\section{ECONOMIC STRATEGIES FOR THE DEVELOPMENT OF SOCIETY}

actual state to the desired one, the information is conditionally considered the subject and product of managerial work [5].

Information used as a control element or subject of managerial work must necessarily provide a high-quality idea of the tasks and state of the managed and control systems and ensure the development of ideal models of their desired state.

Thus, information support is a part of the management system, which is a set of data on the actual and possible state of production elements and external conditions for the functioning of the production process, as well as on the logic of changing and transforming production elements [6].

To avoid problems with regularity, it is advisable to automate the operation of the management system. When describing an information system, as a rule, the movement of various information flows, as well as their intensity and constancy, various types of information transformation algorithms, and the document flow scheme corresponding to these conditions at the moment are studied. The solution is a perfect description of the desired state of the object and how to achieve this state. They are a product of limited use, as they are aimed at a specific object under clearly described conditions. The quality of the solution as a finished product is manifested indirectly in the activity of the object to which this solution is directed [7].

Insufficient level of information support of the management system leads to an increase in the risk of making economically unjustified management decisions, suboptimal use of internal reserves of the enterprise, an increase in the risk of entrepreneurial activity, underestimation of the level of supply and demand in the market of goods and services, and so on. Too much analytical information can lead to the inability to process all the information, reduce the probability of evaluating the most appropriate and reliable information, and make erroneous management decisions. The management system requires only the information on the basis of which decisions are formed [8].

The development of Information Technologies has led to the fact that information has become an integral part of the activities of enterprises. Information becomes both a resource and a means of production. The greater the role of information support, the 


\section{ECONOMIC STRATEGIES FOR THE DEVELOPMENT OF SOCIETY}

more important the problem of correct and timely analysis of the information received becomes.

We can say that the movement «accounting $\rightarrow$ analysis $\rightarrow$ management decision» is the main information flow in enterprise management. Management decisions cannot be rational and effective without preliminary analysis, and analysis, in turn, is impossible without obtaining the primary information provided by accounting. Thanks to modern software, comprehensive automation of accounting and analytical processes guarantees the provision of complete and timely information for decision-making by Enterprise Management.

We can make a forecast that in the near future management processes will become more automated, that is, more subordinate to machine logic and less dependent on the subjective opinion of managers. This process will reduce the number of errors in management decisions caused by the human factor. However, this will raise many new questions. For example, which of the solutions can be entrusted to the program, and which should be with the mandatory participation of a person. 


\section{ECONOMIC STRATEGIES FOR THE DEVELOPMENT OF SOCIETY}

\subsection{Positive and normative accounting theory in the modern world}

Accounting theory is an invariable attribute of accounting as a science that changes under the influence of various factors, especially economic conditions, practical problems, scientific and technological progress, and so on. The theory of accounting has been developing for several centuries; in various accounting theories, which together form a general theory of accounting or its metatheory, reflect the regular and significant links of economic relations, as well as explain, predict and form trends in accounting practice as a field of human activity $[9,10]$.

The term «accounting theory» is actually quite incomprehensible and variable, so there are many of its definitions throughout the accounting literature. Among scientists and researchers, there has been and will continue to be an extensive debate, discussion, and argumentation of accounting theory contents; thus, it's definition will never be a final and finished product. Dialogue always continues, particularly as new issues and problems arise.

To explain the essence of accounting theory, Hendriksen E. used the definition from Accounting dictionary «.... a set of propositions, including axioms and theorems, which, together with definitions and formal or informal rules of inference, is oriented toward the explanation of a body of facts or treatment of a class of concrete or abstract operations». However, two parts of this definition, according to Hendriksen E., must be qualified with respect to accounting theory. First, theory does not explain all accounting practice. Theory is based on logic, and not all logically conceived. But if the emphasis is placed on the explanation of concepts and results rather than on techniques, the definition is generally correct. Second, the body of facts being explained by accounting theory can be assumed to be either (1) the financial facts as presented in accounting statements, (2) the concepts implied in the presentation of accounting data, or (3) the economic relationships of firms with other firms, individuals, and the economy as a whole as measured and summarized in accounting statements. Of these three, the first - the explanation of financial facts presented by accountants - is not the function of theory [11]. 


\section{ECONOMIC STRATEGIES FOR THE DEVELOPMENT OF SOCIETY}

Summarizing the research of scientists, Kavrar Ö. mentioned that it is possible to define accounting theories as a set of logical principles which provides a better understanding and conceptual framework to evaluate existing practices for the managers, investors, academicians etc. who need a guidance for the development of new procedures and practices. Today, there are several accounting theories in practice that would be better understood if we knew their historical perspective. This would also lead us to find out why accounting is what it is today [12].

Accounting theory plays a dual role in originating and explaining accounting practices. But at the same time, modern practices and problems serve the basis for the development of new theories (including accounting theories), and accounting theory also tries out to explain the rationale behind the modern problems and practices.

Accounting theories are deferring due to the nature of accounting environment, nature of business environment, nature of economic and political environment and from user to user. Besides, the nature of accounting information and data, sources of information and so on are influencing the accounting theories1all these aspects serve or provide frame of reference termed as structure of accounting theory [13]. These frame of references or accounting theory structure helps in judging to what extent and accounting theory adequate. The relationship between accounting theory and policy making (the establishment of rules and standards) shows accounting theory to be one of the three major inputs into the standard-setting process, the others being political factors and economic conditions. There are numerous and complex interrelationships among these three inputs, but Ex.1. graphically provides a useful basic understanding of the process [14].

All facets of the accounting theory and the modern environment are important and are considered by scientists and researchers. They focus on that part of the track running between accounting theory and the changes in the modern world. Following the development of accounting theories, we can observe the ascent from the concrete to the abstract. Each subsequent theory, as a rule, had a more abstract character. 


\section{ECONOMIC STRATEGIES FOR THE DEVELOPMENT OF SOCIETY}

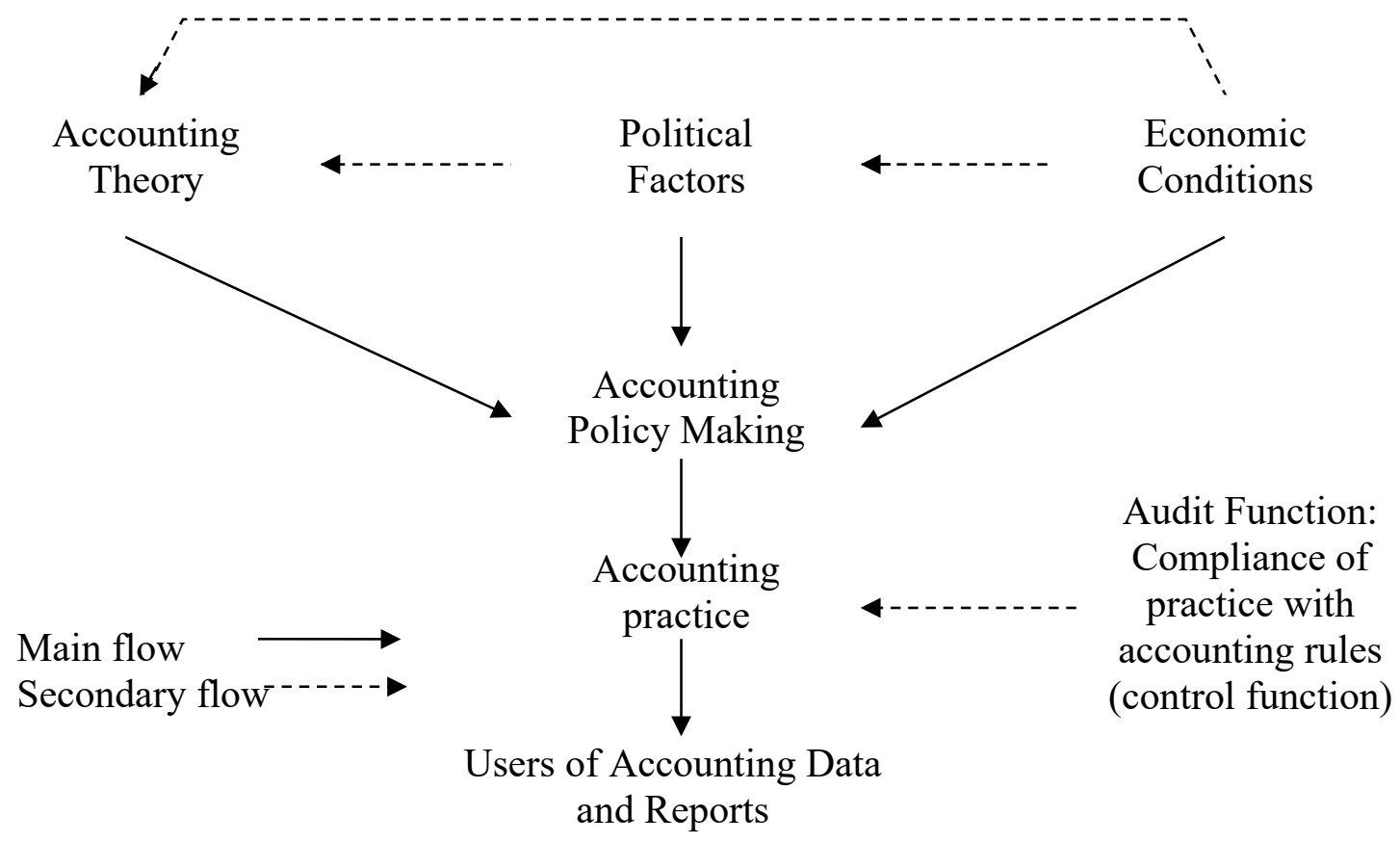

Exhibit 1.1. The Financial Accounting Environment

Personalistic theories explain phenomena directly from the individual, believing that accounting reflects the rights and responsibilities of individuals involved in the business process. The next object of observation was more abstract because the researchers realized that it is necessary to take into account the reasons that give rise to changes in rights and obligations, namely the consequences of the movement of values, their exchange. Philosophical accounting theories, according to which economic phenomena are explained as a set of causes and consequences of the enterprise, are even more abstract, and the use of mathematical equations in accounting at a certain stage was a higher degree of abstraction. But the essence of the development of accounting is that abstract theories can solve problems of practice [9].

While there is not a single generally accepted theory it is possible to mention two main tendencies that guide accounting research namely normative accounting theory and positive accounting theory. Normative accounting theories (known from the early 1900s) dealing with what accounting should be, are the theories that determine the rules, explain the real cases not as they are but as they should be. That is why normative theories are called normative because they are based on the norms (values and beliefs) of the researchers who construct the theory. Normative theories have a principle-based 


\section{ECONOMIC STRATEGIES FOR THE DEVELOPMENT OF SOCIETY}

and deductive structure. As a result, till the late 1960s accounting research and literature had a normative structure, where rules, orders, and empirically untested hypotheses were dominated [12].

The developments of economics and finance between the 1950s and 1960s led to the beginning of positive researches in the accounting field and the establishment of the concept of positive theory. The thought behind the paradigm change is that a working theory of existing accounting was not as critical as finding cures for deficiencies. The term positive refers to the theory that attempts to explain and make good predictions of particular phenomena. In fact the positive accounting theory is developed by Watts and Zimmerman and is based on work undertaken in economics and is heavily dependent on the efficient market hypothesis, the capital assets pricing model, and agency theory [15].

Practical accountants often have a tendency to appreciate effective managerial solutions in which the results reflecting practical value are simple, easy to use, and have a positive cost-benefit ratio. For this reason, as Kavrar Ö. notes in his study of the publications of many scholars on the subject, can be assumed, that managers will pay attention to the theory that gives the best results when choosing an accounting method. The positive and normative theories are likely to contribute to the managers with practical issues by demonstrating practical approaches that can explain the choice of accounting and making predictions for the future. These theories and other derivatives undoubtedly contribute to the diversity of accounting research approaches as well as practical aspects of accounting. Although there are extreme oppositions between positive and normative accounting theories, it is evident that methodology does not have to be either prescriptive or normative [12].

The rules and regulations the accountants follow in the modern world, forms the basis of the entire profession, but are variable, unstable, changeable, and nonpredictive. Instead, they are birthed from meticulously formulated theories and ideologies that endeavor to give the most intuitive and economically authentic approach to understanding an accounting practice. In addition, other accounting theoretical studies 


\section{ECONOMIC STRATEGIES FOR THE DEVELOPMENT OF SOCIETY}

have not yet fully completed their evolution and actually will never complete while economics will evolve. 


\section{ECONOMIC STRATEGIES FOR THE DEVELOPMENT OF SOCIETY}

\subsection{Outline of historical concepts and stages of capital formation as an economic category}

Management of the structure of the enterprise's capital can be considered as one of the most complicated problems in the process of enterprise management. The consistent use of available capital provides the opportunity to get the most benefit for the business owners. Its size defines the property situation, financial capacity and economic strength of the enterprise. It also performs the function of guarantying for creditors, is a permanent base for financing and source of funding.

Business-capital is one of the most important financial parameters of an enterprise, which solves the problem of effective and safe work. When the company grows, its equity capital should systematically increase its value, e.g. by "adding" the net profit, obtained in the reported period.

When the enterprise is established and has no debts, in the ideal variant, the assets are equal to its capital.

Equity capital is one of the external sources, i.e. invested by share-holders (initial capital, resource as a capital and internal sources), net profit, related with the enterprise activity and left at its disposal.

The main part of the company capital is the capital, which consists of:

- contributes of the capital owners in the form of shares, subscription of shares, etc.;

- profit, the company spends to cover the future risks and financial strength of the company (e.g. investment fund).

Thus, capital of an enterprise is an important index of the future development of its activity, like the first artist's move on an easel. During the centuries, its importance and role was much discussed and described in the studies and books. However, capital is still a permanent argument securing development and progress of business.

The notion of "capital" comes from the Latin word "capitalis", meaning "principal", "significant", "very important" and stresses its great importance.

The following figure demonstrates some stages of the study of capital as a concept (Fig. 1). 


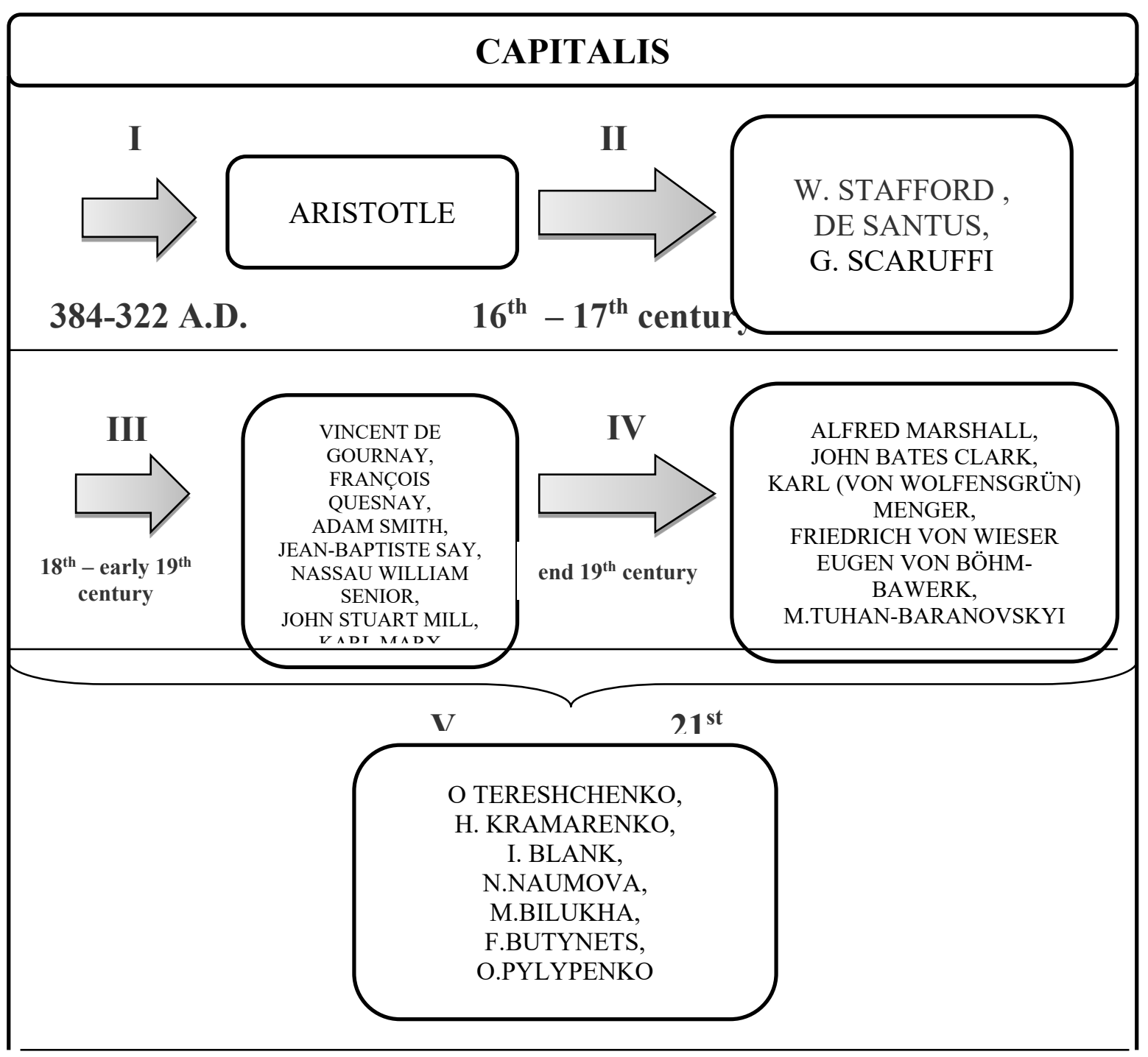

Fig. 1. Stages of development of the concept of "capital" in the history of economic thought

Aristotle (384-322 A.D.) was the first scientist, who described the concept of "capitalis". He studied capital through the prism of wealth and divided that category into two kinds. The first one included natural wealth, which was related with continuous accumulation of the means, necessary for life and useful for the state or a household unit, which was "not endless, but had its limits". According to Aristotle, the second kind of wealth suggested the process of money accumulation - "...the art to make a fortune, related with the idea, that wealth and gain had no limits". Aristotle called the mentioned kinds of wealth "economy" and "chrematistics" [22]. 
ECONOMIC STRATEGIES FOR THE DEVELOPMENT OF SOCIETY

The next stage of the capital development as an economic category was characterized by the studies of mercantilists (Table 1).

Table 1

\section{The authors' approaches to understanding of the concept of "capital" at the second stage of development}

\begin{tabular}{|c|l|}
\hline \multicolumn{2}{|c|}{ CAPITALIS - II STAGE } \\
groups of scientists & \multicolumn{1}{|c|}{ Tractates } \\
\hline Scientists, & $\begin{array}{l}\text { Representatives of that school (called after the Italian word "mercante" - a } \\
\text { merchant, a buyer) considered the notion of "capital" as a process of money } \\
\text { accumulation, particularly in gold, silver and jewelries. In the study of money } \\
\text { as a specific form of capital, the concept of "capital" was not used by } \\
\text { mercantilists. However, they understood that money should be invested in } \\
\text { production processes to increase the wealth, i.e. money had to get a production } \\
\text { form and be transformed into the form of commodities. Mercantilists stood } \\
\text { up for their corner that only things, which could be sold and transformed into } \\
\text { money, were considered as wealth, i.e. wealth was viewed as a process of } \\
\text { money accumulation. Moreover, mercantilists suggested that only production } \\
\text { process supplied the necessary fundamental for wealth creation and thus, it } \\
\text { required permanent support and development, and the sphere of turnover, } \\
\text { where the products were transformed into money, was the immediate source } \\
\text { of wealth [18]. }\end{array}$ \\
\hline
\end{tabular}

Representatives of that school first related the concept of capital with the production process and gave significance to its development as one of the main stimuli to make a fortune.

At the third stage of capital development, it was divided into the fixed and floating capital (Table 2). At that stage, the scientists considered capital as a specific reserve of the accumulated products of previous work. 


\section{The authors' approaches to interpretation of the "capital" notion at the third stage of development}

\begin{tabular}{|c|c|}
\hline \multicolumn{2}{|r|}{ CAPITALIS - III STAGE } \\
\hline $\begin{array}{c}\text { Scientists, groups of } \\
\text { scientists }\end{array}$ & Tractates \\
\hline 1 & 2 \\
\hline $\begin{array}{c}\text { physiocrats: } \\
\text { Vincent de Gournay (1712- } \\
\text { 1759), François Quesnay } \\
\text { (1694-1774), } \\
\text { Anne Robert Jacques Turgot } \\
\text { (1727-1781), } \\
\text { Honoré-Gabriel Riqueti de } \\
\text { Mirabeau (1715-1789), } \\
\text { Pierre Samuel du Pont de } \\
\text { Nemours (1739-1817) }\end{array}$ & $\begin{array}{l}\text { Representatives of the school of physiocrats (François Quesnay, Anne } \\
\text { Robert Jacques Turgot) transferred the study on the reasons of wealth from } \\
\text { the sphere of turnover into the sphere of production, where, to their } \\
\text { opinion, the wealth was created as a result of combination of work and } \\
\text { natural resources. Industry, transport and trade were called the fruitless } \\
\text { spheres, whereas the work of people in those fields was not beneficial for } \\
\text { the society. } \\
\text { According to A. Turgot, capital was considered a mobile property, which } \\
\text { was a result of saving. Moreover, it is worth noting that the important } \\
\text { theoretical findings of physiocrats included their scientific analysis of the } \\
\text { total social product, move of its elements as the necessary condition of } \\
\text { production process and classes reproduction. That move of the social } \\
\text { product through the spheres of production, distribution, exchange and } \\
\text { consumption was called economic turnover. } \\
\text { In the history of economic though, F. Quesnay first introduced the notion } \\
\text { of "reproduction of social product". He also distinguished its cost and } \\
\text { natural forms, specifying the concepts of capital and income. Speaking } \\
\text { about capital, F. Quesnay said that not money, but the production assets, } \\
\text { which were used to create a "net product", i.e. "wealth, which made } \\
\text { income of nations and was the product, left after paying all expenses from } \\
\text { the income obtained from possessions" [8, p. 194, 223]. He first developed } \\
\text { a model of economic turnover considering move of the fixed and floating } \\
\text { capitals and substantiated the rule, which said that at the macroeconomic } \\
\text { level, social product could be sold following some proportions between its } \\
\text { natural and cost elements. }\end{array}$ \\
\hline Adam Smith (1723-1790) & $\begin{array}{l}\text { Considering capital as a reserve, which was accumulated in the process of } \\
\text { production, A. Smith made the conclusion that capital was a result of the } \\
\text { previous work and for some time it could stay uninvolved in the production } \\
\text { process [16]. In general, the system of economic ideas of A. Smith was } \\
\text { based on the study of capital as a reserve, which was used in the production } \\
\text { process. Moreover, he stressed that all reserves could act as capital. In case } \\
\text { that are limited in quantity and used only for consumption, according to A. } \\
\text { Smith, they could not be the source of income. Both physiocrats and A. } \\
\text { Smith specified two forms of capital performance, i.e. fixed and floating. } \\
\text { However, contrary to physiocrats, he applied those forms to any product } \\
\text { capital, not only to the one, used in agricultural sphere, and noted that the } \\
\text { total capital of any businessman was divided into fixed and floating one. } \\
\text { In addition, A. Smith classified fixed and floating capital on a principally } \\
\text { new base. He said the fixed capital included machines and working tools, } \\
\text { buildings and constructions, land, useful abilities of all members of the } \\
\text { society. Therefore, A. Smith considered the fixed capital was the capital, } \\
\text { being long used, not involved in turnover, and had the same owner for a } \\
\text { long period. The floating capital included food products, materials and } \\
\text { ready goods, money, i.e. such kind of capital, which was in a continuous } \\
\text { turnover and produced profit while transiting from the hands of one owner } \\
\text { to another one. }\end{array}$ \\
\hline
\end{tabular}


ECONOMIC STRATEGIES FOR THE DEVELOPMENT OF SOCIETY

Continuation of the Table 2

\begin{tabular}{|c|l|}
\hline Nassau William Senior & \multicolumn{1}{|c|}{2} \\
\hline (1806-1873) & $\begin{array}{l}\text { Natural resources and human work were considered the primary factors of } \\
\text { production, whereas maintenance was the secondary one. The factor of } \\
\text { maintenance was viewed as the fundamental of capital. According to N. } \\
\text { Senior, maintenance has some specific differences from work and natural } \\
\text { resources. It is a necessary condition for capital existence and the category } \\
\text { adjacent to profit, similar to work and salary [5, p. 110]. }\end{array}$ \\
\hline $\begin{array}{l}\text { In his fundamental work "Capital", Karl Marx made a deep analysis of the } \\
\text { importance of capital in the extended reproduction [14]. According to the } \\
\text { conclusions of the famous scientist, capital can exist under specific social } \\
\text { and economic conditions, particularly in case of highly developed } \\
\text { marketable production and turnover, motivation of the entrepreneur's } \\
\text { activity like personal enrichment, concentration of a significant share of } \\
\text { production means (i.e. certain degree of capital concentration) in the hands } \\
\text { of economic agents, deficit of personal production means, experienced by } \\
\text { some economic agents, forcing them to ask for employment by others. [10, } \\
\text { p. 292]. The fundamental for the economic theory was made by the study } \\
\text { by K. Marx on the peculiarities of capital turnover, in which the capital } \\
\text { changed its form and came through three stages, particularly money, } \\
\text { production, commodity. The money capital performed the function of the } \\
\text { basis for creation of added value, production capital - immediate } \\
\text { production process of the added value creation, whereas commodity one - } \\
\text { the function of sale of the value and added value and again transformation } \\
\text { into money capital. However, K. Marx clearly determined the cyclic } \\
\text { character of money turnover as capital. He said that ".. having finished the } \\
\text { move, money make their new start" [7, p. 162-163]. Karl Marx confirmed } \\
\text { that in the process of change of capital forms, the primary advanced value } \\
\text { was not just preserved, but changed its figure due to the growth of the value } \\
\text { (added value) that transformed it into capital. }\end{array}$ \\
\hline
\end{tabular}

It is worth noting the idea of Karl Marx, who first differentiated the notions of money and capital. At the same time, he proved their interdependence, because under certain conditions, money could perform the function of capital and vice versa. Marx first interpreted the notion of added value and created the theory of capital turnover that was the base for all following studies.

Later, the notion of capital got a clearer definition. Scientists agreed on the idea to divide it into the fixed and floating capital, new theories appeared concerning the development of capital not only as a natural resource and fortune of people, but also the capital of human potential and resource. In particular, John Bates Clark proposed the theory of borrowed capital, making conclusion that borrowed resources could help the enterprise to develop with the same efficiency as the personal ones (Table 3). 


\section{The authors' approaches to interpretation of the "capital" notion at the fourth stage of development}

\begin{tabular}{|c|c|}
\hline \multicolumn{2}{|r|}{ IV STAGE - CAPITALIS } \\
\hline $\begin{array}{c}\text { Scientists, groups of } \\
\text { scientists }\end{array}$ & Tractates \\
\hline \multicolumn{2}{|l|}{ Neoclassic economic school: } \\
\hline Alfred Marshall (1842-1924 ) & $\begin{array}{l}\text { The theory of Marshall was based on the synthesis of the marginal theory of } \\
\text { value, factors and costs of production, demand and supply. } \\
\text { According to Marshall, capital consists of the things, without which production } \\
\text { cannot be performed with equal efficiency, but which are not free gifts of the } \\
\text { nature [11, p. 307]. He made the conclusion that capital was the depositary of } \\
\text { some things, a result of human efforts and sacrifices. However, capital differs } \\
\text { from other forms of wealth by being able to secure employment of workers. A. } \\
\text { Marshall considered capital to be a part of wealth, which is determined for } \\
\text { obtaining income in the form of money or buying some things in the field of } \\
\text { turnover. He divided capital into the fixed and floating. He considered capital } \\
\text { included knowledge, organizational abilities and appropriate production and } \\
\text { state formations. }\end{array}$ \\
\hline John Bates Clark (1847-1938) & $\begin{array}{l}\text { According to J. Clark, the structure of a society, its production organism and } \\
\text { dynamics are influenced by five factors, particularly growth of population, } \\
\text { growth of capital, improvement of production methods, transformation of the } \\
\text { forms of industrial enterprises: from liquidation of small low-efficient ones to } \\
\text { survival of the most productive. Each of those transformations makes effect on } \\
\text { the society, changing the correlation of different industrial groups. Another } \\
\text { important aspect is the scientist's idea that efficiency of the social work } \\
\text { depends on its quantitative correlation to the capital. Referring to the concept } \\
\text { of income distribution on the principles of threshold analysis of the price of } \\
\text { production factors, which J. Clark's called the "law of diminishing returns", } \\
\text { production factors, i.e. work or capital, can be increased until the price of the } \\
\text { product, produced by the factor is not equal with its price. Thus, the permanent } \\
\text { capital can be transformed into other forms, escaping from the worse and } \\
\text { getting better ones under increase of its size, and transform into a worse one } \\
\text { when it stays unchanged. The practical importance is embodied in the } \\
\text { conclusion by J. Clark on the proportions of profitability on the capital and the } \\
\text { interests on the borrowed capital. If the enterprise is equipped in the way } \\
\text { securing } 5 \% \text { of the net profit on capital, and if the same level of the interest on } \\
\text { loans, the enterprise is capable to stand competition for some period. }\end{array}$ \\
\hline $\begin{array}{l}\text { Austrian marginalism school } \\
\text { Carl Menger (1840-1921), } \\
\text { Friedrich Freiherr von Wieser } \\
\quad \text { (1851-1926), } \\
\text { Eugen von Böhm-Bawerk } \\
\quad(1851-1919)\end{array}$ & $\begin{array}{l}\text { The scientists paid much attention to the essential functional features of capital. } \\
\text { In particular, O. Böhm-Bawerk concluded that capital was the result of savings } \\
\text { and production, and specified two forms of its performance, i.e. private capital } \\
\text { as an integrity of means, intended for buying different rewards, and social } \\
\text { (productive) capital in the form of production constructions, raw material, } \\
\text { current resources, transport means, etc. [1]. }\end{array}$ \\
\hline $\begin{array}{l}\text { M. Tuhan-Baranovskyi } \\
(1865-1919)\end{array}$ & $\begin{array}{l}\text { Capital includes the things, which get the capability to increase their price } \\
\text { under some social conditions and thus, secure a permanent income for owner } \\
{[17, \text { p. } 89] \text {. }}\end{array}$ \\
\hline
\end{tabular}




\section{ECONOMIC STRATEGIES FOR THE DEVELOPMENT OF SOCIETY}

Considering the economic essence of the capital of enterprises, one should mention its specific features:

- capital of enterprises is the principal production factor. In the system of production factors (capital, land, labour), capital takes the leading position, because it combines all factors into an integral production complex;

- $\quad$ capital characterizes profit-making financial resources of enterprises. In that case, it can be considered separately from the production factor in the form of invested capital;

- capital is the main source of its owners' prosperity. A share of capital in the current period comes from its content and occurs in the owners' "pocket", whereas a share of accumulated capital is used for satisfaction of owners' needs in the future;

- capital of an enterprise is the main measurement of its market price. The function is performed by equity capital of the enterprise, which determines the amount of its net assets. Moreover, the amount of used equity capital at the enterprise characterizes the potential of attraction of borrowed financial means, securing obtaining extra profit. In complex with other factors, it makes a base for assessment of the enterprise market price;

- dynamics of the enterprise's capital is the most important factor determining the level of efficiency of its economic activity. The capacity of equity capital to self-development at high rates characterizes a high level of formation and effective distribution of the enterprise's profit, its capacity to support financial balance by means of internal sources. Moreover, reduction of the amount of equity capital is normally the consequence of inefficient, unprofitable activity of the enterprise.

Therefore, analyzing all four stages of capital studying, three aspects are specified, particularly economic, juridical and accounting (Fig. 2).

The capital accounting determines assets minus liabilities. Nevertheless, scientists have their opinions on the study of that economic category (Table 4). 
ECONOMIC STRATEGIES FOR THE DEVELOPMENT OF SOCIETY

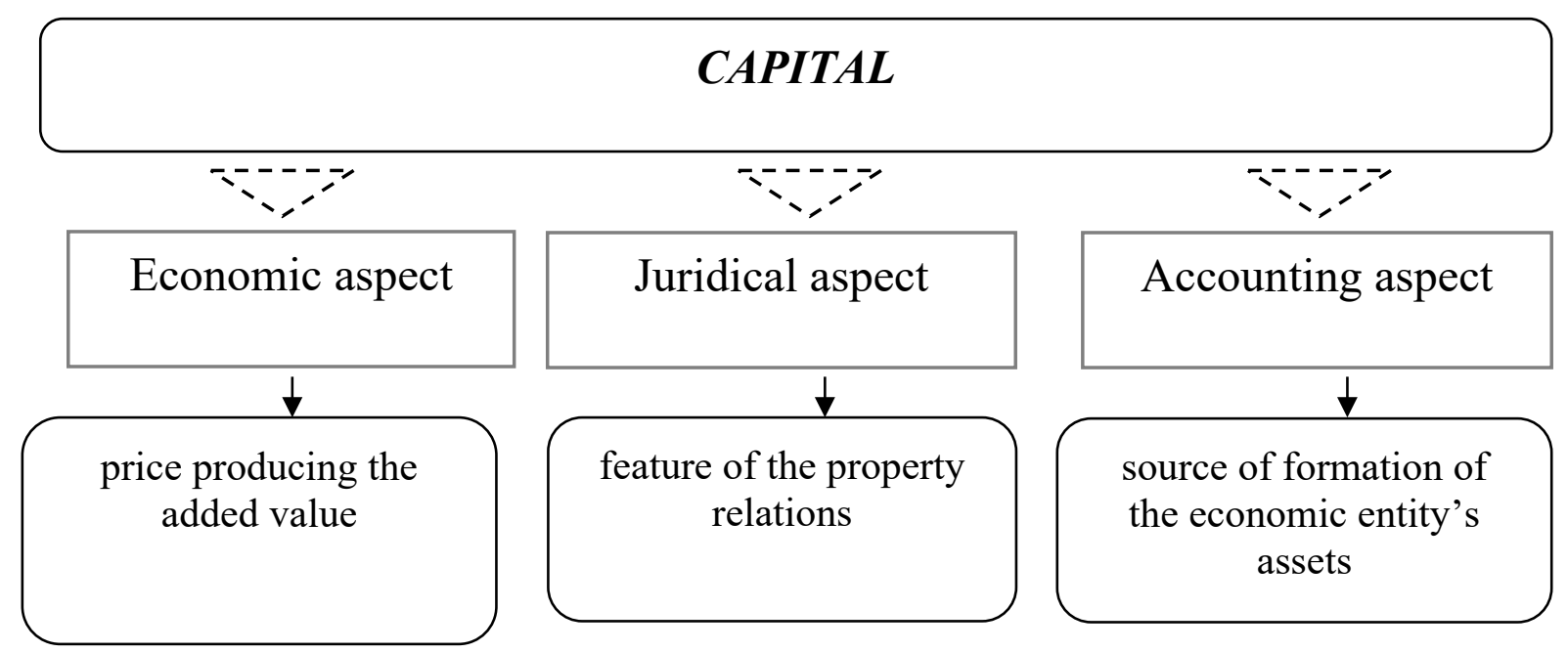

Fig. 2. Interpretation of capital through the aspects of its essence description.

Table 4

The authors' approaches to application of the essence of "equity capital" category

\begin{tabular}{|c|l|}
\hline Author & \multicolumn{1}{|c|}{ Essence of the notion of "equity capital" } \\
\hline A.P. Bobiak & $\begin{array}{l}\text { The total value of the means, obtained from founders in different forms with } \\
\text { the transfer of the right of ownership of those means to the enterprises, or left } \\
\text { by founders at the enterprises, obtained in the process of the enterprise's } \\
\text { activity (due to personal activity and obtained free) [17]. }\end{array}$ \\
\hline O.Y. Vivchar & $\begin{array}{l}\text { The aggregate of personal financial resources of enterprises, manifested in the } \\
\text { first chapter of liabilities of the accounting balance, being in the fund (statute } \\
\text { capital, additional capital, reserve fund) and non-fund (undistributed profits) } \\
\text { forms and belong to it on the right of ownership, economic activity and total } \\
\text { disposal [19]. }\end{array}$ \\
\hline O.I. Pylypenko & $\begin{array}{l}\text { The total value of the internal means of enterprises, which belong to it on the } \\
\text { right of ownership and are used for formation of its assets [30]. }\end{array}$ \\
\hline
\end{tabular}

Therefore, equity capital can be considered as:

- total value of the enterprise' means, possessed on the right of ownership and used for profit making;

- a category, which determines the share of production means, belonging to owners;

- a share in the enterprise's assets, left after paying liabilities;

- capital, invested by owners (founders) of the enterprise; 


\section{ECONOMIC STRATEGIES FOR THE DEVELOPMENT OF SOCIETY}

- source of property creation, main source of financing.

During the centuries, theoretical scientists discussed on the essence of the notion of "capital". Its multi-aspect character has prevented on determining the only definition. Thus, the capital can be considered in three aspects, particularly economic, juridical and accounting. According to the scientists' opinions, the authors of the article supply their personal interpretation of the "equity capital". The equity capital is considered as a total of personal sources of assets funding, which belong to the enterprise and are created by means of owners' contribution and additional internal costs, created and obtained in the process of economic activity of the enterprise.

The scientists pay great attention to the issue of classification, structure, assessment, analysis and management of the equity capital. However, not much attention is paid to the problem of control and reproduction of the equity capital and therefore, to its impact on the investment attractiveness of the enterprise. It is the reason for the search of the ways for solution of the above-mentioned problems in the further researches. 


\section{SECTION 2. ADMINISTRATIVE REGION AND BUDGET}

\section{1 Обліково-аналітичне забезпечення управління підприємством на основі збалансованої системи показників}

Сучасним підприємствам необхідні організаційні зміни у процесах інформаційного супроводу прийняття стратегічних рішень шляхом впровадження обліково-аналітичного забезпечення управління на основі збалансованої системи показників, який спрямований на задоволення потреб керівництва в актуальній, достовірній, релевантній, повній інформації з метою локалізації декларативних, інтуїтивних, емоційних, ситуативних підходів у визначенні стратегічної поведінки і розширення обгрунтованих аналітикопрогнозних методів визначення стратегічних пріоритетів.

Розробники збалансованої системи показників (ЗСП) Каплан Р.С. та Нортон Д.П., зазначають, що в інформаційну епоху всі нові програми, ініціативи і зміни процесу управління на підприємствах відбуваються в умовах дії системи квартальної і річної фінансової звітності. Вона донині залишається в тисках моделі бухгалтерського обліку, розробленої сторіччя тому для здійснення довгострокових угод між незалежними суб'єктами. Ці древні моделі бухгалтерського обліку дотепер використовуються компаніями інформаційної епохи, коли вони намагаються сформувати внутрішні активи i реалізувати невикористані можливості, а також зміцнити зв'язки і створити стратегічні союзи з партнерами [34].

За «нової економіки» суттєво змінюються критерії оцінки ефективності фінансово-господарської діяльності підприємства. Сучасна практика переконливо доводить, що однофакторний аналіз традиційних показників фінансового стану (чистий прибуток, рентабельність основних засобів чи основної діяльності, фондовіддача тощо) не відображають реальної картини на підприємстві. Відомий американський економіст Б. Ліберт пише, що за «нової економіки» додана вартість на підприємствах створюється передусім за 


\section{ECONOMIC STRATEGIES FOR THE DEVELOPMENT OF SOCIETY}

допомогою нематеріальних активів, людського капіталу, знань, інтелектуальної власності, професіоналізму та комунікацій [36].

Одним із ефективних інструментів, який здатний активізувати функції управління, що спрямовані на підвищення ефективності та діяльності підприємства є впровадження збалансованої системи показників. Яка, крім фінансових, включає показники, що характеризують ключові сфери діяльності підприємства, від яких залежить успішна реалізація стратегії.

Використання ЗСП дозволяє підприємству використовувати абсолютно новий інструмент бачення інноваційної стратегії розвитку у вигляді збалансованих між собою показників, які критично оцінюють не тільки поточні, але й майбутні перспективи. Вона орієнтує підприємство на перспективу i приводить тактичні плани у відповідність зі стратегічними; робить можливою широку орієнтацію на навчання та комунікацію на всіх рівнях управління підприємством; підтримує підсистеми управління підприємством, такі як бюджетування, управління персоналом, маркетинг і таке інше[33].

Збалансована система показників забезпечує менеджмент універсальним механізмом, який інтерпретує світогляд та стратегію підприємства через набір взаємозалежності показників. Показники даної системи згруповані за чотирма блоками: фінанси, клієнти, внутрішні бізнес-процеси, навчання та кар'єрне зростання персоналу. Таким чином ЗСП доповнює систему фінансових параметрів вже здійсненого минулого системою оцінок перспектив.

Концепція збалансованості є центральною для всієї системи та забезпечує рівновагу між фінансовими і нефінансовими показниками, внутрішніми та зовнішніми компонентами підприємства, випереджаючими індикаторами та тими, які запізнюються, орієнтацією на короткострокові та довгострокові цілі [35].

На нашу думку, система обліку на підприємстві повинна будуватися таким чином щоб забезпечити менеджмент фінансовою та нефінансовою інформацією як про внутрішні господарські процеси, так і про зовнішнє середовище підприємства. В цьому аспекті необхідно додати, що інформація фінансового та 


\section{ECONOMIC STRATEGIES FOR THE DEVELOPMENT OF SOCIETY}

управлінського обліку повинна бути порівняльною. Адже в іншому випадку ставиться під сумнів можливість прийняття якісних рішень щодо управління стратегічним розвитком підприємства і досягнення бажаної результативності.

Обліково-аналітичний супровід управління доцільно здійснювати на основі концепції збалансованої системи показників та реалізації процедур фінансового та управлінського обліку (рис. 1). Обліково-аналітичне забезпечення передбачає організацію всеохоплюючої системи обліку процесів створення вартості. Ця система передбачає організацію первинного, аналітичного та синтетичного обліку внутрішніх факторів генерування вартості в розрізі сегментів діяльності, центрів відповідальності, функціональних підрозділів та видів продукції.

Кожне підприємство розробляє систему критеріїв залежно від специфіки своєї діяльності та цільових орієнтирів в розрізі чотирьох складових (фінанси, маркетинг, складова внутрішніх бізнес-процесів, складова навчання і розвитку).

Параметри фінансової складової призначені для характеристики фінансово-інвестиційного забезпечення. Ці параметри, 3 одного боку, $є$ вихідними передумовами функціонування підприємства, а 3 іншого $€$ результативними характеристиками його розвитку.

На основі даних фінансового обліку формуються розрахунково-аналітичні показники, які відображають наявний фінансовий стан підприємства та сприяють виявленню резервів його зміцнення.

Важливим завданням є вибір оптимальної кількості показників, достатньої для відображення найважливіших результатів діяльності підприємства. 


\section{ECONOMIC STRATEGIES FOR THE DEVELOPMENT OF SOCIETY}

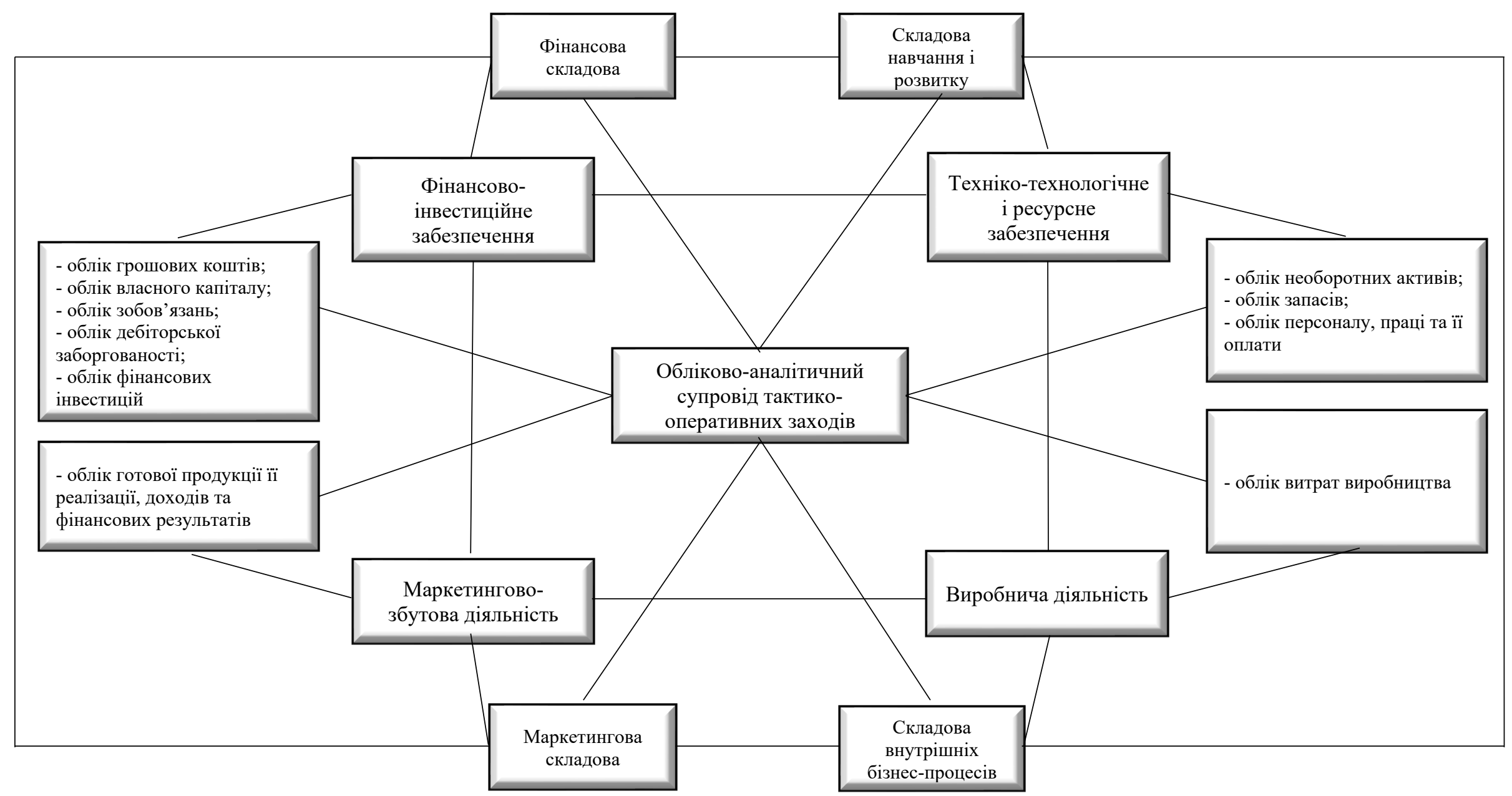

Рис. 1. Взаємозв'язок концепції збалансованої системи показників та реалізації процедур фінансового та управлінського обліку

Примітка. Розроблено автором 


\section{ECONOMIC STRATEGIES FOR THE DEVELOPMENT OF SOCIETY}

На нашу думку, до показників, що відображають фінансову складову можна віднести: коефіцієнт автономії (фінансової незалежності); коефіцієнт покриття (коефіцієнт загальної платоспроможності); коефіцієнт абсолютної платоспроможності; коефіцієнт рентабельності продажів; коефіцієнт достатності чистого грошового потоку підприємства; коефіцієнт рентабельності активів (ROA); прибуток до сплати податків, дивідендів та до вирахування амортизації $(E D I T D A)$; операційний прибуток до вирахування амортизації (OIBDA); прибуток до вирахування податків і відсотків (EBIT); чистий операційний прибуток (NOPLAT); рентабельність інвестованого капіталу (ROIC). Поряд iз абсолютними показниками прибутку в практиці використовуються і відносні показники - маржі. Вони є відсотковим виразом величини прибутків по відношенню до чистого доходу (EDITDA margin, OIBDA margin).

Отже, обліково-аналітичне забезпечення управління побудоване на основі ЗСП має вирішальне значення для ефективної адаптації підприємством до динамічного зовнішнього середовища та підвищення ефективності бізнесу. Показники, які інтегрують чотири складові збалансованої системи повинні бути узгодженими, характеризуватися гнучкою зміною, швидким пристосовуванням до цілей, що обновляються, і завданнями підприємства, змінами в зовнішньому економічному середовищі, у внутрішніх умовах своєї власної діяльності. 


\section{ECONOMIC STRATEGIES FOR THE DEVELOPMENT OF SOCIETY \\ SECTION 3. DEMOGRAPHY, ECONOMY, SOCIAL POLICY}

\subsection{Adult education in Ukraine: post-quarantine challenges}

The driving force of the economic development of country is experienced, competitive specialists. The specialists, who create the potential for the development of the country and the economy. The main role in the formation of intellectual potential is playing education and education's market. The boundaries of personal contacts have changed their spatial landmarks in modern conditions and, accordingly, accents have changed in all spheres of human life.

The education market is no exception. After all, the education market is a very specific niche, and it is worth noting the following features of its operation [41]:

1. combines features of private and public benefit;

2. asymmetric information, which implies a difference in the knowledge of some participants compared to others;

3. formation of market relations in the field of education is based on competition under the influence of state regulation;

4. high elasticity of demand in the education market, rapid market response to changes in demand;

5. structuring of education market is carried out by economic and territorial locality, conjuncture and segmental signs;

6. individuality and non-standard services and technologies provided, high product differentiation according to one and the same specialty.

Thus, according to the UN, quarantine restrictions have affected more than 3.3 billion people, or $81 \%$ of the world's workforce [37]. As a result of such changes on a global scale, the education market in Ukraine is no exception. It should be noted that the modern Ukrainian education market must quickly adapt to today's challenges. When mass diseases or epidemics spread, it is particularly education market which is undergoing dramatic changes, because the first institutions to be closed are schools and institutions of higher education. That is why it is necessary to analyze and study the post-quarantine challenges that the education market overcomes. 


\section{ECONOMIC STRATEGIES FOR THE DEVELOPMENT OF SOCIETY}

One of the main problems that arose in the post-quarantine period was the comprehensive necessity to transfer students and schoolchildren to distance learning. After all, it was necessary to transform the vast majority of educational processes in a relatively short time and prepare the consciousness of the participants in such processes.

Another problem is the lack of technical equipment of "home office" for all participants of the educational process that led to some delays in time in implementing the concept of online education.

The education market was also unprepared to work with the youngest participants in the educational process. Thus, younger students are not able to master the approved program remotely without the support of adults in the learning process. Given the challenges described above, we can conclude that the values of the student during the distance learning and their ability to work independently, critical thinking, ability to collect, process and analyze relevant information and as a result - the successful application of knowledge become more important.

The next problem of the educational market in Ukraine in the post-quarantine period is a significant reduction in the number of foreign students among the contingent of local universities. Thus, the low level of dissemination of information about distance learning opportunities in Ukraine among potential foreign students significantly reduces the competitive advantages of Ukrainian universities among universities in neighboring countries.

It's therefore necessary to coordinate regularly the central and local events of information and promotional campaign in order to invite foreign students to study in Ukraine [39].

At the same time, the problem of employment of older people in the labor market in the field of education remains relevant. Much less attention is given to this problem among the business community than to those mentioned above.

However, the problem of employment of older people deserves attention and a comprehensive approach to solving it, given the existence of another demographic problem in Ukraine - the aging of the nation. 


\section{ECONOMIC STRATEGIES FOR THE DEVELOPMENT OF SOCIETY}

Older people are those who are preparing to retire or already have the status of a pensioner [42]. As of the day, people over the age of 50 have difficulty finding a job, as well as the elderly between the ages of 60 and older. The presence of such a problem is associated not only with the behavior of employers who prefer to work with young people, but also with the behavior of the unemployed older ("elegant") age.

The key barriers to the development of the relationship between employers and employees of the "elegant" age are: stereotypes in society, discriminatory actions of employers; lack of self-belief and self-discrimination of the unemployed. The last two problems have a psychological basis, the solution of which also needs to be worked on systematically with the involvement of relevant specialists in order to change the situation for the better. Today, the employment of people of the "elegant" age is more associated with volunteering - with the creation of appropriate projects of caring people in order to find jobs for the elderly.

In our opinion, the strategy for solving this problem should be comprehensive and include the following main directions:

1. Popularization of the problem in society in order to draw attention to its solution of absolutely all segments of the population, regardless of age and gender. The upbringing function of the state is to form a dignified attitude in young people, honor and respect for older people and the elderly.

2. Eradication of social and psychological problems. The stronger and more diverse the support is - government and business - the more confident older people feel, the more willing they are to continue looking for a job.

3. Interaction of business, state and public initiatives. In the labor market there are many cases of employers wanting to work with older people, as more experienced and responsible than young people. The main problem is that this principle is mainly followed by representatives of big business as socially-oriented participants in the business environment. Economic incentives would allow companies to become more involved and employ older people. The activities of relevant public organizations would allow to more actively attract public attention and to form the feeling of importance and usefulness in elderly people. 


\section{ECONOMIC STRATEGIES FOR THE DEVELOPMENT OF SOCIETY}

4. Adult education. Lifelong learning is one of the key tools for solving key labor market problems. As of the day, Government policy is actively aimed at realizing adult learning opportunities. However, in our opinion, it is worth emphasizing and focusing on the creation and expansion of appropriate modern programs and conditions for education people of "elegant" age. The University of the Third Age deserves special attention - it is an innovative socio-pedagogical service aimed at implementing the principle of "Lifelong Learning". The purpose of the University of the Third Age is to adapt the older generation to modern social life; support of physical and intellectual health, promotion of employment and association, expansion of world outlook, improvement of life's quality of the elderly; organization of such activities that create conditions for communication, self-realization and active participation in life.

According to the memorandum of continuing education, the EU education systems have to adapt to modern conditions. Therefore, it is necessary to show the benefits, pleasures, benefits and new horizons that open up through lifelong learning in the "Universities of the Third Age". The role of the teacher is specific, because this is more as a consultant, mentor, mediator and organizer [42].

5. Collaboration of young people and the elderly - within one enterprise, in the framework of participation in projects, on a volunteer basis in order to share experiences and provide professional and moral support to each other.

Summarizing the above stated, attention should be paid to the necessity for comprehensive reform of the employment sector and the education market in Ukraine. Throughout life, the role of adult education is growing, which is associated with demographic changes and the need for regular updating and development of skills in accordance with changes in socio-economic conditions [46]. The voucher system was to become a new program to strengthen the competitiveness of people over 45 years of age.

Voucher is a standard document that gives a person the right to retraining, training at the next educational - qualification level, specialization, advanced training at the expense of the state. [38]. It can be obtained by a person who has a higher or vocational education at the age of 45 before reaching retirement age. A vocational training 


\section{ECONOMIC STRATEGIES FOR THE DEVELOPMENT OF SOCIETY}

voucher can be obtained only for those specialties that are listed by the Ministry for Development Economic, Trade and Agriculture of Ukraine. According to the list, the person chooses a specialty of his own volition. [44]

As far as the voucher system has been relevant for Ukrainian science since 2013, a relatively small circle of modern scientists studied this issue. These included L. Tkachenko, V. Yurovska, V. Schwegler-Rohmeis, O. Balakireva, T. Bondar, and others. However, there is a need for further study of the current state and prospects for the development of the education voucher program in Ukraine.

The training voucher program started in Ukraine in 2013 and was aimed at people over 45 years old. This group of people was given the opportunity to undergo

free retraining with a voucher at the expense of the State social insurance for unemployment and receiving new knowledge and improve their competitiveness in the labor market. However, the program was not as popular as expected and did not spread among the population.

To clarify the problems and prospects for the development of the voucher program, the State Employment Service applied to the UN Development Program for technical assistance.

Due to the economic crisis in 2014, Ukraine lost about 900 thousand people of economically active population, employment decreased by 1.2 million people - to 18 073 thousand, the unemployment rate increased by $2 \%$, or 340 thousand people. At the same time, employment is being transformed and the professional quality of the workforce is becoming the most important strategic commodity. Due to the "gap" in the qualifications of the adult population, older people are at risk regarding the employment. Thus, among the working population of Ukraine, people over 40 make up 50\% in cities and $62 \%$ in rural areas. That is why the State Employment Service is the largest informant and consultant on the voucher program. The State Employment Service is interested in further implementation and development of modern tools to increase the competitiveness of the workforce, especially new vulnerable groups, such as displaced persons and participants in the anti-terrorist operation. In our opinion, in order to adapt these citizens, it is necessary to expand 
ECONOMIC STRATEGIES FOR THE DEVELOPMENT OF SOCIETY

the network of institutions with the necessary list of licensed professions, increase the license of educational institutions for certain professions, as well as more actively introduce distance and evening education for adults.

A sociological research of the voucher program prepared by Ukrainian Institute of Sociological Studies named after Olexander Yaremenko for the Order of UNDP demonstrated that $51 \%$ of the surveyed voucher recipients $(30 \%$ of them have already completed their studies, $70 \%$ are studying now) believe that they have received the expected result from the voucher program. Almost the same number of respondents ( $49 \%$ of respondents, $9 \%$ of them have already completed their studies, $91 \%$ are studying now) said that they do not feel the result yet, but they hope to get it in the future [47].

These researches allowed to assess the set of recipients of vouchers for training, as shown in Fig.1,2,3.

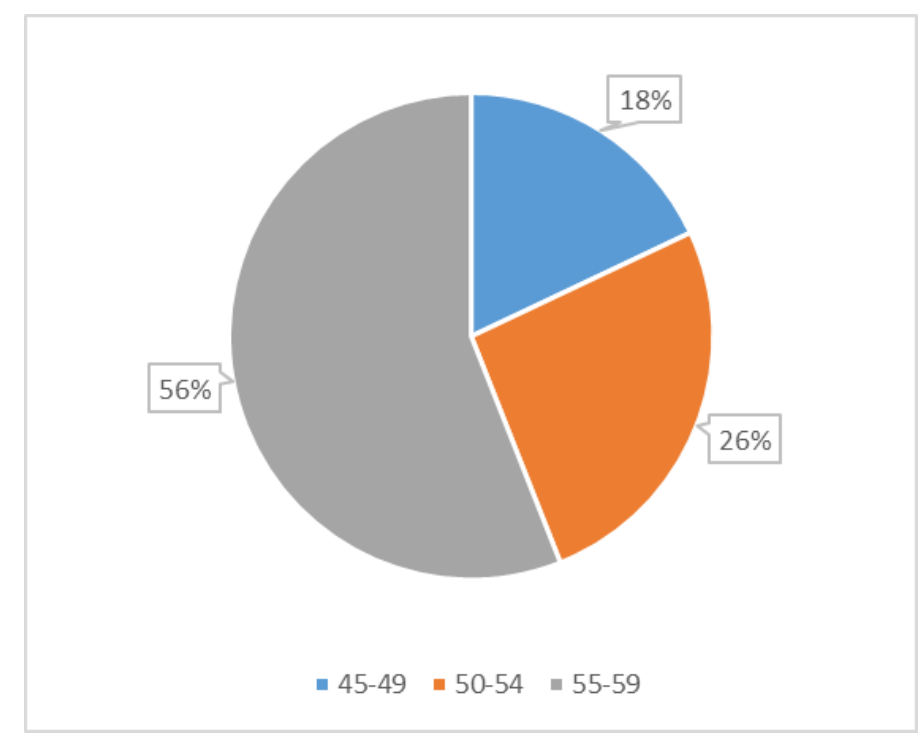

Fig.1. Percentage of Age distribution of voucher recipients 


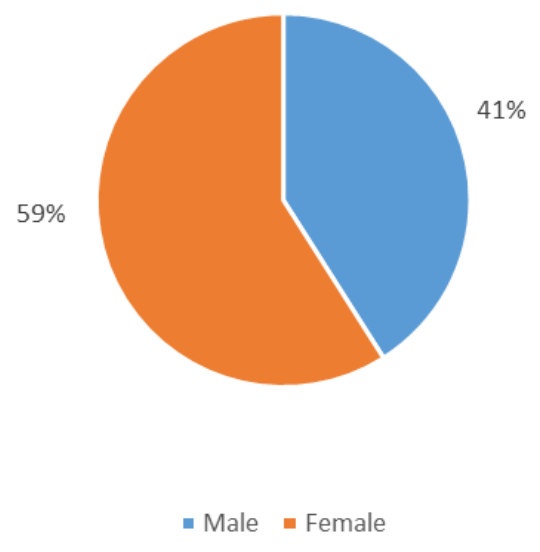

Fig. 2. Gender distribution of voucher recipients

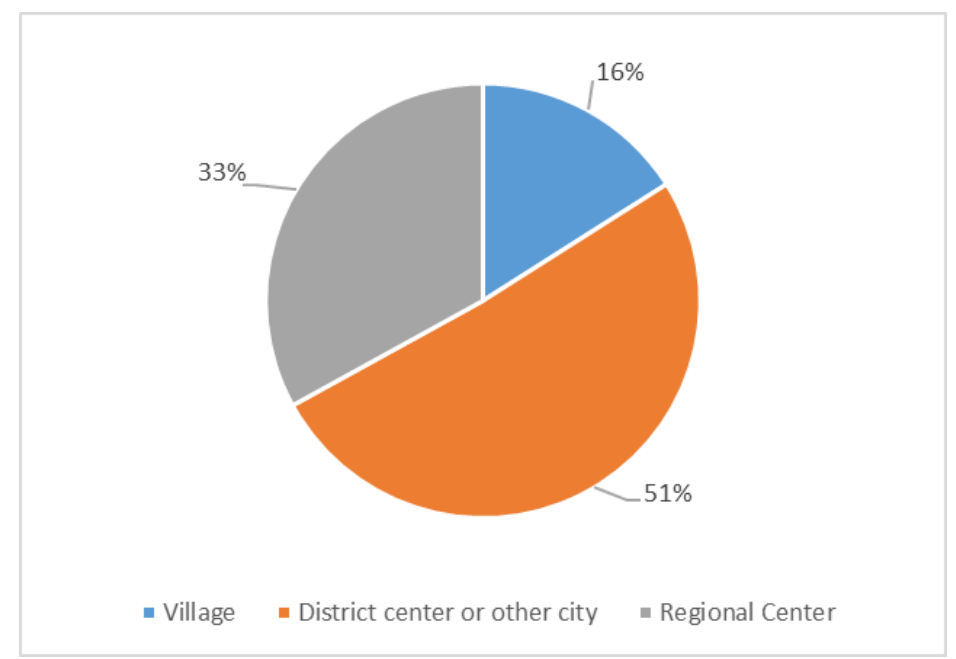

Fig. 3. Settlement type of residence of voucher recipients

According to the results of a sociological research, it was found that the implementation of the voucher program at the stages of counseling and issuance of vouchers by the state employment service is organized quite well. The vast majority of surveyed users expressed satisfaction with the completeness of the information provided and the comfort of communication with employees of employment centers. But not all the received vouchers are used in the future. The results of the research showed that the main reason for not using the issued voucher are problems with the selection of a suitable educational institution. Although educational institutions are interested in participating in the voucher program, not all offer training programs that are convenient for the adult working population. 


\section{ECONOMIC STRATEGIES FOR THE DEVELOPMENT OF SOCIETY}

After analyzing the above statistical information, we identified the following reasons for the unpopularity of the voucher program:

1) a difficult macroeconomic situation, which in fact guarantees voucher recipients further unemployment;

2) lack of analysis of the needs of enterprises in employees belonging to the categories for which training is carried out on a voucher;

3) ambiguous level of training;

4) doubts about the prospects of further employment of persons;

5) discrimination against persons living in rural areas;

6) doubts about the free training in relation to the person - the recipient of the voucher;

7) the possibility of recruiting freelance students for educational programs that were not popular before the introduction of voucher training.

The assessment provided shows that, unfortunately, the concept of lifelong learning has not yet found practical implementation. There are stereotypes in society, that it is too late to learn in "elegant" age. At the same time, the voucher program is a real tool of state policy in the labor market and educational services, which makes it possible to reduce educational inequality between generations. Among the recommended changes being discussed today is the expansion of the potential participants of the voucher program, for example, the inclusion in the voucher program of persons without vocational or higher education; expanding the list of professions and areas of training; as well as extending the voucher program to other areas.

Thus, the voucher program cannot be developed in the actual absence of vacancies and without guarantees of further employment of program users. Another important factor is the reduction of public funding for vouchers.

Based on the identified problems, we have made recommendations for improving the program: 


\section{ECONOMIC STRATEGIES FOR THE DEVELOPMENT OF SOCIETY}

1) a person may undergo training on a voucher only on condition of signing a contract with his future employer, where the latter will guarantee the recipient of the voucher further employment:

2) to remove professions, specialties and areas that are least in demand from the list of areas of training under the voucher system;

3) The State Employment Service must clearly determine the number of vouchers to be issued next year, as well as indicate the number of available vouchers for a particular area / specialty / profession;

4) subject to the previous paragraph, the selection of persons to whom a voucher may be provided must take place on a competitive basis;

5 ) increase the level of general awareness of the population about the existence of the voucher system through the use of social advertising.

It is of fundamental importance to sign an agreement that can guarantee further employment for the user of the program.

Today, the voucher program is unpopular and does not justify itself. However, in the current pandemic crisis, when a large number of skilled middle-aged workers return to Ukraine and face the problem of finding a job, such a system can significantly affect the labor market by filling relevant and in-demand niches and maintaining the competitiveness of people over 45 in the labor market.

Thus, building an effective mechanism for solving the problem of employment of the elderly will balance the labor market and the education market of Ukraine, as well as contribute to the formation of a rational approach to the use of labor resources in Ukraine, attracting "elegant" people. Often people of "elegant" age, disappointed in the offers of the labor market in Ukraine, choose to go abroad as an alternative to finding a job. Solving the problem of employment of the elderly will reduce the intensity of emigration flows and the outflow of Ukrainians abroad. Therefore, ensuring the optimization of the structure of labor and educational services in Ukraine is possible only on condition of overcoming the above challenges caused by the impact of the global pandemic. 
(1) UNDP will assist to improve the system of vouchers for free adult education (Electronic resource). - Access mode: https://naiu.org.ua/proon-dopomozhevdoskonalyty-systemu-vaucheriv-na-bezkoshtovne-navchannya-doroslyh/ 
ECONOMIC STRATEGIES FOR THE DEVELOPMENT OF SOCIETY

\section{SECTION 4. ECONOMICS AND MANAGEMENT OF THE} NATIONAL ECONOMY

\subsection{The impact of tourism development in the hotel business in the context of management}

As defined by the United Nations World Tourism Organization (UNWTO), international tourism includes the activities of persons who travel and stay outside their place of residence for a period not exceeding 12 months, for leisure, business and other goals. Based on this broad definition, the tourism industry includes all socio-economic activities that directly and / or indirectly participate in the provision of goods and services to tourists. The Standard International Classification of Tourism (SICTA) identifies 185 supply-related activities that have significant links to the tourism sector. These include services in various sectors, such as transport and communications, hotels and housing, food and beverages, cultural and entertainment services, banking and financial activities, advertising [48].

It should be noted that the hotel business is part of the tourism sector, which, in turn, is an important strategic sector of the economy (partly one of the most profitable, tourism revenues account for a significant share of GDP and exports [49]), which stimulates the development of elements infrastructure, causes an increase in the revenue side of the budget and has ample opportunities to attract foreign currency and various investments, contributes to the diversification of the economy as a result of the formation of the tourism industry serving the tourism sector.

Given the above, it is necessary to identify and justify the trends that generally characterize the current state of this area and have an impact on the economic development of the world in general and the hotel business in particular. Such trends include:

1. Unstable dynamics of increasing the number of tourists. Yes, according to table. 1 the total number of tourists increased during 2014-2019 by $27.26 \%$ (from 1147 to 1459.7 million people), but in the countries that are most popular for tourism, the number of tourists to Thailand increased the most (60.48\%), Mexico 53.58\%) and Italy 


\section{ECONOMIC STRATEGIES FOR THE DEVELOPMENT OF SOCIETY}

$(32.72 \%)$, to Ukraine - by $7.09 \%$.

Table 1. The number of tourists to the world and their growth rate

\begin{tabular}{|l|c|c|c|c|c|c|}
\hline \multirow{2}{*}{$\begin{array}{c}\text { TOP-10 most popular countries for } \\
\text { tourism / years }\end{array}$} & \multicolumn{6}{|c|}{ Number of tourists, million people } \\
\cline { 2 - 7 } & $\mathbf{2 0 1 4}$ & $\mathbf{2 0 1 5}$ & $\mathbf{2 0 1 6}$ & $\mathbf{2 0 1 7}$ & $\mathbf{2 0 1 8}$ & $\mathbf{2 0 1 9}$ \\
\hline Total & 1147,0 & 1202,4 & 1243,6 & 1333,0 & 1408,8 & 1459,7 \\
\hline Growth rates & $\mathrm{X}$ & 4,83 & 3,43 & 7,19 & 5,69 & 3,61 \\
\hline France & 83,7 & 84,5 & 82,7 & 86,9 & 89,4 & 90,2 \\
\hline Growth rates & $\mathrm{X}$ & 0,96 & $-2,13$ & 5,08 & 2,88 & 0,89 \\
\hline Spain & 64,9 & 68,2 & 75,3 & 81,9 & 82,8 & 83,7 \\
\hline Growth rates & $\mathrm{X}$ & 5,08 & 10,41 & 8,76 & 1,10 & 1,09 \\
\hline USA & 75,4 & 77,8 & 76,4 & 77,2 & 79,7 & 79,3 \\
\hline Growth rates & $\mathrm{X}$ & 3,18 & $-1,80$ & 1,05 & 3,24 & $-0,50$ \\
\hline China & 55,6 & 56,9 & 59,3 & 60,7 & 62,9 & 65,7 \\
\hline Growth rates & $\mathrm{X}$ & 2,34 & 4,22 & 2,36 & 3,62 & 4,45 \\
\hline Italy & 48,6 & 50,7 & 52,4 & 58,3 & 61,6 & 64,5 \\
\hline Growth rates & $\mathrm{X}$ & 4,32 & 3,35 & 11,26 & 5,66 & 4,71 \\
\hline Turkey & 39,8 & 39,5 & 30,3 & 37,6 & 45,8 & 51,2 \\
\hline Growth rates & $\mathrm{X}$ & $-0,75$ & $-23,29$ & 24,09 & 21,81 & 11,79 \\
\hline Mexico & 29,3 & 32,1 & 35,1 & 39,3 & 41,3 & 45 \\
\hline Growth rates & $\mathrm{X}$ & 9,56 & 9,35 & 11,97 & 5,09 & 8,96 \\
\hline Thailand & 24,8 & 29,9 & 32,5 & 35,6 & 38,2 & 39,8 \\
\hline Growth rates & $\mathrm{X}$ & 20,56 & 8,70 & 9,54 & 7,30 & 4,19 \\
\hline Germany & 33 & 35 & 35,6 & 37,5 & 38,9 & 39,6 \\
\hline Growth rates & $\mathrm{X}$ & 6,06 & 1,71 & 5,34 & 3,73 & 1,80 \\
\hline UK & 32,6 & 34,4 & 35,8 & 37,7 & 36,3 & 37,5 \\
\hline Growth rates & $\mathrm{X}$ & 5,52 & 4,07 & 5,31 & $-3,71$ & 3,31 \\
\hline Ukraine & 12,7 & 12,9 & 13,6 & 14,4 & 14,2 & 13,6 \\
\hline Growth rates & $\mathrm{X}$ & 1,57 & 5,43 & 5,88 & $-1,39$ & $-4,23$ \\
\hline Source Formenyyyyy
\end{tabular}

Source: Formed and determined on the basis of data [50-52].

2. Redistribution of income from international tourism. Yes, according to table. 2 total revenues from international tourism during 2014-2019 increased by $15.40 \%$ (from 1281.0 to 1478.3 billion US dollars), but in countries such as France, China, Germany and the United Kingdom there was a decrease in revenues from international tourism, which is especially noticeable in 2019 and indicates the redistribution of global cash flows from countries that have traditionally been in demand among tourists to less traditional tourist centers. Thus, during 2014-2019, Thailand's revenues from international tourism (73.85\% in 2019 compared to 2014 ) and Mexico (51.85\%) grew steadily, while the revenues of European countries, including Italy, although increased during this period (9.01\%), but in 2015 compared to 2014 there was a significant decrease, which amounted to $13.41 \%$. It should be noted that such dynamics of cash flows from the tourism business was typical for almost all 


\section{ECONOMIC STRATEGIES FOR THE DEVELOPMENT OF SOCIETY}

countries, the most popular among tourists.

Table 2. Revenues of the world from international tourism and their growth rates

\begin{tabular}{|l|c|c|c|c|c|c|}
\hline \multirow{2}{*}{$\begin{array}{c}\text { TOP-10 most popular countries } \\
\text { for tourism / years }\end{array}$} & \multicolumn{6}{|c|}{ Revenues from international tourism, billion dollars } \\
\cline { 2 - 7 } & $\mathbf{2 0 1 4}$ & $\mathbf{2 0 1 5}$ & $\mathbf{2 0 1 6}$ & $\mathbf{2 0 1 7}$ & $\mathbf{2 0 1 8}$ & $\mathbf{2 0 1 9}$ \\
\hline Total & 1281,0 & 1223,0 & 1249,8 & 1347,1 & 1457,4 & 1478,3 \\
\hline Growth rates & $\mathrm{X}$ & $-4,53$ & 2,19 & 7,79 & 8,19 & 1,43 \\
\hline France & 71,7 & 58,3 & 55,2 & 58,9 & 66,0 & 63,8 \\
\hline Growth rates & $\mathrm{X}$ & $-18,69$ & $-5,32$ & 6,70 & 12,05 & $-3,33$ \\
\hline Spain & 71,6 & 62,5 & 66,8 & 75,3 & 81,5 & 79,7 \\
\hline Growth rates & $\mathrm{X}$ & $-12,71$ & 6,88 & 12,72 & 8,23 & $-2,21$ \\
\hline USA & 191,9 & 206,9 & 206,7 & 210,7 & 214,7 & 214,1 \\
\hline Growth rates & $\mathrm{X}$ & 7,82 & $-0,10$ & 1,94 & 1,90 & $-0,28$ \\
\hline China & 44 & 45 & 44,4 & 38,6 & 40,4 & 35,8 \\
\hline Growth rates & $\mathrm{X}$ & 2,27 & $-1,33$ & $-13,06$ & 4,66 & $-11,39$ \\
\hline Italy & 45,5 & 39,4 & 40,2 & 44,2 & 49,3 & 49,6 \\
\hline Growth rates & $\mathrm{X}$ & $-13,41$ & 2,03 & 9,95 & 11,54 & 0,61 \\
\hline Turkey & 29,6 & 26,6 & 18,7 & 22,5 & 25,2 & 29,8 \\
\hline Growth rates & $\mathrm{X}$ & $-10,14$ & $-29,70$ & 20,32 & 12,00 & 18,25 \\
\hline Mexico & 16,2 & 17,7 & 19,6 & 21,3 & 22,5 & 24,6 \\
\hline Growth rates & $\mathrm{X}$ & 9,26 & 10,73 & 8,67 & 5,63 & 9,33 \\
\hline Thailand & 34,8 & 41,2 & 44,8 & 52,4 & 56,4 & 60,5 \\
\hline Growth rates & $\mathrm{X}$ & 18,39 & 8,74 & 16,96 & 7,63 & 7,27 \\
\hline Germany & 43,3 & 36,9 & 37,5 & 39,9 & 43 & 41,6 \\
\hline Growth rates & $\mathrm{X}$ & $-14,78$ & 1,63 & 6,40 & 7,77 & $-3,26$ \\
\hline UK & 51,5 & 50,8 & 47,9 & 47,5 & 48,6 & 50,4 \\
\hline Growth rates & $\mathrm{X}$ & $-1,36$ & $-5,71$ & $-0,84$ & 2,32 & 3,70 \\
\hline Ukraine & 1,6 & 1,1 & 1,1 & 1,3 & 1,4 & 1,6 \\
\hline Growth rates & $\mathrm{X}$ & $-31,25$ & 0,00 & 18,18 & 7,69 & 14,29 \\
\hline Sourc: Foryyyyyy \\
\hline
\end{tabular}

Source: Formed and determined on the basis of data [51,53].

At the same time, it should be noted that the generalized negative trends in general indicate the development of the tourism industry in the world as a whole and individual countries, the most popular among tourists. In particular, it is advisable to conduct an in-depth analysis, which would show the level of GDP in the world as a whole, and the most popular countries among tourists and the share of income from the tourism business. Thus, in general during 2014-2019 there was an unstable increase in GDP of the world, in particular, according to table. 3 , it increased by $9.70 \%$ during 2014-2019 (from 78944.5 to 86598.8 billion USD), but the GDP of countries such as France, Italy, Turkey, Mexico, Germany and the United Kingdom decreased. Thus, in France, GDP decreased by 5.24\% in 2019 compared to 2014, Italy - by $7.73 \%$, Turkey - by $20.38 \%$, Mexico - by $3.07 \%$, Germany - by 0.69 , Great Britain - by $9.64 \%$ 


\section{ECONOMIC STRATEGIES FOR THE DEVELOPMENT OF SOCIETY}

respectively.

However, only the US GDP grew steadily during 2014-2019 $(22.32 \%$ in 2019 compared to 2014). It should be noted that this situation indicates a slight dependence of GDP on the development of tourism and, as a result, an increase in the number of tourists and incomes of the world from international tourism.

Table 3. GDP of the world and its growth rate

\begin{tabular}{|l|c|c|c|c|c|c|}
\hline \multirow{2}{*}{$\begin{array}{c}\text { TOP-10 most popular } \\
\text { countries for tourism / } \\
\text { years }\end{array}$} & \multicolumn{4}{|c|}{ GDP of countries in current prices, billion dollars USA } \\
\cline { 2 - 7 } & $\mathbf{2 0 1 4}$ & $\mathbf{2 0 1 5}$ & $\mathbf{2 0 1 6}$ & $\mathbf{2 0 1 7}$ & $\mathbf{2 0 1 8}$ & $\mathbf{2 0 1 9}$ \\
\hline Total & 78944,5 & 74779,48 & 75823,65 & 80262,2 & 84929,51 & 86598,8 \\
\hline Growth rates & $\mathrm{X}$ & $-5,28$ & 1,40 & 5,85 & 5,82 & 1,97 \\
\hline France & 2856,7 & 2439,44 & 2472,28 & 2591,78 & 2780,15 & 2707,07 \\
\hline Growth rates & $\mathrm{X}$ & $-14,61$ & 1,35 & 4,83 & 7,27 & $-2,63$ \\
\hline Spain & 1379,1 & 1199,69 & 1238 & 1317,1 & 1427,53 & 1397,87 \\
\hline Growth rates & $\mathrm{X}$ & $-13,01$ & 3,19 & 6,39 & 8,38 & $-2,08$ \\
\hline USA & 17527,3 & 18224,78 & 18715,05 & 19519,4 & 20580,25 & 21439,5 \\
\hline Growth rates & $\mathrm{X}$ & 3,98 & 2,69 & 4,30 & 5,43 & 4,17 \\
\hline China & 10534,5 & 11226,19 & 11221,84 & 12062,3 & 13368,07 & 14140,2 \\
\hline Growth rates & $\mathrm{X}$ & 6,57 & $-0,04$ & 7,49 & 10,83 & 5,78 \\
\hline Italy & 2155,15 & 1833,2 & 1869,95 & 1950,7 & 2075,86 & 1988,64 \\
\hline Growth rates & $\mathrm{X}$ & $-14,94$ & 2,00 & 4,32 & 6,42 & $-4,20$ \\
\hline Turkey & 934,08 & 859,45 & 863,39 & 852,65 & 771,27 & 743,71 \\
\hline Growth rates & $\mathrm{X}$ & $-7,99$ & 0,46 & $-1,24$ & $-9,54$ & $-3,57$ \\
\hline Mexico & 1314,57 & 1170,57 & 1077,91 & 1156,95 & 1222,05 & 1274,18 \\
\hline Growth rates & $\mathrm{X}$ & $-10,95$ & $-7,92$ & 7,33 & 5,63 & 4,27 \\
\hline Thailand & 407,34 & 401,27 & 412,41 & 455,32 & 504,93 & 529,18 \\
\hline Growth rates & $\mathrm{X}$ & $-1,49$ & 2,78 & 10,40 & 10,90 & 4,80 \\
\hline Germany & 3890,1 & 3362,24 & 3468,19 & 3664,51 & 3951,34 & 3863,34 \\
\hline Growth rates & $\mathrm{X}$ & $-13,57$ & 3,15 & 5,66 & 7,83 & $-2,23$ \\
\hline UK & 3036,31 & 2897,06 & 2669,11 & 2640,07 & 2828,83 & 2743,59 \\
\hline Growth rates & $\mathrm{X}$ & $-4,59$ & $-7,87$ & $-1,09$ & 7,15 & $-3,01$ \\
\hline Ukraine & 130,57 & 90,49 & 93,31 & 112,13 & 130,86 & 150,4 \\
\hline Growth rates & $\mathrm{X}$ & $-30,70$ & 3,12 & 20,17 & 16,70 & 14,93 \\
\hline Source: Formyyyyyy
\end{tabular}

Source: Formed and determined on the basis of data [51,54-55].

According to the analysis of the data in table. 1-3, it is considered appropriate to supplement the study by determining the share of revenues from international tourism in GDP in general and the world's most popular countries among tourists. 
Table 4.

The share of revenues from international tourism in the GDP of the world

\begin{tabular}{|l|c|c|c|c|c|c|}
\hline \multirow{2}{*}{$\begin{array}{l}\text { TOP-10 most popular countries } \\
\text { for tourism / years }\end{array}$} & \multicolumn{6}{|c|}{ Share of revenues from international tourism in GDP,\% } \\
\cline { 2 - 7 } & $\mathbf{2 0 1 4}$ & $\mathbf{2 0 1 5}$ & $\mathbf{2 0 1 6}$ & $\mathbf{2 0 1 7}$ & $\mathbf{2 0 1 8}$ & $\mathbf{2 0 1 9}$ \\
\hline Total & 1,62 & 1,64 & 1,65 & 1,68 & 1,72 & 1,71 \\
\hline France & 2,51 & 2,39 & 2,23 & 2,27 & 2,37 & 2,36 \\
\hline Spain & 5,19 & 5,21 & 5,40 & 5,72 & 5,71 & 5,70 \\
\hline USA & 1,09 & 1,14 & 1,10 & 1,08 & 1,04 & 1,00 \\
\hline China & 0,42 & 0,40 & 0,40 & 0,32 & 0,30 & 0,25 \\
\hline Italy & 2,11 & 2,15 & 2,15 & 2,27 & 2,37 & 2,49 \\
\hline Turkey & 3,17 & 3,10 & 2,17 & 2,64 & 3,27 & 4,01 \\
\hline Mexico & 1,23 & 1,51 & 1,82 & 1,84 & 1,84 & 1,93 \\
\hline Thailand & 8,54 & 10,27 & 10,86 & 11,51 & 11,17 & 11,43 \\
\hline Germany & 1,11 & 1,10 & 1,08 & 1,09 & 1,09 & 1,08 \\
\hline UK & 1,70 & 1,75 & 1,79 & 1,80 & 1,72 & 1,84 \\
\hline Ukraine & 1,23 & 1,22 & 1,18 & 1,16 & 1,07 & 1,06 \\
\hline SOunyyyyyy
\end{tabular}

Source: Formed and determined on the basis of data [51,53-55].

In general, the decrease in the share of revenues from international tourism in GDP according to table. 4 (which is observed during 2014-2019 in almost all countries, despite its unstable increase over the years, and in general in the world and especially noticeable in 2019) could be considered a relatively positive trend, as it could lead to other things being equal to increase the competitiveness of world economies and stimulate the development of infrastructure of countries and in general, in the long run - to increase the level of development of their economies through the accumulation of efforts and redirection of funds for the development and preservation of tourist centers. However, in the current conditions of the world economy, this has a negative impact on the development of tourism in the world as a whole and countries in particular, the most popular among tourists.

And due to the spread of coronavirus (COVID-19), which has spread to almost all countries, according to forecasts [56], the demand for travel in 2020 will decline by $5 \%$ in North America, 10\% in Europe and 25\% - in the rest of the world. The losses for the economies of the world in general and those that are most popular among tourists should be quite significant, because this industry provided 300 million jobs in 2018 alone in 2018, and due to the coronavirus pandemic losses could reach 50. According to the World business travel association global tourism sector could lose up 


\section{ECONOMIC STRATEGIES FOR THE DEVELOPMENT OF SOCIETY}

to $\$ 820$ billion USA on canceled business trips, conferences and exhibitions. Such cancellations of trips lead to the loss of all elements of the tourist infrastructure, in particular such as transport carriers, representatives of the hotel business, retail chain, etc. And given their significant interconnectedness and interdependence in the field of tourism, it should be noted that the hotel business, not being able to recoup its losses from the reduction in the number of foreign tourists at the expense of domestic bears significant losses. Thus, it should be noted that in modern conditions, the hotel business is going through difficult times; problems that arise in its operation, due, on the one hand, the crisis in the world, and, consequently, the reduction of the solvency of the population; on the other hand, the intensive development of information technologies and, as a result, the reduction of consumers' dependence on hotel services, for which a significant motivating factor is the increase in the pandemic caused by coronavirus infection. In general, it should be noted that this situation in the tourism sector leads to a widening gap in the development of world economies and certain sectors directly related to the functioning of the tourism sector, in particular the hotel business, which largely due to investments aimed at improving hotel services or expanding hotel activities.

The main factors leading to the modernization of hotels, expanding supply and improving the level of services are: high competition, increasing consumer needs, the need to attract more guests. Given the general conditions of the hotel industry, location and brand of the hotel should be considered important factors among economic factors. The most important factors that determine the development of the hotel business are: climatic and geographical location of the state; economic and political situation in the country; attractiveness of the state and its regions; the state of the security environment and the development of communications; richness of culture, integrity of tourists; state of development of domestic and international tourist transportation; needs of the hotel business, given the demand for hotel services. Recent trends in the tourism business require the creation of an attractive, innovative and large-scale hotel product that would be available to a wide range of consumers [57]. 


\section{ECONOMIC STRATEGIES FOR THE DEVELOPMENT OF SOCIETY}

Improving the efficiency of the hotel industry requires significant changes in the concept of hotel business management, in particular in the context of increasing investment in this area in the main areas of investment. Such areas include: investing in the construction of new and purchase of already built hotels, reconstruction of hotels; investing in the purchase of hotel rooms and apartments; investing in hotel management, modern technology, staff training, etc.; purchase of a well-known brand (franchise) [57].

However, despite the trends outlined above that affect the economic development of the world in general and the hotel business in particular, in the countries surveyed there is a wide range of opportunities for sustainable international tourism business, which requires clearly defined long-term strategies. as well as agreed plans and programs at the national level for the short term perspectives that would be accompanied by the process of creating a favorable environment for cooperation at the regional level and at the level of international cooperation [48], which would result in an increase in the level of development of world tourism and would have a positive impact on the development of the hotel business. 


\section{ECONOMIC STRATEGIES FOR THE DEVELOPMENT OF SOCIETY}

\subsection{Hotel business management in modern business conditions}

In modern economic conditions, tourism occupies a leading position in the economies of developed countries. It is a significant sector of the economy and one of the most important sectors of the world economy, and in part the budget-generating of some countries - tourist centers. At the same time, the hotel business is a major component of the tourism industry, as the state of development affects the development of the tourism industry and affects other key segments of the economy. Thus, it should be noted that there is a directly proportional relationship between the state of development of the tourism sector and the hotel business.

In general, it should be noted that the hotel business is one of the important factors influencing the development of the tourism industry and certain elements of the economy, such as construction, transport, trade, industry, etc., as well as the main component of tourism in terms of resources - material, labor, financial, etc. [58].

Tourism is an important strategic sector of the economy, in part one of the most profitable, tourism revenues account for a significant share of GDP and exports [59]. In developed countries, the share of revenues from foreign tourism in total revenues from exports of goods and services is $60 \%$ in Spain, $40 \%$ in Austria, 36\% in Greece, $12 \%$ in Switzerland, $11 \%$ in Italy, $21 \%$ in Portugal. In developing countries, foreign tourism accounts for 10-15\% of revenues from exports of goods and services (India, Egypt, Paraguay). In some countries, popular among tourists from around the world, this figure is much higher, in particular Colombia - 20\%, Jamaica - 30\%, Cyprus - 52\%, Panama - 55\%, Haiti - 73\% [60].

In general, it should be noted that the growth of revenues from foreign tourism contributes to the growth of the number of hotel farms and revenues from the provision of hotel services.

Thus, in recent years, on average, the world hotel fund has increased by 3-5\% per year, developed countries such as Spain, Greece, France received from the services of the hospitality industry received $70 \%$ of gross national income and provided $75 \%$ of employment [61].

According to the United Nations World Tourism Organization (UNWTO): in 


\section{ECONOMIC STRATEGIES FOR THE DEVELOPMENT OF SOCIETY}

2020 the number of tourists will be reduced by almost a third compared to 2019, which could lead to a reduction of 50 million jobs and as a result will negatively affect the hotel business. This trend is also for Ukraine, in particular in the field of hospitality. Despite the fact that the hotel business has a fairly high profitability - 40-60\% with a significant payback period - 7-15 years, the biggest losses are 5-star facilities (3-8 million UAH), including hotels, which "worked on business travel", as well as located in small towns and regional centers" outside the flow of business traffic", as an exception - the suburban format of hotels, in particular" cottage locations" [62].

However, with the growing pandemic caused by coronavirus infection (COVID19) there is an increasing impact of negative trends (the effect of which can be compared with the effect of "avalanche") on the development of tourism in general and all elements of tourism infrastructure, including hotel business. Is largely due to the fact that hotels perform one of the most important functions in the field of tourist services (providing them with modern housing and household services), and the cost of hotel services for tourists is estimated at $30 \%-50 \%$ of all their costs. Taking into account the above, the expediency of conducting a study to improve the efficiency of hotel business management with the use of adequate modern management models and appropriate adjustment of corporate governance strategies of hotel corporations.

Hotel corporations in modern economic conditions include joint hotel enterprises formed on the basis of joint capital of owners of different states; ownership by a national company of a controlling stake in a foreign hotel corporation; merger of hotel enterprises of several states; mergers of hotel enterprises of several states as a result of an exchange of shares or joint creation of a company in the form of a holding company). Such associations are carried out in order to reduce production costs as a result of joint activities, gain new opportunities for hospitality services, increase the importance of marketing and create a flexible pricing policy, mastering new markets, reducing risk when creating new production facilities, avoiding seasonality in operation [58].

In today's world there are three models of hotel business:

- Ritz model - their feature is the observance of European traditions of sophistication and aristocracy; however, it should be noted that this model is currently 


\section{ECONOMIC STRATEGIES FOR THE DEVELOPMENT OF SOCIETY}

in crisis;

- Holiday Inn hotel chain - significant flexibility in meeting customer needs combined with high standards of service. Its features are: unity of style (architecture, interior); symbols and external information; spacious and functional hall; speed of customer registration; numbers provided for regular customers; buffet breakfast; availability of a conference hall; flexible tariff system; unified management, marketing and communication service. More than $50 \%$ of hotel rooms in the world are controlled by hotel chains built on this model;

- "Independent" hotel chains, such as Best Western - a single brand combines hotels on the basis of uniform characteristics that meet certain standards and sets of services, regardless of location. Hotels-members of the chain pay contributions to a single fund, which is spent on joint advertising and marketing activities, product promotion, while fully preserving their financial, economic and managerial independence [63].

Quite often in modern conditions there is a combination of the second model with the third, an example of which is the Accor hotel chain, which offers hotels of different classes and acts under different brands - Pulman, Sofitel, Novotel (high class hotels), Mercure (medium), and Ibis, Etap , Formule 1, Motel 6 (economy class hotels respectively) [63].

According to the classification of the International Hotel Association, hotel chains are conventionally divided into the following categories: corporate chains - hotel corporations that own numerous enterprises; chains of independent companies that unite to use the overall reservation system, the concept of marketing, advertising and other services expensive for a particular company; chains providing management services.

The main advantages of hotel chains, which ensure the rapid development and success of network companies in the hotel business include the following:

- a single booking system for all companies in the hotel chain;

- a single brand, which in the form of a guarantee of the quality of hotel services, avoids high costs for the development and promotion of a new network brand and 


\section{ECONOMIC STRATEGIES FOR THE DEVELOPMENT OF SOCIETY}

without much effort to attract and retain customers;

- standardization of the hotel product, which by unifying management systems and training, provides better workload, increases the range of additional services, increases the efficiency and profitability of network members;

- cost savings compared to independent hotels for the purchase of materials, engineering, decorator services, marketing research and advertising of hotel services [63].

According to research, when hotels are grouped together, the profitability of one room is 7 times higher than in independent hotels. The main reasons for the success of hotel chains are: consistency of product quality, identity of services at different enterprises, as well as affordability [63].

In terms of investing in the hotel business, given that effective hotel management requires specific knowledge, as well as because the operational performance of the hotel depends on many factors that are difficult to predict, the expected return on the hotel is always $1-1,5 \%$ higher than from the best office or shopping centers "[61].

Currently in the global market of hotel services, the most popular advanced professional developments in automated control systems (ACS) are Fidelio, Libra Hospitality, Lodging Touch. They are installed in more than 120 countries and in the 90 largest international networks, covering 27,500 hotels.

The universal program is offered by the corporation "Micros-Fidelio". MicrosFidelio systems are used in the enterprises of more than 100 largest international hotel chains, including Sheraton, Radisson, Hilton, Marriott, Kempinski, Hyatt, etc. In hotels, it is important to use the capabilities of international computer systems for booking tour services - GDS (Global Distribution Systems): "Amadeus", "Galileo", "Saber" and "Worldspan" - all of these systems solve one problem - provide the consumer with the necessary information about the tourism product and represent a convenient ordering mechanism [64].

The main approaches to the organization of hotel business management include:

- procedural (management is considered as a continuous process of interrelated management functions); 


\section{ECONOMIC STRATEGIES FOR THE DEVELOPMENT OF SOCIETY}

- system (hotel business is considered as a combination of interconnected elements - resources of different types, structural units, management technologies, etc., focused on achieving various goals in the environment);

- situational (is the use of different management methods depending on the circumstances that are formed in the changing environment of hospitality, which is constantly under the influence of internal and external factors).

The most common forms of hotel business management in international practice include the following: contract management; management through a franchise agreement; rent. Other organizational forms of management are quite common: jointstock companies, joint ventures, syndicates, consortia, etc., which differ in content and proportions of functions, structure and degree of centralization of management.

It should be noted that the international recognition and widespread hotel chains are obliged to franchise [65].

In the United States, the hospitality industry is the most developed in terms of franchising, in particular, there is a large hotel corporation "Hospitality Franchising System", which does not have its own hotels, but combines them under a franchise system. The reasons for the success of franchising abroad are the real estate crisis, lack of qualified personnel, expanding the sphere of influence of powerful hotel corporations. At the same time in Europe, in contrast to the United States, the practice of signing contracts for the management of hotel enterprises has been widely successful. The main disadvantage of this type of contract is the transfer to the owner of all costs and risks associated with commercial activities.

In modern conditions (increasing the coronavirus pandemic) for Ukraine to preserve the hotel business and its development is appropriate to use a management model based on a combination of the second and third models of hotel business using a management system based on franchising (despite obvious shortcomings such as: the need for payments to the franchisor, the need to comply with the standards set by the franchisor, the possibility of acquiring a negative image in the case unsatisfactory performance of the franchisor) and a systematic approach. According to research, the closure of franchisees in the first five years of their operation was $4 \%$, among members 
ECONOMIC STRATEGIES FOR THE DEVELOPMENT OF SOCIETY

of the International Organization of Franchise Organizations the number of bankruptcies is less than $1 \%[66]$.

The implementation of this will generally contribute to the implementation of basic management tasks in the hotel business (because the form of hotel management through a franchise agreement is one of the most promising), among which the main are [67]: obtaining reliable management information about the entire hotel complex and each unit; business process optimization; improving the effectiveness of control over the activities of hotel services and staff; optimization of operating costs.

In general, the implementation of this in the context of increasing the pandemic caused by coronavirus infection (COVID-19) by combining the second and third models of hotel business using a management system based on franchising and a systematic approach to hotel management will improve the efficiency of both the hotel and tourism in general and will have a positive impact on the economic development of the state. 


\section{ECONOMIC STRATEGIES FOR THE DEVELOPMENT OF SOCIETY SECTION 5. ECONOMICS OF INDUSTRIES}

\subsection{Sustainable development of industrial enterprises in the conditions of state- private partnership}

Growth of deformation processes in the industrial development of Ukraine negatively affects the economic security of the country and indicates the absence of effective mechanism of the state administration of the industrial potential development aimed to overcome threatening tendencies, both in branch and spatial aspects. The development of the industrial potential anticipates a transition from one condition to another, at the same time previous achievements must be preserved and conditions for future changes must be created. Intensification of the industry growth is impossible without activation of the components of its industrial potential, formation of its balanced structure taking into account the basic provisions of the sustainable development concept. Defining the level of the identified progress trends of separate constituents of the potential allows to mobilize efforts, define reserve stock, set more precisely the planned indexes of the industry development, types of activity, enterprises, etc. It is structuring that allows to shift from a general theoretic area to more applied researches.

Due to the thorough study of scientific works, it is found out that approaches to evaluate innovative, social, and ecological components of the industrial potential are widely examined in modern literature. So, Bogers M. and West J. developed an approach to evaluate the industrial potential based on determination of efficiency of open innovations [68]. Kao Y.-S.; Nawata K.; Huang C.-Y. proposed the scheme of evaluation of system functions on the basis of the technological innovative system and conducted a relevant modelling to establish factor connections from the position of functional approach for providing steadiness in the processing industry [69]. The use of socio-environmental management in small industries will promote the realization of basic principles of corporate social responsibility in the country [70]. Methodological approach aimed at evaluation of social responsibility model for sustainable company growth is disclosed in work [71]. The evaluation of social component of the industrial 


\section{ECONOMIC STRATEGIES FOR THE DEVELOPMENT OF SOCIETY}

potential is carried out by the selection of indicators, that specify the attractiveness of labor, scale of labor resources involvement, and efficiency of their use [72]. To identify cause and effect relations between the components of the industrial potential, as well as to distinguish external influence factors on the industrial, means of econometric modelling are widely used. In the work [73] it is proved by the construction of nonlinear ARDL model, that the economy growth stimulates the economy to increase energy efficiency and to transfer industrial sector on energy-saving technologies. Lee, H.S.; Choi, Y found out by examining industrial enterprises of South Korea that innovative effect leads to the ecological productivity growth of the industry [74], that points out to interrelation between innovative and ecological components of the industrial potential. To evaluate efficiency of the innovative development from the position of ecologically directed management, it is suggested in works $[75,76]$. Bezhentseva T.V., Aleksandrova N.N., Matyus E.G. developed the system of indexes of the evaluation of industrial enterprises activity taking into account the environment factors [77].

Based on the generalization of the above scientific works, as well as taking into account modern strategic directions of economic development of the state, we propose to identify socio-labor, production and economic, financial and investment, innovation and ecological components of industrial potential. However, a component structure of the industrial potential cannot be of a permanent value, as existing elements can be complemented by new ones. Such dynamics is predefined by the change of the economic development types, appearance of new unconventional factors of production, instability of the environment, market condition, etc. As a result, there are structural changes that come forward as factors of the industrial potential development.

The methodological approach, suggested to conduct compound economic evaluation of the state and level of the industrial potential development, is based on the selection of input and output indicators in the context of its constituents. On the whole, input indicators characterize the scale of resources allocation and their capacity for renewal. Output indicators are formed taking into account the effectiveness and efficiency indexes of the resources usage. On the basis of distinguishing of input and 


\section{ECONOMIC STRATEGIES FOR THE DEVELOPMENT OF SOCIETY}

output indicators, we suggest to differentiate the level of the reproductive potential development (available possibility) and the level of the achieved potential development (used possibility), the balanced cooperation of which is the basis of the industrial potential development that should be taken into consideration while developing conceptual bases of the state administration.

The process of management of the balanced development of the industrial potential is an open system, on the input of which we have resources grouped by their functional application, and on the output - the results obtained from their use. Integrated combination of the resource-functional and efficient approaches for industrial potential study gives an opportunity to balance its growth in branch and spatial aspects, to correlate its inner-structure contents taking into account economic viability of resources usage.

In the context of state administration, the balanced development of the industrial potential must be regarded as an integral combination of reproductive ability of its interconnected components that provide the processes of formation and capacity building of the potential, their changes cause growth and economic effect, obtained from the use, that proves the expediency of involving certain type of resources in the process of industrial production.

The primary objective of the concept implementation is to achieve a high level of the industrial potential development both on the input (stage of formation) and on the output (stage of the implementation), as the availability of misbalances proves the problems emerging, irrational use of the available potential can cause structural crises. The achievement of the set goal requires creation of a favorable macro environment for the balanced development of the industrial potential.

Macro environment is characterized by considerable changeability and causes changes in the scale of the industrial potential by input and output indicators. Herewith, components of the industrial potential are dependent variables from the influence factors, which are grouped according to the nature of changes caused by them. Under these conditions, the industrial potential development is the result of a general 


\section{ECONOMIC STRATEGIES FOR THE DEVELOPMENT OF SOCIETY}

influence from integration of institutionally-legal, economic, sociocultural, geopolitical, scientifically-technological, natural and ecological environments.

In general, the goal of state management should be to achieve strategic guidelines for sustainable industrial development.

The main results of conducting state administration of the balanced development of the industrial potential must be:

- improvement of branch structure of the national industry and creation of effective component-by-component structure of the industrial potential towards the development of priority types of industrial activity and increase of its competitiveness at the international market;

- prevention of emerging of crisis phenomena in the industrial sector of the economy due to conducting complex evaluation of the development level of both reproductive and achieved potentials of separate types of industrial activity;

- optimization of actions of government bodies that directly influence the creation of favourable macro environment for sustainable industrial growth and minimization of negative influence of factors-destimulators.

Improvement of state administration of the industrial potential development must be directed towards the achievement of greater flexibility and dynamics, possibility of instant reacting to the necessities of the market and working out of relevant measures capable to stimulate the development of the industrial sector of the economy in a selected direction 
ECONOMIC STRATEGIES FOR THE DEVELOPMENT OF SOCIETY

\subsection{Main areas, legislative and regulatory control of activity of non-budgetary non-profit organizations in Ukraine}

Rapid development of non-government organizations in Ukraine in recent years bears evidence of further democratization of society as well as the country's intention to continue European integration. However, the level of their control is still far behind the global standards.

Our previous studies [78] have shown the following development trends of nonbudgetary, non-profit organizations in Ukraine: a great variety of areas of activity and forms of business organization; gradual improvement of partnership relationship of between non-budgetary non-profit organizations with the state and commercial sector of economic activity; the extension of influence of NNOs on the national economy development.

By some estimates, nowadays there are more than 10 million non-budgetary nonprofit organizations throughout the world. John Hopkins University research demonstrates that one tenth of able-bodied population of the USA is employed in such organizations. Australia has a similar statistics. In India, there is one non-government organization for every 400 people.

According to the research [79], the factors of unprecedented growth of nongovernmental organizations throughout the world are the following:

- democratization and development of civil society;

- growth in demand for true information and services of its processing;

- growth in the number of state-owned, privately-owned and intergovernmental institutions;

- improvement of communication technologies;

- globalization of funding sources of non-governmental organizations;

- underperformance of public sector.

In 2000 , this led to the establishment of the international organization for the promotion of peace and global welfare, and it united non-governmental organizations throughout the world. And it was the World Association of Non-Governmental Organizations, WANGO. 


\section{ECONOMIC STRATEGIES FOR THE DEVELOPMENT OF SOCIETY}

According to World Bank methodology [80], non-governmental organizations are divided into two categories:

- operational NGOs - intended to achieve specific development purposes through the implementation of certain projects on poverty reduction, improvement of healthcare services and education, etc. An example: International Medical Corps, which provides emergency medical services in the regions affected by natural disasters or humanitarian crises;

- advocacy NGOs - created for the implementation of specific cases of informational nature. As opposed to operational non-governmental organizations, they, above all, try to raise the level of awareness among the broad public regarding observance of human rights, environmental protection or social justice, using lobbying methods, cooperation with press and events aimed at the acquisition of activists. An example of such a type of organization is Greenpeace.

Meanwhile, a lot of non-governmental organizations may have the features of both categories.

Other classification features of non-governmental organizations generally accepted in the international practices are the following:

1) level of activity:

- community-based organizations - emerge upon the initiative of some individuals of a certain community;

- city-wide organizations - include a variety of organizations, such as associations of non-governmental organizations; organizations set up by ethnic communities; associations for the protection of business interests, etc;

- regional organizations - organizations, associations and groups at the level of large territorial entities;

- national organizations - operate within the territory of a certain country. Many of them have regional and city branches promoting the implementation of local projects;

- international organizations - include a variety of organizations - from charity funds to religious organizations, operating in different countries. They may be 


\section{ECONOMIC STRATEGIES FOR THE DEVELOPMENT OF SOCIETY}

responsible for financial backing of local organizations, institutions and projects;

2) activity orientation:

- charity - organizations the activity of which is designed to satisfy the needs of individuals and disadvantaged social groups;

- service - organizations implementing projects in service sector, basically medical and educational ones;

- participation - organizations implementing self-help projects with local contribution in the form of monetary resources, materials and labour power, etc.;

- improvement - organizations that raise awareness of people about social, political, economic factors that affect their lives.

Non-budgetary non-profit organizations (hereinafter - NNOs) in the world practice may exist in the following forms of business entities: non-corporate (e.g., clubs) and voluntary associations; trusts, charitable organizations and funds; non-profit companies; other registered non-budgetary non-profit organizations.

The exhaustive list of non-budgetary non-profit organizations in Ukraine is established by the Tax Code and the Procedure for maintaining the Register of nonprofit institutions and organizations, inclusion of non-profit enterprises, institutions and organizations in the Register and exclusion from the Register. Such organizations include (Table 1):

Table 1

Types of non-budgetary non-profit organizations in Ukraine*

\begin{tabular}{|l|l|}
\hline \multicolumn{1}{|c|}{$\begin{array}{c}\text { Indication of } \\
\text { unprofitability }\end{array}$} & \multicolumn{1}{c|}{ Type of non-profit organization } \\
\hline 032 & Public associations \\
\hline 033 & Political parties \\
\hline 034 & Creative unions \\
\hline 035 & Religious organizations \\
\hline 036 & Charitable organizations \\
\hline 037 & Pension funds \\
\hline 038 & Unions \\
\hline 039 & Associations and other organizations of legal entities \\
\hline 040 & Housing cooperatives \\
\hline 041 & Suburban (suburban construction) cooperatives \\
\hline 042 & Horticultural and garage (garage building) cooperatives (societies) \\
\hline 043 & $\begin{array}{l}\text { Apartment house co-owners association, association of owners of residential } \\
\text { buildings }\end{array}$ \\
\hline 044 & Labour unions, their associations and labour union organizations \\
\hline
\end{tabular}


ECONOMIC STRATEGIES FOR THE DEVELOPMENT OF SOCIETY

\begin{tabular}{|l|l|}
\hline 045 & Employers' organizations and their associations \\
\hline 046 & Agricultural service cooperatives \\
\hline 047 & Cooperative associations of agricultural service cooperatives \\
\hline 048 & $\begin{array}{l}\text { Other legal entities, whose activities meet the requirements of non-profitability } \\
\text { established by the Tax Code of Ukraine }\end{array}$ \\
\hline
\end{tabular}

* the list is given according to the Tax code of Ukraine

In the international practices of statistics [81] there are 12 areas in which nonbudgetary non-profit organizations can operate: 1. Culture and recreation. 2. Education and research. 3. Healthcare. 4. Social services. 5. Environmental protection. 6. Development and daily life. 7. Law, protection and politics. 8. Philanthropy and charity promotion. 9. International activities. 10. Religion. 11. Business and labour associations, unions. 12. Other.

Each group may have its own subcategories. For example, for NNOs operating in the field of health care they are the following: outpatient medical services; rehabilitation; medical research and training; preventive care; ancillary and other services.

All NNOs have restrictions on certain activities, which apply to all legal entities; all non-profit organizations; certain types of non-profit organizations (for example, political parties do not have the right to organize paramilitary units).

In Ukraine, an organization may be granted the status of unprofitable if it fulfills all the following four conditions (Pic. 1):

Consequently, non-budgetary non-profit organization is a legal entity independent of commercial enterprises, individuals, and state administration bodies, established to improve the welfare of citizens, characterized by the prohibition on economic benefit for those individuals who control it as well as by the lack of stock capital. The NNO is managed by a group of its employees or an executive committee. 


\section{ECONOMIC STRATEGIES FOR THE DEVELOPMENT OF SOCIETY}

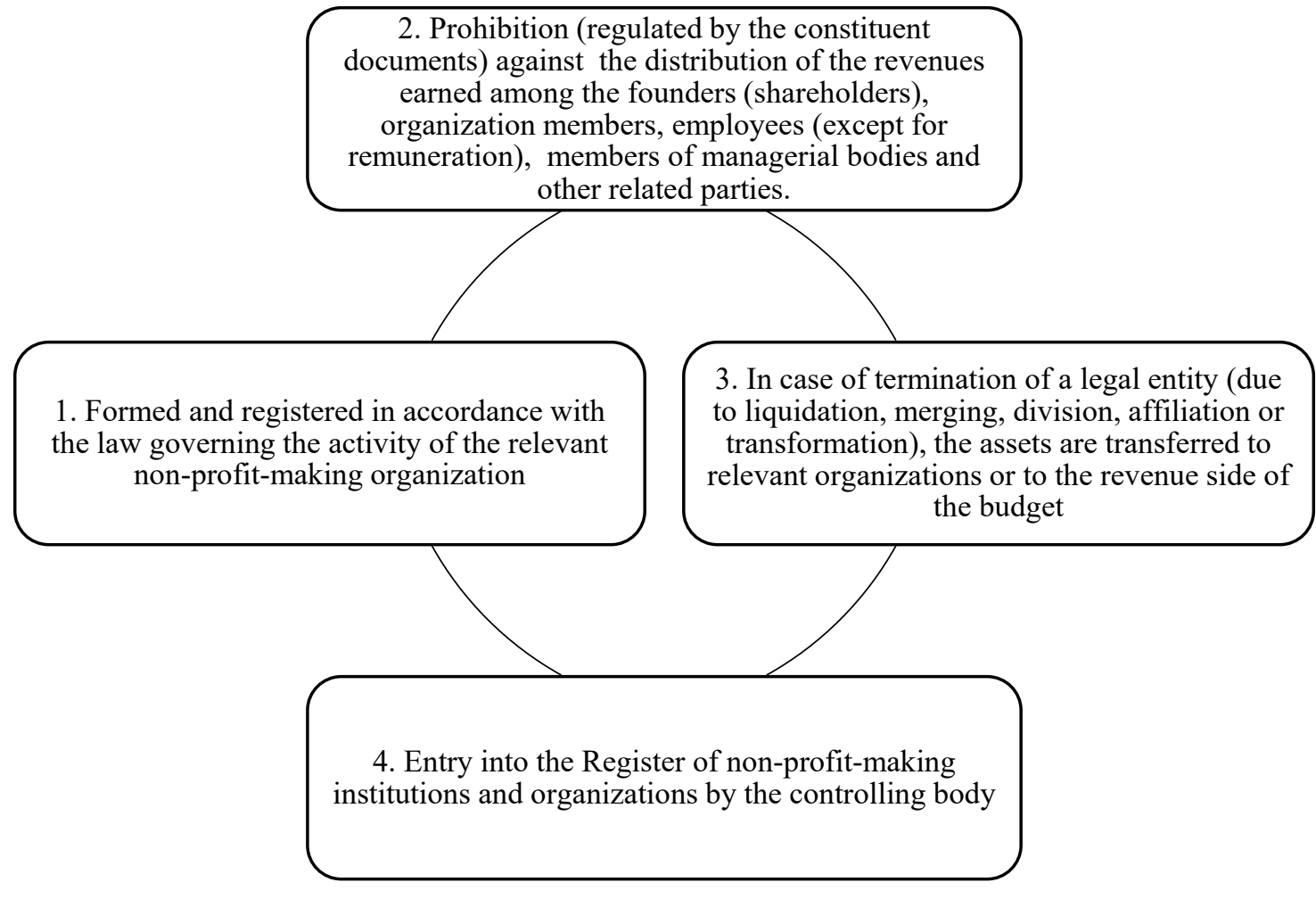

Picture 1. Requirements for non-budgetary non-profit organization*

*author's generalization

Legislative and regulatory control of activity of non-budgetary non-profit organizations may be implemented using one of the following two models:

1) application of one or several basic laws (for instance, in the USA it is the Uniform Unincorporated Nonprofit Association Act, adopted in1996);

2) application of laws (standards, rules), which separately regulate the activities of each type of non-profit non-budgetary organizations (Table 2).

Table 2

Defining the types of non-budgetary non-profit organizations in Ukraine*

\begin{tabular}{|l|l|l|}
\hline \multicolumn{1}{|c|}{ Type of NNO } & \multicolumn{1}{|c|}{ Basic law } & \multicolumn{1}{c|}{ Definition } \\
\hline $\begin{array}{l}\text { Public } \\
\text { association }\end{array}$ & $\begin{array}{l}\text { Law of Ukraine "On } \\
\text { Public Associations" }\end{array}$ & $\begin{array}{l}\text { Voluntary association of individuals and/or legal entities } \\
\text { under private law for the exercise and protection of rights and } \\
\text { freedoms, satisfaction of social, in particular economic, } \\
\text { social, cultural, ecological and other mutual interests. It may } \\
\text { exist in two forms of business entity: public organization } \\
\text { founders and members are individuals) and public union } \\
\text { (founders are legal entities, and members can be both legal } \\
\text { entities and individuals) }\end{array}$ \\
\hline Political party & $\begin{array}{l}\text { Law of Ukraine "On } \\
\text { Political Parties in } \\
\text { inraine" }\end{array}$ & $\begin{array}{l}\text { A legally registered voluntary association of the citizens, that } \\
\text { supports certain national social development program and } \\
\text { seeks to contribute to the formation and expression of the } \\
\text { political will of the citizens, as well as participates in elections } \\
\text { and other political actions }\end{array}$ \\
\hline Creative union & Law of Ukraine "On & A creative union is a voluntary association of professional \\
\hline
\end{tabular}




\section{ECONOMIC STRATEGIES FOR THE DEVELOPMENT OF SOCIETY}

\begin{tabular}{|c|c|c|}
\hline & $\begin{array}{l}\text { Professional Creative } \\
\text { Workers and Creative } \\
\text { Unions" }\end{array}$ & $\begin{array}{l}\text { creative workers of relevant professional direction in the field } \\
\text { of culture and arts with registered membership and acting } \\
\text { upon its statute }\end{array}$ \\
\hline $\begin{array}{l}\text { Religious } \\
\text { organization }\end{array}$ & $\begin{array}{l}\text { Law of Ukraine "On } \\
\text { Freedom of Conscience } \\
\text { andrans } \\
\text { Organizations" }\end{array}$ & $\begin{array}{l}\text { Religious organization is a religious community, an } \\
\text { administration and centre, a monastery, a congregation, a } \\
\text { missionary society (mission), a theological educational } \\
\text { institution as well as the unions of the above mentioned } \\
\text { religious organizations created with the purpose of } \\
\text { satisfaction of citizens' religious needs to profess and spread } \\
\text { their beliefs }\end{array}$ \\
\hline $\begin{array}{l}\text { ble } \\
\text { ation }\end{array}$ & $\begin{array}{l}\text { Law of Ukraine "On } \\
\text { Charity and Charitable } \\
\text { Organizations" }\end{array}$ & $\begin{array}{l}\text { The legal entity of private law which constituent documents } \\
\text { determine charity (voluntary personal and/or property help } \\
\text { which does not provide receipt of profit by the philanthropist) } \\
\text { in one or several spheres as main objective of its activities }\end{array}$ \\
\hline $\begin{array}{l}\text { Non- } \\
\text { pens }\end{array}$ & $\begin{array}{l}\text { Law of Ukraine "On } \\
\text { Non-state } \quad \text { Pension } \\
\text { Provision" }\end{array}$ & $\begin{array}{l}\text { The subject of the second level of system of provision of } \\
\text { pensions, which is created and is effective according to the } \\
\text { legislation for the provision of services in accumulative } \\
\text { system of pension insurance }\end{array}$ \\
\hline Labo & $\begin{array}{l}\text { Law of Ukraine "On } \\
\text { Labour Unions, their } \\
\text { rights and Guarantees } \\
\text { of Activities" }\end{array}$ & $\begin{array}{l}\text { The voluntary non-profitable public organization uniting the } \\
\text { citizens connected by common interests by the nature of their } \\
\text { professional (labour) activity (study) }\end{array}$ \\
\hline $\begin{array}{l}\text { Association of } \\
\text { Local } \\
\text { Government } \\
\text { Bodies }\end{array}$ & $\begin{array}{l}\text { Law of Ukraine "On } \\
\text { Associations of Local } \\
\text { Government Bodies" }\end{array}$ & $\begin{array}{l}\text { The voluntary non-profitable association created by local } \\
\text { government bodies for the purpose of more effective } \\
\text { implementation of their powers, coordination of actions of } \\
\text { local government bodies concerning protection of the rights } \\
\text { and interests of territorial communities, promotion of local } \\
\text { and regional development. }\end{array}$ \\
\hline $\mathrm{Co}$ & $\begin{array}{l}\text { Law of Ukraine "On } \\
\text { Cooperation" }\end{array}$ & $\begin{array}{l}\text { The legal entity formed by individuals and/or legal entities } \\
\text { which voluntarily united on the basis of membership for } \\
\text { conducting joint economic and other activity for the purpose } \\
\text { of satisfaction of their economic, social and other } \\
\text { requirements on the basis of self-government }\end{array}$ \\
\hline $\begin{array}{l}\text { Agricultural } \\
\text { servicing } \\
\text { cooperative }\end{array}$ & $\begin{array}{l}\text { Law of Ukraine "On } \\
\text { Agricultural } \\
\text { Cooperation" }\end{array}$ & $\begin{array}{l}\text { The cooperative formed by individuals and/or legal entities } \\
\text { that are producers of agricultural products and unite for the } \\
\text { purpose of cost reduction and/or increase in the income of its } \\
\text { members from the implementation of agricultural activity as } \\
\text { well as for the purpose of their economic interests protection }\end{array}$ \\
\hline $\begin{array}{l}\text { Association of } \\
\text { co-owners of the } \\
\text { apartment house }\end{array}$ & $\begin{array}{l}\text { Law of Ukraine "On } \\
\text { Associations of Co- } \\
\text { owners of the } \\
\text { Apartment House" }\end{array}$ & $\begin{array}{l}\text { The legal entity created by owners of apartments and/or non- } \\
\text { residential premises of the apartment house for assistance to } \\
\text { use of their own property and management, maintenance and } \\
\text { use of common property }\end{array}$ \\
\hline
\end{tabular}

* generalized on the basis of legal and regulatory framework analysis

NNOs carry out certain types of activities in Ukraine in accordance with certain legislative and regulatory acts. For instance, the Law of Ukraine "On social Services" regulates the activity of non-budgetary non-profit organizations that help individuals or families in difficult vital circumstances and are registered as suppliers of social services.

Non-budgetary non-profit organizations may be founded by individuals and/or 


\section{ECONOMIC STRATEGIES FOR THE DEVELOPMENT OF SOCIETY}

legal entities that have approved the constituent documents, and able-bodied citizens of Ukraine, foreign citizens, stateless individuals at least 18 years of age, as well as legal entities registered in Ukraine may become the members (participants). At the same time, there may be additional restrictions for certain types of NNOs on the establishment and membership in accordance with domestic legislation (Table 3).

Table 3

\section{Requirements for founders and members of various types of non-budgetary non-}

profit organizations in Ukraine *

\begin{tabular}{|c|c|c|}
\hline Type of NNO & Founders & Members (participants) \\
\hline $\begin{array}{l}\text { Public association } \\
\text { in the form of the } \\
\text { organization }\end{array}$ & $\begin{array}{l}\text { Capable citizens of Ukraine, citizens of } \\
\text { other countries and people without } \\
\text { citizenship at least } 18 \text { years of age } \\
\text { (youth and children public } \\
\text { organization - at least } 14 \text { years of age) } \\
\text { consisting of not less than } 2 \text { persons }\end{array}$ & $\begin{array}{l}\text { Capable citizens of Ukraine, citizens of } \\
\text { other countries and people without } \\
\text { citizenship at least } 14 \text { years of age }\end{array}$ \\
\hline $\begin{array}{l}\text { Public association } \\
\text { in the form of the } \\
\text { union }\end{array}$ & $\begin{array}{l}\text { Legal entities of private law, including } \\
\text { public associations with the status of a } \\
\text { legal entity, except for political parties } \\
\text { and legal entities at the stage of } \\
\text { termination of their activity }\end{array}$ & $\begin{array}{l}\text { Legal entities of private law, including } \\
\text { public associations with the status of a legal } \\
\text { entity, capable individuals at least } 18 \text { years } \\
\text { of age }\end{array}$ \\
\hline Political party & $\begin{array}{l}\text { A group of citizens of Ukraine } \\
\text { consisting of at least } 100 \text { people }\end{array}$ & $\begin{array}{l}\text { The citizens of Ukraine who have the right } \\
\text { to vote on elections, except for judges, } \\
\text { prosecutors, police officers, security service } \\
\text { specialists, military personnel, employees } \\
\text { of customs and tax authorities, as well as } \\
\text { some other categories of citizens defined by } \\
\text { the Law of Ukraine "On Political Parties in } \\
\text { Ukraine". The citizen of Ukraine can be at } \\
\text { the same time only in one political party. }\end{array}$ \\
\hline Creative union & $\begin{array}{l}\text { Professional creative specialists of the } \\
\text { corresponding professional direction in } \\
\text { the field of culture and arts consisting } \\
\text { of at least } 100 \text { people for Ukraine-wide } \\
\text { union and } 20 \text { people - for a local one, } \\
\text { who have completed and released to } \\
\text { the public their works of culture and } \\
\text { arts or their interpretation }\end{array}$ & $\begin{array}{l}\text { Professional creative specialists - citizens } \\
\text { of Ukraine, citizens of other countries and } \\
\text { people without citizenship at least } 18 \text { years } \\
\text { of age }\end{array}$ \\
\hline $\begin{array}{l}\text { Religious } \\
\text { organization in the } \\
\text { form of a religious } \\
\text { community }\end{array}$ & $\begin{array}{l}\text { A group of citizens consisting of at } \\
\text { least } 10 \text { people at least } 18 \text { years of age }\end{array}$ & $\begin{array}{l}\text { Citizens being believers of the same } \\
\text { religion, confession, trend, movement or } \\
\text { tradition }\end{array}$ \\
\hline $\begin{array}{l}\text { Religious } \\
\text { organization in the } \\
\text { form of a religious } \\
\text { administration and } \\
\text { centre }\end{array}$ & \multicolumn{2}{|l|}{ Religious communities } \\
\hline $\begin{array}{l}\text { Charitable } \\
\text { organization in the } \\
\text { form of a company, }\end{array}$ & \multicolumn{2}{|c|}{$\begin{array}{l}\text { Capable individuals and legal entities, except for public authorities, local } \\
\text { governments, other legal entities under public law }\end{array}$} \\
\hline
\end{tabular}




\section{ECONOMIC STRATEGIES FOR THE DEVELOPMENT OF SOCIETY}

\begin{tabular}{|c|c|c|}
\hline institution or fund & & \\
\hline $\begin{array}{l}\text { Open non-state } \\
\text { pension fund }\end{array}$ & One or several legal entities & \multirow{3}{*}{$\begin{array}{l}\text { Citizens of Ukraine, citizens of other } \\
\text { countries and people without citizenship. } \\
\text { An individual can be a member of several } \\
\text { pension funds out of preference }\end{array}$} \\
\hline $\begin{array}{l}\text { Corporate non-state } \\
\text { pension fund }\end{array}$ & $\begin{array}{l}\text { Legal entity-employer or several legal } \\
\text { entities-employers, which employers- } \\
\text { taxpayers can join }\end{array}$ & \\
\hline $\begin{array}{l}\text { Professional non- } \\
\text { state pension fund }\end{array}$ & $\begin{array}{l}\text { Associations of legal entities- } \\
\text { employers, associations of individuals, } \\
\text { including labour unions (associations } \\
\text { of labour unions), or individuals } \\
\text { related by the nature of their } \\
\text { professional activity (occupation) }\end{array}$ & \\
\hline Labour unions & Citizens of Ukraine & $\begin{array}{l}\text { Employees of an enterprise, institution or } \\
\text { organization, regardless of ownership and } \\
\text { type of management, employees of } \\
\text { individuals who use hired labour, self- } \\
\text { employed persons, persons who study in an } \\
\text { educational institution }\end{array}$ \\
\hline $\begin{array}{l}\text { Association of } \\
\text { local government } \\
\text { bodies }\end{array}$ & \multicolumn{2}{|c|}{$\begin{array}{l}\text { Village, settlement, town, town district, district (raion) and regional (oblast) councils. } \\
\text { A local self-government body can be a member of only one all-Ukrainian association }\end{array}$} \\
\hline Cooperative & $\begin{array}{l}\text { Citizens of Ukraine, citizens of other } \\
\text { countries and people without } \\
\text { citizenship as well as Ukrainian and } \\
\text { foreign legal entities }\end{array}$ & $\begin{array}{l}\text { Citizens of Ukraine, citizens of other } \\
\text { countries and people without citizenship } \\
\text { aged at least } 16 \text { as well as Ukrainian and } \\
\text { foreign legal entities who paid the entrance } \\
\text { fee and share. The number of members of } \\
\text { the cooperative cannot be less than } 3 \text { people }\end{array}$ \\
\hline $\begin{array}{l}\text { Agricultural } \\
\text { servicing } \\
\text { cooperative }\end{array}$ & \multicolumn{2}{|c|}{$\begin{array}{l}\text { Producers of agricultural products - legal entities and/or individuals who paid } \\
\text { entrance fee and made share contribution }\end{array}$} \\
\hline $\begin{array}{l}\text { Agricultural } \\
\text { production } \\
\text { cooperative }\end{array}$ & \multicolumn{2}{|c|}{$\begin{array}{l}\text { Individuals who voluntarily united for the implementation of joint production activity } \\
\text { on the basis of compulsory labour participation, paid entrance fee and made share } \\
\text { contribution }\end{array}$} \\
\hline $\begin{array}{l}\text { Association of co- } \\
\text { owners of the } \\
\text { apartment house }\end{array}$ & \multicolumn{2}{|c|}{ Owners of apartments and non-residential premises of the apartment house } \\
\hline
\end{tabular}

* generalized on the basis of legal and regulatory framework analysis

Membership in a non-budgetary non-profit organization is individual and voluntary.

To ensure the effective functioning and development of NNOs, the organizational structure of management is arranged.

The structure of the governing bodies of a non-budgetary non-profit organization usually includes:

1) the highest governing body (general meeting or supervisory board) - approval of the statute (memorandum of association, foundational agreement) and symbols of the organization, determination of the core guidelines for activity, admission and 
ECONOMIC STRATEGIES FOR THE DEVELOPMENT OF SOCIETY

expulsion of organization members, election of institutional statutory bodies and head of the organization, etc.;

2) statutory body (executive board, governing council, etc.) - management of current activities of the organization;

3) executive director of the organization - representing the interests of the organization, concluding agreements, managing the executive apparatus;

4) control and auditing body (auditing committee, auditor) - control over financial performance results of the organization, legitimacy of income acquisition and expenditures;

5) executive apparatus - regular staff employed to carry out the current activities of the organization.

This way, the regulatory framework governing the activities of NNOs in Ukraine includes more than 10 laws and dozens of bylaws that are designed to prevent them from going beyond the legitimate field of operation. 


\section{ECONOMIC STRATEGIES FOR THE DEVELOPMENT OF SOCIETY}

\section{3 Конкурентоспроможність Еквадору на світовому ринку туристичних послуг}

Сучасною тенденцією в економіці фактично усіх країн світу є зростання частки туристичних послуг, як у структурі валового внутрішнього продукту, так i в структурі споживання. Саме міжнародний туризм є однією 3 провідних галузей світової економіки, що розвивається найбільш динамічно. За даними, Всесвітньої туристичної організації (UNWTO), постійне зростання туристичної індустрії буде незворотнім і у XXI ст.

Американський туристичний регіон за даними UNWTO посідає третє місце у світі за кількістю міжнародних туристичних прибуттів - 216 млн. осіб станом на 2019 рік. У межах регіону домінує Північна Америка (2/3 туристичних прибуттів). Найбільший приріст туристів характерний для Мексики та США.

Однак за приростом прибутків від міжнародного туризму лідирує субрегіон Південна Америка [82].

Досліджувана туристична дестинація - Еквадор, належить до Південноамериканського туристичного макрорегіону (за О.О. Бейдиком). Він має значний рекреаційний потенціал, який в основному представлений різноманітними природними та історико-культурними ресурсами. Найвищою рекреаційною привабливістю серед країн регіону характеризується Бразилія. Окрім неї до регіону входять: Аргентина, Болівія, Венесуела, Еквадор, Гайана, Колумбія, Парагвай, Перу, Суринам, Уругвай, Французька Гвіана, Чилі. Потужний туристичний потенціал цих країн наразі використовується досить мало. Проте, прогнозується зростання частки Південної Америки в міжнародних прибуттях у найближчій перспективі.

Сьогодні Республіка Еквадор - це аграрна експортоорієнтована держава 3 часткою первинного сектору 30\%. Розвиток сфери послуг відбувається за залишковим принципом.

Левову частку у третинному секторі економіки займає туристична сфера. Вона розвивається на основі потужного природно-рекреаційного потенціалу. Так, пляжні ресурси оцінюються приблизно в 2000 км. Найкращими пляжами 


\section{ECONOMIC STRATEGIES FOR THE DEVELOPMENT OF SOCIETY}

країни вважаються Атакамас, Сан Вінсент, Байя-де-Манта, Салінас, Плайас. В Еквадорі налічується близько 20 національних парків і заповідників, які займають $16 \%$ території. Найпопулярніший - національний парк на Галапагоських островах. Острови називають «унікальним живим музеєм і наочним прикладом еволюції» [83]. У національній системі природоохоронних територій Еквадору (SNAP) виділяють Державну спадщину природних територій, яка налічує 49 об'єктів, що охоплюють 48220 км² (близько 20\% площі) [84]. Історико-культурна спадщина Еквадору являє собою комбінацію пам'яток доколумбійської епохи та об'єктів колоніального минулого. Історико-культурну цінність являє собою центральна частина міста Кіто, Мітта-дель-Мундо, Гуаякіль, Куенка.

3 червня 2008 року запроваджено безвізовий режим для в’їзду в країну громадян більшості країн світу, які приїздять в якості туристів на строк до 90 діб, що, безумовно, спряє розвитку міжнародного туризму в Еквадорі. Сьогодні країна вважається однією з найбезпечніших країн Південної Америки.

За кількістю туристичних прибуттів країна займає 92-е місце у світі [82]. За останні три роки цей показник демонстрував стабільну позитивну динаміку (таблиця 1).

Таблиця 1.

Кількість та динаміка туристичних прибуттів Еквадору [85]

\begin{tabular}{|c|c|c|}
\hline Рік & Значення & Зміна, \% \\
\hline 2012 & 1272000 & $11,48 \%$ \\
\hline 2013 & 1364000 & $7,23 \%$ \\
\hline 2014 & 1557000 & $14,15 \%$ \\
\hline 2015 & 1544000 & $-0,83 \%$ \\
\hline 2016 & 1418000 & $-8,16 \%$ \\
\hline 2017 & 1608000 & $13,40 \%$ \\
\hline 2018 & 2535000 & $40,37 \%$ \\
\hline
\end{tabular}

Частка туристичних прибуттів країни у світовому масштабі є незначною (малюнок 1). Як видно з малюнку 2 станом на 2018 рік кількість туристів, що 


\section{ECONOMIC STRATEGIES FOR THE DEVELOPMENT OF SOCIETY}

прибули в країну, становила 2,4 млн. осіб. Порівнюючи з 2017 роком цей показник зріс на 51\%. Переважна більшість іноземних туристів, а саме $84 \%$ представники внутрірегіонального туризму, тобто американці та канадці, частка європейців становить 12\% (переважно з Німеччини, Франції та Іспанії), туристів 3 Азійсько-Тихоокеанського регіону - 4\%. П'ятдесят чотири відсотки 3 усіх туристів прибули в досліджуваний регіон власним авто або залізницею, 44\% відповідно літаком.

\section{International tourist arrivals (change, \%)}

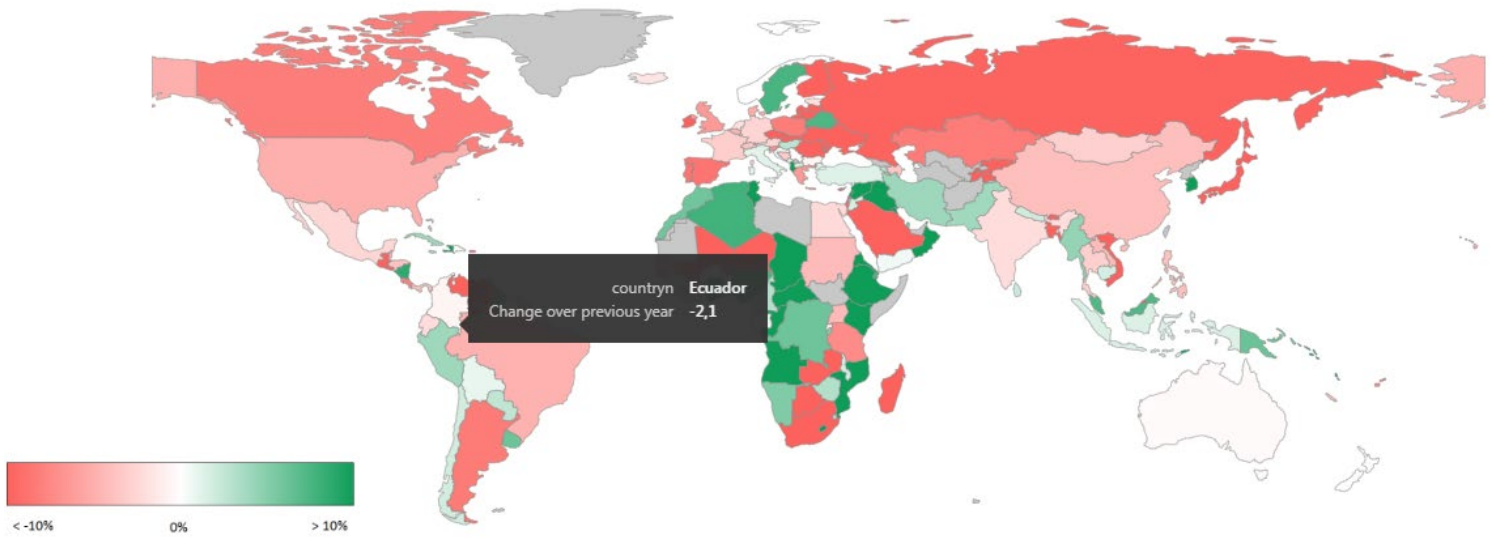

Малюнок 1. Міжнародні туристичні прибуття світу ,\% [82]

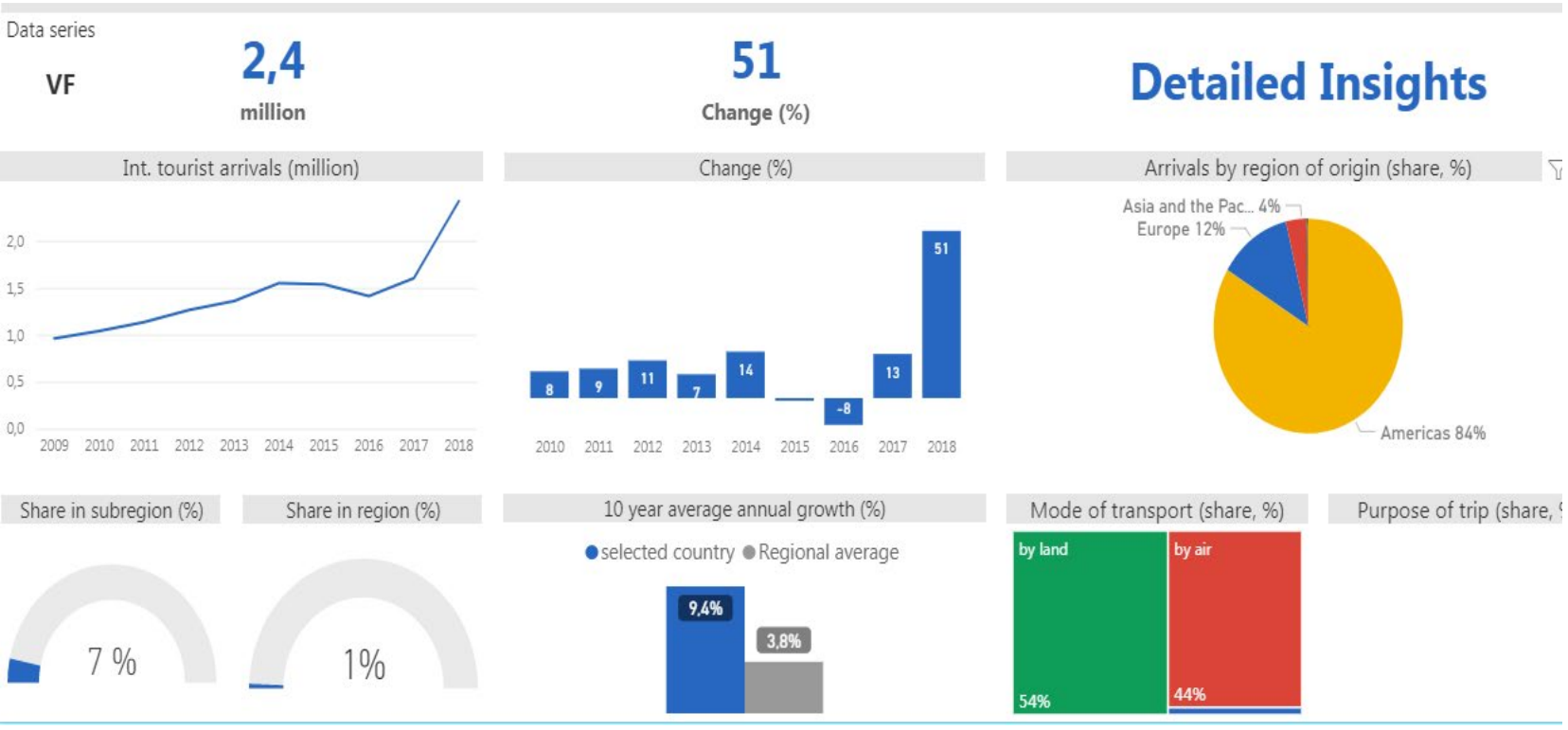

Малюнок 2. Статистика міжнародного туризму Еквадору [82]

На малюнку 3 представлені витрати іноземних туристів в середині країні. 
ECONOMIC STRATEGIES FOR THE DEVELOPMENT OF SOCIETY

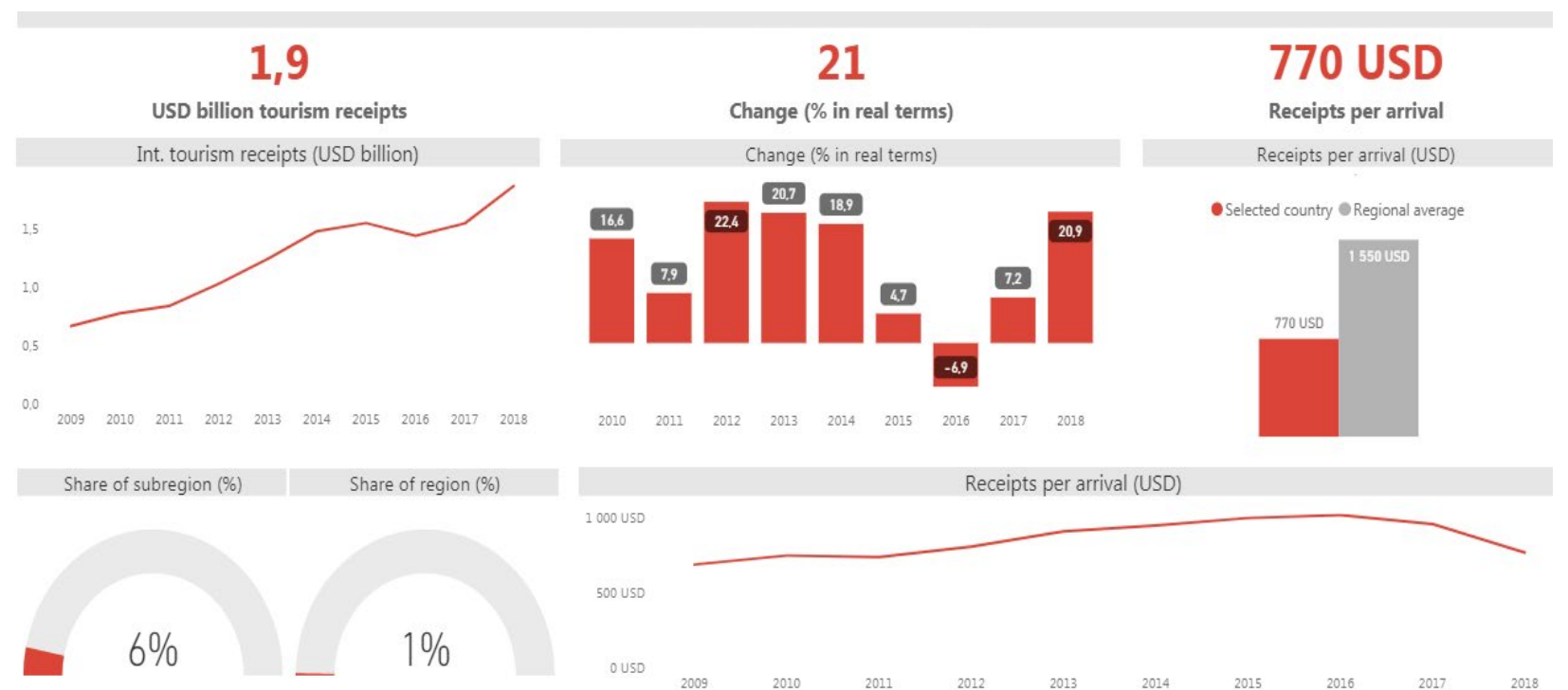

Малюнок. 3. Витрати іноземних туристів у Еквадорі [1]

Аналізуючи його, можна зробити наступні висновки:

- станом на 2018 рік витрати іноземних туристів усередині країні становили 1,9 млрд. дол. США;

- показник витрат іноземних туристів у 2018 році зріс майже на $21 \%$ порівняно з попереднім роком;

- частка туристичних витрат Еквадору в межах Південноамериканського туристичного субрегіону становить $6 \%$, і $1 \%$ відсоток від усіх туристичних витрат Американського туристичного регіону\%;

- якщо середні витрати одного туриста в межах Американського туристичного регіону оцінюються в 1550 дол. США, то в Еквадорі середньостатистичний турист витрачає майже вдвічі менше - 770 дол. США;

- найвищі туристичні витрати фіксуються у 2016 році, відтоді даний показник дещо знизився, що пояснюється політичною та економічною кризою в країні.

За статистикою виїзного туризму Еквадор займає 66-е місце у світі [82]. Динаміка даного показника показує, що за досліджуваний період кількість еквадорців, що виїжджає з країни з туристичною метою поступово збільшується. Лише з 2016 року фіксуємо незначне падіння частки виїзного потоку (малюнок 4). Таку ситуацію можна пояснити високим рівнем інфляції в країні та зниженням платоспроможності населення. 


\section{ECONOMIC STRATEGIES FOR THE DEVELOPMENT OF SOCIETY}

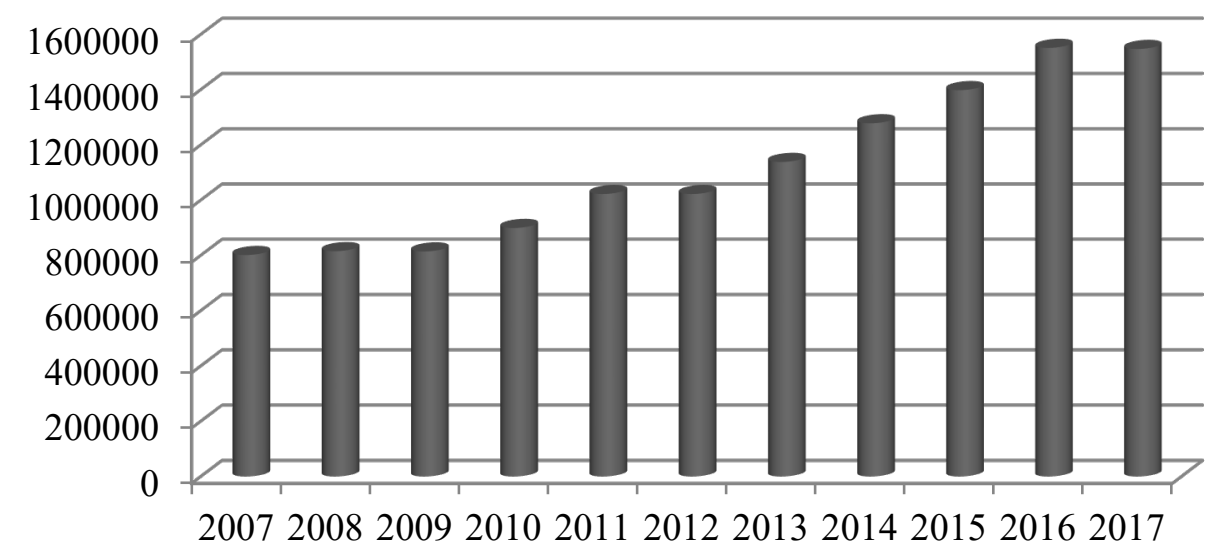

Малюнок 4. Динаміка виїзного туризму, осіб (створено авторами)

В Еквадорі, незважаючи на економічну кризу та нестабільну політичну ситуацію, для туристичної сфери характерний поступальний перманентний розвиток, тому що країна пропонує за невисокими цінами, неймовірне поєднання екзотичності природи, гастрономії, культури, історії, яке, в свою чергу, робить еквадорський туристичний продукт конкурентоспроможним на світовому ринку.

Еквадор за показником витрат на туризм займає 49 -е місце у світі (1,2\% ВВП країни) [82]. Зважаючи на комплекс об'єктивних причин, в останні 3 роки витрати на туризм в країні дещо зменшились, порівняно 3, наприклад, 2013 роком.

Серед галузей спеціалізації рекреаційного господарства Еквадору виділяємо пляжно-купальний відпочинок, екологічний туризм, екстремальні види туризму, пізнавальний туризм.

Вагомими лімітуючими чинниками розвитку міжнародного туризму дестинацій країни вважаємо природні катаклізми, на кшталт землетрусів, ураганів, для подолання наслідків яких країна не завжди готова; віддаленість від Європи - основного постачальника міжнародних туристів, а також економічна та політична нестабільність країни.

Тому, варто відмітити, що перспективи розвитку туризму в Еквадорі значною мірою залежать від політичної стабільності країни, від підтримки 
ECONOMIC STRATEGIES FOR THE DEVELOPMENT OF SOCIETY уряду у разі форс-мажорних обставин, гарантій якості туристичних продуктів і конкретних заходів щодо забезпечення безпеки туристів.

Щоб оптимізувати функціонування туристичної індустрії Еквадору, необхідно ефективне управління туризмом і правильна організація туристичної діяльності, удосконалення існуючої та створення нової туристичної інфраструктури, у першу чергу закладів розміщення та розваг, залучення досвідчених і кваліфікованих кадрів, щоб підвищити рівень якості туристичних послуг, а також забезпечення більш високого рівня безпеки для туристів.

Таким чином, беручи до уваги всі ці елементи, туризм може гармонійно розвиватися і суттєво впливати на зайнятість населення, що, в свою чергу, сприятиме збільшенню їх доходів, зниженню рівня злочинності, створенню сприятливих умов для туристів і задовольнятиме потреби внутрішнього та міжнародного туризму. 


\section{ECONOMIC STRATEGIES FOR THE DEVELOPMENT OF SOCIETY}

\section{4 Комплексний аналіз ринку послуг автомобільного транспорту в Україні}

Автомобільний транспорт $є$ невід’ємною частиною транспортного комплексу України та являє собою «галузь транспорту, яка забезпечує задоволення потреб населення та суспільного виробництва у перевезеннях пасажирів та вантажів автомобільними транспортними засобами» [86].

Важко переоцінити важливість послуг автомобільного транспорту як для суб'єктів господарювання, так і для пересічних громадян. Автомобільний транспорт, без сумніву, є потужним драйвером економіки, забезпечуючи переміщення вантажів і пасажирів у межах населених пунктів, між населеними пунктами, регіонами та, навіть, країнами.

У контексті беззаперечних переваг автомобільного транспорту перед іншими видами транспорту за інтегральним критерієм «ціна - швидкість гнучкість» закономірною є лідерська позиція цього виду транспорту в обсягах перевезення вантажів і пасажирів.

Зокрема, в Україні протягом останніх 15 років автомобільним транспортом перевозилось у середньому 68-73\% усіх перевезених вантажів (натомість перевезення вантажів іншими видами транспорту складали: залізничним транспортом - 25-30\%, морським транспортом - 0,2-0,5\%, річковим транспортом - 0,1-0,8\%, авіаційним транспортом - 0,005-0,008\%) і 88-90\% усіх перевезених пасажирів (натомість перевезення пасажирів іншими видами транспорту складали: залізничним транспортом - 9-11\%, морським транспортом - 0,14$0,26 \%$, річковим транспортом - 0,02-0,05\%, авіаційним транспортом - 0,08$0,21 \%)[87]$.

У цілому не став винятком і 2019 рік, що був ознаменований наступною структурою перевезень вантажів і пасажирів за видами транспорту в Україні (малюнки 1-2) 3 незначними посиленням лідерської позиції автомобільного транспорту на ринку вантажних перевезень і послабленням лідерської позиції автомобільного транспорту на ринку пасажирських перевезень. 
ECONOMIC STRATEGIES FOR THE DEVELOPMENT OF SOCIETY

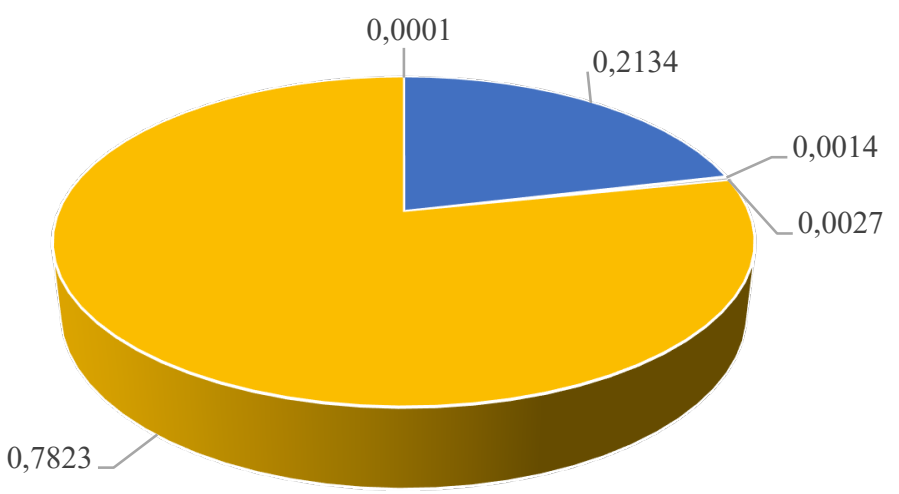

- Залізничний " Морський "Річковий " Автомобільний " Авіаційний

\section{Малюнок 1. Структура перевезення вантажів за видами транспорту}

в Україні у 2019 році (побудовано авторами за даними [88])

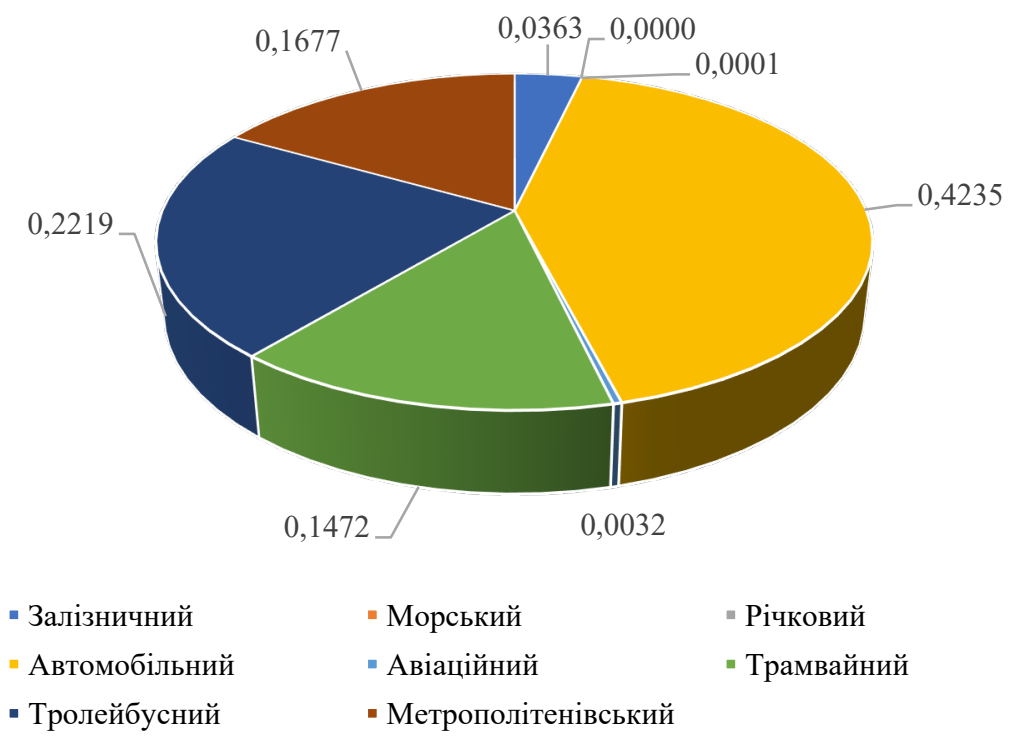

\section{Малюнок 2. Структура перевезення пасажирів за видами транспорту} в Україні у 2019 році (побудовано авторами за даними [88])

За даними Міністерства інфраструктури України на сьогодні найбільше ліцензій видано на надання таких послуг автомобільного транспорту: внутрішні перевезення пасажирів автобусами - 13687, внутрішні перевезення пасажирів на таксі - 10840, міжнародні перевезення вантажів вантажними автомобілями (крім перевезень небезпечних вантажів та небезпечних відходів) - 10400, внутрішні перевезення пасажирів легковими автомобілями на замовлення - 3802, внутрішні 


\section{ECONOMIC STRATEGIES FOR THE DEVELOPMENT OF SOCIETY}

перевезення небезпечних вантажів та небезпечних відходів вантажними автомобілями - 3396, міжнародні перевезення пасажирів автобусами - 2502, міжнародні перевезення небезпечних вантажів та небезпечних відходів вантажними автомобілями - 909, міжнародні перевезення пасажирів легковими автомобілями на замовлення - 147, міжнародні перевезення пасажирів на таксі 74 [89]. Відповідно, на здійснення внутрішніх перевезень вантажів і пасажирів наразі видано 31725 ліцензій, на здійснення міжнародних перевезень вантажів і пасажирів - 14032 ліцензії.

Не дивлячись на здавалося б явну за кількістю ліцензій направленість вітчизняних автоперевізників на внутрішній ринок, таке враження є дещо хибним, адже експорт послуг автомобільного транспорту з України традиційно є більшим за імпорт послуг автомобільного транспорту в Україну (малюнок 3).

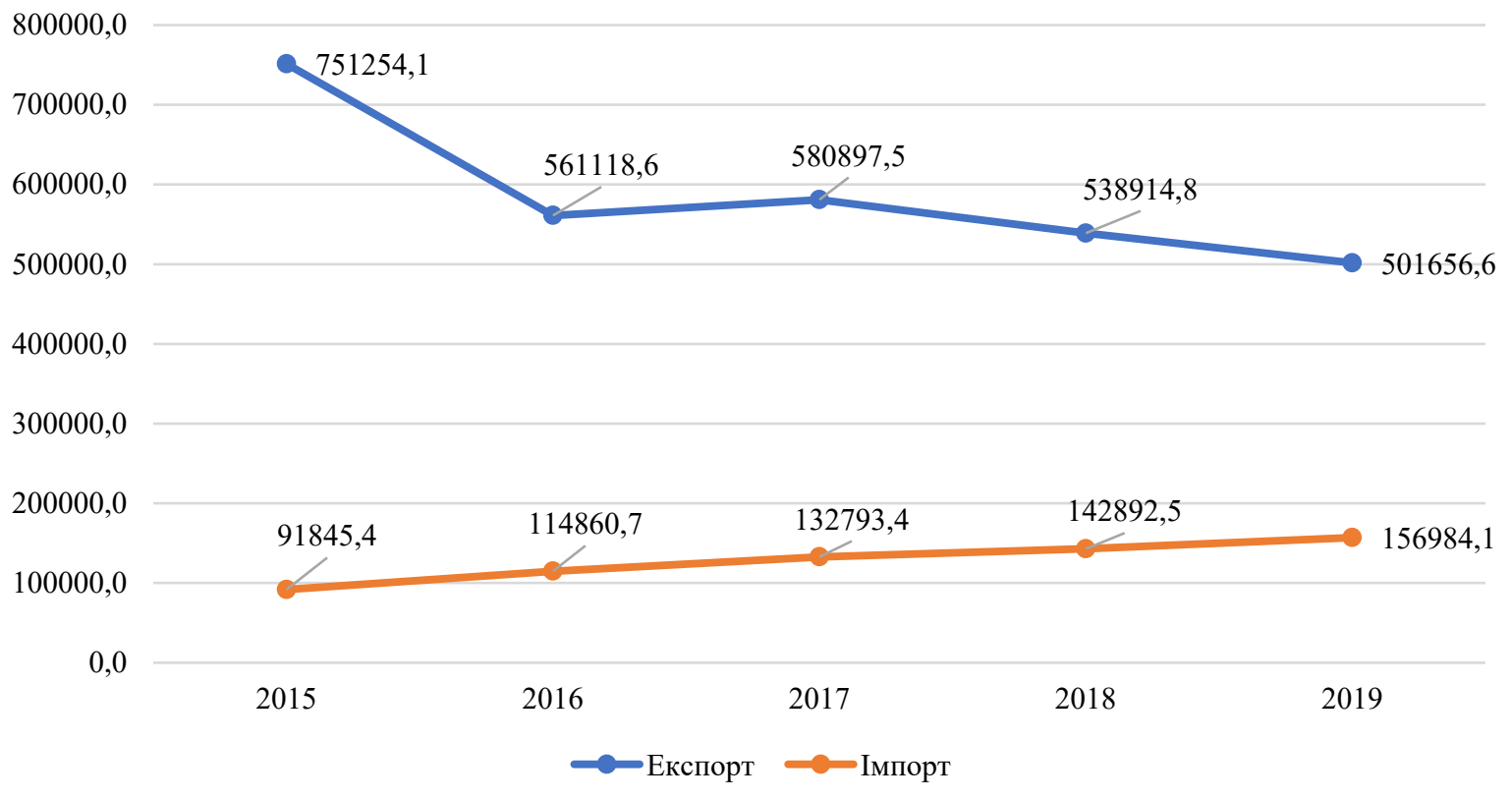

\section{Малюнок 3. Експорт і імпорт послуг автомобільного транспорту}

у 2019 році, тис. дол. США (побудовано авторами за даними [90])

Але досить тривожною видається динаміка зменшення обсягу експорту та збільшення обсягу імпорту послуг автомобільного транспорту. Сьогодні спостерігається деяка «центричність» розподілення послуг автомобільного транспорту за регіонами України (малюнки 4-5). 


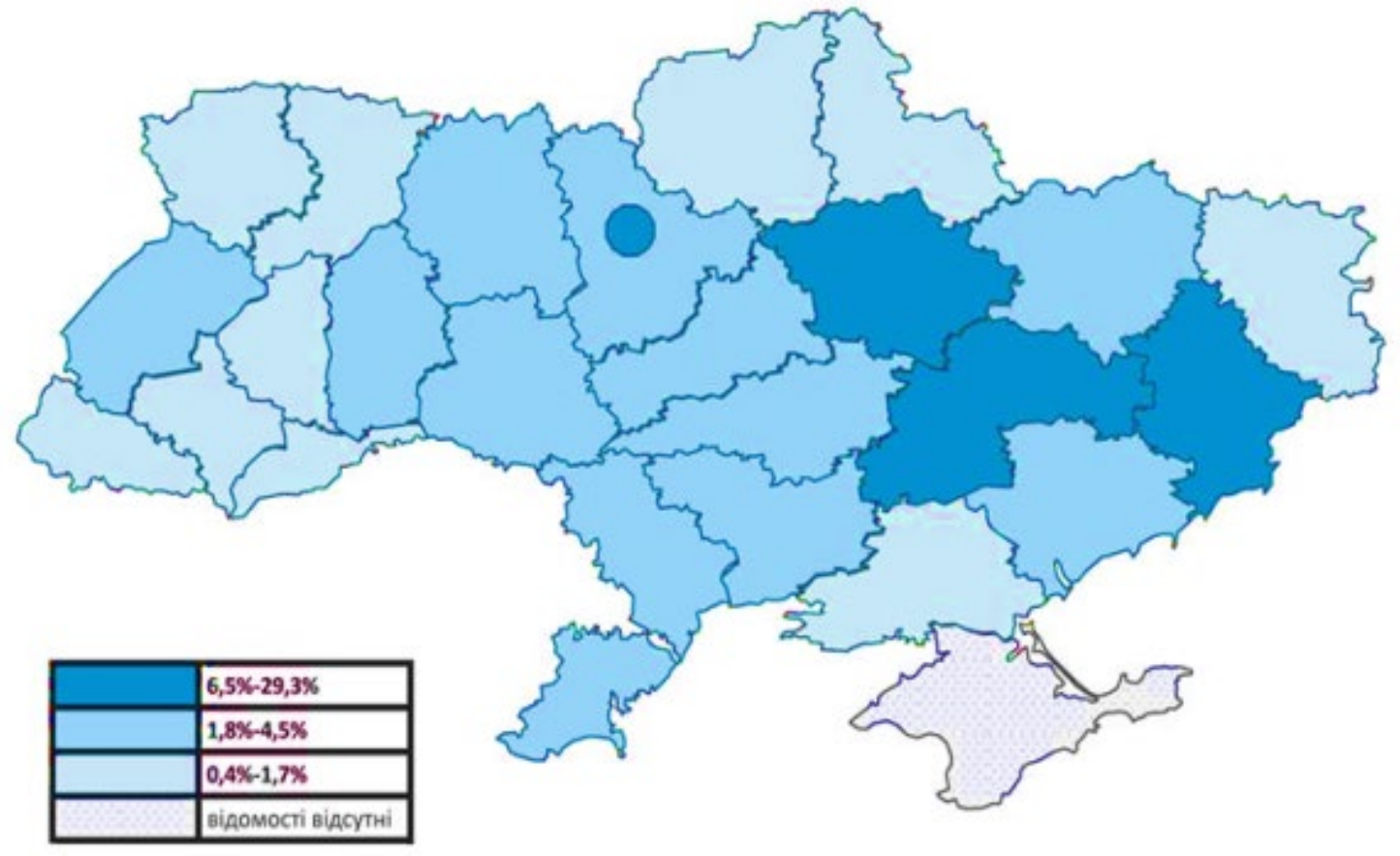

Малюнок 4. Розподілення перевезених автомобільним транспортом вантажів за регіонами України у 2019 році [90]

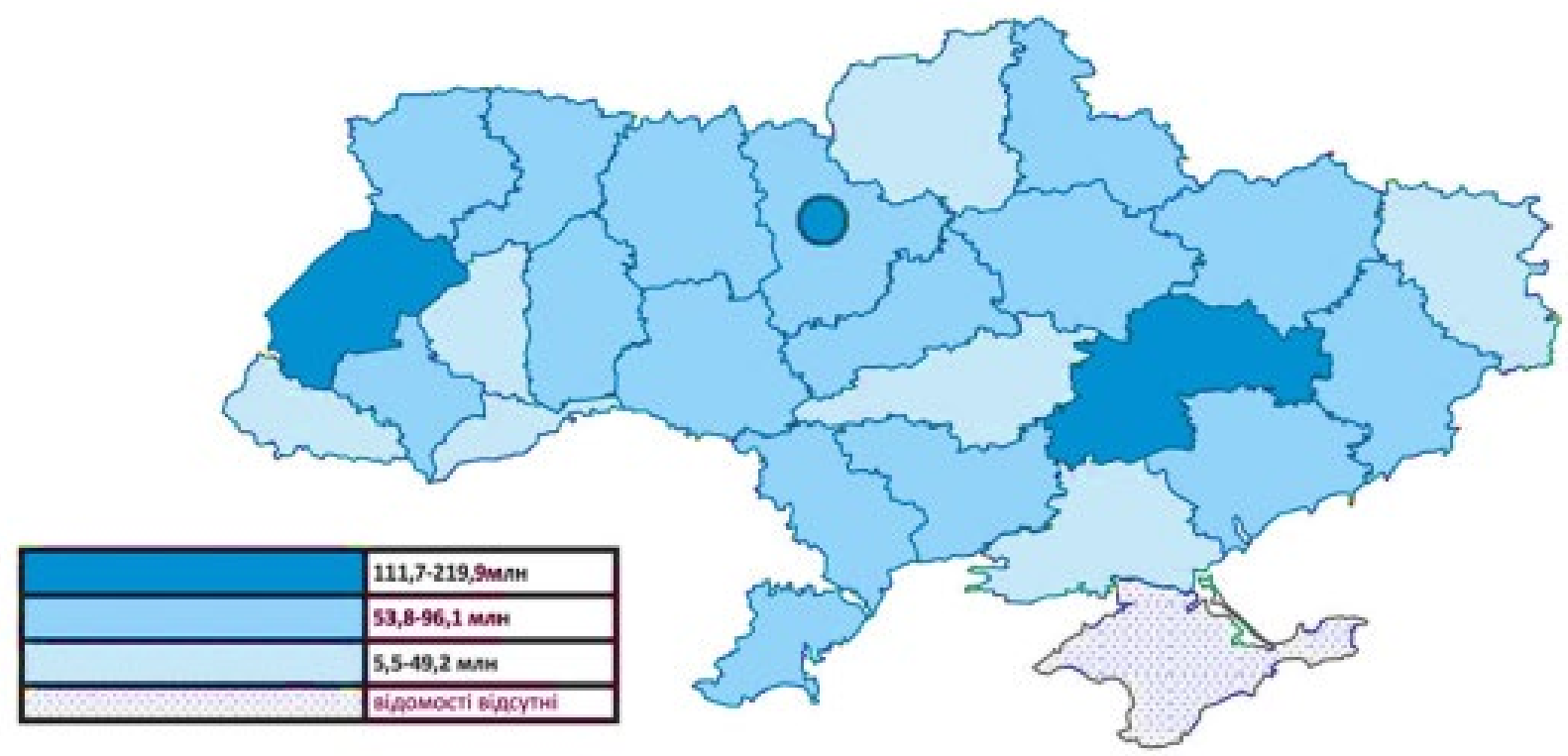

Малюнок 5. Розподілення перевезених автомобільним транспортом пасажирів за регіонами України у 2019 році [90]

Регіонами-лідерами за обсягом перевезення вантажів автомобільним транспортом наразі є Дніпропетровська область, Полтавська область, Донецька область і м. Київ. Перевезення вантажів автомобільним транспортом можна віднести до показників соціально-економічного розвитку регіонів, адже 


\section{ECONOMIC STRATEGIES FOR THE DEVELOPMENT OF SOCIETY}

перерозподілення новоствореного продукту характеризує потреби економічних суб'єктів і матеріальне благополуччя населення.

Дніпропетровська область, Львівська область і м. Київ лідирують за обсягом перевезення пасажирів автомобільним транспортом. Звичайно, значною мірою обсяг перевезення пасажирів автомобільним транспортом залежить не лише від економіки регіону, а й від густоти населення регіону, розвиненості дорожньої мережі та якості дорожнього покриття у регіоні, тощо. Визначальним є i географічне положення регіону: зокрема, стрімкий пасажиропотік автомобільним транспортом через м. Київ пояснюється його роллю ключового транспортного хабу України. Натомість, Львівська область вже тривалий час $є$ «воротами» до Європейського Союзу. 


\section{ECONOMIC STRATEGIES FOR THE DEVELOPMENT OF SOCIETY \\ SECTION 6. ECONOMY AND MANAGEMENT OF STATE GRATITUDE}

\subsection{Interdependence between level of trust and economic growth. Manifestation of trust through economic indices}

Annotation: Trust is an underestimated index, which is relatively young, compared to such index as GDP of a country, which in its turn is considered to be one of the main indices. Here we would like to do an attempt to prove that those two are correlated and both must be taken into account.

Key words: Harmful economy policy, trust; distrust; GDP; confidence; level of life; quality of life for the population.

Trust as one of the major tools of economic growth has already been studied for decades by may famous scientist all over the world and though now in the world where we live now this issue is getting more vitally important and actually on the edge of contemporary science taking inti account the huge distress for the economies all over the world being exposed to quarantine measures, trust is something that relly matters.

Among those who studied trust we can list the following scientists: T. Veblene, F. Fukuyama, K. Otty, O. Orlova, O. Sivash, Kupreychenko V.A., Obosov N.N.

Te aim of the work is to show the connection between trust and economy that can manifest through such economic indices as GDP or rate of birth.

Before we get down to analysis let's give definition to the notions we are going to analyze.

Trust or confidence, to our opinion, is something that cannot be touched or seen, but can be literally felt through the freedom and the way of communication.

It actually manifests through the communication; the way it is conducted. [91]

To give more or less ground picture of the changes going on now, we would like to make a small excurse to history of economic development and regression at times. After Russia, the Republic of Ukraine was undoubtedly the most important economic 


\section{ECONOMIC STRATEGIES FOR THE DEVELOPMENT OF SOCIETY}

component of the former Soviet Union, producing about four times more products than the next union republic behind it. More than a quarter of Soviet agricultural products were grown on its fertile black soil, and its farms provided significant volumes of meat, milk, grain, and vegetable production. Similarly, its diverse heavy industry supplied unique equipment (such as large-diameter pipes) and raw materials for industrial and mining areas in other areas of the former Soviet Union. Shortly after gaining independence in August 1991, the Ukrainian government released most prices and established a legal framework for privatization, but widespread resistance to reform within the government and legislature soon nullified all reform efforts and led to an economic downturn. GDP by 1999 was only 40\% of the 1991 level.

Ukraine's dependence on Russia in terms of energy resources and the lack of significant structural reform have made the Ukrainian economy vulnerable to external crises. Ukraine imports three-quarters of oil and natural gas and 100\% nuclear fuel. After Ukraine agreed to sign a 10-year gas supply and transit contract with Russia in January 2009 as a result of the "gas war", which led to a reduction in gas supplies to Europe, gas prices for Ukraine have approached "world" prices. levels. Strict contract terms further hampered the cash-bound state gas company of Ukraine, Naftohaz.

External institutions - especially the International Monetary Fund - have called on Ukraine to accelerate and expand its reforms. Ukrainian government officials eliminated most taxes and customs privileges in the March 2005 budget law, creating the conditions for greater business activity and the arrival of business from the shadow sector. However, the country needs even greater changes, including the fight against corruption, the development of capital markets, and an improved legal framework. Ukraine's economy was in good shape until mid-2008, despite political turmoil between the prime minister and the president. Real GDP growth exceeded 7\% in 200607, fueled by high world steel prices - Ukraine's main export - and strong domestic consumption, stimulated by growth in pensions and wages. Ukraine reached an agreement with the International Monetary Fund to support the economy during the global economic crisis of $\$ 16.4$ billion in November 2008, but slow reforms by the Ukrainian government have twice delayed the allocation of IMF assistance. As a result 


\section{ECONOMIC STRATEGIES FOR THE DEVELOPMENT OF SOCIETY}

of falling steel prices and the impact of the global economic crisis, Ukraine's economy shrank by almost $15 \%$ in 2009, one of the worst in the world; growth resumed in 2010 , supported by exports. External conditions are likely to hamper economic recovery efforts in 2011.

Trust is more easily transformed into distrust than distrust into trust [92]. Thus, every unsuccessful or irresponsible step of state power leads to a decrease in trust and social capital in society.

Let's see the side effect of harmful political economy in the fig. 1

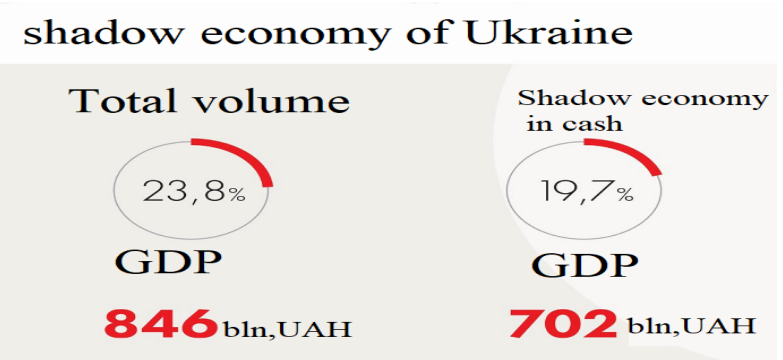

Fig. 1. Shadow economy of Ukraine [93]

The above figure gives us exponential picture of how the consequences to which the policy that bad been conducted by after-revolutionary authority led and what the level of trust to that policy that is? Especially in the field of economy in Ukraine.

To ground our opinion, we would like to offer to your attention the table №1, where we can actually observe how the GDP of Ukraine was changing during the period, when a set of dramatic events has taken place. 


\section{Fluctuation of the GDP of Ukraine for the period from 2012 to 2018[94]}

\begin{tabular}{|l|l|l|l|}
\hline year & blm, Uah & bln, USdollars & $\begin{array}{l}\text { Compared to previous } \\
\text { year }\end{array}$ \\
\hline 2012 & 1404,669 & 175,707 & $\mathbf{A} 0,239$ \\
\hline 2013 & 1465,198 & 179,572 & $\mathbf{\nabla}-0,027$ \\
\hline 2014 & 1586,915 & 132,343 & $\mathbf{\nabla}-6,553$ \\
\hline 2015 & 1988,544 & 90,939 & $\mathbf{\nabla}-9,773$ \\
\hline 2016 & 2383,182 & 93,263 & $\mathbf{\Delta} 2.441$ \\
\hline 2018 & 3558,706 & 130,832 & $\mathbf{4} 3,291$ \\
\hline
\end{tabular}

We can see a sharp drop at the period from 2013 to 2014 and this pit is not surprising, at all. Especially for those who know what was happening at the above period. It was revolution.

Abrupt los of the key economy partners and loss of some part of territories of Ukraine made many enterprises stop and many people leave the country.

In contrast we can see steady, but slow growth in the period after 2015, when, at least mass disorders in the streets were reduced.

Also incomes of the country started being filled through the taxes of a great deal of those who actually left the country and paid taxes for transactions related to sending money to their relatives, who stayed in the country.

That might seem ridiculous, to speak of this article of income in the country's budget, but it is the harsh reality of post-revolution war economy of Ukraine.

Necessary moves, to be taken to overcome the situation and direct the economy to the path of recovery are to be taken first of all within the country itself. 


\section{ECONOMIC STRATEGIES FOR THE DEVELOPMENT OF SOCIETY}

\subsection{The essence of personnel management and its main tasks}

Personnel management is a purposeful influence on personnel aiming the fullest usage of its potential. For the usage of potential, one has to create material (salary), spiritual and social conditions, and teach personnel new technologies in time.

The human role in the enterprise has been changing with the flow of time. At the beginning of the previous century an employee was considered to be the working force without taking his material or spiritual needs into account. Later a «labor resources» category appeared. At the beginning of century this concept defined the part of the population that had the opportunity to work and participate in social production. It was suggested that by using this term, scientists were referring to a passive object of management.

Beginning in 1960, the term «human factor» began to be used in economic literature. This term emphasises the active role of a human in the production system and in improving production efficiency. Just then scientists came to the conclusion that it is necessary to create conditions for the development of professional and creative abilities. This is how the term «labor potential» appeared. To fulfil the abilities of employees it is necessary to stimulate (encourage) for conscientious work, as well as to involve employees in the decision-making process.

Personnel (or staff) is the main assigned staff of the organisation, performing various production and economic functions. It is characterised, above all, by its number. The number, in its turn, is determined by the nature, scale, complexity, labor input of production processes, the degree of their mechanisation, automation, computerisation [95].

The personnel of the organisation is one of the types of resources of the enterprise. This type differs from others (financial, material, raw materials) in the fact that the employee has the right to refuse the conditions under which he is going to be used, to negotiate the level of wages, retrain other professions, participate in strikes, quit the job at will, decide which professions are socially unacceptable. In general, personnel cannot be considered as a homogeneous substance; each employee has individual motives and values[96]. 


\section{ECONOMIC STRATEGIES FOR THE DEVELOPMENT OF SOCIETY}

In general, it can be determined that the concepts of «personnel» and «staff» are not identical, because personnel is the personnel assets of the organisation, including part-time and seasonal workers who draw up a contract with the organisation; and staff is full-time (permanent) staff of the organisation without part-time and seasonal workers. Thus, the concept of «personnel» is more modern and broader than «staff», as it refers to the social community of employees. Moreover, the concept of «personnel» has a deep meaning, namely, it differs in the need to pay attention to the identity of the employee. Using the term «personnel» in the title of the department or position, it is assumed that the functions of the personnel service will be expanded, i.e. the personnel service will have to take care of employees, create comfortable conditions, and pay more attention to personnel policy.

People are the main resource of any enterprise. The quality of production, level of service, general growth and development of the company depends on the personnel. Adjusting the work of staff is the first thing a company manager should do.

Personnel management is very complex. Eventually the number of problems grows. For, in order to manage, one needs to have knowledge in various fields (management, psychology, strategic planning, etc). It is important to build a personnel management system at the enterprise, which will help to fulfil the tasks of a company and get rid of some problems of personnel management. Human resource management of the enterprise is a set of measures for the creation and development of qualified personnel that is capable of achieving business goals. Experts note that while the company has no problems with staff, one pays little attention to the management of these resources. The understanding of the importance of human resources comes only when it becomes clear that the source of company's profits is its staff.

The global goal of personnel management is to form, develop and realise human resources of the organization with highest efficiency. This means improving the work of each employee so that they could optimally build and use their working and creative potential to contribute to the goals of the enterprise, as well as support the activities of other employees in this direction. The peculiarity of the goals of personnel management is to take into account not only the target concepts of the organisation 


\section{ECONOMIC STRATEGIES FOR THE DEVELOPMENT OF SOCIETY}

(organisational goals), but also the individual goals of employees. The latter should not be outside the goals of the organisation. The basic principle of personnel management is to seek compromises between the goals of employees and the goals of organisation in case of conflict, rather than prefer the goals of the latter.

The main goals of personnel management include: promoting the goals of the organization by providing the company with necessary staff and promoting the effective use of qualifications, experience, working capacity of staff and their creative potential; formation of corporate culture of the organization, involvement of employees in the values of the organization and corporate style; resolving conflict situations and creating normal socio-psychological climate in the team. Thus, the purpose of personnel management is to ensure the development and realisation of human resources.

There is a saying: «You can bring a horse to the water, but you cannot force it to drink. It will drink only if it is thirsty». It goes the same with people. They will do what they want to do or what motivates them to do. They can be motivated by both internal and external motivation.

Motivation is an inner process of a person's conscious choice of one or another type of behavior, which is determined by the complex influence of external (stimuli) and internal (motives) factors. Possible motivation strategies are: positive reinforcement / high expectations; effective discipline and punishment; fair relations with people; meeting the needs of employees; competent statement of work goals; restructuring of workplaces; reward for performance of work.

The motivational system must be adapted to the situation and the organisation. In one of the most complex studies conducted in the United States over 20 years, involving more than 40,000 employees of a large company, it was found that the most important motivating factor was safety. The following three factors were: promotion, type of work, the ability to be proud of your company. Surprisingly, factors such as wage level, benefits and working conditions were rated relatively low. That means that money did not appear to be the main motivational stimulus. Psychological tests and other methods of psychodiagnostics will help HR-manager to determine the true 


\section{ECONOMIC STRATEGIES FOR THE DEVELOPMENT OF SOCIETY}

motivations of employees. For example, the pyramid of needs by A. Maslow systematizes material and intangible incentives in motivation, and also carries out diagnostics of motivation. It is necessary to implement diagnostics of motives in professional activity to construct a successful system of stimulation. Employees are customarily diagnosed for the motivation to succeed / avoid failure, on the orientation of the individual. There is also the concept of motivation of D. McClelland, according to which three groups of needs can be distinguished: the need for power, the need for success, the need for involvement.

Any manager responsible for the productivity of subordinates has the function of personnel management. In recent years, more and more attention is paid to the concept of «leadership», gaining recognition of the team at the level of team groups, employees' understanding of the goals of the organization and the desire to achieve them. This is one of the most important aspects of human resource management, but not the only one. In modern conditions, the desire of senior management to meet the needs of consumers comes first, and in the context of this goal, the coordination of actions of different departments is of paramount importance.

Heads of departments face constant pressure and the need to achieve goals with minimal staff costs. On the agenda, the efficiency of «white-collar workers» is on a par with the efficiency of production staff. There is a withdrawal from the elements of explicit bureaucracy. Gender and ethnic equality, unity of working conditions in the field of safety and health, equality of rights of employees in the handling of complaints and taking appropriate measures - all this leads to the fact that modern management is becoming more technological than before.

In such a situation, knowledge of the company's procedures and personnel policy is equally important for both the line manager and the head of the personnel department. Heads of departments are expected to contribute to the development of human resources of the organisation. In today's dynamic environment, when most business processes are controlled by automated management systems, many employees are forced to learn certain skills as the work advances. And they are trained with the support of their colleagues. 


\section{ECONOMIC STRATEGIES FOR THE DEVELOPMENT OF SOCIETY}

As for the top management of the organisation, the heads of departments place their hopes on it in terms of promoting learning and career growth. For the decline in management levels in organisations has deprived many of the opportunity to move up the career ladder. The task is not an easy one, taking in consideration the fact that the company's management, in addition to their immediate responsibilities, is forced to pay sufficient attention to human resource management.

Each chief differs in: - features of the structure of his power, ie a combination of status, economical and spiritual power; - their special character traits, ie unique personal qualities, - interaction between themselves and followers, ie the ability to increase the «amount» of power on the basis of successful interaction with the group features of personnel management in the group, ie group management techniques. These features of the leader's personality influence the choice of personnel management style. There are different types of styles and their varieties. Authoritarian - a form of individual centralized manifestation of power. Absolutely dictatorial employees are forced to comply with strict individual orders under threat of punishment. Autocratic - the chief has a large apparatus of power. Bureaucratic - the authority of the leader is determined by his formal position as leader. Patriarchal - the leader wields the authority of the «head of the family», employees are subordinated on the basis of unlimited trust. Democratic (cooperative). Communicative - employees can express their opinion, though they must follow orders. Advisory - the manager makes decisions only after receiving detailed information and discussion, employees perform tasks, in the development of which they participated. Management of the joint decision - the chief sets up a problem and restrictions, employees make decisions on actions, the chief reserves the right to vote. Autonomous - the manager takes on the role of moderator, ie to restrain, employees are given independence, control and responsibility remain with the manager. There is no ideal management style, and they can only be effective when one considers a specific situation.

The leader must use a situational approach. Based on this, there are different views of scientists on personnel management. In particular, Sitnik N.I. [97] believes that 


\section{ECONOMIC STRATEGIES FOR THE DEVELOPMENT OF SOCIETY}

personnel management is the provision with the required number of employees performing the necessary production functions for organisation.

In his turn, Vinogradsky M.D. [98] considers personnel management as a socioeconomic system in the organisation. Its main complex tasks and functions are planning, forecasting, marketing of personnel, its development, analysis of motivation, creating optimal working conditions, developing organisational management structure, labor relations regulation, accounting staff, legal services and social infrastructure development.

Desler G. [99] is of another opinion. He argues that personnel management is a part of management that concerns employees and their relationships within the enterprise. Personnel management is carried out for the realization of two major and interrelated goals: improving the efficiency of the organisation; and improving the quality of working life of staff.

Personnel management is a purposeful activity of the management of the organisation, aimed at development of the concept, strategies of personnel policy and methods of human resource management. This is what Kibanov A.Ya. [100] considers. Menshikova M.O. [101] believes that personnel management is a set of mechanisms, forms and methods of interaction in the formation, development and activities of personnel of the organisation, which is implemented as a number of interrelated trends and activities.

According to Pelikh A.S. [102], personnel management is a set of logically related actions aimed at optimizing the labor resources of the enterprise (personnel) in terms of their activities, qualitative and quantitative characteristics, in order to achieve the goals of the organisation rationally. Such a scientist as A.V. Lynenko [103] offered his vision: personnel management is a complex system of measures aimed at improving the professional qualification level, motivation, stimulation of personnel and full use of its capabilities to manage the development of the enterprise.

We are inclined to the following statement: personnel management is a set of principles, methods, tools and forms of influencing the interests, behavior and activities 


\section{ECONOMIC STRATEGIES FOR THE DEVELOPMENT OF SOCIETY}

of employees in order to maximize the use of their intellectual and physical abilities in performing job functions [104].

These concepts speak of a systematic approach to personnel management, which consists in the formation of effective personnel activities, in increasing the role of employees, in knowledge of their motivational attitudes, in ability to organize and direct them according to the goals and objectives of the organisation, and also in coordinated interaction. Thus, the essence of personnel management consists in the fact that «people are seen as a competitive asset in the company», so it is necessary to improve human resources constantly.

The effectiveness of personnel management is determined by the degree of realisation of the overall goals of the organisation. Therefore, personnel management should become an organisational strategy. The strategy means the definition of longterm goals of the organisation, methods and time of their achievement, as well as a system for evaluating the degree of implementation of these goals.

The structure of personnel management includes the following activities:

- resource planning: elaboration of a plan to meet the needs in human resources and necessary costs for it;

- recruitment: creating a reserve of potential candidates for all posts;

- selection: evaluation of candidates for jobs, selection of the best from the reserve created in the course of work;

- determination of wages and compensation: elaboration of the structure of wages and benefits in order to attract, hire and retain staff; career guidance and adaptation of employees in the organisation and departments, the development of employees' understanding of what the organisation expects from them and what work in it receives well-deserved evaluation;

- training: development of personnel training programs in order to effectively perform the work and its promotion; 


\section{ECONOMIC STRATEGIES FOR THE DEVELOPMENT OF SOCIETY}

- evaluation of labor activity: elaboration of methods of labor activity evaluation and bringing it to the employee's notice; increase, decrease, transfer, dismissal, development of methods of staff rotation, development of their professional experience by rotation, as well as procedures for termination of the employment contract;

- training of management staff, management of promotion: elaboration of programs aimed at developing skills and improving the efficiency of management staff;

- labor relations: implementation of negotiations on collective agreements;

- employment: elaboration of programs to ensure equal employment opportunities (employment guarantees and reduced staff turnover provide a significant economic effect and encourage employees to increase the efficiency of their work) [105].

The construction of a personnel management system is based on certain principles that are realised within interaction. Their combination depends on the specific conditions of the personnel management system of any enterprise. Their diversity is classified into two major groups: the principles that characterize the requirements for the formation of a personnel management system, and the principles that determine the direction of the personnel management system.

Methods of personnel management of the enterprise are divided into three groups: administrative, economic and socio-psychological. They are used to develop ways to influence teams and individual employees to carry out their activities. All types of methods are organically interconnected. For many years, the main structural units for personnel management at the enterprise were personnel departments, which performed mainly the functions of hiring and firing employees. Occasionally they organised their training. These departments did not perform all personnel management functions and were staffed by untrained employees.

During the transition to market conditions, new structural subdivisions began to be created: personnel management services on the basis of the personnel department, the department of labor and wage organisation, the department of labor protection and safety, the department of social development, and others. Among the many qualities that should be possessed by personnel management specialists, the most important are: 
ECONOMIC STRATEGIES FOR THE DEVELOPMENT OF SOCIETY

- business knowledge (areas of enterprise activity);

- professional knowledge and skills in the field of personnel management;

- leadership and management skills;

- ability to learn and develop [106]. 


\section{ECONOMIC STRATEGIES FOR THE DEVELOPMENT OF SOCIETY}

\subsection{Marketing aspects of feed market development}

Протягом останніх років спостерігається активізація розвитку ринку кормів. Основна його місія - забезпечення продовольчої безпеки за рахунок виробництва екологічно безпечних кормів та підвищення продуктивності сільськогосподарських тварин $[107,108]$. Для забезпечення тваринництва високобілковим кормом необхідно активізувати маркетингову діяльність.

На сучасному етапі комплекс маркетингу є стандартом в теорії та практиці маркетингової діяльності, але через швидкі зміни ринкового середовища, споживчі цінності покупців та специфіку товару концепція «4Р» потребує доповнення. Враховуючи специфіку ринку кормів система «4Р» потребує такого поєднання інструментів маркетингу, який би забезпечив перевагу сільськогосподарського товаровиробника на ринку. Система «маркетингу» ринку кормів складається $з$ окремих підсистем: «Товар», «Ціна», «Розподіл» $\mathrm{i}$ «Комунікації», відомих із робіт зарубіжних маркетологів [109,110] як «4р» (Р1 product, $\mathrm{P} 2$ - price, $\mathrm{P} 3$ - place, $\mathrm{P} 4$ - promotion) (рис.1).

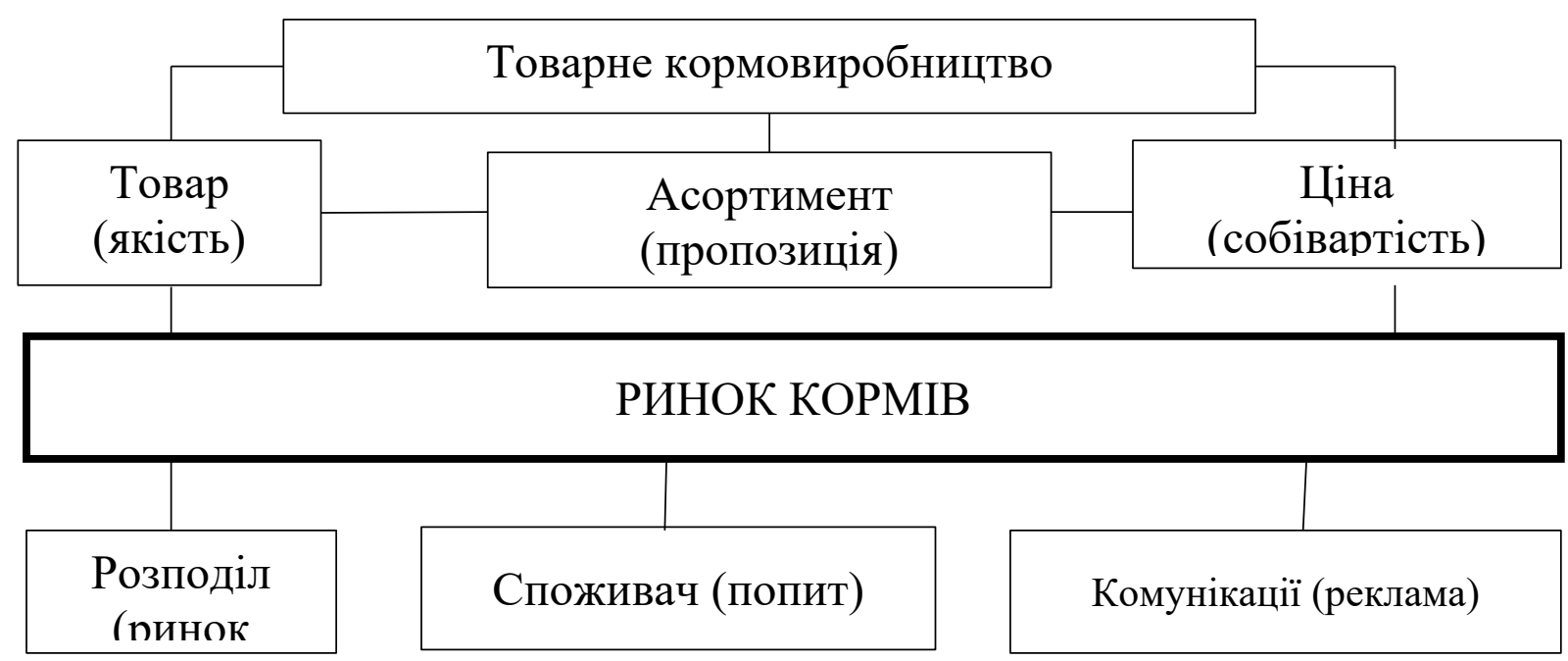

Рис. 1 - Маркетингові інструменти ринку кормів

Планування комплексу маркетингу підприємства починається 3 комплексного дослідження ринку, тому що воно орієнтоване на задоволення потреб споживачів. Досвід ряду вітчизняних підприємств свідчить про те, що товарне кормовиробництво може бути вигідним і тому ця ніша нині є економічно привабливою i потребує дослідження перспектив iii розвитку [111]. 


\section{ECONOMIC STRATEGIES FOR THE DEVELOPMENT OF SOCIETY}

Маркетингове дослідження передбачає вивчення поведінки споживачів, їх смаків та уподобань, потреб, споживчих переваг, мотивів, що спонукають їх купувати корми для задоволення підприємницьких потреб. Дослідження ринку кормів передбачає вивчення і прогнозування попиту на різні види товарних кормів, аналіз цін і пропозиції різних виробників, визначення місткості ринку і частки підприємства на ньому. Такий аналіз допомагає оцінити ринкові можливості і визначити привабливий напрям маркетингової діяльності, на якому підприємство може набути конкурентних переваг. Водночас ведеться пошук своїх потенційних споживачів, потреби яких підприємство прагне задовольнити. А також використовується дуже важливий маркетинговий прийом - сегментація ринку, тобто розподіл споживачів на групи на підставі різниці в їх потребах, характеристиках та поведінці. Ринок кормів в включає три базових сегмента.

Перший сегмент - це корми, призначені для годівлі тварин, птахів і риб, як промислового виробництва, так і виготовлені безпосередньо в господарстві.

Другий сегмент - функціональні компоненти і кормові добавки, до яких належать вітаміни, мінерали, амінокислоти, пробіотики і пребіотики, органічні кислоти і ферменти, дріжджові культури і бактерії, антиоксиданти та інші компоненти, а також комплекси з декількох складових, які вирішують ту чи іншу задачу.

До третьої групи відносяться премікси - суміші для балансування кормових раціонів. Вони можуть містити різні функціональні компоненти, в більшості випадків в складі присутні вітаміни і мінерали, але в складні премікси включені також амінокислоти, ферменти (ензими) і інші складові.

Крім того, існує ще один сегмент, який знаходиться між готовими кормами і преміксами - це кормові концентрати (білкові мінерально-вітамінні добавки БМВД, білково-вітамінно-мінеральні концентрати - БВМК, вітамінномінеральні концентрати - ВМК). За своєю суттю концентрати - це менш концентровані премікси, збагачені білком (за винятком ВМК), а в деяких рецептурах також вуглеводами і жирами, які більше підходять для використання в тому числі господарствами, що мають кормову базу і такими, що потребують 


\section{ECONOMIC STRATEGIES FOR THE DEVELOPMENT OF SOCIETY}

iï збагаченні і балансуванні, але при цьому що не володіють технологічними можливостями для використання преміксів.

Разом $з$ тим, слід виділити інші категорії кормів для сільськогосподарських тварин - рослинні корми, сухі корми тваринного походження, корми з риби, м'яса китів та інших водних ссавців, кормові консерви, корми варені, комбікорми та інші. У 2019 р. в загальному обсязі виробництва на комбікорми довелося 88,5\%, на корми інші - 6,1\%, рослинні - ще 5,1\% [112]. У всіх перерахованих вище категоріях готових кормів імпорт незначний, таким чином, обсяги внутрішнього виробництва в цілому характеризують ринок. Після цього приймається рішення щодо маркетингової політики підприємства на ринку кормів (табл.1).

Таблиця 1

Маркетингова політика суб'єктів господарювання на ринку кормів

\begin{tabular}{|c|c|c|}
\hline $\begin{array}{c}\text { Інструменти } \\
\text { комплексу } \\
\text { маркетингу } \\
\end{array}$ & Мета політики & $\begin{array}{c}\text { Інтеграція інструментів } \\
\text { маркетингу }\end{array}$ \\
\hline Товар & $\begin{array}{l}\text { Формування достатнього асортименту та } \\
\text { обсягів виробництва товарних кормів (сіно, } \\
\text { силос, сінаж, кормові добавки, комбікорми), } \\
\text { виведення товару на ринок }\end{array}$ & $\begin{array}{l}\text { Виробництво різних видів } \\
\text { кормів, якість та безпека } \\
\text { кормів, підготовка товару до } \\
\text { продажу, } \\
\text { брендінг, сертифікація та } \\
\text { маркування }\end{array}$ \\
\hline Ціна & $\begin{array}{l}\text { Визначення обгрунтованої ціни відповідно } \\
\text { до споживчої цінності та ії належне } \\
\text { обгрунтування } 3 \text { точки зору сприйняття } \\
\text { споживачами }\end{array}$ & $\begin{array}{l}\text { Преміальна цінова стратегія: } \\
\text { висока ціна відповідає } \\
\text { високій якості товару }\end{array}$ \\
\hline Розподіл & 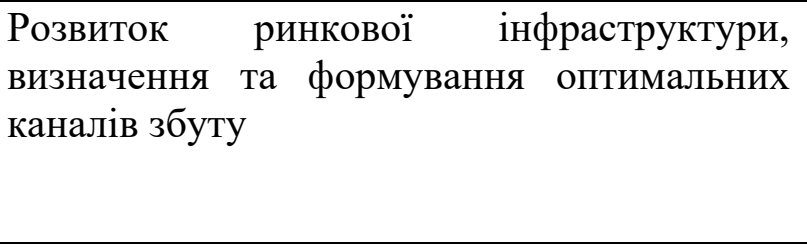 & $\begin{array}{l}\text { Організація фірмової та } \\
\text { спеціалізованої торгівлі, } \\
\text { інтернет-магазинів, } \\
\text { кормових центрів, доставки } \\
\text { та зберігання продукції }\end{array}$ \\
\hline Комунікації & $\begin{array}{l}\text { Формування попиту на промислові корми } \\
\text { (концкорми, премікси, кормові добавки) } \\
\text { готові корми для споживання (повноцінні } \\
\text { кормові раціони, збалансовані за } \\
\text { поживними речовинами відповідно до виду } \\
\text { с.г. тварин та кінцевої продукції } \\
\text { тваринництва), стимулювання збуту грубих } \\
\text { кормів (сіно, сінаж, силос), }\end{array}$ & $\begin{array}{l}\text { реклама, пропаганда, } \\
\text { зовнішня реклама, WOM- } \\
\text { маркетинг, } \\
\text { маркетинг }\end{array}$ \\
\hline
\end{tabular}

Особливістю українського кормовиробництва $є$ вертикальна інтеграція, при якій одне підприємство холдингу вирощує зернові, друге - виробляє 3 них 


\section{ECONOMIC STRATEGIES FOR THE DEVELOPMENT OF SOCIETY}

комбікорми, а третє - згодовує худобі чи птиці, тоді як в Свропі виробники комбікормів - незалежні підприємства. Відтак основне кормовиробництво у нас «прив'язане» до власного споживання, а основні потужності з виробництва комбікормів зосереджені у регіонах 3 найбільшим поголів'ям. Особливістю $є$ також те, що 40\% ринку кормів знаходиться в тіні, а 8 найбільших підприємств виробляють 53\% всіх кормів [112]. Ферми, що не мають матеріально-технічної бази для власного виробництва кормів, змушені купувати їх за ринковими цінами, що часто не відповідає їх купівельній спроможності Тому фермери часто використовують для годівлі тварин зернофураж в чистому вигляді або у вигляді простих зернових сумішей, що знижує продуктивність худоби і конверсію корму, а значить підвищує собівартість виробництва.

Нині існує широкий вибір типів ланцюгів постачання кормів для тваринницьких ферм. Хоча вони не обов'язково присутні у кожному ланцюгу постачання, типові етапи включають виробництво, переробку кормів та приготування кормів на фермі, промислове виробництво кормів на комбікормових заводах та транспортно-логістичну діяльність, що пов’язує їх в етапи життєвого циклу товарного корму (табл. 2).

Таблиця 2

Етапи життєвого циклу в ланцюгах постачання кормів

\begin{tabular}{|c|c|}
\hline Етапи & Характеристика етапу \\
\hline $\begin{array}{l}\text { Виробництво } \\
\text { кормів }\end{array}$ & $\begin{array}{l}\text { Більшість кормових продуктів рослинного походження, їх виробництво } \\
\text { починається } 3 \text { вирощування сільськогосподарських культур. Вирощування } \\
\text { кормових культур відбувається в широкому діапазоні систем посіву з різними } \\
\text { практиками, включаючи міжкультурні, багаторічні культури, пасовищні } \\
\text { системи та лукопасовищні системи. Важливими не рослинними джерелами } \\
\text { сировини для кормів є супутні продукти тваринного походження, такі як } \\
\text { молочні продукти, тваринні жири та олії, кров, рибне борошно. }\end{array}$ \\
\hline Стадія обробки & $\begin{array}{l}\text { Переробка кормів може варіюватися від простої переробки в сільському } \\
\text { господарстві рослинних залишків із використанням різальних машин для } \\
\text { подрібнення або подрібнювачів кормів з низьким рівнем енергії, до складніших, } \\
\text { спеціалізованих промислових процесів, що виробляють більше одного } \\
\text { побічного продукту, наприклад, процес заготівлі вологого консервованого зерна } \\
\text { кукурудзи. }\end{array}$ \\
\hline Eтап комбікорму & $\begin{array}{l}\text { Цей етап включає виробництво в спеціалізованих заводах (цехах) суміші кормів } \\
\text { для різних груп тварин та добавок. }\end{array}$ \\
\hline Ферма & $\begin{array}{l}\text { Етап включає всі ті заходи, пов'язані з підготовкою корму для тварини. Перший } \\
\text { варіант - тварин годують без будь-якої подальшої обробки або змішування. } \\
\text { Другий варіант - первинна переробка кормів (подрібнення, закладання силосу } \\
\text { та сінажу, заготівля сіна). Третій варіант - готові раціони, збалансовані за } \\
\text { поживністю. }\end{array}$ \\
\hline
\end{tabular}




\section{ECONOMIC STRATEGIES FOR THE DEVELOPMENT OF SOCIETY}

\begin{tabular}{|l|l|}
\hline транспортування & Це можна вважати проміжним етапом, що пов'язує чотири основні етапи, і він \\
та зберігання & відрізняється залежно від типу ланцюга живлення. Коефіцієнт використання \\
& транспорту через подачу кормів змінюєтся і може варіюватися від нуля \\
& (наприклад, у системах годівлі на випасі) до використання сили тяги тварин \\
& (наприклад, у змішаних системах вирощування худоби) або залежності від \\
& кормових матеріалів, що торгуютья на міжнародному рівні. Зберігання на \\
& проміжній стадії використовується лише тоді, коли це пов'язано з транспортом і \\
& торгівлею. У ситуаціях, коли зберігання продукту є відповідальністю власника \\
& одного з чотирьох етапів, воно включається в цей конкретний етап. \\
\hline
\end{tabular}

Стратегія ефективного функціонування ринку кормів значною мірою залежить від його маркетингового забезпечення. Маркетинг - це така сукупність відносин і служб організації ринкової діяльності, яка посередництвом забезпечує необхідний рух благ або продукту від виробника до покупця, створюючи сприятливі умови для підприємництва 3 метою найповнішого задоволення потреб споживача [113]. Головне в маркетингу - цільова орієнтація та комплексність, тобто поєднання підприємницької, господарської, виробничої та збутової діяльності. Комплексність означає, що застосування маркетингу забезпечує ефект тільки в тому випадку, якщо він використовується як система. Застосування ж окремих маркетингових дій, як правило, не дає позитивних результатів. Практика застосування маркетингу показала, що використання тільки окремих складових, (наприклад, вивчення товару чи прогнозування ринку) не дає належного ефекту. Тільки комплексний підхід дозволяє ефективно вийти на ринок 3 товарами і послугами, особливо 3 новими товарами й оригінальними послугами $[114,115]$. Таким чином, маркетинг є комплексним, динамічним і складним поняттям у системі суспільного виробництва, в економічній науці та практиці ведення сільськогосподарського виробництва на ринкових засадах.

Однією із особливостей ринку кормів в Україні, є відсутність державного та регіонального регулювання, тобто має місце відсутність або недостатність централізованих стимулів. Держава не здійснює заходів по формуванню цивілізованого конкурентного середовища, що ускладнює здійснення маркетингової діяльності на ринку кормів (табл.3). 


\section{ECONOMIC STRATEGIES FOR THE DEVELOPMENT OF SOCIETY}

Таблиця 3

Нормативно правова база формування ринку кормів в Україні

\begin{tabular}{|c|c|c|}
\hline Назва документа & $\begin{array}{c}\text { Набрав } \\
\text { чинності }\end{array}$ & Основні положення \\
\hline $\begin{array}{c}\text { Закон України «Про } \\
\text { державний контроль за } \\
\text { дотриманням } \\
\text { законодавства про харчові } \\
\text { продукти, корми, побічні } \\
\text { продукти тваринного } \\
\text { походження, здоров’я та } \\
\text { благополучя тварин» } \\
\text { 18.05.2017 № 2042-VIII }\end{array}$ & 04.04 .2018 & $\begin{array}{l}\text { визначає правові та організаційні засади } \\
\text { державного контролю, що здійснюється з метою } \\
\text { перевірки дотримання операторами ринку } \\
\text { законодавства про харчові продукти, корми, } \\
\text { здоров’я та благополуччя тварин, а також } \\
\text { законодавства про побічні продукти тваринного } \\
\text { походження під час ввезення (пересилання) } \\
\text { таких побічних продуктів на митну територію } \\
\text { України. }\end{array}$ \\
\hline $\begin{array}{c}\text { Закон України «Про } \\
\text { безпечність та гігієну } \\
\text { кормів» 21.11.2017 } \\
\text { № 2264-VIII }\end{array}$ & 19.01 .2020 & $\begin{array}{l}\text { визначає правові та організаційні засади } \\
\text { гарантування безпечності кормів у процесі їх } \\
\text { виробництва, обігу та використання, зокрема } \\
\text { встановлює вимоги щодо гігієни, маркування, } \\
\text { пакування та представлення кормів, регулює } \\
\text { відповідні суспільні відносини між операторами } \\
\text { ринку та органами державної влади }\end{array}$ \\
\hline $\begin{array}{c}\text { Постанова КМУ } \\
\text { «Положення про державну } \\
\text { реєстрацію кормових } \\
\text { добавок» від } 3.03 .2020 \text { № } \\
210\end{array}$ & 20.03 .2020 & $\begin{array}{l}\text { визначає порядок державної реєстрації кормової } \\
\text { добавки, підготовку та форму експертного } \\
\text { висновку (експрес-висновку) з рекомендацією } \\
\text { щодо такої реєстрації або її відмови, спрощений } \\
\text { порядок державної реєстрації, перереєстрації } \\
\text { кормових добавок, форму та порядок ведення } \\
\text { Державного реєстру кормових добавок, граничні } \\
\text { обсяги ввезення (пересилання) кормових } \\
\text { добавок, що не включені до Державного реєстру } \\
\text { кормових добавок }\end{array}$ \\
\hline
\end{tabular}

Джерело: сформовано авторами за даними [116]

Попри об’єктивні труднощі з наближенням національного законодавства України про корми до відповідного законодавства Європейського Союзу, в цілому цей процес має позитивний вплив як на розвиток національної правової системи, так і на посилення гарантій безпечності кормів для тварин, людей та навколишнього природного середовища. Крім того, здійснення такого наближення, як правило, має наслідком дерегуляцію та усунення зайвих бюрократичних механізмів, що сприяє створенню кращих умов для ведення бізнесу в цій галузі.

Наявність на ринку агротрейдерів, які повністю контролюють ринок сільськогосподарської продукції робить недоцільним застосування 


\section{ECONOMIC STRATEGIES FOR THE DEVELOPMENT OF SOCIETY}

маркетингових заходів. Сільськогосподарські товаровиробники, які в більшості $€$ дрібними, не можуть контролювати ринок через пропозицію, впливати на ціну, реагувати на незаконні та шахрайські дії більш сильних партнерів. Закони макроекономіки говорять про те, що ситуація, коли на ринку діє дуже велика кількість суб’єктів, які забезпечують пропозицію, є не досить доброю, оскільки вони не здатні впливати на рівень цін.

Корм вважається проміжним продуктом у життєвому циклі ланцюгів постачання тваринницьких ферм, і тому його важко визначити за його функцією щодо споживання людиною. Підхід, прийнятий у цьому посібнику, полягає у визначенні корму за його природою: Будь-який корм, або кормова сировина що призначені для безпосередньої годівлі худобі, кормові добавки, мінерали, синтетичні амінокислоти, тощо розглядаються як кормовий інгредієнт у маркетинговій стратегії ринку кормів.

Безпека кормів і кормових добавок - це відсутність або зведення до мінімуму дії ризиків на всіх етапах (стадіях) процесу їх виробництва (виготовлення), обороту, утилізації та знищення. Управління ризиками для попередження можливого їх шкідливого впливу здійснюється на стадіях вирощування та заготівлі кормів та кормових добавок, а також всіх етапах технологічних процесів їх виробництва (виготовлення), транспортування i зберігання.

Фундаментом системи менеджменту якості кормів та кормової сировини є міжнародні стандарти серії ISO 9000 - системи менеджменту якості (ISO 9000, ISO 9001, ISO 9004), які грунтуються на ідеях і положеннях теорії тотального (загального, комплексного) менеджменту якості. Важливим міжнародним стандартом є ISO 22000 «Системи менеджменту безпеки харчових продуктів. Вимоги до всіх організацій в ланцюзі виробництва і споживання харчових продуктів ». Він узгоджений з ISO 9001 і об'єднує принципи аналізу ризиків у критичних контрольних точках (НАССР) і практичні кроки, розроблені Комісією Кодекс Аліментаріус. Вимоги ISO 22000 призначені для застосування у всіх організаціях в ланцюзі виробництва і споживання харчових продуктів, 


\section{ECONOMIC STRATEGIES FOR THE DEVELOPMENT OF SOCIETY}

незалежно від їх розміру та складності, в т.ч. організаціях прямо або побічно беруть участь в одному або декількох етапах ланцюжка виробництва та споживання харчових продуктів. Виробники кормів i рослинницькі підприємства визначені ISO 22000 як прямі учасники процесу виробництва харчових продуктів.

Маркетингова стратегія ринку кормів в Україні передбачає орієнтацією виробників товарних кормів на цільові групи споживачів (рис.2).

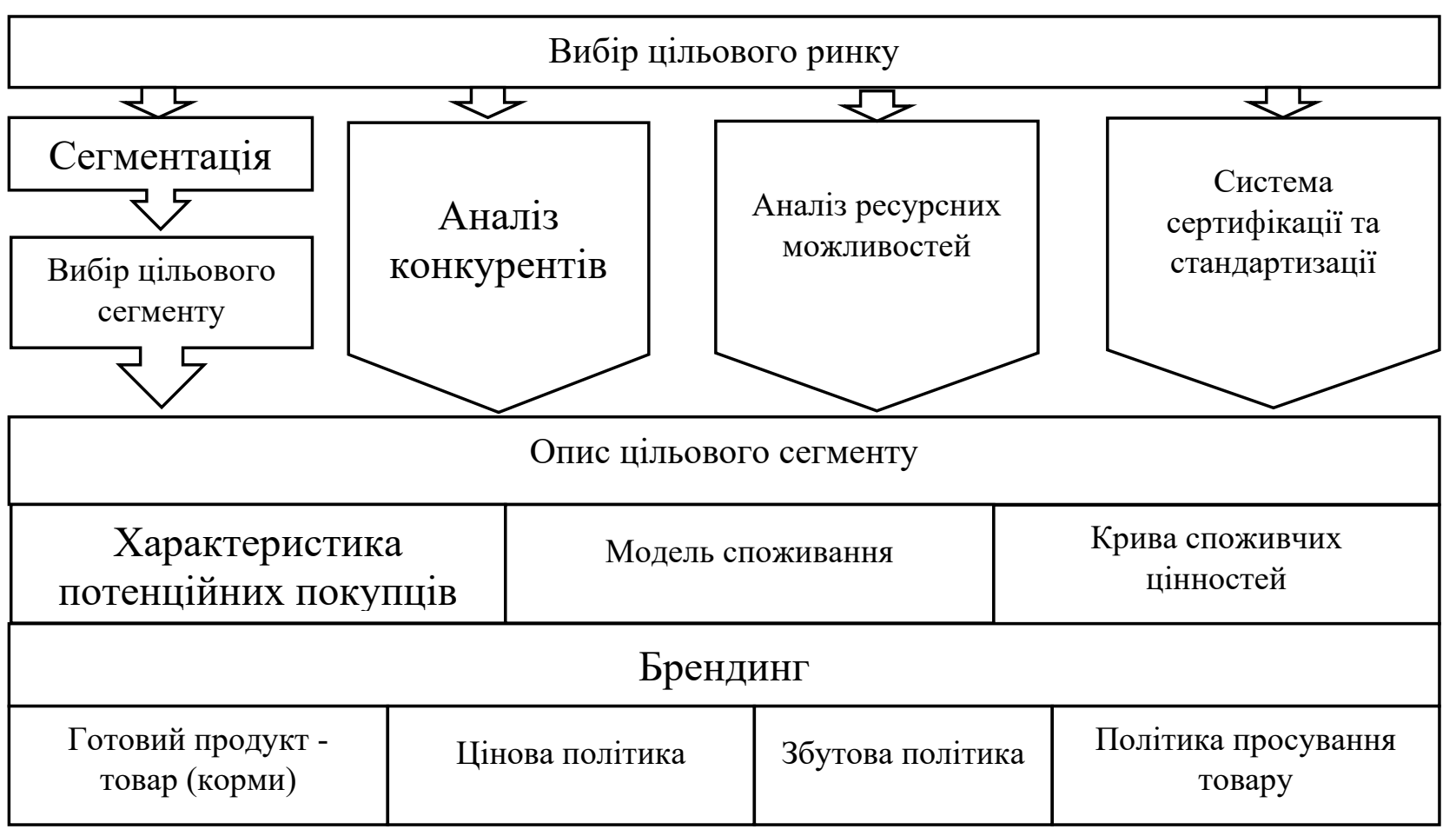

Рис.2 - Етапи формування маркетингової стратегії товаровиробників на ринку кормів (джерело: сформовано авторами за даними $[110,113,115])$

Маркетингова стратегія виробників товарних кормів має базуватися на виокремленні чотирьох ключових аспектів на ринку кормів:

1) прагнення до збільшення прибутку, з огляду на те, що такі показники, як обсяг продажів і частка ринку самі по собі не настільки важливі, як у споживчому маркетингу;

2) визначення потреб клієнтів, для чого потрібне розуміння економічних механізмів поведінки клієнтів, знання структури галузі кормовиробництва, в межах якої вони діють, і їх конкурентних стратегій; 


\section{ECONOMIC STRATEGIES FOR THE DEVELOPMENT OF SOCIETY}

3) відбір цільових груп клієнтів, що мають першорядну важливість, оскільки це $є$ класичною проблемою сегментації ринку, особливе значення якої у агропромислового маркетингу визначається високим ступенем взаємозалежності продавця і споживача після продажу;

4) розроблення продукту чи пакету послуг, тому що в агропромисловому маркетингу продукт рідко буває стандартним, тому необхідно розробляти супутні послуги, часто важливіші, ніж сам продукт.

Зміни в маркетинговій стратегії товаровиробника кормів приведуть до потреби прийняття інвестиційних зобов'язань для придбання нового обладнання, внесення змін у дослідно-конструкторську роботу або відмови від традиційних методів інжинірингу і виробництва. I хоча необхідність у цих кроках можуть виявити маркетологи, саме менеджмент підприємства має визначити напрям, у якому буде працювати товаровиробник і зможе реагувати на потреби ринку кормів, забезпечивши дотримання цього напряму всіма структурними підрозділами.

Залежно від стадії розвитку підприємства та його орієнтації на зовнішнє середовище виділяють три рівні використання маркетингової концепції в управлінні [117] : - на підприємстві ізольовано реалізуються окремі елементи маркетингу (реклама, стимулювання збуту, ціноутворення 3 урахуванням попиту); - на підприємстві використовуються окремі комплекси взаємопов'язаних методів і засобів маркетингової діяльності (розроблення продукції, виходячи 3 оцінки кон'юнктури ринку, післяпродажного обслуговування); - маркетинг стає концепцією ринкового управління підприємства, що зумовлює створення служб маркетингу.

Виробництво, продаж, зберігання й використання кормів і кормових добавок можливе тільки за умови, що вони безпечні, якщо вони використовуються за призначенням i не становлять ризику для здоров'я споживачів. Зокрема, корми, які містять неприпустимі речовини в кількостях, неприйнятних для кормів, повинні бути марковані як непридатні для годування тварин, продаж і використання їх повинні бути заборонені. Тому система 


\section{ECONOMIC STRATEGIES FOR THE DEVELOPMENT OF SOCIETY}

сертифікації та стандартизації готових кормів $\epsilon$ необхідною умовою маркетингової стратегії підприємства на ринку кормів.

Інтерес товаровиробника кормів зосереджений на отриманні найкращої віддачі від своєї продукції, яка зазвичай дорівнює максимальній ціні за необмежену кількість. Фермери хочуть від постачальника кормів продукцію 3 вигідними цінами та найкращу якість. Посередники хочуть високої якості та надійності поставок від виробника за найбільш конкурентоспроможними цінами. Тому сприяючою функцією розвитку ринку кормів є стандартизація продукції, фінансування, прийняття ризиків та аналіз ринку. Функції сприяння це ті заходи, які дозволяють здійснювати процес обміну.

Таким чином, маркетинг ринку кормів - це акт постачання тваринницьким фермам високоякісної продукції за цінами нижче власного виробництва, що сприятимуть підвищенню продуктивності виробництва, ефективності господарської діяльності та зростання доданої вартості. Маркетингова стратегія підприємства-виробника товарних кормів, являє собою систему менеджменту, за якої виробничі рішення приймають після вивчення кон'юнктури й динаміки платоспроможного попиту на продукцію, що виробляється на підприємстві; аналізу зміни цін на продукцію, прогнозування доходів потенційних споживачів, ïx потреб у певному товарі; використання реклами як основного способу нецінової боротьби з конкуруючими фірмами; стимулювання збуту продукції; планування товарного асортименту 3 урахуванням вимог цільових груп споживачів; спеціальна організація після продажного обслуговування споживачів, коли не покупець зацікавлений у товарі, а товар повинен наближатися до потенційного споживача. 


\section{ECONOMIC STRATEGIES FOR THE DEVELOPMENT OF SOCIETY}

\section{4 Процеси централізації та децентралізації в Україні}

Фундаментальною основою структурування та існування апарату державної влади є пов'язаність принципів централізації та децентралізації. Принцип централізації передбачає зміцнення державної влади в центрі, створення ієрархії влади, в якій органи нижчого рівня влади й управління отримують легітимність і юридичну силу від органів вищого рівня. В основі законодавчого регулювання стоїть імперативний метод i метод дозвільного регулювання. Принцип децентралізації побудований на основі територіально-політичної єдності всередині держави 3 допомогою правового розподілення між повноваженнями центральних органів влади та органами місцевого самоврядування. [118]

Варто визначити основні ознаки децентралізації. Серед них: наближення публічної влади до об'єктів управління, громадян; надання населенню можливості долучатися до громадської діяльності на основі прийняття рішень та контролю за їх виконанням; забезпеченість діяльності місцевих органів влади переважно власними ресурсами; гарантована самостійність рішень і дій місцевих владних структур.

Поняття функціонування апарату державного управління передбачає поєднання таких принципів як централізація та децентралізація, які функціонуватимуть в співвідношенні, що забезпечує оптимальний результат.

Принцип централізації будується 3 дотриманням чіткості та єдності, при цьому суть полягає в організації ефективного функціонування органів управління задля впровадження певної політики держави. Централізація передбачає зосередження влади в центрі та єдність політичної влади. Тобто дана система передбачає попереднє ухвалення рішень та передання їх за допомогою вертикалі гілок влади на регіональні рівні. Однак, в зв’язку з неможливістю центральних органів влади володіти повною інформацією щодо стану в регіонах, виникає потреба забезпечення певної автономії органам місцевих рівнів в вирішенні деяких питань, що сприятиме підвищенню оперативності.

В випадку повної централізації складними об’єктами, виникає проблема переробки інформації, тому ефективнішим рішенням є надання максимальної 


\section{ECONOMIC STRATEGIES FOR THE DEVELOPMENT OF SOCIETY}

самостійності. В процесі децентралізації деякі рішення приймаються на нижчих рівнях зі збереженням ефективності функціонування системи як цілого.

Зовнішні та внутрішні обставини змушують організації переходити від централізації до децентралізації чи поєднання цих двох методів, що забезпечувало $б$ реальне здійснення управління. Однак, зважаючи на закономірності розвитку, все більшого значення набуває децентралізація як раціональний спосіб управління.

Розглядаючи процес централізації, слід зазначити, що його перевагами є : зосередження сил на основних напрямках діяльності для задоволення потреб держави; система контролю за діями органів різних рівнів; наявність лідера 3 досвідом та знаннями в даній галузі, який координує діяльність; прийняття рішень здійснюється на рівні держави.

Одночасно, децентралізація має більшу кількість переваг, а саме: гнучке та своєчасне реагування та ситуацію; підвищення швидкості прийняття рішень; підвищення рівня конкуренції в державних органах i, як наслідок, підвищення продуктивності; посилення відповідальності; стимуляція розвитку професійних вмінь службовців; наближення рішень до нижчих рівнів; взаємоконтроль різних гілок влади, що забезпечить ефективніше функціонування владних структур.

Головними недоліками централізації $є$ : неефективність впровадження управлінських рішень; потрібен час для передачі інформації; керівники, які приймають управлінські рішення не здатні повністю оцінити ситуацію на місцевому рівні; безініціативність органів влади в регіонах.

При цьому, можна назвати такі недоліки децентралізації: існує небезпека втрати контролю; з'являється ризик недотримання принципу системного підходу до розробки рішень; між органами влади частково зникає зв'язок, що забезпечує дотримання принципу єдності дій.

Тож поділ між централізацією та децентралізацією повинен підтримувати державне управління та забезпечувати добробут населення, оптимізуючи процеси вирішення питань на загальнодержавному та місцевому рівнях. 


\section{ECONOMIC STRATEGIES FOR THE DEVELOPMENT OF SOCIETY}

Дослідження процесу децентралізації надає можливість отримати певні переваги, а саме: процес децентралізації надає можливість професійного розвитку керівників; децентралізація стимулює ініціативу органів завдяки підвищенню конкуренції, i, як наслідок, підвищення продуктивності їх праці; дана модель організації влади надає більшу самостійність у прийнятті управлінських рішень та дій; в основу даного принципу покладено «механізм стримувань і противаг», суттю якого є збереження взаємоконтролю між гілками влади. [119] Децентралізація є однією з умов демократії та розвитку країни. Для цього необхідно забезпечити доступ громадян до процесу ухвалення рішень, покращення професійного рівня органів місцевого самоврядування з подальшим підвищенням заробітної плати; здійснювати політику, орієнтовану на зменшення диспропорцій між сферами розвитку територіальних об’єднань та самими територіями; створити умови для підвищення ефективності органів самоврядування.

На даному етапі існує 5 основних ознак, що характеризують децентралізацію в європейських державах: оптимальність вирішення питань на місцевому рівні; надання свободи в регіонах завдяки автономії; дотримання мовленнєвої, культурної та культурної різниці між населенням; конкуренція між місцевими та регіональними органами в економічній складовій; демократизація шляхом розвитку місцевої та регіональної автономії.

На території України реформа децентралізації передбачає створення об’єднаних територіальних громад (ОТГ), які створюються шляхом об'єднання на добровільних засадах сусідніх міст, селищ та сіл згідно з Законом України «Про добровільне об'єднання територіальних громад»[120]. При цьому територіальні об’єднання отримують повноваження, які раніше надавалися обласним центрам. В Україні реформу децентралізації планувалося здійснити за допомогою зміни початкової (трьохрівневої) системи управління, тобто провівши адміністративну та фінансову реформи. [121] Сам процес був запущений в 2015 році, було створено 159 громад. В 2016 році - 366 ОТГ, 10 липня 2017 року - 665 ОТГ, в липні 2018 року - 753 ОТГ, в січні 2019 року - 876 


\section{ECONOMIC STRATEGIES FOR THE DEVELOPMENT OF SOCIETY}

ОТГ. Станом на січень 2020 року створено 1029 ОТГ, з який 49 очікують рішення ЦВК про призначення перших виборів, 44 ОТГ з адміністративними центрами в містах обласного значення[122].

До прав, які надаються територіальні громади належать: розроблення стратегії розвитку ОТГ; затвердження та контроль за дотриманням бюджету ОТГ; управління роботою відділів та інших установ, що входять до територіальної громади; змінювати акти, які ухвалені управліннями, службовцями чи іншими суб'єктами, що знаходяться в підпорядкуванні ОТГ та ін. Стратегія розвитку територіальних громад повинна співпадати з стратегією розвитку області. Такі ОТГ мають можливість отримувати фінансування 3 бюджетів своїх областей на програми регіонального розвитку.

В процесі впровадження фінансової реформи були внесені зміни до Податкового та Бюджетного кодексів 3 метою надання органам місцевого самоврядування ширших повноважень в фінансовій сфері. За першими результатами, власні доходи місцевих бюджетів з 2014 по 2017 рік зросли на понад 124 млрд гривень[123]. За підсумками перших 10 місяців 2018 року доходи місцевих бюджетів складали 189,4 млрд грн. [124], а в 2019 році зріст сягнув показника 250,5 млрд грн.

В процесі децентралізації проводилися реформи освіти та медицини. Питання фінансування освітніх закладів було дещо змінено, а саме кошти розподілялися не на заклад, а в розрахунку на кожного учня, що сприятиме підвищенню якості надання освітніх послуг та забезпечить повний доступ населення до середньої освіти [125].

Інститут префектів для нагляду за додержанням законності передбачений проектом закону «Про внесення змін до Конституції України (щодо децентралізації влади)» (№ 2217а від 01.07.2015 р.). Повноваження префектів виписані в ст. 118, 119 документа. Основною ціллю створення інституту префектів є нагляд за дотриманням Конституції та законів України місцевими органами. Діяльність префектів повинна відповідати певним принципам, а саме: верховенства права; законності; відкритості; єдиного правозастосування; 


\section{ECONOMIC STRATEGIES FOR THE DEVELOPMENT OF SOCIETY}

ротації; безперервності; підконтрольності; ефективності; політичної неупередженості. Префектом може призначатися особа, яка на цей момент працює префектом, перебуває в резерві не менше 1 року або ж працювала вже працювала на даній посаді не менше 2 років, а з моменту звільнення пройшло не більше 3 років. Подання на посаду префекта проводиться Кабінетом Міністрів України Президенту України.

Саме надання префектам широких контрольно-наглядових повноважень становить суттєву загрозу для місцевого самоврядування, адже цим самим законом не прописано жодної можливості відстоювати свої законні права та надані їм повноваження, від можливих ситуацій нехтування префектами посадового становища. Та найгіршим $є$ те, що оскаржити рішення про незаконність нормативно-правових актів, органи місцевого самоврядування не мають ніякого права, і їм залишається лише чекати рішення суду. Також, у законопроекті відсутня будь-яка можливість усунення префекта за фактом виявлення недовіри до його рішень певною місцевою радою або можливість дострокового припинення його повноважень, у разі безпідставного i неаргументованого припинення дії певного законодавчого акту. Ще однією із проблем утворення територіальних громад, $є$ те, що велика кількість населення, в тому числі і місцеві державні адміністрації не мають повного розуміння процесу реформування, а тому намагаються запобігти утворенню ОТГ, побоюючись втрати роботи та повноважень.[126]

Досвід різних європейських країн, зокрема Франції, показує, що найбільш сучасна організація державного управління передбачає створення територіальних офісів загальної юрисдикції, очолюваних, як правило, високим представником держави, наділеним загальними функціями управління. Політика децентралізації передбачає передачу послуг і персоналу від місцевих державних адміністрацій до органів місцевого самоврядування. Як наслідок, територіальні офіси/підрозділи центральних державних відомств втрачають операційні функції та легше інтегруються в управління територіального представника центрального уряду[127]. 


\section{ECONOMIC STRATEGIES FOR THE DEVELOPMENT OF SOCIETY}

Українська модель управління має багато спільних рис з моделлю місцевого самоврядування Польщі. Дані моделі підтримують децентралізацію влади, а інститут самоврядування $є$ основою в ії реалізації. Як в Україні, так і в Польщі існує трирівнева система адміністративно-територіального устрою: область/воєводство, район/повіт, громада/гміна. Система місцевого управління України (декларована) та Польщі визначають місцеве самоврядування, як суб’єкт здійснення публічної влади, встановлює баланс між централізацією та децентралізацією в системі управління державою, закріплює існування управлінської моделі, яка базується на двох підсистемах: місцевого самоврядування, в основу функціонування якого покладений принцип децентралізації та урядовій адміністрації, яка діє на засадах централізації.

Ключовою відмінністю системи місцевого самоврядування в Україні та Польщі є наявність державної адміністрації (інститут префекта) в Україні на рівні, як області, так і району. У той час, як у Польщі державної адміністрації на рівні повіту не має, а лише на рівні воєводства функціонує інститут воєводи[128]. 


\section{ECONOMIC STRATEGIES FOR THE DEVELOPMENT OF SOCIETY \\ SECTION 7. ECONOMY OF MANAGEMENT AND ADMINISTRATION OF RADIO TECHNOLOGY}

\subsection{Current state of mechanical engineering of Ukraine, innovations and prospects of its development}

Today the leading role in ensuring the growth of the country's economy is played by industry. Ukraine's industrial production is the basis for scientific and technical, economic and social progress. Domestic mechanical engineering is a component part of industry and the foundation of economic potential of the country. The state of social and economic development of Ukraine depends on the level of efficiency of the enterprises of this branch. So, the actual question is to study the state and trends of development of machine-building complex of Ukraine.

The machine-building complex of Ukraine covers more than 20 specialized branches, that is practically all branches of machine-building. Depending on what market the production let out by the enterprises of a machine-building complex is focused, they are united in following groups:

- investment (heavy) machine-building

- tractor and agricultural engineering

- railroad car

- automotive sector

- electrical engineering, instrument engineering, machine tool engineering.

In Ukraine it is developed wide profile mechanical engineering which enterprises form the difficult, interconnected machine-building complex. It includes all major branches of mechanical engineering. The leading positions are occupied by instrument making, tractor and agricultural engineering. The automotive industry, metal construction industry, machine-tool and tool making industry are developing.

Most of the largest machine-building industries are now focused mainly on the domestic market. Thus, the share of the domestic market in the production of equipment for extractive industry and construction already exceeds $64 \%$, food industry - 67\%, machinery and equipment for agriculture and forestry - 71\%, tools and 


\section{ECONOMIC STRATEGIES FOR THE DEVELOPMENT OF SOCIETY}

equipment for measuring, research and navigation - $77 \%$, batteries and accumulators $78 \%$, electrical wiring and wiring devices $-79 \%$, electrical distribution and control equipment $-84 \%$. The production of components and accessories for motor vehicles remains the most export-oriented among the key branches of mechanical engineering, where $90 \%$ of production was exported, as well as almost $65 \%$ of household appliances, $54 \%$ of electric motors, generators and transformers, $53 \%$ of general purpose machines and equipment, and $46 \%$ of equipment for metallurgy.

Table 1

Characteristics of the pace of development of machine building in Ukraine [1]

\begin{tabular}{|l|c|c|c|}
\hline \multicolumn{1}{|c|}{ Engineering groups } & $\begin{array}{c}\text { Volume of } \\
\text { production in 2018, } \\
\text { Billion UAH }\end{array}$ & $\begin{array}{c}\text { Growth rate of } \\
\text { 2018 to 2012,\% }\end{array}$ & $\begin{array}{c}\text { Share of exports } \\
\text { in the } \\
\text { industry, } \%\end{array}$ \\
\hline Machine building in general & 162,9 & $-22,4$ & 43,8 \\
\hline $\begin{array}{l}\text { Manufacture of machinery and } \\
\text { equipment for agriculture and } \\
\text { forestry }\end{array}$ & 8,35 & $+3,1$ & 28,9 \\
\hline $\begin{array}{l}\text { Manufacture of components, parts } \\
\text { and accessories for motor vehicles }\end{array}$ & 15,47 & $+59,7$ & 90 \\
\hline $\begin{array}{l}\text { Manufacture of electrical } \\
\text { distribution products and control } \\
\text { equipment }\end{array}$ & 4,19 & $+308,2$ & 15,5 \\
\hline
\end{tabular}

Despite the deep decline in recent years, one of the largest industries remains the production of railway rolling stock. By 2018 the enterprises of the industry produced more than 20 billion UAH. The second place is occupied by the production of various components and accessories for motor vehicles (15.5 billion UAH), which now exceeds twice the production of the country's own finished vehicles (6.95 billion UAH). Other largest machine-building sectors in terms of sales volumes are production of machinery and equipment for agriculture, forestry and food industry (10.8 billion $\mathrm{UAH}$ ), production of electrical wiring and wiring devices ( 8 billion UAH), electric motors, generators and transformers (6.06 billion UAH), machinery and equipment for mining and construction (6.2 billion UAH), metallurgy (5.3 billion UAH), electrical distribution and control equipment (4.2 billion UAH), batteries and accumulators (2.6 billion UAH). Large industries of the Ukrainian instrument and machine building 


\section{ECONOMIC STRATEGIES FOR THE DEVELOPMENT OF SOCIETY}

industry also produce tools and equipment for measuring, researching and navigating (5.3 billion UAH), as well as household appliances (4.9 billion UAH).

The analysis of financial results before taxation of large and medium enterprises of industry and machine-building of Ukraine shows that in general the industry of enterprises that have received profit make $116.3 \%$ compared to 2017 , enterprises that have received damage make $84.6 \%$ compared to 2017 . In the machine-building industry, the companies that received a profit make $117.8 \%$ as compared to 2017 , and the companies that received a loss make $76.6 \%$ as compared to 2017 .

Table 2

Financial results before tax for large and medium-sized industrial and machine building companies [1]

\begin{tabular}{|l|c|c|c|c|c|c|}
\hline & \multicolumn{2}{|c|}{$\begin{array}{c}\text { Financial result before } \\
\text { taxation }\end{array}$} & \multicolumn{2}{c|}{$\begin{array}{c}\text { Enterprises, that } \\
\text { made profit }\end{array}$} & \multicolumn{2}{c|}{$\begin{array}{c}\text { Enterprise, } \\
\text { that have received } \\
\text { damage }\end{array}$} \\
\cline { 2 - 7 } & $\begin{array}{c}2018, \\
\text { Million } \\
\text { UAH }\end{array}$ & $\begin{array}{c}2017, \\
\text { Million } \\
\text { UAH }\end{array}$ & $\begin{array}{c}\text { Million } \\
\text { UAH }\end{array}$ & $\begin{array}{c}\text { as a \% } \\
\text { of } \\
2017\end{array}$ & $\begin{array}{c}\text { Million } \\
\text { UAH }\end{array}$ & $\begin{array}{c}\text { as a } \\
\text { of } \\
2017\end{array}$ \\
\hline Industry & 149422,8 & 93970,1 & 256634,6 & 116,3 & 107211,8 & 84,6 \\
\hline Mechanical Engineering & 13446,2 & 8392,2 & 20089,3 & 117,8 & 6643,1 & 76,6 \\
\hline $\begin{array}{l}\text { - computer science, } \\
\text { electronics and optical } \\
\text { industry }\end{array}$ & 1951,5 & 1389,1 & 2073,5 & 133,9 & 122,0 & 76,7 \\
\hline $\begin{array}{l}\text { - electrical equipment } \\
\text { production }\end{array}$ & 4316,8 & 785,4 & 5016,7 & 233,4 & 699,9 & 51,3 \\
\hline $\begin{array}{l}\text { - machinery and equipment } \\
\text { manufacturing, which are } \\
\text { not included in other groups }\end{array}$ & 833,4 & 1030,3 & 5071,9 & 98,8 & 4238,5 & 103,3 \\
\hline $\begin{array}{l}\text { - manufacture of motor } \\
\text { vehicles, trailers and semi- } \\
\text { trailers and other vehicles }\end{array}$ & 6344,5 & 5187,4 & 7927,2 & 96,3 & 1582,7 & 52,1 \\
\hline
\end{tabular}

The research results show that by 2012 the profitability of machine-building enterprises tended to grow. But with the beginning of the political crisis in the country in 2012, since 2013 the profitability of machine-building enterprises tended to decrease and positive values, which indicates the presence of losses in the activities of enterprises. First of all, it is connected with the loss of sales markets in the countries of the Commonwealth of Independent States, the share of which reached $80 \%$ of all machine-building production. 


\section{ECONOMIC STRATEGIES FOR THE DEVELOPMENT OF SOCIETY}

Table 3

Profitability of production facilities for large, medium, small and micro enterprises [1]

\begin{tabular}{|c|c|c|c|c|c|}
\hline \multirow{2}{*}{ Years } & \multicolumn{5}{|c|}{ Profitability of mechanical engineering enterprises, \% } \\
\cline { 2 - 6 } & Total & $\begin{array}{c}\text { Large } \\
\text { enterprises }\end{array}$ & $\begin{array}{c}\text { Medium } \\
\text { enterprises }\end{array}$ & $\begin{array}{c}\text { Small } \\
\text { enterprises }\end{array}$ & Micro enterprises \\
\hline 2010 & 2,6 & 3,0 & 2,1 & 0,0 & $-3,7$ \\
\hline 2011 & 5,2 & 5,8 & 4,7 & 1,4 & 0,1 \\
\hline 2012 & 5,1 & 6,4 & 3,8 & $-0,2$ & 0,1 \\
\hline 2013 & 1,8 & 3,2 & 0,2 & 1,1 & $-1,1$ \\
\hline 2014 & $-13,3$ & $-14,5$ & $-12,3$ & $-10,6$ & $-10,0$ \\
\hline 2015 & $-8,0$ & $-4,3$ & $-11,9$ & $-3,9$ & $-3,5$ \\
\hline 2016 & $-0,4$ & 1,0 & $-2,0$ & 3,5 & $-0,8$ \\
\hline 2017 & 3,0 & 5,4 & 1,5 & 4,5 & 1,3 \\
\hline 2018 & 3,2 & 11,3 & $-1,1$ & 3,4 & 2,8 \\
\hline
\end{tabular}

The export of engineering products from Ukraine in 2018 increased by 9\% from 5,05 to 5,51 billion dollars. With the exception of the countries of the Eurasian Economic Union (EAEC) (Russia, Belarus and Kazakhstan), the growth is higher $14,8 \%$. But such growth is not sufficient to achieve the pre-crisis level. In 2012, machine building exports amounted to $\$ 13,3$ billion. In 2012, the machine-building export amounted to $\$ 13.3$ billion, and outside the EAEC countries it is also more - $\$ 4,7$ billion. The growth is due to the electrical products of international campaigns located on the western border of the country. All other industries, old enterprises in general, reduce exports. Table 4 shows the export volumes of the main groups of engineering products - equipment and machinery, railway transport and electrotechnical industries. Railway transport is mainly wagons. In 2012 they accounted for $20 \%$ of all engineering export from Ukraine. In 2015 the export of wagons, as well as of other railway transport, fell to the minimum values. Exports of equipment and machinery decreased during the crisis in 2015 and almost did not recover. At the same time, exports of electrical products are catching up with pre-crisis indicators. 


\section{ECONOMIC STRATEGIES FOR THE DEVELOPMENT OF SOCIETY}

Exports of major groups of engineering goods, million dollars [1]

\begin{tabular}{|c|c|c|c|}
\hline Years & $\begin{array}{c}\text { Exports of } \\
\text { equipment, million } \\
\text { US dollars }\end{array}$ & $\begin{array}{c}\text { Export of electric transport, } \\
\text { a million US dollars. }\end{array}$ & $\begin{array}{c}\text { Export of railway } \\
\text { transport, } \\
\text { a million US dollars }\end{array}$ \\
\hline 2008 & 3498 & 2843 & 2856 \\
\hline 2012 & 3795 & 3232 & 4107 \\
\hline 2013 & 3841 & 3134 & 2464 \\
\hline 2014 & 2977 & 2682 & 839 \\
\hline 2015 & 1965 & 1979 & 211 \\
\hline 2016 & 2077 & 1561 & 238 \\
\hline 2017 & 2549 & 1728 & 220 \\
\hline 2018 & 2931 & 1726 & 254 \\
\hline
\end{tabular}

If in 2012 the main commodity group were railway wagons, in 2018 their contribution is not visible. Wagons were exported to Russia and other post-Soviet countries. The crisis of 2014-2015 reduced the opportunities for fuel and raw materials countries to buy railcars, besides, they built their factories in Russia. The demand for railcars in the post-Soviet countries fell naturally, no other people appeared. The second place was occupied by engines, mainly turbojet engines. They were sold mainly in Russia and countries bought Russian vehicles. Political reasons led to a sharp decrease in supplies to the Russian Federation, to other countries - old contracts were fulfilled, there were fewer and fewer new ones, because the engines came with Russian supplies. Therefore, the sales of engines did not drop to 0 at once, but is significantly reduced every year.

But the automobile wire came out on the first place and provided the main growth of machine-building export. To a lesser extent the growth was provided by electronic enterprises of foreign investors producing electronic products at enterprises on the western border.

Based on the results of the analysis of the functioning of machine-building enterprises in Ukraine, it can be noted that machine-building plays a major role in strengthening the economic condition of the state, actively influencing the formation of indicators of socio-economic development of Ukraine. Strategic stabilization and 


\section{ECONOMIC STRATEGIES FOR THE DEVELOPMENT OF SOCIETY}

sustainable development of the machine-building industry should become a priority direction for the enterprises and the country as a whole.

All the above problems are to a large extent caused by the lack of real sources of financing, which causes deterioration of material and technical resources, increased depreciation of fixed assets and, consequently, low quality and high cost of products.

The main goal of Ukraine's machine-building development is to satisfy the domestic demand for machine-building products and to expand its presence in foreign markets. The goal should be achieved by transforming the machine-building industry into a competitive, efficient, high-tech and innovation-prone complex that is dynamically developing and integrated into the system of international division of labor.

The conducted analysis shows that the machine-building complex of Ukraine has a significant innovation potential, significant opportunities for formation of new and strengthening of existing competitive advantages both on the external and internal markets gives a great hope for the revival of the machine-building industry. Thus, the further actions of the management of the machine-building enterprises should be directed on development of the effective mechanism of management of financial resources, as a basis of formation of sufficient volume of financing of the activity. 


\section{ECONOMIC STRATEGIES FOR THE DEVELOPMENT OF SOCIETY}

\section{2 Шляхи підвищення конкурентоспроможності вітчизняних підприсмств}

На сьогоднішній період часу, особливо в умовах економічної та політичної нестабільності в Україні, проблема конкурентоспроможності стоїть достатньо гостро, адже саме вона виступає найважливішим фактором забезпечення подальшого динамічного, ефективного та стійкого розвитку підприємства в «суворих умовах дійсності». Основним джерелом забезпечення високого рівня конкурентоспроможності підприємства виступає виробництво високоякісної інноваційної продукції, вдосконалення існуючих та впровадження існуючих i нових прогресивних технологій. Дані характеристики можуть бути забезпечені саме за рахунок розвитку інноваційного потенціалу підприємства.

Якість продукції визначається тим, наскільки повно задовольняються потреби споживача при експлуатації товару. Таким чином, забезпечення якості продукції та дослідження у сфері розвитку інноваційного потенціалу вітчизняних підприємств набувають все більшої актуальність, особливо в умовах сьогодення.

На сьогоднішній час, питання трактування якості продукції відбувається дещо інакше, ніж це було донедавна. Основна увага управління якістю зосереджується на контролі, а це управління якістю старого типу, оскільки якість повинна закладатись в кожен процес створення нової продукції. Вона не може бути досягнутою за допомогою контролю вже випущеної продукції.

Розглядаючи проблему забезпечення якості зарубіжними та вітчизняними вченими, слід звернути увагу, що для забезпечення випуску нової якісної продукції важливим є такі основні елементи [131]:

- якість - це системний процес, відповідає організаційній структурі підприємства. Забезпечення якості не технічна функція, яка контролюється відділом технічного контролю, а системний процес. Новій концепції якості продукції повинна відповідати організаційна структура підприємства;

- якість, орієнтована на задоволення потреб споживача, завдяки застосуванню нових технологій виробництва. Якість забезпечується у виробничому циклі та у процесі підготовки виробництва. Якість має 


\section{ECONOMIC STRATEGIES FOR THE DEVELOPMENT OF SOCIETY}

орієнтуватися на задоволення потреб споживача; для підвищення рівня якості потрібно застосовувати нові технології виробництва;

- зацікавлена участь працівників, процес постійного навчання персоналу. Рівень якості стає кращим при зацікавленій участі працівників, тому що 80-90 \% заходів, спрямованих на підвищення якості, не контролюється відділом технічного контролю; для підвищення рівня якості продукції важливим є процес постійного навчання персоналу [131].

Один із визначних фахівців з проблем якості А. Фейгенбаум (США) звертає увагу на те, що в умовах конкуренції фірми повинні розвиватися, впроваджуючи у практику такі основні напрямки:

- якість $є$ не одним з напрямків діяльності фірми, а безперервним процесом, який стосується всіх функцій апарату управління;

- якість залежить від ступеня участі в ії формуванні кожного працівника фірми;

- якість не перешкоджає, а сприяє зниженню собівартості продукції;

- якість вимагає використання нової техніки і технологи;

- якістю необхідно управляти так само безпосередньо та ефективно, як управляють виробництвом, устаткуванням, фінансами [132].

Випуск ефективної та високоякісної продукції дозволяє підприємству отримати додатковий прибуток за рахунок низьких виробничих витрат, більш високих чистих доходів та більшої частки ринку, а також забезпечити самофінансування виробничого і соціального розвитку. Значна міра чинників, що впливають на якість продукції припадають на етап проектування продукції $80 \%$, потім на процес контролю і регулювання технологічних процесів $15 \%$ і на процес контролю якості готової продукції 5\% [133].

Таким чином, ми бачимо, що якість має першочергове значення для споживача, а для виробника - це запорука конкурентноздатності його продукції на ринку Американські фахівці вважають, що якість це така категорія, яка не підлягає об'єктивному вираженню і кожен визначає iï на власний розсуд. Наприклад, Ф. Кросбі визначає іï як відповідність вимогам, У. Демінг вважає, що 


\section{ECONOMIC STRATEGIES FOR THE DEVELOPMENT OF SOCIETY}

досконалість означає отримання такого рівня якості, на який розраховує ринок, А.В. Фейгенбаум називає якість сукупністю складних ринкових, технічних, виробничих і експлуатаційних характеристик виробу (або послуги), завдяки яким виріб, що використовується (або послуга) відповідає очікуванням споживача [134]. Американське товариство з контролю якості і Американський інститут стандартів визначають якість, як сукупність властивостей i характеристик виробу (або послуги), які визначають його (ii) спроможність задовольнити певні потреби [135].

Варто пам’ятати, що покращення якості продукції на підприємстві вимагає додаткових виробничих витрат, отже, зростає собівартість продукції i, відповідно, iї ціна. Проте додаткові витрати повністю відшкодовуються у вищій ціні більш якісного товару, що забезпечує зростання рівня рентабельності та обсягу прибутку.

Покращення якості товару є ефективним засобом розширення масштабів виробництва і збуту, росту прибутків, розширення сегменту ринку. Слід вкладати кошти не стільки в поліпшення якості існуючих зразків продукції, скільки на оновлення продукції. Саме це є одним із головних завдань підвищення конкурентоспроможності продукції в галузі сільського господарства пріоритетної галузі економіки України.

Для того, щоб витримати конкуренцію на вітчизняному, а в подальшому і на світовому ринку, необхідно вести нові розробки, мати новітні технологи та більш досконалі, ніж у конкурентів, засоби для того, щоб забезпечити відповідну якість випущеної продукції.

Як відомо, рішенню про розробку нової продукції і випуску перших зразків повинно передувати ретельне вивчення асортименту продукції, яка випускається іншими підприємствами у даній галузі, співставлення функціональних параметрів різних моделей нових видів продукції 3 реальними запитами споживачів.

Якість - це не виробнича категорія, а споживча. Категорією виробництва i успішного функціонування підприємства в ринковому середовищі є стабільність 


\section{ECONOMIC STRATEGIES FOR THE DEVELOPMENT OF SOCIETY}

якості, яка визначається, як уже згадувалось, кваліфікацією персоналу, технікотехнологічним забезпеченням виробничого процесу.

Загальновідомо, що у період ринкових перетворень успішний економічний розвиток будь-якої держави зумовлений ефективним функціонуванням вітчизняних суб'єктів господарювання, яке досягається завдяки інноваціям одному із найважливіших факторів забезпечення конкурентоспроможності підприємства. Найефективнішим засобом вирішення даної задачі може служити комплексне моделювання конкурентоспроможності промислового підприємства [136]. Даний підхід дозволяє здійснити оцінку впливу розвитку інноваційного потенціалу підприємства на рівень його конкурентоспроможності на практиці 3 високою долею достовірності.

Щодо переліку параметрів оцінки та ступеня їx конкретизації, рекомендується групувати конкурентні переваги за такими аспектами: конкурентоспроможність виробу; фінансовий стан підприємства; ефективність маркетингової діяльності; рентабельність продажів; ефективність менеджменту; інноваційний потенціал підприємства. Взаємозв'язок розвитку інноваційного потенціалу та рівня конкурентоспроможності можна зобразити на рис.1 [137].

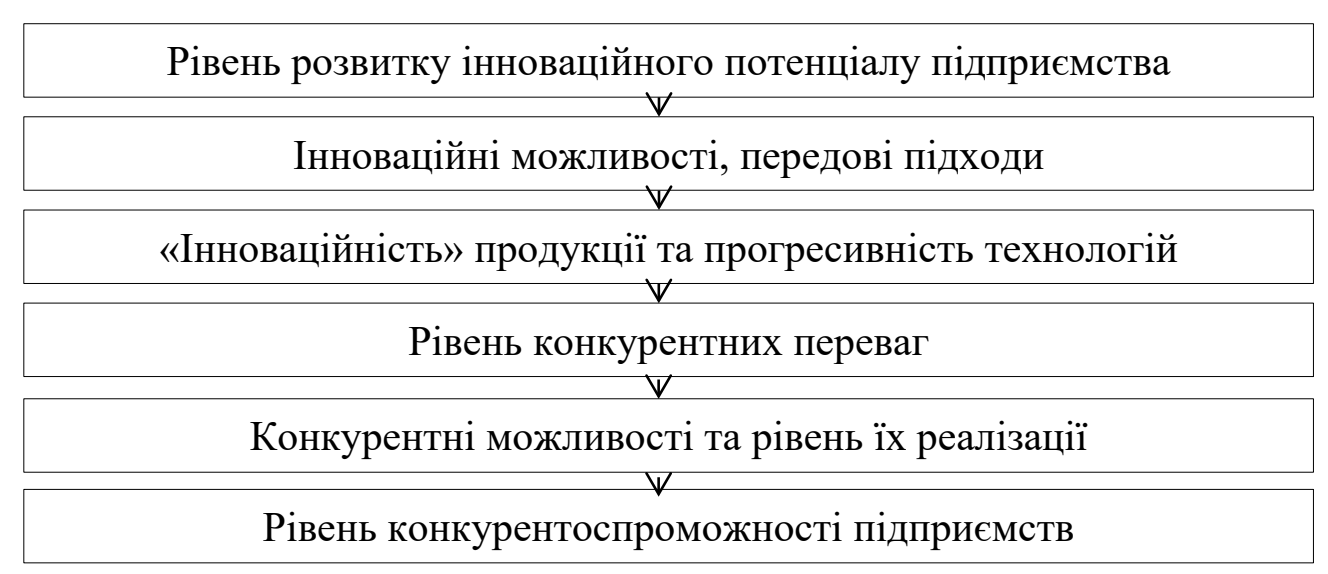

Рис. 1. Взаємозв'язок розвитку інноваційного потенціалу та рівня конкурентоспроможності 


\section{ECONOMIC STRATEGIES FOR THE DEVELOPMENT OF SOCIETY}

Ми бачимо, що схема взаємозв'язку проста. Однак таке зображення дає можливість наочно відобразити роль інноваційного потенціалу в забезпеченні конкурентоспроможності підприємства.

Щодо аграрних підприємств та їхньої конкурентоспроможності, то варто зазначити, що в умовах формування інноваційної економіки ефективність його розвитку визначаються використанням сучасних інноваційних технологій. Впровадження інновацій на аграрних підприємствах сприяє зростанню продуктивності праці, економії різних видів ресурсів, скороченню витрат, зниженню собівартості агропродовольчої продукції і підвищенню економічної ефективності діяльності сільськогосподарських підприємств у довгостроковій перспективі. За предметом і сферою застосування у сільському господарстві доцільно виділяти 8 типів інновацій (табл. 1) [138].

Таблиця 1

Класифікація інновацій за предметом та сферою застосування у сільському господарстві

\begin{tabular}{|c|c|}
\hline Ознака класифікації & Вид інновацій \\
\hline Біологічні & $\begin{array}{l}\text { - нові сорти і гібриди сільськогосподарських рослин; } \\
\text { - нові породи, типи тварин і птиці; } \\
\text { - створення рослин і тварин, стійких до хвороб і шкідників, } \\
\text { несприятливим факторам навколишнього середовища. }\end{array}$ \\
\hline Технічні & - використання нових видів техніки і обладнання. \\
\hline Технологічні & $\begin{array}{l}\text { - нові технології обробки сільськогосподарських культур; } \\
\text { - нові технології в тваринництві; } \\
\text { - науково-обумовлені системи землеробства і тваринництва; } \\
\text { - нові ресурсозберігаючі технології виробництва і зберігання } \\
\text { сільськогосподарської продукції; } \\
\text { - екологізація землеробства. }\end{array}$ \\
\hline Хімічні & $\begin{array}{l}\text { - нові добрива і їх системи; } \\
\text { - нові засоби захисту рослин. }\end{array}$ \\
\hline Економічні & $\begin{array}{l}\text { - нові форми організації, планування і управління; } \\
\text { - нові форми і механізми інноваційного розвитку підприємства. }\end{array}$ \\
\hline
\end{tabular}


ECONOMIC STRATEGIES FOR THE DEVELOPMENT OF SOCIETY

\begin{tabular}{|l|l|}
\hline Соціальні & $\begin{array}{l}\text { - забезпечення сприятливих умов для життя, праці і відпочинку } \\
\text { сільського населення. }\end{array}$ \\
\hline $\begin{array}{l}\text { Інновації } \\
\text { менеджменті }\end{array}$ & $\begin{array}{l}\text { - нові форми організації і мотивації праці; } \\
\text { - нові методи ефективного управління персоналом. }\end{array}$ \\
\hline Маркетингові & $\begin{array}{l}\text { - вихід на нові сегменти ринку; } \\
\text { - удосконалення якості продукції та розширення асортименту; } \\
\end{array}$ \\
& - нові канали розподілу продукції. \\
\hline
\end{tabular}

Найбільш поширеними інноваціями є: нові сорти та гібриди рослин і породи тварин, штами мікроорганізмів, марки і модифікації сільськогосподарської техніки, технології, хімічні та біологічні препарати (вакцини), економічні розробки (документально оформлені методики, різні рекомендації тощо).

Так, станом на початок 2020 до рейтингу «інноваційних компаній» ТОП-100, увійшло п'ять потужних агропідпримств України, серед яких МХП (у 2018 році компанія проінвестувала інновації на 2,5 млн. дол.), Кернел, Нібулон (загальна сума інвестицій в реалізацію проектів компанії в 2019 маркетинговому році склала 85 млн. дол.), Астарта (у 2018 році інвестувала \$ 1 млн. дол. на впровадження інновацій) та ІМК [139].

Роблячи висновок 3 найактуальніших пропозицій, основними шляхами розвитку інноваційного потенціалу вітчизняних підприємств, мають бути [140]:

- освоєння нової техніки та технології;

- впровадження найпрогресивніших технологій зберігання сировини та ресурсів;

- розвиток прогресивних форм організації виробництва;

- проведення технічної реструктуризації підприємства;

- перехід до культури цільового управління, в рамках якої кожна діяльність усередині організації чітко спрямовується на досягнення іiї кінцевих цілей, у тому числі за допомогою працівників інноваторів;

- постійне підвищення рівня кваліфікації персоналу всіх категорій відповідно до сучасних вимог та напрямів знань; 


\section{ECONOMIC STRATEGIES FOR THE DEVELOPMENT OF SOCIETY}

- оптимізація кадрової структури персоналу, стимулювання творчих працівників;

- соціальний розвиток підприємств як одна із складових їх інноваційного потенціалу;

- вивчення та застосування досвіду провідних підприємств світу;

- залучення інвестицій у власні розробки;

- підвищення ефективності планування, організації й контролю інноваційної діяльності;

- використання сучасних засобів та методів підтримки прийняття рішень;

- удосконалення механізмів управління інноваційною діяльністю підприємства в цілому.

Підсумовуючи викладений матеріал, ми бачимо, що створення системи управління якості продукції на підприємствах сільського господарства $\epsilon$ актуальною проблемою.

Для того, щоб висока якість стала дійсно пріоритетом у діяльності підприємств, необхідно вдосконалити систему управління 3 орієнтацією на якість. Така переорієнтація викликана не лише економічними міркуваннями, але й політичними обставинами. Розвинуті країни світу усвідомили необхідність посилення акценту на якості продукції, а не кількості чи ціні. Українські виробники повинні прийняти виклик i активно включитись у міжнародну конкурентну боротьбу на основі якості продукції.

Результати дослідження щодо питань взаємозв'язку розвитку Інноваційного потенціалу вітчизняних підприємств та рівня їх конкурентоспроможності свідчать про безперечну ефективність комплексного розгляду даних компонент управління підприємством. При цьому важливе значення необхідно приділяти врахуванню основних проблем, що стримують інноваційний розвиток українських підприємств, а також його позитивним тенденціям. В свою чергу, дотримання зазначених вище пріоритетів розвитку інноваційного потенціалу як на рівні держави, так i на рівні окремих компаній повинно забезпечити активізацію інноваційної діяльності вітчизняних підприємств, поширення 


\section{ECONOMIC STRATEGIES FOR THE DEVELOPMENT OF SOCIETY}

інновацій в усіх сферах національної економіки, а отже, формування інноваційної моделі розвитку конкурентоспроможності України. Адже саме інноваційний розвиток може забезпечити захоплення стійких позицій на світовому ринку як вітчизняними підприємствами, так і нашою державою в цілому. 
ECONOMIC STRATEGIES FOR THE DEVELOPMENT OF SOCIETY

\subsection{International project management methods as a factor in improving the efficiency of modern domestic management}

The main task of any enterprise is to maximize the use of available financial, production and human resources, which provides:

1) reduction of costs for operational and project activities;

2) implementation of performance appraisal systems;

3) achieving high productivity after possible staff reductions.

To implement this, first of all, helps the design approach, as well as the use of technologies that are based on it. A project is a tool to achieve the goals of an organization or an individual.

The main source of the project is currently considered to be the needs of business, new opportunities, the requirements of the legislature, the need to achieve any technological advantages. By purpose, projects can be divided into three groups:

- strategic - the implementation of which makes significant changes in the work of the organization;

- improvement of operational activities - improve the properties of the components of the organization;

- compliance support - aimed at maintaining the characteristics of the elements of the organization at the required level.

Effective project management is the skillful application of experience, tools, knowledge and techniques needed to achieve the objectives [141].

Today, there are two main independent standards, PMI and IPMA.

PMI (Project Management Institute). The American Institute of Project Management was founded in 1969. PMI has developed and is actively promoting the well-known project management standard The Guide to the PMBOK (Project Management Body of Knowledge).

The US Project Management Institute (PMI) has also developed the following core standards:

- PMI Practice Standard for Work Breakdown Structures - standard for hierarchical structure of works; 


\section{ECONOMIC STRATEGIES FOR THE DEVELOPMENT OF SOCIETY}

- Project Management Competency Development Framework - a guide to assessing and developing organizational skills of project managers;

- Organization Project Management Maturity Model - the standard of technological maturity of corporate project management.

IPMA (International Project Management Association) - an international project management association - was founded in 1965 in Zurich as a non-profit professional association.

These standards are collected in the form of instructions that are widely used in private and public structures around the world. These Project Management Instructions gather all the world's experience in implementing various projects. At the same time, they are constantly improving.

There are several methods of effective project management. The most famous are the Project Management Body of Knowledge and PRojects IN Controlled Environments.

Project Management Body of Knowledge - an organization that has systematized various knowledge and techniques and designed them in the form of standards. The Project Management Institute is based in the United States, unites more than 200,000 management professionals from almost every field of human activity and represents 125 countries. In Ukraine there is a branch of this organization - PMI Kiev Chapter.

The PRojects IN Controlled Environments standard, developed in the United Kingdom, is used mainly in the British Commonwealth.

As for Ukraine, we can say that there are projects in any organization, but most domestic companies are not aware of this. In our country, project management is associated mainly with the construction and implementation of corporate information systems.

The reasons for Ukraine's lag in project management are:

- young age of Ukrainian business,

- lack of qualified personnel in the labor market,

- not always a sufficient level of education of managers,

- general inefficiency of organizational and management structures of enterprises, 


\section{ECONOMIC STRATEGIES FOR THE DEVELOPMENT OF SOCIETY}

- high marginal profit, which was received by companies in the pre-crisis years, which did not contribute to the search for effective management tools.

It can be stated that according to the degree of development of project management, our country is at the level of the United States in the early 1970s. Projects are implemented in Ukraine, but their quality, success rate and final results do not meet modern conditions.

Two technologies based on the application of project management are widespread in the world: "Management by Objectives" (MBO) and "Six Sigma".

Goal Management technology organizes the operational process and contains the following components:

- measured goals obtained as a result of operating activities and set for a short period (usually not more than three months);

- a system for assessing these objectives (KPI);

- tools and techniques, as well as terminology, taken from the field of project management, for planning three-month operational work, their management, control and closure;

- setting the following short-term operational goals, etc.

The "Goal Management" technology is a very successful attempt to combine the implementation of operational (functional) tasks with extremely effective tools for initiating, planning, monitoring and closing project work.

The disadvantage is that Management by Objectives (MBO) is hardly mentioned in any domestic review of the application of the Management by Objectives approach, which significantly reduces the level of understanding and the likelihood of successful implementation in Ukraine.

Six Sigma's quality management strategy was developed by Motorola in 1986 and has been widely used in many sectors of the economy - it identifies and eliminates defects and inconsistencies in business processes and production [143].

When implementing projects aimed at improving existing business processes, a sequence of stages of the DMAIC concept is used: 


\section{ECONOMIC STRATEGIES FOR THE DEVELOPMENT OF SOCIETY}

1) Define (definition of project objectives and consumer requests - internal and external);

2) Measure (measurement of key aspects of the process);

3) Analyze (analysis and determination of the root causes of defects);

4) Improve - process improvement - reduction of defects;

5) Control (control of the further course of the process).

The sequence of the DMADV concept, which is used in the development of new products / services, provides:

1) Define (definition of project objectives and consumer requests - internal and external);

2) Measure (measurement of key aspects of the product / service);

3) Analyze (analysis and determination of the root causes of defects);

4) Develop (development);

5) Verify (verification of compliance of the developed product characteristics necessary) [142].

As an important, but not the only element of the overall quality system of the organization can be considered a project management system. Its need in modern conditions is caused both by the essence of the MBO methodology (it can also be considered an element of quality) and by the very definition of "Six Sigma". In both approaches we see the use of project management as a tool for managing targets.

In general, Ukrainian companies do not work according to a single system "Management by Objectives", and even more so - according to the method of "Six Sigma". Their elements may be present, but just as elements. Thus, project offices (one of components of system of management of projects) in organizational structures sometimes meet. If you compare the situation today and a few years ago, then this is a good indicator [144].

To solve this problem, it is necessary to improve the skills of project managers, the understanding of senior managers of the need for project management, the level of organization of structures in companies. 


\section{ECONOMIC STRATEGIES FOR THE DEVELOPMENT OF SOCIETY}

Today, the presence or absence of at least an idea of the project management system indicates the degree of compliance of the organization with modern conditions. The company's ability to apply modern management methods in practice is actually an

indicator of successful project implementation and the most important factor that separates amateurs from those who are able to survive in the current environment. 


\section{ECONOMIC STRATEGIES FOR THE DEVELOPMENT OF SOCIETY}

\section{4 Ризики зовнішньоекономічної діяльності агропромислових підприємств}

Досліджено питання терміну «ризик», зокрема його значення у різних мовах, еволюцію наукових поглядів та сучасні теоретичні підходи до тлумачення сутності поняття «ризик ЗЕД» із урахуванням особливостей ризику. Запропоновано визначення економічної категорії «ризик зовнішньоекономічної діяльності» - як можливості позитивних та негативних відхилень від прогнозованого бажаного результату прийнятих рішень, пов'язаних 3 інтеграцією вітчизняного підприємства у світову економіку та здійсненням зовнішньоекономічних угод.

Досліджено погляди різних науковців щодо систематизації причин виникнення зовнішньоекономічних ризиків. Встановлено, що наявні систематизації ризиків ЗЕД не охоплюють всього переліку ризиків у ЗЕД; ознаки та визначені на їх основі групи ризиків не в повній мірі відповідають цілям управління. Систематизація ризиків зовнішньоекономічної діяльності агропромислових підприємств передбачає розподіл ризиків на групи за такими ознаками: відношення до договірного процесу, вид зовнішньоекономічної діяльності та напрямок здійснення зовнішньоторговельних операцій.

Розвиток зовнішньоторговельних зв'язків агропромислових підприємств потребує розширення спектра знань та поінформованості товаровиробників для досягнення успіху та формування гідного іміджу на міжнародних ринках. Нині неможливо досягти успіху на зовнішньому ринку без розуміння і врахування світових тенденцій у бізнесі. Саме тому вихід на зовнішні ринки є об'єктивною необхідністю для агропромислових підприємств.

Однак нині процес освоєння товаровиробниками міжнародних ринків супроводжується труднощами і проблемами. Управління ризиками є однією 3 найважливіших складових економічної діяльності під час ведення зовнішньоекономічної діяльності (ЗЕД) будь-яких підприємств і зачіпає не лише економічну систему, а й політичну. Дане питання особливо актуальне, оскільки 


\section{ECONOMIC STRATEGIES FOR THE DEVELOPMENT OF SOCIETY}

Україна веде активну інтеграцію в світову економічну систему, в умовах якої управління зовнішньоекономічним ризиком виступає основним критерієм успішності, тому що обсяг і рівень ризиків під час ЗЕД є відповідно більшим та вищим, ніж у інших сферах діяльності підприємства.

Проблемі ризиків зовнішньоекономічної діяльності агропромислових підприємств присвячені роботи численних іноземних і вітчизняних науковців. Серед вітчизняних слід відзначити Л.Бірдус [145], В. Вітлінський [146,147], В.Готра [148], О.К.Гудим [149], В. Кігель [150] та інших. Аналіз наукових робіт зазначених авторів дає можливість здійснити класифікацію основних причин виникнення ризиків зовнішньоекономічної діяльності агропромислових підприємств

Дослідженням встановлено, що зовнішньоекономічна діяльність агропромислових підприємств свідчить про те, що вона супроводжується значною кількістю перешкод, які спричинені ризиками.

Дослідження ризиків зовнішньоекономічної діяльності агропромислових підприємств підтверджує актуальність і в той же час складність досліджуваної проблеми, важливість і1і рішення для підвищення ефективності функціонування сільськогосподарських підприємств, сприяння нарощуванню обсягів виробництва, конкурентоспроможності сільськогосподарської продукції та дає можливість доступу до міжнародних ринків.

Практичне значення отриманих результатів полягає у тому, що отримані результати і запропоновані висновки допомагають приймати виважені рішення щодо вдосконалення організації зовнішньоекономічної діяльності агропромислових підприємств.

Термін - ризик у різних мовах означає близькі поняття: у перекладі 3 грецької слова - ridsikon, - ridza означають «скеля»; в італійській мові -risiko «небезпека, загроза» і - risicare - «лавірувати між скелями»; у французькій - risqoe - «оминати стрімчак, скелю» [151]. Версія запозичення англійського терміну risk iз французької мови в середині XVIII ст. як варіант французького слова risqué у значенні «ризикований, сумнівний» [152]. Г. М. Коломієць та Ю. Г. 


\section{ECONOMIC STRATEGIES FOR THE DEVELOPMENT OF SOCIETY}

Гузненков вважають початком застосування терміна - risk в англійській страховій практиці 30-ті pp. XIX ст. До цього часу в англомовній економічній літературі широко застосовувався термін - hazard «небезпека» [153]. Вперше термін “ризик” на науковому рівні було використано у 1786 році Йоганном Ніколасом Тетенсом у праці “Вступ до розрахунку життєвої ренти і право на їі отримання".

В сучасній українській мові термін - «ризик» визначено як «усвідомлену можливість небезпеки», а також як «ініціативний вчинок за сподіванням на успіх чи можливість збитків у разі невдачі в якійсь справі» [154].

В сучасній економічній системі будь-яка діяльність обумовлена появою ризиків, які призводять до небажаних наслідків (в тому числі збитків) для системи чи іï структурних складових. Самі ж ризики - це можливі несприятливі події, що з певною вірогідністю можуть відбутися, і в результаті яких можуть виникнути збитки, майнові втрати.

Ризик - це вибір, дії, які необхідно здійснити, при умові нестачі інформації. Сама по собі суб'єктивність ризику зумовлюється тим, що в економіці діють реальні люди зі своїми досвідом, психологією, інтересами, смаками, схильністю чи несхильністю до ризику, зі своєю поведінкою тощо. Суб'єктами ж ризику є особа або певний колектив, які зацікавлені в результатах управління об'єктом ризику i мають відповідну компетенцію щодо управління i прийняття відповідних рішень стосовно об'єкта ризику[155].

Дослідження ризику, як економічного явища, питання, пов'язані з змістом, джерелами, видами, класифікацією ризиків зовнішньоекономічної діяльності, проаналізовано та вивчено в роботах закордонних та вітчизняних науковців, зокрема: А.Свтєєва, Д.Счкалова[, О.С. Крупицької, Н.Ларіонової, О.Л.Маханець[156], С.Подрєзи, М. Салун, Ф.Найт, Майкл Є. Портер, Ф.Хайек та інші. Дослідники та науковці по-різному вирішують проблему визначення сутності ризику ЗЕД, оскільки ризик ЗЕД вважається багатофункціональною складовою ризику діяльності підприємства.

Визначення ризику у довідниках міжнародних організацій: 


\section{ECONOMIC STRATEGIES FOR THE DEVELOPMENT OF SOCIETY}

- ризик - це вплив невизначеності на досягнення цілей, при чому даний вплив може бути позитивним, негативним або зумовити відхилення від очікуваного результату. Маємо три категорії: ризики як небезпека (чисті ризики), ризики як невизначеність, ризики як можливість (спекулятивні ризики). (ISO Міжнародна організація зі стандартизації ) [157];

- ризик - невизначеність події, настання якої може мати суттєвий вплив на досягнення цілей. Ризик вимірюється наслідками та ймовірністю їх прояву. (IIA - Інститут внутрішніх аудиторів) [157].

Узагальнюючи результати проведеного дослідження існуючих наукових підходів, вважаємо, що зовнішньоекономічним ризиком $є$ можливість позитивних та негативних відхилень від прогнозованого бажаного результату прийнятих рішень, пов’язаних з інтеграцією підприємства у світову економіку та здійсненням зовнішньоекономічних угод.

Зовнішньоекономічна діяльність підприємства, як і будь-яка інша, пов ‘язана 3 необхідністю приймати ризиковані управлінські рішення, що можуть призвести до відхилень від намічених цілей. Однак обсяг та рівень ризиків у ЗЕД є відповідно більшим та вищим, ніж у інших сферах діяльності підприємства. Оскільки ризик ЗЕД - багатофункціональна складова ризику [158], різні дослідники та науковці по-різному вирішують проблему визначення сутності ризику ЗЕД.

Результати опрацювання трактування сутності ризику представлені в узагальненні поняття «ризики зовнішньоекономічної діяльності» за ознаками класифікації такими, як «вид зовнішньоекономічної діяльності», «напрямок здійснення зовнішньоторговельних операцій підприємства», «відношення до договірного процесу» в Таблиці.1.1. 


\section{ECONOMIC STRATEGIES FOR THE DEVELOPMENT OF SOCIETY}

Табл. 1.1

\section{Ризики зовнішньоекономічної діяльності}

\begin{tabular}{|c|c|c|c|c|}
\hline $\begin{array}{l}\text { Групи ризиків } \\
\text { ЗЕД }\end{array}$ & \multicolumn{4}{|c|}{ Класифікації ризиків } \\
\hline \multirow[b]{2}{*}{$\begin{array}{c}\text { Ризики зовнішньо- } \\
\text { економічної } \\
\text { діяльності } \\
\text { підприємства за } \\
\text { напрямками } \\
\text { зовнішньо- } \\
\text { торгівельних } \\
\text { операцій }\end{array}$} & $\begin{array}{c}\text { виробничо-збутової } \\
\text { кооперації }\end{array}$ & $\begin{array}{r}\text { науков } \\
\text { о-технічної } \\
\text { кооперації }\end{array}$ & $\begin{array}{l}\text { зовнішньоекономіч } \\
\text { них кредитних } \\
\text { операцій }\end{array}$ & $\begin{array}{c}\text { міжнародн } \\
\text { их операцій } 3 \\
\text { цінними } \\
\text { паперами } \\
\end{array}$ \\
\hline & $\begin{array}{c}\text { зовнішньо- } \\
\text { економічних } \\
\text { лізингових та } \\
\text { орендних операцій }\end{array}$ & $\begin{array}{c}\text { ризик } \\
\text { витоку } \\
\text { секретної } \\
\text { інформації, } \\
\text { розкриття } \\
\text { комерційно } \\
\text { ї таємниці } \\
\text { підприємст } \\
\text { ва } \\
\end{array}$ & $\begin{array}{c}\text { участі у } \\
\text { міжнародних заходах } \\
\text { (семінари, виставки, } \\
\text { ярмарки, конференції } \\
\text { тощо }\end{array}$ & $\begin{array}{c}\text { - ризик } \\
\text { плинності } \\
\text { кадрів - } \\
\text { стажування } \\
\text { управлінських } \\
\text { кадрів за } \\
\text { кордоном }\end{array}$ \\
\hline \multirow{2}{*}{$\begin{array}{c}\text { Ризики } \\
\text { зовнішньоекономіч } \\
\text { ної діяльності } \\
\text { підприємства щодо } \\
\text { основних видів } \\
\text { ЗЕД }\end{array}$} & $\begin{array}{l}\text { експорт і імпорт } \\
\text { товарів та послуг }\end{array}$ & $\begin{array}{l}\text { інвестиційн } \\
\text { а діяльність }\end{array}$ & $\begin{array}{c}\text { виробничо-технічна } \\
\text { співпраця }\end{array}$ & $\begin{array}{c}\text { науково- } \\
\text { технічна } \\
\text { співпраця } \\
\end{array}$ \\
\hline & політичні & $\begin{array}{c}\text { загально } \\
\text { економічні } \\
\text { (валютні, } \\
\text { конкуренці } \\
\text { я, } \\
\text { інфляційні) } \\
\end{array}$ & $\begin{array}{c}\text { правові (податкові, } \\
\text { загальні ЗЕД, } \\
\text { сертифікації і } \\
\text { стандартизації, загальні } \\
\text { господарські) }\end{array}$ & $\begin{array}{c}\text { ризики форс- } \\
\text { мажорних } \\
\text { обставин }\end{array}$ \\
\hline \multirow{3}{*}{$\begin{array}{c}\text { Ризики } \\
\text { зовнішньоекономіч } \\
\text { ної діяльності } \\
\text { підприємства за } \\
\text { відношенням до } \\
\text { договірного } \\
\text { процесу }\end{array}$} & $\begin{array}{c}\text { пов'язані із ціною } \\
\text { товару }\end{array}$ & $\begin{array}{c}\text { ризики } \\
\text { контрагент } \\
\mathrm{a} \\
\end{array}$ & \multirow{2}{*}{$\begin{array}{c}\text { ризики виконання } \\
\text { контракту } \\
\text { підприємством } \\
\text { (виробничі, збутові, } \\
\text { ризик фінансової } \\
\text { стійкості та } \\
\text { ліквідності, } \\
\text { транспортні, } \\
\text { сертифікації та } \\
\text { митного оформлення) }\end{array}$} & $\begin{array}{c}\text { зовнішні щодо } \\
\text { контракту }\end{array}$ \\
\hline & $\begin{array}{c}\text { пов'язані із } \\
\text { пред‘явлен- } \\
\text { ням } \\
\text { рекламацій та } \\
\text { застосуван-ням } \\
\text { штрафних санкцій }\end{array}$ & $\begin{array}{c}\text { пов'язані із } \\
\text { умовами } \\
\text { поставки та } \\
\text { оплати }\end{array}$ & & $\begin{array}{c}\text { пов'язані із } \\
\text { визначенням } \\
\text { форс- } \\
\text { мажорних } \\
\text { обставин }\end{array}$ \\
\hline & $\begin{array}{c}\text { пов ‘язані вимогами } \\
\text { щодо упаковки та } \\
\text { маркування } \\
\text { продукції за } \\
\text { зовнішньоекономіч } \\
\text { ним контрактом, }\end{array}$ & $\begin{array}{c}\text { невірного } \\
\text { визначення } \\
\text { характеру } \\
\text { зовнішньо- } \\
\text { економічно } \\
\text { го } \\
\text { контракту }\end{array}$ & $\begin{array}{c}\text { пов ‘язані із предметом } \\
\text { контракту, кількісними } \\
\text { та якісними } \\
\text { характеристиками } \\
\text { продукції }\end{array}$ & $\begin{array}{l}\text { ризики, } \\
\text { пов’язані } 3 \\
\text { умовами } \\
\text { контракту }\end{array}$ \\
\hline
\end{tabular}

Джерело: побудовано автором

Проведений аналіз дозволяє зробити висновок, що на даний час існує значна кількість підходів до класифікації ризиків, проте досі не розроблено єдину систему класифікації ризиків ЗЕД, яку б можна було застосувати для ефективного управління ними.

В залежності від виду ризиків на їх зростання можуть впливати: 


\section{ECONOMIC STRATEGIES FOR THE DEVELOPMENT OF SOCIETY}

- раптове виникнення проблем (виробничих, політичних, соціальних);

- нереальність виконання поставлених завдань у зв'язку зі зміною обставин;

- недосконале нормативне законодавство;

- відсутність додаткової інформації.

До принципів класифікації ризиків ЗЕД відносять відповідність цілям підприємства, системний підхід, деталізацію одного порядку для ризикових ситуацій однієї групи та іiї відповідність цілям класифікації, наявність різноманітних ризиків у певній ризиковій ситуації [159].

Отже, ризиком у зовнішньоекономічній діяльності є:

- можливі несприятливі події з негативними наслідками для ЗЕД;

- комбінація події, взаємопов'язаної із ЗЕД, ймовірності цих подій та їх результатів несприятливого характеру;

- небезпеку втрат внаслідок невиконання зобов“язань стороною контракту, політичних чи макроекономічних змін на рівні країни;

- сукупність ризиків окремих зовнішньоторговельних угод; сукупність факторів, що мають негативний вплив на ЗЕД i результати діяльності підприємства; категорію, яка відображає результат реалізації рішення у вигляді успіху, невдачі або відхилення від мети у ЗЕД;

- особливий вид підприємницького ризику, що відображає системну невизначеність результатів інтеграції підприємства у світову економіку; характеристику ситуації прийняття рішення в ЗЕД з можливими втратами та загрозами для виробництва та реалізації.

Неминучість ризику господарської діяльності викликана дією об'єктивних законів ринкового механізму, свободою підприємництва і конкуренцією. При цьому чинники ризику ділять на зовнішні і внутрішні $[160,161]$.

Виникнення об'єктивних чинників зовнішнього ризику обумовлене системою взаємозв'язку і взаємодії господарюючих суб'єктів між собою, 3 державними структурами, податковими, фінансовими інститутами, зовнішньо торговельними організаціями тощо. Чинниками зовнішнього ризику виступають соціально-політичні умови, загальноекономічна обстановка, 


\section{ECONOMIC STRATEGIES FOR THE DEVELOPMENT OF SOCIETY}

зовнішньоекономічна ситуація, ринкова обстановка, соціально-демографічна ситуація, нормативно-правова база, науково-технічний рівень, інформаційна база, природно-кліматичні умови.

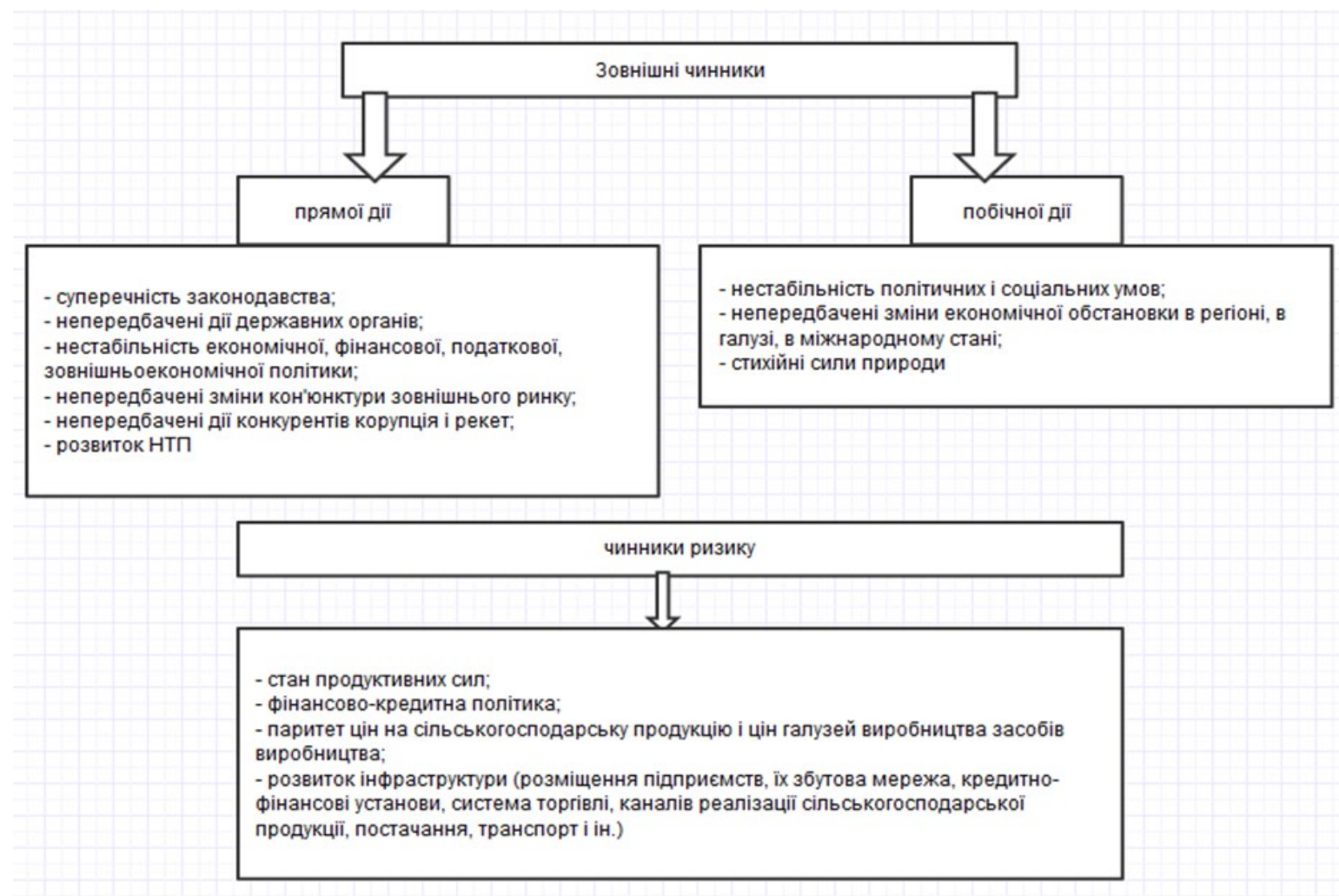

Рис. 1.2. Зовнішні чинники виникнення ризиків

Джерело: побудовано автором [160,161]

Крім зовнішньої дії галузі аграрного сектора випробовують на собі вплив величезної кількості чинників внутрішнього середовища сільськогосподарського виробництва, таких як інтенсивність (екстенсивність) виробництва, ресурсний потенціал, система ведення землеробства, сорти вирощуваних культур, система вирощування сільськогосподарських тварин, їх породи, форма організації виробництва, кваліфікація персоналу, тощо. При цьому особливу групу чинників серед внутрішніх займають чинники ризику у сфері управління економічними процесами. 


\section{ECONOMIC STRATEGIES FOR THE DEVELOPMENT OF SOCIETY}

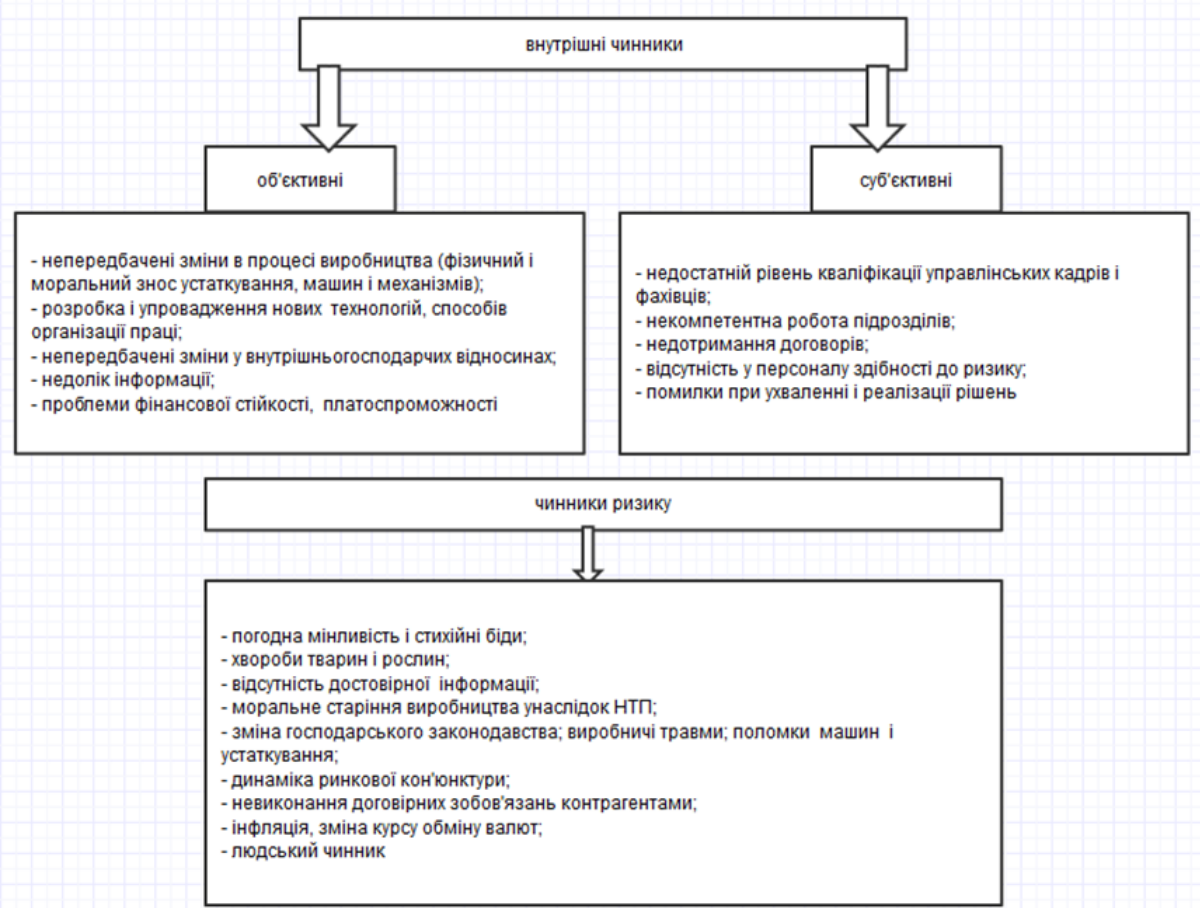

Рис. 1.3. Внутрішні чинники виникнення ризиків

Джерело: побудовано автором [160,161,162].

Сільськогосподарським виробникам необхідно аналізувати ретроспективу $\mathrm{i}$ формувати перспективу, оцінюючи послідовність і пріоритетність своїх зусиль 3 підвищення конкурентоспроможності та врахуванням ризиків у зовнішньоекономічній діяльності.(Табл. 1.2).

Табл. 1.2

Етапи діяльності агропромислових підприємств 3 метою підвищення конкурентоспроможності

\begin{tabular}{|c|c|}
\hline Етапи & Зміст діяльності \\
\hline I & $\begin{array}{l}\text { головні зусилля слід спрямовувати на: } \\
\text { - } \quad \text { виробництво сільськогосподарської товарної продукції } \\
\text { - } \quad \text { придбання сільськогосподарських } \quad \text { машин, пристроїв } \\
\quad \text { первинної обробки сировини } \\
\text { - } \quad \text { впровадження сучасних технологій. }\end{array}$ \\
\hline II & $\begin{array}{ll}\text { - } & \text { впровадження конкурентноспроможних технологій } \\
\text { - } & \text { оновлення видів продукції рослинництва і тваринництва } \\
\text { - } & \text { впровадження комплексних систем управління якістю праці і } \\
& \text { продукції, }\end{array}$ \\
\hline
\end{tabular}




\begin{tabular}{|c|c|}
\hline III & $\begin{array}{l}\text { об’єктивною необхідністю є : } \\
\text { - } \quad \text { якісне навчання маркетинговим процесам, методам вивчення } \\
\text { попиту в умовах існуючої кон'юнктури зовнішнього ринку та } \\
\text { ін. } \\
\text { - } \\
\text { інтенсифікації комерційних зусиль, тобто збуту. }\end{array}$ \\
\hline IY & $\begin{array}{l}\text { - } \text { орієнтація на закордонного споживача, його потреби, його } \\
\text { інтереси, його запити } \\
\text { - } \text { створення маркетингової концепції. }\end{array}$ \\
\hline
\end{tabular}

Визначаючи специфіку ризиків у сфері аграрного виробництва, переважно мають на увазі небезпеку виникнення різних втрат і збитків. Однак, якщо б ризик був пов'язаний лишень 3 можливими негативними наслідками, то єдине рішення - вийти із зони ризику. Однак господарські рішення, пов'язані з ризиком, передбачають і можливість одержання додаткових прибутків. Тобто ризик дає шанс одержати додатковий дохід і водночас допускає ймовірність опинитися в програші. Джерелом небажаних обставин можуть бути всі стадії відтворення, починаючи із придбання необхідних засобів виробництва (насіння, посадковий матеріал, добрива, агрохімікати, корми) і закінчуючи виробництвом продукції та iii реалізацією. Кваліфіковане застосування усього інструментарію управління ризиками у зовнішньоекономічній діяльності дозволить визначити їх оптимальний рівень, який сприятиме розвитку агропромислових підприємств та зростанню прибутку від діяльності на міжнародних ринках.[163]

Таким чином, проведений аналіз сучасного стану зовнішньоекономічної діяльності агропромислових підприємств на світовому ринку свідчить про те, що вона супроводжується значною кількістю обмежень i труднощів, які зумовлюють торгівельні ризики. У вітчизняній та зарубіжній літературі розрізняють кілька видів ризиків зовнішньому ринку:

- $\quad$ ринкові (збутові), які пов'язані зі зниженням попиту на певних зарубіжних ринках або зі зниженням світових цін;

- політичні, які пов'язані з введенням обмежень, ембарго тощо; 


\section{ECONOMIC STRATEGIES FOR THE DEVELOPMENT OF SOCIETY}

- комерційні, які зумовлені недобросовісністю або неплатоспроможністю покупця;

- виробничі (зміни собівартості продукції та послуг через ріст затрат на матеріали та комплектуючі, на оплату праці тощо, труднощі в організації виробництва, підготовці кадрів і т. д.)

- науково-технічні, які зумовлені труднощами освоєння нових технологій під час ліцензійного обміну, спільної діяльності;

- інфляційні;

- валютні, які пов'язані з можливою зміною валютного курсу;

- непередбачувані ризики, які пов'язані зі стихійним лихом та іншими нездоланними труднощами.

Проведений аналіз і структуризація ризиків, а також використання відповідних моделей дають змогу приймати правильні рішення в цій сфері діяльності. Воднораз для розв'язання існуючих проблем і сприяння розвитку діяльності товаровиробників на зовнішніх ринках необхідно забезпечити:

- розвиток ринкової та транспортної інфраструктури, зокрема підприємств із надання страхових, консалтингових, інжинірингових, експедиторських послуг;

- підтримку експорту вітчизняних товаровиробників;

- удосконалення форм фінансових розрахунків під час зовнішньоторговельних операцій;

- посилення ролі державного регулювання зовнішньоторговельної діяльності;

- оптимізацію структури експорту та імпорту, розширення товарної пропозиції та стимулювання процесу надходження іноземного капіталу.

Формуючи власні експортні стратегії виходу на ринок виробники мають враховувати, що існує два шляхи імпорту товарів. Перший спосіб здійснюється через реекспортні поставки спеціалізованими компаніями, а інший варіант передбачає спільне підприємництво з партнерами. 


\section{ECONOMIC STRATEGIES FOR THE DEVELOPMENT OF SOCIETY}

В результаті дослідження можна зробити висновок, що в межах зовнішньоекономічних відносин 3 партнерами реалізуються очікування щодо залучення іноземних інвестицій в аграрний сектор. Така співпраця дозволить диверсифікувати структуру експорту вітчизняних товарів сільськогосподарського виробництва, а також розширить експортний потенціал. Зокрема, Україна має оптимальні кліматичні умови та природні й трудові ресурси для розвитку експортного потенціалу аграрного сектора економіки, проте існує багато проблем. Значний вплив політичних факторів та корупція перешкоджають розвитку та реалізації експортного потенціалу. Наразі держава може зберегти європейські ринки і географічно диверсифікувати азіатські, проте без державного регулювання спроби виробників можуть бути марними, тож стабілізація політичної системи та збереження унітарності держави виходять на перший план в розвитку будь-якого сектора економіки. 


\section{ECONOMIC STRATEGIES FOR THE DEVELOPMENT OF SOCIETY}

\section{5 Формування корпоративної культури як фактору конкурентоспроможності підприємств сфери туризму}

В сучасних умовах практика управління потребує нових інструментів підвищення ефективності діяльності та підтримки сталого розвитку соціальноекономічної системи. Сучасні керівники вбачають основні важелі впливу на підвищення конкурентоспроможності підприємства переважно в чинниках економічного характеру, але необхідно пам'ятати, що люди є одним з ключових факторів внутрішнього середовища підприємства і від культури його персоналу та культури підприємства в цілому залежить результативність діяльності. Саме тому корпоративну культуру необхідно та потрібно вважати одним з основних чинників підвищення конкурентоспроможності підприємства туристичної сфери. Отже, корпоративна культура є управлінським інструментом та одним 3 сучасних дієвих методів управління персоналом, оскільки «вона дозволяє м'яко та ненав'язливо» прищепити певні цінності, традиції, що приводять до організаційної єдності й створення фірмового стилю поведінки підприємства сфери туризму [164].

В рамках управляння трудовими ресурсами керівництво більшості сучасних підприємств вбачають у підтримці сильної культури, починаючи з набору та вибору кандидатів, які поділять переконання підприємства та процвітатимуть в рамках цієї культури. Впровадження корпоративної культури на туристичному підприємстві урівноважують та балансують економічні та виробничі відносини шляхом формування конкурентних переваг через культурні цінності, дотримання працівниками яких дозволяє сформувати унікальність туристичного підприємства на ринку. Це є досить актуальним та важливим, оскільки підприємства сфери туризму в рамках своєї господарської діяльності співпрацюють з багатьма підприємствами суміжних галузей, а також не тільки 3 вітчизняними, а й закордонними партнерами. Тому питання ефективної корпоративної культури для туристичних підприємства є досить важливим.

Пропонуємо більш детально визначити сутність поняття «корпоративна культура» як комплекс матеріальних і духовних цінностей, які поєднуються між 


\section{ECONOMIC STRATEGIES FOR THE DEVELOPMENT OF SOCIETY}

собою та відображають індивідуальність підприємства, проявляються в поводженні, взаємозв'язках та комунікаціях працівників між собою із зовнішнім оточенням [165]. Ми погоджуємося з думкою Т. Чернишова та Т. Немченко, які визначають сутність корпоративної культури як специфічної форму існування взаємозалежності системи, яка включає ієрархію цінностей, що домінують серед співробітників організації, та сукупність способів їх реалізації, що переважають у ній на певному етапі розвитку [166].

Узагальнюючи вище вказане, корпоративну культуру доцільно визначати як комплексну систему цінностей, принципів, вірувань, бачення, очікувань, символів, норм поведінки співробітників підприємства, його традицій, ритуалів, які складаються протягом часу його існування та приймаються більшістю. Зауважимо, що більшість конкурентоспроможних та відомих туристичних підприємств й організацій мають власну корпоративну структуру, яка формує ключові елементи упізнаваності серед інших та формує атмосферу індивідуальності та причетності серед персоналу, які є ïi частиною. Так, на приклад, відомі мережі готелів Hilton, Reikartz Hotel GroupB, Radisson, або відомих туроператорів Join UP!, PEGAS Touristik, Coral Travel i TEZ TOUR, або авіакомпаній та інші мають чітко сформовану корпоративну культуру. Відомий соціолог С. Роббінс застосував досить оригінальний підхід до трактування корпоративної культури як своєрідного спеціального клею, що допомагає утримувати цілісність організації за рахунок створення власних стандартів мислення й поведінки [167]. Отже, можна зробити висновок, що корпоративна культура є певним показником рівня розвитку підприємства, оскільки вона в першу чергу впливає на внутрішній соціально-психологічний клімат в колективі, що формує загальний настрій та емоційний фон, а відповідно впливає й на продуктивність праці, відданості працівників спільній справі. Зауважимо, шо корпоративна культура підприємства сфери туризму являє собою ефективний управлінський інструмент, що дає змогу керувати колективом, формувати унікальні конкурентні переваги, ефективно здійснювати позитивні зміни. Зазначимо, що впровадження ефективної корпоративні культури на 


\section{ECONOMIC STRATEGIES FOR THE DEVELOPMENT OF SOCIETY}

туристичному підприємстві дозволить вирішити два ключові завдання: поперше, сформувати збалансовані взаємозв'язки підприємства 3 зовнішнім оточенням (шляхом органічної адаптації до зовнішнього середовища), а подруге, сформувати здорову атмосферу в колективі, що сприятиме продуктивній праці та партнерству (внутрішня інтеграція) [167]. Відповідним чином, виділяють наступні напрями корпоративної культури: внутрішньо фірмову культуру та культуру, яка орієнтована на зовнішнє середовище - корпоративну бізнес-культуру.

На рис. 1. представлені основні етапи формування ефективної корпоративної культури на туристичному підприємстві.

Етап 1. Опрацювання місії підприємства, визначення стратегії, основних цілей і цінностей (пріоритетів, принципів, підходів, норм і бажаних зразків поведінки).

Етап 2. Вивчення існуючої корпоративної культури. Визначення ступеня відповідності існуючої корпоративної культури стратегії розвитку організації, виробленої керівництвом. Виявлення позитивних і негативних цінностей.

Етап 3. Розробка організаційних заходів, спрямованих на формування, розвиток або закріплення бажаних цінностей і зразків поведінки.

Етап 4. Цілеспрямований вплив на корпоративну культуру з метою подолати негативні цінності і розвити настанови, що сприяють реалізації розробленої стратегії.

Етап 5. Оцінювання успішності впливів на корпоративну культуру і внесення необхідних коректив.

Рис. 1. Етапи формування корпоративної культури на туристичному підприємстві (систематизовано на основі [168]

Визначимо основні чинники, що впливають на формування внутрішньофірмової культури: демократичність у взаємовідносинах працівників підприємства; доступ до інформації; рівень довіри персоналу керівництву підприємства; рівень освіти, досвід, кваліфікація та професіоналізм керівництва всіх рівнів; рівень розвитку комунікацій на підприємстві та їх ефективність; система мотиваційних заходів; система управління персоналом, кадрова політика, управління кар'єрою та навчання персоналу; тип управління, стиль керівництва, форма влади керівника тощо [169]. 


\section{ECONOMIC STRATEGIES FOR THE DEVELOPMENT OF SOCIETY}

До чинників, що впливають на формування бізнес-культури туристичного підприємства відносять:

етичні норми, цінності, особливості культури, які притаманні зовнішньому середовищу в якому функціонує підприємство;

менталітет, що є характерний для певної національності;

рівень адаптованості підприємства до змін в зовнішньому середовищі;

рівень взаємної довіри між партнерами;

шляхи та інструменти впровадження стратегії підприємства, виконання основних завдань для досягнення поставленої мети [169].

На основі визначних чинників охарактеризуємо визначимо основні складові корпоративної культури підприємств сфери туризму:

корпоративні цінності - цінності підприємства складаються 3 кодексу поведінки і очікуваного поведінки персоналу, який при впровадженні направляє повсякденні ділові операції і допомагає в більш ефективному прийнятті рішень i комунікаціях;

атмосфера на робочому місці - робоче середовище на підприємстві повинно бути позитивним, стимулювати формування мотивованого i щасливого колективу;

графік робочого часу - час роботи і тривалість робочого дня є частиною культури прийнятої на підприємстві. Якщо графіки зручні, а тривалість робочого часу відповідає універсальним стандартам, працівники матимуть додатковий стимул виконувати свої посадові інструкції;

дрес-код працівника, будь то формальний або неформальний, є частиною культури підприємства. Зазвичай традиційно підприємства туризму мають уніформу, що сприяе дисципліні і одноманітності. На сьогодні, дедалі більше підприємств 3 новим сприйняттям допускають повсякденний дрес-код для забезпечення комфорту співробітників і підвищення їх творчого потенціалу та продуктивності;

персоналізація на робочому місці - корпоративна культуру передбачає дозвіл співробітникам оформляти свій робочій простір особистими речами 


\section{ECONOMIC STRATEGIES FOR THE DEVELOPMENT OF SOCIETY}

(фотографіями, квітами, іншими предметами декору), щоб вони відчували себе як вдома;

взаємодія з співробітниками - досить часто на підприємствах, де існує жорстка конкуренція серед співробітників, відсутнє дружнє інтерактивне середовище, з цією метою для формування командної роботи і координації між працівниками, заохочують більше спілкування;

взаємодія зі спільнотою - підприємство також несе певну відповідальність перед місцевою громадою, де вона працює. Це частина його корпоративної культури та нагадує, як компанія взаємодіє з спільнотою в цілому;

організація вільного часу - те, як співробітники проводять неробочий час, наприклад, у вихідні або святкові дні, відображає культуру компанії. Якщо вільний час проводиться з колегами і друзями, в організації з'являється більше дух товариства;

громадський активізм - для деяких підприємств прибуток - це ще не все. Вони 3 нетерпінням чекають досягнення задоволення, вносячи свій внесок в розвиток суспільства. Таким чином, ці підприємства підтримують культуру, що сприяє благодійності, внескам для різних соціальних цілей, таких як освіта, розширення прав і можливостей жінок тощо [170].

Доцільно зазначити, що загальні цінності, взаємовідносини в колективі, стандарти, які характеризують трудовий колектив туристичного підприємства i визначають їі природу. В основі корпоративної культури лежать цілі, стратегія, структура та підходи до організації трудового процесу, підходи до співпраці 3 клієнтами, інвесторами, партнерами та суспільством в цілому. Тому підході до формування корпоративної культури являється важливим компонентом для кінцевого успіху чи невдачі в сфері туристичного бізнесу.

Отже, у підсумку доцільно зауважити, що корпоративну культуру підприємства повинна бути визначена як таку, що охоплює цінності, правила, переконання та припущення щодо поводження та поведінки підприємств зацікавлених сторін, що відображає як внутрішню, так і зовні поведінку підприємства. 


\section{ECONOMIC STRATEGIES FOR THE DEVELOPMENT OF SOCIETY}

\section{6 Технологія блокчейну як новий підхід просування органічної продукції на ринок}

На сучасному етапі, щоб досягти ефективного просування органічних продуктів необхідно ув'язувати його з новими технологіями, інформацією, грошима і численними документами. Для досягнення тих чи інших завдань доводиться залучати численних посередників, співпраця з якими передбачає проведення десятки різних операцій.

Ми пропонуємо використовувати при просуванні органічної продукції технологію blockchain, завдання якої полягає у виправленні проблем, пов'язаних зі значними матеріальними (оплачувані посередницькі послуги) і тимчасовими витратами (паперова та інша тяганина при оформленні документації). Розглянемо головні особливості цієї технології. За своєю структурою blockchain - це ланцюг блоків, які містять в собі певну інформацію. При цьому всі блоки ланцюжка пов'язані один з одним. Блок наповнений групою записів, а нові блоки завжди додаються в кінець ланцюга і дублюють інформацію, що міститься в раніше створених структурних одиницях системи, додаючи до неї нову. Побудова ланцюжка blockchain відбувається на базі трьох головних принципів розподіленість, відкритість і захист. Користувачі системи формують собою комп'ютерну мережу. При цьому в кожному з персональних комп'ютерів зберігається копія кожного з блоків. Такий принцип робить систему майже невразливою. Сдиний варіант збою системи - можлива поломка всіх комп'ютерів одночасно, що, з огляду на загальну кількість розкиданих нерівномірно по всій поверхні планети обчислювальних вузлів, неможливо. Всі дані в системі захищені. Ланцюг blockchain надійно зашифрований, що відкриває шляхи для отримання достовірної і відкритої інформації, а для споживачів органічної продукції це $є$ дуже важливим. Для входу в систему та ідентифікації користувач системою застосовує спеціальний ключ.

Дана технологія здешевлює: фінансові операції; оформлення та перевірку достовірності документів; ідентифікацію користувачів; охорону інтелектуальної 


\section{ECONOMIC STRATEGIES FOR THE DEVELOPMENT OF SOCIETY}

власності; зберігання інформації; ведення різних реєстрів; управління підприємствами; ланцюги доставок; укладання та виконання контрактів.

Так як органічні продукти на сьогодні є занадто дорогими - це дозволить вирішить питання їх здешевлення. На ринку не потрібні будуть різні посередники: нотаріат, банківські платежі, експедитори, фірми, що займаються зберіганням, обробкою та захистом інформації та ін. Це спричине значні зміни у ринковій інфраструктурі.

Основними позитивними сторонами впровадження технології blockchain, на нашу думку, $є$ : економічна ефективність; прозорість; безпека; захист від корупції; можливість створювати галузеві альянси, підключаючи до них постачальників, партнерів та навіть конкурентів.

Серед недоліків функціонування технології blockchain слід відзначити наступне: її продуктивність нижче, ніж високонавантажених систем; недостатня кількість розробників; великі інвестиції в IT інфраструктуру; підтримка системи вимагає формування штату власних фахівців.

Розглянемо ефект від використання системи blockchain на прикладі трьох логістичних потоків і визначимо іï переваги при здійсненні міжнародних перевезень вантажів.

При обслуговуванні матеріального потоку система blockchain скорочує:

- термін виконання замовлення за рахунок зменшення кількості посередників в ланцюгу;

- зменшує час доставки (3\% на кожному експедиторі);

- значно збільшує реальну суму заробітку для самого перевізника.

Система blockchain оптимізує інформаційні потоки, створюючи передумови до:

1) формування єдиного інформаційного простору;

2) появи всіх документів про перевезення у відкритому доступі;

3) зниження часу обробки документів;

4) зменшення часу перевірки податковою інспекцією;

5) страхування вантажів в один клік; 


\section{ECONOMIC STRATEGIES FOR THE DEVELOPMENT OF SOCIETY}

6) надання митним органам документів з головного офісу;

7) мінімізації супутнього інформаційного потоку [171, 173$]$.

Підтримка фінансового потоку за технологією blockchain формує систему взаємодії з наступними характеристиками:

1) повна відсутність посередників;

2) непотрібність посередницьких банків;

3) стягнення комісії єдиноразово;

4) скорочення витрат, пов'язаних з вартістю перевезення вантажу;

5) зменшення часу на обробку операцій;

6) мінімізації ризиків;

7) оптимізація руху фінансового потоку на кожному етапі дозволяє заощадити до 3\% річних $[172,174]$.

Проаналізувавши досвід Республіки Білорусь, відзначимо, що реалізацією і створенням системи blockchain для підвищення ефективності транспортної логістики, а також впровадженням технології на всіх підприємствах i транспортно-логістичних компаніях може займатися координаційна організація, створена на базі Асоціації міжнародних автомобільних перевізників «БАМАП» і Асоціації міжнародних експедиторів та логістики «БАМЕ».

Отже, до переваг технології блокчейн можна віднести: відкритість інформації для всіх і завжди; легкість іï перевірки та відстеження; повна децентралізація і незалежність, жоден орган влади не може заборонити транзакції або заблокувати доступ до блокчейну.

Серед міжнародних IT-компаній IBM вже запропонувала деяким великим компаніям з різних сфер діяльності протестувати свої розробки, засновані на принципі blockchain. Міжнародний Blockchain-консорціум Hyperledger був запущений Linux Foundation в 2015 році і на даний момент об'єднує понад 115 компаній з різних сфер, включаючи фінанси, автомобілебудування, охорону здоров'я, ІТ-технології і авіацію. Головна мета консорціуму - створення єдиної blockchain-платформи з відкритим вихідним кодом, яка дозволить організаціям по всьому світу впровадити технологію blockchain в свої бізнес-процеси [176]. 


\section{ECONOMIC STRATEGIES FOR THE DEVELOPMENT OF SOCIETY}

Прозорість ланцюга доставок принесе користь і кінцевим споживачам, які зможуть переконатися в безпечності продукції, іiї свіжості, відсутності ГМО і небажаних добавок. Також можна точно дізнатися, що, наприклад, куплений тунець пійманий не браконьєрським способом - саме з метою захисту себе від подібних звинувачень blockchain став використовувати британський стартап Provenance. Компанія за допомогою технології blockchain відстежує рух тунця, контролюючи його ловлю і доставку [175]. Компанія EverLadger використовує blockchain в ланцюжку поставок для підтвердження джерела походження в торгівлі алмазами [175]. Стартап Assetcha.in за допомогою blockchain підвищує безпеку зберігання цінних речей. Компанія Midasium за допомогою blockchain укладає в оперативному режимі угоди про оренду житла на ринку нерухомості [176].

Таким чином, потенціал використання технології blockchain, захищеність від несанкціонованого доступу, повна прозорість роблять іiі ідеальним інструментом для революційного способу управління ланцюгами поставок сьогодні.

Постачання фізичних товарів зазвичай включає в себе інтеграцію потоку інформації, транспортування, складування i часто забезпечення безпеки. Логістичні ланцюги часто охоплюють численні етапи і сотні географічних місць. Зрозуміло, що через це важко відслідковувати події у всьому ланцюжку, перевіряти, як транспортуються товари, і швидко реагувати на непередбачені обставини. Це $є$ актуальним і при транспортуванні органічної продукції, особливо на зовнішній ринок.

Блокчейн має потенціал для вирішення всіх перелічених вище питань. Будучи прозорим публічним регістром, він буде надавати клієнтам і аудиторам прості та ефективні інструменти для відстеження всього маршруту. Однією 3 важливих особливостей блокчейна $\epsilon$ те, що він може забезпечити свої переваги, тільки якщо всі члени логістичного ланцюжка мають доступ до мережі. Крім усунення специфічних для галузі проблем, блокчейн забезпечує ряд миттєвих переваг. Він не тільки усуває посередників і значно зменшує обсяг робочого 


\section{ECONOMIC STRATEGIES FOR THE DEVELOPMENT OF SOCIETY}

потоку, але також пропонує надійний захист, скорочення помилок, запобігання неправильного маркування незаконних товарів та інших спроб шахрайства. Крім того, нова парадигма обіцяє величезні потенційні переваги економії витрат для галузі.

Дана технологія своїми позитивними характеристиками дозволить виробникам органічної продукції збільшити кількість потенційних споживачів. Адже блокчейн надасть можливість досконало та прозоро постачати органічну продукцію не лише на внутрішньому ринку, а й на міжнародному ринку, знизити їі ціну. 


\section{ECONOMIC STRATEGIES FOR THE DEVELOPMENT OF SOCIETY \\ SECTION 8. ECONOMY PROTECT THE MIDDLE OF THE MIDDLE}

\subsection{The world experience and mechanisms of "greening" university campuses}

Заклади вищої освіти «постачають» суспільству законодавців, політиків, керівників державної та місцевої влади всіх рівнів. Тому в умовах сучасних еколого-економічних викликів саме вони, демонструючи студентам переваги сталого господарювання, мають виконувати місію 3 підготовки державних та громадських діячів нової формації, які мислитимуть категоріями виключно сталого розвитку, «зеленої» економіки та енерго(ресурсо)збереження.

Рух щодо «озеленення» закладів освіти в останнє десятиліття став глобальним трендом, охопивши університети різних країн світу. 32010 року за ініціативою Університету Індонезії складається щорічний UI GreenMetric World University Ranking. Він відображає результати інтернет-опитування щодо поточного стану та політики, пов'язаної із екологічним студмістечком і сталим розвитком закладів вищої освіти усього світу. Оцінка проводиться за 6 основними критеріями: 1) облаштування та інфраструктура; 2) енергія і зміна клімату;

3) відходи; 4) вода; 5) транспорт; 6) освіта та дослідження (UI, 2020).

У 2019 році до топ-10 «зелених» університетів світу увійшли: 1 місце Вагенінгенський дослідницький університет (Wageningen University \& Research, Нідерланди), 2 місце - Оксфордський університет (University of Oxford, Великобританія); 3 місце - Каліфорнійський університет Девіса (University of California, Davis, США), 4 місце - Університет Ноттінгема (University of Nottingham, Великобританія); 5 місце - Nottingham Trent University (Великобританія); 6 місце - Екологічний кампус Біркенфельда Університету прикладних наук Tpipa (Umwelt-Campus Birkenfeld, Trier University of Applied Sciences, Німеччина); 7 місце - Лейденський університет (Leiden University, Нідерланди); 8 місце - Гронінгенський університет (University of Groningen, Нідерланди); 9 місце - Університетський коледж Корк (University College Cork, 


\section{ECONOMIC STRATEGIES FOR THE DEVELOPMENT OF SOCIETY}

Ірландія); 10 місце - Університет Бангора (Bangor University, Великобританія) (UI, 2020). До глобального рейтингу, сформованого 3780 університетівучасників, потрапили і 10 українських університетів, місця яких розподілилися таким чином (табл. 1).

Як слідує з таблиці, лише 2 українських університети (Український національний лісотехнічний університет та Сумський державний університет) увійшли до першої половини світового рейтингу, 3 університети (Уманський національний університет садівництва, Полтавський національний технічний університет імені Юрія Кондратюка i Тернопільський національний економічний університет) демонстрували середні рейтингові показники, решта характеризувалися показниками нижче середнього рівня. Отже, українським закладам вищої освіти є над чим працювати для подальшого «озеленення» своєї діяльності.

Таблиця 1. Місце закладів вищої освіти України у UI GreenMetric World University Ranking 2019 (UI, 2020)

\begin{tabular}{|c|l|c|c|c|c|c|c|c|}
\hline Рейтинг & \multicolumn{1}{|c|}{ Заклад вищої освіти } & \multicolumn{3}{|c|}{$\begin{array}{l}\text { Загальна } \\
\text { кількіст } \\
\text { Україні }\end{array}$} & & \multicolumn{3}{|c|}{ Кількість балів за компонентами* } \\
\hline $111 / 1$ & $\begin{array}{l}\text { У балів } \\
\text { Український національний } \\
\text { лісотехнічний університет }\end{array}$ & 6900 & 1000 & 1125 & 1050 & 650 & 1275 & 1800 \\
\hline $208 / 2$ & $\begin{array}{l}\text { Сумський державний } \\
\text { університет }\end{array}$ & 6050 & 950 & 1450 & 750 & 600 & 1100 & 1200 \\
\hline $409 / 3$ & $\begin{array}{l}\text { Уманський національний } \\
\text { університет садівництва }\end{array}$ & 4900 & 1050 & 820 & 600 & 475 & 875 & 1075 \\
\hline $419 / 4$ & $\begin{array}{l}\text { Полтавський національний } \\
\text { технічний університет імені } \\
\text { Юрія Кондратюка }\end{array}$ & 4850 & 820 & 650 & 525 & 550 & 1000 & 1300 \\
\hline $423 / 5$ & $\begin{array}{l}\text { Тернопільський } \\
\text { національний економічний } \\
\text { університет }\end{array}$ & 4800 & 650 & 1000 & 675 & 125 & 1075 & 1275 \\
\hline $590 / 6$ & $\begin{array}{l}\text { Харківський національний } \\
\text { універсітет імені } \\
\text { В. Н. Каразіна }\end{array}$ & 3950 & 750 & 700 & 1125 & 100 & 650 & 625 \\
\hline $628 / 7$ & $\begin{array}{l}\text { Харківський національний } \\
\text { університет } \\
\text { радіоелектроніки }\end{array}$ & 3675 & 250 & 1000 & 600 & 150 & 925 & 750 \\
\hline $673 / 8$ & $\begin{array}{l}\text { Ужгородський } \\
\text { національний університет }\end{array}$ & 3100 & 600 & 650 & 525 & 100 & 500 & 725 \\
\hline
\end{tabular}


ECONOMIC STRATEGIES FOR THE DEVELOPMENT OF SOCIETY

\begin{tabular}{|c|l|c|c|c|c|c|c|c|}
\hline $675 / 9$ & $\begin{array}{l}\text { Національний університет } \\
\text { «Острозька академія» }\end{array}$ & 3100 & 350 & 325 & 375 & 500 & 500 & 1050 \\
\hline $701 / 10$ & $\begin{array}{l}\text { Львівський національний } \\
\text { університет імені Івана } \\
\text { Франка }\end{array}$ & 2700 & 900 & 650 & 150 & 0 & 475 & 525 \\
\hline
\end{tabular}

*) 1 - облаштування та інфраструктура; 2 - енергія та зміна клімату; 3 - відходи; 4 - вода; 5 - транспорт; 6 - освіта та дослідження.

Важливим показником у UI GreenMetric World University Ranking є енергія і зміна клімату. Сучасні університетські студмістечка є значними споживачами енергії, яка витрачається на забезпечення навчальної та наукової діяльності, функціонування соціальної й іншої інфраструктури освітніх закладів. Водночас, саме університети є центрами генерації і трансферу нових знань, у тому числі про новітні технології та методи енергозбереження. Тому цілком логічно, що саме ці освітні установи мають всі передумови для перетворення їх на флагманів впровадження енергоефективних змін, насамперед, щодо оптимізації енергоспоживання будівлями на території університетських студмістечок із застосуванням найбільш прогресивних «зелених» енерготехнологій. Реалізація пілотних енергозберігаючих проєктів викладачами і студентами за підтримки державних і місцевих органів влади, бізнесу сприятиме покращенню якості підготовки майбутніх фахівців, розвитку наукової діяльності, зростанню екологічної свідомості здобувачів освіти та співробітників університету, скороченню обсягів енерговитрат та зниженню викидів $\mathrm{CO}_{2}$ в атмосферу.

Враховуючи вищезазначене, провідні освітні заклади світу активно впроваджують енергозберігаючі заходи. Зокрема, серед американських університетів Сльський університет постійно вживає кроки щодо зниження емісії парникових газів шляхом раціоналізації енергоспоживання будівель, у тому числі гуртожитків. Гарвард зосереджується на формуванні навичок у студентів щодо енергозбереження та вимагає від кожного першокурсника вивчення Зеленого путівника перед вступом до університету, пропагуючи ентузіазм щодо придбання енергозберігаючих продуктів. У Массачусетському технологічному інституті приділяють увагу технічним аспектам енергозбереження, навчаючи студентів принципам енергоефективного 


\section{ECONOMIC STRATEGIES FOR THE DEVELOPMENT OF SOCIETY}

освітлення, оптимізації систем опалення і вентиляції тощо. Родзинкою освітньонаукової діяльності в Каліфорнійському університеті в Берклі $є$ проведення наукових досліджень у сфері відновлювальної енергетики, а також акцент на формуванні енергоефективної поведінки здобувачів освіти, заснованої на повсякденних невеликих зусиллях щодо економії та оптимального витрачання енергіï (Zhao, 2010; Ying et al., 2015).

Токійський університет послідовно впроваджує стратегію переходу свого студмістечка до низьковуглецевого енергоспоживання, активно впроваджуючи «зелені» енерготехнології у будівлях університету і досягаючи зниження викидів $\mathrm{CO}_{2}$ та енерговитрат (Sun, 2011; Ying et al., 2015).

Переможець UI GreenMetric World University Ranking 2019 Вагенінгенський дослідницький університет, який вже третій рік поспіль очолює цей рейтинг, також приділяє велику увагу розвитку та впровадженню технологій відновлювальної енергетики на території університету. Прикладом $\epsilon$ використання жорстких критеріїв сталості для будівництва, обслуговування та реконструкції будівель закладу. Крім того, університет генерує «зелену» енергію за допомогою вітрових турбін (80\%) у Лелістаді, біо-теплоенергоцентралей (комбіноване виробництво тепла та енергії) (7\%), теплових насосів на території студмістечка (11\%) та сонячних батарей (1\%). У 2018 році 106\% спожитої енергії було отримано за допомогою відновлювальних джерел, тобто заклад виробив більше «зеленої» електроенергії, ніж зміг ії спожити. На території університету встановлені 24 зарядні станції для електромобілів, 60 - для електронних велосипедів та 11000 велосипедних стійок. При цьому 55\% персоналу університету використовують саме велосипеди для поїздок на роботу (Wageningen, 2020).

Університети Великої Британії, багато з яких займають високі позиції в UI GreenMetric World University Ranking протягом останніх років, мають власні стратегії та плани зі сталого розвитку студмістечок й зростання енергоефективності. Наприклад, Університет Брістоля взяв на себе зобов'язання стати вуглецево нейтральним до 2030 року, вже скоротивши викиди $\mathrm{CO}_{2}$ на 27\% 


\section{ECONOMIC STRATEGIES FOR THE DEVELOPMENT OF SOCIETY}

у 2019 році. Ініціативи «зеленого університету» Брістоля включають переробку понад 95\% відходів, заохочення «зелених» подорожей через спільне користування автомобілем та безкоштовні автобусні проїзні квитки, а також будівництво i реконструкцію будівель в університетському містечку із використанням сонячних батарей, світлодіодних ліхтарів та систем природної вентиляції. Університет також приєднався до Глобальної програми дій ЮНЕСКО, метою якої є навчання студентів навичкам, знанням та цінностям, необхідним для створення сталого майбутнього (10 of the Greenest, 2019). Університет Метрополітену в Манчестері пропонує навчання вуглецевій грамотності, програму обміну одягом та книгами, яка реалізується у студентському містечку з метою зменшення відходів, та інші «зелені» заходи. Освітній заклад також прагне повторно використовувати або переробляти $60 \%$ усіх відходів до кінця 2020 року, нагороджуючи матеріально найактивніших студентів. В Університеті Ноттінгема студентів заохочують до економії енергії, нагороджуючи вечірками та морозивом найощадливіших. Університет Ноттінгема у Тренті прагне зменшити вуглецевий слід кожного студента та співробітника на 29\% до кінця 2020 року і вже переробляє понад 90\% утворюваних ним відходів. Університет Плімута має потужну стратегію сталого розвитку, що передбачає зниження викидів вуглецю на 80\% до 2050 року (вже скоротивши їх на 42\% з 1990 року) та перероблення 70\% відходів до кінця 2020 року (10 of the Greenest, 2019).

Наведені приклади енергоефективної та ресурсозберігаючої політики закладів освіти створюють підгрунтя для підготовки фахівців, націлених на підтримку і популяризацію сталого розвитку як у local communities, так і світі в цілому, поряд з отриманням екологічних, соціальних, економічних переваг від такої діяльності безпосередньо університетами.

Водночас, незважаючи на досягнуті вражаючі результати щодо реалізації енергозберігаючого потенціалу закладів вищої освіти у розвинених країнах світу, багато університетів в державах з транзитивною економікою та таких, що розвиваються, стикаються із суттєвими бар'єрами для впровадження 


\section{ECONOMIC STRATEGIES FOR THE DEVELOPMENT OF SOCIETY}

енергоефективних змін. Зокрема, специфічними перешкодами, характерними для країн третього світу, є технічні обмеження, обумовлені нерозвиненістю національної та локальної енергетичної інфраструктури, низькою пропускною здатністю електромереж, нестабільністю та ненадійністю режимів енергопостачання тощо (Maistry and McKay, 2016; Sineviciene et al., 2017; Sotnyk et al.). Для транзитивних економік зазначені технічні бар'єри є менш актуальними, оскільки такі країни, як правило, мають розгалужену енергетичну інфраструктуру. Проте тут акценти зміщуються на питання оновлення та модернізації зношених електро-, газо- та тепломереж, відновлення і розширення їх пропускної здатності й ін. (Kurbatova, 2018; Sineviciene et al., 2017; Енергоефективність, 2019).

Як зазначають M. Mohammadalizadehkorde and R. Weaver (2018), переважна більшість перешкод енергоефективному розвитку університетів в країнах 3 транзитивною економікою та таких, що розвиваються, пов'язана не 3 технічними, а саме 3 організаційними та економіко-фінансовими, інформаційними бар'єрами. Часто такі перешкоди актуальні і для розвинених держав (Maiorano and Savan, 2015). Неефективна організація енергозберігаючої діяльності в університеті, відсутність достатньої інформації про обсяги енергоспоживання та можливості персональної участі в енергоефективних проєктах освітнього закладу зумовлюють зневажливе ставлення співробітників і студентів до реалізації його енергозберігаючого потенціалу. Надзвичайно важливими $є$ організаційна роль ініціативної команди енергоменеджерів, визнання і постійна підтримка керівництвом енергоефективного розвитку університету, широке залучення викладачів і студентів до енергозберігаючої діяльності.

Системний підхід до організації енергозберігаючої діяльності в університетському кампусі на основі вдосконалення механізмів управління дозволяє досягати поставлених цілей зростання енергоефективності навіть за наявності багатьох бар'єрів. Водночас, слід враховувати, що комплекс управлінських заходів для розбудови енергоефективного університету залежить 


\section{ECONOMIC STRATEGIES FOR THE DEVELOPMENT OF SOCIETY}

від стадії розвитку політики енергозбереження закладу і має коригуватися у процесі енергоефективних змін, що може виступати напрямом для подальших досліджень. 


\section{ECONOMIC STRATEGIES FOR THE DEVELOPMENT OF SOCIETY SECTION 9. FINANCE, PENNILESS AND CREDIT}

\subsection{Problem aspects of regulatory regulation of market activities securities in Ukraine}

For any developing country, the issue of creating an attractive climate for investment capital, which contributes to the recovery and modernization of the real sector of the economy, as well as further its competitiveness, is of particular importance. However, the investment market is extremely sensitive to negative factors that cause various risks and threaten investors and their businesses. One of the most important reasons why investors do not want to invest in the Ukrainian economy is imperfect legal legislation in Ukraine that would protect the interests of investors. Therefore, the problem of increasing confidence in the effectiveness of state regulation of the stock market is currently a priority for our country.

The low efficiency of the RCP investment mechanism in Ukraine is due to many reasons, including:

- reduction of the already narrow range of RCP instruments due to excessively high requirements for issuers whose securities could be admitted to stock exchanges;

- strict requirements set by the legislation regarding the composition and structure of NPF assets, which significantly complicates the improvement of the investment portfolio of NPFs during the exclusion of securities from the listing;

- loss of a significant part of the RCP and assets as a result of the annexation of Crimea, military action in eastern Ukraine. The protracted military conflict in the East is depleting both Ukraine's economy in general and hindering the development of the $\mathrm{RCP}$ in particular;

- virtually no issues of new shares and bonds due to lack of issuers, issues of new RCP instruments;

- significant increase in the cost of living in the country, a significant increase in prices for utilities, consumer goods and services, instability in the country - all this significantly inhibits the desire of citizens to invest in financial instruments for more than 3-6 months and so on. 


\section{ECONOMIC STRATEGIES FOR THE DEVELOPMENT OF SOCIETY}

One of the major shortcomings of the Ukrainian RCP is the very narrow range of instruments offered to investors in the market.

In order to expand the range of RCP instruments in which investors can invest their funds, it is necessary to ensure their issuance and circulation at the legislative level, namely:

-to create a temporary profile committee of the NSSMC, the task of which should be to analyze existing types of securities in Ukraine and international RCPs, development and implementation of new types of securities, organize public meetings and discussions with all RCP participants, primarily professional RCP participants, to clarify real needs in certain RCP instruments, discuss the best mechanisms for their introduction to the market, etc.

- The result of the profile committee should be the development of draft legislative proposals for the introduction, issuance and circulation of new financial instruments on the RCP. This draft should be adopted in the form of amendments to the Law "On Securities and Stock Market" of 29.05.2020 № 3480-IV;

- to introduce and differentiate at the legislative level short-term, medium-term and long-term government securities of various types;

- open access of institutional investors to international Eurobond markets;

- to reform the tax legislation, to work out the optimal regime of taxation of transactions with individual securities and income from them. We propose not to tax the sources of dividend payments and interest paid to the investor; not to tax exchange rate differences during the exchange of the investor's foreign currency for the national currency at the exchange rate of the NBU; not to tax the profit from operations on trade in RCP instruments, which are part of the investment portfolios of institutional investors.

Specific economic and legal recommendations for further reform of the RCP are offered in the Concept of its development, which takes into account the potential opportunities in attracting investment resources. The mission of the Concept is to ensure accelerated economic development of Ukraine by qualitatively increasing the competitiveness, stability and institutional efficiency of the securities market, 


\section{ECONOMIC STRATEGIES FOR THE DEVELOPMENT OF SOCIETY}

providing other markets with financial resources and services, maintaining social stability and a high standard of living, taking into account national interests and international standards.

The scientific and theoretical basis for the preparation and implementation of the Concept are the accepted working hypotheses: 1) the inevitability of increasing the impact of globalization on the formation of the institutional structure of the securities market; 2) intensification of competition in the national and world capital markets, when the possibility of access to large and inexpensive investment resources is one of the important competitive advantages; 3 ) changes in state regulation of financial institutions, investment activities; 4) diversification of activities and blurring of borders between markets; 5) increasing the role of information technology and reducing transaction costs; 6) aging population and changing its investment preferences, which requires the creation of conditions for the formation of a mass retail investor and increase its confidence in financial institutions.

The basic principles of the Concept are: a) coordination of public and private interests in the investment sphere; b) the priority of national interests in the import and adaptation of new institutions; c) unification of regulatory procedures (rules and regulations) for capital market participants; d) supervision based on prudential rules; e) enhanced control over the owners and heads of financial institutions; f) participation of self-regulatory organizations in solving problems hindering the development of the securities market; g) operational independence and financial autonomy of regulators; h) taking into account the characteristics of different types of investment activities and sectors of the securities market.

The problem of the national RCP is the lack of clear planning and development strategy for both the RCP and the economy as a whole. In this regard, we offer:

- to create a special unit for economic planning and strategic development of Ukraine, which would coordinate the development of all sectors of the economy in accordance with the developed strategic development programs, first of all, would coordinate the relationship between financial and real sectors of the economy. 


\section{ECONOMIC STRATEGIES FOR THE DEVELOPMENT OF SOCIETY}

- support and import of new investment technologies; - coordination of financial education in the country, especially in the direction of combining theoretical science with practice; increasing the financial literacy of the population and involving public organizations in participation in the development of the RCP;

The implementation of these tasks is provided for in the Concept and should be based primarily on the principles of the program-target approach, which will provide for the implementation of regulatory-organizational and methodological tasks.

Regulatory and organizational tasks of the Concept concern the definition of the model of regulators, objects of regulation and their institutional support.

The choice of the optimal mechanism for the organization of regulators requires the solution of many issues, including the choice of sectoral or cross-sectoral model of regulation.

The network scheme of regulation is becoming popular in the world, when certain financial units act as intermediaries of services related to the common tasks of financial and economic policy of the state. Such a model could be appropriate in Ukraine as well.

At the micro level, in addition to the external constraints listed above, internal management mechanisms can be used, which are generally accepted methods and models in the industry, but their choice and application is determined by the financial corporations themselves.

Today, regulatory functions in the financial sector in Ukraine are performed by the National Bank of Ukraine, the National Securities and Stock Market Commission, and the National Financial Services Commission. Recently, there has been talk of liquidation of Natskomfinposlug and delimitation of its functions and powers between the NBU and the NSSMC, in particular, that the NBU should control and monitor the activities of insurance companies, and the NSSMC should undertake to act as a regulator of pension funds - to the NSSMC.

In our view, this should help to improve government regulation, as such a division will prevent duplication of functions and promote a clear understanding of the responsibility of regulators for their responsibilities. 


\section{ECONOMIC STRATEGIES FOR THE DEVELOPMENT OF SOCIETY}

As for self-regulation at the RCP, it should be based on the adoption of the Law "On Self-Regulation", which will determine its principles, standards of SRO activity, their status and mechanism of interaction with regulators. It must pursue the following objectives: counteracting financial risks; improving capital market infrastructure; achieving the optimal ratio between state regulation and self-regulation. The system of self-regulation tools is shown in Fig.1 [190].

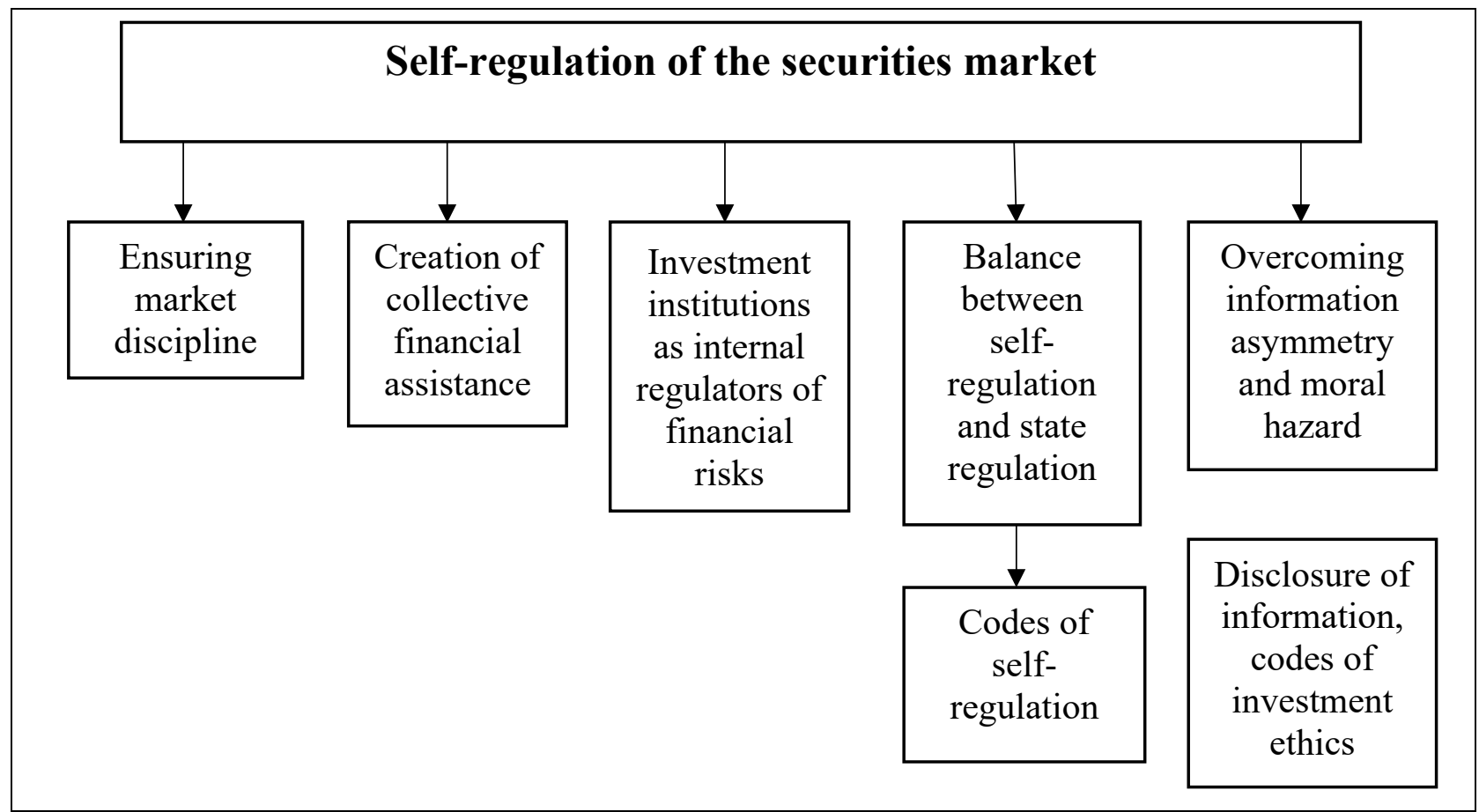

Fig. 1. The system of self-regulation on the RCP

In European countries, stock exchanges and central depositories perform the functions of self-regulators, ie, are self-regulatory organizations. In Ukraine, however, these RCP entities are not endowed with such functions.

According to Ukrainian law, stock exchanges and the central depository cannot be self-regulatory organizations, unlike in European countries and the United States, where stock exchanges are endowed with the functions of self-regulators. This means that some professional participants of the RCP do not participate in the processes of $\mathrm{RCP}$ regulation.

Although Ukraine's SROs are unable to compete with global SROs, the SRO Institute in Ukraine itself has been built. Given the reform of domestic legislation and 


\section{ECONOMIC STRATEGIES FOR THE DEVELOPMENT OF SOCIETY}

changes taking place within the country, there is significant potential and prospects for further development of SROs, close to European standards.

In our opinion, the fact that the Ukrainian RCP does not play such a role in investment processes as in the developed countries of the world is also due to historical factors. After all, for a long time in our country the role and importance of the securities market were underestimated. The securities market was used only as a mechanism for privatization, without the necessary infrastructure.

For a clearer understanding of the peculiarities of the functioning of the securities market, we consider it appropriate to explore the historical preconditions for the formation and development of the domestic RCP. The history of the formation and awareness of the role and place of the securities market in the economic processes of the country has passed a contradictory and difficult path of development. Only in the late 1990 s - early 2000 s began to form in our country the realization that the priority of the securities market is the redistribution of investment resources between sectors of the economy.

The situation changed slightly when on March 31, 2016 the Verkhovna Rada of Ukraine adopted in the first reading a package of bills on regulated markets and derivatives, the main of which is the draft Law of Ukraine on registration № 3498 “On Amendments to Certain Legislative Acts of Ukraine on Regulated Markets and Derivatives )».

The innovations of this project are the creation of a legal framework and infrastructure for the derivatives market, the introduction of the institution of qualified investors, changes in the regulation of professional activities and more. The law provides a definition of the concept of "derivative" and their classification (deposit / settlement, money market derivatives, commodity derivatives, stock derivatives and others). Derivatives include options, swaps, futures, forwards, as well as other agreements that meet the requirements established by law.

The Verkhovna Rada instructed the Committee of the Verkhovna Rada of Ukraine on Financial Policy and Banking to finalize the draft law taking into account the 


\section{ECONOMIC STRATEGIES FOR THE DEVELOPMENT OF SOCIETY}

comments and suggestions of the subjects of the legislative initiative and submit it to the Verkhovna Rada of Ukraine in the second reading.

It is hoped that the deputies will reach an agreement and make the right decisions in adopting these bills.

The derivatives market is a young segment of the Ukrainian RCP, represented mainly by futures contracts, options and option certificates. It should be noted that in 2016 the volume of issuance of option certificates increased sharply compared to previous years. The volume of trades in option certificates compared to the total volume of trades in other market instruments is extremely meager, and is used only to meet the needs of the construction industry of Ukraine's economy. But, unfortunately, this type of instrument is the only one whose trading volume increased in 2016, as the volume of trading in other types of securities decreased so much that it reached a sixyear low.

We offer the following ways to improve the regulatory regulation of the RCP:

- regulate the process of transferring RCP instruments serviced by the NBU to the competence of the Central Depository; to improve the work of the Central Depository in the direction of expanding its functions, in particular: updating and modernization of depository accounting; guarantees for securities transactions; creation of a single information database on the activities of securities issuers, etc .;

- regulate the activities of rating agencies, as well as monitoring and control over the quality of rating construction; - to improve the legislation on taxation of financial transactions on the RCP, to regulate the process of circulation of derivatives on the $\mathrm{RCP}$, as well as tax incentives for long-term investment in RCP instruments.

Effective regulatory and legal regulation of investment processes is the key to successful development and functioning of the securities market in Ukraine. The world's leading economists believe that Ukraine's investment market has significant potential for successful development, but emphasize the need to clearly harmonize relations between all stakeholders in the securities market, as well as the need to ensure proper judicial protection of all market participants. 


\section{ECONOMIC STRATEGIES FOR THE DEVELOPMENT OF SOCIETY}

\subsection{The stock market: the entity and the definition}

The relevance of the study of the regulation of the national securities market is clearly increasing. It is the securities market that is able to ensure the efficient allocation of free financial resources to those industries that can use them most productively. Additional infusion of financial resources into the activities of enterprises will allow them to invest in the expansion of fixed assets, increase production capacity, access to international markets, intensification of research and innovation.

However, at present the securities market is not functioning effectively enough, which is due to a number of negative trends and phenomena. The level of public confidence in the securities market remains low due to the lack of transparency in the protection of shareholders, especially minority shareholders. In addition, the high volatility of the national currency leads to the fact that investing in the Ukrainian economy looks less promising in the eyes of investors than investing in the economies of foreign countries, such as Western Europe and North America. In addition, the domestic financial system is bank-centric, which means that banks account for the bulk of financial services. Most citizens are familiar with the functioning of commercial banks, but the number of private investors in the securities market remains small. Bank deposits have a high degree of protection, which is due to the state guarantee of a significant amount, which is placed on the deposit. Such a competitive advantage is not typical for the securities market, which reduces its potential to attract money.

However, the securities market is able to provide higher returns, as in this case there is the elimination of the intermediary, which aims to obtain a net profit from its activities. The bank attracts deposits from individuals and businesses, and then places them at higher interest rates, including margins. The development of the securities market will reduce this impact, which will reduce the cost of raising funds by enterprises and increase the profitability of investors. Thus, it is the stock market that can become a tool that will restore the country's economic development. 


\section{ECONOMIC STRATEGIES FOR THE DEVELOPMENT OF SOCIETY}

The stock market in developed countries is an important element of the country's financial system, as it allows companies to mobilize financial resources, individuals to more effectively accumulate their own funds compared to the deposit mechanisms of banks and more. In Ukraine, the securities market has not developed enough to effectively provide the real sector with financial resources.

It is essential for the authors to understand the technical aspects of securities market regulation, including to determine the essence of this concept, which will allow in future research to conduct a better analysis of the current state of affairs in this area.

The securities market, also called the stock market, acts as an important mechanism that ensures the efficiency of management and functioning of the economy of any country, wherever it is, but the level of efficiency will fluctuate [194]. The author gives a fairly general definition, and it identifies the securities market with the mechanism of redistribution of financial resources between different participants.

The securities market is the sphere of relations between the participants regarding the issue, circulation of securities, as well as their redemption. In the securities market there is a redistribution of financial resources between suppliers of these resources (investors) and consumers (issuers) based on the circulation of securities as a commodity. This mainly determines the functions of the market of valuables in the economy, pricing, the composition of market participants, regulation, etc. [196]. We believe that this definition is narrow, as the securities market involves a number of other entities, such as regulators, intermediaries, non-profit organizations, whose activities are aimed at ensuring uninterrupted trade between participants. Thus, the securities market or stock market is the area of relations between suppliers and consumers of financial resources, regulators, intermediaries, bidders, other parties to ensure the issuance, circulation and redemption of securities.

The concept of the securities market consists of two parts, namely the concept of the market and the concept of securities. Market means a place where there is interaction between buyers and sellers on the acquisition of certain tangible and intangible resources. In turn, a security is a document that confirms the existence of 


\section{ECONOMIC STRATEGIES FOR THE DEVELOPMENT OF SOCIETY}

property rights, such as receiving commission income, repayment of a liability or the right to part of the assets of the enterprise.

The main role of the stock market can not be identified unambiguously, as this market is very diverse and includes many elements, and its structure also includes two major markets: the capital market and the debt market [194]. The capital market is more focused on providing financial resources for a long period, for example, to finance various investment projects, the payback of which exceeds a year or more. In turn, the money market is more needed to cover cash gaps in the payment calendar, replenish working capital to ensure the smooth production and marketing activities of the enterprise, increase short-term resources for other financial purposes. Of course, the securities market in each of these cases will be different, so it can be argued that its impact on the economy is diverse.

A key factor in improving the efficiency of production and strengthening its innovation orientation in a developed economy is the ability of enterprises to flexibly use a variety of market tools and mechanisms in the process of financial support of their economic activities [198]. Providing a large number of tools to attract financial resources is one of the most important areas of influence of the stock market on the functioning of the domestic economy. On the other hand, high competition between different consumers of financial resources leads to the most attractive conditions for the placement of their free funds by their suppliers.

The main task of the securities market is to provide trade stock values to attract funds needed for enterprise development [201]. 


\section{ECONOMIC STRATEGIES FOR THE DEVELOPMENT OF SOCIETY}

The easiest way to explain the impact of the securities market on the country's economy is to determine the functions that they perform (Fig. 1.1).

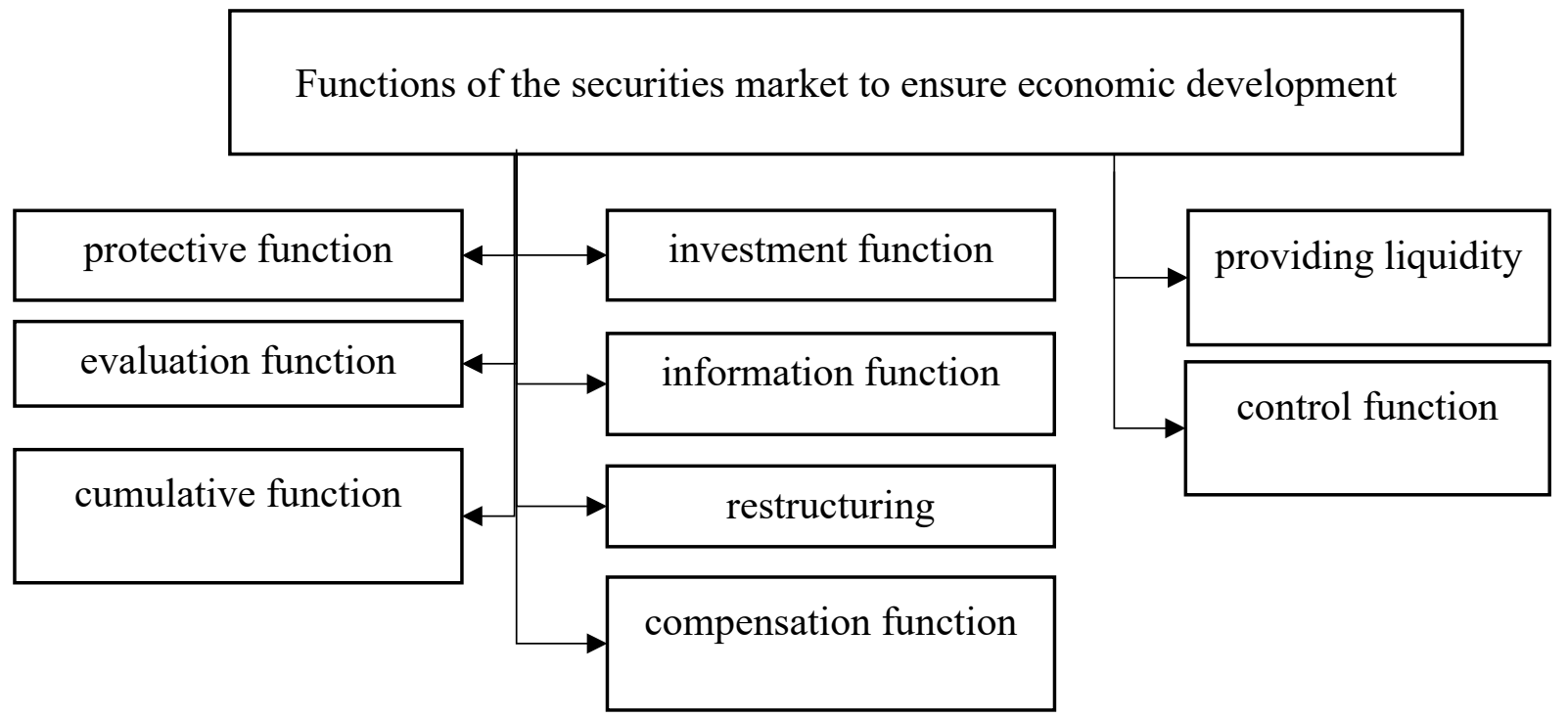

Fig. 1.1 Functions of the securities market to ensure economic development Source: compiled by the author based on materials [195, 196, 197, 203]

Consider the presented functions of the securities market in more detail.

Investment function - the distribution of investment resources required for expanded reproduction [195]. The positive side of the securities market is that it allows you to redistribute investment resources from participants who use them inefficiently to those participants who use them most effectively in the current economic environment. For example, an individual who has received a salary and wishes to defer their funds will not be able to ensure the accumulation of these funds without the availability of appropriate financial instruments. On the other hand, the company will not be able to attract additional financial resources, and will have only the owners' funds, net profit, depreciation. The securities market allows you to connect these participants, which will increase the return on capital of an individual through the use of its funds by a profitable enterprise. Also, in the process of forming their investment portfolios, investors take on additional risk, which is associated with the possibility of non-repayment of their funds due to the bankruptcy of the enterprise. In this case, the purchase of a large number of shares and bonds of various economic entities will ensure 


\section{ECONOMIC STRATEGIES FOR THE DEVELOPMENT OF SOCIETY}

significant diversification of the portfolio, which will also minimize the level of financial risk of the market participant.

It is also important to increase the liquidity of liabilities, including government [195]. The securities market cannot function effectively without ensuring its high liquidity. Liquidity means that the owner of a security will be able to sell it quickly at the market price. Efficient market activity allows to attract a large number of potential suppliers of financial resources, which ultimately ensures stable trading and the presence of a large number of participants. On the scale of the economy, the high liquidity of the securities market allows to accelerate various financial transactions. If an investor has the opportunity to invest more effectively, he will be able to quickly sell his shares and bonds for further investment in alternative instruments. You should also pay attention to the evaluation function. In any market, the price of the product is formed, respectively, and the security receives its assessment [196]. It is not always possible to know the exact price of a particular asset. There are a large number of methods that are aimed at determining the value of enterprises. For example, this includes the cost approach, income approach and others. The results of the evaluation using these methods give different results. For the most accurate estimate, you can sell part of the asset in a competitive and unlimited market, which will determine the value of the rest of the asset. For example, if you issue 5\% of the shares on the stock exchange, you can understand how the market evaluates the remaining $95 \%$ of the company. Throughout the economy, this leads to an increase in the quality of transactions of purchase and sale of assets, as it allows to obtain a realistic estimate of their value.

The information function is also important. All market participants have access to all necessary information related to market events, etc. [196]. Of course, it is impossible to ensure information asymmetry, but an effectively functioning market can minimize the negative impact of this well-known problem. Given the availability of quality regulatory support, different investors will have the same information about the current state of affairs of the company that issued the securities. In this context, the experience of the United States is especially valuable, where for providing information 


\section{ECONOMIC STRATEGIES FOR THE DEVELOPMENT OF SOCIETY}

to a journalist in a manner not prescribed by law, an official may be held liable for creating unequal conditions for investors.

The cumulative function of the securities market is performed during the formation of the authorized capital of a corporation through its placement on the primary market of its shares [199].

Restructuring of the country's economy is through the stock market, as in the absence of investment, production development slows down [203]. As mentioned, the stock market provides a redistribution of resources from less efficient enterprises to more efficient ones, which provides restructuring of the entire economy and increasing the role of the most efficient industries.

The market is also able to perform the function of control: its various quantitative indicators reflect the reproduction process through the ownership structure and capital structure [199]. It is easier for the state to control the movement of funds if the securities market is sufficiently developed.

Also important is the compensatory function, which is manifested in the financing of the budget deficit of different levels of the budget system of Ukraine on a non-inflationary basis, ie without the issuance and circulation of additional funds [200]. The securities market allows the state to quickly raise funds, which ensures the smooth implementation of socio-economic functions of government at the central and local levels.

Securities are of great importance in the economy, namely, legal entities and individuals use them as a tool for investing free cash. In addition, placing securities, the investor mobilizes resources to develop production and meet their needs [202].

To summarize, the analysis formulates our own opinion on the essence of the securities market - a sphere of relations between suppliers and consumers of financial resources, regulators, intermediaries, bidders, other parties to ensure the issuance, circulation and redemption of securities. It is determined that the influence of the securities market on the country's economy occurs through the implementation of appropriate functions: protective, investment, liquidity, valuation, information, accumulation, restructuring, control and compensation. 


\section{ECONOMIC STRATEGIES FOR THE DEVELOPMENT OF SOCIETY}

\subsection{Modern mechanisms of bank lending to agricultural enterprises}

The current state of Ukraine's economy is determined by deep processes of market transformation, the main objectives of which are to achieve the appropriate level of sustainable socio-economic development in the agricultural sector.

The priority source of financial support and support for agricultural enterprises in the direction of creating and maintaining their own material and technical base is to raise funds through bank loans. In this case, both the lender and the borrower want to make a profit from their activities: the lender seeks to provide credit for the highest fee and for a short time, and the borrower seeks to obtain credit for the lowest fee and for a longer period. The importance of this issue increases if we take into account the large financial needs for the development of farmers through bank lending to agricultural enterprises. Therefore, during the agrarian reform, the problem of credit security of rural producers as one of the sources of financial stability and economic growth remains relevant.

The issues of improving credit and investment policy at the macroeconomic and especially at the microeconomic regional level are becoming increasingly important, as the regions bear almost all the main responsibility for their socio-economic development.

Thus, the problem of credit relations can be solved at the macro- and microeconomic levels by developing and improving the credit system and the lending process aimed at agricultural production.

In a market economy, commercial banks will always remain subjects of the entrepreneur activity in the credit system. Their owners make important management decisions about the bank's activities and only they receive a profit in proportion to the share of capital invested in the bank. Customers of commercial banks use only their services on the basis of those introduced in this credit institution. However, customers choose the commercial bank whose services they use.

A characteristic feature of a commercial bank is that its main purpose is to maximize profits from its activities. This is largely due to the volume of active and passive operations. Commercial banks are constantly concerned about obtaining 


\section{ECONOMIC STRATEGIES FOR THE DEVELOPMENT OF SOCIETY}

guarantees from the borrower for timely repayment of loans and interest on them, which is very important for them. Commercial banks pay less attention the aims borrowers receive loans to, what responsibility the agricultural enterprise takes in relation to the risk when carrying out operations with borrowed funds. Undoubtedly, such approaches of commercial banks are not positive in terms of effective credit relations between the parties to the credit process.

Commercial banks seek to raise funds at the lowest possible interest rate, although the bank's capabilities are limited by objective factors of the financial market and depend little on it. In some cases, banks even raise interest rates on borrowed funds in order to quickly attract additional financial resources or fight competitors. However, such a financial policy can never become a long-term strategy of a commercial bank, because it contradicts the main purpose of its activities. At the same time, commercial banks seek to provide loans at the highest interest rates and charge the highest fees for other banking services. However, these intentions of the bank are also limited by a number of objective reasons, the main of which is the regulatory actions of the Central Bank.

It can be noted that a commercial bank is a financial institution created by a limited group of legal entities and individuals to provide financial services to others in order to obtain the maximum return on invested capital. A commercial bank is an organizational form of entrepreneurship in the financial sphere, which will always exist in a market economy, will be an important component of the credit infrastructure, it will be significantly different from cooperative banks.

In order to support domestic agricultural producers, reduce the cost of loans, improve credit relations of agricultural enterprises with credit institutions, it is necessary to move to the creation of an agricultural credit corporation to support agricultural enterprises. After all, the volume of the loan portfolio of the banking system of Ukraine is insufficient to meet the full need for lending to agriculture. As banks cannot allocate enough money for low-profit and high-risk industries, we believe that the government's decision to set up an agricultural credit corporation to support agricultural producers is on time to make up for this shortfall. 


\section{ECONOMIC STRATEGIES FOR THE DEVELOPMENT OF SOCIETY}

The perspective mechanism of creation of system of crediting of the agricultural enterprises at the expense of attraction of the agrarian credit corporation is shown in Fig.1.

This corporation will establish contacts and ensure the production and economic interaction of entrepreneurs-farmers, coordination of their efforts in solving common problems and protecting common interests.

The corporation must be formed due to the intersectoral redistribution of income in the economic complex. Such sources of its formation should be: the direction of funds from the privatization of agricultural facilities, revenues from interest payments on loans, revenues from customs duties on imported and exported agricultural products, value added tax on export goods, budget financing and foreign investment, funds various forms of assistance, etc.

At the present stage of development of credit relations, the urgent need is the creation of the Ukrainian State Peasant Mortgage Bank with operations of investment and credit support of small and medium-sized agricultural enterprises.

The most important factor in the transition period of development of the agricultural sector of Ukraine's economy is the organization of an effective credit management system and the construction of such a credit mechanism aimed at restoring agricultural production and meeting the needs of the credit and banking system. 
ECONOMIC STRATEGIES FOR THE DEVELOPMENT OF SOCIETY

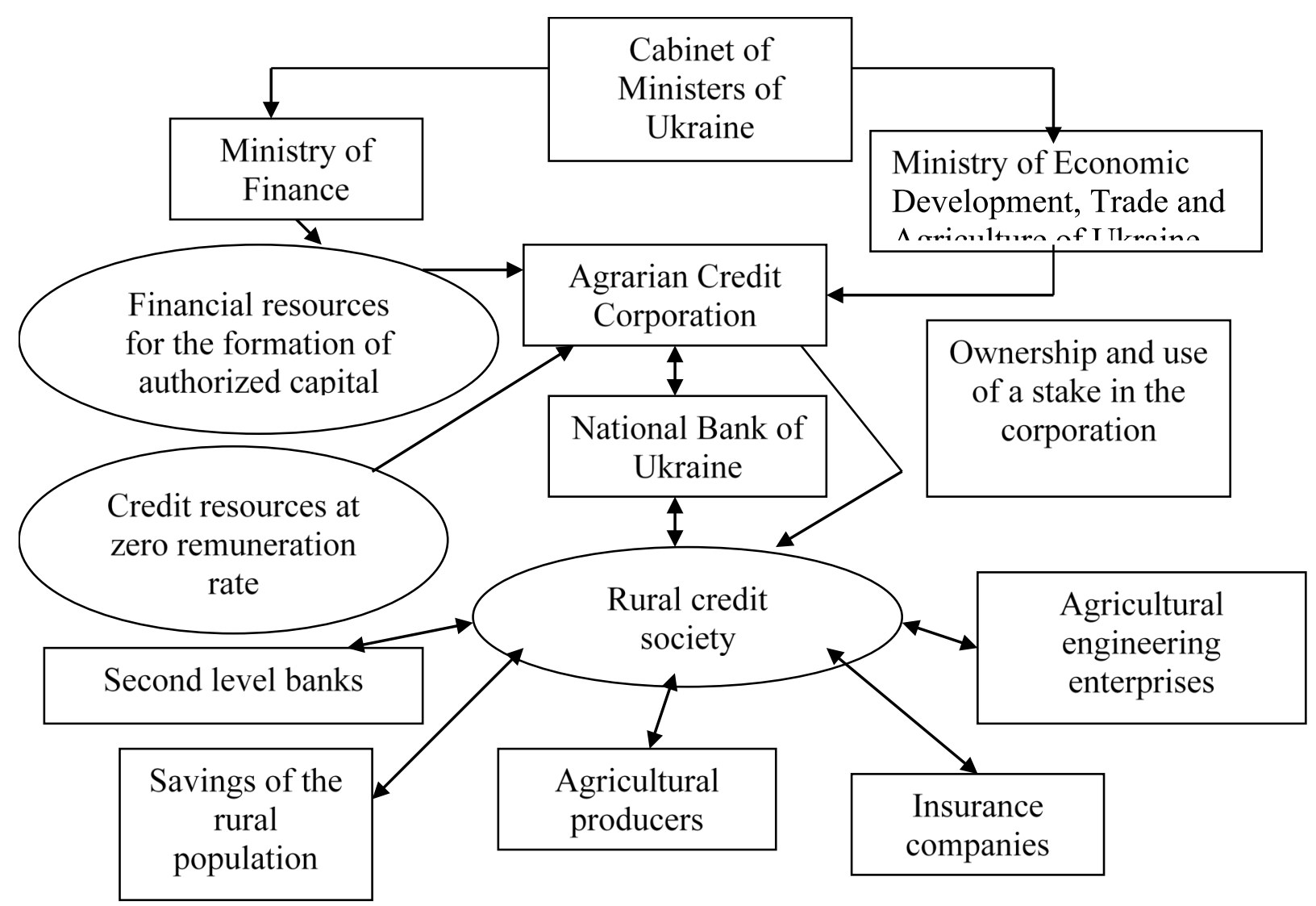

Figure 1. The mechanism of creating a system of lending to agricultural enterprises through the involvement of agricultural credit corporations

Therefore, to create favorable conditions for improving the current state of bank lending to agricultural enterprises it is necessary:

- to carry out an individual comprehensive approach to the formation of collateral;

- use different loan repayment schemes;

- expand the range of new banking products for lending;

- to improve the organizational structure and management system of the loan portfolio;

- pursue a prudent policy of risk assessment of active-passive operations;

- manage risks based on common approaches using information technology;

- create a reliable system for assessing the effectiveness of bank credit management.

Thus, to achieve significant development of the agricultural sector of Ukraine's economy, there must be an effective international and governmental program to 


\section{ECONOMIC STRATEGIES FOR THE DEVELOPMENT OF SOCIETY}

support the development of agricultural credit policy, which requires modern credit relations and scientifically sound proposals that acquire theoretical and practical significance. 


\section{ECONOMIC STRATEGIES FOR THE DEVELOPMENT OF SOCIETY}

\subsection{Budget strategy as a tool for the development of the innovation environment in the conditions of transformational changes in the economics}

Modern financial science pays significant attention to the issues of justifying the budgetary strategy of social development. The essence of it is the formation and implementation of a long-term dynamic system of goals, principles, directions, tasks of public authorities and local self-government on the basis of coordinated and adequate regulatory measures for internal and external changes in the socio-economic environment aimed at ensuring economic growth and improving the welfare of citizens. The budget strategy is a significant tool for implementing the strategic goals of social development, ensuring the creation of conditions for sustainable economic growth, improving the level and quality of life of the population, modernizing the economics and social sphere. The basis of the budget strategy is made up of directions and tasks that determine the long-term prospect of the formation and use of financial resources of budgets of different levels of the budget system, ways of solving problems arising from the peculiarities of the country's social development, the stability and sustainability of the budget system functioning, dynamic balance. Achieving the strategic goals of the country's socio-economic development depends on the degree to which the budget strategy considers the development trends of the institutional environment of financial and budgetary relations.

Increasing the effectiveness of the budgetary strategy and its relationship with financial institutions at the present stage of the public finance system development necessitates deepening the study of budgetary relations. Coordination of actions of state authorities and local self-government will allow responding to the impact of endogenous and exogenous factors while maintaining the appropriate budget parameters of integral economic development and ensuring the financial stability of the state. Strengthening globalization processes predetermines the need to update the regulatory potential of the budget strategy both in terms of revenues and expenditures, and change their architectonics. The following tasks are significant: improving the toolkit for long-term budget planning through the full implementation of medium-term budget planning, which will contribute to the dynamic coordination of ways to 


\section{ECONOMIC STRATEGIES FOR THE DEVELOPMENT OF SOCIETY}

implement financial and budgetary tasks based on sound fiscal rules, as well as the balance of budget parameters; improving the mechanism for management the budget deficit and public debt; development of an institutional environment favorable for public and private partnership as a tool to reduce the level of budgetary burden; directing budget funds to diversify the economics.

The introduction of medium-term budget planning provides the following: the development of financial and budgetary tools that will contribute to the consistency of the methodology of budgetary, strategic and economic state planning; justification of verified medium-term planning boundaries; improving the institutional components of the budget process, increasing the responsibility of its participants and strengthening fiscal discipline; assessment of the impact on the budget of exogenous and endogenous factors. Also, a significant task is to improve the mechanism for applying the programtarget method in the budget process as a tool for making effective management decisions and rational use of public financial resources. The solution to this problem implies an increase in the level of responsibility of managers of budgetary funds for achieving certain results and an increase in the level of effectiveness of budget programs implementation; implementation of effective monitoring of making and a comprehensive assessment of the effectiveness of directing budget funds to the relevant sectors; strengthening the relationship of budget programs with the strategic goals of the country's development.

It is important to note that in accordance with the Stability and Development Pact and the EU Directive on the Development of Financial and Budgetary Relations, the countries of the European Union are obliged to develop forward-looking budget plans that determine the main directions and objectives of financial and budgetary policy, as well as the expected distribution of available public financial resources that are necessary to achieve the strategic development goals of countries. In particular, in accordance with the Directive of the EU Council, the member states of the European Union define a realistic, reasonable framework for budget planning for the medium term, in order to ensure a multi-year perspective in national financial and budgetary planning. The framework of budget planning for the medium term contains: long-term 


\section{ECONOMIC STRATEGIES FOR THE DEVELOPMENT OF SOCIETY}

goals of budgetary policy in relation to the level of budget deficit, public debt and other financial and budgetary indicators; prospective estimates of financial and budgetary parameters based on assumptions about the invariability of state policy for each item of budgetary receipts and expenditures; a description of the activities planned for the medium term that have an impact on public finances, with the disclosure of the main items of budget revenues and expenditures; assessment of the actions of government bodies, taking into account their long-term consequences.

With differences in the mechanisms and tools for the formation and implementation of budgetary strategies in foreign countries, it is planned to smooth out imbalances in the socio-economic development of territories and create prerequisites for economic growth based on the modernization of the system of financial and economic relations and effective management of public finances, ensuring the consistency of budgetary and monetary policies, social and economic development of the country based on medium- and long-term budget planning; transparency and realistic formation of budgets at all levels; the effectiveness of control and audit of the effectiveness of budget funds management.

The budgetary policy for the formation of budget revenues should be based on the principles of a systematic study of financial and economic phenomena and processes, social justice, efficiency and neutrality of taxation, predictability of the level of tax burden and stability of budget receipts, balanced provision of tax benefits. Increasing the level of validity of the tax burden involves analyzing the uniformity and proportionality of its distribution in the regional context, assessing the possible change in the level of the tax burden depending on the influence of exogenous and endogenous factors. In this case, the reliability of forecasts of macroeconomic parameters, the assessment of their change likelihood, and reasonable forecast financial and economic indicators are important.

The adoption of rational and effective management decisions on the use of budgetary funds should be carried out on the basis of measures taken based on the results of monitoring and assessing the effectiveness and efficiency of budget programs, taking into account the degree of their validity based on strategic modeling 


\section{ECONOMIC STRATEGIES FOR THE DEVELOPMENT OF SOCIETY}

of socio-economic processes, medium-term planning of financial support of budgetary institutions, strategic programs, investment and innovation projects, improving the quality level of control and audit over the use of budget funds.

The importance of capital investments for ensuring economic growth and the limited resources of the budget actualize the tasks of improving approaches to planning budget investments, taking into account the strategic objectives aimed at diversification, ensuring stability and sustainability of the development of the domestic economics, revising existing procedures, establishing clear criteria for the preliminary identification of investment projects and their further selection, changing the procedure for the formation, approval of investment programs and reporting on their implementation, the transition to the formation of lists of objects of investment programs, based on the investment opportunities of the budget for the medium and long term. Budget investments should be concentrated on projects with a significant level of economic return, providing their selection to consider the priority areas of economic sectors and interregional balances development.

Improving the mechanism for management the budget deficit provides the development of new approaches to the sources of its financing, determination of the level of the budget deficit based on a reasonable assessment of the level of sustainability of public debt in the medium and long term. Improving the efficiency of the public debt management mechanism provides the following: minimizing the cost of government borrowing; increasing the level of debt sustainability; a decrease in the level of public debt, in foreign currency and an increase in the national currency; creating conditions for the development of an investment and innovation environment.

In particular, according to the Medium-Term Strategy for Public Debt Management for 2018-2020 in Ukraine, significant objectives of public debt management are determined. These are: to attract the necessary financing at the lowest possible cost, taking into account financial risks; to increase the share of government debt in national currency; to continue the average maturity period and ensuring an even schedule of public debt repayment; to attract long-term concessional financing; to continue developing strong relationships with investors; and further to improve public 


\section{ECONOMIC STRATEGIES FOR THE DEVELOPMENT OF SOCIETY}

debt management policies. Ensuring the sustainability of the budgetary system in Ukraine is expected by setting the marginal share of the state budget deficit and state debt in GDP at the level of $2.2 \%$ and 56\%, respectively. According to the Concept of a new budgetary policy of the Republic of Kazakhstan, in order to ensure debt sustainability, the share of external debt in GDP should not exceed $100 \%$, the share of public debt and the debt of the quasi-public sector should not exceed $60 \%$. In the Republic of Belarus, for the medium-term perspective, it is envisaged to form a surplus budget: in $2019-1.5 \%$ in GDP; in $2020-1.2 \%$ in GDP; in $2021-0.8 \%$ in GDP. The share of public debt in GDP should not exceed $45 \%$.

In the context of strengthening financial and economic crisis processes, the private sector can become a significant partner for state authorities and local governments in the implementation of strategic investment and innovation programs and projects. To this end, it is necessary to develop an institutional environment favorable for public and private partnership, which provides the improvement of legislation in this area, justification of its application directions, a clear distribution of functions and tasks between government bodies, creation of conditions for effective interaction between the public and private sectors, and the involvement of public associations to the implementation of strategic projects for the development of the country.

In order to ensure stability, sustainability and balance of the budget in the context of economic transformations, the budgetary policy should be formed on the basis of fiscal restrictions on the share of redistribution of gross domestic product through the budget system, the level of state and local debt, budget deficit, providing conditions for minimizing financial risks; the formation of budget indicators based on expenditure obligations, taking into account the need for their optimization, effective and rational use of budget funds; ensuring the validity of planning budget expenditures and creating mechanisms to increase their effectiveness to achieve the set results.

The cyclical nature and dynamism of economic processes necessitates an increase in the efficiency of budget funds management. The solution to this problem is possible when determining the main directions for the development of the system of state financial control and conceptual approaches to conducting state financial audit in the 


\section{ECONOMIC STRATEGIES FOR THE DEVELOPMENT OF SOCIETY}

budget process. At the same time, important tasks are the interconnection of the components of state control aimed at carrying out a system analysis and assessment of financial resources and state assets management; development, in accordance with international standards, of a methodological basis for conducting an audit in the budget process, forming a balanced structure of state financial audit bodies, taking into account a clear delineation of their powers and effective interaction; creation of an integrated information system for governmental audit and assessment of the effectiveness of budget funds management.

In modern conditions of development of financial and budgetary relations, the budgetary strategy is a complex, multifaceted and multi-aspect instrument of state regulation of socio-economic processes. The development of a budgetary strategy provides an opportunity to ensure the relationship of financial and budgetary measures with the strategic objectives of the country's socio-economic development. The effectiveness of the budget strategy is based on the validity and realism of long-term forecasts of the macroeconomic development of countries; it is an important factor for determining the strategic goals of budgetary policy, substantiating the ways of their implementation and the basis for a comprehensive assessment of the long-term balance of state and local budgets. In the context of institutional transformations, a significant task is the implementation of prudential budgetary policy based on the application of measures of budget regulation instruments, prevention of instability of the budget system by developing new approaches to fiscal constraints of budget parameters, and increasing the validity of budget architectonics.

The efficiency and effectiveness of the budgetary strategy in the context of economic transformations depends on the degree of consistency of goals, objectives and instruments of socio-economic, budgetary, tax and monetary policy, which will allow us to assess their impact on economic development and social stability. The institutional framework of fiscal policy is based on the integration of the financial mechanism components in the field of budget revenue formation, budget expenditure planning, regulation of interbudgetary relations, public debt management, based on the 


\section{ECONOMIC STRATEGIES FOR THE DEVELOPMENT OF SOCIETY}

cyclical nature of economic development, the stability margin of public finances, assessment of the quality and efficiency of budget funds use.

An effective mechanism for the implementation of priority areas of budgetary policy of an innovative nature should be the development costs of state and local budgets, the degree of efficiency of which significantly affects the effectiveness of the long-term strategy of economic development. An important condition for achieving the strategic goals of budget policy is the development of tools for assessing and monitoring the socio-economic implementation of budget programs, which will ensure the relationship between the results achieved and the amount of budget funds used, determine the factors that make it possible to execute the budget program at the required level and ensure the achievement of the planned effective indicators.

Strategic directions of financial and budgetary strategies are the basis for the development of effective practical measures to ensure fiscal sustainability, stability and balance, which contributes to accelerating the pace of economic growth. Fiscal sustainability is characterized by the ability of public authorities and local governments to finance budget expenditures in a timely manner and in full, to maintain the share of the budget deficit and public debt in gross domestic product at an economically sound level. Fiscal stability is the stability of the budget architectonics over time. The essence of budget architectonics lies in the optimal ratio of budgetary, tax, social, monetary and state debt components of financial and budgetary policy; it is a dynamic institutional process of its development and implementation in the corresponding socio-economic conditions of the country's development.

The development of a financial and budgetary strategy allows: to assess the necessary financial resources for their solution and determine the main sources of their receipt based on the key tasks of the country's socio-economic development; to make informed, rational decisions based on an assessment of their consequences in the future, to take into account the possible trajectories of the development of financial and budgetary relations based on the development of new programs, reforms, legislative acts; timely to determine methods and instruments of financial and budgetary policy in 


\section{ECONOMIC STRATEGIES FOR THE DEVELOPMENT OF SOCIETY}

any way roundabout to achieve the set goals; to assess unfavorable trends and risks of violation of budgetary stability, sustainability, balance and preventive measures.

When justifying the financial and budgetary strategy, important tasks are to take into account the institutional characteristics, trends and cyclical nature of economic processes without losing the unity of goals and objectives of the public finance system development as a whole.

The uncertainty of the fiscal strategy is associated with a significant level of volatility in incomes, interest rates, negative influence of the factors determining global demand, natural disasters, political decisions and the amplitude of exchange rate fluctuations.

Among the approaches to management uncertainty, it is advisable to single out the following: conservative budget forecasts, according to which key budget parameters are predicted conservatively, therefore, the actual implementation of budgets may be better than previously laid down in the budgets; central reserves, according to which the determination of the budgetary reserve at an economically justified level creates the necessary margin of safety to ensure fiscal sustainability and stability in the conditions of an increase in the negative influence of exogenous or endogenous factors. It is determined that a sufficient amount of budgetary reserves contributes to the development of the investment environment; the establishment of the margin consists in reserves determined by the ministries, which financing of technical or political adjustments of budgetary expenditures can be carried out from; exclusion of volatile expenses from the limits of medium- and long-term budget planning.

It is worth noting that spending limits can be determined in real or nominal values. As a rule, setting the nominal values for the current year creates a solid basis for budget planning. Setting limits in real terms for future years may provide a better basis for planning in the event of high and volatile inflation rates. When making decisions on setting limits in real terms, the fiscal impact is considered. In this case, the creation of budgetary reserves is considered justified. In particular, in New Zealand, the budget forecasting process takes into account the budget reserve, which can be recalculated when economic conditions change, but changes in the limits of new expenditures that 


\section{ECONOMIC STRATEGIES FOR THE DEVELOPMENT OF SOCIETY}

can be covered by the next annual budget are not allowed. By limiting the new policy initiatives that can be taken, it does not place strict limits on the actual costs at the same time in case that country's economic indicators deteriorate. 


\section{ECONOMIC STRATEGIES FOR THE DEVELOPMENT OF SOCIETY}

\section{5 Сучасні реалії розвитку інвестиційних процесів на ринку цінних паперів України}

Розвиток економіки держави, iї ефективне функціонування значною мірою забезпечується наявністю в ній стабільно працюючого розвиненого ринку цінних паперів, який забезпечує акумуляцію та перерозподіл вільних фінансових ресурсів як між різними сферами економіки, так і між різними їі інститутами. Адже задоволення потреб національної економіки в інвестиціях реалізується саме на ринку цінних паперів, головним завданням якого і $є$ забезпечення найбільш повної та швидкої перелив трансформації заощаджень (накопичень) в фінансові інвестиції, які, своєю чергою, $є$ необхідною умовою розвитку економіки. Саме інвестиції дають можливість інститутам реального сектору економіки формувати на базі найновіших досягнень науки і техніки виробничий потенціал, задають їх конкурентні позиції на внутрішньому і зовнішньому ринках. Тому, на сучасному етапі розвитку вітчизняної економіки актуальними $\epsilon$ питання, що пов'язані із активізацією процесів інвестування, що здійснюються на теренах національного ринку цінних паперів.

Питанням сутності інвестицій, інвестиційного процесу та інвестиційної діяльності присвячено багато наукових праць таких вчених-економістів: О. Вовчак, Ю. Герасименко, А. Гулей, Н. Ковтун, П. Куцик та ін. Водночас, дослідження сучасних реалій розвитку інвестиційних процесів на ринку цінних паперів України потребують подальшого розвитку.

Успішне вирішення завдань підвищення темпів економічного зростання, що є особливо актуальним у сучасних умовах фінансової нестабільності, а також збільшення інвестицій багато в чому залежать від ефективної роботи фінансового ринку, зокрема такого його сегменту, як ринок цінних паперів. Згідно Закону України «Про цінні папери та фондовий ринок» ринок цінних паперів є сукупністю учасників цього ринку та правовідносин між ними щодо розміщення, обігу та обліку цінних паперів і похідних (деривативів) [209]. Цей ринок функціонує у тісному взаємозв'язку із різними сегментними ринками, що виділяються у структурі фінансового ринку. Однак, варто відмітити, що ринок 


\section{ECONOMIC STRATEGIES FOR THE DEVELOPMENT OF SOCIETY}

цінних паперів вирізняється серед інших ринків притаманними йому характерними особливостями, а саме:

- на ринку цінних паперів продається і купується особливий товар - цінні папери;

- на ринку цінних паперів функціонують особливі учасники: емітенти, інвестори, посередники;

- ринок цінних паперів має двоступеневу структуру: первинний і вторинний ринок (організований і неорганізований);

- на ринку цінних паперів формується кон'юнктура, яка відображає пропозицію цінних паперів (надається емітентами та посередниками) та попит на цінні папери (створюється фінансовими можливостями інвесторів);

- регулювання ринку цінних паперів здійснюється двома «регуляторами»:

1) державою (державне регулювання);

2) саморегулівними організаціями: фондовими біржами, небіржовими фондовими торговельними системами, асоціаціями учасників фондового ринку, професійними асоціаціями брокерів, дилерів, реєстраторів, депозитаріїв тощо (саморегулювання ринку цінних паперів).

Таким чином, можна стверджувати, що формування саморегульованого механізму перерозподілу фінансових ресурсів держави між секторами іiі економіки (підвищення ефекту від використання фінансових ресурсів через їх перелив з менш прибуткових секторів до більш прибуткових) уможливлюється через вільний доступ до фінансових ресурсів через здійснення інвестиційних процесів на ринку цінних паперів, які є процесами вкладення інвестиційних ресурсів в об'єкти фінансового інвестування з метою досягнення очікуваного рівня дохідності у вигляді прибутку або соціальних вигод (ефектів).

Інвестиційний процес, як і будь-який інший процес, починається 3 формування інвестиційного бачення, тобто позиції, до якої повинна прагнути конкретна система, і його складовими є мета, цілі та завдання [210]. 


\section{ECONOMIC STRATEGIES FOR THE DEVELOPMENT OF SOCIETY}

Головна мета інвестиційного процесу — це вкладення капіталу в найбільш привабливі об'єкти з метою одержання максимального прибутку або досягнення соціального або іншого корисного для інвестора ефекту [211].

Здійснення інвестиційних процесів на ринку цінних паперів характеризується різноманіттям підходів до вибору саме об'єктів інвестування (цінних паперів, деривативів, банківських металів тощо). Тому, інвестиційні процеси передбачають проведення досліджень, які характеризують:

- дослідження пріоритетів інвестування, а також механізму реалізації інвестиційних процесів, що включає аналіз інвестиційної привабливості (інвестиційних якостей) об'єктів інвестицій;

- дослідження стратегічних напрямків інвестиційної політики держави на регіональному, галузевому і загальнодержавному рівнях. Розробка зовнішньої і внутрішньої інвестиційної політики держави в рамках інвестиційних пріоритетів, інновацій, а також пріоритетних напрямків державного інвестування. Дослідження методів державного регулювання ринку цінних паперів;

- дослідження можливостей поведінкових аспектів інвесторів на ринку цінних паперів, щодо надання пріоритетів інвестування коштів у фінансові інструменти, випущені як державними, так і недержавними емітентами.

Звичайно, залежно від характеру та специфіки прийняття інвестиційних рішень залежить і специфіка здійснення інвестиційних процесів на ринку цінних паперів. Першочергово інвестиційні процеси диференціюються на основі поділу самих інвесторів на індивідуальних (приватних), корпоративних та інституційних.

Так, індивідуальним (приватним) інвестором на ринку цінних паперів $\epsilon$ будь-яка фізична особа (домогосподарство), що має вільні кошти, які використовуються для інвестування. Тобто індивідуальні (приватні) інвестори самостійно здійснюю інвестиційну діяльність. Корпоративні інвестори, по суті, $€$ не фінансовими корпораціями різних організаційно-правових форм і форм власності. 


\section{ECONOMIC STRATEGIES FOR THE DEVELOPMENT OF SOCIETY}

Відтак зазначимо, що притік інвестицій в економіку країни на сьогодні уповільнюється все ж не стільки через відсутність інвестиційних коштів, а й у зв'язку із тим, що недостатньо прозорими $є$ механізми трансформації заощаджень індивідуальних (приватних) та корпоративних інвесторів в інвестиції. Тобто індивідуальні (приватні) та корпоративні інвестори, не маючи можливостей, необхідних знань, а також часу для того, щоб ефективно розміщувати свої заощадження на фінансовому ринку шляхом прямого інвестування, потребують професійного управління їх інвестиційними ресурсами, яке вони отримують від інституційних інвесторів. Інституційними інвесторами є спеціалізовані фінансові посередники - юридичні особи, що акумулюють заощадження (кошти) різних за статусом інвесторів для подальшого їх інвестування на професійній основі в інтересах дрібних інвесторів 3 метою отримання доходу (прибутку) та збереження вартості колективних фінансових активів [212].

За результатами ретроспективного аналізу обсягів випусків емісійних цінних паперів, які були зареєстровані Національною комісією з цінних паперів та фондового ринку у 2015-2019 р.p. можна визначити основні аспекти активності здійснення інвестиційних процесів на ринку цінних паперів щодо конкретних об'єктів інвестування. Так, загальний обсяг випусків емісійних цінних паперів, зареєстрованих Національною комісією 3 цінних паперів та фондового ринку у січні-грудні 2019 року, становив 112,68 млрд. грн., що більше на 52,3 млрд грн порівняно з відповідним періодом 2018 року (60,34 млрд. грн) [213].

Протягом 2015-2019 p.p. Національною комісією 3 цінних паперів та фондового ринку зареєстровано 575 випусків акцій на суму 748,5 млрд грн та облігацій підприємств 585 випусків акцій на суму 54,21 млрд грн (табл. 1). Порівняно з аналогічним періодом 2018 року обсяг зареєстрованих випусків акцій збільшився на 41,3 млрд грн. 


\section{ECONOMIC STRATEGIES FOR THE DEVELOPMENT OF SOCIETY}

Таблиця 1. Обсяг та кількість випусків акцій та облігацій підприємств, зареєстрованих Комісією протягом 2015-2019 p.p.

\begin{tabular}{|l|c|c|c|c|}
\hline \multicolumn{1}{|c|}{ Рік } & $\begin{array}{c}\text { Обсяг } \\
\text { випуску } \\
\text { акцій, } \\
\text { млрд грн }\end{array}$ & $\begin{array}{c}\text { Кількість } \\
\text { випусків, }\end{array}$ & $\begin{array}{c}\text { Обсяг } \\
\text { випуску } \\
\text { облігацій, } \\
\text { млрд грн }\end{array}$ & $\begin{array}{c}\text { Кількість } \\
\text { випусків, } \\
\text { шт. }\end{array}$ \\
\hline 2015 & 128,5 & 158 & 12,4 & 155 \\
\hline 2016 & 209,4 & 128 & 6,76 & 118 \\
\hline $\begin{array}{l}\text { Зміна до попереднього } \\
\text { року: абсолютна (+,-) }\end{array}$ & $+80,9$ & -30 & $-5,64$ & -37 \\
\hline відносна (\%) & $+62,96$ & $-18,99$ & $-45,48$ & $-23,87$ \\
\hline 2017 & 324,8 & 118 & 8,35 & 114 \\
\hline $\begin{array}{l}\text { Зміна до попереднього } \\
\text { року: абсолютна (+,-) }\end{array}$ & $+115,4$ & -10 & $+1,59$ & -4 \\
\hline відносна (\%) & $+55,11$ & $-7,81$ & $+23,52$ & $-3,39$ \\
\hline 2018 & 22,3 & 93 & 15,5 & 110 \\
\hline $\begin{array}{l}\text { Зміна до попереднього } \\
\text { року: абсолютна (+,-) }\end{array}$ & $-302,5$ & -25 & $+7,15$ & -4 \\
\hline відносна (\%) & $-93,13$ & $-21,19$ & $+85,63$ & $-3,51$ \\
\hline 2019 & 63,5 & 78 & 11,2 & 88 \\
\hline Зміна до попереднього \\
року: абсолютна (+,-)
\end{tabular}

Складено автором за даними джерела [213]

3 даних табл. 1 видно, що найбільша кількість випусків цінних паперів відзначається у 2015 р. (емісія акцій 158 шт. і облігацій підприємств 155 шт.). Що ж стосується обсягу емісій, а отже і обсягу інвестицій здійсненних на ринку 


\section{ECONOMIC STRATEGIES FOR THE DEVELOPMENT OF SOCIETY}

цінних паперів, то за аналізований період найбільш продуктивним був по акціям 2017 р. (324,8 млрд грн) і по облігаціям підприємств 2018 р. (15,5 млрд грн). Варто зауважити, що емісійна активність, а отже і активність інвестиційних процесів на ринку цінних паперів за 2015-2019 р.р. значно знизилась (за обсягом випуску акцій на 50,58\% та за обсягом випуску облігацій підприємств на 9,68\%).

Підсумовуючи відмітимо, що здійснення інвестиційних процесів на ринку цінних паперів України, хоча і відзначається диференційованістю щодо суб'єктів їх здійснення та об’єктів інвестування, все ж потребує їх активізації. Мотиваційні особливості такої активізації лежать у площині подальших досліджень щодо розкриття особливостей інвестиційних процесів на ринку цінних паперів та їх удосконалення. 


\section{ECONOMIC STRATEGIES FOR THE DEVELOPMENT OF SOCIETY}

\section{6 Шляхи покращення управління фінансовими ресурсами в сільськогосподарських підприємствах}

В умовах інтеграції України до світового економічного простору сільське господарство $€$ однією 3 пріоритетних і стратегічно важливих галузей національної економіки. Проте сьогодні більшість сільськогосподарських підприємств гостро відчуває дефіцит фінансових ресурсів. Основними чинниками, які спричинили таку ситуацію, стали кризові явища в економіці та відсутність ефективної системи менеджменту формування та використання фінансових ресурсів. Тому пошук шляхів покращання фінансової ситуації в сільському господарстві є актуальним і потребує подальших досліджень.

Зважаючи на накопичений науковий та практичний світовий досвід розвитку фінансових відносин в аграрному секторі, подолання кризових явищ у сільському господарстві можливе при створенні дієздатної системи забезпечення його фінансовими ресурсами. Адже зміни, що відбуваються в аграрній сфері, збіглися в часі з періодом глибокої кризи економіки України. Дефіцит бюджету, інфляція, підвищення кредитних ставок, неплатежі підприємств негативно вплинули на всі сфери агропромислового комплексу [217], і внаслідок цього нездатність сільськогосподарських підприємств забезпечити самоокупність i самофінансування не тільки розширеного, але й простого відтворення, а також зберігається інвестиційна непривабливість. Результати досліджень дають підстави для того, щоб підтримати думку та погодитись з I. Ткаченко в тому, що наслідком кризових явищ економічного розвитку підприємств стала значна нестача фінансових ресурсів, яка істотно позначилася на ефективності господарювання. При цьому, низька забезпеченість підприємств фінансовими ресурсами супроводжується неефективним рівнем їх використання [219]

Крім того, у більшості сільськогосподарських підприємств через низку об’єктивних причин, обмежені можливості залучення позикових ресурсів. Недостатня і державна підтримка сільськогосподарських товаровиробників, яка в наш час, по суті, не впливає на результати виробництва, незважаючи на наявність великої кількості державних програм. 


\section{ECONOMIC STRATEGIES FOR THE DEVELOPMENT OF SOCIETY}

Специфіка сільськогосподарського виробництва, а саме наявність значного часового лагу між операційним та фінансовим циклом не дозволяє задовольняти фінансові потреби виключно за рахунок власних джерел [218]. Успішно функціонуючі сільськогосподарські підприємства при формуванні фінансових ресурсів користуються не лише власними джерелами. Значну питому вагу в джерелах формування фінансових ресурсів повинні займати залучені фінансові ресурси, а серед них - кредити та кредиторська заборгованість. Залучення кредитів для сільськогосподарських товаровиробників $\epsilon$ не вимушеним заходом, а об’єктивною необхідністю ефективної господарської діяльності. Як зазначає В.М. Попов, своєчасне підключення позикових засобів до виробничого процесу усуває небезпеку його призупинення з причини відсутності фінансових ресурсів на придбання основних і оборотних засобів [216]. Сезонний розрив між вкладенням і надходженням коштів, безперервність процесів відтворення, значна потреба в обігових засобах перетворюють кредит в основне джерело поповнення фінансових ресурсів.

Для раціонального формування та використання фінансових ресурсів у процесі господарської діяльності слід сформувати сучасну систему фінансового менеджменту в сільському господарстві в контексті фінансової політики держави.

Система управління фінансовими ресурсами сільськогосподарських підприємств - це процес впливу на сукупність організаційно-економічних відносин, пов'язаних із залученням, розміщенням і використанням фінансових ресурсів на основі принципів самоокупності та самофінансування, через джерела, форми i методи фінансування, 3 врахуванням особливостей функціонування, з метою ефективного їх використання. Очевидно, що система

управління фінансовими ресурсами сільськогосподарських підприємств знаходиться в тісному зв'язку з розвитком ринку капіталів (див. малюнок 1). 
ECONOMIC STRATEGIES FOR THE DEVELOPMENT OF SOCIETY

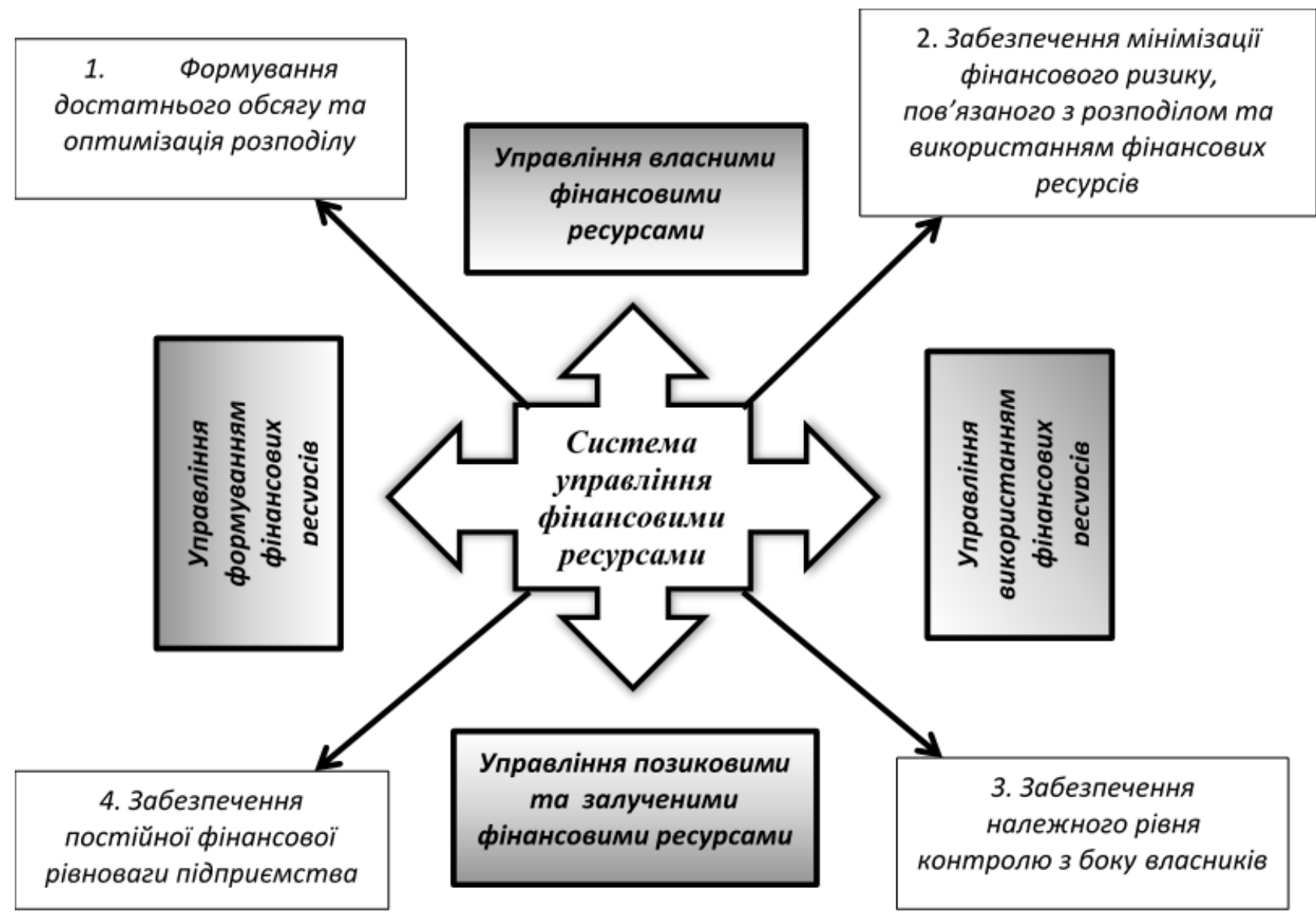

Малюнок 1 - Система управління фінансовими ресурсами підприємства*

* сформульовано та доповнено автором

Управління фінансовими ресурсами є достатньо складним завданням для підприємства, оскільки разом із платоспроможністю та дохідністю необхідно забезпечувати і кругообіг фінансових ресурсів. Саме тому, при формуванні і використанні фінансових ресурсів необхідно підтримувати своєрідний баланс між збільшенням обсягів фінансових ресурсів для забезпечення постійної платоспроможності підприємства, та забезпечення ефективності виробництва $\mathrm{i}$ конкурентоздатності готової продукції шляхом раціонального використання цих ресурсів [214]. Окрім цього, однією із важливих задач системи управління фінансовими ресурсами сільськогосподарських підприємств - нарощування власного капіталу, зміцнення їх ринкової вартості та позицій, забезпечивши мінімум фінансового ризику, пов'язаного 3 розподілом та використанням фінансових ресурсів.

В управлінні фінансовими ресурсами підприємств, безумовно, особливу увагу слід приділяти формуванню оптимальної структури їхніх джерел. Як 


\section{ECONOMIC STRATEGIES FOR THE DEVELOPMENT OF SOCIETY}

відомо, фінансові засоби формують із власних, залучених і позичених каналів. Висока частка власних джерел має позитивний вплив на фінансову діяльність підприємства. Нарощування в складі капіталу залучених і позикових ресурсів значно утруднює виробничо-фінансову діяльність товаровиробників, тому що підприємцям слід буде здійснювати додаткові дивідендні виплати за акціями або відсотки за кредитами чи облігаційними позиками. 3 огляду на це в кожному визначеному випадку слід серйозно підходити до формування структури капіталу, доцільності використання власних, залучених і позичених засобів. Звичайно, фінансове забезпечення сільськогосподарських підприємств лише за рахунок власних джерел зміцнює фінансову стабільність, дає змогу фінансувати ризикові проекти, під які важко залучити кошти інвесторів. Проте господарська діяльність не відбувається без залучення позикових ресурсів. Їхнє використання в обороті підприємства зумовлене, з одного боку, об’єктивною необхідністю, а саме: невідповідністю у часі між надходженнями коштів й витратами, сезонністю виробництва, впровадженням інвестиційних проектів, які потребують значних обсягів капіталовкладень. 3 іншого боку, за допомогою позикових коштів забезпечується розширення виробничо-господарської діяльності, оновлення технічної бази, використання ефекту фінансового левериджу та ін. [215].

Вагому нішу в системі управління фінансовими ресурсами слід відвести питанню розрахунків, оскільки несвоєчасна оплата оптовими покупцями за відвантажену продукцію тягне за собою утворення значних сум дебіторської заборгованості. Звідси виникає дефіцит грошових коштів у підприємств для розрахунків з кредиторами за поставлену сировину, матеріали, виконані роботи та надані послуги, а також утворюється кредиторська заборгованість за розрахунками з бюджетом.

Ситуація в системі управління фінансовими ресурсами ускладнюється ще й тим, що можливість проводити свою цінову політику у сільськогосподарських підприємств практично відсутня. В реальності це виражається в значному диспаритет цін не тільки між сільським господарством і ланками АПК, а й між іншими галузями національної економіки. 


\section{ECONOMIC STRATEGIES FOR THE DEVELOPMENT OF SOCIETY}

Сільське господарство є галуззю, яка не може самостійно існувати i розвиватися без державного регулювання та підтримки, навіть при економічно сприятливих умовах господарювання. Обумовлено це об'єктивними особливостями, які виражаються у високій капіталоємкості виробництва, уповільненій оборотності коштів, низькій нормі прибутковості, сезонності і високій залежності результатів виробництва від природно-кліматичних умов. Найсуттєвішим недоліком чинного механізму державної фінансової підтримки $є$ те, що бюджетні кошти виділяються 3 істотним запізненням, тобто не враховується сезонність сільськогосподарського виробництва. Цими параметрами поряд з роллю аграрної економіки в системі продовольчої безпеки країни визначається особлива роль держави як регулятора продовольчого ринку та аграрної економіки.

Отже, в період ринкових перетворень сфера АПК практично вийшла 3 під управління держави, а її вплив і підтримка зведені до мінімуму. Тому, однією 3 основних проблем існуючої системи управління фінансовим ресурсами сільськогосподарських підприємств $\epsilon$ відсутність ефективної системи фінансового менеджменту і стратегії розвитку не тільки на рівні підприємств, а й на рівні країни в цілому. Це послужить для подальших наших досліджень. 
ECONOMIC STRATEGIES FOR THE DEVELOPMENT OF SOCIETY

\section{7 Інституційні фактори корпоративного шахрайства на підприсмствах міжнародного бізнесу}

Сучасні підприємства міжнародного бізнесу функціонують в умовах посиленої глобальної невизначеності та нестабільності. В цих умовах збільшуються масштаби корпоративного шахрайства, в результаті якого міжнародний бізнес втрачає мільярди доларів. Відомі схеми побудови фінансових пірамід, шахрайство 3 податками, корпоративні шахрайства iз звітністю, використання інсайдерської інформації, крадіжки конфіденційної інформації та банківських реквізитів приносять мільярдні збитків для міжнародного бізнесу.

В світовій практиці проблеми корпоративного шахрайства знаходяться у центрі уваги державних регуляторів, аудиторських та консалтингових організацій та науковців. В Україні ж ці питання досліджуються більше з точки зору правового регулювання. Отже, питання розгляду інституційних факторів корпоративного шахрайства на підприємствах міжнародного бізнесу $\epsilon$ першочерговим завданням для ефективної роботи будь-якого бізнесу. Проблема корпоративного шахрайства широко досліджується в працях зарубіжних та вітчизняних авторів, таких як О. Барановський, С. Головко, М.Зубка, С.Мельник, Уеллс Дж, С.Яровенко, К. Эйхенвальд та ін. Однак збільшення кількості корпоративних шахрайств на міжнародних підприємствах в кризових умовах нестабільної глобальної економіки, актуалізує необхідність дослідження цих проблем.

Інституційні фактори, що сприяють вчиненню корпоративного шахрайства діють на різних інституційних рівнях - на міждержавному рівні, на рівні окремих держав та на рівні корпорацій. Деякі автори виділяють дві групи факторів об’єктивні фактори корпоративного шахрайства (відсутність системи алгоритмізації взаємодії структурних елементів, відсутність чіткої обліку товарів та матеріальних цінностей; наявність на підприємстві функціональних розривів у технології виробничих процесів) та суб’єктивні фактори (клановість, фаворитизм; відсутність формалізації відносин власників та прозорої системи 


\section{ECONOMIC STRATEGIES FOR THE DEVELOPMENT OF SOCIETY}

відбору та перевірки персоналу; наявність працівників - ексклюзивних носіїв інформації; відсутність адаптації та підвищення кваліфікації працівників; відсутність ефективної системи контролю виконання розпоряджень) [220].

Випадки корпоративного шахрайства призводять до негативних наслідків в офіційній економіці через втрату податкових надходжень до бюджету, в результаті чого ускладнюється виконання фінансових зобов'язань держави. Знижується інвестиційний рівень країни через неможливість тіньовими структурами відкрито витрачати приховані від оподаткування доходи, в результаті чого збільшується відплив грошей за кордон. Враховуючи, що діяльність компаній міжнародного бізнесу тісно пов’язана із застосуванням комп'ютерних технологій та новітніх програмних продуктів, то стрімкого поширення набуває віддалене заволодіння ресурсами компанії.

В літературних джерелах відомою $є$ гіпотеза про «трикутник» шахрайства Дональда Р. Крессі [221]. На його думку, шахрайство є результатом складного поєднання умов та мотивації людей для його скоєння. Для здійснення шахрайського вчинку потрібно наявність можливості для скоєння, тобто наявність сприятливих умов для шахрайства, вільний доступ працівника до фінансових ресурсів, слабкий механізм контролю в організації та внутрішне виправдання таких дій. Можливість включає в себе наявність системи організації праці на підприємстві, яка може в подальшому сприяти вчиненню шахрайських дій. Фактори, що збільшують ймовірність скоєння корпоративного шахрайства, а також обставини, які вказують на можливі недобросовісні дії з боку співробітників, можуть бути найрізноманітнішими (табл. 1). Таким чином, серед факторів ризику, що збільшують ймовірність корпоративного шахрайства на підприємствах міжнародного бізнесу є неефективний контроль за управлінцями всіх ланок з боку власників бізнесу, тобто ситуація, коли повноваження керівництва не врівноважуються наявними засобами контролю з боку власників. 


\section{ECONOMIC STRATEGIES FOR THE DEVELOPMENT OF SOCIETY}

Таблиця 1

Фактори ризику й обставини, які обумовлюють шахрайські дії

\begin{tabular}{|c|c|}
\hline Фактори & Обставини \\
\hline $\begin{array}{l}\text { Неефективний контроль за } \\
\text { управлінцями всіх ланок з боку } \\
\text { власників бізнесу }\end{array}$ & $\begin{array}{l}\text { повноваження управлінців не забезпечені } \text { наявною } \\
\text { системою контролю з боку власників }\end{array}$ \\
\hline $\begin{array}{l}\text { Здійснення угод } 3 \text { пов'язаними } \\
\text { особами або спеціально } \\
\text { створеними компаніями }\end{array}$ & $\begin{array}{l}\text { може використовуватися керівництвом міжнародної } \\
\text { компанії для виведення прибутку/збитків та/або активів } \\
\text { у власних інтересах або з метою прикрашання фінансової } \\
\text { звітності. }\end{array}$ \\
\hline $\begin{array}{lr}\text { Систематична } & \text { зміна основних } \\
\text { контрагентів } & \text { міжнародної } \\
\text { компанії } & \\
\end{array}$ & $\begin{array}{l}\text { укладання угод } 3 \text { організаціями-одноденками, які } \\
\text { створюються в шахрайських цілях }\end{array}$ \\
\hline $\begin{array}{lr}\text { Складна } & \text { організаційна } \\
\text { структура бізнесу, розгалужена } \\
\text { філіальна мережу, велика } \\
\text { кількість дочірніх компаній }\end{array}$ & $\begin{array}{l}\text { фінансові результати, активи та зобов'язання багато } \\
\text { переміщуються між учасниками групи, що створює } \\
\text { потенційний ризик шахрайства }\end{array}$ \\
\hline $\begin{array}{l}\text { Специфічні/нетипові } \\
\text { укладених договорів }\end{array}$ & $\begin{array}{l}\text { - відстрочка платежів на тривалий термін; } \\
\text { - укладання угод з некредитоспроможними партнерами; } \\
\text { - відсутність в договорі відповідальності покупця за } \\
\text { прострочення оплати; } \\
\text { - використання векселів в рахунок оплати, разовий } \\
\text { характер операцій; } \\
\text { - систематичне здійснення збиткових операцій }\end{array}$ \\
\hline $\begin{array}{ll}\text { Використання окремих видів } \\
\text { операцій }\end{array}$ & $\begin{array}{l}\text { оренди, лізинг, факторинг, безоплатна передача майна у } \\
\text { власність, кредит, посередницькі операції, аутсорсинг }\end{array}$ \\
\hline
\end{tabular}

Джерело: складено авторами

В моделі, яка зазначена на мал.1, елементи циклу шахрайства, з одного боку функціонують самостійно, але результат більший за суму результатів його елементів (так званий синергетичний ефект). При відсутності якогось 3 елементів, шахрайство відбудеться, проте наслідки будуть менш загрозливими.

Аналізуючи основні причини, що змушують співробітників компанії чинити шахрайства, важливо не переоцінити значення тільки фінансових стимулів. Крім того, ситуативні персоналізовані механізми контролю на підприємстві зможуть дати відповідь на запитання, чи не призводять занадто агресивні плани 3 продажів до шахрайських дій. Також, ефективна система попередження потенційних проблем на підприємстві може бути реалізована шляхом «політики відкритих дверей» та «гарячої лінії», про які необхідно повідомляти всім співробітникам. 
ECONOMIC STRATEGIES FOR THE DEVELOPMENT OF SOCIETY

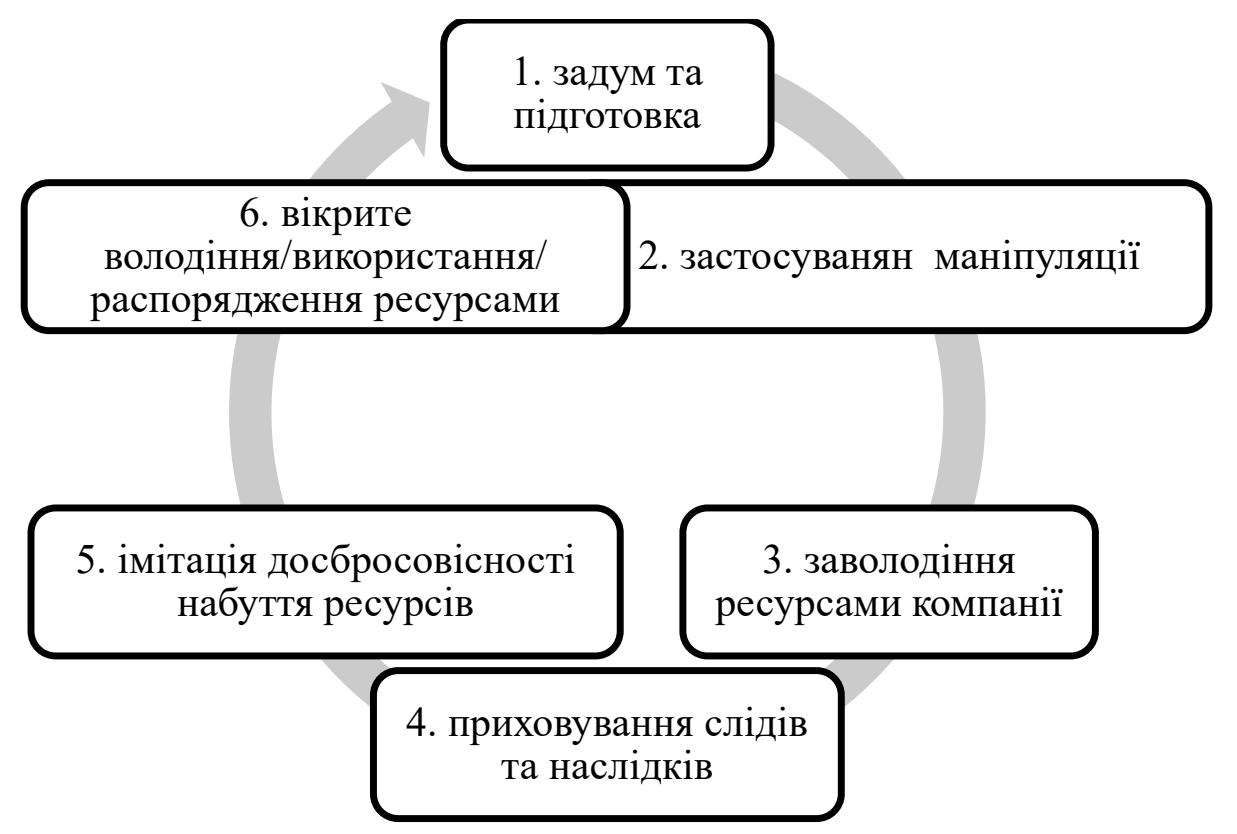

Джерело: [222]

Малюнок 1. Цикл корпоративного шахрайства на підприємстві міжнародного бізнесу

Серед соціально-психологічних чинників вчинення корпоративного шахрайств необхідно зазначити:

- здатність майнових потреб особи випереджати у своєму розвитку формування дієвого економічного підгрунтя для їх задоволення;

- низький рівень юридичної культури та правосвідомості громадян, які виражаються як в незнанні законів, зневажливому ставлення до них, так й в низькій ймовірності притягнення до кримінальної відповідальності за корисливі злочини через низьку довіру до судової системи; створення ілюзії безкарності осіб, які займають високе положення в суспільстві;

- низький рівень культури та свідомості, культ збагачення та моральнопсихологічна криза, яку загострює брак ідеології та прагнення до наживи будьяким шляхом;

- брак сучасних традицій чесного підприємництва, непопулярність серед населення виконання міжнародних стандартів бізнесу, стереотипи ухиляння від виконання своїх зобов'язань (наприклад, сплата податків);

- високий рівень недовіри до правоохоронних та державних органів. 


\section{ECONOMIC STRATEGIES FOR THE DEVELOPMENT OF SOCIETY}

Наявність в міжнародній компанії слабкої системи контролю або ж взагалі іiї відсутність, може спонукати співробітників до економічних правопорушень. Враховуючи, що однією 3 головних причин корпоративного шахрайства $\epsilon$ можливість зробити неправомірний вчинок безкарно, то особливе місце має атмосфера, що склалася на підприємстві, так як саме в колективі закладаються норми поведінки, того, що допустимо, а що ні в бізнес-процесі.

Таким чином, корпоративне шахрайство спрямовано на розкрадання активів суб'єкта господарювання шляхом привласнення його прибутку або шляхом обману та зловживанням довірою і характеризується навмисним втручанням посадових осіб у фінансову та господарську діяльність компанії з метою здійснення i/aбо приховування шахрайських дій. Корпоративне шахрайство - це глобальна проблема, що стосується всіх компаній міжнародного бізнесу. Конкретна сфера діяльності компанії не впливає на ймовірність апропріації корпоративних активів.

Проведений аналіз сутності та схем корпоративного шахрайства будуть сприяти розробці найбільш ефективних методів його запобігання, що в перспективі матиме вирішальне значення для зниження проявів корпоративного шахрайства на міжнародних підприємствах, в тому числі й в Україні. 


\section{ECONOMIC STRATEGIES FOR THE DEVELOPMENT OF SOCIETY \\ SECTION 10. INNOVATIVE ECONOMY}

\section{1 Інноваційна діяльність та інтелектуальна власність як основа розвитку держави}

Прагнучи до стабільного і стійкого економічного зростання, що забезпечує у результаті поліпшення добробуту населення, практично усі країни світу проголосили третє тисячоліття ерою інтелектуальної власності. За останні сто років технологічне лідерство стало визначальним фактором у створенні національних багатств більшості держав. Провідні економічно розвинені країни приділяють значну увагу належній охороні результатів інтелектуальної творчої діяльності, де об’єкти промислової власності відіграють важливу роль у досягненні економічних успіхів. У сучасному світі об’ єкти права інтелектуальної власності відіграють значну роль у забезпеченні конкурентоспроможності товарів та послуг і стають, таким чином, вирішальним чинником економічного розвитку кожного окремого підприємства та держави в цілому [223].

Забезпечити стабільний економічний розвиток на основі постійного вдосконалення технологічних процесів дозволяють науково-технічні досягнення, їх надійна правова охорона й використання.

Інновації стають останнім часом одним 3 головних рушіїв прогресу та розвитку економічного потенціалу світу. Винаходом писемності, друкарства, радіо, телебачення, комп'ютерів, з покращенням умов життя практично будь-яка людина може проявити свої творчі здібності.

Бурхливий розвиток засобів масової інформації дав можливість автору дуже швидко доносити своє творіння до споживача в будь-яку точку земної кулі. Завдяки цим факторам до процесу створення нової інтелектуальної власності долучаються все більше й більше людей.

Інтелектуальна діяльність - це творча діяльність, а творчість - це цілеспрямована розумова робота людини, результатом якої є щось якісно нове, що відрізняється неповторністю, оригінальністю, унікальністю. Чим вищий інтелектуальний потенціал індивідуума, тим цінніші результати його творчої 


\section{ECONOMIC STRATEGIES FOR THE DEVELOPMENT OF SOCIETY}

діяльності - інтелектуальна власність [224].

Перший вид творчості людини відноситься до ії культурних та мистецьких досягнень. Другий тип творчості становить науково-технічна діяльність, результати якої називають промисловою власністю. Результатом художньої творчості $є$ літературні і художні твори. Результатом технічної творчості винаходи, торговельні марки, комерційні таємниці тощо.

Україна поставила собі за мету докорінно оновити суспільство, перебудувати господарський механізм i, врешті-решт, істотно поліпшити добробут народу. Для розв'язання цих завдань велике значення має використання потужного науково-технічного потенціалу країни, зокрема такого невичерпного джерела, як технічна творчість, і вищого іiі рівня - винахідництва.

Рівень розвитку науки і техніки $€$ визначальним чинником прогресу суспільства, підвищення добробуту громадян, їх духовного та інтелектуального зростання. Цим зумовлена необхідність пріоритетної державної підтримки розвитку науки як джерела економічного зростання і невід’ємної складової національної культури та освіти, створення умов для реалізації інтелектуального потенціалу громадян у сфері наукової i науково-технічної діяльності, забезпечення використання досягнень вітчизняної та світової науки і техніки для задоволення соціальних, економічних, культурних та інших потреб [225].

Винахідництво - це одна 3 об'єктивно необхідних стадій у процесі перетворення науки на безпосередню продуктивну силу. 3 одного боку, воно стикується з науковою діяльністю, насамперед з іï вищими результатами відкриттями, а з другого - забезпечує суспільне виробництво необхідними засобами, знаряддями, технологіями, матеріалами того. Досягнення науки стають фундаментальною базою для технічної творчості, яку постійно стимулює гостра потреба суспільного виробництва у новій техніці, технології, матеріалах, інших знаряддях і засобах [226]. Таким чином, винахідництво є однією із ланок інноваційного процесу.

В сучасних умовах суспільне виробництво не зможе успішно розвиватися й функціонувати без належного науково-технічного забезпечення. Розвиток 


\section{ECONOMIC STRATEGIES FOR THE DEVELOPMENT OF SOCIETY}

наукової діяльності і розвиток суспільного виробництва не можна розглядати як окремі ізольовані процеси. Виробництво у своєму розвитку постійно спирається на досягнення науки і техніки, але у свою чергу ставить перед наукою все нові й нові проблеми, завдання, на які наука має знайти відповіді, розв'язати виниклі проблеми.

Але досягнення науки не можуть бути використані безпосередньо у виробництві. Треба знайти способи використання наукових досягнень у доцільній діяльності людини. Пошуки таких способів використання фундаментальних наукових досягнень у практичній діяльності суспільства і має здійснити винахідництво.

3 огляду на ці фактори значення винахідництва як елементу інноваційнокреативного процесу для підвищення ефективності суспільного виробництва, розв'язання соціально-економічних проблем важко переоцінити. Створення i впровадження технічних удосконалень значною мірою залежить від правильного регулювання творчої діяльності, яка полягає у пошуках нових рішень з метою підвищення рівня виробництва, його ефективності і в підсумку - підвищення рівня добробуту народу України. Тому такі пошуки мають всебічно стимулюватися державою.

Вони потребують чіткого правового забезпечення. Розробка таких рішень, їх оформлення, використання у народному господарстві породжують ряд правових відносин між авторами пропозицій, їхніми володільцями та особами й організаціями, що їх використовують. Ці відносини регулюються правом промислової власності або патентним правом, оскільки основним правоохоронним документом, який захищає об’єкти промислової власності, $є$ патент (деякі результати науково-технічної творчості охороняються свідоцтвами або посвідченнями) [227].

У зарубіжній та вітчизняній літературі є цілий ряд досліджень, присвячених теорії та практиці інноваційної діяльності. Загальні питання управління інтелектуальною власністю, а також управління об’ єктами права інтелектуальної власності на різних етапах їх життєвого циклу знайшли своє відображення у 


\section{ECONOMIC STRATEGIES FOR THE DEVELOPMENT OF SOCIETY}

наукових працях Александрової В. П., Алімова О. М., Варгатюка А. П., Вачевського М. В., Геєця В. М., Дахна І. І., Доброва Г. М., Капіци Ю. М., Лахтіна Г. А., Маліцького Б. А., Павловського М. А., Перерви П. Г., Пригожина А. І., Санто Б., Фатхутдінова Р. А., Чухрай Н. І., Шкворця Ю. Ф., Шумпетера Й., Яковлєва А. І. та ін.

При дослідженнях окремих питань управління інтелектуальною власністю основна увага зосереджувалася не на винахідницькій діяльності, а на соціальноекономічних аспектах використання вже готових (тобто створених) об'єктів інтелектуальної власності (зокрема, на проведенні організаційних заходів, скерованих на вдосконалення роботи патентних підрозділів [228], поліпшення системи підготовки фахівців, стимулювання винахідницької активності і т. ін.) та на економіко-правових проблемах управління (зокрема, на маркетингових дослідженнях, набутті прав, на впровадженні інтелектуальної власності в господарський оборот) [229].

Перебільшення правової і економічної складових деякі фахівці пояснюють тим, що створені об’єкти права інтелектуальної власності є найбільш зручними об'єктами для управління (вони достатньо чітко визначені законами, підлягають оцінці й бухгалтерському обліку як нематеріальні активи, а також дозволяють здійснювати з ними бухгалтерські операції) [230]. Безумовно, таку точку зору необхідно враховувати, але і винахідницька діяльність не може залишатись без належної уваги.

Інноваційна інфраструктура в Україні $є$ функціонально неповною, недостатньо розвинутою і не охоплює всі ланки інноваційного процесу. Не підтримується належним чином діяльність винахідників, раціоналізаторів, науковців, що мають завершені науково-технічні розробки. Водночас аналіз стану інноваційної діяльності в Україні, зокрема розробки, впровадження та використання охороноздатних науково-технічних досягнень, свідчить, що однією 3 найважливіших є проблема створення організаційно-економічного механізму стимулювання розробки, створення та використання нововведень на усіх рівнях господарювання. 


\section{ECONOMIC STRATEGIES FOR THE DEVELOPMENT OF SOCIETY}

Інноваційні процеси в Україні не набули достатніх масштабів і не стали суттєвим фактором зростання ВВП. Інноваційна діяльність як засіб досягнення конкурентоспроможності не має альтернативи, а для України характерне скорочення кількості інноваційно активних підприємств.

Економічне зростання сучасних високотехнологічних компаній визначається не стільки їх товарно-матеріальними цінностями, скільки нематеріальними активами, які не випадково отримали назву інтелектуального капіталу. В нього включаються як наукові співробітники, так і нові технології, постійне підвищення кваліфікації персоналу, його професіоналізм тощо. Можна стверджувати, що впровадження об'єктів інтелектуальної власності створює капітал, який грунтується на знаннях і у подальшому використовується у сфері господарства та особливо діяльності суб’єктів господарювання [231].

Сукупність знань, професійних практичних навичок та творчих здібностей персоналу юридичної особи $є$ складовими людського капіталу. Вони $є$ моральними цінностями. Іншим капіталом є технічне і програмне забезпечення, організаційна структура, патенти, торгові марки тощо. Такий капітал на відміну від людського може бути об'єктом купівлі-продажу.

У аналітичному звіті «Промислова власність у цифрах. Показники діяльності у сфері промислової власності за 9 місяців 2019 р.» державного підприємства «Український інститут інтелектуальної власності» зазначено, що протягом 9 місяців 2019 р. найбільш активними серед національних заявниківюридичних осіб були організації, які працюють у галузі «Освіта» й «Наукові дослідження та розробки» (90,8\% заявок), і лише 9,2\% заявок припадає на інші галузі. Кількість заявок на винаходи і корисні моделі від юридичних осіб у галузі «Освіта» зросла на 5,4\%, кількість заявок у галузі «Наукові дослідження та розробки» зменшилася на 4,5\% порівняно з відповідним періодом попереднього року. Кількість заявок, поданих закладами освіти, щороку перевищує кількість заявок, поданих науковими організаціями [232].

Найбільш активними за 9 місяців 2019 р. були організації, підпорядковані Міністерству освіти і науки України (МОН України), Міністерству охорони 
ECONOMIC STRATEGIES FOR THE DEVELOPMENT OF SOCIETY здоров я України (МО3 України), Національній академії наук України (НАН України), Національній академії медичних наук України, Національній академії аграрних наук України. Заявниками МОН протягом аналізованого періоду подано 2772 заявки 47,8\% від загальної кількості заявок, поданих юридичними особами); МОЗ України - 1449 (25,0 \%), НАН України - 523 (9,0\%), Національної академії медичних наук України - 193 (3,3 \%); Національної академії аграрних наук - 136 (2,3\%). Серед вищих навчальних закладів, підпорядкованих МОН України, які показали найвищу активність за 9 місяців 2019 р. у звіті «Укрпатенту» названі такі: Національний університет харчових технологій, КПІ ім. Ігоря Сікорського, Національний університет біоресурсів і природокористування України, НТУ «ХПІ», Таврійський державний агротехнологічний університет, Харківський національний університет міського господарства ім. О. М. Бекетова, Вінницький національний технічний університет, Одеська національна академія харчових технологій, XAI, Національний університет «Львівська політехніка» [232].

Статистичні дані свідчать про наявність інтелектуальної власності в Україні, однак головною перешкодою залишається відсутність розробки механізму їх комерціалізації.

Найдорожчий ресурс суспільного виробництва - це людський розум i людські здібності, інноваційний потенціал особистості. Тому інвестиції в науку, виховання, освіту, тобто в людський капітал, є найефективнішими. 


\section{ECONOMIC STRATEGIES FOR THE DEVELOPMENT OF SOCIETY}

\subsection{The impact of economic cycles on the activities of enterprises}

World economic development and the development of individual countries are accompanied by different in nature and period fluctuations, which are described by the cycles of Kitchin (3-4 years), Juglar (7-11 years), Kuznets (20-22 years) and Kondratieff (40-60 years). The presence of these fluctuations, which are not accidental, but natural is fundamentally important, because they reveal specific mechanisms of market economic development associated with the renewal of inventories, the dynamics of investment in fixed capital, investment in infrastructure development, technological changes and socio-political development.

Nikolai D. Kondratieff's theory of long cycles has received much attention [233]. As is known in the mid-1920's N. D. Kondratieff described the natural fluctuations of world economic development with a period of 40-60 years, which he called long cycles [234]. Analyzing the objective basis of long cycles, N. D. Kondratieff found their causes in the process of reproduction, in the periodic renewal of fixed assets as a result of technological upheavals, in the development of significant technical inventions and discoveries. The consolidated system of Kondratieff waves (K-waves) and technological modes is given in table.1 $[235,236]$.

The alteration of downswings and upswings is connected with the need of the industrial economy to expand; this expansion, however, inevitably meets serious obstacles. One may speak about the alteration of two developmental trends:

- prevalence of qualitative innovations (creation of new technologies);

- prevalence of quantitative development - implying a wide introduction/diffusion of innovations.

Both tendencies are simultaneously present in economic systems, however, in some periods one of these tendencies prevails, whereas in the other periods the other tendency does. Processes of qualitative innovation are connected with periods of emergence and validation of new technologies of various types (production technologies, financial technologies, social technologies including technologies of counter-crisis management). Quantitative processes are connected with such periods when such technologies diffuse widely - up to the exhaustion of their potential [237]. 
Table 1.

The system of K-waves and the appropriate technological modes

\begin{tabular}{|c|c|c|c|}
\hline Cycle & Upswing wave & Downswing wave & Background (technological basis) \\
\hline 1 & 2 & 3 & 4 \\
\hline $\mathrm{I}$ & $\begin{array}{l}\text { From the late } \\
1780 \text { 's to } 1810- \\
1817\end{array}$ & $\begin{array}{l}\text { From } 1810-1817 \\
\text { to the end of the } \\
1840 \text { s }\end{array}$ & $\begin{array}{l}\text { textile factories, industrial use of } \\
\text { coal }\end{array}$ \\
\hline II & $\begin{array}{l}\text { From the late } \\
1840 \text { 's to the early } \\
1870 \text { 's }\end{array}$ & $\begin{array}{l}\text { From the early } \\
1870 \text { 's to the late } \\
1890 \text { 's }\end{array}$ & $\begin{array}{l}\text { coal mining and ferrous metallurgy, } \\
\text { railway construction, steam engine }\end{array}$ \\
\hline III & $\begin{array}{l}\text { From the late } \\
1890 \text { 's to 1914- } \\
1921\end{array}$ & $\begin{array}{l}\text { From } 1914-1921 \\
\text { to } 1944-1948\end{array}$ & $\begin{array}{l}\text { heavy engineering, electric power, } \\
\text { inorganic chemistry, production of } \\
\text { steel and electric motors }\end{array}$ \\
\hline IV & $\begin{array}{l}\text { From } 1944-1948 \\
\text { to the end of the } \\
1960 \text { s }\end{array}$ & $\begin{array}{l}\text { From the late } \\
1960 \text { s to the early } \\
1980 \text { s }\end{array}$ & $\begin{array}{l}\text { production of cars and other } \\
\text { machines, chemical industry, oil } \\
\text { refining and internal combustion } \\
\text { engines, mass production }\end{array}$ \\
\hline V & $\begin{array}{l}\text { From the early } \\
1980 \text { s to the early } \\
2000 \text { s }(2001- \\
2005)\end{array}$ & $\begin{array}{l}\text { From the early } \\
2000 \text { s to 2017- } \\
2020\end{array}$ & $\begin{array}{l}\text { development of electronics, } \\
\text { robotics, computer, laser and } \\
\text { telecommunications equipment }\end{array}$ \\
\hline VI & $\begin{array}{l}\text { From the early } \\
2020 \text { s to the early } \\
\text { to mid-2040s }\end{array}$ & $\begin{array}{l}\text { From the early to } \\
\text { mid-2040s to the } \\
2060 \text { s (forecast) }\end{array}$ & $\begin{array}{l}\text { possible convergence of nano-, bio- } \\
\text { information and cognitive } \\
\text { technologies, artificial intelligence, } \\
\text { environmentally friendly energy } \\
\text { sources }\end{array}$ \\
\hline
\end{tabular}

The table. 1 shows that on the border of upswing and downswing waves of Kondratieff cycles, there are large technological changes associated with the change of leading technologies, the dominant technological structure (modes). Epochs of increased economic activity are periods during which the development of technology and the discovery of new resources create a favorable basis for growth, and above all - for investment growth. During such periods, the pace of technological progress becomes much faster. In long periods of expansion, revolutionary technology is put into operation, which profoundly changes the nature of the whole economy. Most often innovations have historical significance and irreversible changes in the method of production. For example, the introduction of the conveyor, the procedures for 


\section{ECONOMIC STRATEGIES FOR THE DEVELOPMENT OF SOCIETY}

organizing the labor process, the scientific and technological revolution of the 1960s, computerization and informatization of the 1980-90s.

Deep global economic crises in the final stage of the declining wave of Kondratieff cycles are regularly repeated every $40-50$ years [234]. Thus, at the end of the downswing wave of the fifth Kondratieff cycle, we can expect such a crisis in the 2020s [238], the beginning of which can be observed today. The author's forecast of the dynamics of economic environment (conjuncture) within the VI long Kondratieff cycle is shown in Fig.1.

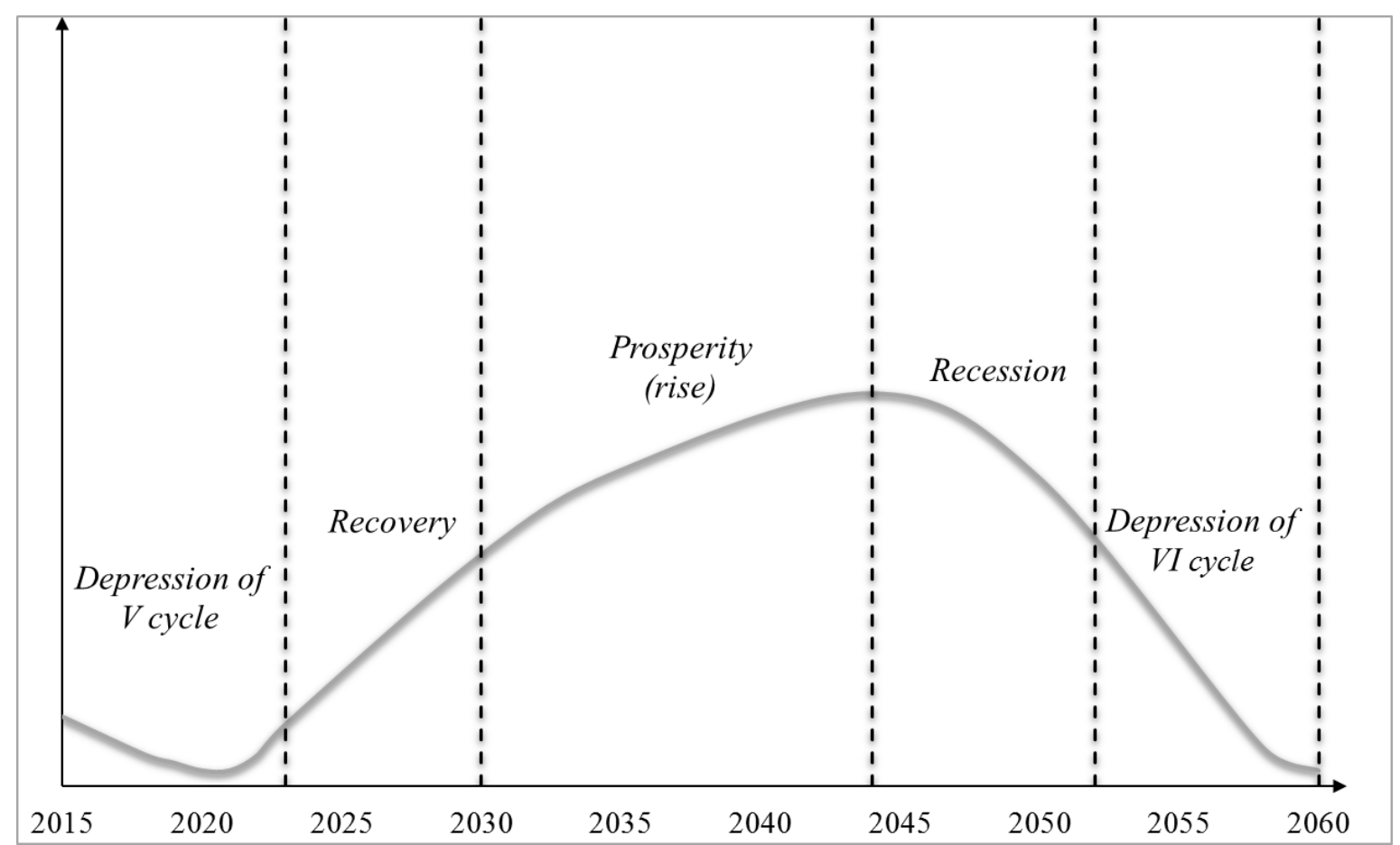

Figure 1. Forecast of the dynamics of changes of the economic environment of the VI long Kondratieff cycle.

In the phase of reduction of the K-wave and at the bottom of the depression phase, important inventions are made (not only technical, but also in the field of management), which will be implemented at the beginning of the growth phase and will create new industries, a new technological mode. The new mode, in addition to changes in industry, usually involves a new paradigm in education, a new type of energy, transport, a new way of communication (Zoom, Viber, cryptocurrencies, social networks and sales development through them are spreading fast now, also the 


\section{ECONOMIC STRATEGIES FOR THE DEVELOPMENT OF SOCIETY}

production of electric cars is actively going on, the share of distance learning is growing rapidly - during the pandemic in 2020 almost the whole world for the first time in history switched to distance learning and partly to distance work of enterprise personnel). Obviously, based on the above, the world economy is now in a phase of depression, at the lowest point of the downswing wave of the $\mathrm{V}$ cycle.

The main phenomenon of the $\mathrm{K}$-wave is a relatively regular period of the change from K-wave upswings to K-wave downswings, and vice versa:

1) Both trends (upward and downward) are present in the modern economy at the same time and always (so periods when there is no qualitative or quantitative development at all, but at every phase one or those trends predominates).

2) The change of the trend is largely prepared by its exhaustion, i.e. the weakening of one trend paves the way for the strengthening of the other.

3) Rising prices and profit margins, as well as high demand cumulatively lead to the expansion of production. The falling rate of profit, reduction of the growth rates, etc. lead to the reduction in investment and the search for new innovative solutions [237].

The large number of innovations that appear in the period of prosperity is exactly the same factor that disturbs the balance and so changes the conditions of industrial life that it inevitably comes a period of adjustment of prices, values and production.

Enterprises producing means of production and consumer durables are most sensitive to cyclical fluctuations. These enterprises benefit the most from the recovery in the economy, but at the same time they are harder enduring the downturn. The purchase of capital equipment can often be postponed to the future, in difficult times for the economy, manufacturers tend to refrain from purchasing new machinery and equipment. During a prolonged downturn, enterprises often prefer to repair or upgrade obsolete equipment instead of spending heavily on new ones. As a result, investment in industrial goods declines sharply during economic downturns [239,240].

So the slowdown in growth may not always be due to the approach of the decline of the product. The impact of cyclical development and crisis phenomena in the economy on the view of the product life cycle curve should not be the cause of a 


\section{ECONOMIC STRATEGIES FOR THE DEVELOPMENT OF SOCIETY}

temporary slowdown in growth as a final trend. Signals indicating a slowdown in growth in such situations should be considered as false and temporary.

Thus, the trajectory of the product life cycle in practice may deviate from the reference under the influence of changes in economic environment, caused primarily by short-, medium- and long-term cycles. Thus, receiving signals about the slowdown in the growth of product efficiency should be compared with macroeconomic dynamics. 


\section{ECONOMIC STRATEGIES FOR THE DEVELOPMENT OF SOCIETY}

\subsection{Innovation networks of an enterprise}

In today's globalized and highly competitive world focus on continuous innovation is the key to market success of any company. Constant monitoring of the market situation with the possibility of providing modifications of products, services and methods of work in the market is of high importance today. It is important to implement innovation strategy aimed at using the potential of the external market environment and building an innovative network of the enterprise to ensure innovative development. Modern experience of the most successful enterprises demonstrates the popularity of using network innovative models of an enterprise development, which allow to maximize the possibilities of innovation development.

Modern business networks are networks of cooperation, collaboration and are becoming more and more innovative, focused on building value chains, focused on innovation. Business models are being restructured and organizational capabilities are being developed, such as networking opportunities to create "values" that lead to efficiency. The development of the innovation strategy of a modern enterprise in conditions of high dynamism of the market environment and increased competition, which stimulates the need for continuous innovation, should be based on finding a wide range of opportunities to use innovation potential, both internal and external. This means the need to build an innovation network of the enterprise, which includes the widest possible range of resources for innovation or the establishment of innovation cooperation. Nowadays many innovation leaders are increasingly focusing on "mixed" innovation strategies by combining internal innovation drivers and external partners and thus open innovation to the outside world.

Innovation network is a complex organizational structure that provides maximum use of available scientific and technical resources for the development, production and sale of innovative goods and services, implementation of technological innovations, development of innovation, production and human resources within a single information and communication space. In fact, it is a specialized large-scale information network that brings together various businesses that help companies disseminate information about their projects, provide organizational support at various 


\section{ECONOMIC STRATEGIES FOR THE DEVELOPMENT OF SOCIETY}

stages of technology transfer, organizational assistance in finding partners. The organization of scientific, technical and innovation spheres on a network basis causes fundamental changes in the mechanism of innovation. It allows participants (both national and global) to make changes in the model of innovation at their production facilities: to commercialize their developments and form a powerful expert environment.

Business networks can be built in various forms: franchising networks, building value and value chains, joint ventures, strategic alliances, clusters, partnerships and digital networks [241]. In addition to the emergence of new network forms, enterprises are creating new markets for innovation, which are formed through alliances and the implementation of cooperation strategies as an opportunity to reduce or avoid uncertainty and barriers to market entry. In this sense, the globalized digital economy reinforces this effect through the formation of markets "without borders", in which the need to build adaptive and innovative business models and new flexible forms of work is becoming increasingly popular [242].

Fig. 1 shows the elements that form an innovation network of the enterprise. The internal innovation network focuses on strengthening the internal innovation cooperation of the company's organizational units and includes employees and R\&D departments of the company, the opportunities for which the innovative potential should be taken into account as much as possible. The external innovation network of the enterprise includes external market entities and organizations that can be involved in various forms of cooperation and collaboration in order to access the generation of innovative ideas and the implementation of innovative projects. 
ECONOMIC STRATEGIES FOR THE DEVELOPMENT OF SOCIETY

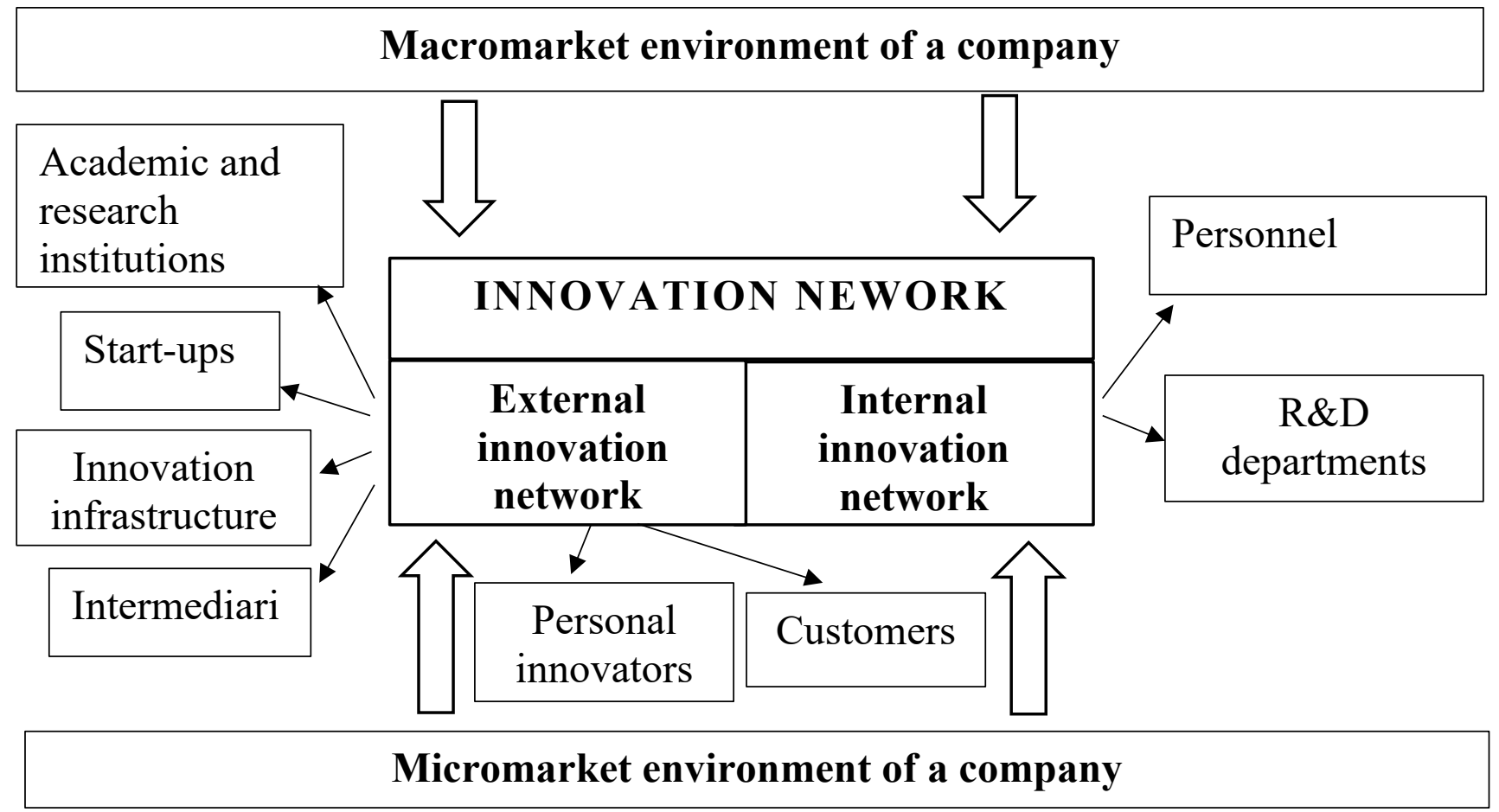

Source: Complied by the author

Fig.1. External and internal innovation network of an enterprise

Innovation centers and $R \& D$ departments is of high importance for any company today. For example, IBM has 12 laboratories on five continents, bringing together more than 3,000 researchers. In 2016, the company created an internal project "Knowledge Management", dedicated to finding better opportunities to generate ideas and develop the internal potential of the company, aimed at strengthening the horizontal links between different departments of the corporation and teams to share experiences [243]. The world's leading corporations are actively investing in innovative development, development of internal potential of employees, creating a corporate culture that maintains a high system of staff motivation and provides opportunities for continuous improvement and development. The concept of building "teal companies" focused on the integrity, self-government, focus on the work of teams that work to achieve a common goal, which provides a high motivation for these teams [244], is becoming more widespread today. Such organizations make it possible to find innovative solutions.

External innovation network of the enterprise includes the following elements:

1. Academic and research institutions. The basis for the development of an 


\section{ECONOMIC STRATEGIES FOR THE DEVELOPMENT OF SOCIETY}

innovative economy is the connection between education, universities, scientists and entrepreneurship. Most of the world's leading companies actively cooperate with research institutions and universities, funding educational programs and allocating research grants to address their target needs. The tendency to place the company's research centers near universities, academic institutions, the center of science and research has increased significantly in recent decades. Examples are Silicon Valley near the University of Stanford and the University of California, Greater Boston, which spans 55 higher education institutions and continues to attract companies focused on innovation.

2. Startups, which today are actively experimenting with new technology, robotics, artificial intelligence and are actively implementing new principles of creating business models and bringing value to the consumer. According to recent research, many companies today see the need and importance of working with startups to stimulate innovative development. According to the publication of the World Economic Forum 2018 regarding the development of cooperation between technology startups and corporations, most modern companies try to cooperate with startups in order to promote innovation. Both sides benefit from such cooperation. Cooperation with startups allows companies to expand the innovative view, to adjust the corporate culture to openness to innovation, to focus on the consumer, to search for innovative suppliers, to focus on the latest developments in a particular market. A successful example of such a strategy is Samsung's acquisition of Smart Things in the field of information technology, thus gaining access to new technology [245].

3. Innovation infrastructure. Acceleration of innovation processes is possible through the establishment of innovative cooperation, creation of innovative alliances of enterprises in the form of purposeful scientific and technical cooperation with business incubators, innovation centers, technology transfer centers, science and technology parks, technopolises, innovation clusters, innovation banks, innovation banks. An example is the operation of the Samsung Incubator business incubator, created in 2017 in Poland to support innovative companies in the field of information technology. Entrepreneurs can become members of the incubator if there is a business 


\section{ECONOMIC STRATEGIES FOR THE DEVELOPMENT OF SOCIETY}

concept or product prototype. During the three-month participant support program, the company provides space for creative work, as well as equipment, management support and expert advice at each stage of the innovation project. In addition, the business incubator provides training services and provides support and support to participants in finding the necessary technology and business partners. IBM cooperates with the high-tech park of the Ministry of Communications and High Technologies of Azerbaijan, focusing on software development, cooperation in the field of banking services and telecommunications.

4. Intermediaries. Establishing innovative cooperation and creating horizontally integrated management systems is possible with suppliers and intermediaries, which are strategic development partners and which are part of the "value chain" of the enterprise. Consulting companies can help to search for and build an ecosystem of innovation management of the organization by auditing the company, collecting data on innovative technologies in the market, new market trends and building business models.

5. Personal innovators. The scientific community, individuals who are experts in various fields, actively participate in innovative competitions can be a source of innovative ideas. For example, AT\&T and American Express organize creative innovation contests and innovation hackathons to find innovative ideas among consumers and the public. The Kickstarter crowdfunding platform organizes competitions for ideas to find funding. Procter \& Gamble uses crowdsourcing to develop P \& G's "Connect + Development" electronic platform, which highlights current issues and needs of different business units and anyone can submit a proposal to solve the problem [245].

6. Consumers. Customer support, communication with customers, working with feedback and suggestions, creating vertically integrated systems give a powerful impetus to the introduction of innovations in the service and modifications of products and services. In 2018, IKEA introduced a digital platform for cooperation with consumers in order to co-create new products and innovations with consumers "CoCreate IKEA". 


\section{ECONOMIC STRATEGIES FOR THE DEVELOPMENT OF SOCIETY}

The basis for building an innovation network of an enterprise is a thorough monitoring of its business environment in order to find opportunities to attract innovative ideas and search for market players to build effective cooperation. It is important to use all potential opportunities to find innovations, use forms of cooperation, collaboration, work with the innovation infrastructure of the market and other market participants. Establishing effective innovative forms of work and innovation management mechanisms at an enterprise is a factor of increasing its competitiveness in an innovative economy and the spread of business networks. 
ECONOMIC STRATEGIES FOR THE DEVELOPMENT OF SOCIETY

\subsection{Military tourism development in Ukraine: actual problems in modern conditions (on example of Kamyanets-Podilskyi, arpad line and molotov line)}

Relevance of research topic. More than a century has passed since proclamation of Kamyanets-Podilskyi the capital city of the UPR, and the further away from these events, the greater interest represents every detail of the establishment of Ukrainian statehood. So the period of Kamyanets-Podilskyi's staying in the status of the capital of the UPR provides great opportunities for development of military-patriotic tourism, which are not fully discovered now.

Formulation of the problem. Kamyanets-Podilsky, which is mentioned first among the tourist wonders of Ukraine, is known generaly for Ukrainian and foreign tourists, because of its historical fortress from the XV-XVIII centuries of PolishTurkish origin (more correct - a castle, because in the Middle Ages the inaccessible fortress represented the whole city) [264]. But the tourist potential of the city is far from exhausted, since the Ukrainian Liberation Competitions of 1917 - 1920 gave it the opportunity to become for a long time (about 1 year) the capital of the UPR and ZUPR (Soborna (United) Ukraine) with full implementation of the capital functions and the availability of all relevant structures. Almost all the buildings where they were situated, have remained in the city until our time and are directly related to the activities of the most famous heads of the UPR and ZUPR, first of all, the Head of the Directoriate and the Chief Commander of the UPR Army Simon Petliura. All these facts should be reflected on the image and development of tourist flows and brands of this destination, especially as in the world practice (USA, China) tourism brands are sometimes created artificially, cities change their names according to tourist demand [250]. In Kamianets-Podilskyi there is nothing to think of and to change - its days, as the capital of the UPR and ZUPR (that is, United Ukraine), have left in itself both photo-documentary and material - architectural heritage. It's impossable not to use this heritage in order to diversify the tourist offer of the city in the direction of priority development of national-patriotic and military-patriotic tourism in modern conditions of independent Ukraine. 


\section{ECONOMIC STRATEGIES FOR THE DEVELOPMENT OF SOCIETY}

Analysis of recent researches and publications. A study of the source-base of the article revealed that there are many publications, but they are mostly historical nature - without any connections to tourism. One can refer, first of all, to online sources [248, 249, 260, 261, 263, 265], as well as to guidebook "Kamyanets - the last capital of the UPR" [266], Polish - language [249, 257] and other sources [250, 264]. Sources [251-253,254,256,262] devoted to the military-tourist potential of the Arpad Line and the Molotov Line are found mainly in Ukrainian-language and Polish-language sources. Problems of restaurant business development in Ukraine in the Covid-19 epidemic are reflected in the materials of the current press and Internet materials [255, $258,259]$.

Forgotten capital of the United Ukrainian State: capacity for militarypatriotic tourism development in city of Kam'yanets-Podilskyi. One can say that Kamyanets-Podilsky became the capital of the Soborna (United) Ukrainian State in 1919, since both the UPR Directoriate and its ministries and the ZUPR Dictatorship with the state secretaries (ministers) were located here, as well as the Head of the Directoriat, Chief Commander S. Petliura and ZUPR Dictator E.Petrushevich. Kamianets also housed the highest organs of the UPR and ZUPR Armed Forces - the UPR Active Army (Ministry of Military Affairs and General Staff) and the Ukrainian Galician Army (Chief Command). So in Kamianets there was an attempt to integrate the two Ukrainian states and their Armed Forces into a single body. Contemporaries emphasized the great importance of this period for Ukrainian national construction. General M. Omelyanovich-Pavlenko later wrote: "In the second half of 1919, Kamyanets of Podillya played an outstanding role during our liberation struggle. Here in a small space gathered everything that was saved from the long-lasting, fierce previous struggle that was running on both sides of the muddy river Zbruch (former border)... It was for the first time that the Great and Western lands of the United and Single Ukraine became one against the other, as two worlds that have been politically divided for centuries; after all, they came together so closely and by force of circumstances were forced to look each other directly to the eyes, and that was for the good! The common woe did its thing: it fermented two branches of numerous nation 


\section{ECONOMIC STRATEGIES FOR THE DEVELOPMENT OF SOCIETY}

into one community" [265]. The two Ukrainian governments had a difficult relationships, which also affected the military situation. Thus, among the units stationed in Kamianets was the 1st Brigade of the USS (Infantry) of the Ukrainian Galician Army (UGA), which during July - September 1919 actually served as E. Petrushevich's guard. UPR government tried to create a similar elite division in the form of the Haidamak Brigade. As M. Kapustiansky (the quartermaster-general of the UPR Army) noted, "A unique combination was created. On the one hand - UGA, which had the features of the former Austrian army: positive (rational organization, punctuality even in the smallest detail, accuracy, stubbornness and endurance in battle, but without proper tenacity and perseverance to bring it to an end at all costs) and negative (extra centralization, fear for their flanks and rear, lack of broad initiative and waiting for orders from above). The infantry of UGA did not require much and listened strictly to their officers orders. The Dnieper army had the properties of a former Russian army, with some biases for better or worse. Strong fitures included stubbornness, dedication, endurance, contempt for death. But in general the Army of the UPR was less organized than the UGA, with less discipline, rear and supplies. From the purely combat side, as the ability to maneuver on wide fronts, to fight on all four sides of the world, personal initiative, the Army of the UPR was stronger than the UGA in the conditions of the Maneuver-Bolshevik front. It was supposed to be a perfect combination of carefulness, limited desires, obedience of Halychyna style UGA with initiative, militancy and a wide reach of the UPR Army. They complemented each other. Together, they could create, under favorable conditions (equipment, weapons), a formidable, invincible Ukrainian Weapon" [252]. Concentration of the UGA and UPR Army on the Podillya soil opened a new page of combat cooperation between them. The transformation of Kamyanets to the capital city (even forced and temporary) of the United Ukraine contributed to the revitalization of cultural life in the city as well.

Almost all the buildings, which housed the various state institutions of the UPR and ZUPR, have been preserved in the city up to the present time and are directly related to the activity of the most famous heads of the UPR and ZUPR, first of all, to the Head of the Directoriat and the Chief Commander of the UPR Army, Simon 


\section{ECONOMIC STRATEGIES FOR THE DEVELOPMENT OF SOCIETY}

Petliura. Military historical festivals and reconstructions are essential for attracting tourists to Kamianets-Podilsky, as the former capital of the UPR. In general, the city can be recommended annually to hold "UPR Days" lasting several days, the purpose of which is to recreate the events of the few months of 1919, when the capital of independent Ukraine was located in Kamianets-Podilskyi. These can be military parades, training of units of UPR and ZUPR armies, theatrical performances, performances of poets and singers with authentic works of the UPR times, stage performances of "UPR leaders" at rallies, the reconstruction of fights and more. If you involve university students together with high school students and dress them in the military uniforms of the UPR and ZUPR armies to participate in staged events, then the whole city will find itself in the atmosphere of the "capital of the UPR in 1919." For tourists (Ukrainian and foreign) it would be an unforgettable festival. Appropriate program of activities should be prepared in advance, submitted in print and electronic media, advertised on the Internet, on television, etc. The basis for such a festival already egsits - it's the military-historical festival "The Last Capital", dedicated to the Kamianets Era of the Ukrainian People's Republic, which was held on August 24-25, 2019 after a five-year break. During the festival, two clashes were reconstructed between the UPR Active Army and the Armed Forces of the South of Russia (A. Denikin's Army), and later during the tactical game - between the UPR Active Army and Bolshevik units. The event took place in the park opposite the "Rosmay" Trading Centre on Shevchenko Street - at 16.00 and at the Polish Market Square - at 17.30. During the two battles the audience was commented on by well-known Kyiv historian and heraldist Alex Rudenko. The tactical game took place on the second day of the festival at the Polish Filwarks, when: "The enemy was very close. The Bolsheviks were on a nearby field, and the guys from infantry reconnaissance squord of the Third Iron Division of the UPR Army did not know about it. Their detachment was divided: half left on the left bank of the river Smotrych, and then crossed the river fording. Others set off along the ancient Polish Gate. "Petlyura" armored car followed the detachment, then stopped, waiting for his time. The Bolsheviks saw and prepared the approach of the reconnaissance men: they barricaded the road to the field, and three ambushes were 


\section{ECONOMIC STRATEGIES FOR THE DEVELOPMENT OF SOCIETY}

prepared in shrubs of bushes and trees. The muzzle of the rifles was sticking out of the corn, and sometimes the shaggy papakhas could be seen in the reeds. Shots reflected off the high cliffs of the canyon. The battle lasted for a quarter of an hour: the field was covered with the bodies of the fallen, only a cabin boy from the Bolshevik detachment survived, and the people who came to Kamyanets-Podilskyi beach to sunbathe were filming everything on their phones, sometimes without even lifting from towels spread out on the bank of Smotrych river [253]. There were a lot of spectators (tourists) watching the street fights in the city, but, alas, few people watched the tactical game, although all the events of the festival were free.

More than 200 reconstructors participated in this event, including members of the city military-historical society, the Victims of War Search Society "Memory" (Lviv), NGO "Living History" (Vinnytsia), the Vinnytsia History Center; Protector of Water (Odessa); Age "172 Infantry Regiment" (Kyiv); Plastun Water Company (Kyiv); 44th Infantry Regiment (Kyiv), Insurgent Regiment (Kyiv), reconstructors from Khmelnytskyi, 46th Dobrich Regiment from Dobrych (Bulgaria). Among the reconstructors there were many ATO (Anti - Terorist Operation) / OUF (Operation of the United Forces) participants who went from the front to the "historic front", defending the position of independence of Ukraine through the reconstruction of the Liberation events. Among the reconstructors were women who recreated the mourning sisters who provided first aid during and after the battle, and "paramedics". Three armored cars ("Chernik" from Kamenets, "Petliura" from Vinnytsia and unnamed one from Lviv) drove through the streets of the city, as well as an antique-looking Fiat truck and several passenger cars of that era. In their free time from the "fighting" the reconstructors practiced in the studio and demonstrated the camp soldiers life from the early twentieth century for all Kamyanets Castle guests. The festival began with a free concert by the People's Artist of Ukraine Taras Kompanichenko and "Horia Cossack" in the courtyard of the Old Castle. The team brought the program "Songs of the Ukrainian Revolution" from the works of the time of the Liberation Competitions of 1917-1921. The Kamyanets event became the "godfather" of a similar festival in city of Vinnitsa, and in the plans of the organizers - the reproduction of the events of 1920, 


\section{ECONOMIC STRATEGIES FOR THE DEVELOPMENT OF SOCIETY}

namely the episode of the Polish-Bolshevik war [249, 257]. This is an interesting and important topic that is practicly unknown to the vast majority of the Ukrainian population. The reconstructions plans also include an educational component of the festival.

In such a way, Kamianets-Podilsky restores the memory of its time as the capital of Ukrainian Revolution. The gains and losses of the UPR Directoriat become the topic of military-historical festivals and reconstructions (like "The Last Capital"), publications, guides and excursions. Kamyanets is slowly recollecting its past and its capital status, which it had under UPR, but its tourism potential in this context is not fully revealed. For exsample, the tourist guide-book "Kamyanets as the last capital of the UPR", published in 2011 [266], has not been republished since then and has become a rarity even in online stores, and excursions under the same name do not have proper advertising in Ukraine and abroad, that was noted by correspondent of the Lviv newspaper "Vysokyi Zamok" during a visit to the city, paying attention to the proposal of an city excursion about... witches [248]. The Military History Festival and Reconstruction under name "Last Capital", which took place in Kamianets-Podilskyi in August 2019 after a 5-year break, was also unheard of in all Ukrainian advertising and publicity. As a result, the organizers of this festival, which is very interesting for tourists, boasted that it gathered over 200 reconstructors from Ukraine and abroad, but the number of tourists remained silent, and although most of the festival's events were free for spectators, only a few casual tourists came to see the tactical game.

Conclusion. Kamianets-Podilskyi, as a significant tourist destination of Ukraine, needs to diversify its tourist image by attracting into it the capital city's past in the time of the UPR Directoryat, which is especially important nowadays aspecially for the education of school pupils and students (taking into account the Ministry of Education requirement for their tourist mobility), and secure that image with the right brand (logo, slogan). In any case, the city's capital status obliges to it.

Comparative characteristics of the Arpad Line (Ukraine) and the Molotov Line (Poland) as border military tourist objects. Military tourism is actively developing today in Ukraine and the world and attracts more and more not only fans 


\section{ECONOMIC STRATEGIES FOR THE DEVELOPMENT OF SOCIETY}

of the history of war and postwar times, but also more ordinary tourists, both from Ukraine and from other, especially neighboring countries (like Hungary, Poland, etc.). This type of tourism is developing in the post-quarantine period as well, although it is forced to adapt to the relevant requirements of national and international scale. A powerful resource base for the development of this type of tourism is, in particular, fortifications of the Second World War. Let's consider the development of military tourism in Ukraine on the example of the Arpad Line and the Molotov Line. The first one was built in the Carpathians mountains by Hungarian and German military engineers and scientists in 1943-1944 to protect from the Red Army offensive (now this fortifications are situated in the Ukraine's Transcarpathian region), and the second one was created by the former Soviet Union in 1939 -1941 on its new western borders for protection from German offensive (now these fortifications are situated in Eastern Poland). If the Arpad Line has long been a special tourist highlight in Transcarpathia region, the Molotov Line is still waiting for its tourist "discovery", in particular for tourists from Ukraine.

The legendary Arpad Line is a unique object of world importance and is one of the most complex large-scale defensive facilities of World War II. It was created by the military and engineers from Hungary and Germany and its size is really impressive: the length is $600 \mathrm{~km}$, half of which is in Ukraine, and rest - in Romania [251]. Basis of the Hungarian-German military project "Arpad Line" were multiple separate "defense units". There were almost 100 of them in Transcarpathia. They included 800 long-term defense units (DOTs), 400 wood-earth fire points (DZOTs), 430 open fire structures, $135 \mathrm{~km}$ of anti-tank obstacles and $400 \mathrm{~km}$ of trenches. This fortifications system was named after Prince Arpad, the founder the Hungarian state in the late 800 s, who united tribes of ancient Hungarians. The fortifications plan was designed by talented Hungarian military engineer Teofil Horoszy. The Arpad line was created with the conviction that this defense system would save Hungary and Germany from the Soviet offensive, and that it should be built on hard-to-reach Carpathian ridges. The greatest attention during construction was concentrated on such passes as Uzhotsky, Veretsky, Yablunetsky, Torunsky. Emphasis was placed on the defense of tunnels, roads and 


\section{ECONOMIC STRATEGIES FOR THE DEVELOPMENT OF SOCIETY}

bridges, defense units were built in the valleys of the rivers Latorytsia, Uzh, Tysa. In total, in Transcarpathia region, researchers counted six defense lines, including four Hungarian (whith Arpad line), and two - Czechoslovak. There are currently more than 1,500 former military facilities in the region since World War II. Warehouses, hospitals, barracks, bakeries, ventilation shafts and control exits, as well as churches were located in powerful reinforced concrete bunkers. All construction operations were conducted under the seal "top secret" and by October 1944 were fully completed. One of the most powerful defense units was built on the Uzhotsky Pass, which defended Uzhgorod, Veretsky Pass defense unit controlled the Mukachevo direction. The outskirts of Synevyr lake were defended by defensive points of Khust direction. Many defensive units were built in the village of Yasinya (then Kereshmez) to protect the Rakhiv direction. However, the Germans and the Hungarians mistook - such a powerful fortifications did not protect them. The Red Army went on the offensive in another direction - through the Svydovets mountain range, descended to the village of Yasinya, where the decisive battle took place. In fact, this maneuver saved other parts of Transcarpathia from bloody battles. As almost all fortifications of the Arpad line were mined, the Hungarian army retreated and blew up the bunkers. Some of them that survived after the war were destroyed by the Soviet militaries. Today, the ruins of military facilities remain from the Arpad Line, as well as small stone pyramids obstacles for tanks. One of the surviving bunkers is located in the village Verkhnya Grabivnytsia in the Volovets region, not far from the Veretsky Pass. It is a $150 \mathrm{~m}$ long tunnel carved right into the rock. To this day, weapons and some military equipment are preserved here. In the village Kolochava in the Mizhhirya region $100 \mathrm{~m}$ of the Arpad Line have become local historical and military museum with thousands of exhibits, and it is wildly popular today among Ukrainian, Hungarian and tourists from other countries. Dozens of tunnels, residential barracks, hundreds of bunkers, anti-tank pyramids and ditches, mortars, guns, trenches, hospitals - all this was only in one such stronghold! Now Transcarpathian entrepreneurs have made a real tourist hotels from some defence bunkers. 
Table 1. Comparative characteristics of the Arpad Line (Ukraine) and the Molotov Line (Poland) as border military tourist objects*

\begin{tabular}{|c|c|c|c|}
\hline № & $\begin{array}{l}\text { Object's } \\
\text { name } \\
\text { Characteristic } \\
\text { features }\end{array}$ & Arpad line (Ukraine) & Molotov Line (Poland) \\
\hline 1 & Territory (region) & Carpathians mountains & Roztocze \\
\hline 2 & $\begin{array}{l}\text { Time of } \\
\text { construction }\end{array}$ & 1941-1943 & 1940-1941 \\
\hline 3 & What state built & Hungary & USSR, the Ukrainian SSR \\
\hline 4 & $\begin{array}{l}\text { Purpose of } \\
\text { construction }\end{array}$ & $\begin{array}{l}\text { Protection against the Soviet } \\
\text { offensive during World War II }\end{array}$ & $\begin{array}{l}\text { Protection against possible } \\
\text { aggression by Nazi Germany } \\
\text { at the beginning of World War } \\
\text { II }\end{array}$ \\
\hline 5 & $\begin{array}{l}\text { Stage of completion } \\
\text { and equipment }\end{array}$ & Fully completed and equipped & $\begin{array}{l}\text { Only concrete bunkers were } \\
\text { built, no heavy weapons were } \\
\text { installed }\end{array}$ \\
\hline 6 & Military use & $\begin{array}{l}\text { None, the Soviet offensive took } \\
\text { place in another direction }\end{array}$ & $\begin{array}{l}\text { Inefficient, powerful weapons } \\
\text { have not been installed, } \\
\text { German troops passed } \\
\text { Molotov Line in two days }\end{array}$ \\
\hline 7 & Current location & Ukraine, Zakarpattia region & $\begin{array}{l}\text { Republic of Poland, Lublin } \\
\text { Voivodeship }\end{array}$ \\
\hline 8 & Use in tourism & $\begin{array}{l}\text { Very active and intensive - by } \\
\text { tourists from Ukraine, Hungary } \\
\text { and other countries }\end{array}$ & $\begin{array}{l}\text { One-sided, sluggish - mostly } \\
\text { by Polish tourists, for } \\
\text { Ukrainian tourists this object } \\
\text { is almost unknown }\end{array}$ \\
\hline
\end{tabular}

* Author's working out [251, 252, 253, 254]

Another unique tourist resource for military tourism is the Molotov Line, which located in the Lublin Voivodeship in Eastern Poland. These are formidable from the outside, but, as it turned out, completly powerless defence concrete bunkers, many of which are scattered throughout modern Eastern Poland, and in particular in the Roztocze region of the Lublin voivodship [256]. This region some 120 years ago had no military-strategic value, as the state borders of that time divided it between the Russian Empire (north) and Austria-Hungary (south), so powerful defensive forts were then built in the modern Rivne region of Ukraine (Tarakanivsky fort) and in Przemyśl (modern Poland). No wonder that Przemyśl has a monument devoted to the famous literary hero of Czech writer J. Hasek - a soldier of the Austro-Hungarian army J. Schweik, who took part in hostilities during World War I exactly in these places. Nothing like this was built in Roztocze at that time and no major battles were recorded. The political - geographical and military situation of the region changed with the 


\section{ECONOMIC STRATEGIES FOR THE DEVELOPMENT OF SOCIETY}

formation of an independent Polish state - in the 20-30s of the twentieth century, when Roztocze became one of the eastern border regions of Poland adjacent to the Western Bug. This became apparent at the beginning of World War II, after the German attack on Poland, when in Roztocze, near the town of Tomaszów in September 1939, one of the largest tank battles between Polish and German troops took place. Roztocze did not lose its military-strategic value even after the territory of Poland was captured and divided between Nazi Germany and the former USSR in 1939 under the RibbentropMolotov Pact. On September 17, 1939, with the beginning of World War II, the Soviet Union introduced troops into the territory of Eastern Poland (modern western regions of Ukraine and Belarus). The Treaty of Friendship and Borders, signed the USSR with Hitler's Germany on September 28 of the same year, established the new western border of the USSR as a whole along the Curzon line, with the exception of the Bialystok district, where it passed slightly further west. After the annexation of Western Ukraine and Western Belarus by the USSR the Stalin Defense Line, built in the 1920s and 1930s, lost its significance, as Soviet border line was moved $300 \mathrm{~km}$ to the west, where the Molotov Line originated. This name is informal and has come into use relatively recently [250]. It is believed that it was first used by Victor Suvorov (Rizun), a Soviet spy defector, and later - a writer who revealed soviet military secrets in the French edition of his book "Icebreaker" (1988)[262]. Today, most of the Molotov Line defense bunkers are located in eastern Poland, and there are some in the Roztocze region. These reinforced concrete monsters can now be found in fields, forests, near popular highways and even in the middle of small towns. Some of them are partially destroyed, others are completely intact. Most of bunkers are still interesting only to fans of military history, and for locals these concrete "sarcophags" are just unnecessary obstacles in everyday affairs. Tourists until recently also didn't pay much attention to these objects from the military past. All these bunkers are united by one name - they belong to the Molotov Line. The history of these fortifications is very instructive. Built quickly, they could not significantly prevent a German attack on the Soviet Union, so the latter tried to forget about them as soon as possible, so there are no monuments here, and the personal data of the dead Soviet soldiers are unknown. The Molotov line 


\section{ECONOMIC STRATEGIES FOR THE DEVELOPMENT OF SOCIETY}

can be considered as a complete failure of the Soviet military fortifications theory and practice, as example of how huge financial resources and efforts of thousands of people were spent without any practical benefits. Among the fortifications built in Europe between the First and Second World Wars (the Maginot Line in Alsace, France, the Eastern and Atlantic Ramparts in Poland and Normandy, the Mannerheim Line in Finland), the Molotov Line is the last to be built. It's construction began when the war was already in full swing in Europe. Means were not spared, well understanding the situation in the world. The construction of 13 military fortification complexes on the new western border of the USSR - from the Baltics to Galicia - was started at an accelerated pace with the participation of the local population and soldiers. At the same time most of the buildings and bunkers were built in a very short time, but there were no time to prepare and equip them with proper weapons. Bunkers had no minefields, no engineering fences, no camouflage. More - most of the bunkers were not equipped with artillery guns, but with Maxim machine guns of 1910 year of production. As a result, the Molotov Line was captured by the Germans in two days. And only in some cases in deep German rear, Soviet soldiers continued the unequal battle for almost two more weeks. The remnants of the Molotov Line in Roztocze, Poland, are good illustration of the futility of building such very expensive but inefficient fortification systems. There are still many of these concrete "sarcophags" in Polish fields, which local farmers see as obstacles to agricultural work, but there is nothing they can do about it because they cannot demolish these concret monsters. But today in tourism, these objects are now used and are of considerable interest, in particular for Polish tourists, cyclists (there are bike paths), etc., which is mentioned widely in advertising materials on tourism in Roztocze [256]. At the same time, the state of many of these objects is impressive. Despite the fact that more than 80 years have passed, it can be seen that most of them have not even been fired upon, the original black paint has been preserved on their surface still. The construction of the fortified units is approximately the same - most had two casemates, several embrasures, a separate room for an

observer and an entrance vestibule, which can be shot through a special loophole. According to the project, these bunkers were to be equipped with an air filtration 


\section{ECONOMIC STRATEGIES FOR THE DEVELOPMENT OF SOCIETY}

system, an electric generator, chemical protection, water tanks for cooling guns and machine rifles, as well as telephone and radio communications. Dugouts were built nearby for garrison. But almost all of this did not have time to be completed whith and use. Despite the fact that the Molotov Line did not fulfill its main task - to stop the German offensive, it still played a certain role in the development of military fortifications during World War II and is a valuable monument. The weapons that remained in the bunkers, as well as the bunkers themselves, were later used by detachments of the Polish Krajowa Army, and after the end of World War II, these bunkers were used by the Ukrainian Rebellion Army as their bases. For the local population, the equipment of bunkers, where it was preserved, was a source of various technical materials like fuel and electric motors, pumps, electric generators, etc. Within modern Poland borders, there are objects of six fortification complexes of the Molotov Line, in particular in the Lublin region - that is hundreds of bunkers belonging to the Rava-Rusky fortification complex and they considered now as interesting objects for military tourism and as local tourist attractions.

Problems of restaurant branch development in Ukraine in conditions of covid-19 pandemia. The development of the tourism industry is inextricably linked with the restaurant business, as the nutrition of tourists is an integral part of the tourism service. As we know, the tourism industry due to the corona virus has suffered significant problems in its development in 2020 both in the world and in Ukraine. But the restaurant industry has even bigger problems now. According to the director of "Restaurant Consulting" O. Nasonova, the restaurant business was the most vulnerable and least protected [258]. Yes, in Kyiv there is still no exact data on how many restaurants will not be able to open after the quarantine, as it is still ongoing. These establishments will not disappear completely, as some of them will be sold. The new owners will try to keep the previous format, others will try something new. The costs of restaurateurs, in particular in Kyiv, are almost the same as before, but the revenue is twice less. That is, in this area, one is not talking about profit at all, according to experts, it will appea not earlier than in six months or even in a year. Experts also warn 


\section{ECONOMIC STRATEGIES FOR THE DEVELOPMENT OF SOCIETY}

that the most difficult times for restaurateurs will not be quarantine, but postquarantine. This is due to the following reasons:

First, there has been an outflow of customers who are afraid of contracting the coronavirus; these people are few (about 10-15\%), but they are quite active, do not hide their position and agitate the rest to follow their example and ignore restaurants.

Second, the holiday season in Ukraine started quite unexpectedly. O. Nasonova notes that this happened immediately after the news about the delay of Ukrainian tourists in Greece in late June 2020. Exactly at that moment, many Ukrainians finally realized that this year's foreign vacation was not "shining" for them and began to actively gather on vacation in Ukraine. Thus, the holiday season in Ukraine started in full force in mid-July. This meant that restaurants in Odessa and other resort towns in Ukraine feel good, which cannot be said of establishments in Kyiv (which became empty in summer), Lviv (without Polish tourists who paid for local restaurants) and other cities.

Third, the family audience has disappeared, especially families with children, some of whom was sent to the grandmothers in the village, someone - took the children to the sea, but many were staying in city apartments. Children in masks feel very uncomfortable, so it is impossible to go with them to public places.

Fourth, food prices began to rise gradually.

Fifth, there are no more discounts from landlords that they provided during the quarantine period; restaurants have been launched full rent, despite the fact that they had no increase in profitability.

And, finally, the influence of the inflation expectation factor, which for restaurants is "worse than quarantine" [258].

Under such conditions, it is expected that in October-November 2020, some restaurateurs in Ukraine will close their businesses in anticipation of the second wave of the pandemic. They have borne the costs since the beginning of this year and will survive the crisis only those who have several points and they have a choice when it comes to closing unprofitable establishments and leave more or less profitable, or those who are willing to wait and continue to invest. 


\section{ECONOMIC STRATEGIES FOR THE DEVELOPMENT OF SOCIETY}

According to O. Nasonova [258], even before the announcement of quarantine, she talked to colleagues who have been in this business for more than a decade and all of them came to the conclusion that the crisis will last for a year and a half. Experienced restaurateurs who survived the crises of 2008-2009 and 2014-2015 did not hope for a miracle from the very beginning. It was clear that a major systemic crisis was coming, which was likely to continue until the middle of next year at least. Therefore, experienced restaurant specialists from the very beginning of the quarantine were preparing for the outflow of customers, for the fall of the average check, for the fact that it will be necessary to close unprofitable points, reduce costs and just wait through the quarantine period. But in the restaurant market of Ukraine and Kyiv, in particular, there were many newcomers who have no experience of doing business in a crisis - so they first began to panic. It was the newcomers who could not wait for the restrictions to be lifted, as they were sure that as soon as the restaurants opened, customers would come to them. But now the restaurants have opened and there was no customer wave, and it was a shock for many owners. So, now the fear of autumn is present in all players of the restaurant market in Ukraine: beginners do not understand what will happen next, and old-timers know that there will be nothing good.

The crisis of the restaurant "genre" in Ukraine has powerful psychological component, because even for those people who treated the coronavirus quite balanced and calm, after several months of severe quarantine, it is very difficult to psychologically force yourself to take ready meals from stranger (waiter). That is, the coronavirus was replaced by the corona-phobia, when people were "returned to their past lives", literally forcing themselves to take handles in the hallway with their bare hands or press the elevator button (not to say about restaurants). But restaurants also have such customers: they are afraid, but still go. At the same time, before entering the institution, they put on mask, choose a table far away from other visitors, and at lunch require gloves so as not to touch the knife and fork with bare hands. Therefore, the restaurant business must take into account the psychological phenomenon of the coronavirus in the minds of customers and the fact that it will take certain time to overcome it. 


\section{ECONOMIC STRATEGIES FOR THE DEVELOPMENT OF SOCIETY}

O.Nasonova's statement that quarantine is the beginning of a great restaurant plague is popular now [258]. She believes restaurants and cafes have become convenient "scape goats" during quarantine time, and they are under administrative and moral pressure from the state, so when almost all businesses were opened, restaurants were banned from working after $11 \mathrm{pm}$ (now after $10 \mathrm{pm}$ ) for unknown reasons. The restaurateurs had little choice: either accept the further restriction of income, or "pay off" from the inspectors, or continue to work after 23.00 and tremble with fear. This attitude towards restaurants and cafes is partly due to the fact that it is not a daily need of people, such as market or grocery store, one can do without them. The social attitudes that still live among the inhabitants of the post-Soviet countries (Ukraine including) also made a contribution as restaurants are still considered to be a kind of money waste for the rich. And, finally, the fact that they are quite remarkable, are in plain sight, did not benefit the restaurants. Today, people can gather anywhere - in a beauty salon, sports club, visiting, but it will not be as noticeable as in a restaurant, which in a sense is a "public living room." Because of this, restaurants have become a good target: they can be demonstratively "punished" as a lesson for others. At the same time, no one helps them, more - not even sympathizes with them, because in the mass consciousness of Ukrainians almost every restaurateur is considered to be a "sloth", "grabber" and "baryga", who lives so well. Thus alas there is an element of "class, social hatred."

Quarantine, on the other hand, has caused restaurants to turn to new forms of activity, such as delivery service, which now provides about $15 \%$ of revenue.

What restaurants have suffered most from quarantine? According to restaurant experts and founders of the Ukrainian Restaurant Association S. Trakhachev and S. Kolomytseva [259], first of all - those who were in business centers, as many companies have not yet returned to full-fledged work in offices. The next loss is catering as it almost completely "extincted" with no outreach activities are currently held, and this service for many restaurants accounted for a significant portion of revenue. The next question is: what innovations that appeared during quarantine time will remain after it? Clear that first of all it's delivery service, both on the restaurant 


\section{ECONOMIC STRATEGIES FOR THE DEVELOPMENT OF SOCIETY}

menu and delivery of semi-finished products. In general, delivery in the spring of 2020 has become a national idea of the restaurant business in Ukraine: about $70 \%$ of establishments have tried themselves in this service. As for QR-codes on restaurants tables, they turned out to be inconvenient for many customers, consumers reacted quite nervously to this innovation. Also, QR-codes did not contribute to the possibility of additional ordering, the probability of which is much higher when the waiter brings the traditional menu- list. Therefore, QR-codes did not displace paper menus from restaurant service, as expected earliar.

Another question: how did quarantine affect the development of restaurants with Ukrainian and foreign cuisines? Although the number of Georgian restaurants in Kyiv has been growing steadily for the last few years, this trend has almost exhausted itself. Food halls are beginning to become fashionable - such as Kyiv Food Market (the venue of the first press conference of V. Zelensky as Ukraine's President) or D.Borisov's restaurant project in "Bessarabka" market, where many food courts with different concepts are presented. This is a reflection of popular trend in the global restaurant business - the creation of multicuisine's establishments. There is a growing interest in Italian cuisine, namely the alternative to pizza, which is called pintsa. The difference between them is in the dough: in pintsa it's lighter, made of three types of flour - soy, rice and wheat. Mexican cuisine is gaining momentum - such restaurant is about to open near the velodrome in Kyiv. But this cuisine will not become as popular in Ukraine as Georgian one, because the latter is the production of an inexpensive product made from local Ukrainian ingredients. It is enough to bring from Georgia only spices, and the rest can be made in Ukraine. As a result, one can eat well in a Georgian restaurant for little money, but Mexican or Italian cuisines both will cost much more.

As for Ukrainian cuisine, there is a difference between regional cuisines (for example, Galician or Poltavian), but currently the most popular is the kind of ukrainian rural cuisine, which is good on the one hand, but on the other - not so well. Still 10-15 years ago national restaurants all over Ukraine were decorated in the form of a country houses, waiters were in kozak dress, and food included mainly borsch, dumplings, cabbage rolls and lard. All this looked very much like an attraction for foreign visitors, 


\section{ECONOMIC STRATEGIES FOR THE DEVELOPMENT OF SOCIETY}

so the people of Kiev took guests from USA, first of all, to such restaurants, but they practically did not visit them themself. Explanation: when looking in menu at borsch whith price 80-100 UAH people calculate in their mind and understand that at home a whole pot of borsch will cost only 15-20 UAH. That is why Ukrainians are more interested in cuisines of other countries, and in these countries - on the contrary, the first place in popularity is occupied by their national dishes. But Ukrainian cuisine is much broader than its rural version. Only now Ukrainians are beginning to understand the differences and tastes of regional cuisines: Carpathian, Galician, Odessian and so on. This trend should lead to the opening of new Ukrainian restaurants. Conceptual establishments (restaurants and cafes) such as Lviv's "Kryivka" or Vinnytsia's "Horse in Gas Mask" will remain popular. The last named restaurant-pub is located at 20 Symon Petliura Street. The interior is in military-style: in one of the arches one can even see a machine gun, chairs near the bar - like horse seats, and cutlery is served in army cauldrons. The waiters wear "Petliurivka" (UPR soldiers and oficers wore such soft caps). On the walls - photos of military life in the early twentieth century. on some of them one can see horses in gas masks - they protected animals from gas attacks during World War I. It is not only very atmospheric, but also delicious, and most importantly - serves Podillya region cuisine, such as pate in tiles (in fact - a pie stuffed with liver and baked in tile forms), and for dessert one can order Vinnytsia sweets - an analogue of lazy dumplings, made from soft dough, served with cherry sauce. The sity of Vinnytsia has recently become famous for other interesting restaurants, such as "Marseille" jewish restaurant, "New Province" restaurant with a summer terrace on the roof of a ten-story building, and "Ribs" restaurant, where the main dish are of course ribs.

As for Kyiv, luxury restaurants "for the elite" are a constant success here: "Sanahant Lounge" on Hrushevsky Street (a film-packed QR-menus are used), "San Paolo" in Museum Lane, "San Tori" in Podil, "Gorchytsia" (Mustard) near the Supreme Court building etc., despite the fact that the borsch here costs UAH 400, fried potatoes with mushrooms - UAH 650 a portion, vinaigrette - UAH 480, chebureks - UAH 550 


\section{ECONOMIC STRATEGIES FOR THE DEVELOPMENT OF SOCIETY}

, tuna tartare with avocado - UAH 750, pasta with lobster - UAH 3000 (the most expensive dish) [255].

Other world original restaurant concepts were also used in Ukraine. For example, project "Food in the air", when a strapped client is lifted on a $50 \mathrm{~m}$ platform - it's called "Dinner in the Sky". They were touring in different countries, in 2013 - in Kyiv. The experience "Eating in the dark" was offered by a bar in Kyiv's Podil: clients in complete darkness were served by waiters with night vision goggles. When a person eats in complete darkness, he gets completely different sensations from food. When ordering, food was offered in three categories: meat, fish and vegetarian cuisine. The client did not know what dish he will get. As a result, customers understood that people eat with their eyes. In the dark, it was often impossible to identify familiar dishes by smell and taste alone, for example, ordinary strawberries were not always recognizable when eaten blindly. But "Dinner in the Sky" and "Restaurant in the dark" were places to visit once, just an attraction, there was no point in having lunch there every week. So the restaurant in Podil did not survive. Ani Lorak`s and Potap`s restaurants, opened in Kyiv earliar, became also quarantine's "victims". S. Trakhachev and S. Kolomytseva explain this by the fact that everyone should do their job [259]. Restaurateurs also sometimes sing in karaoke, but they do not become pop stars. It is unlikely that any of the stars seriously tried to engage in gastronomy. It was just an attempt to attract the audience to the restaurant due to the popularity of the artist. At initial stage, it worked - people came to see what their idol had discovered. But the restaurant is not a marginal business at all, it is a business for those who like to cook and communicate with guests. One can create a restaurant named after a star, but it is a short-term project. Therefore, there are also few examples in the world when the stars managed to keep a successful restaurant chains for a long time. 


\section{ECONOMIC STRATEGIES FOR THE DEVELOPMENT OF SOCIETY}

\section{5 Соціальне підприємництво: тренд сучасного економічного розвитку}

Перші згадки про соціальне підприємництво з'явились у 1970-х роках і були пов'язані з започаткуванням і успішною діяльністю Грамін банку (Grameen Bank) по наданню мікрокредитів найбіднішим верствам населення, що дозволило покращити добробут великої кількості людей.

Водночас у наукових публікаціях термін «соціальне підприємництво» 3’являється завдяки Б. Дрейтону, засновнику міжнародної організації «Ашока», діяльність якої спрямована на вирішення актуальних соціальних проблем.

Так, Б. Дрейтон визначає соціальне підприємництво як інноваційний підхід, завдяки якому громадяни можуть вирішити соціальні проблеми, з якими стикається їх громада, а також підкреслює, що соціальне підприємництво $є$ важливим інструментом для економічного та соціального розвитку не лише для слаборозвинутих, але й для країн, що розвиваються, та розвинутих країн [267].

Не менш цікавим $є$ підхід до визначення соціального підприємництва Норта, а саме як до рушійної сили в адаптації суспільства до кризових явищ у економіці. Вирішальна роль щодо розробки та впровадження таких альтернативних способів вирішення соціальних проблем відводиться саме соціальним підприємцям, тобто людям, які самостійно займаються вирішенням проблем. При цьому Д. Норт вважає, що ефективність адаптації посилюється при децентралізованому прийнятті рішень, що дозволяє суспільству направляти максимальні зусилля на вивчення альтернативних способів вирішення проблем [268].

При визначенні соціального підприємництва варто також згадати концепцію «змішаної цінності» Дж. Емерсона, що отримала популярність у зв'язку 3 активною участю бізнесу в реалізації принципів соціальної відповідальності. Концепція комбінованої цінності грунтується на безперервній взаємодії соціальних та економічних цілей діяльності фірми та включає в себе такі три компоненти, як економічну, соціальну та екологічну цінності [269]. 


\section{ECONOMIC STRATEGIES FOR THE DEVELOPMENT OF SOCIETY}

Концепція “змішаноі” або “комбінованої цінності” безпосередньо пов'язана 3 потрійним результатом діяльності соціального підприємства, а саме 3 фінансовою життєздатністю, створенням суспільного багатства та екологічною відповідальністю [270].

Так, фінансова життєздатність означає що соціальне підприємство повинно бути комерційно успішним, щоб бути незалежним та здійснювати контроль над своїми рішеннями. Створення суспільного багатства передбачає досягнення мети колективно, а не індивідуально окремою особою, та має приносити соціальну користь, а також при здійсненні своєї діяльності підприємство повинно зважати на баланс між очікованою комерційною вигодою та ціною для екології, тобто повинно бути екологічно відповідальним. Останнім часом світ все частіше стикається 3 потрійною загрозою економічної стагнації, соціального поділу та руйнуванням навколишнього середовища, тож соціальні підприємства своєю діяльністю намагаються впоратися з цими викликами. Тож, тільки за умови поєднання вищезгаданих трьох складових, підприємство можна вважати соціальним.

Соціальні та екологічні цілі є ключовими для соціальних підприємств, оскільки вони створюють «соціальну цінність» та є основною метою такого бізнесу як для команди, так і для громади. Діяльність соціальних підприємців орієнтована на покращення світу та може здійснюватись в будь яких галузях і бути спрямована як на зменшення безробіття, заохочення до здорового способу життя і харчування, збереження навколишнього середовища, так і на полегшення доступу до медичних послуг.

Соціальне підприємництво можна також розглядати 3 огляду на рівень його прояву. Так, на мікрорівні соціальне підприємництво визначається через особистості соціальних підприємців. Г. Діз виділяв наступні риси цього типу підприємців: прийняття на себе зобов'язань щодо створення благ соціального значення (не лише приватного значення); знаходження та використання нових можливостей щодо обслуговування цих зобов'язань; забезпечення безперервного процесу нововведень, адаптації і навчання; діяти сміливо, не обмежуючись 


\section{ECONOMIC STRATEGIES FOR THE DEVELOPMENT OF SOCIETY}

наявними ресурсами; висока відповідальність підприємця за результати своєї діяльності по відношенню до клієнтів та суспільства в цілому [271]. Отже соціальний підприємець - це особа, яка шукає інноваційні шляхи вирішення традиційних проблем працюючи над створенням стійких змін та справжньої соціальної трансформації не лише в конкретному місці, але має більш глобальну перспективу і прагне створити модель, яка може бути відтворена в інших містах.

На мезорівні соціальне підприємництво розглядається як організація, основною місією якої є створення соціальної цінності (впливу) або позитивних соціальних змін за допомогою діяльності, що дозволяє досягти зазначеної місії фінансово стійким способом, використовуючи інноваційні та тиражовано здатні бізнес-моделі [272]. Відповідно до класичної економічної моделі місія компанії полягає в максимізації фінансової вигоди та корисності для акціонерів, тоді як місія неприбуткової організації - максимізувати соціальну вигоду та корисність.

На макрорівні соціальне підприємництво розглядається через взаємозв'язок з їх економічним, соціальним та організаційним контекстом. Усі нові підприємства, незалежно від бізнес-моделі, повинні визначити соціальні можливості існуючого ринку та подолати будь-які перешкоди у створенні свого бізнесу. Що стосується соціальних підприємств, обрана ними соціальна місія значною мірою визначатиме бізнес-середовище, в якому вони працюють, та їхні конкретні труднощі та потреби. Щоб подолати ці труднощі, експерти виступають за інновації, які традиційно визначаються як впровадження нових моделей виробництва або розширення на нові ринки.

Саме такої думки дотримуються сучасні підприємці і науковці, які стверджують, що соціальним підприємцям потрібно впроваджувати інновації, створюючи готові рішення для створення цінності для суспільства. Для подальшого розвитку соціального підприємництва доведеться пропонувати інноваційні, якісніші рішення для проблем, які вони визначають у своєму суспільстві та в усьому світі.

Соціальне підприємництво - це вже не лише вирішення проблем суспільства. Насправді соціальні підприємства зараз зосереджені на розширенні 


\section{ECONOMIC STRATEGIES FOR THE DEVELOPMENT OF SOCIETY}

можливостей суспільства, щоб вони могли допомогти собі, тобто відіграють величезну роль у зміні життя людей.

За даними Social Enterprise UK, майже 50\% соціальних підприємств повідомляють про прибуток та додаткові 26\% про беззбитковість, що свідчить про те, що більшість з них монетарно стабільні [273].

Майже половина $42 \%$ соціальних підприємств працює близько п'яти років, що втричі перевищує аналогічний показник для малого та середнього підприємництва (14\%). У звіті зазначається, що соціальне підприємство випереджає аналогічні малі та середні підприємства майже за всіма ключовими показниками бізнесу, причому не лише стартовими, але й ріст товарообігу, різноманітність керівництва, інновації, ріст робочої сили та оптимізм бізнесу.

Ще одним вражаючим статистичним показником є те, що 52\% соціальних підприємств збільшили свій оборот за останні 12 місяців, чим довели, що їх ідеї працюють. Аналогічний показник малих та середніх підприємств - лише 37\%.

Частка соціальних підприємств по випуску нових товарів або послуг у 2019 році склала $56 \%$, що знову вище, ніж у попередні роки, і значно випереджаючи аналогічний показник малих та середніх підприємств, а саме 36\% [274].

Вищенаведені показники свідчать про важливість ринку соціальних підприємств і про їх стрімкий розвиток. У світі виділяють такі тренди подальшого розвитку соціального підприємництва:

- Вирішення соціальних проблем, що виникають внаслідок старіння населення та інших демографічних змін. Ці проблеми пов'язані як зі збільшенням середнього віку виходу на пенсію так і з забезпеченням потреб зростаючої кількості людей похилого віку.

- Зміна характеру праці вимагає навчання впродовж життя, створює зростаючу стурбованість соціально-економічним майбутнім країн усього світу.

- Спрямування соціальних проектів на вирішення проблем, пов'язаних 3 урбанізацією, оскільки надшвидкими темпами зростають міста і кількість населення, що там проживають. Міста у всьому світі, такі як Сеул, Мехіко та Токіо, зростають швидше, що призводить до нових соціальних проблем. 


\section{ECONOMIC STRATEGIES FOR THE DEVELOPMENT OF SOCIETY}

- У 2019 році, за даними ООН, кількість міжнародних мігрантів у всьому світі досягла приблизно 272 мільйонів. Міграція стає актуальною та складною проблемою, особливо для Європи, яка як регіон приймає найбільшу кількість міжнародних мігрантів (82 мільйони). Соціальних інновацій, що допоможуть вирішити питання міжнародної міграції потребують як з боку державного та приватного секторів так і з боку суспільства.

- Останнім часом все гостріше постає питання освіти. Протягом останнього року, у зв'язку з пандемією COVID 19, питання організації освітнього процесу набуло ще більшої актуальності. У наступні роки з'явиться більша потреба у розвитку компетентностей та навичок щодо соціальних інновацій на всіх рівнях системи освіти.

- Ще одною надзвичайно актуальною проблемою цього століття $\epsilon$ зміна клімату. Боротьба зі зміною клімату привертають увагу практиків соціальних інновацій, новаторів та спільноти в цілому. Так, одним 3 пріоритетних напрямів 3 вирішення цієї проблеми $\epsilon$ розбудова «зеленої» економіки, що передбачають запровадження таких ініціатив як відхід від твердого палива, пошук альтернатив використанню пластику, сприяння відновленню лісів тощо.

- Ще одне питання, яке потребує уваги - це перетворення, що спричиняються впровадженням нових цифрових технологій і впливає як на життя кожної окремої людини так і на суспільство в цілому, починаючи від сфери освіти до робочого середовища і відносин між людьми [275].

Отже, у світі постійних змін суспільства повинні бути більш інтуїтивними, відчувати і реагувати на нові технологічні можливості, соціальні виклики та потреби громадян, і саме тут соціальні інновації можуть відіграти важливу роль, щоб зробити суспільства більш інклюзивними та стійкими.

Водночас для України явище соціального підприємництва є доволі новим, а тому законодавчо визначених критеріїв, згідно з якими підприємства можна було б віднести до соціальних, не існує. 


\section{ECONOMIC STRATEGIES FOR THE DEVELOPMENT OF SOCIETY}

Так, фонд WNISEF вважає підприємництво соціальним, якщо виконується один з таких критеріїв:

- $\quad 20 \%$ прибутку відраховується на благодійність або інші соціальні цілі;

- $\quad 50 \%$ співробітників відносяться до соціально вразливих категорій населення;

- $\quad$ менше $50 \%$ співробітників з соціально вразливих категорій і $10 \%$ прибутку відраховується на благодійність або вирішення соціальних проблем [276].

При цьому, розвиток соціального підприємництва в Україні останніми роками тільки набирає обертів. За останні роки громадяни, особливо молодь, стають більш свідомими та все частіше проявляють інтерес до суспільних проблем. Саме тому, наявність відповідного маркування, що свідчить про його виробництво соціальним підприємством, спонукає споживача придбати товар та підтримати виробника.

Саме за допомогою соціальних підприємств намагаються вирішувати суспільні проблеми у тих галузях економіки, які не вирішуються або не можуть бути вирішені завдяки державним органами чи то через відсутність коштів, знань, навичок чи безперспективність отримання економічної вигоди.

Основними перспективними напрямами діяльності соціальних підприємств в Україні можна вважати такі:

- Особливого значення соціальне підприємництво набуває для вирішення численних проблем в контексті війни на Донбасі, оскільки відновлення і розвиток цього регіону потребує значної підтримки всіх можливих інституцій.

- е одна проблема, яка стала актуальною з появою соціальних мереж і смартфонів - це самотність. Одним з можливих рішень міг би стати колівінг нова форма спільного проживання, своєрідний інкубатор, де молоді, творчі люди живуть і взаємодіють - або створення коворкінгів. 


\section{ECONOMIC STRATEGIES FOR THE DEVELOPMENT OF SOCIETY}

- Задоволення зростаючого запиту суспільства на нові товари i послуги, що з'явились 3 розвитком нових технологій, а саме за останні десятиліття стали затребувані освітні програми 3 навчання літніх людей комп'ютерної та мобільної грамотності, а також програми навчання та працевлаштування для людей старшого віку.

- Питання зовнішньої трудової міграції набуло масштабного виміру, що включає в себе і проблему виїзду молоді за кордон для навчання та подальшого працвлаштування.

Суспільні проблеми, які потребують негайного вирішення, стали рушійною силою, що створила соціальне підприємство. Соціальні підприємці, які використовують інноваційні ідеї та різноманітні ресурси для вирішення соціальних проблем, у свою чергу є драйверами стійких позитивних змін у суспільстві.

Отже, в сучасних економічних системах соціальне підприємництво допомагає реалізовувати концепцію сталого розвитку, завдяки інноваційному використанню і поєднанню ресурсів для реалізації можливостей 3 метою прискорення соціальних змін та вирішення соціальних потреб, адже в результаті соціальна підприємницька активність формує ефективне конкурентне середовище, забезпечує робочі місця і знімає соціальну напругу. 


\section{ECONOMIC STRATEGIES FOR THE DEVELOPMENT OF SOCIETY}

\section{6 Логіка, форми та інструменти глобальної інноваційної інтеграції}

Починаючи з 1990-х років світове наукове і експертне співтовариство почало осмислювати феномен інноваційної та технологічної глобалізації. Він відображав серйозні зрушення в міжнародному економічному розвитку, які потребували відповідної інтерпретації. Хоча дослідники і до цього сходилися на думці, що саме нові технології зробили можливим і незворотнім процес глобалізації, але саме 1990i роки виявилися якісним кордоном, який змусив по-новому поглянути на роль інновацій як одночасно фактора конкуренції і глобальної та регіональної інтеграції. 3 одного боку, інноваційні процеси набули небачених раніше масштаб та інтенсивність. Одночасно посилилася міжнародна економічна конкуренція, що супроводжувалася диференціацією темпів зростання різних країн і наростанням нерівності в технологічному розвитку [277, 278]. На початку XXI ст. п'ятірка країн - США, Японія, Німеччина, Франція і Велика Британія - витрачали на НДДКР більше коштів, ніж всі інші держави, разом узяті, причому частка США у зазначеній групі перевищувала 50\% [279]. Але одночасно, незважаючи на очевидне домінування розвинених постіндустріальних держав, у цей період проявилася тенденція зростаючої ролі нових індустріальних країн і ринків, що розвиваються, в інноваційному розвитку. Крім цього, в 1990-і роки відбулася суттєва лібералізація економічного обміну, зросла роль СОТ як організації, що визначає стратегію глобальної економічної архітектури. Все це позначилося на значущості інноваційних процесів у світовій економіці - вони перетворилися як на чинник інтеграції, так і на двигун динамічної міжнародної конкуренції, найважливішу умову виживання компаній і підприємств на все більш глобалізованому ринку.

Важливе значення в процесах, що розгортаються, відіграє міжнародне застосування технологій, які народжуються в окремих країнах. Даний аспект глобального поширення інновацій в даний час превалює над іншими як чинник дифузії нових технологій. Стимулюється цей процес прагненням підприємців 3 тієї чи іншої країни вийти на світові ринки, закріпитися на них й отримати при цьому конкурентні переваги. Більш того, інноваційний розвиток служить засобом 


\section{ECONOMIC STRATEGIES FOR THE DEVELOPMENT OF SOCIETY}

виживання підприємців зараз і на перспективу, коли найбільш далекоглядні з них «грають на випередження», роблячи свої компанії не тільки локальними, а й глобальними інноваторами. Формами реалізації цього процесу $\epsilon$ експорт інноваційної продукції, переуступка ліцензій і патентів, організація виробництва інноваційної продукції за межами країни, в якій були розроблені відповідні технології [277]. Якщо приймаюча іноземних інноваційних підприємців економіка отримує можливість самостійно виробляти подібну продукцію 3 аналогічним інноваційним контентом, конкуренція між країнами неминуче зростає. Міжнародна конкуренція на ринках високотехнологічної продукції сьогодні носить незрівнянно більш запеклий характер, ніж на традиційних. Однак багато чинників у сучасному світі робить процес глобальної інноваційної інтеграції незворотнім, незважаючи на протиріччя національних інтересів.

Зокрема, важливим інструментом транскордонного поширення інновацій $є$ прямі іноземні інвестиції (ПІІ). Умови для успішності цього процесу добре відомі й головними серед них $є$ політична i економічна стабільність, інституційне середовище в країні, що приймає ПІІ з високим інноваційним контентом. Ще одним важливим фактором розвитку інтеграції в галузях високих технологій є процес глобального генерування інновацій. Виробництво все більше інтернаціоналізується, в чому найважливішу роль відіграють великі міжнародні компанії. Вони створюють і розвивають дослідницькі підрозділи в різних країнах, фінансують університетські дослідницькі програми по всьому світу. Крім того, мова йде і про співпрацю компаній з різних країн, що проявляється в обміні науково-технічною інформацією. При цьому для успішної інтеграції інноваційних потенціалів міжнародних учасників мають дотримуватися трьох умов: спільне підприємство має бути заснованим на тісних зв'язках і кооперації; компанії зберігають права власності на створювані інноваційні продукти; співпраця має включати обмін ноу-хау та розробками нових продуктів і процесів [277].

Поява численних міжнародних комерційних проектів викликала до життя різноманітні економічні механізми, спрямовані на зниження витрат і максимізацію ефекту від співпраці. Поряд з названими, виділяється такий стратегічний тип 


\section{ECONOMIC STRATEGIES FOR THE DEVELOPMENT OF SOCIETY}

глобальної інтеграції інноваційних процесів як глобальне науково-технічне співробітництво, основною формою прояву якого $є$ співпраця університетів, дослідницьких центрів і лабораторій. За останні роки, які в цьому аспекті процесу глобалізації інновацій виявилися граничними, переломними, кількість наукових статей, написаних міжнародними колективами авторів i опублікованих у високорейтингових виданнях, значно збільшилася. При цьому, величезну роль у процесі розвитку глобального науково-технічного співробітництва зіграло поширення інтернету. На зміну традиційним формам поширення знань приходять наукові сесії за участю представників громадськості та політики, презентації результатів досліджень на веб-сайтах, комерціалізація наукових розробок, проведення інтернет-конференцій та вебінарів [279].

Аналогічні тенденції спостерігаються і в області створення наукових знань. Інформаційні технології та нові технологічні можливості університетів і наукових інститутів дозволяють вченим активніше включатися в реалізацію спільних дослідницьких проектів, обмінюватися думками на форумах і сайтах, брати участь у проведенні досліджень. Можна говорити про виникнення наразі глобального науково-технічного i технологічного середовища, важливими структурними елементами якого є університети і дослідницькі мережі. Стає очевидним, що ядро сучасної науки утворюють мережі вчених, наукових інститутів, організацій, лабораторій всіх країн світу, залучених до проведення спільних досліджень і виконання спільних науково-дослідних проектів. Його формування передбачає використання особливої системи поширення інформації, яка дозволить кожному учаснику отримувати доступ до інформації і взаємодіяти з колегами.

Очевидно, що прикладом подібної системи можуть послужити комп'ютерні мережі, що забезпечують користувачам доступ до інформації по всьому світу. При цьому, комп'ютерна мережа повинна мати особливу конфігурацію, яка полегшує роботу вченого, тобто містити інструменти управління персональними даними користувача, наприклад, його резюме; інструменти управління проектами користувача, що полегшують пошук інформації щодо питань, що його цікавлять; комунікативний блок, що забезпечує можливість синхронного й асинхронного 


\section{ECONOMIC STRATEGIES FOR THE DEVELOPMENT OF SOCIETY}

спілкування користувача 3 іншими представниками наукового середовища; інструменти управління інформацією користувача; базу знань, що включає всю актуальну для користувача інформацію, його записи і коментарі, приклади 3 практики, замітки інших користувачів тощо; інші блоки та інструменти [280-281].

Таким чином, передумовою успішної глобальної інтеграції в інноваційній сфері є подальше поглиблення процесів тісної взаємодії в економіці, науці і освіті.

Важливу роль в економічній інтеграції у сфері інновацій відіграють транснаціональні компанії (ТНК), які мають великий досвід створення і поширення інноваційних продуктів на регіональному, національному та глобальному рівнях. Для ТНК, вміння створювати i поширювати інновації $\epsilon$ найважливішою конкурентною перевагою, що визначає стабільність місця компаній у галузі i перспективи ії подальшого розвитку. Не випадково в кожній ТНК склалися власні традиції генерування, зберігання та поширення нового знання, велика частка 3 яких пов'язана із запуском інтеграційних механізмів і залученням до інноваційного процесу всіх структурних одиниць компанії.

Аналіз досвіду ТНК дозволяє виділити наступні типи інтеграції їх структурних одиниць 3 метою забезпечення створення i поширення нового знання та інноваційних продуктів:

- «Центр - увесь світ». Цей тип інтеграції пов'язаний 3 активною взаємодією головного офісу ТНК з усіма структурними одиницями, що базуються в інших країнах. Центр дає імпульс структурним одиницям на створення інноваційного продукту та координує їх дії.

- «Регіон - регіон». Цей тип інтеграції передбачає створення інноваційного продукту тієї чи іншої структурною одиницею ТНК у конкретному регіоні. Процес інтеграції запускається на етапі поширення інноваційного продукту і до нього підключаються всі структурні одиниці компанії.

- «Регіон - увесь світ». Цей тип інтеграції заснований на генеруванні інноваційної ідеї на рівні головного офісу. Ї реалізація здійснюється структурною одиницею ТНК, що базується в найбільш сприятливому регіоні [277]. 


\section{ECONOMIC STRATEGIES FOR THE DEVELOPMENT OF SOCIETY}

Вибір того чи іншого типу інтеграції структурних одиниць ТНК для вирішення інноваційних завдань багато в чому залежить від особливостей поширення інформації всередині компанії. На основі цього критерію виділяють наступні типи ТНК: «глобальний інноватор» - інтенсивний потік інформації зі структурних одиниць до головного офісу і низький рівень поширення інформації у зворотньому напрямку; «місцевий інноватор» - низький рівень поширення інформації між структурними одиницями та головним офісом; «гравець-інтегратор»-інтенсивний потік інформації як з головного офісу до структурних одиниць компанії, так і у зворотньому напрямку; «реализатор» - інтенсивний потік інформації з головного офісу до структурних одиниць компанії і низький рівень поширення інформації у зворотньому напрямку [282].

Можна припустити, що тип інтеграції «центр - увесь світ», перш за все, характерний для ТНК «гравець-інтегратор», а тип інтеграції «регіон - увесь світ», навпаки, властивий компанії «глобальний інноватор».

Постійна взаємодія ТНК із зовнішніми організаціями - партнерами, конкурентами, консалтинговими компаніями, університетами тощо, закладає основу для формування інноваційних мереж - співдружності учасників інноваційної діяльності, що надають інформаційну, консультаційну, освітню та організаційну підтримку один одному з метою отримання і поширення нових знань і інноваційних продуктів. До низки основних переваг інноваційних мереж входить регулярний обмін інформацією між суб'єктами інноваційного процесу, консультаційна допомога та технічні ресурси, що надаються ними один одному в тимчасове користування [283].

Прикладом регіону з розвиненими інноваційними мережами може послужити Баден-Вюртемберг (Німеччина). У цьому регіоні працюють філії та представництва таких ТНК, як Daimler-Benz, Robert Bosch, Alcatel-SEL, IBM, Heidelberg тощо. Також до їх діяльності причетні й університети, які надають освітню та дослідницьку підтримку всім організаціям регіону. Особливу роль у здійсненні інноваційної діяльності в регіоні відіграють юристи, консультанти, інженери, чия діяльність пов'язана з обслуговуванням інноваційного сектору [283]. 


\section{ECONOMIC STRATEGIES FOR THE DEVELOPMENT OF SOCIETY}

Ще один приклад інноваційних мереж - банківські. Інформаційні технології та пов'язані з ними нові можливості розвитку банківської сфери змусили банки включитися в інноваційну мережу. Інновацій в банківській сфері так багато, їхня кількість так значно збільшується щороку, що банки змушені ділитися досвідом і спільно включатися у вирішення проблем підвищення ефективності банківської діяльності. 3 цією метою банки створюють спільні підприємства, що займаються реалізацією тієї чи іншої інновації, а також проводять спільні навчальні семінари $і$ тренінги для своїх працівників і топ-менеджерів [284].

I зовнішня, і внутрішня інтеграція ТНК, спрямована на отримання нових знань, створення і поширення інноваційних продуктів, передбачає використання набору інструментів, що забезпечують успішне завершення інтеграційних процесів. Особливості використання даних інструментів описують дві моделі:

- Модель «Люди» орієнтована на інтенсифікацію інтеграційних процесів у ТНК за рахунок забезпечення міграції менеджерів і фахівців як між структурними одиницями компаній, так і між учасниками інноваційної мережі. Проведення тренінгів, зустрічей, нарад і дискусій за участю представників усіх суб'єктів інтеграційного та інноваційного процесів розглядається як обов'язкова умова успішного створення інноваційного продукту.

- Модель «Інформація» передбачає обмін інформацією та знаннями між структурними одиницями ТНК та іншими учасниками інноваційних мереж через комунікаційні системи - інтернет, електронну пошту, інтранет, бази даних [285]. Беручи участь в обміні інформацією і знаннями, суб'єкти інноваційного процесу швидше отримують інформацію, необхідну для створення інноваційного продукту. Модель «Інформація» знайшла застосування, зокрема, в компанії Bankco найбільшому європейському банку з філіями в 70 країнах світу. У банку склалася децентралізована структура. В середині 1990-х років найбільший клієнт банку закрив свій рахунок, пояснюючи це тим, що якість послуг, що надаються банком в різних країнах світу, сильно розрізняється. Перед банком постала проблема інтеграції філій і реалізації в них тотальної системи якості. 3 цією метою в банку була впроваджена система інтранету для уніфікації потоку документів у філіях. 


\section{ECONOMIC STRATEGIES FOR THE DEVELOPMENT OF SOCIETY}

Крім того, для представників всіх філій стали проводитися регулярні майстеркласи. Таким чином, проблема 3 якістю послуг була вирішена [286].

Конкретними прикладами інтеграційних інструментів, що сприяють успішній інноваційної діяльності транснаціональних компаній, можуть послужити:

- Розвиток навчальних мереж за участю партнерів по бізнесу, університетів, експертів. Так, далеко не всі, навіть великі, організації можуть знайти внутрішні ресурси і знання для розвитку. Виникає необхідність у створенні спільних освітніх альянсів і центрів, мета яких - поширювати знання, необхідні для успішного здійснення інноваційного процесу [287]. Прикладом навчальних мереж можуть служити корпоративні університети, відкриті багатьма THК (IBM, Microsoft, Telefonica тощо). Будучи місцем зосередження експертів - викладачів університетів, кращих фахівців компаній-засновників, консультантів корпоративні університети задовольняють освітні потреби всієї галузі, є джерелом нових знань, центрами консультаційної підтримки та, що не менш важливо, є додатковим джерелом доходів для засновників.

- «Співтворчість» або «спільна практика». Цей інструмент передбачає участь всіх підрозділів ТНК у різних видах інноваційної активності, в реалізації спільних інноваційних проектів. Такі проекти можуть тривати роками, забезпечуючи повну інтеграцію суб'єктів, що беруть в них участь. Однією зі складових «співтворчості» $є$ міграція топ-менеджерів всередині компанії. Прикладами «співтворчості» можуть також служити програми обміну, програми взаємодопомоги колег, короткострокові візити фахівців до інших структурних одиниць компанії [288]. Основною перевагою «співтворчості» $\epsilon$ розвиток неформальних міжособистісних контактів між працівниками компанії, що сприяє постійному обміну знаннями і ноу-хау.

- Аутсорсинг фахівців. Використання цього інструменту пов'язано 3 тимчасовим залученням фахівців, чиї знання і вміння представляють цінність для ТНК-замовника, з інших організацій. Прикладом використання цього інструменту може послужити практика THК Liftco - найбільшого європейського виробника вантажопідйомних механізмів зі штаб-квартирою в Швеції. Компанія Liftco 


\section{ECONOMIC STRATEGIES FOR THE DEVELOPMENT OF SOCIETY}

складається 312 відокремлених бізнес-підрозділів, розкиданих по європейським країнам. 3 метою поширення знань та інтеграції працівників в одну команду Liftco уклала договір із консалтинговою компанією Consultco. Співпраця виявилася настільки тривалою і плідною, що компанія Consultco створила спеціальну структуру, що займається реалізацією проекту Liftco. Співробітники цієї структури, уклавши трудовий договір з Consultco, щодня проводять робочий день на території замовника, що, по суті, прирівнює їх до фахівців, взятих на аутсорсинг [289].

Отже, виходячи на нові ринки, зав'язуючи нові зв'язки, ініціюючи й реалізовуючи спільні проекти, беручи участь у створенні інноваційних мереж, ТНК стирають державні кордони. Їх діяльність виходить на новий глобальний рівень $\mathrm{i}$ сприяс успішній міждержавній інтеграції в інноваційній сфері.

Ще одним ключовим аспектом міжнародної інтеграції в інноваційній сфері, ще вимагає свого комплексного наукового осмислення, є створення та функціонування транскордонних інноваційних мереж. Термін інноваційні мережі (innovation networks) є відносно новим в економічній теорії, тому що самі ці мережі з'явилися недавно - близько тридцяти років тому. Виникненню цього явища сприяли процеси глобалізації, інтенсивність яких із розвитком сучасних технологій зв'язку різко зросла наприкінці XX століття. Розвиток подібних технологій також прискорило зростання ринків високотехнологічної продукції, які пережили справжній бум на рубежі 1980-1990-х років.

Отже, стрімкий розвиток інформаційних технологій дозволив організаціям 3 різних країн легше налагоджувати контакти одна 3 одною, а зростаючі ринки забезпечили стимул для розвитку бізнесу в сфері високих технологій. Обмін знаннями та інформацією значно прискорився, що призвело до створення нових міждержавних горизонтальних структур - інноваційних мереж, які представляли собою децентралізовані утворення, що складаються з окремих комерційних i некомерційних організацій. Принциповою відмінністю інноваційних мереж від більш ранніх форм взаємодії стала справжня свобода комунікації між окремими організаціями-осередками мережі. Інноваційні мережі, засновані на принципах відкритості та екстериторіальності, виявилися зручними тим, що всередині них став 


\section{ECONOMIC STRATEGIES FOR THE DEVELOPMENT OF SOCIETY}

можливий обмін будь-якою інформацією і знаннями. Учасникам необхідно було тільки підключитися до глобальної комп'ютерної мережі. Такий спосіб взаємодії не вимагав значних витрат, істотно прискорював комунікацію і вироблення спільних рішень. Географічний чинник, що протягом багатьох століть був однією з основних стримуючих сил ефективного виробництва, завдяки розвитку інноваційних мереж став поступово втрачати своє значення.

Таким чином, процеси інтеграції в сфері інноваційного розвитку мають свою логіку, що відповідає сучасним тенденціям розвитку світової економіки. Інновації і зближують економіки різних країн, i, одночасно, призводять до інтенсифікації міжнародної конкуренції, і в цьому полягає діалектична суперечливість процесів переходу до постіндустріальної стадії розвитку. У світі формується глобальне інформаційне, технологічне, науково-дослідницьке середовище, що визначає інтернаціоналізацію інноваційних процесів. Істотну роль у глобальному процесі інноваційної інтеграції відіграють транснаціональні компанії. Одним з найбільш яскравих і перспективних проявів комунікаційних аспектів глобалізації в сфері високих технологій є розвиток інноваційних мереж. 


\section{ECONOMIC STRATEGIES FOR THE DEVELOPMENT OF SOCIETY}

\section{7 Фінансове забезпечення інноваційності розвитку окремих галузей аграрного сектора}

На сучасному етапі посилення конкурентної боротьби на ринку сільськогосподарської продукції та інтеграцією України в міжнародний економічний простір обов’язковою умовою є формування інноваційної моделі розвитку сільського господарства. Аграрний сектор економіки України поки що залишається недостатньо чутливим до нововведень, порівняно 3 іншими сферами. В певній мірі така інноваційна пасивність сільськогосподарських підприємств гальмується значною мірою вкрай незадовільними фінансовими можливостями, а також нездатністю частини управлінських кадрів адаптуватися до ринкових умов господарювання.

У цьому контексті оцінка інноваційності розвитку аграрного сектора $є$ об’єктивно необхідною та потребує аналітичного осмислення для виявлення можливих джерел його фінансового забезпечення.

Питанням запровадження інновацій та оцінки інноваційного розвитку аграрного сектора економіки присвячена низка досліджень та публікацій як вітчизняних, так і зарубіжних вчених. Серед них: Бухонова С. М., Гохберг Л. М., Грицаєнко М.I., Дерев’янко Т.О., Іщейкін Т.I., Крисанов Д.Ф., Кузьмина О.Е., Молдаван Л.В., Пасхавер Б.Й., Саблук П.Т., Трифилова А. А., Чернов В. А., Шпикуляк О.Г., Шубравська О.В., [290-301]. Проте поки що не існує загальноприйнятого підходу до оцінювання інноваційності розвитку підприємств аграрного сектора.

Методика інноваційного аналізу є комплексною і дає можливість отримати різнобічну характеристику інноваційних проектів підприємства, але безліч нововведень в аграрному секторі, які в значній мірі визначають інноваційність розвитку сільськогосподарського підприємства, здійснюється без оформлення у вигляді проекту. I таких інновацій в межах одного підприємства і навіть однієї галузі може бути досить велика кількість. У зв’язку з цим виникає цілком закономірне питання чи є інноваційний розвиток на підприємстві і які його темпи? 


\section{ECONOMIC STRATEGIES FOR THE DEVELOPMENT OF SOCIETY}

На наш погляд, основою інноваційного розвитку сільськогосподарських товаровиробників $є$ перш за все запровадження технологічних інновацій, результативність яких виявлясться у підвищенні урожайності сільськогосподарських культур. Разом 3 тим, за нашим абсолютним переконанням, інноваційність розвитку аграрного сектора не обмежується лише технологічними інноваціями і не може характеризуватися тільки тенденціями зміни урожайності сільськогосподарських культур. Більш того, попередні дослідження, проведені нами свідчать про те, що тенденції зміни різних економічних показників (урожайності, валової, товарної, чистої продукції, прибутку) можуть бути суперечливими, а тому потребують детального дослідження і пояснення в кожному такому випадку. Проте на першому етапі зазначеного вище дослідження ми обмежились лише аналізом динаміки урожайності основних сільськогосподарських культур за період з 1995-2019 pp. (табл. 1).

3 одного боку дані таблиці 1 надають вже певну інформацію про наявність чи відсутність інноваційного розвитку в господарствах усіх категорій України та Харківської області. Якщо, в період 1995-1999 рр. урожайність основних сільськогосподарських культур скорочувалася, то це свідчить про відсутність інноваційного розвитку. Починаючи вже з 2000-2004 pр. середньорічний приріст урожайності зернових культур та цукрових буряків мав позитивне значення. Також відмітимо, що найбільш швидко урожайність сільськогосподарських культур зростала в період з 2010 по 2014 рр.: зернових та зернобобових культур 


\section{ECONOMIC STRATEGIES FOR THE DEVELOPMENT OF SOCIETY}

Таблиия 1

Тенденції зміни урожайності сільськогосподарських культур в господарствах усіх категорій

\begin{tabular}{|c|c|c|c|c|c|}
\hline & \multicolumn{5}{|c|}{$\begin{array}{l}\text { Тенденції зміни урожайності сільськогосподарських культур в господарствах усіх } \\
\text { категорій по п’ятиріччям, ц/га }\end{array}$} \\
\hline & 1995-1999 pp. & $2000-2004$ pp. & $2005-2009$ pp. & $2010-2014$ pp. & 2015-2019 pp. \\
\hline & \multicolumn{5}{|c|}{ Україна } \\
\hline $\begin{array}{l}\text { Зернові та } \\
\text { зернобобові }\end{array}$ & $y=-0,8 x+24,18$ & $y=0,89 x+21,39$ & $y=1,81 x+21,83$ & $y=3,65 x+24,79$ & $y=1,73 x+40,05$ \\
\hline Соняшник & $y=-0,96 x+13,98$ & $y=-0,48 x+12,18$ & $y=0,65 x+11,87$ & $y=1,21 x+14,57$ & $y=0,86 x+19,98$ \\
\hline $\begin{array}{l}\text { Цукрові } \\
\text { буряки }\end{array}$ & $y=-10,7 x+210,9$ & $y=14 x+155,6$ & $y=20,5 x+238,1$ & $y=43,2 x+256,2$ & $y=7,7 x+449,5$ \\
\hline \multicolumn{6}{|c|}{ Харківська область } \\
\hline $\begin{array}{l}\text { Зернові та } \\
\text { зернобобові }\end{array}$ & $y=0,15 x+20,41$ & $y=0,64 x+23,32$ & $y=1,26 x+24,1$ & $y=5,57 x+17,27$ & $y=-0,1 x+40,8$ \\
\hline Соняшник & $y=-1,56 x+18$ & $y=-1,28 x+16,02$ & $y=1,8 x+10,34$ & $y=2,54 x+16,12$ & $y=-0,22 x+27,74$ \\
\hline $\begin{array}{l}\text { Цукрові } \\
\text { буряки }\end{array}$ & $y=-24,3 x+216,3$ & $y=17 x+123$ & $y=3,5 x+226,5$ & $y=64 x+120,4$ & $y=4,9 x+389,7$ \\
\hline
\end{tabular}

в середньому щороку на 3,65 ц/га, соняшнику - на 1,21 ц/га, цукрових буряків на 43,2 ц/га.

Крім того, слід наголосити, що по всім культурам 3 кожним наступним п’ятирічним періодом дослідження (включно до 2010-2014рр.) підвищувалось поступово і значення середньорічного приросту урожайності культур, що $є$ проявом інноваційності розвитку технологічного характеру. Але за останні 5 років темпи зростання урожайності всіх без винятку культур значно знизились, що, в свою чергу, свідчить про уповільнення темпів інноваційного розвитку.

В порівнянні з даними в середньому по Україні, по господарствам всіх категорій Харківської області були зафіксовані подібні тенденції змін урожайності сільськогосподарських культур в розрізі по п’ятирічним періодам дослідження. Лише за 2015-2019 pр. по зерновим і зернобобовим культурам та соняшнику темпи зростання урожайності не просто знизились, як в цілому по 


\section{ECONOMIC STRATEGIES FOR THE DEVELOPMENT OF SOCIETY}

Україні, а навіть набули тенденції до скорочення (в середньому щороку на 0,1 та 0,22 ц/га відповідно).

Водночас дослідження лише вищенаведених абсолютних показників позбавляє можливості порівняння досягнутого рівня урожайності, як критерію інноваційного розвитку, між культурами, бо вони $є$ не співставними. Так, 43,2 ц/га щорічного приросту урожайності цукрових буряків у період з 2010 по 2014p. в середньому по Україні не $є$ ознакою того, що інноваційний розвиток по даній галузі $є$ в декілька разів вищим, ніж по зерновим культурам з щорічним приростом урожайності - 3,65 ц/га. I навіть порівнювати між періодами отримані абсолютні показники є неможливим через неспівставність, тому що в кожному періоді є різним досягнутий рівень.

В зв'язку з цим, виникла необхідність переходу до відносних показників базисних індексів урожайності сільськогосподарських культур в господарствах усіх категорій, як в цілому по Україні, так і по Харківській області, в розрізі 5-тирічних періодів дослідження (табл. 2).

Табличя 2

Тенденції зміни базисних індексів урожайності сільськогосподарських культур в господарствах усіх категорій

\begin{tabular}{|c|c|c|c|c|c|}
\hline & \multicolumn{5}{|c|}{$\begin{array}{l}\text { Тенденції зміни базисних індексів урожайності сільськогосподарських культур в } \\
\text { господарствах усіх категорій по п’ятиріччям, \% }\end{array}$} \\
\hline & 1995-1999 pp. & 2000-2004 pp. & 2005-2009 pp. & 2010-2014 pp. & 2015-2019 pp. \\
\hline & \multicolumn{5}{|c|}{ Україна } \\
\hline $\begin{array}{l}\text { Зернові та } \\
\text { зернобобо } \\
\text { ві }\end{array}$ & $\begin{array}{c}y=-3,29 x+ \\
99,51\end{array}$ & $\begin{array}{l}y=4,59 x+ \\
110,26\end{array}$ & $y=6,96 x+83,96$ & $\begin{aligned} & y= 13,57 x+ \\
& 92,16\end{aligned}$ & $y=4,21 x+97,45$ \\
\hline Соняшник & $\begin{array}{c}y=-6,76 x+ \\
98,45\end{array}$ & $y=-3,93 x+99,84$ & $y=5,08 x+92,73$ & $y=8,07 x+97,13$ & $y=3,98 x+92,5$ \\
\hline $\begin{array}{l}\text { Цукрові } \\
\text { буряки }\end{array}$ & $\begin{array}{c}y=-5,22 x+ \\
102,9\end{array}$ & $\mathrm{y}=7,91 \mathrm{x}+87,91$ & $y=8,27 x+96,0$ & $\begin{array}{c}y=15,48 x+ \\
91,83\end{array}$ & $y=1,77 x+103,1$ \\
\hline \multicolumn{6}{|c|}{ Харківська область } \\
\hline $\begin{array}{l}\text { Зернові та } \\
\text { зернобобо } \\
\text { ві }\end{array}$ & $\begin{array}{l}y=0,81 x+ \\
110,3\end{array}$ & $\begin{array}{l}y=3,56 x+ \\
129,56\end{array}$ & $y=4,24 x+81,15$ & $\begin{aligned} & y= 29,79 x+ \\
& 92,35\end{aligned}$ & $\begin{array}{c}y=-0,25 x+ \\
103,03\end{array}$ \\
\hline Соняшник & $\begin{array}{c}y=-8,48 x+ \\
97,83\end{array}$ & $\begin{array}{c}y=-8,89 x+ \\
111,25\end{array}$ & $y=16,36 x+94$ & $\begin{array}{c}\mathrm{y}=15,68 \mathrm{x}+ \\
99,51\end{array}$ & $y=-0,76 x+95,33$ \\
\hline $\begin{array}{l}\text { Цукрові } \\
\text { буряки }\end{array}$ & $\begin{array}{l}y=-11,19 x+ \\
99,7\end{array}$ & $\begin{array}{c}\mathrm{y}=11,49 \mathrm{x}+ \\
83,11\end{array}$ & $\begin{array}{c}\mathrm{y}=1,65 \mathrm{x}+ \\
106,84\end{array}$ & $\begin{array}{c}\mathrm{y}=42,38 \mathrm{x}+ \\
79,74\end{array}$ & $\begin{array}{c}\mathrm{y}=1,40 \mathrm{x}+ \\
111,66\end{array}$ \\
\hline
\end{tabular}




\section{ECONOMIC STRATEGIES FOR THE DEVELOPMENT OF SOCIETY}

Аналіз тенденцій зміни базисних індексів урожайності сільськогосподарських культур також підтвердив висновок про те, що в період 3 1995 по 1999 р. навряд чи можна говорити про наявність інноваційного розвитку через скорочення урожайності всіх без винятку досліджуваних культур в цілому по Україні. Щодо господарств Харківської області, то лише зернові та зернобобові культури мали тенденцію до щорічного нарощування урожайності в середньому на 0,8 ц/га протягом зазначеного періоду.

Відмітимо, що на відміну від зернових культур і соняшнику по цукровим бурякам інновації накладаються на скорочення посівних площ. Здійснивши аналіз тенденцій зміни базисних індексів посівних площ під цукровими буряками, нами було встановлено, що по цукровим бурякам по кожній п’ятирічці зафіксовано тенденцію до зменшення посівних площ. Найбільше скорочення посівних площ під даною культурою було встановлено в період 32005 по 2009 pр. $з$ щорічним зменшенням по Україні на 16,8 \%, а по Харківській області - на 18,8 \% (табл. 3 ).

Таблиия 3

Тенденції зміни базисних індексів посівних площ сільськогосподарських культур в господарствах усіх категорій

\begin{tabular}{|c|c|c|c|c|c|}
\hline & \multicolumn{5}{|c|}{$\begin{array}{l}\text { Тенденції зміни базисних індексів посівних площ сільськогосподарських культур в } \\
\text { господарствах усіх категорій по п’ятиріччям, \% }\end{array}$} \\
\hline & 1995-1999 pp. & 2000-2004 pp. & 2005-2009 pp. & 2010-2014 pp. & 2015-2019 pp. \\
\hline & \multicolumn{5}{|c|}{ Україна } \\
\hline $\begin{array}{l}\text { Зернові та } \\
\text { зернобобов } \\
\text { i }\end{array}$ & $y=-1,1 x+101,2$ & $\mathrm{y}=0,4 \mathrm{x}+105,4$ & $y=1,9 x+95,9$ & $y=-0,1 x+102,6$ & $y=1,1 x+97,1$ \\
\hline Соняшник & $y=10,7 x+82,9$ & $\mathrm{y}=9,0+80,3$ & $y=3,5 x+95,5$ & $y=3,7+97,5$ & $y=3,3 x+104,7$ \\
\hline $\begin{array}{l}\text { Цукрові } \\
\text { буряки }\end{array}$ & $y=-8,5 x+106,4$ & $y=-5,2 x+114,4$ & $y=-16,8 x+135,6$ & $y=-11,8 x+119,4$ & $y=-1,9 x+119,2$ \\
\hline & \multicolumn{5}{|c|}{ Харківська область } \\
\hline $\begin{array}{l}\text { Зернові та } \\
\text { зернобобов } \\
\text { i }\end{array}$ & $y=-0,8 x+99,1$ & $\mathrm{y}=0,2 \mathrm{x}+106,0$ & $y=4,9 x+95,5$ & $y=6,8 x+102,8$ & $\mathrm{y}=0,01 \mathrm{x}+95,8$ \\
\hline Соняшник & $y=11,7 x+83,1$ & $y=6,6 x+84,0$ & $y=6,8 x+87,7$ & $y=-0,2 x+92,2$ & $y=7,03 x+99,4$ \\
\hline $\begin{array}{l}\text { Цукрові } \\
\text { буряки }\end{array}$ & $y=-7,9+105,5$ & $y=-4,0 x+106,2$ & $y=-18,8 x+137,7$ & $y=-16,7 x+130,2$ & $\mathrm{y}=-18,+162,8$ \\
\hline
\end{tabular}




\section{ECONOMIC STRATEGIES FOR THE DEVELOPMENT OF SOCIETY}

Оскільки, як правило, посівні площі під цукровими буряками скорочуються у неефективних господарствах, для яких був характерним низький рівень урожайності, то в наслідок цього відбувається підвищення середньої урожайності даної культури. Але це не є ознакою інноваційності розвитку. Тому в подальшому необхідно нівелювати вплив даного чинника при дослідженні інноваційності розвитку на основі показника урожайності.

Найвищий рівень інноваційного розвитку всіх досліджуваних галузей в цілому по Україні, внаслідок запровадження технологічних інновацій (удосконалення вже існуючих технологій вирощування сільськогосподарських культур чи застосування більш продуктивних сортів або гібридів, використання добрив тощо) було зафіксовано в період 2010-2014 pр., що в кінцевому підсумку обумовило найвищий рівень середньорічного приросту базисного індексу урожайності культур: по зерновим культурам - 13,5 \%, соняшнику $-8,1$ \%, цукровим бурякам $-15,5 \%$.

При цьому зауважимо, що запровадження вищезазначених технологічних інновацій абсолютно очевидно потребують певного фінансового забезпечення. Тому таке поступове нарощування темпів інноваційного розвитку впродовж 3 2000 по 2014 р. обумовлено, в першу чергу, сприятливою ситуацією для сільськогосподарських товаровиробників в сфері фінансування за цей період.

Фінансове забезпечення інноваційного розвитку окремих галузей аграрного сектора може здійснюватися або за рахунок прибутку, або за рахунок зовнішніх джерел таких, як державна підтримка в різних їі формах. Так, якщо проаналізувати рівень державної підтримки сільськогосподарських товаровиробників по цим періодам, то можна дійти наступних висновків.

Законом України № 320-XIV від 17.12.1998 р. 31 січня 1999 р. було запроваджено для аграрних виробників фіксований сільськогосподарський податок, в результаті чого їх було виведено з загальної системи оподаткування.

31 січня 2005 р. на підставі Закону України № 1878-IVвід 24.06.2004 p. було введено спеціальний режим податку на додатну вартість, який звільняв сільськогосподарські підприємства від обов'язків сплати цього податку до 


\section{ECONOMIC STRATEGIES FOR THE DEVELOPMENT OF SOCIETY}

бюджету. Натомість сума податку, отримана сільськогосподарськими підприємствами внаслідок застосування спеціального режиму податку на додану вартість, повністю залишалась у розпорядженні суб'єкта господарювання і могла бути використана виключно за цільовим призначенням.

Зауважимо, що за перерахунком на 2019 р. сума пільг від запровадження спеціального режиму оподаткування податком на додану вартість становила б 1500-2000 грн з розрахунку на 1 га сільськогосподарських угідь.

Все це значно зменшило податковий тиск на вітчизняних аграріїв та позитивно відобразилось на їх можливостях для фінансування розвитку, в тому числі і інноваційного.

Однак на підставі Закону України № 71-III від 28.12.2014 р. фіксований сільськогосподарський податок було скасовано $\mathrm{i}$ на його зміну для сільськогосподарських товаровиробників було запроваджено єдиний податок на 4 групи. Абсолютно негативним моментом для платників даного податку було суттєве збільшення ставок оподаткування. Наприклад, для ріллі ставка оподаткування зросла з 0,15 в 2005 р. до 0,45 в 2015 р. та 0,95 в 2017 р., а також введено обов'язкове індексування грошової оцінки земель, від якої залежить сума нарахованого податку. В наслідок цього сума податку стрімко зросла 34 5 грн до 250-300 грн з розрахунку на 1 га ріллі за вказаний період. Крім того значно скоротився і перелік тих податків, які раніше входили до складу єдиного податку.

Відносно спеціального режиму оподаткування діяльності у сфері сільського господарства податком на додану вартість, то 32016 р. було запроваджено перехідні умови у застосуванні сільськогосподарськими виробниками спец режиму оподаткування.

Відповідно до цих умов перераховувалося до держбюджету та на спеціальні рахунки сільськогосподарських підприємств у різних частках залежно від виду продукції:

1) по операціях із зерновими та технічними культурами підлягає перерахуванню: до держбюджету - 85 \%; на спеціальні рахунки -15\%; 


\section{ECONOMIC STRATEGIES FOR THE DEVELOPMENT OF SOCIETY}

2) по операціях із продукцією тваринництва підлягає перерахуванню: до держбюджету - 20\%; на спеціальні рахунки - 80\%.

3) постачанні інших с.-г. товарів та послуг:

$50 \%$ - до державного бюджету; 50\% - на спецрахунок.

31 січня 2017 p. спеціальний режим для сільськогосподарських підприємств втратив свою чинність.

Отже, всі вищенаведені зміни, які відбулись у податковому законодавстві за 2015-2019 pp. значно погіршили фінансове забезпечення сільськогосподарських товаровиробників, в наслідок чого їх темпи інноваційного розвитку дуже істотно уповільнились.

Таким чином, в економічній літературі відсутній загальноприйнятий підхід до кількісної оцінки інноваційності розвитку аграрного сектора в цілому, а також окремих сільськогосподарських підприємств і галузей.

В якості критеріальних показників інноваційності розвитку аграрного сектора можуть виступати показники середньорічного приросту валової, товарної продукції та прибутку в розрахунку на 1 га сільськогосподарських угідь.

Темпи інноваційного розвитку окремих галузей можуть характеризувати показники середньорічного приросту урожайності окремих культур або продуктивності тварин, а також виходу товарної продукції та прибутку в розрахунку на 1 га посівної площі або голову тварин.

В результаті дослідження тенденції зміни урожайності основних сільськогосподарських культур в цілому по Україні і по Харківській області встановлено, що у 1995-1999 рр. інноваційний розвиток цих галузей був відсутній; з 2000 по 2014 рр. відбувалося прискорення темпів інноваційного розвитку; у 2015-2019 pр. інноваційний розвиток дуже істотно уповільнився.

Однією з головних причин зміни темпів інноваційності розвитку галузей аграрного сектора $є$ його фінансове забезпечення, зокрема за рахунок державної підтримки. Період прискорення інноваційного розвитку розглянутих галузей співпадає з періодом дії фіксованого сільськогосподарського податку та 
ECONOMIC STRATEGIES FOR THE DEVELOPMENT OF SOCIETY спеціального режиму оподаткування сільськогосподарських товаровиробників податком на додану вартість. Скасування або трансформація зазначених податкових режимів у 2015-2017 рр. призвело до стрімкого зниження темпів інноваційного розвитку, яке межую з повною його відсутністю.

Подальші дослідження доцільно спрямувати на удосконалення методів кількісної оцінки інноваційності розвитку окремих секторів національної економіки, зокрема співставлення можливих різних напрямів тенденцій зміни показників валової, товарної, чистої продукції, прибутку, урожайності сільськогосподарських культур та формування такого механізму фінансового забезпечення аграрного сектора (а саме удосконалення системи державної підтримки, оподаткування сільськогосподарських товаровиробників та їх кредитного забезпечення), який би сприяв прискоренню темпів інноваційного розвитку в ньому. 


\section{ECONOMIC STRATEGIES FOR THE DEVELOPMENT OF SOCIETY}

\section{8 Формування методичного підходу до оцінювання розвитку еколого-інноваційної діяльності}

В наш час значного поширення набула концепція сталого розвитку. Теорія сталого розвитку протиставляється екстенсивній моделі економічного зростання, яка не звертає уваги на можливі негативні впливи на екологічну ситуацію. Концепція сталого розвитку визначає необхідність балансу між задоволенням сучасних потреб людства та потребами майбутніх поколінь, важливе місце серед яких займає життя в безпечному та здоровому довкіллі. При реалізації даної концепції економічне зростання, матеріальне виробництво та споживання відбуваються в межах, які дають можливість відновлення екосистем для забезпечення життєдіяльності теперішніх та майбутніх поколінь.

Концепція сталого розвитку передбачає оптимальне використання ресурсів, застосування екологічно-інноваційних технологій, створення екологічно прийнятної продукції, мінімізацію, переробку і знищення відходів.

Сталий розвиток являє собою керований процес. Керування повинно здійснюватися на основі системного підходу із використанням сучасних інформаційних технологій та засобів математичного моделювання, що дозволяє досліджувати різні варіанти керуючих впливів, прогнозувати їх наслідки та обирати серед них оптимальний. Для ефективного застосування наведених вище засобів необхідно визначити ряд індикаторів, тобто обчислених на основі первинних даних показників, які визначають поточний стан та динаміку економічної, соціальної та екологічної складової соціально-економічної системи.

Індикатори поділяються на два види: індикатори для відображення певних аспектів розвитку (екологічних, соціальних, економічних) та інтегральні індикатори, за допомогою яких можна комплексно оцінювати розвиток країни або регіону. Важливою проблемою при визначенні інтегральних індикаторів $\epsilon$ визначенні ваги початкових показників в інтегральній оцінці. Для розв'язання цієї проблеми можна використати експертне оцінювання або методи економікоматематичного моделювання. 


\section{ECONOMIC STRATEGIES FOR THE DEVELOPMENT OF SOCIETY}

Для організації стратегічного планування в різних секторах національного розвитку України за ініціативи Програми розвитку ООН розроблено проект Стратегії сталого розвитку для України на період до 2030 року. В Стратегії визначальним $є$ інноваційне спрямування розвитку, що передбачає активне використання знань та наукових досягнень, стимулювання інноваційної діяльності, створення сприятливого інвестиційного клімату, оновлення виробничих фондів, формування високотехнологічних видів діяльності, підвищення енергоефективності виробництва, стимулювання збалансованого економічного зростання.

Особливу роль в інноваційному розвитку економіки відіграють екологічні інновації. В науковій літературі існують різні підходи до означення екологічних інновацій. К. Ренінгз і Т. Цвік розглядають екологічні інновації, як нові або змінені процеси, обладнання, продукцію, методи й системи управління, що дають змогу уникнути або зменшити шкідливий вплив на навколишне середовище [302]. За означенням О. В. Прокопенко екологічні інновації - це зміни в соціально-економічному розвитку системи господарювання, які поряд із позитивним соціально-економічним ефектом покращують стан довкілля або значно зменшують негативний вплив на нього [303].

Екологічні інновації поділяються на технічні (випуск екологічної продукції та розроблення інноваційних технологій іiі виготовлення), організаційні, економічні та соціальні. Основними завданнями екологічних інновацій $\epsilon$ вирішення проблем забезпечення паливно-енергетичними ресурсами, екологічно чистими продуктами харчування, впровадження ресурсозберігаючих технологій.

Актуальною проблемою в Україні є формування інструментів управління екологічними інноваціями, механізмів регулювання та стимулювання екоінноваційних розробок. В умовах децентралізації особливого значення набуває розроблення методів забезпечення сталого розвитку регіонів, формування механізмів підвищення ефективності інноваційної діяльності на регіональному рівні, визначення ролі та місця екологічних інновацій в економічній системі регіонів. Пошук і використання нових засобів реалізації економічного 


\section{ECONOMIC STRATEGIES FOR THE DEVELOPMENT OF SOCIETY}

потенціалу, які включають впровадження екологічних інновацій, та сприяють досягненню позитивного соціального та еколого-економічного ефекту складає зміст інноваційного розвитку регіонів та країни в цілому. Міжнародний досвід показує, що ефективний інноваційний розвиток можливий лише в рамках інноваційної системи. Отже, створення такої системи $є$ першочерговим завданням державного управління.

Впровадження екологічних інновацій істотно залежить від інноваційноінвестиційного клімату що $\epsilon$ на даний час в Україні. Під інноваційноінвестиційним кліматом розуміють сукупність політичних, соціальноекономічних, фінансових, науково-технічних, дослідницьких, організаційноправових, інституційних і географічних факторів, що притаманні той чи іншій країні, які приваблюють (стимулюють) або відштовхують інвесторів [304].

За даними Міністерства розвитку економіки, торгівлі та сільського господарства України в 2019 році в економіку України іноземними інвесторами вкладено 33724,4 млн. дол. США прямих іноземних інвестицій (акціонерного капіталу) проти 31606,4 млн. дол. США у 2018 році (рис.1). Темп приросту прямих іноземних інвестицій в 2019 році склав 4,3\%. Обсяги освоєння капітальних інвестицій підприємств України в I півріччі 2019 року склали 233,9 млрд. грн, що на 12,3 \% більше від обсягу капітальних інвестицій за відповідний період 2018 року. Провідною сферою економічної діяльності за обсягами освоєння капітальних інвестицій у I півріччі 2019 року є промисловість - 40,3\%.

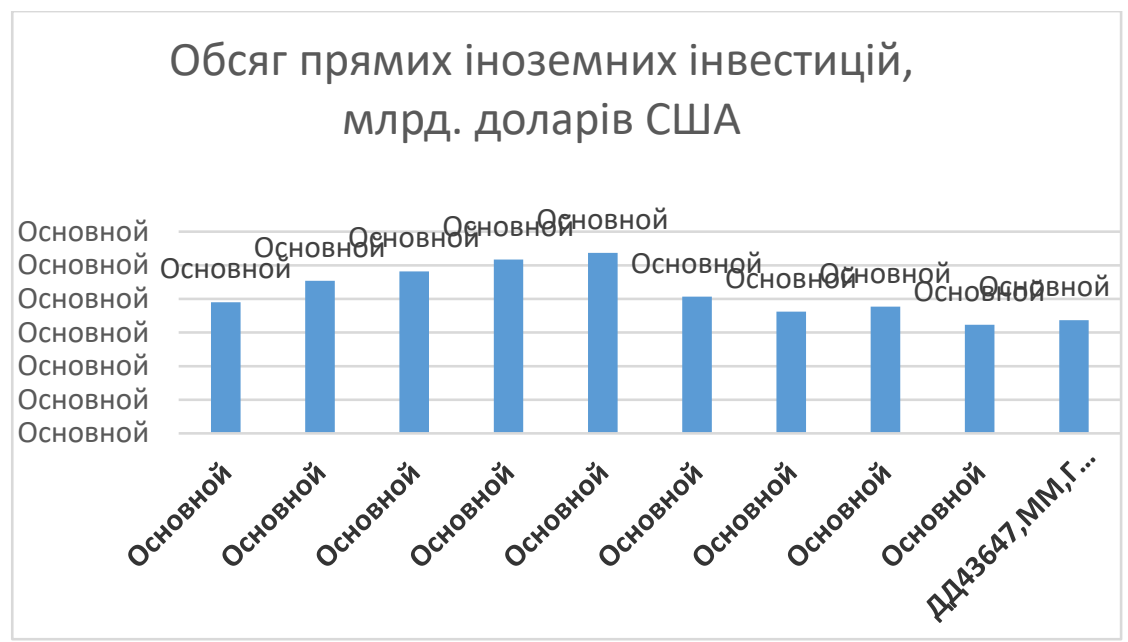

Рисунок 1. Динаміка прямих іноземних інвестицій за 2010-2019 pp, [305] 


\section{ECONOMIC STRATEGIES FOR THE DEVELOPMENT OF SOCIETY}

Роль держави в розвитку інноваційного процесу полягає в формуванні економічного середовища та інвестиційного клімату, що підвищить привабливість даного процесу для власників капіталу.

Специфічною особливістю інноваційного розвитку є його циклічність, яка пов'язана із циклами Кондратьєва. М. Кондратьєв вказав, що початок кожної хвилі в цих циклах пов'язаний із впровадженням в промисловість значних досягнень науки та техніки. Цей факт приводить до висновків щодо джерел та направленості економічного розвитку, що відображено в теорії «довгих хвиль» як теорії інноваційного розвитку. Дана теорія стверджує, що інновації та науково-технічний прогрес являються стимуляторами фази зростання в економічних циклах, а технологічний розвиток пов'язаний з групами базисних інновацій [306].

Недостатне застосування новітніх технологій на сучасному етапі розвитку економіки призводить до значних втрат сировини та забруднення навколишнього середовища. Отже, важливим напрямом розвитку підприємств $\epsilon$ еколого-орієнтована структурна перебудова, зокрема впровадження екологічних інновацій. У розв'язанні проблеми еко-інноваційного розвитку підприємств важливу роль відіграють ендогенні та екзогенні фактори, що безпосередньо впливають на впровадження екологічних інновацій [307].

Серед зовнішніх чинників впливу можна відзначити: рівень економічного зростання, політичну ситуацію в країні, національну та міжнародну законодавчу базу, податкову політику, наявність зовнішніх джерел фінансування, науковотехнічний прогрес, екологічну ситуацію в країні та міжнародні програми 3 екологічної безпеки. До внутрішніх чинників належать: цілі організації в напрямку реалізації екологічних заходів; рівень забезпеченості внутрішніми джерелами фінансування; наявність фахівців 3 екологічної безпеки та відповідних структурних підрозділів [308].

Дослідження показало, що найбільш ефективними ендогенними факторами, що визначають появу еко-інновацій на підприємствах вважається формалізовані системи управління та екологічна політика. Тому необхідності набуває постійне 


\section{ECONOMIC STRATEGIES FOR THE DEVELOPMENT OF SOCIETY}

вдосконалення екологічних аспектів управління, які є основою функціонування цих систем. На впровадження екологічних інновацій негативно впливають ряд факторів, серед яких можна відзначити наступні: відсутність стабільної економічної бази підприємств та обмеженість їх фінансових ресурсів, недостатнє розуміння важливості природоохоронної діяльності, відсутність орієнтації на ресурсозбереження, недосконалість податкового законодавства, довільне поводження із відходами виробництва, відсутність науково обгрунтованої методики оцінювання ефективності екологічних інновацій.

При оцінюванні варіантів управлінських рішень потрібно поряд із економічними брати до уваги і екологічні критерії. Екологічно орієнтоване виробництво може вважатися ефективним лише за тієї умови, якщо шкода, заподіяна навколишньому природному середовищу перевищує результат господарської діяльності.

В аграрній сфері серед екологічних інновацій важливе місце займає виробництво екологічно чистої продукції, тобто продукції, при виготовленні якої не застосовують ГМО, гербіцидів, фунгіцидів та інші хімікати. На даний час в країнах Євросоюзу екологічна продукція користується значним попитом, зростає попит на неї і в Україні. Отже, перехід аграрних підприємств до виробництва органічної продукції не тільки відповідає екологічним вимогам, але і дає значний економічний ефект та сприяє підвищенню конкурентоспроможності підприємства.

Вкладення капіталу в інноваційні проекти пов’язане з певним ризиком для інвесторів, оскільки ці проекти можуть як забезпечити високий прибуток, так i принести збитки. Отже, для реалізації таких проектів необхідно надати інвесторам науково обгрунтовані докази того, що ці проекти є прибутковими. Прийняття рішення щодо інвестування екологічних проектів залежить від їх екологічної обгрунтованості, загального інвестиційного клімату в країні чи регіоні та ситуації на ринку аналогічних та споріднених товарів. 


\section{ECONOMIC STRATEGIES FOR THE DEVELOPMENT OF SOCIETY}

Для оцінювання впливу екологічних інновацій на економічну, продовольчу та екологічну безпеку потрібно розробити методику оцінювання екологоінноваційної діяльності.

На першому етапі обираємо індикатори $\mathrm{x}_{\mathrm{i}}$, які відображають стан екоінноваційної діяльності. Для національного рівня пропонується такий набір індикаторів:

1) $\mathrm{x}_{1}$ - рівень видатків на науково-технічні роботи, пов'язані з екологічними інноваціями, \% від ВВП;

2) $x_{2}$ - рівень фінансування еколого-інноваційної діяльності, \% від ВВП;

3) $\mathrm{x}_{3}$ - частка спеціалістів, які виконують науково-технічні роботи, пов'язані з екологічними інноваціями, осіб на 1000 зайнятих, \%;

4) $\mathrm{x}_{4}$ - частка підприємств, що займалися еко-інноваційною діяльністю, у загальній кількості промислових підприємств, \%;

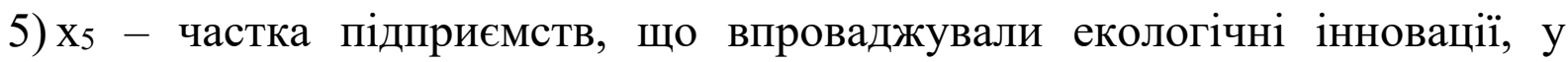
загальній кількості промислових підприємств, \%;

6) $\mathrm{x}_{6}$ - частка підприємств, що реалізовували екопродукцію, у загальній кількості підприємств, \%;

7) $\mathrm{x}_{7}$ - частка реалізованої екопродукції у загальному обсязі реалізованої продукції, \%.

Всі ці індикатори являються стимуляторами, тобто їх збільшення підвищує інтегральну оцінку.

На другому етапі визначаємо нормалізовані показники уі, що відповідають вибраним індикаторам. Для дослідження вибираємо ретроспективний період тривалістю Т років. Позначимо через $\mathrm{x}_{\mathrm{i}}(\mathrm{t}), t=\overline{1, T}$, значення i-того індикатора в $\mathrm{t}$ тий рік ретроспективного періоду. Через $\mathrm{x}_{\mathrm{i}}(\mathrm{T}+1)$ позначимо прогнозне значення i-того індикатора на наступний рік, а через $x_{i}^{N}$ - нормативне значення цього індикатора, визначене експертами. Значення нормалізованих показників визначаємо за формулою

$$
y_{i}(t)=\frac{x_{i}(t)-x_{i}^{\min }}{x_{i}^{\max }-x_{i}^{\min }}
$$


ECONOMIC STRATEGIES FOR THE DEVELOPMENT OF SOCIETY

де $x_{i}^{\min }=\min \left\{\left\{x_{i}(t)\right\}_{t=1}^{T+1}, x_{i}^{N}\right\}, x_{i}^{\max }=\max \left\{\left\{x_{i}(t)\right\}_{t=1}^{T+1}, x_{i}^{N}\right\}$.

На третьому етапі визначаємо вагові коефіцієнти $\mathrm{w}_{\mathrm{i}}$ нормалізованих показників $\mathrm{y}_{\mathrm{i}}$. Для розрахунків даних вагових коефіцієнтів застосуємо метод модифікованої головної компоненти. Визначаємо коваріаційну матрицю $\operatorname{Cov}=\left(\operatorname{cov}\left(y_{i}, y_{j}\right)\right)_{i, j=1}^{n}$, де $\mathrm{n}=7$.

Позначимо через $\lambda^{\max }$ максимальне власне значення цієї матриці, а через $V=\left(v_{i}\right)_{i=1}^{n}$ відповідний цьому значенню власний вектор. Вагові коефіцієнти визначаємо за допомогою формули

$$
w_{i}=\frac{v_{i}^{2}}{\sum_{j=1}^{n} v_{j}^{2}} .
$$

Інтегральна оцінка еко-інноваційної діяльності визначається рівністю

$$
W=\sum_{i=1}^{n} w_{i} y_{i} .
$$

Для інтегрального оцінювання економічної та продовольчої безпеки країни використаємо методичні рекомендації, затверджені наказом Міністерства економічного розвитку і торгівлі України 29.10.2013 № 1277. Згідно цих рекомендацій складовими економічної безпеки є: виробнича, демографічна, енергетична, зовнішньоекономічна, інвестиційно-інноваційна, макроекономічна, продовольча, соціальна, фінансова безпеки. Із екологічними інноваціями безпосередньо пов'язані інвестиційно-інноваційна та продовольча безпеки.

Для оцінювання екологічних інновацій та прийняття рішення про їх впровадження важливе значення має визначення їх впливу на екологічну безпеку країни або регіону. Для інтегрального оцінювання екологічної безпеки доцільно використати систему показників, запропоновану на регіональному рівні в роботі [309]: викиди забруднюючих речовин в атмосферне повітря, скидання забруднених зворотних вод у поверхневі водні об'єкти та утворення промислових відходів I-III класів небезпеки. Оскільки всі дані показники 


\section{ECONOMIC STRATEGIES FOR THE DEVELOPMENT OF SOCIETY}

являються дестимуляторами, то значення відповідних нормалізованих показників обчислюються за формулою

$$
y_{i}(t)=\frac{x_{i}^{\max }-x_{i}(t)}{x_{i}^{\max }-x_{i}^{\min }} .
$$

Вагові коефіцієнти показників визначаємо методом модифікованої головної компоненти.

Вплив екологічних інновацій на економічну, продовольчу та екологічну безпеку країни може бути оцінений коефіцієнтами кореляції між інтегральними оцінками еко-інноваційної діяльності та відповідного виду безпеки. Якщо значимість коефіцієнтів кореляції підтверджується критерієм Стьюдента, то екологічні інновації є ефективними для економічної, продовольчої та екологічної безпеки країни. Доцільно також оцінити залежність фінансових результатів діяльності підприємств від загального обсягу інноваційних витрат у промисловості та обсягу витрат на охорону навколишнього природного середовища. Важливу роль в розвитку екологічних інновацій відіграє застосовування сучасних інформаційних технологій, тобто інформаційного забезпечення екологічної діяльності, а саме: створення баз даних науководослідних розробок в галузі екології, екологічних інновацій, екологічної інформації та екологічних показників; спільний веб-ресурс, на якому регіони України надавали б екологічну інформацію за заздалегідь узгодженим форматом і переліком показників. Необхідно здійснювати постійний моніторинг рівня шкідливих викидів у навколишнє середовище, для контролю стану довкілля та рівня його забруднення. Для вирішення існуючих екологічних проблем регіонів буде доцільно створювати спеціалізовані екологічні технопарки, які стануть центрами екологічно-інноваційної діяльності. 


\section{ECONOMIC STRATEGIES FOR THE DEVELOPMENT OF SOCIETY SECTION 11. INSURANCE}

\section{1 У правління процесами страхування сільськогосподарських культур та організаційно-економічні основи його проведення}

Сільськогосподарське виробництво - одна з важливих і водночас найризикових галузей економіки, яка постійно перебуває під впливом стихійних сил природи, тобто залежить від низки факторів, які неможливо передбачити наперед. Тому, щоб надати гарантії стабільного розвитку виробництва, необхідна унікальна система управління ризиками, яка дає змогу попередити і вчасно компенсувати збитки сільгоспвиробника.

Страхування сільськогосподарських культур $є$ найважливішим засобом зменшення ризикованості сільськогосподарського виробництва. Сільське господарство є однією $з$ найперспективніших галузей економіки України, а рослинництво - це одна з найбільш ризикових галузей суспільного виробництва, оскільки відтворювальний процес пов'язаний із природничо-кліматичними, біологічними та фінансовими чинниками. Тому, до найактуальніших питань в аграрній сфері відноситься захищення врожаю, сільськогосподарської діяльності, за допомогою яких можна стабілізувати розвиток господарств, агропромислового комплексу та економіки держави в цілому.

Аналіз наукових джерел свідчить про те, що страхування сільськогосподарських культур $є$ актуальною темою сучасних досліджень, але визначення даного поняття науковцями зустрічається у фаховій літературі зрідка, або просто копіюється вченими, повторюючи формулювання. Поряд із дефініцією поняття «страхування сільськогосподарських культур» у науковій літературі наводяться поняття «сільськогосподарське страхування», «агрострахування», «страхування врожаю сільськогосподарських культур». Інколи страхування сільськогосподарських культур ототожнюється 3 наведеними поняттями та визначається як «економічні відносини щодо захисту майнових інтересів суб'єктів господарювання, що здійснюють свою діяльність у виробництві сільськогосподарських культур». 


\section{ECONOMIC STRATEGIES FOR THE DEVELOPMENT OF SOCIETY}

Наприклад, науковець О.В. Кравчук розуміє під сільськогосподарським страхуванням «сукупність заходів стосовно захисту майнових інтересів громадян, організацій і установ, що займаються сільськогосподарською діяльністю у разі настання певних подій за рахунок страхових резервів, організованих спеціалізованими страховими державними i недержавними структурами» [317]. Варто погодитися із думкою науковця стосовно того, що сільськогосподарське страхування - це, насамперед, заходи стосовно захисту суб'єктів та об'єктів сільськогосподарської діяльності. Сільськогосподарські культури також є об'єктами сільськогосподарської діяльності і тому таке визначення може застосовуватися і по відношенню до культур.

Проте, значна кількість науковців інтерпретують сільськогосподарське страхування не як «заходи», а «відносини», такого ж підходу дотримується i законодавець [326]. Вчені М.К. Бондарчук та І.Ю. Кондрат у своєму дослідженні визначають сільськогосподарське страхування як «сукупність добровільних економічних відносин щодо страхового захисту майнових інтересів сільськогосподарських товаровиробників» [311]. Сільськогосподарське страхування як систему економічних відносин називає і О.М. Лобова, яка під цим поняттям розуміє "систему економічних відносин між конкретними суб'єктами господарювання, де, 3 одного боку виступають страховики - фінансовокредитні установи, а 3 іншого - страхувальники - сільськогосподарські підприємства, орендарі, селянські (фермерські) господарства, які за певну плату передають свої ризики майнових, фінансових втрат у сільськогосподарській діяльності з метою отримання відшкодування при настанні страхового випадку" [320]. Такі визначення сільськогосподарського страхування мають певний сенс у трактуванні, оскільки охоплюють діяльність учасників страхового процесу, страхових і нестрахових посередників та державних установ.

Доцільно буде з'ясувати, що в перекладі з англійської мови визначення «сільськогосподарське страхування» та «агрострахування» є синонімами, тому що переклад їх однаковий - agricultural insurance. Тому ці два поняття багатьма науковцями інколи вважаються тотожними та близькими за значеннями. Так, 


\section{ECONOMIC STRATEGIES FOR THE DEVELOPMENT OF SOCIETY}

зарубіжний науковець Р. Ітуріос зазначає, що агрострахування - це спеціальний спосіб страхування майна, що застосовується для сільськогосподарських підприємств [331]. За таким визначенням вченого агрострахування має широкий спектр об’єктів страхування і також може застосовуватися по відношенню до характеристики поняття «страхування сільськогосподарських культур».

Деякі вітчизняні вчені визначають агрострахування ще й як «механізм управління». Так, фахівець О.П. Зоря вважає агрострахування «перевіреним механізмом управління сільськогосподарськими ризиками» [315]. 3 ним погоджується науковець О.О. Яцух, стверджуючи, що агрострахування - це «механізм управління усіма сільськогосподарськими ризиками, який забезпечує часткову чи повну компенсацію суб'єкту господарювання втрат через негативний вплив погоди і природних ризиків» [329]. Учені мають рацію в такому трактуванні, адже агрострахування виступає не тільки як управління ризиками вирощування сільськогосподарських культур, а й повинно сприяти пошуку їх вирішення, розробляючи стандартні угоди страхування, процедури врегулювання збитків, що визначені на основі актуальних розрахунків тарифів і ставок для пропонованого покриття, процедури вирішення спорів, вимоги до сторін угоди, механізми збору даних.

При дослідженні у процесі визначення сутності «сільськогосподарського страхування» вирізняється декілька підходів, яких дотримуються науковці. Так, О.М. Остапенко, О.М. Лобова, Ю.В. Самойлик, М.М. Александрова визначають сільськогосподарське страхування як вид (систему) економічних, цивільноправових відносин. На відміну від попередніх науковців, О.Т. Прокопчук, С. Навроцький, Р. Ітуріос, представники Міжнародної фінансової корпорації та інші роблять акцент на тому, що сільськогосподарське страхування $є$ окремим видом або класом страхування.

Вітчизняний науковець Ю.В. Алескерова наголошує, що головна мета страхування аграрних ризиків полягає в компенсації майнової шкоди врожаю, викликаного впливом природно-кліматичних явищ [310], хоча, на нашу думку, проблема аграрних ризиків та їх страхування є більш широкою та потребує 


\section{ECONOMIC STRATEGIES FOR THE DEVELOPMENT OF SOCIETY}

подальшого вивчення.

Основним базовим поняттям у страхуванні є поняття «ризик». Науковці його розглядають з різних позицій. Так, О.О. Рудич [327] виділяє два напрями у визначенні цього поняття. Перший підхід пояснює ризик із позиції фінансових результатів діяльності господарства. Ризик - це небезпека або можливість втрат у разі настання певних небажаних подій. Другий підхід об’єднує спроби дослідників визначити ризик за допомогою інструментів теорії ймовірності. Тоді ризик - це вартісне вираження ймовірності подій, що призводять до втрат.

Сільськогосподарські ризики можна ідентифікувати як один iз різновидів підприємницького ризику, що виникає в аграрному секторі продовольчих ринків і генерує загрозу втрати ринковими суб’єктами частини їх доходів.

Учені В.С. Гайдук і В.С. Луцько зазначає, що без ефективної підтримки держави та застосування сучасних методів регулювання питання подальшого розвитку та поширення страхування сільськогосподарських ризиків є досить проблематичне [312], оскільки сільськогосподарські ризики найнепередбачуваніші від усіх, a сільськогосподарське виробництво $\epsilon$ найризикованішою галуззю економіки, що потребує державного втручання, контролю та регулювання.

У наукових працях i, зокрема, у визначенні вчених В.С. Гайдука i В.С. Луцько зустрічаємо дефініцію «страхування сільськогосподарських ризиків» [312]. Інколи його ототожнюють iз сільськогосподарським страхуванням. Так, дійсно, у сільськогосподарському страхуванні, яке об'єднує в собі об’єкти галузей майнового, особистого і страхування відповідальності, на які направлений страховий захист у страхуванні сільськогосподарських ризиків, виникає дефініція «ризики», які власне також можна віднести до категорії майнових (пошкодження шкідниками рослин, стихійні лиха), особистих (шкода, завдання життю і здоров’ю працівників сільськогосподарського виробництва) та відповідальності (шкода завдана працівниками агропідприємств третім особам). Але в другому випадку вони розглядаються в контексті переліку небажаних подій. 


\section{ECONOMIC STRATEGIES FOR THE DEVELOPMENT OF SOCIETY}

Розглянувши підходи, сформовані в розумінні страхування сільськогосподарських ризиків, які отримали найбільше розповсюдження в науковій літературі, ми запропонували власне визначення поняття «страхування сільськогосподарських ризиків, як найбільш ефективний інструмент захисту виробництва, збутової чи фінансової діяльності сільськогосподарського товаровиробника у вигляді часткової або повної компенсації втрат від соціальноекономічних і природно-кліматичних негативних чинників».

Поряд із поняттям «страхування сільськогосподарських культур» у зарубіжних джерелах зустрічається поняття crop insurance («страхування врожаю»). Страхування врожаю визначається як окремий вид страхових послуг, якими користуються сільськогосподарські товаровиробники, для захисту від втрат сільськогосподарських культур у результаті таких страхових подій, як: град, посухи та повені, або втрати доходів через зниження в цінах сільськогосподарських товарів [321].

На наш погляд, поняття «страхування врожаю сільськогосподарських культур» більш вужче за зазначенням від поняття «страхування сільськогосподарських культур», тому що об'єктом страхування в даному випадку виступає виключно врожай і врожайність сільськогосподарських культур, оскільки у страхуванні сільськогосподарських культур може бути застрахована і сама культура, іiі збут, планові агровитрати, тощо.

Дослідження економічного змісту, об’єктів страхування та порівняння значень наведених понять дало змогу визначити та структуровано, графічно представити місце страхування сільськогосподарських культур у загальній системі страхування та його підпорядкованість (ієрархію) на рис. 1. 


\section{ECONOMIC STRATEGIES FOR THE DEVELOPMENT OF SOCIETY}

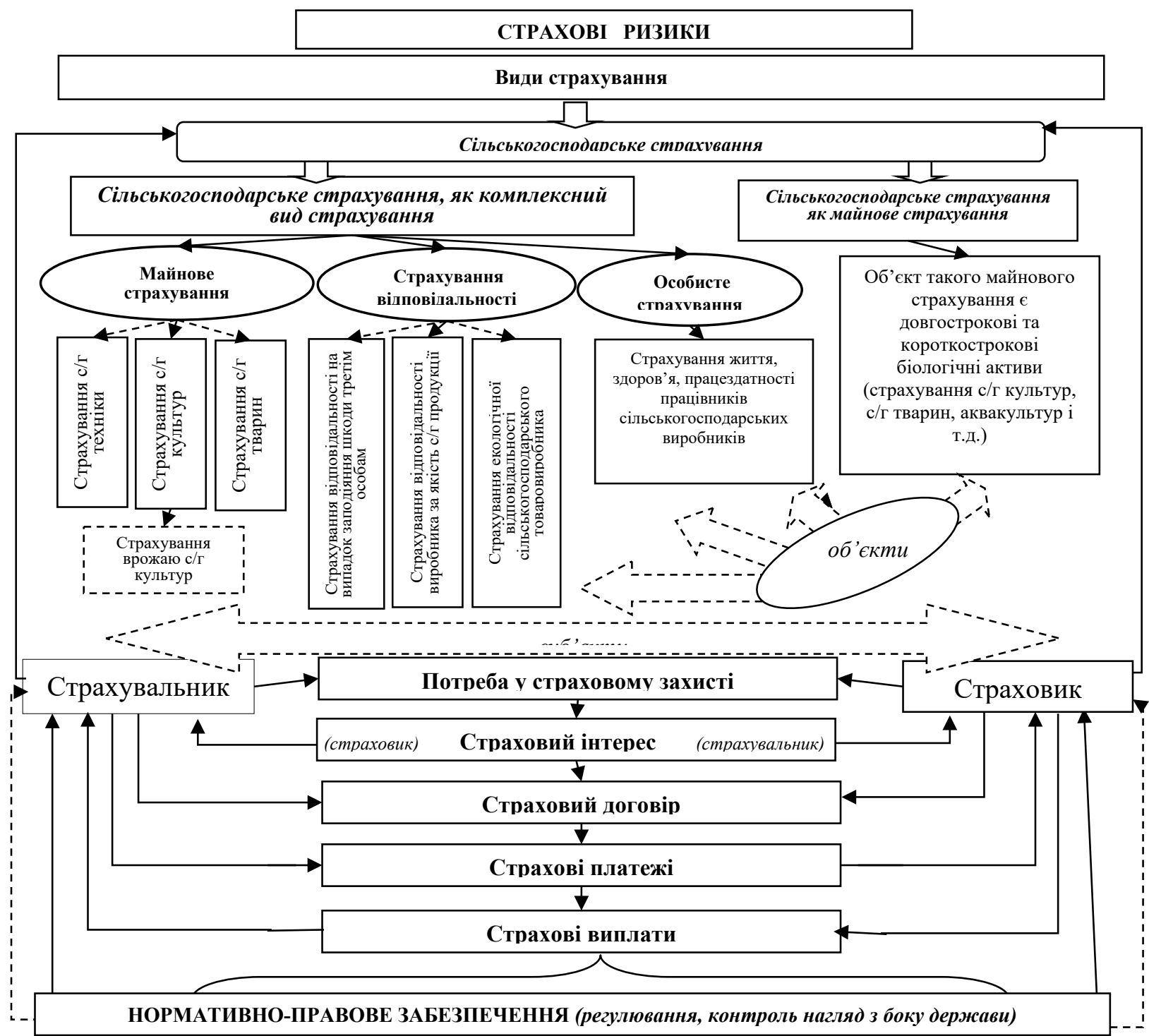

Рис. 1. Місце страхування сільськогосподарських культур у загальній системі страхування

Як уточнює рис. 1, поняття «сільськогосподарське страхування» зорієнтоване на об'єкти галузей майнового, особистого і страхування відповідальності. Іншими словами, воно є комплексним (як автотранспортне страхування, автоцивільне, морське тощо), включає в себе страхування витрат, будівель, споруд, сільськогосподарської техніки, рослинництва і тваринництва. Більш вужчим $є$ зміст поняття «агрострахування», оскільки виникає в контексті рослинництва i тваринництва [319]. За твердженням Р. Шинкаренка «агрострахування - значно відрізняється від видів страхування, оскільки тут страхують біологічні об’єкти, що знаходяться в розвитку. Так, при страхуванні врожаю сільськогосподарських культур на страхування спочатку приймаються паростки рослин, які через певний період повинні сформувати урожай, тобто 


\section{ECONOMIC STRATEGIES FOR THE DEVELOPMENT OF SOCIETY}

товарну продукцію. Ми маємо справу зовсім з іншим профілем ризику, бо здійснюється страхування об'єкта, якого на момент страхування ніби не існує» [328]. У сфері агрострахування застрахованими мають бути як самі культури, так i всі агровитрати на вирощування сільськогосподарських культур (посадка насіння, їх щільність сходження, обробка землі добривом та рослин тощо) на ризики реалізації сільськогосподарської продукції.

До агрострахування доцільно віднести страхування сільськогосподарських культур (зернові, польові, овочеві, плодові, технічні, кормові, баштанні та аква культури, багаторічні насадження). Але тут страховий захист направлений на компенсацію витрат агровиробника через природно-кліматичні негаразди та можливу втрату сільськогосподарських культур.

У страхуванні врожаю сільськогосподарських культур об’єктом захисту є знищення повністю врожаю або його недобір.

Головною метою страхування сільськогосподарських культур є часткова або повна компенсація власнику втрат врожаю, що відбулася через несприятливі природні явища (повінь, град, посуха тощо). Не менш важливою метою страхування $\epsilon$ покращення фінансового стану сільськогосподарського виробника 3 точки зору його кредитоспроможності. Кредитні організації, банки віддають перевагу тому сільськогосподарському виробнику, який має гарантію збереження певного рівня свого доходу при настанні страхового випадку та втраті врожаю.

Страхування сільськогосподарських культур обумовлюється трьома основними ознаками: випадковим характером настання руйнівної події, лиха, надзвичайністю нанесеного збитку (шкоди) в натуральному і грошовому вигляді, об’єктивною необхідністю попередження і подолання наслідків вказаної події та відшкодування матеріальних чи інших втрат [324]. Основні ознаки страхування сільськогосподарських культур впливають на визначення особливостей страхування та спонукають до пошуку удосконалення страхування сільськогосподарських культур.

Страхувальниками сільськогосподарських культур можуть виступати всі 


\section{ECONOMIC STRATEGIES FOR THE DEVELOPMENT OF SOCIETY}

юридичні та фізичні особи, що використовують земельні угіддя та мають майновий інтерес.

Об'єктами страхування сільськогосподарських культур є майнові інтереси власників, що не суперечать законодавству і пов'язані 3 неотриманням або недоотриманням врожаю сільськогосподарських культур: зернові, зернобобові, технічні, овочеві, кормові, баштанні тощо,- та збитках при їх реалізації.

Страхування сільськогосподарських культур має свої особливості, складності та відмінності, на які наголошують багато вчених, досліджуючи специфіку агрострахування.

Згідно із думкою адепта вітчизняного страхування С.С. Осадця, який визначає страхування сільськогосподарських культур як одну із найбільш складних ділянок страхової роботи, вказуючи на велику різноманітність сільськогосподарських культур, що вирощуються на теренах України, відмінність технології їх вирощування, специфічні особливості стихійних явищ, інших причин, подій, що заподіюють шкоду посівам, врожаю сільськогосподарських культур, багаторічним насадженням - усе це вимагає від страховика глибокого знання страхового законодавства, організації та методики страхування, прийомів і методів вирощування сільськогоспкультур [323].

Також головною особливістю страхування сільськогосподарських культур вважається, що об'єктами страхування є «живі організми» - рослини. Водночас інші об'єкти страхування, які належать сільськогосподарським підприємствам (будівлі, споруди, техніка), деякі науковці не відносяться до аграрного страхування, оскільки можуть бути застраховані за іншими договорами тим самим страховиком. На цьому аспекті акцентують увагу представники Міжнародної фінансової корпорації Групи Світового банку [314].

На основі аналізу наявних у науковій літературі визначень потрібно зробити висновок, що особливості страхування сільськогосподарських культур полягають у тому, що страхування є дієвим у довгостроковій перспективі, як правило, лише за умови, що уряд забезпечує фінансову підтримку системи страхового захисту, тому що у рослинництві ризики є системними, а це в багатьох 


\section{ECONOMIC STRATEGIES FOR THE DEVELOPMENT OF SOCIETY}

випадках означає збитки для великої кількості суб'єктів аграрного ринку одночасно. А за таких обставин страхові виплати будуть значно вищими від зібраних премій.

Для успішного управління ризиками виробництва сільськогосподарських культур існують стратегії, спрямовані на зменшення їх негативного впливу на доходи сільськогосподарського виробництва.

Виробництво сільськогосподарських культур є дуже ризиковим і складним, яке потребує спеціальних глибоких знань, а для успішного управління ризиками виробництва сільськогосподарських культур $\epsilon$ необхідність застосування спеціальних стратегій. Пояснюється це тим, що це сфера діяльності, успішність якої значною мірою залежить від різноманітних погодних та кліматичних факторів, дію яких у багатьох випадках контролювати не можливо. А ризики коливання цін на ресурси та готову продукцію посилюються непередбачуваністю державної політики, яка відчутно впливає на розвиток сільськогосподарського виробництва та ринку сільськогосподарської продукції [323].

Однак, не всі ризики, що загрожують вирощуванню та реалізації сільськогосподарських культур, належать до категорії страхових ризиків, тобто таких, які страхові компанії на суто ринкових умовах готові приймати на страхування. Тому, буде важливим охарактеризувати страхові ризики виробництва сільськогосподарських культур, які зображено на рис. 2 


\section{ECONOMIC STRATEGIES FOR THE DEVELOPMENT OF SOCIETY}

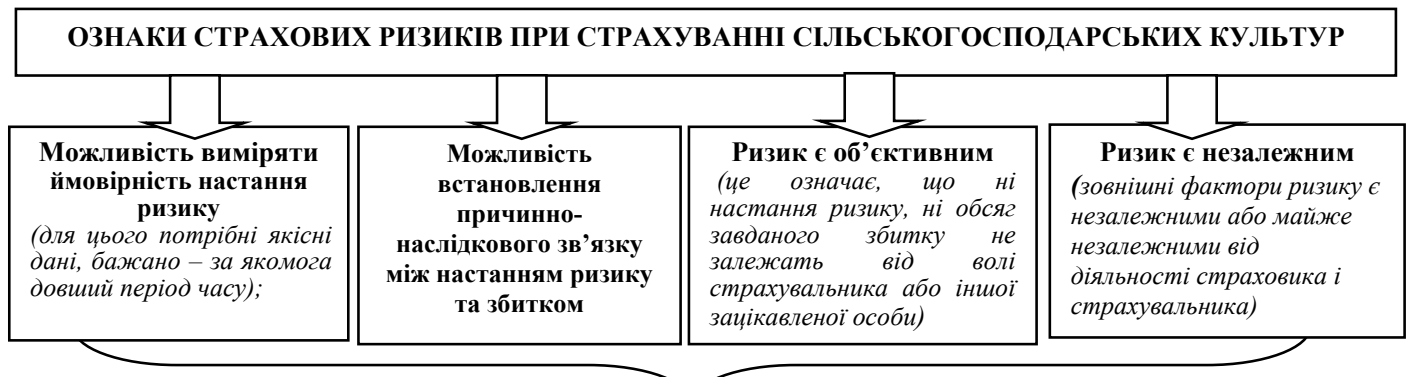

Специфіка ризиків виробництва сільськогосподарських культур

Специфіка виробничих ризиків, притаманних виробництву сільськогосподарських культур, полягає в тому, що дуже часто ці ризики не можуть бути віднесені до категорії страхових ризиків, оскільки вони не відповідають наведеним ознакам. Наприклад, такий ризик, як посуха, може спричинити загибель сільськогосподарських культур на великій території та одночасне звернення за відшкодуванням великої кількості господарств, отже, він $є$ системним. Страховий захист від посухи найбільше цікавить страхувальника, але страховики остерігаються приймати цей ризик на страхування. Якщо приймати такі ризики на страхування на виключно ринкових засадах, то вартість такого страхування для сільськогосподарського виробника буде надто високою.

Складність страхування виробництва сільськогосподарських культур полягає в тому, що, з одного боку, перспективи його розвитку на виключно ринкових засадах є досить обмеженими, а 3 іншого - наявність страхування сільськогосподарських культур І розцінюється суспільством як необхідний елемент підтримки сільськогосподарського виробництва та сільського населення. Це

। створює передумови для державної підтримки страхування сільськогосподарських культур. Наявність державної підтримки, у свою |

І чергу, додає складності аграрному страхуванню, оскільки тепер це вже не лише інструмент управління ризиками у сільському

господарстві, але й інструмент державної політики.

\section{Рис. 2. Специфіка ризиків та особливості страхування сільськогосподарських культур}

Страхування сільськогосподарських культур розвивалося в усьому світі, як головний інструмент управління ризиками з метою зменшення негативного впливу погодних факторів та природних ризиків. Тому з'являється необхідність застосування економічних заходів, які дозволили б відновити постраждалі об'єкти та відшкодувати збитки, завдані підприємству. За даних умов необхідним складовим елементом ринкової інфраструктури є мінімізація ризиків рослинницької галузі виробництва, яка $є$ комплексом ефективних механізмів, інструментів держави, приватного сектору та однією із базових частин сталого розвитку галузі.

У країнах 3 державною підтримкою виробників сільськогосподарської продукції існує велика кількість різноманітних страхових продуктів. Всі страхові продукти для виробництва сільськогосподарських культур можна поділити на дві великі категорії - індивідуальні (або традиційні) та індексні [323].

Індивідуальні страхові продукти - це такі продукти, для яких умова виплати відшкодування та ставка страхової премії встановлюються на основі індивідуальних даних кожного конкретного виробника щодо врожайності культури, що страхується. Підставою для виплати відшкодування у таких продуктів є встановлення факту падіння фактичної врожайності застрахованої 


\section{ECONOMIC STRATEGIES FOR THE DEVELOPMENT OF SOCIETY}

культури (або фактичного доходу від виробництва цієї культури) нижче встановленого договором страхування граничного рівня, який називають тригерним рівнем врожайності або тригером виплати відшкодування. Від англійського слова “trigger” - пусковий гачок, пускова схема. Індивідуальні страхові продукти ще називають традиційними продуктами, оскільки 3 них починався розвиток аграрного страхування, і до цього часу вони залишаються найрозповсюдженішими у світі [320].

У цій категорії виділяють індивідуальні продукти страхування врожайності та індивідуальні продукти страхування доходу.

Індивідуальні продукти страхування врожайності спрямовані на те, аби частково компенсувати виробнику втрати, які виникли через нижчу, ніж очікувалося, врожайність культури. Ці продукти передбачають, що на основі індивідуальних даних господарств щодо врожайності культури за попередні роки розраховується очікувана (ймовірна) врожайність культури. Далі виробник обирає рівень покриття врожайності, який визначає тригер страхової виплати, тобто той рівень врожайності, при падінні фактичної врожайності якого виникає право виробника на отримання відшкодування. Відшкодуванню підлягає різниця між фактичним рівнем врожайності культури та тригерним рівнем врожайності, а для розрахунку суми відшкодування використовується очікувана ціна продукції, заздалегідь визначена та зазначена в договорі страхування.

Індивідуальні продукти страхування доходу сільськогосподарських товаровиробників направлені частково компенсувати недоотримання доходу від виробництва певної культури, яке може бути спричинене або нижчою за очікувану врожайність, або нижчою за очікувану ціну. Такі продукти схожі на індивідуальні продукти страхування врожайності тим, що для розрахунку очікуваної (ймовірної) врожайності використовуються індивідуальні дані господарств та фіксуються в договорі очікувана ціна на продукцію.

Проте, відмінність полягає в тому, що замість рівня покриття очікуваної врожайності виробник обирає рівень покриття очікуваного доходу, тобто певний відсоток від результату (множення очікуваної врожайності на очікувану ціну). 


\section{ECONOMIC STRATEGIES FOR THE DEVELOPMENT OF SOCIETY}

Обраний рівень покриття доходу визначає тригер страхової виплати, тобто той рівень доходу, при падінні фактичного доходу нижче якого виникає право виробника на отримання відшкодування. Відшкодуванню підлягає різниця між фактичним рівнем доходу, отриманим у результаті множення фактичної врожайності на фактичну ціну продукції на момент збору врожаю, та тригерним рівнем доходу [326].

Залежно від кількості аграрних ризиків страхування може бути моноризиковим чи мультиризиковим. Моноризикове страхування в аграрному секторі є одним із найпростіших, оскільки надає можливість страхувальнику застосовувати вибірковий підхід до страхування ризиків, пов'язаних із виробництвом та переробкою сільськогосподарської продукції. У вітчизняній практиці найпоширенішим $\epsilon$ страхування врожаю сільськогосподарських культур від граду та вогню. Порівняно з комплексним страхуванням врожаю сільськогосподарських культур страхування від поіменних ризиків проводиться за значно нижчими тарифами, однак цей страховий продукт не забезпечує страхового захисту в разі настання непередбачених страховим договором ризиків. У випадку, коли врожай сільськогосподарської культури істотно знижується через вплив багатьох ризиків, доцільніше укладати договір мультиризикового страхування, хоч він має значно вищу вартість.

Мультиризикові продукти позиціонуються українськими страховиками як головний вид страхування для агросектору. Особливістю мультиризикового страхування врожаю сільськогосподарських культур є вимога страхувати всі посіви. Страхові виплати здійснюються лише за умови, коли врожай з усіх посівів буде нижчим від заздалегідь погодженого рівня. Це означає, якщо врожай на одному полі загинув, але загальна врожайність культури знаходиться на рівні страхової врожайності, то страхова виплата не здійснюватиметься. На практиці зазвичай застосовується франшиза - 50\% від страхової суми. Оцінка врожайності здійснюється до збирання врожаю сільськогосподарської культури, причому врожайність визначається за біологічною врожайністю або методом контрольного збирання [312, 317, 324]. 


\section{ECONOMIC STRATEGIES FOR THE DEVELOPMENT OF SOCIETY}

Подолати недоліки моноризикового та комплексного видів страхування можна шляхом здійснення постійного моніторингу поведінки страхувальника. Тому, у штаті страхової компанії потрібна достатня кількість кваліфікованих спеціалістів із сільськогосподарською освітою та компетентних актуаріїв в аграрній сфері [322], а також необхідні адміністративні витрати на виконання робіт із моніторингу. Крім того, моніторинг ефективний лише тоді, коли в країні по діловому виконуються норми договірного права та спірні питання можуть швидко й справедливо бути вирішені в суді.

Г.I. Зуб вважає, що другим шляхом вирішення даної проблеми $\epsilon$ використання нового виду страхування на основі погодного індексу [316]. Такий метод унеможливлює ризик викривлення інформації, тому що стан настання страхового випадку підтверджується даними метереологічних станцій, які спостерігають за погодними факторами.

Індексні страхові продукти - це такі продукти, в яких умова виплати відшкодування та ставка страхової премії не залежать від показників врожайності конкретного виробника. У цих продуктах, на відміну від індивідуального страхування, підставою для виплати відшкодування $\epsilon$ встановлення факту відхилення спеціальним чином побудованого індексу від тригерного рівня, визначеного умовами договору страхування. Крім тригерного рівня індексу, договір індексного страхування визначає характер (напрямок) відхилення, який є підставою для виплати відшкодування, та грошову вартість однієї одиниці відхилення, як основу для розрахунку відшкодування [323].

Індексне страхування 3'явилося на вітчизняному ринку агрострахування відносно недавно, але у світовій практиці воно застосовується як рівноцінна альтернатива традиційним страховим продуктам завдяки простоті і дешевизні. Розрахунок індексів, які корелюють 3 ризиками виробництва сільськогосподарських культур, базується на інформації про погодні параметри та урожайність культур.

Поняття індексного страхування визначалося п. 10.3 Закону України «Про державну підтримку сільського господарства України» [326], який разом з усім 


\section{ECONOMIC STRATEGIES FOR THE DEVELOPMENT OF SOCIETY}

III розділом був виключений у 2012 р. Індексним вважається страхування ризику втрати врожаю окремої сільськогосподарської культури у відношенні до усереднених натуральних показників ії врожайності на визначеній території за попередні п’ять маркетингових періодів. Для цілей розрахунку розміру страхової виплати за індексним страхуванням використовується спотова ціна метричної одиниці застрахованої сільськогосподарської продукції, діюча на організованому аграрному ринку на момент виникнення страхового випадку.

Залежно від індексу, всі індексні страхові продукти можна умовно поділити на три групи. Страхування за індексом врожайності подібне до індивідуального страхування врожайності. Основна відмінність полягає в тому, як визначають очікувану та фактичну врожайність. При страхуванні за індексом врожайності використовують дані середньої врожайності культури на рівні адміністративної одиниці (району). На основі цих даних за попередні роки розраховується очікувана (ймовірна) врожайність культури. Далі виробник індивідуально обирає рівень покриття врожайності, який визначає тригер страхової виплати. Якщо фактична середня врожайність по району виявиться нижчою за тригерний рівень врожайності, то виникає право виробника на отримання відшкодування. Відшкодуванню підлягає різниця між фактичним середнім рівнем врожайності культури по району та тригерним рівнем врожайності, а для розрахунку суми відшкодування використовується очікувана ціна продукції, визначена та зазначена у договорі страхування [321].

Перевагою страхування за індексом врожайності є відсутність потреби в багаторічних даних врожайності кожного конкретного виробника. Використовуються індивідуальні дані лише щодо посівних площ, прав власності та застрахованих культур. Основний недолік таких продуктів полягає в тому, що врожайність сільськогосподарської культури в певному господарстві може мати дуже слабку кореляцію з середньою врожайністю цієї культури по району. Виробник може отримувати врожай вище середнього рівня в роки, коли врожайність на районному рівні $є$ низькою (i, відповідно, отримувати страхове відшкодування). Водночас виробник може мати низький врожай у роки, коли 


\section{ECONOMIC STRATEGIES FOR THE DEVELOPMENT OF SOCIETY}

врожайність на районному рівні перевищує середній рівень, і не отримати відшкодування, незважаючи на низький рівень врожайності в його господарстві. Саме тому ці страхові продукти вважаються такими, що пропонують нижчий рівень захисту, порівняно 3 індивідуальними продуктами страхування врожайності господарств. Проте, витрати, пов'язані із визначенням ставки премії і моніторингом врожайності для них, є значно нижчими.

Страхування за індексом доходу схоже на страхування за індексом врожайності та з індивідуальними продуктами страхування доходу. Очікувана врожайність при страхуванні за індексом доходу визначається таким самим чином, як і при страхуванні за індексом врожайності. Очікувана ціна на продукцію, визначається так само, як для індивідуального продукту страхування доходу [319].

До страхування 3 використанням «проксі»-індексів належить продукти, в яких для побудови індексу використовують різноманітні «замінники» врожайності (так звані «проксі-індикатори» відображають умови розвитку рослин. На сьогодні «проксі»-індексні продукти представлені погодними індексами (побудованими, наприклад, на основі показників температури повітря чи рівня опадів) та індексами вегетації рослин, побудованими на основі фотографування полів із супутників [322].

Основною перевагою індексних страхових продуктів над індивідуальними страховими продуктами є відсутність мотивації страхувальника фальсифікувати дані врожайності або впливати на фактичну врожайність у спосіб, який кваліфікується як моральна шкода.

Різноманітність програм аграрного страхування досить широка, але в них практично завжди бере участь держава. Існує два види програм: програми страхування врожайності і програми страхування доходів, які гарантують компенсацію втрат виробника сільськогосподарської продукції не тільки від неврожаю, а й від падіння цін на вироблену продукцію [322].

Ознайомившись із різними видами страхування, можна стверджувати, що індексне страхування $є$ більш привабливим для аграріїв на ринку 


\section{ECONOMIC STRATEGIES FOR THE DEVELOPMENT OF SOCIETY}

агрострахування внаслідок його меншої вартості, прозорості, зрозумілості, зменшення фактору суб'єктивності при визначенні настання страхового випадку і визначення страхового відшкодування, стандартизації умов. Але розвиток мультиризикового та індексного страхування в Україні уповільнюється відсутністю статистичних баз даних сільськогосподарських ризиків, низьким рівнем актуарної діяльності, відсутністю єдиних підходів до розробки умов страхування і розрахунку страхових тарифів.

Для ліквідації цих факторів необхідно формувати централізовані бази даних, посилити вимоги національного регулятора до страхових компаній у частині звітування і розкриття інформації щодо умов договорів страхування сільськогосподарських культур у розрізі окремих рослин і тварин, технічно забезпечити дистанційні методи урегулювання катастрофічних ризиків [324].

Таким чином, страхування сільськогосподарських культур - це один із найскладніших видів страхового захисту, який має свої особливості, що полягають у системності аграрних ризиків, залежності від погодних та кліматичних факторів, політики ціноутворення, а тому і необхідності державної підтримки та державного регулювання стосовно удосконалення тарифної політики і збільшення кількості різноманітних страхових продуктів. 


\section{ECONOMIC STRATEGIES FOR THE DEVELOPMENT OF SOCIETY SECTION 12. INTERNATIONAL ECONOMIC NEWS}

\section{1 Інтеграційна місія фінансових інститутів у формуванні глобальної та регіональних фінансових систем}

Сучасні глобальна та регіональні фінансові системи розглядаються в науковій літературі як результат впливу провідних тенденцій світогосподарського розвитку другої половини XX - початку XXI століть: глобалізації, інтенсифікації міжнародної економічної інтеграції, а також регіоналізації. Один з найвідоміших дослідників формування глобалізованої економіки К. Оме, відзначаючи взаємозв'язок між утворенням регіональних, 3 одного боку, та зближенням соціально-економічних систем різних рівнів, 3 іншого боку, підкреслює домінування фінансової глобалізації у цих процесах [332].

Посилення взаємозалежності економічних суб'єктів на основі фінансових потоків. Отже, фінансова глобалізація є наслідком дії процесу фінансової інтеграції на рівні світової економіки, тоді як регіоналізація тлумачиться здебільшого як зростання транскордонних потоків товарів, ідей, робочої сили та капіталу у межах певної географічної області. Глобалізація сфери фінансів має власні специфічні риси, пов'язані 3 перебігом розвитку окремих держав i економічних територій та фінансових ринків. «Нерівномірна фінансова глобалізація»...багато в чому визначає тренди, тенденції й цикли сучасного економічного розвитку всіх країн і регіонів світу» [333]. Це має особливе значення у випадках проблем 3 фінансовим забезпеченням економічного розвитку через структурні перетворення господарства.

Вимір фінансових потоків дає змогу оцінки ступень інтегрованості суб'єкта світового господарства до міжнародних фінансових ринків. Валові потоки дають відносно менш мінливу і більш зрозумілу картину інтеграції. Співвідношення суми валових надходжень і відпливу до національного ВВП перебуває у певній симетрії з показником відкритості торгівлі, що вимірюється як співвідношення суми імпорту та експорту до ВВП. Сьогодні для досліджень у цій сфері 


\section{ECONOMIC STRATEGIES FOR THE DEVELOPMENT OF SOCIETY}

застосовується Індекс відкритості рахунку капіталу Ван-Джахана, який надає змогу дослідникам та розробникам політики віднайти нові шляхи для встановлення змін у політиці де-юре та пов'язаними із ними зміни фактичних потоків капіталу. Цей показник побудований на основі інформації, що міститься у Річному звіті МВФ про домовленості та обмеження обміну (Annual Report on Exchange Arrangements and Exchange Restrictions, AREAER). Він показує загальну відкритість рахунку капіталу, а також відкритість за різними типами субрахунків: напрям потоків, резидентність та типи активів (наприклад, власний капітал, облігації, прямі інвестиції тощо).

«Фінансова глобалізація передбачає вільний рух капіталів між країнами за допомогою відповідної фінансової інфраструктури: банків, ТНК, фондових бірж, міжнародних фінансових інституцій тощо» [334]. Отже, сукупність фінансових інститутів $є$ наріжним каменем архітектури фінансового ринку національного й глобального масштабів, регіональних інтеграційних угруповань. В основі діяльності фінансових інститутів лежать три взаємопов'язані ланки єдиного

механізму: (1) залучення залишків (вільних) грошових коштів, (2) спрямування цих коштів до тих економічних агентів, які цього потребують, (3) використання фінансових інструментів кредитного характеру, прав власності, гібридних інструментів. Фінансові інститути, опосередковуючи інвестиційні процеси, відіграють вирішальну роль у прискоренні розвитку економічних агентів усіх рівнів.

Безумовно провідною $\epsilon$ роль фінансових інститутів у перетворенні міжнародних фінансів на глобальні, зокрема, а) при скасуванні системи фіксованих обмінних курсів та б) у процесі масштабної фінансової лібералізації. Фінансові системи різних рівнів залучаються до інтеграційних процесів через всю інфраструктуру руху фінансових потоків, включаючи ринки й інститути. Звідси логічним висновком $є$ те, що інтеграція $є$ процесом, який зближує, поєднує між собою фінансові системи та їх структурні елементи. Водночас i власне фінансові інститути мають еволюціонувати разом із еволюцією потреб суспільно-господарських систем у фінансовому обслуговуванні. 


\section{ECONOMIC STRATEGIES FOR THE DEVELOPMENT OF SOCIETY}

Функціонування фінансових ринків завжди пов'язане з низкою ризиків як для інвестора/кредитора, так і для позичальника. У зв'язку з цим необхідно делегування кредитним інститутам функції регулювання ризику невизначеності 3 метою мінімізації неефективності розміщення капіталу. В основі даного положення лежить суперечність між двома чинниками використання капіталу заощадженням, що $є$ синонімом очікування, та невизначеністю щодо інвестування. Оскільки зростання заощаджень за умов невизначеності скорочує обсяг капіталу, вкладеного в розвиток, існує необхідність розмежування функцій заощаджень та інвестування. Розуміння ролі фінансових посередників у процесах розподілу й перерозподілу фінансових ресурсів грунтується на розмежуванні каналів прямого й непрямого фінансування в складі фінансових ринків. Фінансове посередництво базується на великій кількості інститутів та контрактів, тобто на «ефекті великих чисел», або ефекті масштабу, який дає змогу суттєво зменшити трансакційні витрати. Скорочення трансакційних витрат разом із моніторингом посередниками найважливіших параметрів кредитних угод є ключовим положенням трансакиійного підходу в дослідженні фінансового посередництва. Вагомий внесок у розвиток даного підходу зробили Дж. Бенстон та К. Сміт (1976). Вчені пропонують власну відповідь на наріжне запитання щодо причин існування фінансових посередників. Вони пов'язують трансакційні витрати з процесом реалізації специфічних фінансових товарів, створюваних фінансовими фірмами-посередниками та. формулюють три джерела порівняльних переваг фінансових посередників на основі аналізу взаємозв’язку цін, витрат, спеціалізації та диверсифікації. По-перше, ціна розглядається як функція загальної суми накопичених виробничих витрат, включаючи витрати виробника на адміністрування, моніторинг та обробку. Ефект масштабу й точне врахування виробничих витрат створюють можливість оптимізувати ціноутворення. По-друге, завдяки зростаючій спеціалізації, посередники збирають інформацію 3 меншими витратами, а отже здатні зменшити трансакційні витрати, пов'язані з пошуком. По-третє, диверсифікація сприяє зменшенню ймовірності банкрутства, хоча в багатьох випадках варто 


\section{ECONOMIC STRATEGIES FOR THE DEVELOPMENT OF SOCIETY}

зіставляти вигоди від диверсифікації та збитки від звуження спеціалізації [335].

Іншим підходом у дослідженні фінансового посередництва $\epsilon$ інформаційний, пов'язаний із явищем асиметрії ринкової інформації. Ця асиметрія може бути типу: ex ante, що породжує так звану проблему несприятливого відбору та супутній ризик морального збитку; або ex post, що призводить до необхідності застосування деяких витратних процедур перевірки, аудиту або навіть примусу боржника до виконання зобов'язань. Інформаційна асиметрія й породжувані нею ризики ілюструють відхилення від теорії ідеальних ринків. Згідно з інформаційним підходом, фінансові посередники з'явилися саме задля усунення, хоча б частково, цих ризиків і витрат. Так, Ф. Ален (1990) пояснює мотивацію посередників з погляду проблеми надійності/безпеки, яка пов'язана із ступенем достовірності інформації при іiї продажу, тобто із ризиком iii недостовірності. Фірми, які витрачають значні ресурси на збір хорошої інформації, втратять гроші, оскільки отримають вартість на рівні саме середньої, тобто низької якості. У цьому зв'язку продавець не може отримати повну вартість своєї інформації. Це сприяє посередницькій діяльності, оскільки посередник може бути зацікавлений у захопленні решти інформаційної вартості [336].

3 інституціонального погляду, сукупність фінансових інститутів, будучи підсистемою, структурним елементом фінансової системи і водночас провідною ланкою системи фінансового посередництва. охоплює: банки, центральні банки, державні фінансові установи, інвестиційні фонди, пенсійні фонди, страхові компанії, хедж-фонди, трастові та фінансові компанії, кептивні фінансові інститути, структуровані механізми фінансування, фонди фінансової допомоги та ін. Розвиток глобального бізнесу та фінансів сприяв створенню транснаціональних організацій управління, таких як G20, Банк міжнародних розрахунків (BIS), Базельський комітет з банківського нагляду (BCBS) та Рада фінансової стабільності (FSB), та поширив у сфері фінансового нагляду діяльність міжнародних фінансових установ (МФІ), таких як Світовий банк реконструкції та розвитку (Світовий банк) та Міжнародний валютний фонд 


\section{ECONOMIC STRATEGIES FOR THE DEVELOPMENT OF SOCIETY}

(МВФ). До складу небанківських фінансових інститутів належать: страхові корпорації, пенсійні фонди, інші фінансові інститути, допоміжні інституційні одиниці, зайняті обслуговуванням фінансових ринків, що не приймають у власність фінансові активи та зобов'язання, якими вони займаються). Категорія інших фінансових інститутів складається 3 таких інститутів: інвестиційні фонди, кептивні фінансові компанії, брокери-дилери, хеджеві фонди, фонди грошового ринку, структуровані фінансові механізми, трастові та фінансові компанії тощо.

У перебігу сучасних ринкових трансформацій, передусім, технологічних, зростає спектр фінансових інструментів, якісно збагачується перелік фінансових послуг, утворюються їх нові організаційні форми, відбувається перехресне інтегрування активів фінансових інститутів. Наразі фінансова взаємозалежність посередницьких структур є відзначною рисою глобальної фінансової системи, індикатором її інтегрованості. На даний час не існує єдиної повної статистичної бази даних у цій сфері, але деякі доступні показники дають змогу окреслити загальну ситуацію. Так, зокрема, взаємозв'язок найбільших за обсягом активів категорій посередників - банків 3 іншими фінансовими інститутами характеризується високим рівнем взаємного використання коштів. Страхові корпорації та пенсійні фонди замість прямого кредитування інвестують кошти в інші фінансові інститути, хоча, як правило, не отримують значного фінансування в зворотному напрямку [337].

Фінансова взаємозалежність інститутів посередництва може сприяти диверсифікації ризиків по всіх фінансових секторах, але може також поширювати певні ризики у періоди стресу. Взаємозалежність може спричиняти наслідки для фінансової стабільності через канали фінансування та кредитного ризику, особливо у тих випадках, коли ці канали пов'язані з нарощуванням левереджу або невідповідності між термінами погашення та ліквідністю. Тому зв'язки між банками, небанківськими та іншими фінансовими інститутами можуть слугувати важливими показниками потенційного «зараження» як всередині країн, так і поза їхніми межами. 3 позицій традиційної теорії, логічним 


\section{ECONOMIC STRATEGIES FOR THE DEVELOPMENT OF SOCIETY}

має бути теоретичний висновок про непотрібність фінансового посередництва, або принаймні зниження його ролі у фінансових процесах, але фактично його значення вочевидь зростає, отже має місце своєрідний парадокс.На нашу думку, коріння цього парадоксу перебуває у площині причинно-наслідкового зв'язку процесів регіоналізації та глобалізації, з одного боку, та розвитку фінансових установ, з іншого боку.

Зниження інституційних бар'єрів дозволяє фірмам та приватним особам 3 більшою легкістю коригувати свої вимоги та зобов'язання з метою покращення ліквідності своїх портфелів та диверсифікації їх ризиків. Таким чином, рух до міжнародної диверсифікації 3 боку інституційних інвесторів (особливо пенсійних фондів, страхових компаній та пайових фондів) є головною силою, що лежить в основі інтернаціоналізації та інтеграції фінансових ринків.

Спираючись на аналіз взаємозалежності фінансових інститутів, вважаємо, що воно стосується не лише банків, але й усього сучасного спектра фінансових посередників, оскільки вони так само здійснюють трансформацію ліквідності, ступеня зрілості й левериджу, трансфер кредитного ризику тощо. Важливо також додати, що у сфері фінансового посередництва вже з'явилися нові гравці Великі технологічні компанії (big technology companies, BigTech), які суттєво впливають на функціонування глобальної та регіональних фінансових систем. Збагачення спектру й функцій фінансових посередників, формування їх нових організаційних утворень, перелив фінансових технологій між країнами й регіонами в сукупності забезпечує подолання ризиків неефективного розподілу капіталу та інформаційної асиметрії, сприяє розвиткові фінансових ринків на основі їх інтегрування. Феномен фінансової взаємозалежності інститутів посередництва також несе потенціал зближення фінансових систем, хоча має суперечливу природу з точки зору поширення ефекту зараження у кризові періоди. Отже, місія фінансових інститутів в інтеграџійному контексті це фінансове посередництво, спрямоване на поліпшення доступу економічних суб'єктів до фінансових ресурсів шляхом запобігання та/або подолання трансакційних, інформаційних ризиків та ризиків фінансової взаємозалежності 
ECONOMIC STRATEGIES FOR THE DEVELOPMENT OF SOCIETY

на основі інтеграції організаційно-управлінських, технічних, технологічних та соціально-економічних аспектів посередницької діяльності. 


\section{ECONOMIC STRATEGIES FOR THE DEVELOPMENT OF SOCIETY}

\subsection{Key trends in the development of IT in the world}

As scientists point out, during the XIX - first third of the XXI century, the trends in the development of IT in the world have changed significantly: from the gradual growth of volumes of world commodity turnover; expansion and complication of the commodity nomenclature; the changes in the geographical structure of the IT in the nineteenth century ..; through the prism of trade policy liberalization; transnationalization of IT; and the most intensive "growth" in the volume of trade between different departments of the same transnational corporation located in different countries, and the volume of trade of services; in the close connection between trade activity and foreign direct investment in the XX century; we are observing an increase in the role of developing countries and, the most importantly, the rapid development of trade between them; regionalization of IT; increase of influence of nontariff barriers of XXI century [338].

It also became clear that in the second half of the twentieth century. trade and economic relations between the countries have become more profound, having a longterm character, including not only the traditional trade in goods, but also trade in services, foreign investment, intellectual property regulation and regulatory modes [339].

The experts from the international organizations such as the WTO, the World Bank Group, the IMF, are investigating the trends in the development of IT and indicators of the global economy, have developed forecasts of global economic performance. The researchers from the World Bank Group in the 2016 report "Global Economic Outlook. Secondary effects in light of weak growth" predicted a slight increase in global GDP, to 2.9\%, 3.1\% and 3.1\% in 2016, 2017 and 2018. As we see, relative to the 2015 indicator ( $2.47 \%$ ) growth is very slow, namely $0.43 \%$ and $0.63 \%$ in 2016 and 2017, 2018 accordingly. There is a tendency that the GDP of the country increases with the growth of its exports of goods [340].

According to the WTO, at the beginning of 2011, there were 453 regional trade agreements in the world, a record number of them (slightly more than a half) was made 


\section{ECONOMIC STRATEGIES FOR THE DEVELOPMENT OF SOCIETY}

during the first ten years of the XXI century. The rapid expansion of the regional trade agreements in recent years is due not only to the liberalization of tariff regulation within the framework of intra-regional trade, and with the slowdown in the development of multilateral regulation of trade and economic relations under the auspices of the WTO [339].

The key role in the markets is focused on the EU countries, whose exports are currently increasing, while others are markets in which Ukrainian producers have significant potential for exporting products. There were identified the top 20 markets, which, if they choose the right forms and tools to work with them, are able to show fairly fast results. Among them, except the EU countries: Turkey, China, India, Egypt, Saudi Arabia, Canada, OAU, USA, Israel, Belarus, Georgia, Moldova, Japan, Indonesia, Thailand, Bangladesh, Lebanon, Philippines, Nigeria and Switzerland. To this end, an expanded analysis is carried out, opportunities and forms of optimal presence of Ukraine in these markets are determined, as well as strategic programs for entering these markets are developed [341].

The extension of IT occurs by:

due to the development of the international division of labor, which manifests itself in the intensification of international economic relations (liberalization with simultaneous reduction of various barriers);

intensification of migration processes, covering the resource base of world production (capital, labor force, technology, knowledge);

strengthening the integration of the countries (including through the mechanism of action of international organizations) and the creation of regional integration associations, the action of which is also more influential [339].

The rapid expansion of regional trade agreements in recent years is due not only to the liberalization of tariff regulation within intra-regional trade. In the development of regional integration there are new specific features.

First, countries are increasingly struggling to make Regional Trade Agreements (RTAs) a central objective of national trade policy due to their inability to regulate trade relations through the WTO's multilateral mechanism. Secondly, RTAs are more 


\section{ECONOMIC STRATEGIES FOR THE DEVELOPMENT OF SOCIETY}

complex, establishing in many cases such regulatory modes that go beyond the rules of the multilateral mechanism. Thirdly, the formation of regional agreements among the key developing countries points to the strengthening of South-South cooperation. Fourthly, the number of transregional RTAs in the total number of regional agreements is significantly increasing [339].

As Ishchenko said, "the need to develop and strengthen national export support systems is intensifying. Thirdly, there was a change in the geo-economic format of commodity flows, which is due to a change in the leadership card in the world market. Recall that a characteristic feature of the last two decades was the rapid growth of commodity exports of the countries of Eastern and Southeast Asia, including China, to developed western markets, primarily the United States. From January 1, 2010 officially began operating China FTA, ASEAN - KAFTA (China-ASEAN Free Trade Area)» [340].

The research of key trends in the development of IT point out that today in the world economy the countries are pursuing both liberal and protectionist policies for the organization of foreign trade relations.

Thus, the main approaches to the organization of foreign trade relations, which is used by the European Commission, are based on several principles [342]:

- There are no sectors in the economy that can be protected from business struggle due to their origin - all markets of both goods and services should be liberalized;

- Each EU Member State is free to define its own common services that can be provided through a mechanism to restrict business struggle;

- the restriction of business struggle should be adequate, that is, the state regulation should not be greater than the provision of the guarantees necessary for the fulfillment of the tasks by natural monopoly entities;

- EU legislation does not provide for enterprises with special market rights to meet public needs, mandatory state or private ownership. However, the attitude to such an enterprise should be the same as to its business competitors. 


\section{ECONOMIC STRATEGIES FOR THE DEVELOPMENT OF SOCIETY}

Agreed statements within the multilateral negotiations in the WTO lead to more desirable trade policy implications [339].

The liberalization of foreign economic activity, which is the leading tendency of foreign economic policy of developed countries, and replaced protectionism in the middle of the last century, encompassed not only the sphere of trade but also migration processes (labor, capital, technologies, etc.). For developing countries and countries with economies in transition, the processes of liberalization began much later [339].

The mechanism of regulation of IT in the US is to comply with laws aimed at counterfeiting of products, the implementation of customs control, regulation of communal and rail transport activities, control over the implementation of labor laws and social security, the establishment of minimum and maximum prices, and so on.

Considering the analysis of the dynamics and structural dominants of world trade in goods, scientists have established quantitative and qualitative indicators that have revealed a number of the most common trends affecting the foreign trade activity of the state. The quantitative ones include: the rapid growth of commodity exports of developing countries during the last twenty years (in 1990, their share of exports was $24.1 \%$, in $2000-31.9 \%$, and in $2015-44.8 \%$ ); diversification of the commodity nomenclature, which is due to the qualitative improvement of export goods due to the deepening of processing (raw materials - finished products), standardization and unification (finished industrial products - components), scientific and technological progress (low-high-tech goods), ecologization of demand and supply (traditional "green" goods) and is characterized by an increase in the share of world exports of the last groups of goods in the specified pairs; an increase in the number and a change in the geographical structure of regional trade agreements (over the past 20 years, their number has increased by almost 10 times, while $60 \%$ of signatories are in Asian, Latin American and African developing countries). To qualitative tendencies A.Ishchenko considers: actualization for the majority of countries of necessity of modernization of national export support systems; the change in the geo-economic format of export flows due to the dynamism of the changes of the countries-leaders in the world commodity markets (by 2002 - the USA, by 2008 - Germany, from 2009 - to date, 


\section{ECONOMIC STRATEGIES FOR THE DEVELOPMENT OF SOCIETY}

China holds a leading position, although even in 1990, it even 142 did not enter to Top 20 exporters); politicization and ecologization of marketing and marketing activities [340].

Thus, international experience can distinguish several spheres of influence. Firstly, for the sake of implementing social tasks and protecting small businesses as employment, regulatory measures are aimed at curbing the organic growth of networks and their consolidation through territorial zoning and operational constraints. Secondly, countries, seeking to ensure a level playing field, have often intervened in the pricing process to prevent predatory business competition in the industry, in particular through the establishment of a lower price limit. In this case, the negative international experience is piled far more than positive. Setting the lower price threshold leads to the fact that the networks reduce the opportunity to influence the purchase prices, which contributes to the transfer of business competition between them from the sphere of price competition to the non-price forms of competition. Thirdly, the state is trying to promote harmonization of relations in the supply chain as a direction of optimization of retail prices. Thus, international practice confirms the multivariate approach of regulatory policy to the regulation of trade activity.

The current state of export and import of goods and services

in the economy of Ukraine

Ukraine has free trade agreements with the European Free Trade Association (EFTA), Canada, the CIS countries, as well as with Montenegro, Macedonia, Georgia, and Turkmenistan. Since January 1, 2016, the free trade agreement with the EU has been fully operational, which has already been implemented by the European Union in the autonomous trade preferences regime since April 2014 in favor of goods from Ukraine and provides duty free access to the world's largest regional market [340].

If we consider the world map, Ukraine carried out foreign trade, according to the calculations of the State Statistics Service in 2018, with 223 countries. At the same time, goods were exported to 201 countries of the world, and imported from 206 (see Figure 1.). 


\section{ECONOMIC STRATEGIES FOR THE DEVELOPMENT OF SOCIETY}

Fig. 1. General picture of foreign trade operations in Ukraine in 2017 Source: compiled by the author according to the State Statistics Service

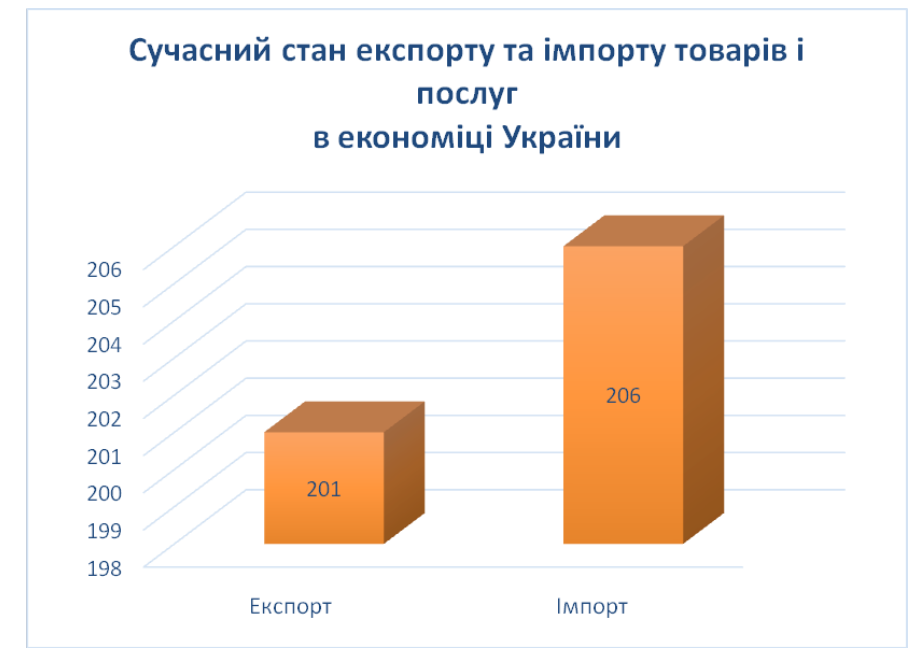

The overall picture of foreign trade in goods in Ukraine in 2017 amounted to 43.3 billion dollars (according to the State Statistics Service). Exports of such commodities as ferrous metals, electric, grain and mechanical machines, ash, ore, fats, cereals, vegetable and animal oils, oilseeds, clothing, textiles, products of inorganic chemistry to Poland, Italy, Germany, Russia, Turkey, India, as shown in Fig. 2.

Fig. 2. Chart of the percentage of exports of goods by country Source: compiled by the author according to the State Statistics Service

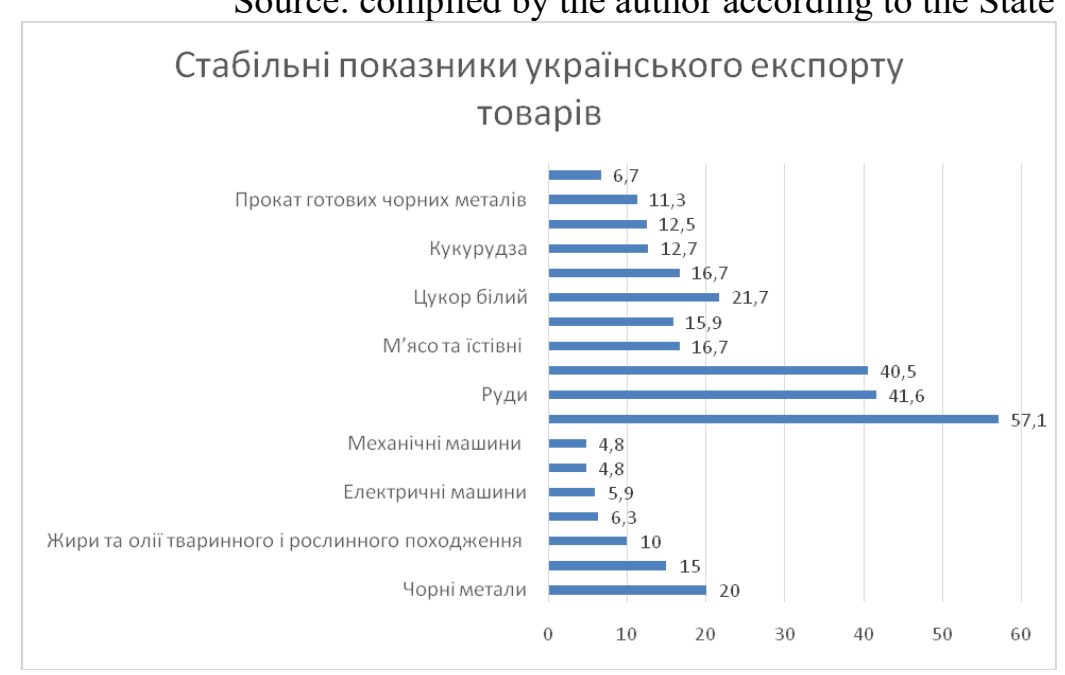




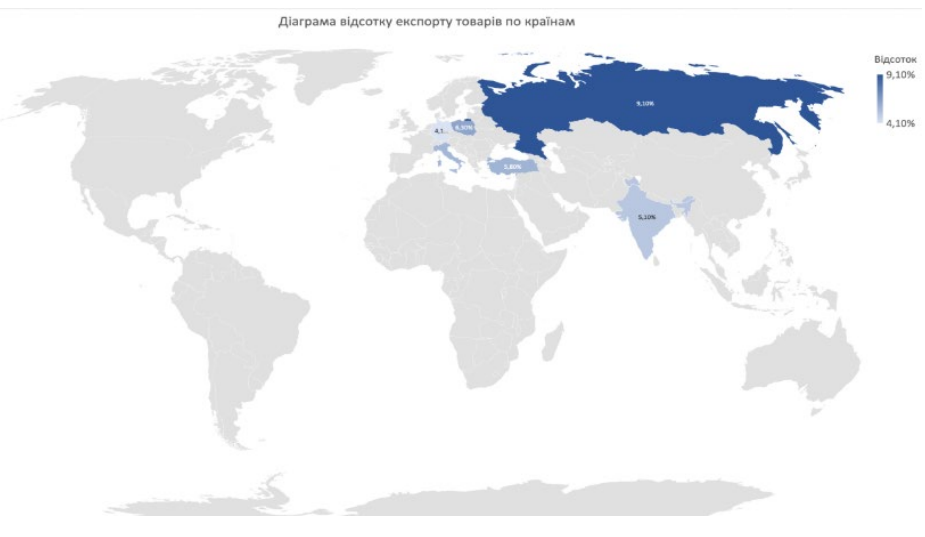

Fig. 3. Stable indicators of Ukrainian exports of goods Source: compiled by the author according to the State Statistics Service

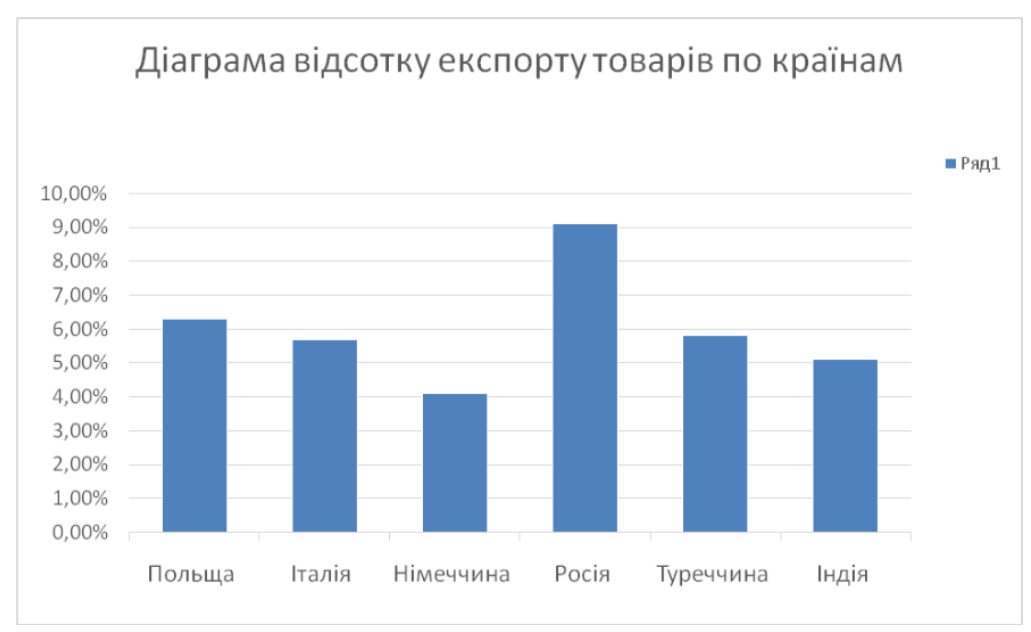

In recent years (2016-2018), the unchanged indicators of Ukrainian exports of goods were ferrous metals, cereals, fats and oils of animal and vegetable origin, ore, slag, ash, electric machines, extinguishing and oilseeds, mechanical machines, ferroalloys, ores, pipes from cast iron, and ferrous metals, meat and edible, sunflower oil, white sugar, timber, corn, cigarettes and tobacco, rental of finished ferrous metals, barley (Fig. 3).

Imports of goods to Ukraine in 2017 were carried out from Germany, Poland, Italy, Russia, China, Belarus. These were goods: mineral fuels and products of their distillation, land transport, plastics, polymer materials, pharmaceuticals, electric and mechanical machines, fertilizers (Fig. 4). 


\section{ECONOMIC STRATEGIES FOR THE DEVELOPMENT OF SOCIETY}

Fig. 4. Imports of goods to Ukraine in 2017 Source: compiled by the author according to the State Statistics Service

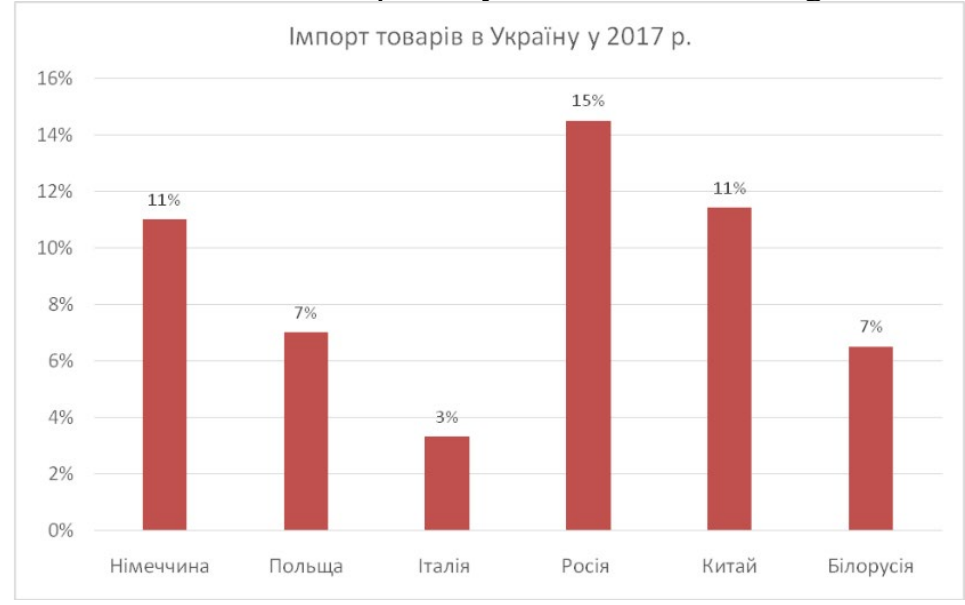

The analysis, conducted in 2018 by the State Statistics Service, says that more stable imports were recognized mineral fuels, oil and products of its processing, which is $26,3 \%$, and the least stable was pharmaceutical products $-3,6 \%$. Also, the import of mechanical machines was $11.7 \%$, electric vehicles $-8.3 \%$, land transport vehicles, except for railways $-8 \%$, plastics and polymer materials $-5 \%$. And such commodities as petroleum products, coal, ore and concentrates of manganese, fertilizers, coke, natural gas, cars, ferrous metal rolling, mineral or chemical fertilizers, agricultural machinery, oil, diesel fuel, televisions, grain harvesters, sunflower seeds, fish, medicines, on the contrary, the percentage in the structure of commodity imports was increased from $10 \%$ (medicines) to $87,3 \%$ (coal).

We found (based on the calculations of the Statistical Service) that the total foreign trade balance in 2017 was: exports - 107149369, 5 thousand dollars, imports 5476148, 9 thousand dollars. As a result, Austria, Belarus, the United Kingdom, Denmark, Estonia, Israel, Italy, Cyprus, Germany, Poland, Russia, the USA, Turkey, Hungary, and France were the countries with record-breaking goods exports. The geography of export / import in 2016-2017 was rather wide - 58 countries.

Considering the structure of export of services in 2017, the minimum percentage is $3,7 \%$ it is belong to professional and consulting services, $5,4 \%$ - rail services, $5,7 \%$ - marine, and pipeline services are the most exported $-28 \%$. However, $13.1 \%$ belongs to the processing of goods for the purpose of selling abroad, $12.2 \%$ - computer services, 10, 2\% - services of air transport. The most imported services were in 2017 


\section{ECONOMIC STRATEGIES FOR THE DEVELOPMENT OF SOCIETY}

government and government services; travel services; air transport services; services related to financial activities; services related to the use of intellectual property; professional and consulting services; rail services.

The partner countries of Ukraine for the export of services are OAU, Cyprus, Poland, Germany, the United Kingdom, Switzerland, the United States, Russia, which in percentage terms is $2.4 \%, 2.6 \%, 2.8 \%, 5 \%, 5,5 \%, 7.1 \%, 7.9 \%$ and $31,9 \%$, respectively. The partner countries of Ukraine on import services are Austria, the Netherlands, the OAU, Poland, China, Switzerland, Cyprus Turkey, Germany, Russia, the United Kingdom, USA. At the same time, the United States, the United Kingdom and Russia are leading this list of countries, while China, Austria, the OAU and the Netherlands have about $2 \%$ barrier to import of services.

The strategic task for Ukraine is the growth of its role in foreign markets. Let's look at the drawing, which presents the main partners of Ukraine, namely: Moldova, Iran, USA, Belarus, China, Egypt, India, Turkey, Russia (Fig. 5).

Fig. 5.Top of the largest trading partners of Ukraine Source: Created by the author according to (Ministry of Economic Development and Trade of Ukraine)

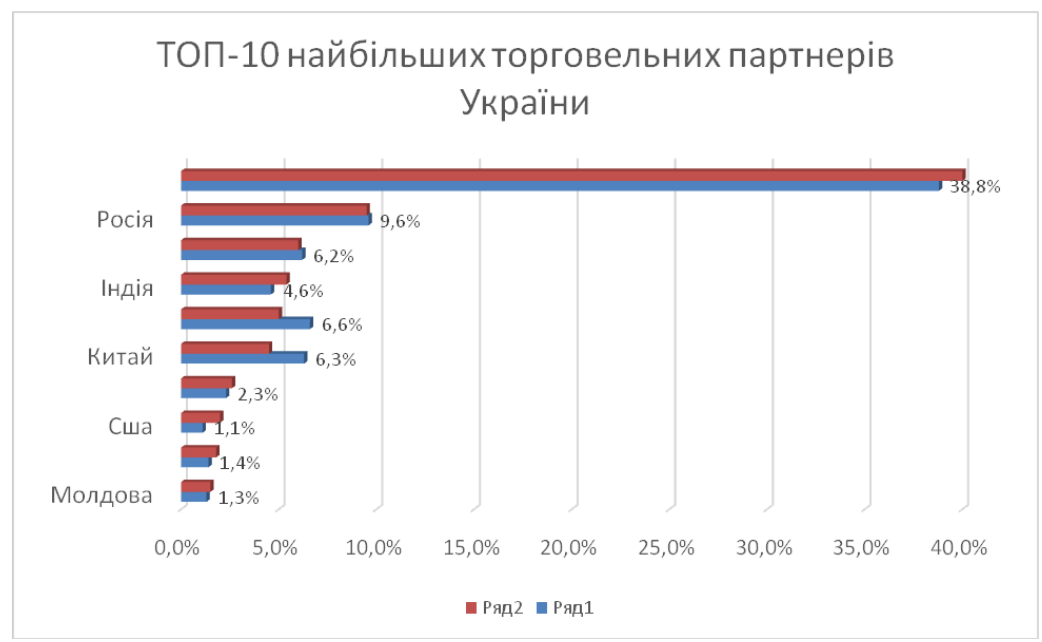

Modern economic development of Ukraine and its integration into the European space mainly depends on such factors as the use of advanced technologies, the availability of high-tech production, and the development of human capital.

The ratio of exports and imports is just one of many macroeconomic proportions that characterizes the state and development of the economy, changes in foreign 


\section{ECONOMIC STRATEGIES FOR THE DEVELOPMENT OF SOCIETY}

economic activity. According to the calculations of the Ministry of Economic Development and Trade on the base of the National Bank of Ukraine (NBU), over January-August 2017 the coefficient of exceeding the import of goods and services for the export of goods and services amounted to 1.12 (in January-August 2016-1.11). In 2016, the total exports of goods and services amounted to $49.3 \%$ of GDP or 46 billion USA dollars (according to the NBU), of which $72.9 \%$ is for the export of goods, the rest is the export of services (27.1\%) [341].

Consider the information (Fig. 6), which shows the total results of exports of goods in Ukraine as of 2017. Based on the results of 10 months of 2017, the export of goods in relation to 2016 increased by 6072, 3 million dollars. The total export growth is amounted to $84.6 \%$. Therefore, we can talk about the positive dynamics of export growth of goods. In Kiev $+4,2$ percentage points, Dnipropetrovsk $+3,6$, Donetsk + 2,4, Zaporizhzhya $+1,7$, Poltava and Odessa oblasts $+1,3$ percentage points, Lviv and Mykolaiv regions - plus 0,9 percentage points, in Vinnitsa and Zakarpattya - by 0.8 and 0.7 percentage points, respectively. Thus, all the regions, except Luhansk (- 0.6 percentage points), demonstrated a positive contribution to the development of the IT of Ukraine, which totals to 17.7 percentage points.

Fig. 6. Export of goods to Ukraine

Source: compiled by the author according to the State Statistics Service

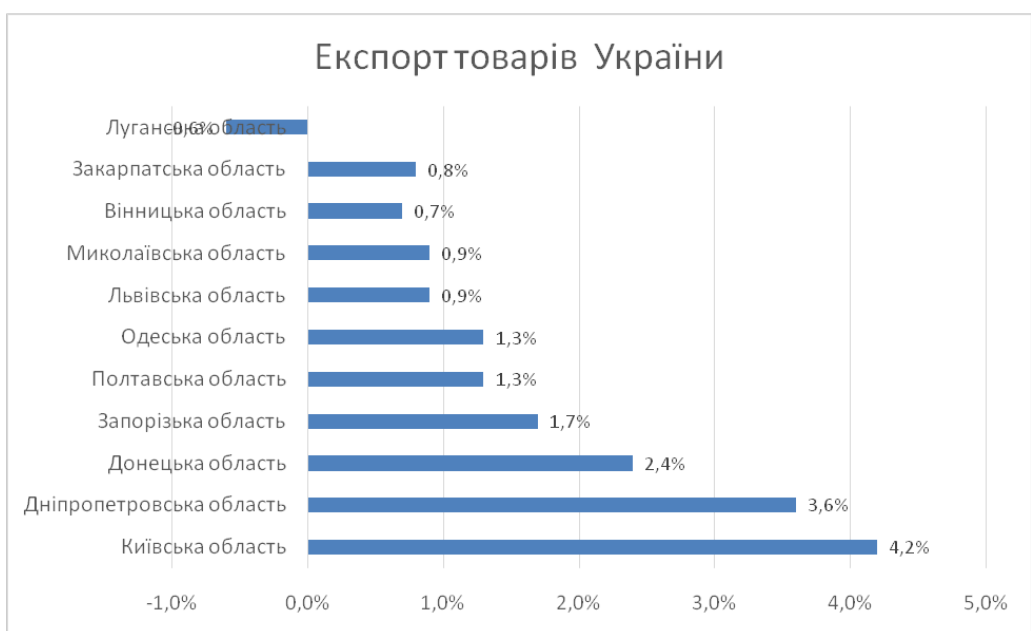

Exports of goods from Ukraine in January-February 2018 increased by 17.9\% (or \$ 1.1 billion) compared to the same period in 2017 and amounted to $\$ 7.4$ billion. Among the main trading partners of Ukraine in the export of goods in January-February 


\section{ECONOMIC STRATEGIES FOR THE DEVELOPMENT OF SOCIETY}

2018 there are the following countries: the EU $-45.1 \%$ of the total exports, Russia $7.3 \%$, Turkey $-6.6 \%$, India $-5.2 \%$, Egypt $-4.5 \%$, Belarus $-2.8 \%$ and others.

Traditionally, the main groups of goods of Ukrainian exports on the basis of the results were agricultural products and food industry $-37.6 \%$, metallurgy complex $26.8 \%$, machinery $-11.4 \%$, mineral products $-9 \%$, chemical industry $-5.1 \%$, wood and paper weight $-4.2 \%$, various industrial goods $-3.2 \%$, light industry products $2.7 \%$.

Export growth was recorded for all major product groups in comparison with the same period in 2017. Thus, exports of agricultural products and food industry grew by $3.4 \%$, metallurgical complex by $28.2 \%$, machinery $-27.9 \%$, mineral products $-15 \%$, chemical industry $-35.3 \%$, wood and paper mass $-49.6 \%$, various industrial goods $53.9 \%$, light industry products $-24.5 \%$ [343].

In general, the structure of Ukraine's exports is predominantly raw materials (see Figure 7.) - according to the State Statistics Service, almost 70\% of exports of goods (USD 25.3 billion) are: agricultural products, metallurgical and chemical industries, mineral products, timber, raw materials for light industry [341].

Fig. 7. Imports of goods to Ukraine as of 2017, measured in billion equivalent of US dollars Source: compiled by the author on the basis of indicators of the total volume of import and export of commodity items fixed by the State fiscal service

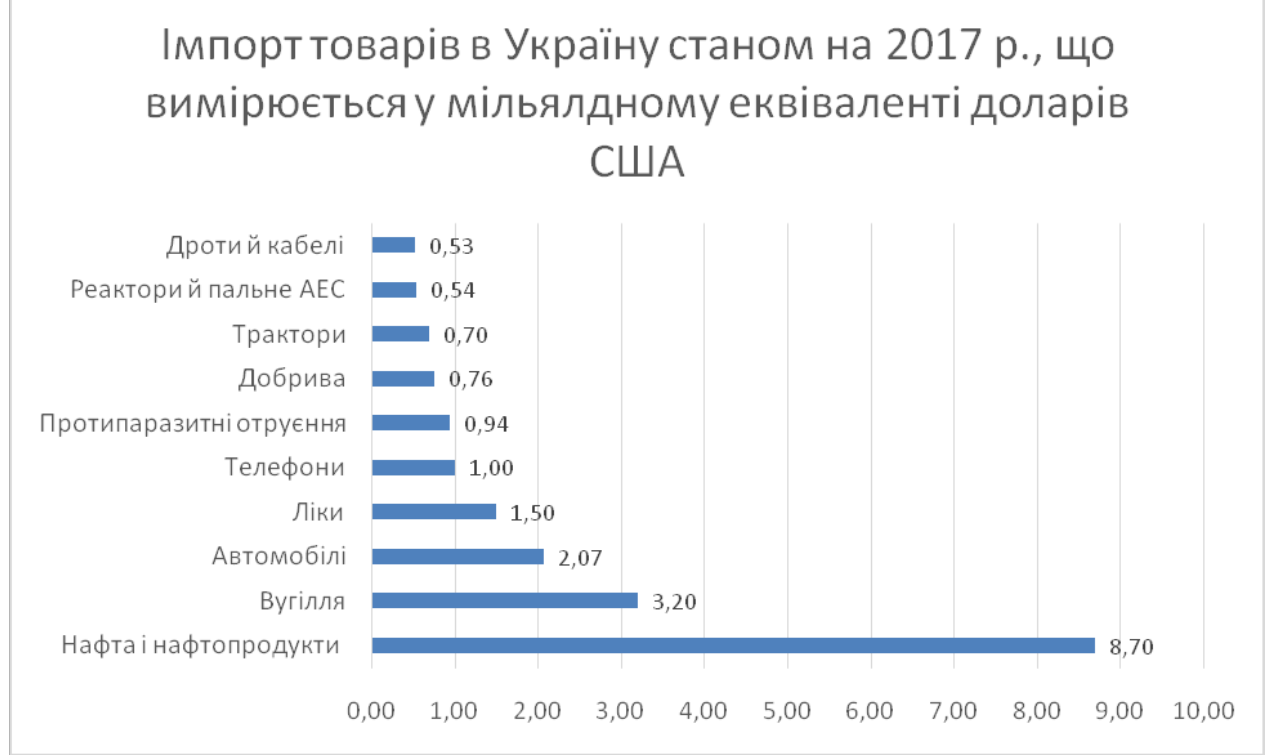

Thus, in 2017 Ukraine imported most of the oil products and coke (8.7 billion dollars), stone and anthracite coal (3.2 billion dollars), as well as motor vehicles intended primarily for transportation people and cars ( $\$ 2.07$ billion). In the billionth 


\section{ECONOMIC STRATEGIES FOR THE DEVELOPMENT OF SOCIETY}

equivalent of US dollars, imports of medicine (dosated or packaged) were also measured; phones and their variants; insecticides, fungicides, herbicides, disinfectants; fertilizers, which include $\mathrm{K}$ and $\mathrm{P}$; tractors; nuclear reactors and fuel cells for them; insulated wires, cables and other insulated electric conductors; fiber optic cables; machines for automatic processing of information and their blocks; magnetic or optical readers. In the millionth equivalent of US dollars it was measured the import of machines or mechanisms for harvesting, threshing of crops; lawn mowers and mowers; Machines for sorting eggs, fruits or other agricultural products; flat-rolled products of carbon steel of a width of $600 \mathrm{~mm}$ or more, clad, galvanized or other; motor vehicles for transportation of goods; ethylene polymers; parts and devices of vehicles; tires and rubber pneumatic tires; fertilizers, mineral or chemical, nitrogenous; electrical equipment for switching, protection, connection to electrical circuits for voltage not exceeding $1000 \mathrm{~V}$; machinery and equipment for agriculture, gardening or forestry for the preparation or cultivation of soil; roller skates for sports grounds; frozen fish; other plastic products (plates, sheets, films, tapes, plates).

Ukraine has the smallest import of tobacco raw materials; blood of humans, animals, serums, vaccines, toxins; manganese ores and concentrates; other plastic products; electric heating devices and apparatus, electric irons; television equipment, video monitors and video projectors; evices for usage in medicine, surgery, dentistry or veterinary medicine; aluminum ores and concentrates; refrigerators, freezers, heat pumps, as shown in Fig. 8.

Fig. 8. Imports of goods to Ukraine in 2017, measured in millionth equivalent of US dollars Source: compiled by the author on the basis of indicators of the total volume of import and export of commodity items fixed by the State fiscal service

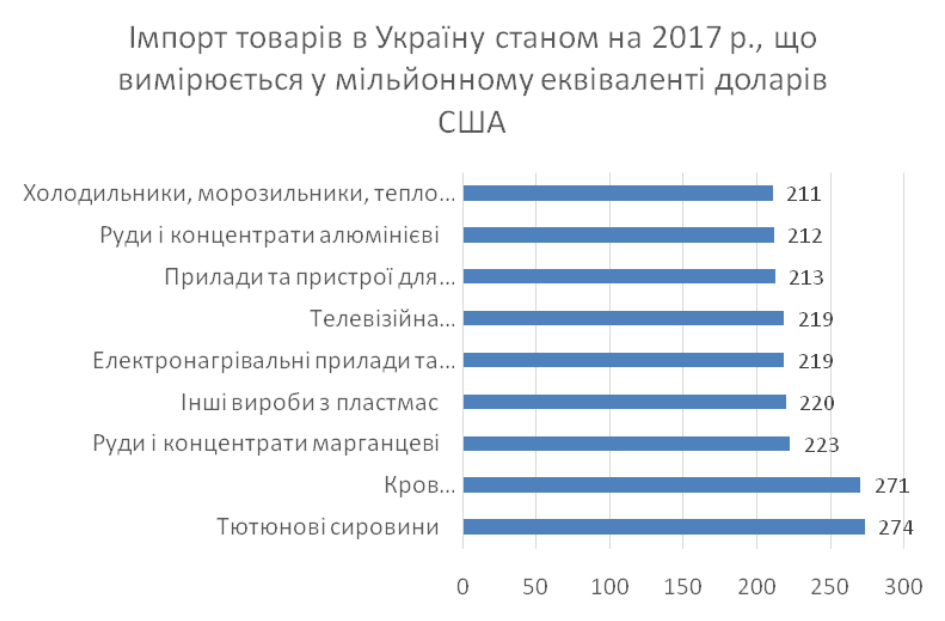




\section{ECONOMIC STRATEGIES FOR THE DEVELOPMENT OF SOCIETY}

Thus, today the EU (28) is Ukraine's largest trading partner. The EU share (28) in the total volume of Ukrainian exports was $40.0 \%$ versus $38.8 \%$ in January-July 2016. The share of CIS countries in exports of goods from Ukraine in January-July 2017 amounted to $16.2 \%$ (16.4\% in January-July 2016). As a result of the application of restrictive measures by the RF, there is a decrease in exports of Ukrainian goods from Ukraine to the CIS countries and countries of the Asia-Pacific region (in particular, exports to China in January-July this year decreased by $13.8 \%$ ).

Consequently, taking into account IT volumes, taking into account the geographical structure of Ukraine's trade in goods and services, one can say that the priority of state policy is the formation of export competitiveness and the provision of guarantees to it. Another important argument in favor of the current state of IT is the fact that Ukraine is under significant influence of the deployment or contraction of political relations with other countries, the development of their economies, and the growth of scientific and technological potential. That is, it is safe to assert that our country is confidently stepping in the international community of states.

Specifics of regulation of IT of Ukraine

The development of IT and exports is one of the urgent issues for reforming and developing the national economy of Ukraine.

With this purpose, the Ministry of Economic Development and Trade of Ukraine, with the participation of representatives of scientific and business circles, the expert environment, as well as heads of interested central executive authorities, developed the Export Strategy of Ukraine: Road Map of Strategic Trade Development for the period 2017-2021 (hereafter - ESU).

At present, work on the adoption of the draft CMU "On Approval of the Export Strategy of Ukraine: Road Map for Strategic Trade Development for 2017-2021" is ongoing.

The main task of the ESU is to increase the competitiveness of Ukrainian exports by removing obstacles and identifying specific opportunities with clear steps. 


\section{ECONOMIC STRATEGIES FOR THE DEVELOPMENT OF SOCIETY}

Restricting access to traditional export markets leads to the geographical diversification of Ukrainian exports, readiness to change the situation on international markets and the search for new, promising markets.

In order to identify such markets during the preparation of the ESU, the experience of the experts of the International Trade Center and the identified markets in which Ukrainian enterprises are not currently fully using the potential of foreign trade are used.

By conducting an additional analysis on the basis of a wide range of criteria, namely market size, actual and projected growth, the stability of the growth of imports, current market access conditions (preferential regimes, the existence of free trade agreements), territorial, cultural and historical proximity, the mutual compliance of the export-import structure, focused markets have been identified that are potentially attractive to most sectors of the Ukrainian economy and can serve as a benchmark for the further development of the export activity.

The main players on the IT market are called the three states - the United States, the EU and China. In fact, they also dictate foreign trade policy at the global level. And Ukraine, which has long been at the crossroads of trade routes from the Vikings to the Greeks, can not but feel this powerful influence.

On December 7, 2013, WTO members completed negotiations on the Trade Facilitation Agreement ("TFA"). On November 27, 2014, the General Council of the WTO formally adopted the Protocol on the Supplement of the Agreement Establishing the WTO with the Agreement on Trade Facilitation. The fact that Ukraine is one of the $2 / 3$ countries that ratified the TFA has significantly improved the image of Ukraine in the WTO. In addition, it is a positive signal for the international trade and investment community about the seriousness of Ukraine's intentions to improve its trade and investment climate (legislation). This is very important at the current stage of Ukraine's economic development [342].

The medium-term plan of the Government's priority actions for the period up to 2020 provides for the establishment of the Office for the Development of Innovations, whose purpose is to support and encourage the development of innovative enterprises 


\section{ECONOMIC STRATEGIES FOR THE DEVELOPMENT OF SOCIETY}

and start-ups by providing them with financing, necessary consulting services and technical assistance at all stages from the innovative idea to the final product.

In Ukraine, at the national level, the IT regulation system includes the following elements:

1) forms of foreign investment;

2) requirements for results of activity of a foreign partner;

3) transfer (repatriation) of the foreign investor's profit;

4) investment privileges and restrictions;

5) guarantees of compliance with the rights of a foreign partner.

Here's how Mr. V. Mashtabey analyzes this issue, he is extraordinary and plenipotentiary Ambassador of Ukraine, Assistant Professor at the Diplomatic Academy under the Ministry of Foreign Affairs: "Experts-pragmatists are convinced that, in the case of conclusion of trade agreements, the advantages of their use will arise at the expense of the newest means of regulation that go beyond the provisions predictable WTO agreements. First of all, it concerns the cross-border movement of personnel, the resolution of investment contradictions associated with state-owned enterprises, regulation of access to goods and services markets, e-commerce, competition in the supply chain, small and medium-sized businesses " [346].

1.The harmonization of standards at the international level contributes to reducing production and other costs. By identifying the problem of using standards as a brake on global trade, the United States and the EU are paying a lot of attention to the negotiation of a transatlantic partnership agreement, in particular with regard to electronic commerce. A similar approach is also being used by the United States in negotiations on a South Pacific partnership agreement. First of all, it is about reaching agreements on the introduction of a number of international standards that would contribute to the active development of "digital economy" and related e-commerce.

2. The legal framework for international e-commerce has been introduced by the UN Convention on the Use of Electronic Communications in International Contracts since 2005. At the same time, plurilateral agreements on information technology and basic telecommunication services ("Information Technology Agreement", "Basic 


\section{ECONOMIC STRATEGIES FOR THE DEVELOPMENT OF SOCIETY}

Telecommunication Services" Agreement) are used. According to the EU, e-commerce has significant potential, not only to restructure existing markets, but also to create new, built on the principles of free circulation of ideas within the global economy.

3. The transatlantic trade and investment partnership between the USA and the EU (TTIP) is declared to be the most ambitious in the history of cooperation between the parties. It is about the representation of $45 \%$ of world production, USD 5 trillion in total trade per year and 15 million jobs, as well as the further resolution of non-tariff barriers and related regulation, and it is expected that the implementation of appropriate measures will ensure by $17 \%$ increase in exports from both the USA and the EU. It is estimated that removing $25 \%$ of the differences in the system the topics of regulation and standardization, non-tariff barriers can increase the total GDP of the parties by 106 billion US dollars.

Therefore, instruments for regulating world trade should be called harmonization of standards, introduction of international e-commerce, observance of transatlantic agreements.

Implementation of the world experience in regulating IT of Ukraine

Taking into account the macroeconomic indicators presented by the State Statistics Service of Ukraine, at the beginning of February 2019, the change in real GDP as a percentage of the previous years (2015-2018) increased by $1.1 \%$; the consumer price index and producer index (2018-2019) is 101,1\%; the export of goods (2017-2018) decreased by 14.5\%, import of goods also decreased by $9.6 \%$, cargo turnover fell by $23.1 \%$; passenger turnover dropped by $7.9 \%$; output of industrial products declined by $1.6 \%$; output of construction products by $6.9 \%$; the share of direct investments (equity) in comparison with 2016-2017 has decreased significantly - by $2.7 \%$, and the expenses of the population increased by $2.1 \%$.

After analyzing «Notification of category a commitments under the agreement on trade facilitation. Communication from Ukraine» (14 August 2014 та 22 May 2018) within the limits of the Agreements on Trade Facilitation, the Ministry of Economic Development and Trade of Ukraine, the implementation of the provisions of the TFA was proposed: 


\section{ECONOMIC STRATEGIES FOR THE DEVELOPMENT OF SOCIETY}

1) procedures for import, export and transit (including procedures applied at the port, airport and other border crossing points) and necessary forms and documents;

2) current rates of duties and taxes;

3) fees and payments, rules for the classification or determination of the value of goods for customs purposes;

4) laws, regulations and administrative rules of general application concerning the rules of origin;

5) restriction or prohibition of import, export or transit;

6) penalties for violation of import, export or transit procedures;

7) agreements or parts thereof with any country or countries that are related to import, export or transit; procedures relating to the administration of tariff quotas.

In order to simplify and expedite the customs control and customs clearance procedures, the Customs Code (Article 23) and the WTO Agreement on Trade Facilitation (Article 3) [344].

Each state itself defines the methods and means of implementation. Foreign experience shows that there are no universal models for regulation of the network structures of the wholesale and retail trade, as this depends on the needs of a particular country. For example, France, the United States and Poland paid attention to the active development of large-format trade, while Japan, by contrast, seeks to limit the opportunities for the development of large formats, supporting the development of small shops [345].

As noted by V. Mashtabey in his report "Made in the World, or Evolution of World Trade", during the years of independence, Ukraine has done a lot to intensify its involvement in world markets. The cumulative result of this work was the acquisition of membership in the WTO and the conclusion of an agreement with the European Union (EU) on free trade. "However, the practical consequences of the accomplished do not cause enthusiasm in power cabinets and companies engaged in export-import operations. Corresponding criticism can be further reduced to the absence of system reforms in the country, which itself is true. But there are other reasons for the 


\section{ECONOMIC STRATEGIES FOR THE DEVELOPMENT OF SOCIETY}

unsatisfactory work of the foreign trade complex of Ukraine, due to the lack of consideration of those objective changes that have occurred in world trade in the last few decades " [346].

The country also conducts monthly monitoring of the promotion of trade in Ukraine, the product of the project "Facilitation of trade development through the promotion of dialogue between representatives of civil society and state authorities (Trade Dialogue)", which aims to disseminate the most up-to-date information on trade facilitation procedures.

The priority task at the present stage for Ukraine is to develop an effective system for promoting national interests in the global market. At present, in the world practice, IT is associated with the implementation of trade operations with foreign partners based on economic, legal, organizational and informational principles, as well as with global finances, international innovation management and international politics, and it is an integral part of the international economy.

The IT regulation system is a multilevel phenomenon, which depends on the aggregate trade policy implications among trading partners. All of the listed levels of the IT regulations are complementary and interdependent. However, a significant influence on the IT is caused by a national level in which, among all subjects of international economic relations, the state has a priority.

Nowdays in the world practice the international trade relations are regulated by a complex system of methods and tools, which allows countries to choose the best way to implement the policy of protectionism of foreign trade relations.

The key role among the markets due to the IT focus is on the EU countries, whose exports are currently increasing, while others are markets in which Ukrainian producers have significant potential for exporting products. Top 20 were identified: Turkey, China, India, Egypt, Saudi Arabia, Canada, the OAU, the USA, Israel, Belarus, Georgia, Moldova, Japan, Indonesia, Thailand, Bangladesh, Lebanon, Philippines, Nigeria and Switzerland. The key role in the markets is focused on the EU countries, whose exports are currently increasing, while others are markets in which Ukrainian producers have significant potential for exporting products. There were identified the 


\section{ECONOMIC STRATEGIES FOR THE DEVELOPMENT OF SOCIETY}

top 20 markets, which, if they choose the right forms and tools to work with them, are able to show fairly fast results. Among them, except the EU countries: Turkey, China, India, Egypt, Saudi Arabia, Canada, the OAU, the USA, Israel, Belarus, Georgia, Moldova, Japan, Indonesia, Thailand, Bangladesh, Lebanon, Philippines, Nigeria and Switzerland. For further work with selected markets, an expanded analysis will be carried out, opportunities and forms of optimal presence of Ukraine in these markets are identified, as well as strategic programs for entering these markets.

International experience allows us to distinguish several spheres of influence. Firstly, for the sake of implementing social tasks and protecting small businesses as employment, regulatory measures are aimed at curbing the organic growth of networks and their consolidation through territorial zoning and operational constraints. Secondly, countries, seeking to ensure a level playing field, have often intervened in the pricing process to prevent predatory competition in the industry, in particular through the establishment of a lower price limit. In this case, the negative international experience piled far more than positive. Setting the lower price threshold leads to the fact that the networks reduce the opportunity to influence the purchase prices, which contributes to the transfer of competition between them from the sphere of price competition to the non-price forms of competition. Thirdly, the state is trying to promote harmonization of relations in the supply chain as a direction of optimization of retail prices. Thus, international practice confirms the multivariate approach of regulatory policy to the regulation of trade activity.

Taking into account the indicators of IT volumes and taking into account the geographical structure of Ukraine's trade in goods and services, it can be said that the priority of state policy is to form the export competitiveness and provide guarantees to it. Another important argument in favor of the current state of IT is the fact that Ukraine is under significant influence of the deployment or contraction of political relations with other countries, the development of their economies, and the growth of scientific and technological potential. That is, it is safe to assert that our country is confidently stepping in the international community of states. 


\section{ECONOMIC STRATEGIES FOR THE DEVELOPMENT OF SOCIETY}

Instruments for regulating world trade should be called harmonization of standards, introduction of international e-commerce, observance of transatlantic agreements.

Each state itself defines the methods and means of implementation. Foreign experience shows that there are no universal models for regulation of the network structures of the wholesale and retail trade, as this depends on the needs of a particular country.

The study also examines the factors that influence the economic development of Ukraine. These include the use of new technologies, capital development, and hightech manufacturing.

With the aim of the gradual transition to a more innovative economy, it is necessary to encourage the attraction of foreign direct investment for the development of innovation through the transfer of technologies and their import. In Ukraine, it is necessary to introduce measures to reach the modern level of production and technological base and to introduce mechanisms for encouraging innovation.

Consequently, the current state of development of IT requires Ukraine to focus its efforts simultaneously in several directions:

1) an increase in exports to the EU market,

2) capturing of the large markets with high growth rates (Asia, Africa),

3) renewal of its positions in traditional markets (CIS).

There is a need to study and apply the best practices that are observed in many developed countries in terms of cooperation between universities and the business sector, the development of joint training programs, internship programs for young entrepreneurs, as well as various types of public-private partnerships in the field of innovation. 


\section{ECONOMIC STRATEGIES FOR THE DEVELOPMENT OF SOCIETY}

\section{3 Формування міжнародної підприємства

Складність і нестабільність середовища, у якому функціонують вітчизняні підприємства, загрози та виклики, пов'язані зі складною геополітичною ситуацією, мінливість кон'юнктури світового господарства змушують підприємців шукати нові сфери та перспективні напрями розвитку своєї діяльності не лише на національному, але й міжнародних ринках. Останні тенденції розвитку міжнародної економіки значно актуалізували дослідження, орієнтовані на подолання кризових явищ, пов'язаних як 3 макроекономічними диспропорціями, так і з численними проблемами функціонування окремих суб'єктів господарювання. Для запобігання зазначеним негативним явищам перед підприємствами України виникає необхідність застосування більш дієвого інструментарію в управлінні бізнесом, що посилюється в умовах міжнародної диверсифікації. Із метою посилення власних конкурентних позицій - як всередині країни, так і на міжнародних ринках - підприємства застосовують програми ресурсозбереження та мобілізації резервів підвищення якості продукції, зростання сприйнятливості до інновацій та випереджаюча адаптація до технологічних змін, залучення інвестицій в технологічне оновлення та оптимізація структури використаних у виробництві ресурсів. Агрегація означених напрямків дозволяє говорити про необхідність розвитку потенціалу підприємств на основі формування міжнародної конкурентоспроможної стратегії в управлінні розвитком підприємства.

Аналіз опублікованих праць за темою дослідження засвідчив, що здебільшого вони присвячені управлінню діяльністю підприємств на внутрішньому ринку, проте недостатньо дослідженими залишаються питання формування та запровадження механізму управління підприємствами в умовах міжнародної диверсифікації. Процес розвитку конкурентоспроможності підприємства має орієнтуватися на стратегічне підгрунтя, що дозволяє говорити про доречність утворення міжнародної стратегії такого розвитку та про іiі включення як складовий елемент чи зовнішню настанову до означеного 


\section{ECONOMIC STRATEGIES FOR THE DEVELOPMENT OF SOCIETY}

механізму управління конкурентоспроможністю підприємства. Нажаль у реалізації даного твердження виникає ряд проблем теоретичного та емпіричного характеру. Проблеми теоретичного характеру містяться в розрізі досить великої кількості тлумачень категорії «стратегія». Хоча всі вони сходяться на тому, що стратегія відображає вимоги до руху підприємства як соціально-економічної системи в часі, тому саме ресурсний підхід до міжнародного стратегічного управління, особливо при прийнятті динамічної концепції Д. Тіса [347] вимагає зв'язування стратегічних настанов підприємства 3 плином його бізнес-процесів. Показовою тут є робота яка обгрунтовує доречність формування площини "процес (моделі реалізації цілей) - контекст (динамічні спроможності) - контент (цілі на які витрачаються ресурси)" й тим самим забезпечує розгляд бізнеспроцесів підприємства у аспекті надання ними додаткових конкурентних переваг.

Метою наукового дослідження $є$ обгрунтування концептуальних засад формування механізму управління підприємствами в умовах міжнародної диверсифікації бізнесу та науково-практичних рекомендацій щодо імплементації стратегічного управління розвитком конкурентоспроможності підприємства, визначення контурів міжнародної стратегічної спрямованості розвитку конкурентоспроможності підприємства, що носить суб'єктивний характер і вирішальною мірою залежить від природи взаємовідносин між елементами конкурентоспроможності підприємства та відповідним суб'єктом міжнародного управління.

Наукова новизна полягає в розробці механізму управління підприємствами в умовах міжнародної диверсифікації бізнесу як сукупності субмеханізмів, спрямованих на рівень мотивації робітників. Відповідний мотиваційний механізм, формується через визначення так званих мотиваційних комплексів. Пропонована структура мотиваційного механізму базується на доведеній у роботі важливості використання соціальної складової й соціокультурних параметрів середовища підприємницької діяльності. Оскільки ж функціонування такого механізму базується на виконанні функцій планування, організації, 


\section{ECONOMIC STRATEGIES FOR THE DEVELOPMENT OF SOCIETY}

мотивації, контролю тощо, то й особливістю їх взаємодії може бути більша спрямованість на функцію мотивації.

Також встановлено, що результат розвитку рівня конкурентоспроможності впливає на результати господарської діяльності підприємства. Відповідно доведено необхідність включення до формованого механізму динамічних моделей узгодження параметрів конкурентоспроможності 3 параметрами життєдіяльності підприємства.

Визначення форм і способів досягнення обраних міжнародних стратегічних цілей здійснюється шляхом розробки та реалізації комплексу стратегій підприємства.

Серед безлічі існуючих теоретичних поглядів на визначення сутності та змісту поняття «стратегії» можна виділити два основні методологічні підходи процесний та формальний. 3 точки зору процесного підходу, стратегія $\epsilon$ послідовністю формування стратегічних планів і програм, а також генерації відповідних управлінських рішень, які є необхідними для практичної реалізації означених планових документів. За процесним підходом, до складу стратегії обов'язково буде входити функція цілепокладання. Формальний підхід, навпаки, базується на уявленні про стратегію як плановий документ, що визначає пріоритетні напрямки, форми та методи досягнення стратегічних цілей суб'єкта підприємницької діяльності та має певний ступінь формалізації. Таким чином, 3 точки зору формального підходу стратегія відносно встановлення стратегічних цілей носить підпорядкований характер, в той час, як процесний підхід поєднує ці поняття в межах однієї послідовності.

Процесний підхід загалом базується на ствердженні А. Чендлера [348] про те, що стратегія - це визначення головних довгострокових цілей і задач підприємства, прийняття курсу дій та розподіл ресурсів, необхідних для виконання поставлених цілей.

Е. Кемпбел [349] наполягає на доцільності саме процесного підходу до визначення сутності стратегії, оскільки стратегія не є стабільним явищем («раз і назавжди заданим»), а знаходиться в процесі постійних змін відповідно 


\section{ECONOMIC STRATEGIES FOR THE DEVELOPMENT OF SOCIETY}

трансформації середовища господарювання. Такі перетворення обумовлюють нагальну потребу у постійному перегляді стратегічних цілей, які в такому випадку ніяк не можуть виводитися за межі стратегії. Крім того, Е. Кемпбел, вважає, що процесного характеру стратегії також надає чітко виражена послідовність їі розробки та здійснення, яка складається 3 трьох етапів: стратегічний аналіз, стратегічний вибір, реалізація стратегії та менеджмент.

M.I. Бухалков [350] зазначає, що формування стратегії розвитку підприємства як планового документу відбувається в результаті вивчення зовнішнього оточення та можливих перспектив його діяльності з урахуванням впливу непередбачуваних ринкових факторів. 3 точки зору автора, наявність різних підходів до визначення сутності поняття «стратегія підприємства» обумовлена складністю зв'язків та співвідносин між стратегією та стратегічними цілями.

Так, В.М. Самочкін [351] зазначає, що для генерації стратегічних рішень можуть використовуватися як стратегії, так і орієнтири (стратегічні цілі), що неминуче буде приводити до змішування цих понять. Проте, з його точки зору, орієнтир являє собою мету, яку прагне досягнути суб'єкт підприємницької діяльності, а стратегія є лише засобом для досягнення цієї мети. Тому орієнтири слід вважати більш високим рівнем прийняття стратегічних рішень, оскільки стратегія, яку сформовано при одному наборі орієнтирів, не буде такою, якщо орієнтири суб'єкта підприємницької діяльності зміняться. Додаткові труднощі при розмежуванні стратегічних цілей та стратегій їх досягнення виникають також через наявність строгої ієрархії стратегічного планування. В такій ієрархії деякі параметри на одному рівні будуть служити орієнтирами, проте на іншому - стануть носити родові ознаки стратегії. Крім того, в типовій ієрархії елементи певного рівня будуть для вищих рівнів управління стратегіями, а для нижчих стратегічними цілями (орієнтирами).

Наявність складної ієрархії «стратегічні цілі - стратегічні рішення міжнародні стратегії» також суттєво утруднює визначення ієрархічної структури системи планів підприємства. В економічній літературі існує безліч поглядів на 


\section{ECONOMIC STRATEGIES FOR THE DEVELOPMENT OF SOCIETY}

природу, кількість, сутність та зміст, взаємозв'язок та взаємозалежність між стратегіями підприємства. Та досить часто при вивченні системи міжнародного стратегічного планування дослідники загалом не звертають належної уваги на структуру та взаємну залежність усіх стратегій підприємства. Така точка зору, здається, грунтується на припущенні про підлеглий характер міжнародних стратегій відносно до стратегічних цілей підприємства, тобто велика кількість та різноманіття можливих пріоритетів та цільових настанов мають призводити до необхідності суто ситуаційного формування стратегічного портфелю підприємства (цілісного набору міжнародних стратегій, що пропонуються до реалізації). Великою мірою зазначене твердження базується також на чималій кількості та різноманітті самих стратегій та навіть ознак їх класифікації.

Проте відсутність відповідної логіки та системного підходу при формуванні системи міжнародних стратегій загалом суперечить самій сутності та принципам планування. Слушною при цьому стає думка Ю.О. Загривої [352], щодо введення двох основних ієрархічних блоків стратегії: нормативного (верхній рівень стратегіï) та варіативного (нижній рівень стратегіï). 3 оглядом на наведене теоретичне узагальнення принциповими стають наступні моменти. Стратегія розвитку конкурентоспроможності підприємства відноситься до варіативного рівня стратегій, оскільки вона підпорядковується вимозі трансформування зон компетентності підприємства (дана вимога задається та формалізується в рамках декількох ознак стратегій нормативного рівня, розробка яких є обов’язковою для будь-якого суб’єкта господарювання). Більш того, стратегія такого розвитку являє собою не визначену у часі послідовність дій, а узагальнене представлення підходів та принципів, на основі яких досягається відповідність елементів конкурентоспроможності зонам компетентності підприємства.

Означене співвіднесення нормативних та варіативних міжнародних стратегій по іншому представляє й співвіднесення розуміння понять «розвиток підприємства» та «розвиток рівня конкурентоспроможності підприємства». Розвиток рівня конкурентоспроможності підприємства може розглядатися у двох аспектах: 


\section{ECONOMIC STRATEGIES FOR THE DEVELOPMENT OF SOCIETY}

- як адаптування конкурентоспроможності підприємства до умов переходу у нову зону компетентності (екстенсивна або реактивна складова розвитку; по відношенню до бізнес-процесів може розумітися як «тягнуча» система, коли бізнес-процеси та їх забезпечення адаптуються до нових вимог конкурентного ринку);

- як створення умови для переходу у нову зону компетентності (інтенсивна або випереджальна стратегія; по відношенню до процесів розуміється як «штовхаюча» система).

Розкриваючи властивість інноваційності розвитку рівня конкурентоспроможності підприємства також необхідно зробити декілька теоретичних пояснень. Серед існуючих концепції виникнення та комерціалізації інновацій найбільш дієвою є ринкова (конкурентна) концепція. Вона базується на пріоритетності ролі інновацій у забезпеченні реалізації ринкових можливостей підприємства та у досягненні конкурентних переваг. С.М. Ілляшенко [353] зазначає, що інновація являє собою кінцевий результат діяльності по створенню i використанню нововведень, втілених у виді удосконалених чи нових товарів (виробів чи послуг), технологій їх виробництва, методів управління на всіх стадіях виробництва і збуту товарів, що сприяють розвитку і підвищенню ефективності функціонування підприємства, які їх використовують. Головною метою впровадження інновацій, за думкою С.М. Ілляшенка [353], є реалізація певних ринкових можливостей, тобто напрямків діяльності суб’ єкта підприємницької діяльності, що відкриваються залежно від зовнішніх умов та специфіки його господарської діяльності. Н.В. Поповенко, Е.А. Забарна [354] також наполягають, що інновація - це сукупність технічних, виробничих і комерційних заходів, що в результаті призводять до появи на ринку нових і поліпшених промислових процесів й устаткування. 3 точки зору О. Зайцевої [355], навіть природа сучасної конкурентної боротьби передбачає насам-перед змагання за спроможність до втілення нововведень (на відміну від прагнення оволодіти матеріальними цінностями та ресурсами, яке було притаманне доіндустріальним та первинним індустріальним стадіям розвитку 


\section{ECONOMIC STRATEGIES FOR THE DEVELOPMENT OF SOCIETY}

виробництва).

За думкою автора, в умовах сучасних міжнародних ринкових відносин вплив конкурентних факторів на інноваційні процеси безумовно поширюється та буде неухильно поширюватися надалі. Проте слід зазначити, що ринкова концепція переважною мірою відбиває бажані результати інноваційної діяльності міжнародної діяльності, досягнення яких обмежується технікотехнологічними можливостями. Крім того, прийняття рішення щодо вибору інновацій для реалізації ринкових можливостей майже неможливо відділити від носія цих інтересів (новатора, який не $є$ фахівцем-науковцем) та його суб'єктивних уявлень щодо корисності нововведень.

Таким чином, процес формування та реалізації міжнародної стратегії розвитку рівня конкурентоспроможності підприємства можна подати в розрізі системи типових стратегічних рішень щодо параметрів трансформації його елементів в напрямку забезпечення більш дієвої реалізації потенціалу наявних у підприємства зон компетентності.

Котлер Ф. виділяє основні аспекти зовнішнього середовища міжнародного бізнесу [347]:

- розвиток засобів зв’язку, транспорту, туризму призводить до того, що споживачі країн тріади (країни Свропи, Північної Америки, Японії) являють собою досить однорідний ринок. Така рівномірність у споживчій поведінці сприятлива для розвитку «глобальних» товарів;

- результати темпів технічного прогресу доцільно впроваджувати відразу ж на всі ринки тріади. Затримка з виходом хоча б на один із трьох ринків може призвести до втрати можливостей виходу на новий ринок в перспективі;

- витрати на розробку окремих видів продукції можуть бути такі високі, що їх відшкодування можливе тільки під час виходу підприємств на декілька міжнародних ринків;

- більша частина виробництва та споживання багатьох товарів (70-80 \%) здійснюється на території країн тріади [356]. 


\section{ECONOMIC STRATEGIES FOR THE DEVELOPMENT OF SOCIETY}

Розвиваючи наукову думку Ф. Котлера, можна стверджувати, що успіх міжнародної діяльності залежить від факторів, що впливають на формування зовнішнього середовища, наведено на рисунку 1.

Політичні (прозорість кордонів)
Міжнародно-правові (великі міжнародні угоди)

Рисунок 1. Фактори, що впливають на формування зовнішнього середовища міжнародної діяльності підприємства

Наразі, результатом застосування реалізації міжнародної стратегії в сучасних умовах економічної діяльності є формування зовнішнього середовища міжнародного бізнесу, що супроводжується проведенням інноваційних заходів вітчизняними підприємствами на зарубіжних ринках 3 врахуванням сформованих національних традицій, законодавчих обмежень, культурних відмінностей.

Принциповим тут є те, що кожен елемент профілю відповідає означеному на рисунку 1 переліку типових міжнародних стратегічних рішень. Відповідне представлення профілю міжнародної стратегії розвитку рівня конкурентоспроможності підприємства подано у таблиці 1. 


\section{ECONOMIC STRATEGIES FOR THE DEVELOPMENT OF SOCIETY}

Таблиця 1

Профіль міжнародної стратегії розвитку підприємства

\begin{tabular}{|c|c|c|c|c|}
\hline $\begin{array}{l}\text { Елемент профілю } \\
\text { міжнародної }\end{array}$ & \multicolumn{4}{|c|}{ Варіанти розкриття міжнародних стратегічних рішень підприємства } \\
\hline $\begin{array}{c}\text { Фінансування } \\
\text { нововведень }\end{array}$ & $\begin{array}{c}\text { Залучення } \\
\text { міжнародних } \\
\text { аналогів на } \\
\text { рівні } \\
\text { підтримуючих } \\
\text { компетенцій } \\
\end{array}$ & $\begin{array}{c}\text { Залучення } \\
\text { міжнародних } \\
\text { коштів для } \\
\text { більш } \\
\text { радикальних } \\
\text { інновацій } \\
\end{array}$ & $\begin{array}{c}\text { Не радикальна } \\
\text { модернізація } \\
\text { поточного } \\
\text { технічного } \\
\text { забезпечення }\end{array}$ & $\begin{array}{c}\text { Орієнтація на } \\
\text { нововведення } \\
\text { власного } \\
\text { розроблення }\end{array}$ \\
\hline $\begin{array}{c}\text { Визначення рівня } \\
\text { екологічності та } \\
\text { фондозабезпеченост } \\
\text { i }\end{array}$ & $\begin{array}{c}\text { Кардинальні } \\
\text { зміни у } \\
\text { напрямку } \\
\text { нарощення } \\
\text { обсягів } \\
\text { виробництва }\end{array}$ & $\begin{array}{c}\text { Трансформація } \\
\text { параметрів } \\
\text { обладнання й } \\
\text { технологій }\end{array}$ & $\begin{array}{c}\text { Не радикальна } \\
\text { модернізація } \\
\text { поточного } \\
\text { технічного } \\
\text { забезпечення }\end{array}$ & $\begin{array}{c}\text { Підтримка } \\
\text { поточного } \\
\text { рівня } \\
\text { екологічності } \\
\text { й рівня фондів }\end{array}$ \\
\hline $\begin{array}{c}\text { Розвиток } \\
\text { традиційних чи } \\
\text { інноваційних } \\
\text { технологій }\end{array}$ & $\begin{array}{c}\text { Робота в } \\
\text { напрямку } \\
\text { переходу до } \\
\text { будь-якого } \\
\text { іншого сегменту }\end{array}$ & $\begin{array}{c}\text { Розвиток } \\
\text { традиційних } \\
\text { технологій для } \\
\text { розширення } \\
\text { потенціалу }\end{array}$ & $\begin{array}{c}\text { Продовження } \\
\text { роботи з } \\
\text { впровадження } \\
\text { підтримуючих } \\
\text { новацій }\end{array}$ & $\begin{array}{c}\text { Переважне } \\
\text { орієнтування } \\
\text { на поширення } \\
\text { інновацій }\end{array}$ \\
\hline $\begin{array}{c}\text { Регламентування } \\
\text { режимних } \\
\text { характеристик } \\
\text { бізнес-процесів }\end{array}$ & $\begin{array}{c}\text { Кардинальні } \\
\text { трансформації } \\
\text { параметрів } \\
\text { життєдіяльності }\end{array}$ & $\begin{array}{l}\text { Реінжинірінг та } \\
\text { аутсорсинг } \\
\text { бізнес-процесів }\end{array}$ & $\begin{array}{c}\text { Робота з } \\
\text { нарощення } \\
\text { адаптаційних } \\
\text { спроможносте } \\
\text { й }\end{array}$ & $\begin{array}{c}\text { Підтримка } \\
\text { поточного } \\
\text { режиму життє- } \\
\text { діяльності }\end{array}$ \\
\hline $\begin{array}{c}\text { Організація } \\
\text { відтворення } \\
\text { конкурентних } \\
\text { переваг } \\
\end{array}$ & $\begin{array}{c}\text { Орієнтування на } \\
\text { переважне } \\
\text { кількісне } \\
\text { зростання } \\
\end{array}$ & $\begin{array}{c}\text { Нарощення } \\
\text { потенціалу для } \\
\text { проведення змін }\end{array}$ & $\begin{array}{c}\text { Нарощення } \\
\text { ступеню } \\
\text { сприйнятливос } \\
\text { ті інновацій } \\
\end{array}$ & $\begin{array}{c}\text { Відтворення } \\
\text { через власні } \\
\text { інноваційні } \\
\text { розробки } \\
\end{array}$ \\
\hline $\begin{array}{c}\text { Залучення } \\
\text { необхідних ресурсів }\end{array}$ & $\begin{array}{c}\text { Орієнтування на } \\
\text { переважне } \\
\text { кількісне } \\
\text { зростання }\end{array}$ & $\begin{array}{c}\text { Орієнтування на } \\
\text { транс-формацію } \\
\text { параметрів } \\
\text { технології }\end{array}$ & $\begin{array}{c}\text { Ресурси } \\
\text { забезпечують } \\
\text { базові переваги } \\
\text { на ринку }\end{array}$ & $\begin{array}{c}\text { Досягнення } \\
\text { лідерства на } \\
\text { ринку через } \\
\text { складність } \\
\text { копіювання }\end{array}$ \\
\hline
\end{tabular}

3 точки зору надання характеристики окремим елементам означеного у таблиці 1 профілю звернемо увагу, що як вироблення, так і результат дії механізму управління конкурентоспроможністю підприємства передбачає у своєму підсумку організацію належно функціонуючої системи матеріальнотехнічного забезпечення підприємства. Отже, й вибір елементів профілю в таблиці 1 зроблено таким чином, що вони описують окремі функціональні міжнарожні стратегії підприємства, такі як:

- ресурсна міжнародна стратегія підприємства, яка розуміється як частина 


\section{ECONOMIC STRATEGIES FOR THE DEVELOPMENT OF SOCIETY}

стратегії розвитку конкурентоспроможності підприємства та роботи в нових отриманих умовах;

- міжнародну стратегію техніко-технологічного оновлення, що визначає параметри нових організаційно-технологічних умов;

- трансформаційну міжнародну стратегію, яка обгрунтовує принципи й підходи до трансформації параметрів як конкурентоспроможності суб'єкта підприємницької діяльності, так і відповідних до цих параметрів стратегій.

Така система цілей може реалізуватися у помірній, консервативній й агресивній стратегіях змін у створенні й накопиченні потенціалу наявних й потенційних конкурентних переваг підприємства. Саме вибір між ризикованим i стійким розвитком обумовлює можливість застосування підприємства різних варіантів базових міжнародних економічних стратегій, що призводять до різних кількісних або структурних змін, а в остаточному підсумку й до появи нових якісних станів. Такі стратегії можуть бути спрямовані на ріст, поліпшення конкурентних позицій, підвищення ефективності, завоювання нових сегментів ринку, удосконалювання процесів адаптації до оббурювань навколишнього середовища.

Таким чином, можна дійти до висновку, що інноваційний розвиток зовнішнього середовища міжнародної діяльності підприємства являє собою безперервний процес створення, свідомого пошуку, відбору та впровадження низки нововведень (інновацій) в сферах туризму, технології, економіки або організації виробництва і реалізації продукції, що грунтуються на використанні новітніх досягнень науково-технічного прогресу та здатні призвести до якісного підвищення ефективності господарської діяльності підприємства, покращення ринкових позицій або збільшення суспільного ефекту. Специфічний зміст інновації підприємства полягає у забезпеченні (сприянні здійсненню) якісних змін його діяльності [357].

Ієрархічний порядок формування системи міжнародних стратегій підприємства обумовлює наявність тісного зв'язку між прийняттям стратегічних рішень економічного та виробничо-технологічного характеру (насамперед у 


\section{ECONOMIC STRATEGIES FOR THE DEVELOPMENT OF SOCIETY}

сфері маркетингу, інноваційного і науково-технічного розвитку виробництва, інтенсивності використання ресурсів) та ресурсним забезпеченням господарської діяльності. Походження ж факторів формування ресурсної стратегії суб'єкта підприємницької діяльності може мати внутрішній або зовнішній характер.

Разом 3 тим слід звернути увагу на необхідність виділення ще більш вузького аспекту в управління розвитком рівня конкурентоспроможності соціального. Дійсно, організація суб'єкта підприємницької діяльності являє собою відкриту соціально-економічну систему. Саме соціальна сфера, прийнята корпоративна культура й організаційна структуризація можуть або сприяти, або перешкоджати впровадженню змін у характеристики наявних конкурентних переваг підприємства.

В першому випадку прийняття рішення про доцільність впровадження інновацій приймається згідно до суб' єктивного уявлення потенційного інвестора про порівняну прибутковість інвестицій, оцінка якої здійснюється з урахуванням альтернативної доходності, ризику вкладень, рівня конкуренції на фінансовому ринку, суб'єктивних очікувань інвесторів. В кінцевому рахунку, інтегральним чинником, що відбиває стан цього фактору стає так званий «тиск» вільного інвестиційного капіталу, який $є$ в наявності на фінансовому ринку та має бути розміщений для забезпечення прийнятного рівня доходу його власників. Прийняття інноваційних рішень підприємцем великою мірою грунтується на особистих якостях персони підприємця-новатора (сила характеру, здатність до сприйняття ризику, інтуїція, рішучість та ін.), індивідуальні риси якої часто зумовлюють вибір конкретних варіантів інноваційного розвитку. Неабияке значення для інтенсифікації інноваційних процесів має також здатність підприємця забезпечити сприятливість внутрішнього середовища підприємства до сприйняття нововведень, а також «захопити» власним прикладом інших, менш кваліфікованих підприємців, підштовхнути їх до поширення певних інновацій.

Критерієм ефективності розвитку рівня конкурентоспроможності $\epsilon$ 


\section{ECONOMIC STRATEGIES FOR THE DEVELOPMENT OF SOCIETY}

максимізація потенціалу підприємства.

Ресурсний міжнародний підхід до визначення потенціалу підприємства дозволяє його розглядати як здатність задоволення потреб наявними ресурсами. Прийнятий же комплексний підхід орієнтує на виділення ряду складових у потенціалі підприємства, однієї з яких є трудовий потенціал. При цьому саме розмір накопиченого потенціалу (в рамках реалізації вектора цілей) й визначатиме розмір мотивації.

Процес розвитку припускає проведення певних змін, що забезпечують перехід з одного стану використання конкурентних переваг в інший, що характеризуються більшим розкриттям потенціалу підприємства. При цьому до складу конкурентоспроможності повинні вноситися нові, відносно стабільні елементи, які можуть бути чисто матеріальними або соціальними. Відповідно, процес розвитку рівня конкурентоспроможності підприємства включає організаційно-економічні й соціокультурні умови проведення переходу між іï станами.

Процес функціонування механізму управління розвитком рівня конкурентоспроможності підприємства базується на виконанні наступних функцій: планування, організація, мотивація, контроль, комунікація, ухвалення управлінського рішення. Особливістю визначення взаємодії таких функцій є більша спрямованість на функцію мотивації, оскільки саме вона найбільше суттєво впливає на результати діяльності підприємства (на розкриття потенціалу його конкурентоспроможності). Сутність даної функції можна звести до формування комплексу матеріальних і моральних стимулів, спрямованих на підвищення зацікавленості як окремого індивідуума, так і колективу в цілому в кінцевих результатах роботи.

Реалізацію функції мотивації пропонується засновувати на впровадженні відповідного мотиваційного механізму розвитку рівня конкурентоспроможності підприємства, обумовленого як сукупність інструментів і важелів впливу, заданих через упорядковану сукупність мотивів, на свідомість і поведінку працівників, що функціонують у певному інституціональному полі, спрямованих 


\section{ECONOMIC STRATEGIES FOR THE DEVELOPMENT OF SOCIETY}

на досягнення заданих програмою цільових орієнтирів.

Авторський підхід до структурування мотиваційного механізму управління розвитком рівня конкурентоспроможності підприємства представлений на рисунку 2. Він грунтується на представленні такого механізму як системи динамічних економічних i соціальних відносин між діючими особами підприємства [358], та як комплексної системи важелів, інструментів впливу, ціннісних орієнтирів і умов функціонування об’єкта управління розвитком, які формуються 3 урахуванням особливостей соціально-економічних потреб працівників і інтересів підприємства [359].

Динамічні непередбачені умови середовища функціонування підприємства обумовлюють потребу застосування принципу постійного вдосконалення під час роботи створеного мотиваційного механізму.

Принцип постійного вдосконалення повинен застосовуватися стосовно таких складених елементів мотиваційного механізму як: орієнтири дій механізму (перегляд потреби персоналу в певних елементах конкурентоспроможності, необхідних для одержання певного результату роботи), мотивація до вибору напрямку діяльності (до одержання віддачі від використання елементів конкурентоспроможності), мотивації до підвищення ефективності використання потенціалу підприємства тощо.

Дія мотиваційного механізму тісно пов'язана 3 виявленням причин виникнення й форм прояву опору організаційним змінам, проведенням аналізу основних форм, причин і властивостей опору, а також з розробкою методичних рекомендацій щодо коригування робочих взаємин для підвищення ефективності їх організації.

Темпи розвитку рівня конкурентоспроможності залежать від того, наскільки суб'єкт підприємницької діяльності готовий сприймати ту або іншу зміну (реалізується як представлений на рис. 1.2 перехід між станами використання конкурентних переваг). Сприйняття може мати форму визнання нововведення, коли система зацікавлена й підготовлена до його впровадження, або заперечення нововведення, коли воно суперечить інтересам суб'єкта підприємницької 


\section{ECONOMIC STRATEGIES FOR THE DEVELOPMENT OF SOCIETY}

діяльності або коли значна частина системи не готова до його впровадження [360].

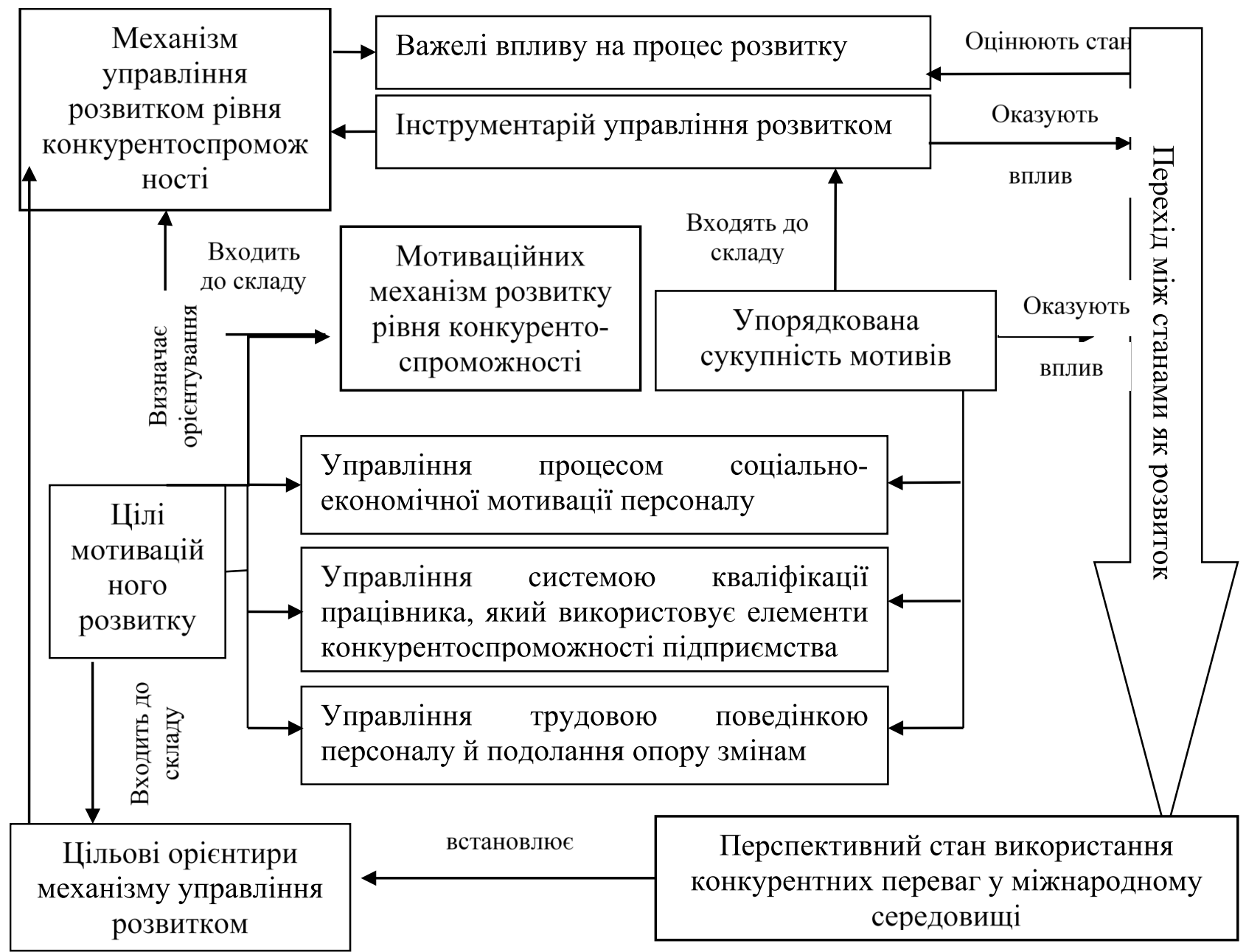

Рисунок 2. Структура мотиваційного механізму і його зв'язок з механізмом управління розвитком рівня конкурентоспроможності підприємства

Ступінь визнання й заперечення змін може бути різною, що залежить від впливу певної системи факторів, які обумовлюють рівень визнання-невизнання. Чим вище ступінь визнання зміни, тем продуктивніше темпи його поширення. Відповідно вибір системи мотивів повинен забезпечувати ріст ступеня визнання необхідності такого розвитку і сприяти залученню персоналу в процес змін.

Систему мотивів слід зв'язати із представленим на рисунку 2 процесом переходу під час розвитку. Для цього кожної з поставлених цілей розвитку рівня конкурентоспроможності слід поставити у відповідність певний мотиваційний 


\section{ECONOMIC STRATEGIES FOR THE DEVELOPMENT OF SOCIETY}

комплекс, який буде спонукати персонал суб'єкта підприємницької діяльності до певних дій. При цьому слід забезпечити відповідність як цілей такого розвитку, так і сформованої системи мотивів (досягти синергії мотиваційних комплексів) [360]. Для досягнення такої відповідності необхідно реалізувати представлений на рисунку 3 контур оцінки адекватності сформованої системи мотивів. Вибір мотиваційних комплексів повинен зіставлятися 3 множиною ситуацій розвитку подій, тобто підкорятися варіанту траєкторії розвитку рівня конкурентоспроможності після зміни позиціонування суб’єкта підприємницької діяльності на ринку через перегляд зон його компетентності.

Таким чином, доведена важливість врахування соціальних факторів у процесі забезпечення розвитку рівня конкурентоспроможності суб'єкта підприємницької діяльності.

Соціальним новаціям при переході між станами використання конкурентних переваг властиві більш тісний зв'язок з корпоративною культурою суб'єкта підприємницької діяльності, більш розширена сфера застосування (любі технічні нововведення вимагають відповідної соціальної підтримки; соціальні ж зміни можуть бути самодостатніми), менша очевидність у необхідності їх реалізації (складніше довести необхідність соціальної інновації й спрогнозувати ефект від ії̈ застосування, у порівнянні з технічної).

Отже, з метою забезпечення фізичного втілення в організаційній структурі механізму управління розвитком рівня конкурентоспроможності необхідно здійснити розподіл функцій між складовими суб'єкта управління, поставивши у відповідність за якість реалізації певної функції окремий елемент мотиваційного комплексу, рисунок 3 [360].

В економічній літературі вказується, що не всі підприємства використовують стратегічне планування i перебудовують організаційну структуру управління, щоб пристосуватися до змін міжнародного середовища. 


\section{ECONOMIC STRATEGIES FOR THE DEVELOPMENT OF SOCIETY}

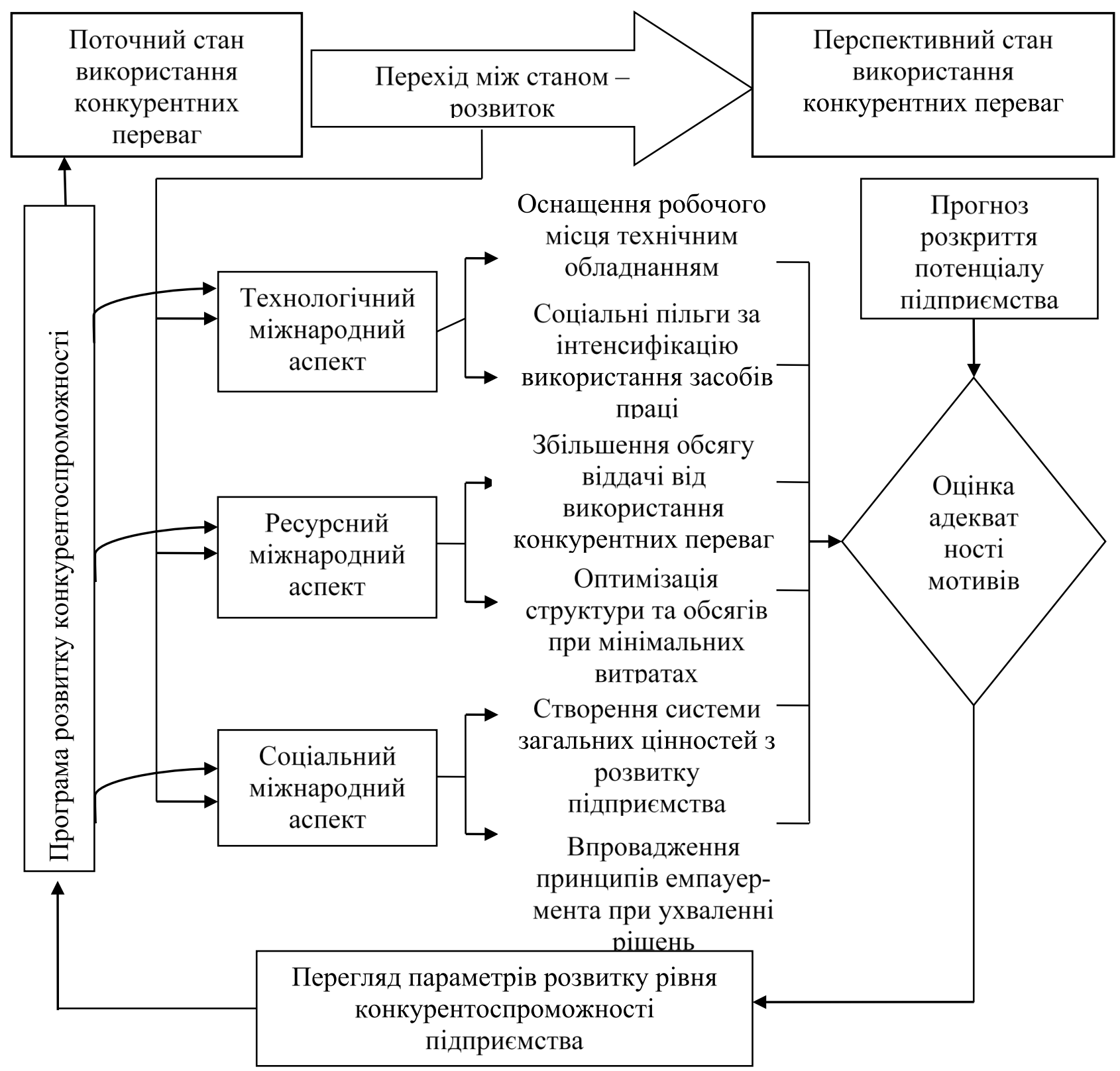

Рисунок 3. Зв'язок мотиваційних комплексів з розвитком рівня конкурентоспроможності підприємства

Однак при зіткненні 3 невизначеністю підприємства починають модернізувати організаційні структури для ефективного управління міжнародною діяльністю підприємства, наведено на рисунку 4.

Сучасні економічні процеси у світі, особливо в Україні, перебувають у нестабільному стані та прагнуть пошуків нових парадигм розвитку виробництва, економічних відносин і суспільства в цілому. 


\section{ECONOMIC STRATEGIES FOR THE DEVELOPMENT OF SOCIETY}

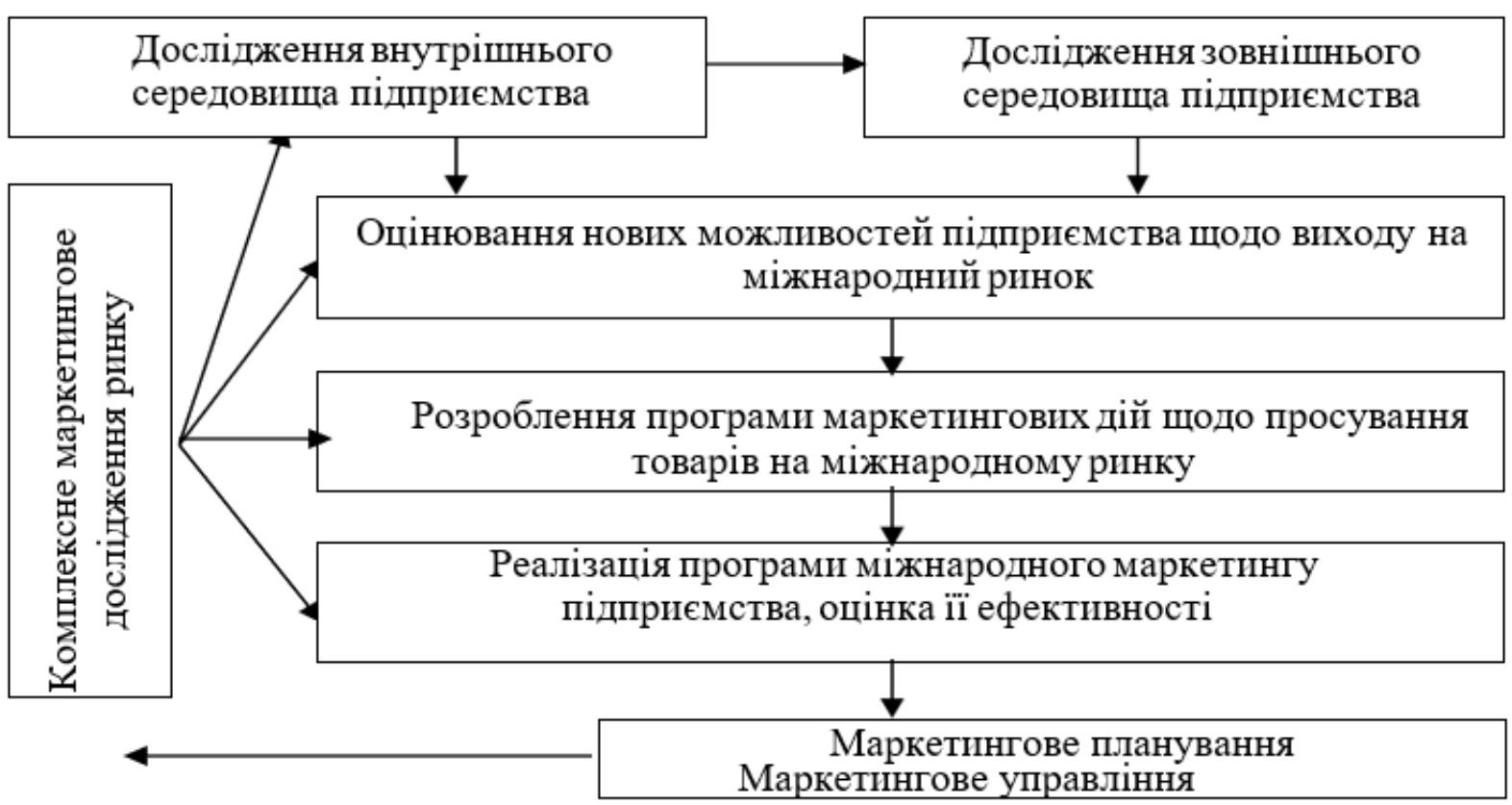

Рисунок 4. Послідовність оцінювання невизначеності змін міжнародного середовища діяльності підприємств

Виробництво набуває інтелектуальної форми, життєві цикли продукції і технологій скорочуються, виникають нові форми конкурентної боротьби, кооперації, з'являються нові альтернативи використання фінансових ресурсів, більшість джерел природних ресурсів виснажуються i супроводжується погіршенням екологічної обстановки. При цьому можна наголосити на доречності використання різних підходів до визначення місця механізму управління таким розвитком у структурі суб'єкта підприємницької діяльності, узагальнене представлення яких подано таблиці 2. При цьому пропонується розглянути організаційні форми в рамках виділення бізнес-процесів. Відповідно й перехід між станами здійснюватиметься через еволюційне удосконалення організації в рамках обраної форми або через революційний перехід на нову форму. Відповідно в залежності від прийняття того чи іншого підходу до здійснення процесу розвитку відбуватиметься й диференціація використовуваного інструментарію механізму управління розвитком рівня конкурентоспроможності підприємства [360]. 


\section{ECONOMIC STRATEGIES FOR THE DEVELOPMENT OF SOCIETY}

Таблиця 2

Узагальнення підходів до організаційно-структурної побудови механізму міжнародної конкурентоспроможної стратегії підприємства

\begin{tabular}{|c|c|}
\hline Форма & Характеристика \\
\hline $\begin{array}{l}\text { Міжнародний відділ, що координує } \\
\text { горизонтальні зв’язки входження } \\
\text { конкурентних переваг поруч зі } \\
\text { звичайними структурними } \\
\text { підрозділами підприємства, які } \\
\text { виконують спеціалізовані операції } \\
\text { менеджменту }\end{array}$ & $\begin{array}{l}\text { Складність виконання інтегруючої функції, } \\
\text { оскільки досить важко знайти достатню кількість } \\
\text { компетентних професіоналів, здатних вирішувати } \\
\text { склад-ні багатоаспектні завдання з управління } \\
\text { трансформаціями у механізмі управління } \\
\text { розвитком }\end{array}$ \\
\hline $\begin{array}{l}\text { Виділення одного міжнародного } \\
\text { головного відділу з існуючих в } \\
\text { організаційній структурі } \\
\text { підприємства, надання йому } \\
\text { повноважень і відповідальності за } \\
\text { рішення комплексного завдання }\end{array}$ & $\begin{array}{l}\text { Недоліком й обмеженням даної форми є те, що з } \\
\text { виділеного відділу не всі виконавці знімають } \\
\text { відповідальність за виконання спеціалізованих } \\
\text { операцій (відділ може бути компетентним, } \\
\text { наприклад, в питаннях розвитку конкурентних } \\
\text { переваг й невірно інтерпретувати сучасні ринкові } \\
\text { умови) }\end{array}$ \\
\hline $\begin{array}{l}\text { Виділення спеціального підрозділу } \\
\text { управління розвитком рівня } \\
\text { конкурентоспроможності } \\
\text { підприємства }\end{array}$ & $\begin{array}{l}\text { Централізація виконуваних операцій дозволяє } \\
\text { полегшити подолання конфліктів при реалізації } \\
\text { переходу до нового стану }\end{array}$ \\
\hline $\begin{array}{l}\text { Призначення керівника окремого } \\
\text { бізнес-процесу з наданням повної } \\
\text { влади над всіма етапами }\end{array}$ & $\begin{array}{l}\text { Таку форму доцільно використати при розробці й } \\
\text { впровадженні складних інноваційних бізнес- } \\
\text { процесів }\end{array}$ \\
\hline $\begin{array}{l}\text { Проектна структура або цільова } \\
\text { команда, що займається реалізацією } \\
\text { функцій управління розвитком в } \\
\text { момент здійснення } \\
\text { трансформаційних змін }\end{array}$ & $\begin{array}{l}\text { У таку команду поєднуються кваліфіковані } \\
\text { працівники різних професій, фахівці для контролю } \\
\text { функціонування певного бізнес-процесу або } \\
\text { декількох родинних бізнес-процесів }\end{array}$ \\
\hline
\end{tabular}

Прийняте у дослідженні розуміння механізму управління розвитком рівня конкурентоспроможності суб'єкта підприємницької діяльності через співвіднесення важелів та інструментів реалізації управлінського впливу вимагає спрямування уваги саме на удосконалення тих інструментів, за допомогою яких й відбуватиметься подальший розвиток (тобто визначення тих методів, способів й прийомів, які адаптуватимуть параметри конкурентоспроможності до змінених у разі реалізації переходу до нових зон компетентності суб'єкта підприємницької діяльності).

Аналізуючи наведені у таблиці 2 підходи до організаційно-структурної розбудови механізму міжнародної конкурентоспроможної стратегії 


\section{ECONOMIC STRATEGIES FOR THE DEVELOPMENT OF SOCIETY}

підприємства, визначення суб’єкта управління таким розвитком розкривається через встановлення різних сценаріїв створення організаційних форм.

Також доречним буде одночасне використання трьох сучасних міжнародних концепцій конкурентних переваг: ринкової (орієнтація на ефективну галузеву й ринкову позицію суб’єкта, обрану з урахуванням його специфіки), ресурсної (концентрація на комбінації унікальних й важких для копіювання специфічних видів ресурсів) та інституціональної (створення полів взаємодії й системи коопераційних зв’язків). Лише взаємне доповнення означених концепцій дозволить забезпечити відбиття динамічних трансформацій всіх основних джерел формування конкурентних переваг у сучасній економіці. Отже в контексті відображення динаміки можна говорити про конкуренцію як про багатомірну, координаційну модель, у якій до основних джерел конкурентних переваг відносять: у рамках ринкового аспекту ефективне позиціювання на основі сполучення специфічних можливостей 3 потребами покупців у рамках обраної ніші; у рамках ресурсного аспекту інноваційну мобільність, засновану на швидкості відтворення й комбінування інновацій, співвіднесену з консолідацією розподілу релевантних ресурсів; у рамках інституціонального аспекту - підтримку необхідної позитивної репутації й формування ланцюжка партнерських відносин.

Завданням програми міжнародної конкурентоспроможної стратегії $\epsilon$ проведення певного комплексу робіт, спрямованих на вдосконалення продукції та/або діяльності підприємства, виконання якого буде сприяти підвищенню рівня їх конкурентоспроможності.

Для впровадження програми міжнародної конкурентоспроможної стратегії доцільно створити спеціальну команду людей, які мають бути звільнені від усіх або більшості своїх звичайних обов'язків, а також мати нестандартне, креативне мислення. I якщо цілі суб’єкта підприємницької діяльності (організаційні) цілком не збігаються з людськими, то такий метод управління не є ефективним, бо він передбачає ігнорування людських цінностей на користь організаційних.

Дослідження дозволило визначити основні напрямки удосконалення 
ECONOMIC STRATEGIES FOR THE DEVELOPMENT OF SOCIETY міжнародної конкурентоспроможної стратегії, розробити відповідні до цих напрямків пропозиції. Доведено, що міжнародні стратегії можуть бути спрямовані на ріст, поліпшення конкурентних позицій, підвищення ефективності, завоювання нових сегментів ринку, удосконалювання процесів адаптації до змін навколишнього середовища.

Оскільки будь-який механізм можна представити як сукупність субмеханізмів, доведено доречність включення до складу механізму управління розвитком рівня конкурентоспроможності підприємства елементів мотивації робітників. Відповідний мотиваційний механізм, формується через визначення так званих мотиваційних комплексів. Запропонована структура мотиваційного механізму базується на доведеній у роботі важливості використання соціальної складової й соціокультурних параметрів середовища. Оскільки ж функціонування такого механізму базується на виконанні функцій планування, організації, мотивації, контролю тощо, то й особливістю їх взаємодії може бути більша спрямованість на функцію мотивації. Доведено необхідність включення до формованого механізму динамічних моделей узгодження параметрів конкурентоспроможності з параметрами життєдіяльності підприємства. 


\section{ECONOMIC STRATEGIES FOR THE DEVELOPMENT OF SOCIETY}

\section{4 Глобальні ризики та економічна безпека України}

Сучасні тенденції до глобалізації та концентрації управління світовими ресурсами, контроль над ринками та стратегічними активами загострення конкуренції та ускладнення характеру зовнішньоекономічної взаємодії компаній різних країн породжує загрози для національної безпеки країн. Такі загрози проявляються у зростанні впливу численних факторів невизначеності на міжнародних ринках, що породжують комплекс специфічних зовнішньоторговельних ризиків і фінансові збитки, яких зазнають більшість зарубіжних і вітчизняних компаній, зайнятих міжнародною діяльністю.

Питанню економічної безпеки та дослідженню глобальних загроз приділяють багато уваги як вітчизняні так зарубіжні науковці, як Л. Абалкін, О. Ф. Новікова, О. Г. Сидорчук, О. В. Панькова[364] , В. Мутріян, В. В. Третяк, Т. М. Гордієнко [365],та інші.

Науковцям вдалось обгрунтувати поняття «економічна безпека» визначити напрями забезпечення економічної безпеки. Проте недостатньо досліджено комплексне поєднання визначення глобальних загроз для економічної безпеки України. Метою дослідження є розгляд основних ризиків для економічної безпеки країни в умовах процесу глобалізації.

Всесвітній економічний форум в опублікованій доповіді зазначив головні ризики, з якими світ може зіткнутися в майбутньому. В доповіді було виділено п'ять основних загроз. В першу чергу, це екологічні проблеми, такі як: зміна клімату, скорочення біорізноманіття видів; проблеми 3 якими стикається охорона здоров'я; соціальна напруженість; проблеми 3 кібербезпекою як результат НТП і всі вони ще посилюються проблемою сповільнення економіки. Останній, має найзначніший вплив.

Загрози, яким піддається економіка, різноспрямовані і можуть мати різну природу виникнення. У цьому контексті класифікація загроз має важливе значення в цілях їх управління. По механізму впливу загрози, діляться на прямі (безпосередні) і непрямі (опосередковані) [366]. Прямі загрози економічній безпеці держави при будь-яких умовах викликають негативні наслідки, адже 


\section{ECONOMIC STRATEGIES FOR THE DEVELOPMENT OF SOCIETY}

часто створюються навмисною діяльністю певних суб'єктів. Непрямі погрози чинять негативний вплив в разі наявності певних додаткових умов, що склалися в зовнішньому i внутрішньому середовищі об'єкта безпеки, адже вони в основному викликані змінами ринкової кон'юнктури або непередбачуваними подіями в умовах відсутності або неефективності антикризового реагування.

Більшість загроз економіки виникають у зовнішньому середовищі під впливом процесів глобалізації та інтеграції економки України до Європейського Союзу. Загрози економічної безпеки, виходячи з природи їх виникнення, можна розподілити на зовнішні та внутрішні, тобто за масштабами їх реалізації. До зовнішніх загроз економічної безпеки відноситься вплив глобальної економіки 3 виокремленням міжнародного рівня та внутрішні загрози зосереджені на макроекономічному та регіональному рівні (рис. 1.)

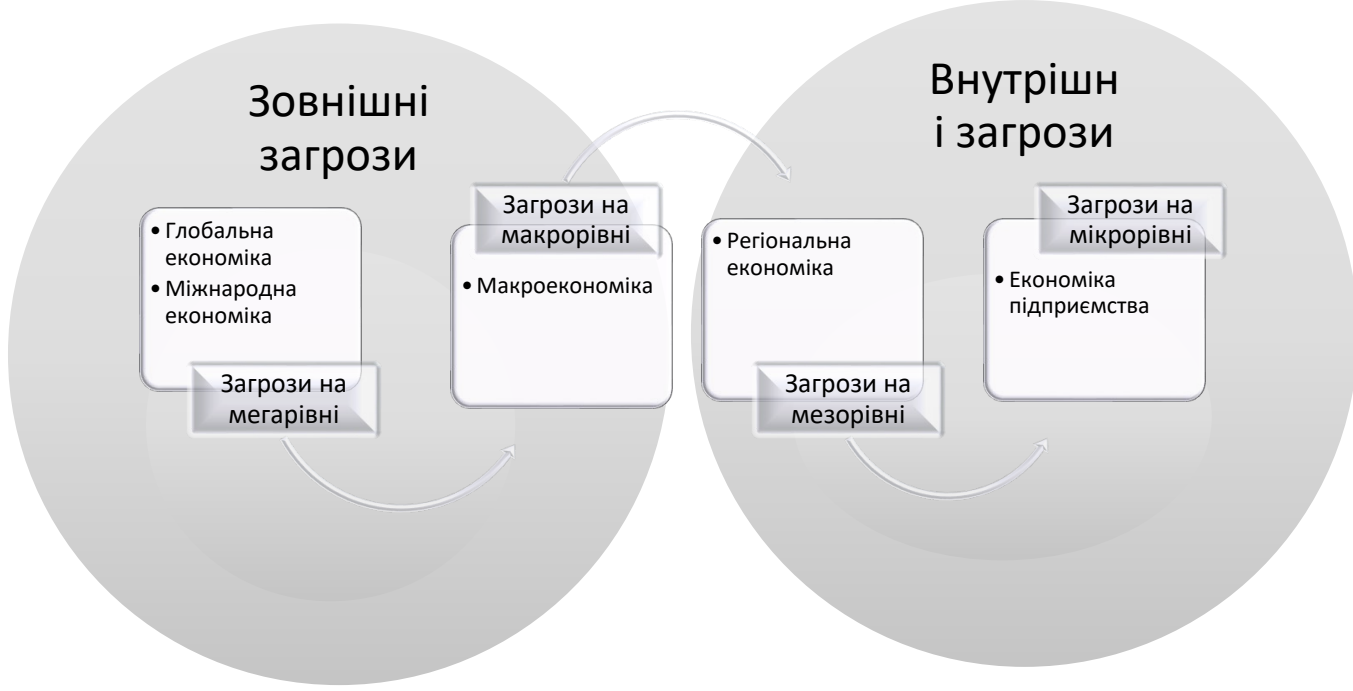

Рис. 1. Структура виникнення загроз економічної безпеки.

До внутрішніх загроз відносять локальні, що виявляються за окремими складовими економічної безпеки і зачіпають національні економічні інтереси певних груп суб'єктів економічної безпеки, або індивідуальні, які перешкоджають реалізації національних економічних інтересів окремих суб'єктів економічної безпеки [367]. До останніх можна включити розподіл та спрямування бюджетних коштів, зменшення регіональної нерівності, що науковці досить часто відносять лише до перспектив. Останнє всупереч теоретичним гіпотезам не зникає, а збільшується в ході економічного розвитку 


\section{ECONOMIC STRATEGIES FOR THE DEVELOPMENT OF SOCIETY}

держави. Але такі загрози легше подолати на відміну від зовнішніх, на які вплинути майже неможливо.

До зовнішніх загроз можна віднести загальнонаціональні, які стосуються всіх суб'єктів економічної безпеки держави i проявляються на загальнонаціональному рівні. У світовій економіці зростає ризик настання стагнації: на розвиток тисне мікроекономічна нестабільність і фінансова нерівність. Низькі торгові бар'єри, податкова обачність і сильні глобальні інвестиції раніше розглядалися як основи економічного зростання. Зараз вони зменшуються через націоналістичну політику світових лідерів. Можливості монетарних і фіскальних стимулів економіки набули меншої впливовості. До негативних факторів можна віднести i торгову напруженість, скорочення інвестицій, невпевненість бізнесу і високі борги. 3 погляду на зазначені проблеми можна сформувати такі основні глобальні загрози економічної безпеки України:

- Процес інтеграції України до світового простору, що підвищує відкритість економіки країни до зовнішнього впливу; ·

- Фінансова залежність процесу реформування економіки України від капіталів міжнародних організацій; ·

- Імпорто-залежність України на товари стратегічного значення: газ, нафту та інші джерела енергії;

- Застаріла матеріально-технічна база та відсутність суттєвих інновацій, що стимулює ввезення в країну технічно застарілих і екологічно небезпечних виробництв.

- Слабка підтримка конкурентоспроможності українських експортоорієнтованих підприємств;

- Відсутність контролю щодо експортно-імпортної збалансованості, велике негативне зовнішньоторговельне сальдо; ·

- Не ефективна направленість експорту країни щодо сировинних ресурсів. 


\section{ECONOMIC STRATEGIES FOR THE DEVELOPMENT OF SOCIETY}

Ці негативні явища підривають національну єдність та консолідованість української нації, знецінюють перспективи на успішне майбутнє і держави, i людини.[ 364]

Проблема захисту та подолання загроз стає однією з найактуальніших для світового суспільства, що потребує кардинально нових науково-методологічних підходів її вирішення. Безпека як система необхідних якостей будь-якої країни має враховувати розвиток різноманітних сторін. Виокремлюють такі основні складові безпеки як інформаційна, інтелектуальна, політична, військова, економічна, соціальна, екологічна та інші підпорядковані елементи.

В умовах інтеграції української економічної системи виникає необхідність формування економічної безпеки країни, що в даний час є однією $з$ головних функцій управління і має стратегічне значення для країни. Сучасна ринкова економіка, відкритість кордонів для міжнародних економічних відносин в процесі децентралізації стали не тільки можливістю розвитку економіки регіонів та країни, але й загрозою для економічного розвитку. Постійні зміни та реформи, що тривають 3 моменту незалежності країни й довготривалі економічна, політична кризи сприяють загостренню протиріч, що $є$ загрозою для безпеки країни. Окрім того, зважаючи на економічну залежність країни від світових тенденцій, загроз виникає ще більше у результаті проблем пов'язаних 3 пандемією Covid-19.

Економічна безпека як фундамент національної безпеки набуває виключної актуальності. Зневажання економічною безпекою може призвести до катастрофічних наслідків: занепаду галузей економіки, банкрутства підприємств та підриву системи життєзабезпечення нації 3 подальшою втратою суверенітету[368]. Необхідне всебічне вивчення загроз та елементів економічної безпеки регіонів та створення механізму подолання зазначених проблем, що виникають.

В світовій практиці вперше поняття «економічна безпека» було використано президентом США Ф. Рузвельтом при пошуку шляхів вирішення для виходу 3 економічної кризи в США в 30-х рр. ХХ століття. Економічна безпека стала 


\section{ECONOMIC STRATEGIES FOR THE DEVELOPMENT OF SOCIETY}

основою для «Нового курсу», що характеризувався рівновагою та стійкістю економіки, завдяки адміністративним змінам. А починаючи з 1985 p, питанню економічної безпеки постійно приділяється увага з боку ООН. Створення економічної безпеки з погляду ООН направлене на міжнародний рівень. Як зазначається в Резолюції 40/173 ООН [369] , необхідною умовою для сприяння виявлення загроз національних економік та їх подальшого усунення $є$ приділення достатньої уваги розвитку економічних відносин між промислово розвиненими країнами і тими, що розвиваються. Однак в даний час економічні взаємини між країнами не націлені на виявлення та усунення ризиків економічного розвитку i, отже, кожна держава забезпечує економічну безпеку з урахуванням регіональних і світових інтеграційних процесів.

В Україні поняття економічної безпеки офіційно визначене у Декларації про державний суверенітет України. В 1990 р. створено управління економічної безпеки. У 1998 р. була розроблена Національна програма забезпечення економічної безпеки України до 2005 р., а у 1999 р. прийнята Концепція економічної безпеки України [365]. Але дослідження питання економічної безпеки продовжувалися і далі. У зв'язку зі складністю та всеосяжністю категорії «економічна безпека» висувалося безліч різноманітних ії трактувань. Найбільше вчених схиляються до думки, що економічна безпека являє собою стан економіки держави, або виокремлюють іï як фактор незалежності та самостійності країни від впливу зовнішніх чинників. Інші ж економічну безпеку асоціюють 3 досягненням такого рівня розвитку країни де головними є соціальні чинники (життєдіяльність населення, добробут). теж буде можливим, насамперед, за рахунок економічних та адміністративних інструментів. Деякі вчені поєднуючи зазначені елементи, характеризують «економічну безпеку» як захищеність життєвих та економічних інтересів держави[370].

В сучасних умовах децентралізації стратегічний розвиток України безпосередньо залежить від рівня економічної самостійності і гнучкості окремих iii регіонів, а загрози економічної безпеки регіону можуть створити дисбаланс економічного розвитку країни. 


\section{ECONOMIC STRATEGIES FOR THE DEVELOPMENT OF SOCIETY}

Окрім того, невтішним є те, що влада в боротьбі за державні кошти та небажання розуміти значущість економічної та інших складових національної безпеки затвердили Закон України “Про національну безпеку України” (2018 р.), де виключено всі сфери національної безпеки, крім воєнної і оборонної. А місце іншим сферам національної безпеки передбачається так само як і у 2018 році визначати в Стратегії національної безпеки і 2020 року [371]. Відповідальність за невиконання законодавчих актів України певною мірою визначена i iï можливо затребувати, але при нереалізованості Стратегій таких каральних заходів не передбачено.

Слід зазначити, що відповідно до обраного зовнішньополітичного вектору економічної інтеграції країни до європейського простору та внутрішнього курсу, завданням державної стратегії $є$ створення умов для економічного зростання виробництва, високої конкурентоспроможності продукції в умовах глобалізації, підтримання науково-технічного потенціалу, недопущення зниження рівня життя населення до порогових значень, збереження соціально-економічної стабільності в суспільстві в умовах сучасної глобальної фінансової кризи, формування гнучкої і змістовної стратегії економічного розвитку з урахуванням як позитивного так і негативного впливу всіх рівнів. Усвідомлення властивих ризиків для безпеки країни, створення запобіжників і належний контроль органів державної влади, дозволять не тільки скористатися усіма перевагами обраного напряму розвитку, а й створити необхідний фундамент для подальшого розвитку країни. Відповідно, забезпечення стійкого економічного зростання можливо досягти лише за умов правильної оцінки зовнішнього та внутрішнього впливу зважаючи на можливості й перспективи розвитку. Необхідною є адаптація економіки до стрімких змін в міжнародному просторі та глобального тиску, створення інвестиційно привабливого клімату, забезпечення технологічної озброєності, стимулювання до політичної активності, суспільної свідомості та саморозвитку, економічної обізнаності для досягнення середнього національного рівня розвитку за умов обов'язкового впровадження світових стандартів. 


\section{ECONOMIC STRATEGIES FOR THE DEVELOPMENT OF SOCIETY \\ SECTION 13. LOCATION OF PRODUCTIVE FORCES, REGIONAL ECONOMY}

\subsection{The analysis of the current state and development of ski tourism in the ukrainian carpathians}

Ski tourism in the world is becoming one of the most popular activities. Ukraine is no exception. Creating a tourist product, ski tourism is a capital-intensive and laborintensive type of tourism. This type of tourism has a number of features that distinguish it from other, simpler types. First of all, it should be noted the peculiarities of accommodation facilities in ski tourism. Accommodation is offered in specialized hotels, such as mountain chalets, architecturally integrated into the surrounding landscape. There should be lifts near the hotels. The hotels are located near the ski slopes.

In ski tourism an important role in terms of cost is played by a number of additional services: instructor services, equipment rental, ski pass. Health insurance is especially important for ski tourism. Despite the fact that ski tourism is a rather expensive type of tourism, the number of tourists who enjoy this type of tourism is growing every year.

The Carpathians are one of the most beautiful regions of Ukraine, where everything for active winter recreation is present. Ski resorts in Ukraine can easily compete with many European ones - the service here is at the highest level.

The Carpathians are a mountain system in Central Europe. The length of the Carpathian Mountains is about $1500 \mathrm{~km}$. The Carpathians are divided into Western, Eastern and Southern. The western ones are located in Slovakia, the Czech Republic, Poland and partly in Hungary, where there is the highest point of the Carpathians Mount Gerlach - $2655 \mathrm{~m}$ above sea level. The Southern Carpathians are located on the territory of Romania and the Eastern Carpathians are located on the territory of Ukraine. The average height of the Ukrainian Carpathians is $1000 \mathrm{~m}$. The mountains stretch from northwest to southeast with an average width of $100 \mathrm{~km}$ for almost 280 km. The highest point of the Ukrainian Carpathians - Mount Hoverla - $2061 \mathrm{~m}$ above 


\section{ECONOMIC STRATEGIES FOR THE DEVELOPMENT OF SOCIETY}

sea level. Within Ukraine, the Carpathians are divided into: external (Beskids, Gorgan and Pokutsko-Bukovynian Carpathians), central (Verkhovyna) and internal (Polonynsko-Chornohorsky).

Carpathian ski resorts in Ukraine are located in three regions:

- Lviv region: Slavske, Volosyanka, Oryavchyk, Tysovets, Plavie, Rozluch;

- Ivano-Frankivsk region: Bukovel, Yablunytsia, Yaremche, Verkhovyna, Vyshkiv;

- Transcarpathia: Dragobrat, Yasinya, Pylypets, Podobovets, Vyshka, Mizhhirya, Izky.

The five best prospects for the development of ski tourism in the Ukrainian Carpathians.

The first is growth potential. By the beginning of the XXI century in Ukraine there were about 200 thousand tourists who considered themselves skiers and were ready to spend a holiday on the track or near the track. It was far from mass, but more tourism for the chosen ones, fans or just for those who paid tribute to fashion.

For comparison, in the 2019-2020 season, this figure exceeded the mark of two million people, which is far from the limit.

When assessing the potential, we can refer to the experience of Poland. Neighbors have a population of 35 million, more than 10 million go skiing every year. It is difficult to say when Ukraine will be ready to put almost a third of its citizens on skis, but in the next three to five years it is quite possible to expect an increase in the flow to five times. However, it should be emphasized that the growth rate of the number of tourists directly depends on the development of transport infrastructure.

The second is the presence of a promoted brand. Bukovel, as a monopolist, is slowing down business development today, eliminating the factor of competition, but on the other hand, Bukovel, as a brand, can become a locomotive for the promotion of winter tourism in the Ukrainian Carpathians. Bukovel makes this type of holiday prestigious, attractive, he managed to instill interest in downhill skiing. 


\section{ECONOMIC STRATEGIES FOR THE DEVELOPMENT OF SOCIETY}

If you do not take into account the big ski quartet (Italy, Austria, Switzerland, France), then few of the neighbors can boast of such a brand. With the right strategy, this is definitely a positive factor.

The third is the interest of investors in the development of the hotel business in the Ukrainian Carpathians. Back in 2007, there were no more than a hundred hotels in the ski area in Ukraine, now it is more than three thousand accommodation facilities in four regions, able to accommodate more than 100 thousand tourists at a time.

It is important to note that even now, when Ukraine is not in the simplest economic and political situation, business continues to show interest in the ski sector and is willing to invest in hotel construction.

Fourth and fifth. Expanding the geography and duration of the season through modern technology.

Even 10 years ago, it was difficult to imagine ski resorts for beginner skiers in Kyiv, Kharkiv, Cherkasy, Chernivtsi, and even more so in the non-ski Odesa region. Trails with artificial snow and hundreds of equipment rental points have made this once elite holiday a mass one. Well, the expansion of geography - is, above all, an increase in potentially interested tourists directly in the mountains.

Previously, only the presence of natural snow made it possible to ride on a limited number of trails through the climatic framework. This narrowed the season, made the vacation risky (unexpected thaws are not uncommon for Ukraine), which in turn made it possible to inflate prices incredibly at the peak of the season.

Now the technology of artificial snowing of slopes has significantly eliminated this problem. At the peak of the season, prices are still quite high, but at the beginning and near the end of the season are available to most Ukrainians.

According to the described most important prospects, we will single out five main opportunities for the development of a ski resort in the Ukrainian Carpathians.

The first is an association of business operators.

Unification in general is difficult for Ukrainians, and the sphere of ski tourism is no exception. However, only the association of tourism business players can force the government to invest budget funds in the region's infrastructure. Without the 


\section{ECONOMIC STRATEGIES FOR THE DEVELOPMENT OF SOCIETY}

development of the region in general, and the transport sector in particular, the further development of tourism will be associated with huge risks. It is the association of tourism businesses that should provide additional opportunities for dialogue with the authorities at all levels.

Second, it is necessary to take full advantage of the political situation and lure former Crimean tourists. The annexation of Crimea made the Carpathians the only mountain holiday in the summer season.

Summer vacation in the Carpathians - has become a powerful trend in the last six years, allowing many hotels focused on winter holidays, to earn income in the summer. Currently, it is extremely necessary to saturate summer offers with the necessary quantity, and the main thing, quality of active entertainments and excursions.

Third, it must be understood that the expansion of interest in downhill skiing only in Ukraine is not the limit. Nowadays, the Ukrainian Carpathians are able to arouse the interest of, for example, Belarusians.

Belarus is our hidden reserve. A country with a population of 10 million, in which the highest peak is only 345 meters above sea level is able to supply Ukraine with a million skiers a year.

Option four - Europe.

Every year the number of tourists from the new Europe grows. If the citizens of old Europe are sitting firmly on the "needle" of the big four ski, then Polish, Romanian and Hungarian tourists are already well heard in Bukovel. This is not the limit. The best task is to get the Baltics as well. Organizing a low-cost from Riga, Vilnius or Tallinn to Ivano-Frankivsk is far from fantastic. However, unfortunately, it is worth returning to the problems.

The lack of English-speaking staff and the restriction of non-cash turnover today are a big stop sign in this direction.

Opportunity five is the absolute underdevelopment of event tourism.

Large bright mass events should become a new catalyst for the development of the winter Carpathians. Unfortunately, neither sports federations nor ski resorts, with the exception of Bukovel, are involved in the promotion and organization of interesting 


\section{ECONOMIC STRATEGIES FOR THE DEVELOPMENT OF SOCIETY}

winter events in the Carpathians. Unfortunately, it has not become a trend for Ukrainians to travel as fans to ski competitions.

As of today, Ukraine lags far behind in implementing measures to support the tourism sector, which poses a serious threat to the competitiveness of the industry in the global market during the projected recovery in 2021.

There are currently two common approaches to overcoming the crisis: the first is to provide affordable credit lines for businesses, and the second is to defer payment of debt and tax liabilities.

Thus, the biggest obstacle to the integrated development of the leisure industry in the Carpathian region is the imperfect infrastructure. At the same time, the issues of investment efficiency and private investment come to the fore. Regarding the problems of operation of ski slopes and the development of recreational tourism in the Carpathian region, we can say with confidence about the need to improve the road network, the importance of building new modern vehicles to transport vacationers directly to ski slopes and cable cars. Language update of ski infrastructure on the slopes. 


\section{ECONOMIC STRATEGIES FOR THE DEVELOPMENT OF SOCIETY}

\section{2 Методика визначення аудиторського ризику за умови проведення автоматизованого аудиту}

Важливим моментом при проведенні автоматизованого аудиту є визначення аудиторського ризику. Сдиної методики визначення аудиторського ризику немає. Вона, як правило, розробляється кожною аудиторською фірмою або окремим аудитором відповідно до умов конкретної перевірки. 3 цією метою створюються так звані моделі аудиторського ризику, які постійно удосконалюються. Вибираючи методику визначення аудиторського ризику та його допустиму величину, необхідно врахувати конкретні умови перевірки, їі термін, характер діяльності клієнта, компетентність і кваліфікацію аудитора та інші фактори.

Для визначення ризику можна використовувати як матричну, так і факторну модель. Наприклад, при здійсненні внутрішнього аудиту в банківській сфері, використовують матричну модель. Заповнення матриці здійснюється залежно від оцінки конкретної ситуації. Матрична модель визначає залежність рівня аудиторського ризику від показника невід’ємного ризику, ризику контролю, ризику не виявлення. На нашу думку, для визначення аудиторського ризику при проведенні аудиту на автотранспортних підприємствах за умови автоматизованої обробки даних, доречно використати факторну модель на основі моделі, розробленої Дж. Робертсоном. Дана модель уже використовувалась для розрахунку аудиторського ризику доктором економічних наук, професором Рудницьким В.С., але в ході перевірки бухгалтерського обліку за ручної форми обробки інформації. Ми пропонуємо використання даної моделі для визначення аудиторського ризику під час проведення внутрішнього аудиту на автотранспортних підприємствах за умови використання інформаційних технологій.

Дана модель може бути виражена такою формулою:

$$
\mathrm{AP}=\mathrm{PO} \times \mathrm{PK} \times \mathrm{PB} \quad(1)
$$

де АР - аудиторський ризик;

РО - ризик системи обліку; 


\section{ECONOMIC STRATEGIES FOR THE DEVELOPMENT OF SOCIETY}

РК - ризик системи внутрішнього контролю;

PB - ризик не виявлення помилок аудитором.

Факторна модель визначення аудиторського ризику передбачає послідовне виконання наступних дій: проведення анкетного опитування експертів 3 метою визначення факторів, які можуть суттєво впливати на елементи моделі; проведення експертної оцінки вагомості кожного чинника у часткових моделях; складання робочих таблиць; визначення аудиторського ризику [382].

На першому етапі було спеціально відібрано групу з 20 експертів, до якої увійшли працівники аудиторських фірм у Хмельницькій області. За методом «мозкової атаки» визначено групи факторів, які справляють найбільший вплив на ризик системи внутрішнього контролю, ризик системи обліку та ризик не виявлення помилок аудитором. Отриманий перелік факторів систематизовано у спеціальних таблицях за видами ризику, після визначено кількість поданих експертами голосів за кожен чинник. При цьому до переліків основних чинників, які потрібно включити в моделі оцінки елементів загального аудиторського ризику, входять лише ті фактори, за які подано голоси більше половини експертів-аудиторів (таблиця 1).

Таблиця 1

Таблиця оцінки вагомості факторів, що впливають на PO, РК і РB

\begin{tabular}{|c|c|c|c|c|c|c|c|c|}
\hline \multirow[t]{2}{*}{ № } & \multirow[t]{2}{*}{ Фактори } & \multicolumn{5}{|c|}{ Кількість балів } & \multirow{2}{*}{$\begin{array}{c}\text { Середня } \\
\text { оцінка }\end{array}$} & \multirow{2}{*}{$\begin{array}{c}\text { Коефіцієнт } \\
\text { вагомості }\end{array}$} \\
\hline & & $\begin{array}{c}1 \\
\text { експерт }\end{array}$ & $\begin{array}{c}2 \\
\text { експерт }\end{array}$ & $\cdots$ & $\begin{array}{c}\mathrm{K} \\
\text { експерт }\end{array}$ & Всього & & \\
\hline 1 & $\mathrm{X} 1$ & a11 & a12 & $\ldots$ & alk & b1 & $\mathrm{B} 1 / \mathrm{k}$ & $\mathrm{b} 1 / 100 \times \mathrm{k}$ \\
\hline 2 & $\mathrm{X} 2$ & a21 & a22 & $\ldots$ & $\mathrm{a} 2 \mathrm{k}$ & b2 & $\mathrm{B} 2 / \mathrm{k}$ & $\mathrm{B} 2 / 100 \times \mathrm{k}$ \\
\hline 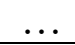 &. & & & & . & $\ldots$ & & \\
\hline $\mathrm{n}$ & $\mathrm{Xn}$ & an1 & an2 & $\ldots$ & ank & bn & $\mathrm{Bn} / \mathrm{k}$ & $\mathrm{bn} / 100 \times \mathrm{k}$ \\
\hline \multicolumn{2}{|c|}{ Всього } & 100 & 100 & & 100 & $100 \mathrm{k}$ & 100 & \\
\hline
\end{tabular}

Наступний етап включає дослідження і експертну оцінку вагомості обраних факторів, яку здійснюємо за кожним фактором у балах таким чином, щоб сума балів усіх факторів дорівнювала 100. Потім розраховуємо середню оцінку (в балах) і визначаємо коефіцієнт вагомості Кв(i) для кожного і-го фактора, що впливає на РО, РК і РВ. Таким чином, кожен експерт повинен визначити, скільки балів розподілити між основними факторами, а скільки залишити для 


\section{ECONOMIC STRATEGIES FOR THE DEVELOPMENT OF SOCIETY}

другорядних (наприклад, 80 і 20, 90 і 10 та ін). За результатами проведеного дослідження з'ясовано, що найбільший вплив на ризик системи внутрішнього контролю, на думку експертів, впливають такі фактори: компетентність контрольного персоналу (21,8 \%), розподіл повноважень між працівниками служби внутрішнього аудиту (13,0 \%), правильність відображення операцій в обліку (12,85 \%) (таблиця 2). В свою чергу, на ризик системи обліку - рівень комп'ютеризації обліку (10,55 \%), його організаційна система $(22,7$ \%), рівень знань бухгалтерського персоналу інформаційних систем (15,9\%); (таблиця 2) на ризик не виявлення помилок аудитором - кваліфікація та стаж внутрішнього аудитора (30,55 \%), компетентність аудитора щодо об’єкта перевірки $(13,9$ \%), доступність інформації, що підлягає перевірці (9,08 \%) (таблиця 2).

Таблиця 2

Оцінка ризику системи внутрішнього контролю

\begin{tabular}{|c|c|c|c|c|c|c|}
\hline $\begin{array}{l}\text { № } \\
\text { 3/п }\end{array}$ & Види ризику & $\begin{array}{l}0 \\
0 \\
\dot{0} \\
\lambda\end{array}$ & 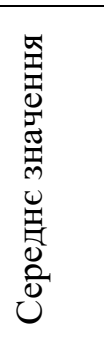 & 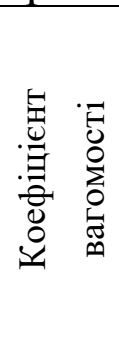 & 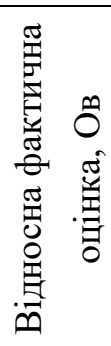 & 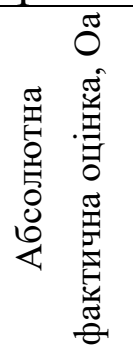 \\
\hline & Ризик систем внутрішнього контролю & & & & & \\
\hline 2 & Компетентність контрольного персоналу & 436,0 & 21,80 & 0,218 & 1 & 21,80 \\
\hline 4 & $\begin{array}{c}\text { Розподіл повноважень і обов’язків працівників } \\
\text { служби внутрішнього аудиту }\end{array}$ & 260,0 & 13,00 & 0,130 & 1 & 13,00 \\
\hline 8 & Правильність відображення операцій в обліку & 257,0 & 12,85 & 0,129 & 1 & 12,85 \\
\hline 5 & Підпорядкованість контрольного персоналу & 170,5 & 8,53 & 0,085 & 0,5 & 4,26 \\
\hline 9 & Частота виявлення помилок в обліку & 169,0 & 8,45 & 0,085 & 0,5 & 4,23 \\
\hline 3 & $\begin{array}{c}\text { Кадрова політика адміністрації та перепідготовка } \\
\text { кадрів }\end{array}$ & 159,0 & 7,95 & 0,080 & 0,5 & 3,98 \\
\hline 6 & Використання контрольних процедур & 154,5 & 7,73 & 0,077 & 0,5 & 3,86 \\
\hline 7 & Контроль за документами та їх зберіганням & 150,0 & 7,50 & 0,075 & 0,5 & 3,75 \\
\hline 1 & Методи адміністративного контролю & 125,0 & 6,25 & 0,063 & 0,5 & 3,13 \\
\hline 10 & Наявність спеціальних засобів контролю & 86,0 & 4,30 & 0,043 & 0 & 0,00 \\
\hline 11 & Інші фактори & 41,0 & 2,05 & 0,021 & 0 & 0,00 \\
\hline & Фактичний ризик & & & & & 143,02 \\
\hline & Ризик системи обліку & & & & & \\
\hline 2 & Організаційна система бухгалтерського обліку & 454,0 & 22,70 & 0,227 & 1 & 22,70 \\
\hline
\end{tabular}


ECONOMIC STRATEGIES FOR THE DEVELOPMENT OF SOCIETY

\begin{tabular}{|c|c|c|c|c|c|c|}
\hline 6 & $\begin{array}{c}\text { Рівень знань бухгалтерського персоналу облікових } \\
\text { інформаційних технологій }\end{array}$ & 318,0 & 15,90 & 0,159 & 1 & 15,90 \\
\hline 3 & Рівень комп’ютеризації обліку & 211,0 & 10,55 & 0,106 & 1 & 10,55 \\
\hline 10 & $\begin{array}{c}\text { Наявність заходів з обмеження несанкціонованого } \\
\text { доступу до комп’ютерних систем }\end{array}$ & 196,2 & 9,81 & 0,098 & 0,5 & 4,91 \\
\hline 1 & Вид діяльності клієнта & 188,0 & 9,40 & 0,094 & 0,5 & 4,70 \\
\hline 5 & $\begin{array}{c}\text { Наявність та функціонування спеціальних систем } \\
\text { контролю програмного забезпечення }\end{array}$ & 151,0 & 7,55 & 0,076 & 0,5 & 3,78 \\
\hline 8 & Частота збою програми & 130,2 & 6,51 & 0,065 & 0,5 & 3,26 \\
\hline 9 & Форми збереження бухгалтерської інформації & 128,2 & 6,41 & 0,064 & 0,5 & 3,21 \\
\hline 4 & Використання ліцензійних програм & 106,0 & 5,30 & 0,053 & 0 & 0,00 \\
\hline 11 & Інші фактори & 68,2 & 3,41 & 0,034 & 0 & 0,00 \\
\hline \multirow[t]{3}{*}{7} & Частота вимкнення електромереж & 47,2 & 2,36 & 0,024 & 0 & 0,00 \\
\hline & Фактичний ризик & & & & & 68,99 \\
\hline & Ризик не виявлення помилок аудитором & & & & & \\
\hline 1 & $\begin{array}{c}\text { Кваліфікація та практичний стаж внутрішнього } \\
\text { аудитора }\end{array}$ & 611,0 & 30,55 & 0,306 & 1 & 30,55 \\
\hline 4 & Компетентність аудитора щодо об'єкта перевірки & 278,0 & 13,90 & 0,139 & 1 & 13,90 \\
\hline 8 & Доступність інформації, що підлягає перевірці & 185,5 & 9,28 & 0,093 & 1 & 9,28 \\
\hline 2 & Освіта внутрішнього аудитора & 181,0 & 9,05 & 0,091 & 1 & 9,05 \\
\hline 7 & $\begin{array}{c}\text { Незалежність внутрішнього аудитора від } \\
\text { адміністрації }\end{array}$ & 177,0 & 8,85 & 0,089 & 0,5 & 4,43 \\
\hline 9 & Об'єктивність та надійність інформації & 173,0 & 8,65 & 0,087 & 0,5 & 4,33 \\
\hline 3 & $\begin{array}{c}\text { Участь аудитора в наукових конференціях, } \\
\text { практичних семінарах }\end{array}$ & 100,0 & 5,00 & 0,050 & 0,5 & 2,50 \\
\hline 10 & $\begin{array}{c}\text { Використання сучасних методик проведення } \\
\text { аудиту }\end{array}$ & 98,5 & 4,93 & 0,049 & 0 & 0,00 \\
\hline 6 & Період проведення аудиту & 82,0 & 4,10 & 0,041 & 0 & 0,00 \\
\hline 11 & Інші фактори & 60,0 & 3,00 & 0,030 & 0 & 0,00 \\
\hline \multirow[t]{2}{*}{5} & Мета та завдання аудиту & 55,0 & 2,75 & 0,028 & 0 & 0,00 \\
\hline & Фактичний ризик & & & & & 74,03 \\
\hline
\end{tabular}

Маючи узагальнені експертні оцінки вагомості факторів впливу на РО, РК і PB, можна отримати корисні практичні результати під час проведення аудиторських перевірок. Для цього необхідно мати фактичні оцінки щодо кожного фактора, який впливає на дані категорії ризиків.

Для того, щоб отримати ці фактичні оцінки щодо кожного фактора, необхідно скласти спеціальні таблиці-анкети, в яких величини ризиків за певними критеріями слід поділити на три категорії: високий ризик, середній i низький. Відповідно до цих категорій визначаються відносні фактичні оцінки 


\section{ECONOMIC STRATEGIES FOR THE DEVELOPMENT OF SOCIETY}

Ов (i) кожного і-го фактора впливу на відповідний елемент аудиторського ризику - АР. Абсолютну фактичну оцінку Оа (i) кожного і-го фактора розраховують, помноживши відносну оцінку Ов (i) на коефіцієнт вагомості відповідного фактора Кв (i), а фактичну оцінку Оф можна вирахувати за формулою:

$$
\underset{\mathrm{i}=1}{\mathrm{O}} \underset{\mathrm{i}}{\mathrm{O}=1} \underset{\mathrm{Oa}(\mathrm{i})}{\mathrm{n}}=\Sigma \text { Ов}(\mathrm{i}) \times \mathrm{Kв}(\mathrm{i})
$$

де $\mathrm{n}$ - кількість факторів оцінки відповідного елемента аудиторського ризику (РО, РК і РB).

Для здійснення розрахунку за значення АР обираємо послідовно три константи: 0,$01 ; 0,05 ; 0,1$. Значення показників РО та РК є змінними, які підлягають впливу різних факторів. За результатами проведеного аналізу розрахунки показали, що ризик не виявлення має становити лише 1,4 \%, якщо вимоги до аудиторського ризику є дуже високі (АР = 1\%). Відповідно за середніх і низьких вимог до аудиторського ризику, ризик не виявлення може становити $6,8 \%$ та 13,7 \%. Розрахований показник дозволяє регулювати обсяг вибірки та глибину дослідження.

Отже, проблеми щодо організації та проведення комп’ютеризованого аудиту можна вирішити за умови розробки конкретних напрямків автоматизації аудиту (розробити єдині методологічні основи обробки та узагальнення інформації при застосуванні аудиторських комп'ютерних програм; при визначенні аудиторського ризику застосовувати факторну модель) та вивчення практичного досвіду зарубіжних та вітчизняних аудиторських фірм. 


\section{ECONOMIC STRATEGIES FOR THE DEVELOPMENT OF SOCIETY \\ SECTION 14. MECHANISMS OF REGULATION OF THE ECONOMY}

\subsection{Concepts and dimensions of cultural distance as a tool of international economic regulation}

Cultural distance is a phenomenon of socio-psychological nature, however, its impact on economic processes is undeniable, because the diversity of approaches to management, business, features of interpersonal and inter-institutional interactions form complex relationships that can be analyzed and partially predicted.

Consequently, the collaboration of employees who have different cultural backgrounds leads to higher intraorganizational transaction costs as compared to organizational units whose members conform to one culture.

Lower CD in homogenous group cultures or between separate groups economizes on these costs and enables the putting together of disjoint skills and competencies more efficiently [384].

If we talk about the peculiarities of management in culturally heterogeneous groups (for example, in multinational companies or companies in which employees belong to different groups according to a certain system of cultural distance assessment), an important aspect is to study the basics of their socialization. That is, having the experience of education in certain cultural settings, to change the basic behavioral traits of man is extremely difficult. Differences are especially evident in the interstate aspect on such criteria as attitudes towards individualism or collectivism, gender bases, etc. Having formed a clear understanding of such differences, we can hope for the possibility of building a flexible management system that will take into account these features in both the processes of strategic and operational management of the company or other social group.

Socio-psychological studies, which are combined with management, show that joint socialization in groups leads to a decrease in intragroup variance in the values of cultural characteristics, such as norms of behavior, values, evaluation criteria, etc. (for example, [385-386]). 


\section{ECONOMIC STRATEGIES FOR THE DEVELOPMENT OF SOCIETY}

Consider the basic approaches to understanding the actual the term "cultural distance".

Cultural distance is a function of differences in values and communication styles that are rooted in culture (demographic OR organizational). Distance is created when individuals or groups perceive that their values and communication styles differ from others [387].

It is important to realize the existence of this difference, because globalization carries important elements of the so-called "erasure" of cultural borders and the unification of values and cultural features in the international aspect. However, despite the existence of certain homogenizing tendencies, the cultural distance today is especially noticeable between certain groups of countries.

Cultural distance is a difference in human values that are rooted in national culture, which affect individuals' attitude and behavior [388].

The peculiarities of cultural identification lie deep in the consciousness of each person and determine his behavior in social interactions. Cross-cultural differences persist even in times of intensified interstate interaction.

Cultural distance is a differences of cultural values amongst countries, organizations, and stakeholders [389]

We can talk not only about the cultural distance between representatives of different countries, but also about the cultural distance between organizations or different social groups. That is, taking for evaluation analytical data on estimates of cultural distance, which are based on a simplified assumption of the relative homogeneity of the population, it is necessary to understand their average.

Researchers insist on the need to form such management structures that take into account socialization as the possibility of reducing internal organizational transaction costs between employees of organizations and between individual groups [390].

Some researchers focus on the geographical distance between countries (8), differences in economic development and welfare (9), differences in public and corporate governance systems such as institutional distance (10), linguistic distance 


\section{ECONOMIC STRATEGIES FOR THE DEVELOPMENT OF SOCIETY}

(11), etc. However, in our opinion, cultural distance is a generalization of all the above, because it assesses the consequences of the degree of their manifestation.

Speaking of certain definitions, it is important to determine the methodological tools for their multi-criteria evaluation. The most common method is the model of culture of Hert Hofstede [395], which is based on value indicators that characterize the national culture:

1. Power Distance Index (Power Distance Index - PDI)

2. Individualism / collectivism (Individualism index - IDV)

3. Masculity index (MAS)

4. Uncertainty Avoidance Index (UAI)

Together, they form a four-dimensional model of differences between national cultures. The country in the model is characterized by an estimate for each of the four dimensions.

The "distance of power" determines how the difference in the social aspect is perceived by individuals.

Studies of this indicator (PDI) show the nature of expectations and relationships between subordinates and management, not only in business relationships, but also, for example, in the family, schools, etc.

In countries with low levels of distance from government, respondents prefer a consultative nature of cooperation, while great value is given to countries where the relationship between different levels in the hierarchy of power is based on autocratic or paternalistic scenarios and society uncritically accepts the presence.

Power distance can therefore be defi ned as the extent to which the less powerful members of institutions and organizations within a country expect and accept that power is distributed unequally.Institutions are the basic elements of society, such as the family, the school, and the community; organizationsare the places where people work [396].

Summarizing the conclusions of the researchers, we can form the following comparison of key features related to the distance of power, which is based on the assessment of 76 states (Table 1). 


\section{ECONOMIC STRATEGIES FOR THE DEVELOPMENT OF SOCIETY}

Table 1

Key Differences Between Small- and Large-Power-Distance Societies

\begin{tabular}{|c|c|}
\hline Низький рівень «дистанції влади» (PDI) & Високий рівень «дистанції влади» (PDI) \\
\hline $\begin{array}{c}\text { Mostly wealthier countries with a large } \\
\text { middle class. }\end{array}$ & $\begin{array}{c}\text { Mostly poorer countries with a small middle } \\
\text { class. }\end{array}$ \\
\hline All should have equal rights. & The powerful should have privileges. \\
\hline $\begin{array}{c}\text { Power is based on formal position, expertise, } \\
\text { and ability to give rewards. }\end{array}$ & $\begin{array}{c}\text { Power is based on tradition or family, } \\
\text { charisma, and the ability to use force. }\end{array}$ \\
\hline $\begin{array}{c}\text { There are small income differentials in } \\
\text { society, further reduced by the tax system. }\end{array}$ & $\begin{array}{c}\text { There are large income differentials in } \\
\text { society, further increased by the tax system }\end{array}$ \\
\hline $\begin{array}{c}\text { Decentralization is popular. } \\
\text { Managers rely on their own experience and } \\
\text { on subordinates. }\end{array}$ & $\begin{array}{c}\text { Managers rely on superiors and on formal } \\
\text { rules. }\end{array}$ \\
\hline $\begin{array}{c}\text { Inequalities among people should be } \\
\text { minimized }\end{array}$ & $\begin{array}{c}\text { Inequalities among people are expected and } \\
\text { desired. }\end{array}$ \\
\hline $\begin{array}{c}\text { Less powerful people are emotionally } \\
\text { comfortable with inter dependence. }\end{array}$ & $\begin{array}{c}\text { Less powerful people are emotionally } \\
\text { polarized between } \\
\text { counterdependence. }\end{array}$ \\
\hline $\begin{array}{l}\text { Sourcendence } \\
\text { and }\end{array}$ \\
\hline
\end{tabular}

Source: formed on the basis of [396]

It was found that the countries of Eastern Europe and Latin America, Asia and Africa are characterized by a high level of distance from power, ie, members of such societies are ready and even expect inequality of social groups, a rigid social hierarchy (Malaysia -104, Saudi Arabia - 95, Philippines - 94, Russia - 93).

At the same time for the countries of Western Europe and America - low. This means that in society there is no axiomatic perception of inequality as a natural phenomenon (Austria -11, Denmark - 18, New Zealand - 22, Ireland - 28, Iceland - 30).

As for Ukraine, it received a score of 92, which puts it alongside Romania, Moldova and Montenegro.

A conclusion was obtained regarding cross-cultural interactions, which was reduced to the fact that representatives of different cultural groups in the same social models of interactions (for example, the model "supervisor-subordinate", "teacherstudent", "senior-junior", etc. .e.) demonstrate different behaviors, which in turn affects the effectiveness of the management models used. 


\section{ECONOMIC STRATEGIES FOR THE DEVELOPMENT OF SOCIETY SECTION 15. MICRO AND MACRO ECONOMY}

\subsection{The formation of the energy saving management mechanism of regional system based on the experience of European Union countries}

The development and implementation of the energy efficiency strategy for regions is the relevant issues for all developed countries, regardless of their state structure and level of economic development. The main directions of the regional energy-saving policy, as well as mechanisms and tools for its implementation, are specific to each country, which is due to the energy intensity of GDP, the potential of alternative energy sources, the existing regional strategy for implementing energy-saving measures, and the level of implementing energy-efficient innovations at enterprises. Consider the main policy instruments to stimulate energy saving in the EU.

In June 2012, the EU Directive on Energy Efficiency (EU Directive 2012/27/EU) was adopted, which defines a common set of measures to improve energy efficiency and contains the following provisions: building renovation - EU member states must renovate at least $3 \%$ of the area of buildings heated; increase in efficiency of energy systems; energy audit performance; increasing the efficiency of heating systems; development of financing mechanisms [399].

British scientists, such as Needleman, 1965, Thomas i Storey, 1971, Brown, 1972, Sadler, Archer and Owen, 1973, studied important economic factors in the formation of effective regional policy [398, 400, 404-405].

In the current state of development, scientists propose to introduce state management mechanisms through a system of incentives, benefits and financing mechanisms for programs related to energy saving and energy efficiency. However, the studies on the development of a mechanism for the formation of a regional energy saving management system, taking into account the experience of European countries, remain almost without attention [397].

Based on the data from the European Commission's website Keep.eu [403], we have analyzed existing international projects for the development of regional energy efficiency policy and support enterprises implementing energy saving measures. 


\section{ECONOMIC STRATEGIES FOR THE DEVELOPMENT OF SOCIETY}

Keep.eu serves the entire professional audience that needs consolidated data on projects and beneficiaries of cross-border, transnational and interregional cooperation programs of the European Union. As the study shows, project implementation requires a holistic, effective system of evaluation of results by certain criteria (Table 1).

Table 1

Components of the Project Results Assessment System based on defined criteria

\begin{tabular}{|c|c|c|c|c|}
\hline Project title & \multicolumn{3}{|c|}{ Business criteria for assessing project results } \\
\hline & $\begin{array}{c}\text { Smart technology } \\
\text { development }\end{array}$ & $\begin{array}{c}\text { Implementation } \\
\text { of financial } \\
\text { instruments }\end{array}$ & $\begin{array}{c}\text { Interregional } \\
\text { cooperation } \\
\text { (integration entities) }\end{array}$ & $\begin{array}{c}\text { Intellectual } \\
\text { specialization } \\
\text { strategies }\end{array}$ \\
\hline $\begin{array}{c}\text { Smart Clusters for Smart } \\
\text { Growth through Joint } \\
\text { Business Intelligence (4 } \\
\text { Smart Growth) }\end{array}$ & $\checkmark$ & & $\checkmark$ & $\checkmark$ \\
\hline $\begin{array}{c}\text { Cross-border Cooperation } \\
\text { and Competitiveness for } \\
\text { SMEs (3C4SME) }\end{array}$ & & $\checkmark$ & $\checkmark$ & \\
\hline $\begin{array}{c}\text { Access to Microfinance for } \\
\text { Small and Medium-sized } \\
\text { Enterprises (ATM for } \\
\text { SMEs) }\end{array}$ & & & & \\
\hline $\begin{array}{c}\text { Baltic Entrepreneurship } \\
\text { Laboratories (BELT) }\end{array}$ & $\checkmark$ & $\checkmark$ & $\checkmark$ & $\checkmark$ \\
\hline $\begin{array}{c}\text { Stimulating smart } \\
\text { specialization ecosystem } \\
\text { through engaging SMEs in } \\
\text { open innovation processes } \\
\text { ( BSR Stars S3) }\end{array}$ & $\checkmark$ & & $\checkmark$ & \\
\hline $\begin{array}{c}\text { Boost regional } \\
\text { Entrepreneurship by } \\
\text { Enabling cross border } \\
\text { cooperation }\end{array}$ & & & & \\
\hline Having analyzed & & & & \\
\hline
\end{tabular}

Having analyzed a number of projects in the field of energy efficiency, digitalization, "smart innovation", which are being implemented in the European Union countries, it would be advisable to use the following instruments of regional policy development in the regions of our country:

- formation of clusters based on the green economy in order to spread the use of alternative energy sources and smart technology implementation.;

- Creating coaching networks, developing the potential of startups and project incubators for energy efficiency;

- Cooperation development between enterprises, research centers and universities with the purpose of technology transfer, introduction of social and eco innovation; 


\section{ECONOMIC STRATEGIES FOR THE DEVELOPMENT OF SOCIETY}

- The support of technological and applied studies in the field of energy efficiency, improvement of production capabilities;

- Implementation of services for the development and promotion of entrepreneurship in the region, formation of creative, informational infrastructure for business support;

Transition from the use of public funds for innovation to attracting crowdfunding and crowdsourcing for financing.

An effective energy-saving management system can be determined by studying the external and internal environment factors of the management facility and the specifics of energy-saving measures. When creating an energy-saving management system, it is reasonable to solve the following tasks [400, 401-402, 404]: to form an organizational management structure; improve the efficiency and effectiveness of the management system by creating a direct link between management bodies and participants in energy saving projects; to establish cooperation between coimplementers of energy saving activities, which entails coordination of the energysaving project participants' goals and adjustments to the target setting; to increase the responsibility of management bodies and each individual energy saving project implementer for the results and deadlines of energy-saving activities and projects.

The stakeholders of regional energy saving management specialists and scientists are focused on a number of problems and issues: ensuring that strategic guidelines for developing energy-saving programs and reforms at the state and regional levels are interlinked; creating conditions for effective interaction of public authorities in addressing the problems of implementing energy-saving measures; defining the main vectors of the regional investment policy; use methods of effective regional energysaving management; improving the regional energy-saving management system.

An important vector for solving these problems is ensuring conditions for balancing practical and theoretical aspects of regional energy saving management. These problems should be solved by forming a certain regional energy saving management system. 


\section{ECONOMIC STRATEGIES FOR THE DEVELOPMENT OF SOCIETY}

Based on the results of the study of global trends in energy-saving management at the regional level, we propose a mechanism for the formation of a regional energysaving management system as a set of principles, goals, objectives, functions, subjects, and processes, taking into account the existing needs and opportunities for implementing measures related to energy saving. The elements of a regional energy saving the system of management formation mechanism should be suggested: objectives: (economic, social; environmental), tasks (organizational; institutional; infrastructural, investment-related; innovative; socio-economic; environmental; informational), principles (rational use of resources; scientific rationale management; public-private partnership, adaptation and mobility), management subjects, management functions; management tools. Regional energy saving management process is a purposeful and manageable process of transformations in the field of energy saving.

The current international projects on development of regional energy efficiency policy and support of enterprises implementing energy saving measures in the European Union countries were analyzed. The elements of the system of evaluation of the project results by the following criteria are given: development of smart technology, implementation of financial instruments, interregional cooperation, strategies of intellectual specialization. According to the results of study of world tendencies of energy saving management on the level of the region, we proposed a mechanism for forming a regional energy saving management system as a set of principles, goals, objectives, functions, subjects, process, taking into account the current needs and opportunities for implementing energy saving measures. 


\section{ECONOMIC STRATEGIES FOR THE DEVELOPMENT OF SOCIETY \\ SECTION 16. QUANTITATIVE METHODS IN ECONOMICS}

\subsection{Econometric analysis of regional grain production In Ukraine}

Cereals are wide spread and strongly demanded crops in the world. The Food and Agriculture Organization of the United Nations (FAO) determined the level of grain provision to be one of the basic indicators of food security. So far, Ukrainian farmers belong to Top 10 producers and exporters of cereals at the global scale. Overall, they harvested record yields in 2018. At present, the national agrarian sector is the most stable in Ukrainian economy. Its contribution to the total GDP increased from $7 \%$ in 2007-2009 up to $12 \%$ in 2015-2018 [406]. This achievement was largely created by the national grain producers. Given the natural climatic conditions, the major grain crops in Ukraine are wheat, barley, and maize.

Namely, Ukraine harvested 26209 thousand tons of wheat which was less than in China, India, Russia, the USA, France, Canada, Australia, and Pakistan. Meanwhile, Ukraine covered $7.3 \%$ of wheat export at $\$ 3$ billion that corresponded to the sixth world rank after Russia, Canada, the USA, France, and Australia. The main importers of Ukrainian wheat were Spain and Italy in Europe, Indonesia and Bangladesh in Asia, as well as Egypt, Morocco, and Tunisia in Africa.

Ukrainian farmers gathered 8285 thousand tons of barley which was less than in Russia, Australia, Germany, and France. At the same time, Ukraine encompassed 8.9\% of barley export at $\$ 0.68$ billion that meant the fourth global rank after Australia, France, and Russia. The prime buyers of Ukrainian barley were Spain in Europe, Saudi Arabia and China in Asia, as well as Libya and Algeria in Africa.

Ukraine harvested 24669 thousand tons of maize which was less than in the USA, China, Brazil, Argentina, India, Indonesia, and Mexico. However, Ukraine occupied $10.3 \%$ of maize export that complied with the fourth world rank after the USA, Argentina, and Brazil. The core importers Ukrainian maize were the Netherlands, Spain, and Italy in Europe, China and Iran in Asia, as well as Egypt, Tunisia, and Libya in Africa. 


\section{ECONOMIC STRATEGIES FOR THE DEVELOPMENT OF SOCIETY}

Outputs of Ukrainian crop production in domestic and international markets accumulate results of 24 regions. High volatilities of the natural and market conditions suppose regular monitoring of dynamics and effectiveness of grain production since it influences the State budget, welfare of rural population, and competitiveness of Ukrainian agriculture. In particular, for the past decade the cereals profitability fluctuated from $1.5 \%$ to $43.1 \%$. Simultaneously, the respective grain harvests varied from 39.3 to 70.1 million tons [406]. Thus, economists had to face the listed pressing issues and provide quantitative analysis of regional grain production. The relevant research was conducted by numerous scientists [407-411].

The most promising approach to improving agribusiness was connected with applying mathematical methods and information technologies [412, 413]. In particular, econometric methods maintained reliable solutions for agricultural problems based on diverse contemporary software [414]. It is worth mentioning that the most valuable outcomes focused on Ukrainian agrarian sector proposed not only econometric calculations but also gave detailed recommendations on improving productivity of the national agriculture $[415,416]$.

Nevertheless, there is still an open question concerning the quantitative evaluation of the regional grain production affecting further development of the cereals segment in Ukrainian agriculture. To tackle such issue this research was aimed at:

- defining econometric trends in total harvests, sown areas, and yields of cereals at the regional level;

- comparing dynamics of wheat, barley, and maize production relative to the national indicators;

- revealing changes in growing grain crops at the regional level.

The methodical framework of this study was formed by simple linear regressions or time series models [414]. With regard to task 1 it made possible to compute annual trends which described dynamics of grain production. Meanwhile, the corresponding coefficients of variation assessed stability of the found indicators. With regard to task 2 the selected approach determined a relative regional contribution to the national grain production and evaluated its stability via standard deviation. Finally, in the context of 


\section{ECONOMIC STRATEGIES FOR THE DEVELOPMENT OF SOCIETY}

task 3 the explored distribution of the sown areas under wheat, barley, and maize grounded contemporary trends over their regional harvests.

The identified technique is appropriate to each of 24 Ukrainian regions. All of them but with different shares participate in growing cereals. For example, this study dealt with the detailed econometric analysis of Dnipropetrovsk region. Given the volatile economic environment typical of Ukrainian farming, the statistical samples reduced to the period of 2014 to 2018 . The research calculations were run through the tools of the spreadsheet LibreOffice Calc.

Thereby, Table 1 aggregated data on dynamics of grain production in Dnipropetrovsk region. It clarified an upward trend in the regional grain production with an annual average increase by 5.16 thousand tons. The bumper harvest of 3866.2 thousand tons was gathered in 2015. According to the computed coefficients of variation, such trend is more stable compared to the national progress. However, it was provided largely by maize which had an annual increment by 71.49 thousand tons and the bumper harvest of 1329.7 thousand tons in 2018. On the contrary, the average wheat harvest of 1691.84 thousand tons was less by $16 \%$ than the maximum of 1996.6 thousand tons in 2015. Wheat and barley had also alarming drops in their harvests by 43.87 thousand tons and 24.75 thousand tons per annum. Besides, the current average barley harvest of 650 thousand tons equaled only $68.4 \%$ of the record 951.5 thousand tons in 2006 . In general, annual shrinks of sown areas under cereals by 13.9 thousand ha were the promising signals (see Table 1). Really, Ukraine belongs to the Top 5 countries by the share of cultivated areas. That is why such land conservation will contribute to restoring soil fertility. The higher coefficient of variance concerning sown areas of wheat and maize in Dnipropetrivsk region meant more optimal crop turnover compared to the state level. 
Table 1.

Absolute dynamics of regional grain production

\begin{tabular}{|c|c|c|c|c|}
\hline \multirow{2}{*}{ Indicators } & \multirow{2}{*}{$\begin{array}{c}\text { Average } \\
\text { value }\end{array}$} & \multirow{2}{*}{$\begin{array}{c}\text { Annual } \\
\text { trend }\end{array}$} & \multicolumn{2}{|c|}{ Coefficient of variance, $\%$} \\
\hline & & & region & state \\
\hline \multicolumn{5}{|c|}{ Production, thousand tons } \\
\hline cereals & 3546.14 & 5.16 & 5.70 & 5.99 \\
\hline wheat & 1691.84 & -43.87 & 11.93 & 4.17 \\
\hline barley & 650.96 & -24.75 & 10.07 & 9.48 \\
\hline maize & 1120.34 & 71.49 & 13.73 & 17.27 \\
\hline \multicolumn{5}{|c|}{ Sown area, thousand ha } \\
\hline cereals & 1135.94 & -13.9 & 3.23 & 1.14 \\
\hline wheat & 502.04 & -2.83 & 11.26 & 5.14 \\
\hline barley & 269.80 & -7.67 & 5.32 & 8.38 \\
\hline maize & 322.80 & -5.35 & 6.54 & 5.17 \\
\hline \multicolumn{5}{|c|}{ Yield, centners per ha } \\
\hline cereals & 31.24 & 0.41 & 4.85 & 5.84 \\
\hline wheat & 33.76 & -0.66 & 6.58 & 4.74 \\
\hline barley & 24.14 & -0.26 & 8.82 & 5.90 \\
\hline maize & 34.94 & 2.71 & 17.42 & 14.56 \\
\hline
\end{tabular}

The world experience convinced that agriculture should reduce utilization of the natural resources but paired with the increasing productivity. Table 1 reported that regional yields of cereals raised by 0.41 centners per ha per annum. Such progress was more stable by 1 percentage point with regard to the national level. Unfortunately, the average yield of 31.24 centners per ha was less than the maximum 35,2 centners per ha in 2001. Like for the total production, the mentioned output was provided by maize with an annual yield increment by 2.71 centners per ha and the record 43 centners per ha in 2018. On the contrary, unfavorable climate conditions and violation of the agrarian technologies caused the negative trend of decreasing regional yields of wheat and barley by 0.66 centners per ha and 0.26 centners per ha, respectively. It resulted in poor wheat yield of 30 centners per ha in 2018 that was less by $30.2 \%$ than the exemplary 43 centners per ha in 2001. Similarly, barley yield dropped to 21 centners per ha that was less by $31.6 \%$ compared to the exemplary 30.7 centners per ha in 2001 . 


\section{ECONOMIC STRATEGIES FOR THE DEVELOPMENT OF SOCIETY}

Table 2 contained the calculated results to task 2 . It revealed a stable contribution of the region in question to the state production of barley and maize with the relative shares of $7.68 \%$ and $4.04 \%$. Wheat growing appeared to be less optimistic. Really, its regional contribution shrank by 0.19 percentage point per annum and was the most unstable among the other grain crops.

Table 2.

Relative dynamics of regional grain production

\begin{tabular}{|l|c|c|c|}
\hline \multicolumn{1}{|c|}{ Indicators } & $\begin{array}{c}\text { Average } \\
\text { value, } \%\end{array}$ & $\begin{array}{c}\text { Annual } \\
\text { trend, p.p. }\end{array}$ & $\begin{array}{c}\text { Standard } \\
\text { deviation, p.p. }\end{array}$ \\
\hline Share of production & & & \\
\hline wheat & 6.63 & -0.19 & 0.68 \\
\hline barley & 7.68 & 0.003 & 0.42 \\
\hline maize & 4.04 & 0.03 & 0.58 \\
\hline Share of sown area & & & \\
\hline wheat & 7.83 & -0.13 & 0.59 \\
\hline barley & 9.90 & 0.21 & 0.35 \\
\hline maize & 7.34 & -0.16 & 0.45 \\
\hline Share of yield & & & \\
\hline wheat & 84.63 & -1.03 & 3.24 \\
\hline barley & 77.70 & -1.6 & 4.91 \\
\hline maize & 55.16 & 1.54 & 8.16 \\
\hline
\end{tabular}

The regional shares of areas under wheat and maize decreased by 0.13 percentage point and 0.16 percentage point per annum and equaled on average $7.83 \%$ and $7.34 \%$. By contrast, the shares of regional areas under barley raised by 0.21 percentage point per annum up to $10.3 \%$ in 2018 . It implied that other Ukrainian regions gradually diminished this crop but Dnipropetrovsk farmers filled the emerging gap in the national husbandry.

The study of relative yields of wheat and barley resulted in a disappointing conclusion on increasing backlog of the regional productivity by 1.03 percentage point and 1.6 percentage point. So far, the yields of wheat and barley in Dnipropetrovsk region appeared to be less than the national level by $19.6 \%$ and $29.1 \%$. Simultaneously, maize 


\section{ECONOMIC STRATEGIES FOR THE DEVELOPMENT OF SOCIETY}

yield amounted to $55.2 \%$ compared to the average in Ukraine. However, there was an upward trend by 1.54 percentage point per annum to bring the regional maize yield closer to the national indicator.

Table 3 combined calculations referred to task 3 . The analyzed data showed the essential regional prevalence of wheat among the other cereals with an annual rise by 0.31 percentage point. It was associated with shrinking areas under barley and maize. Meanwhile, the rest of cereals occupied only $3.65 \%$ of the cultivated area in Dnipropetrovsk region.

Table 3.

Dynamics of specialization of regional grain production

\begin{tabular}{|l|c|c|c|}
\hline $\begin{array}{c}\text { Shares of sown area } \\
\text { under cereals }\end{array}$ & $\begin{array}{c}\text { Average } \\
\text { value, } \%\end{array}$ & $\begin{array}{c}\text { Annual } \\
\text { trend, p.p. }\end{array}$ & $\begin{array}{c}\text { Standard deviation, } \\
\text { p.p. }\end{array}$ \\
\hline Wheat & 44,13 & 0,31 & 3,84 \\
\hline Barley & 23,77 & $-0,39$ & 1,40 \\
\hline Maize & 28,46 & $-0,13$ & 2,35 \\
\hline
\end{tabular}

Official statistics for 2018 informed that Dnipropetrovsk region occupied fifth, third and eleventh ranks among the regional producers of wheat, barley and maize. For 2017 they ranked fourth, third and tenth, as well as fifth, third ra ninth in 2016 [406]. The performed monitoring over the regional production of cereals revealed an urgent need for enhancing effectiveness of farming. Its avenues can be specified as follows.

Firstly, the share of grain production by agricultural enterprises of Dnipropetrovsk region reached $63.2 \%$ which was less by 16.9 percentage point than the average indicator at the national level. Similar indicators of Top 4 cereals producers such as Vinnytsya, Odessa, Poltava, and Kharkiv regions were $85 \%, 71.8 \%, 83.6 \%$, and $70.8 \%$ [406]. Thus, the farmers of Dnipropetrovsk region should focus on integration and cooperation to boost effectiveness of growing cereals.

Secondly, the technical provision of farmers in Dnipropetrovsk region was far from satisfying. In particular, there were 36 grain and 10 combine harvesters per 10000 ha of the cultivated area by 2018 . These indicators ranked sixteenth and eighth among 


\section{ECONOMIC STRATEGIES FOR THE DEVELOPMENT OF SOCIETY}

Ukrainian regions [406]. Therefore, the relevant machinery upgrading would have a positive impact on enhancing the regional grain production via cutting loss of the cereals harvest.

Thirdly, application of chemical fertilizers under cereals in Dnipropetrovsk region was $84 \mathrm{~kg}$ per ha for 2018. It ranked twentieth around the country and was less by $26 \mathrm{~kg}$ than the average national indicator [406]. Thus, to offset the insufficient precipitation farmers of Dnipropetrovsk region should optimize drought management and apply more nitrate and phosphate fertilizers under grain crops.

Overall, the proposed technique of econometric analysis over dynamics and stability of regional cereals production would provide the justified quantitative reference points of

- microeconomic development of growing wheat, barley, and maize at the expense of implementing innovative technologies;

- macroeconomic progress in the grain segment of Ukrainian agriculture and the global food security system by means of raising its structural part in the world production and export.

The further monitoring of the regional grain production using mathematical methods and information technologies will be beneficial for strategic support of Ukrainian farmers. 


\section{ECONOMIC STRATEGIES FOR THE DEVELOPMENT OF SOCIETY}

\subsection{The modeling of the growth rate of fixed assets in the process of innovative production development}

The innovative development is characterized by the fact that different technical and economic production indicators differ in growth rates. Of course, the best ratio between them is the option of innovative development, when the growth rate of profit exceeds the growth rate of production, which in turn is greater than the growth rate of the value of fixed assets.

For the analysis of dynamics of fixed assets it is appropriate to use the following scheme of their renewal (service life of Fixed Assets for simplification is considered equal to 3 years):

\begin{tabular}{|c|c|c|c|c|c|}
\hline $\mathbf{t}$ & 0 & 1 & 2 & 3 & $\ldots$ \\
\hline $1 \rightarrow$ & $\eta^{3}$ & $\eta^{3}$ & $\eta^{3}$ & $\ldots$ \\
\hline$\eta$ & $\eta \rightarrow$ & $\eta^{4}$ & $\eta^{4}$ & $\ldots$ \\
\hline$\eta^{2}$ & $\eta^{2}$ & $\eta^{2} \rightarrow$ & $\eta^{5}$ & $\ldots$ \\
\hline
\end{tabular}

Fig. 1. The scheme of Fixed Asset renovation

On the Fig. 1 the time moment $t=1$ fixed assets with a relative value of 1 , which were used last year, are disposed of and replaced by new value $\eta^{3}$, where the symbol $\eta$ the growth rates of fixed assets are indicated. Over time, the upgrade process continues similarly. According to the scheme, the total Fixed Assets also grow each passing year $\eta$.

It is reasonable to assume that the main sources of investment for the purchase of new assets are the depreciation and profit, the above scheme makes it possible to determine certain parameters of Fixed Assets growth. In particular, the growth rate of health is determined by the equation:

$\eta^{T}=\left(\propto r+a_{f}\right)\left(1+\eta+\eta^{2}+\cdots+\eta^{T-1}\right)$,

where $T$ - life service of Fixed Assets, $r-$ Fixed Assets profitability 


\section{ECONOMIC STRATEGIES FOR THE DEVELOPMENT OF SOCIETY}

$\propto-$ share of capitalized profit.

Due to the fact that such complex equations are not solved in an analytical form, they can be solved by a numerical iterative way. As it turned out, a good enough approximation to determine the growth rate of Fixed Assets is the following:

$\eta=1+1,6 \propto \sigma$

If for example $\propto \sigma=0,04$, we obtain $\eta=1,064$.

It should be noted that the rate does not depend on the term $T$, when they change within a fairly wide range. This is important for business practice, where there is a whole system of terms T. It is important to take into account in addition to fixed assets, as well as working capital. In many enterprises, their share may even exceed the share of fixed assets.

In this version the equation for determining the rate is complicated and takes the form:

$$
\eta^{T}=\left(\propto r+\gamma_{1} a_{\mathrm{H}}\right)\left(1+\eta+\eta^{2}+\cdots+\eta^{T-1}\right)+\gamma_{2},
$$

where $\gamma_{1}-$ share of fixed assets;

$\gamma_{2}-$ share of working capital.

In alternatives, this equation is converted into simpler expressions. In the absence of working capital, ie when $\gamma_{1}=1, \gamma_{2}=0$, the equation becomes equivalent to the previously considered equation for fixed assets.

In the case of insignificant fixed assets, the equation is as follows: $\eta=1+\propto r$.

That is, we immediately have the value of the growth pace. The comparison of alternative structures of production assets shows that the growth rate of production assets differs by 1.6 times. This can be attributed to the effect of depreciation. Depreciable funds are not depreciated. This effect is manifested in the turnover of depreciation. After all, they are accrued from the beginning of the introduction of new fixed assets to the end of period T. In this interval, depreciation funds can be used, in other words, go into financial circulation.

The above scheme of Fixed Assets the movement in the process of production development can be used to determine the growth rate of production, if you involve the 


\section{ECONOMIC STRATEGIES FOR THE DEVELOPMENT OF SOCIETY}

rate of return. The latter makes it possible to determine the volume of production through the cost of health using the rate of return. Directly, the equation for determining the growth rate of production is as follows:

$$
\eta_{P}=\eta+K_{\text {in }}^{F} K_{o n}
$$

where $\eta_{P}$ - production growth rate;

$K_{\text {in }}^{F}$ - indicator of innovation in the production resource "funds";

$K_{o n}$ - the rate of Fixed Assets renewal.

The introduced innovation indicator is calculated as follows:

$$
K_{\text {in }}^{F}=\frac{f_{2}}{f_{1}}-1,
$$

where $f_{1}$ - basic return on assets calculated for existing Fixed Assets;

$f_{2}-$ return on assets in the version of new innovative equipment.

The equation also uses the renovation rate - the ratio of the cost of new Fixed Assets to the base (primary) cost of all Fixed Assets. This indicator is determined by the growth rate of Fixed Assets and the timing of their use and is calculated as follows:

$$
K_{\text {on }}=\frac{\eta^{T}}{\eta^{T}-1}(\eta-1) \text {. }
$$

Initially this formula was proposed by the American economist Domar in 1967 and was developed later on [417].

For the above example of the update at $\mathrm{T}=3$, the update factor $\mathrm{K}$ on is equivalent to a ratio equal to:

$$
K_{\text {on }}=\frac{\eta^{3}}{1+\eta+\eta^{2}} .
$$

Directly quantitative values $K_{\text {on }}$ are given in the Table 1 :

Table.1

The values of reneval rate $K_{\text {on }}$ depending on the service life of Fixed Assets and their growth rates $\eta$

\begin{tabular}{|c|c|c|c|c|c|}
\hline$T, \eta$ & 1,00 & 1,02 & 1,04 & 1,06 & 1,08 \\
\hline 5 & 0,2000 & 0,2121 & 0,2246 & 0,2374 & 0,2505 \\
\hline 10 & 0,1000 & 0,1113 & 0,1233 & 0,1359 & 0,1490 \\
\hline 15 & 0,0667 & 0,0778 & 0,0899 & 0,1030 & 0,1168 \\
\hline 20 & 0,0500 & 0,0612 & 0,0736 & 0,0872 & 0,1019 \\
\hline
\end{tabular}




\section{ECONOMIC STRATEGIES FOR THE DEVELOPMENT OF SOCIETY}

The analysis of tabular data shows that at a constant growth rate of funds $\eta$ renewal rate $K_{o n}$ is shorter for larger fixed assets life terms $T$. In turn, for constant terms $T$, the refresh rate is higher for higher rates $\eta$.

For a simpler interpretation of the relationship between the update factor and these two factors ( $\mathrm{T}$ and $\eta$ ), we have developed the following dependence:

$$
K_{\text {on }}=\frac{1}{T}+0,63 \times(\eta-1) .
$$

Numerical analysis showed that within the data contained in the table, the proposed dependence on the results is quite adequate to the above theoretical dependence. Carry out, for example, calculations for the data contained in the second tape of table 1: $T$ $=10 ; \eta=1,02 ; \eta=1,04 ; \eta=1,06 ; \eta=1,08$. According to the approximate formula,

the following results are obtained: $K_{o n}=0,1126$ (tabular data- 0,1113 ) ; $K_{o n}=$ 0,1252 (tabular data-0,1233); $K_{\text {on }}=0,1378$ (tabular data- 0,1359); $K_{\text {on }}=0,1504$ (tabular data- 0,1490). The comparison of obtained data for the indicator $K_{o n}$ from the table data confirms, that the approximate formula accurately characterizes the renewal rate. The importance of the approximate formula is that it, due to its structure additivity it transparently reflects the influence of each of the two factors on $K_{\text {on }}$. The update factor contains two components. The first of them is equal to the depreciation rate and is lower for longer regulatory life of the equipment. The second component is proportional to the growth rate of Fixed Assets with a coefficient of proportionality 0,63. Because of this, the renewal rate for higher Fixed Assets growth rates is higher.

It should be noted that the renewal rate, in which the main role is played by the service life of the health facility, is significantly used in the equation to determine the growth rate of production. The corresponding component of the right-hand side of the equation characterizes the impact of innovation renewal on production results. For example, consider two options for changing the return on assets:

$$
\begin{aligned}
& \frac{f_{2}}{f_{1}}=1,2 ; \\
& \frac{f_{2}}{f_{1}}=0,8 .
\end{aligned}
$$


ECONOMIC STRATEGIES FOR THE DEVELOPMENT OF SOCIETY

Thus terms of service of Fixed Assets are considered equal $T=10$ (years), the growth rate of Fixed Assets $-\eta=1,08$ ( $8 \%$ annual growth).

The corresponding renewal rate according to the table is:

$$
K_{\text {on }}=0,1490
$$

Then in the first version we will receive an update:

1) $\eta_{P}=1,08+0,2 \times 0,1490=1,1098$

2) In the second version of the renewal as a result of calculations we obtain:

$$
\eta_{P}=1,08-0,2 \times 0,1490=1,0502
$$

Thus, the reduction in return on investment significantly reduces the growth rate of production and it will be even lower than the growth rate of Fixed Assets. This is a negative trend. But such a technique can be effective in other indicators - profit, productivity, environmental parameters, etc. The introduced new indicator of innovation is important for modeling innovative processes of health update. The peculiarity of this indicator is that it is not the result of logical reasoning, but arose as a parameter of the corresponding equation for the rate. Its importance is also that the focus is on any type of equipment of the production system, ie the micro-level is considered. Each type of equipment of the production system has "its" technical progress and therefore requires individual tactics of renewal.

As a rule, in the accepted economic and mathematical models production as a whole is considered as an independent economic object. The need for more detail is a necessary condition for deepening the analysis of innovation processes, in particular, equipment upgrades. 


\section{ECONOMIC STRATEGIES FOR THE DEVELOPMENT OF SOCIETY REFERENCES}

1. Ivashchenko H.A., Skrypai A.S. (2015) Informatsiino-analitychne zabezpechennia pryiniattia upravlinskykh rishen na pidpryiemstvi. Ekonomichnyi analiz Ternopilskoho natsionalnoho ekonomichnoho universytetu. no. 2. Vol. 21. pp. 86-92.

2. Prokopova O., Harkusha N., Tverdokhlib K. (2015) Informatsiine zabezpechennia pryiniattia upravlinskykh rishen $\mathrm{v}$ suchasnykh biznes-systemakh. Ekonomichnyi dyskurs. Mizhnarodnyi zbirnyk naukovykh prats. no. 4. pp. 117-125.

3. Liubar O. O., Vashchilova N. V., Dombrovska V. V. (2019) Bukhhalterskyi oblik yak osnovne dzherelo informatsii pro pryiniattia upravlinskykh rishen. Ekonomika i suspilstvo. no. 20. pp. 701-709

4. Illiashenko K. V. (2012) Analiz informatsiinykh potokiv pidpryiemstva i yikhnie vidobrazhennia u zvitnosti. Ekonomichni nauky. Cer. : Oblik i finansy. no. 9(1). pp. 463-468.

5. Riabenko L.M. (2017) Analitychne zabezpechennia rozrobky i realizatsii upravlinskykh stratehichnykh rishen. Ekonomika i suspilstvo. no. 13. pp. 1400-1407.

6. Bozhenko O. M. (2016) Informatsiine zabezpechennia upravlinnia potentsialom pidpryiemstva. Naukovi zapysky. 2016. no. 2 (53). pp. 189-197.

7. Bezverkhnia Yu. V. (2015) Problemy ta perspektyvy avtomatyzatsii upravlinskoho obliku. Zbirnyk naukovykh prats Tavriiskoho derzhavnoho ahrotekhnolohichnoho universytetu. no. 1(29). pp. 192-198. (in Ukrainian)

8. Skochylias S. M. (2019) Analitychne zabezpechennia yak dzherelo informatsii dlia pryiniattia upravlinskykh rishen. Naukovyi visnyk Uzhhorodskoho natsionalnoho universytetu. no. 25, Vol.2. pp. 123-127.

9. Малюга Н. М. Розвиток теорії бухгалтерського обліку. Розвиток системи обліку, аналізу та аудиту в Украӥні: теорія, методологія, організація. Збірник тез доповідей учасників XIV Всеукраїнської наукової конференції. К.: ДП «Інформ.-аналіт. агентство», 2016. С. 41-44.

10. Семанюк В. 3. Інформаційна теорія обліку в постіндустріальному суспільстві : монографія. Тернопіль : ТНЕУ, 2018. 392 с. 


\section{ECONOMIC STRATEGIES FOR THE DEVELOPMENT OF SOCIETY}

11. Hendriksen E. S. Accounting theory. Illinois: Richard D. Irwin, Inc. Homewood, $1965.510 \mathrm{p}$.

12. Kavrar Ö. The Managerial Implications of Positive and Normative Accounting Theories. Selçuk Üniversitesi Sosyal Bilimler Meslek Yüksekokulu Dergisi. 2020. Vol. 23. Issue 1. P. 305-317.

13. Wolk H.I., Dodd J.L. \& Rozycki J.J. Accounting Theory: Conceptual Issues in a Political and Economic Environment. Ninth Edition. SAGE Publications, Inc. 2017. DOI: http://dx.doi.org/10.4135/9781506300108.

14. Ram M., Tapria R. Accounting theory: concept and importance. International Journal of Education, Modern Management, Applied Science \& Social Science. 2019. Vol. 01. No. 02. P. 129-134.

15. Idil K. Accounting Choices in Corporate Financial Reporting: A Literature Review of Positive Accounting Theory. Soner Gokten (ed.), Accounting and Corporate Reporting - Today and Tomorrow, 2017. DOI: 10.5772/intechopen.68962.

16. Eugen von Böhm-Bawerk. Selected works on value, interest and capital / preface Y.A. Shumpeter; transl. from German by L.I. Forbert, A. Sanina; transl. from English by N.V. Avtonomova; transl. from Latin by A.A. Rossius. Kiev: Eksmo, 2009. $912 \mathrm{p}$.

17. Bobiak A.P. Accounting of equity capital of enterprises of different organizational and legal forms: extended abstract of Candidate of Economics diss. Kyiv, 2011.36 p.

18. Bohacheva H.N., Denysov B.A. On various interpretation of the category of “capital”. Management in Russia and abroad. 2000. № 1. P. 13-24.

19. Vivchar O.Y., Savaryn V.M. Equity capital as a financial source of enterprise operation. Scientific journal of NLTU. 2009. Iss. 19.5. P. 146-150.

20. Grayson J.K., O’Dell K. American management at the beginning of 21 century. Moscow: Economics, 1991. 319 p.

21. Dorosh N.I., Snizhko V.V. Equity capital accounting in terms of national and international standards. Young scientist. 2019. № 2(2). P. 606-610. URL: http://nbuv.gov.ua/UJRN/molv_2019_2(2)_ 66 


\section{ECONOMIC STRATEGIES FOR THE DEVELOPMENT OF SOCIETY}

22. Kvasnytska R.S. Management of enterprise's capital through the prism of evolution of its definition and essence as an economic category. Scientific works of Donetsk National Technical University. Series: economic. Donetsk: DonNTU, 2003. Iss. 56. P. 223-229.

23. Quesnay F., Turgot A.R.J., du Pont de Nemours. Physiocrats. Selected economic works. Moscow: Eksmo, 2008. 1200 p.

24. Koval L.V., Arseniuk A.V. Impact of accounting information concerning equity capital on managerial decision-making. Effective economy. 2017. № 6 . URL: http://nbuv.gov.ua/UJRN/efek_2017 6 14

25. Marx K. Capital. Criticism of the political economy. Moscow: Politizdat. 1088. V.1, Book 1: Process of capital production. 905 p.

26. Marshall A. Principles of economic science. Moscow: Progress, 1993. V. 1. $415 \mathrm{p}$.

27. Melnyk T.H., Dymnich V.V. Peculiarities of equity capital accounting at joint stock companies. Young scientist. 2018. № 3(2). P. 665-669. URL: http://nbuv.gov.ua/UJRN/molv $2018 \quad 3(2) \quad 62$

28. Nazarenko O.V., Chyzhova T.S. Organizational aspects of formation, accounting and audit of equity capital of an enterprise. Economy and the state. 2019. № 9. Р. 30-34.

29. Nazarova I. Essence and structuring of equity capital for the needs of accounting. Bulletin of Ternopil National Economic University. 2017. Iss. 3. P. $117-$ 126. URL: http://nbuv.gov.ua/UJRN/Vtneu 2017312

30. Pylypenko O.I. Accounting and analysis of equity capital: theory and practice: extended abstract of Candidate of Economics dissertation. Kyiv, 2005. 20 p.

31. Smith A. An Inquiry Into The Nature And Causes Of The Wealth Of Nations / Transl. from English; preface by V.S. Afanasiev. Moscow: Eksmo, 2007. 960 p.

32. Tuhan-Baranovskyi M.I. Political economy: popular course. Kyiv: Naukova dumka, 1994. 264 p. 


\section{ECONOMIC STRATEGIES FOR THE DEVELOPMENT OF SOCIETY}

33. Калінеску Т. В. Інноваційна стратегія розвитку підприємств на основі збалансованої системи показників [монографія] Луганськ. Вид-во СНУ ім. В. Даля, 2013. 288 с.

34. Каплан Роберт С., Нортон Дейвид П. Сбалансированная система показателей. От стратегии к действию. 2-е изд., испр. и доп. М. ЗАО «ОлимпБизнем, 2008. 320 с.

35. Мороз Ю.Ю. Моніторинг економічного потенціалу підприємства: теорія, методологія, організація [монографія]. Житомир: ФОП Кузьмін Дн.Л., 2010. $326 \mathrm{c}$.

36. Libert, B. Value Creation A New Economy Definition. Audio Financial Accounting \& Management Report, Nr. 1, 2001.

37. How COVID-19 is changing the world. - A statistical perspective, Volume 1. - May 2020. https://unstats.un.org/unsd/ccsa/documents/covid19-report-ccsa.pdf URL: https://zakon.rada.gov.ua/rada/show/v0326739-11\#Text (дата звернення 20.11.20 p.)

38. Закон України від 05.07.2012 р. № 5067-VI “Про зайнятість населення” (Електронний ресурс). http://zakon3.rada.gov.ua/laws/show/5067-17

39. Лондар С. Л. Визначення конкурентних переваг здобуття вищої освіти в країнах-конкурентах України на ринку освітніх послуг для іноземних студентів: аналіт. записка. Київ: ДНУ «Інститут освітньої аналітики», 2020.

40. Міністерство соціальної політики. Професійне навчання дорослого населення. URL: https://www.msp.gov.ua/content/profesiyne-navchannyadoroslogo-naselennya.html (дата звернення - 20.11.20 p.)

41. Мудра О.В. особливості взаємодії ринку освітніх послуг та ринку праці / О.В. Мудра // Економіка. - 2012. - № 5 (119). - С. 35-40.

42. Наказ Міністерства соціальної політики України «Про впровадження соціально-педагогічної послуги «Університет третього віку» 


\section{ECONOMIC STRATEGIES FOR THE DEVELOPMENT OF SOCIETY}

43. Офіційний веб-сайт Держстату України (Електронний ресурс). - Режим доступу http://www.ukrstat.gov.ua/

44. Перелік навчальних закладів, які мають право здійснювати діяльність у сфері вищої освіти та професійно-технічної освіти, для навчання в яких може бути виданий ваучер (Електронний ресурс). - Режим доступу : https://mon.gov.ua/ua/ministerstvo/poslugi/licenzuvannya/perelik-navchalnihzakladiv-yaki-mayut-pravo-zdijsnyuvati-diyalnist-u-sferi-vishoyi-osviti-taprofesijno-tehnichnoyi-osviti-dlya-navchannya-v-yakih-mozhe-buti-vidanij-vaucher

45. Постанова Кабінет Міністрів України від 20 березня 2013 р. № 207 «Про затвердження Порядку видачі ваучерів для підтримання конкурентоспроможності осіб на ринку праці» (Електронний ресурс). - Режим доступу: https://zakon.rada.gov.ua/laws/show/207-2013-\%D0\%BF\#Text

46. Ткаченко Л. Г. Ваучери на навчання осіб віком старше 45 років як інструмент активної політики ринку праці (Електронний ресурс) / Л. Г. Ткаченко // Демографія та соціальна економіка. - 2015. - № 2. - С. 41-52. - Режим доступу: http://nbuv.gov.ua/UJRN/dse_2015_2_5

47. Фінальний звіт про ваучерну систему в Україні: матер. Круглого столу. - Київ, 2015.

48. Денисенко М. П., Ольшанська О. В., Григорчук Д. В. Розвиток міжнародного туризму в контексті прогнозів всесвітньої туристичної організації. 2019. Вчені записки Університету «КРОК» № 4 (56). С. 41-47.

49. Денисенко М. П., Бреус С. В. Основні тенденції розвитку туристичної сфери у контексті управління готельним бізнесом в сучасних умовах. The $V$ th International scientific and practical conference «Study of modern problems of civilization» (October 19-23, 2020 Oslo, Norway 2020. 516 p. pp. 89-92.

50. UNWTO. Country profile - International Tourist Arrivals (2014-2019). URL : https://www.unwto.org/country-profile-inbound-tourism.

51. Названі найпопулярніші країни для туризму в світі: лідирує Франція (2014-2019). URL : https://www.poglyad.tv/nazvani-najpopulyarnishi-krayiny-dlyaturyzmu-v-sviti-lidyruye-frantsiya/. 
ECONOMIC STRATEGIES FOR THE DEVELOPMENT OF SOCIETY

52. У 2019 році іноземні туристи залишили в Україні \$1,4 мільярда (інфографіка) (2014-2019). URL : https://minfin.com.ua/ua/2020/06/01/46399442/.

53. UNWTO. Country profile - International Tourist Receipts (2014-2019). URL : https://www.unwto.org/country-profile-inbound-tourism.

54. World - Gross domestic product in current prices (2014-2019). URL : https://knoema.com/atlas/World/GDP.

55. Gross domestic product in current prices (2014-2019). URL : https://knoema.com/atlas/ranks/GDP.

56. Коронавірус: скільки втрачає туризм (2020). URL : https://www.bbc.com/ukrainian/features-51870285.

57. Denysenko M.P., Shevchuk Y.A. Investment in the hotel industry development Імперативи економічного зростання в контексті реалізації глобальних иілей сталого розвитку: тези доповідей Міжнародної науковопрактичної Інтернет-конференції, присвяченої 90-річчю Київського наиіонального університету технологій та дизайну, м. Київ, 9 квітня 2020 року. Київ: КНУТД, 2020.2 C. 152-154. URL: https://er.knutd.edu.ua/bitstream/123456789/15740/1/IMPER2020_P152-154.pdf.

58. Мальська М. П., Пандяк I. Г. Готельний бізнес: теорія та практика. Підручник. 2- вид. перероб. та доп. К. : Центр учбової літератури, 2012. 472 с.

59. Денисенко М. П., Бреус С. В. Основні тенденції розвитку туристичної сфери у контексті управління готельним бізнесом в сучасних умовах. The $V$ th International scientific and practical conference «STUDY OF MODERN PROBLEMS OF CIVILIZATION» (October 19-23, 2020 Oslo, Norway 2020.516 p. pp. 89-92

60. Стратегічне управління готельними підприємствами в умовах глобалізації : монографія / колектив авторів ; за заг. ред. проф. В. М. Зайцевої. Запоріжжя : $\quad$ ЗНТУ, $2018 . \quad 120$ c. http://eir.zntu.edu.ua/bitstream/123456789/3231/1/Zaytseva_Strategic_Management. pdf (дата звернення: 12.11.2020).

61. Литвинчук Я., Кляцька А., Терзов, В. (2017). URL: Дослідження: Готельний ринок Києва на карті Європи. Cushman \& Wakefield. URL: 
ECONOMIC STRATEGIES FOR THE DEVELOPMENT OF SOCIETY https://cushmanwakefield.com.ua/en/research-kyiv-hospitality-market-european-map (дата звернення: 12.11.2020).

62. Берещак В. Як COVID-19 змінить готельний бізнес в Україні (2020). URL: https://thepage.ua/ua/exclusive/sho-stanetsya-z-gotelyami-cherez-koronavirus (дата звернення: 12.11.2020).

63. Галасюк К. А. Готельні ланцюги в сучасній індустрії гостинності. Науковий вісник ОНЕУ. 2012. № 21 (173). С. 127-135.

64. Гуменюк Н. В., Паламарчук А. О. Глобальні комп’ютерні системи резервування: практика використання в туристичній галузі України. Вісник Хмельницького національного університету. 2010. № 4. Т. 4. С. 61-64.

65. Мунін Г. Б., Карягін Ю. О., Артеменко А. С., Кошиль Ю. В. Франчайзинг у готельно-ресторанному бізнесі: навч. посібник. К. : Кондор, 2008. 370 с.

66. Шатайло О. А., Черномазюк А. Г. Франчайзинг у сфері готельноресторанного бізнесу. Материали за Х Международна научна практична конферениія «Динамика та на съвременната наука-2014» (Софія, 17-25.07.2014) Софія: «Бял ГРАД-БГ» ООД, 2014. Т.2: Икономики. С. 17-20.

67. Пуцентейло П. Р. Економіка і організація туристично-готельного підприємництва: навч. посібник. К.: Центр учбової літератури, 2007. 344 с.

68. Bogers, M., \& West, J. (2014). Leveraging external sources of innovation: A review of research on open innovation. Journal of Product Innovation Management. $31(4), 814-831$.

69. Kao, Y.-S., Nawata, K., \& Huang, C.-Y. (2019). Systemic functions evaluation based technological innovation system for the sustainability of IoT in the manufacturing industry. Sustainability., 11(8), 2342.

70. da Silva Paiva, \& F.C., Giesta, L.C. (2019). Socio-environmental management in micro and small industries of Pau dos Ferros-RN. Gestao e Producao., 3 (2), 41-45.

71. Park, S.H., \& Shin, W.S. (2019). Assessing a social responsibility model for sustainable company growth in the fourth industrial revolution. International Journal of Quality and Service Sciences., 3 (2), 41-45.

72. Shpak, N. O., Stanasiuk, N. S., Hlushko, O. V., \& Sroka, W. (2018). 


\section{ECONOMIC STRATEGIES FOR THE DEVELOPMENT OF SOCIETY}

Assessment of the social and labor components of industrial potential in the context of corporate social responsibility. Polish Journal of Management Studies., 17 (1), 209220.

73. Marques, A.C., Fuinhas, J.A., \& Tomás, C. (2019). Energy Efficiency and Sustainable Growth in Industrial Sectors in European Union Countries: A Nonlinear ARDL Approach. Journal of Cleaner Production. 1(2), 20-31.

74. Lee, H.S., \& Choi, Y. (2019). Environmental performance evaluation of the Korean manufacturing industry based on sequential DEA. Sustainability, 11 (3), 874.

75. Zhang, X. \& Ye, B. (2019). The evalution of industrial eco-innovation efficiency in China from the perspective of industry heterogeneity. Shengtai Xuebao/ Acta Ecologica Sinica. 39 (14), 5198-5207.

76. Cheng, R., \& Li, W. (2019). Evaluating environmental sustainability of an urban industrial plan under the three-line environmental governance policy in China. Journal of Environmental Management., 20 (251), 54-67.

77. Bezhentseva, T.V., Aleksandrova, N.N., \& Matyus, E.G. (2018). Formation of system of indicators for evaluation of environmental activities. International Conference on Construction, Architecture and Technosphere Safety (pp.1102-1109). Ghelybinsk, Russian Federation: South Ural State University Ghelybinsk; Russian Federation. Retrieved from: http://toc.proceedings.com/47566webtoc.pdf.

78. Vysochan Oleh S., Vysochan Olha O., Hyk Vasyl V. Main characteristics and role of non-budget non-profit organizations in the economy of Ukraine.Scientific approaches to the study of the world economy : collective monography. Boston: Primedia eLaunch, 2020. 145 p.

79. McGann James and Johnstone Mary. The Power Shift and the NGO Credibility Crisis.Brown Journal of World Affairs. 2005. Vol. XI, Iss. 2. Pp. 159-172.

80. Working with NGO's: A Practical Guide to Operational Collaboration between the World Bank and Non-governmental Organizations. Operations Policy Department, World Bank, 1995. 132 p.

81. Salamon, Lester M. and Helmut K. Anheier. The International Classification of Nonprofit Organizations: ICNPO-Revision 1, 1996.Working Papers of the Johns 
ECONOMIC STRATEGIES FOR THE DEVELOPMENT OF SOCIETY Hopkins Comparative Nonprofit Sector Project, no. 19. Baltimore: The Johns Hopkins Institute for Policy Studies, 1996. 24 p.

82. UNWTO Tourism Highlights 2019 Edition: annual report / https://www.eunwto.org/doi/book/10.18111/9789284421152 - Monday, Fabruary 17, 2020.

83. Смаль І.В. Туристичні ресурси світу. Ніжин : Вид-во НДУ ім. М. Гоголя, $2010.336 \mathrm{c}$.

84. Берегут С.I. Порівняльна оцінка категорій природоохоронних територій України та Еквадору // Науковий вісник Національного університету біоресурсів i природокористування України. Серія : Лісівництво та декоративне садівництво. 2016. Вип. 238. С. 84-94.

85. Эквадор // Мировой атлас данных / https://knoema.ru/atlas.

86. Закон України «Про автомобільний транспорт». URL: https://zakon.rada.gov.ua/laws/show/2344-14

87. Шевченко І.Ю. Місце автомобільного транспорту в транспортному комплексі України // Проблеми і перспективи розвитку підприємництва: Збірник матеріалів IX Міжнародної науково-практичної конференції, 27 листопада 2015 р. Х.: ФОП Крамаренко Ю.М., 2015. С. 105-106.

88. Обсяг перевезених вантажів за видами транспорту. URL: Ошибка! Недопустимый объект

гиперссылки..gov.ua/operativ/operativ2018/tr/tr_rik/tr_rik_u/op_vant_vt_u.htm

89. Статистичні дані Міністерства інфраструктури України по галузі автомобільного транспорту. URL: https://mtu.gov.ua/content/statistichni-dani-pogaluzi-avtomobilnogo-transportu.html

90. Транспорт України - 2019: статистичний збірник. URL: http://www. ukrstat.gov.ua/druk/publicat/kat_u/2020/zb/10/zb_trans_19.pdf

91. Oleynik O. Ways of defining the level of trust: how do semiotics and hermeneutics influence such notions as trust and confidence, belief? p.309-312 European integration choice of Ukraine and problems of macroeconomics: XXVIII International scientific-practical conference of young scientists and students: abstracts, 
ECONOMIC STRATEGIES FOR THE DEVELOPMENT OF SOCIETY Dnipro, December 5, 2019 [Electronic resource]. - Dnipro: Alfred Nobel University, 2019. - 476 p. ISBN 978-966-434-469-9

92. Economics and sociology of trust / ed. Yu.V. Veselova. - SPb., 2004.

93. Online source: https://finance.liga.net/ekonomika/novosti/chetvertayachast-vvp-ukrainy-nahoditsya-v-teni-issledovanie-ey

94. Online source: https://seosait.com/dinamika-vvp-ukrainy-s-2002-po2016-gody/

95. Azrilian N.A. Large economic dictionary. Minsk: Institute of New Economy. 2004, p.1376.

96. Alekhina O.E. Indicators of personnel policy efficiency. Personnel directory. 2017. №6, p.117-120.

97. Sitnik N.I. Personnel management: a textbook. Kyiv, 2009, p.472.

98.Vinogradsky M.D., Vinogradskaya AM, Shkanova AM Personnel management: textbook. manual. Kyiv, 2009, p.502.

99. Desler G. Personnel management / per.s English. Moscow: Laboratory of Knowledge, 2014, p.799.

100. Kibanov A.Ya. Personnel management of the organization: student. Moscow, 2015, p.638.

101. Menshikova M.A. On the question of personnel management as a system and integrated subsystem of the organization. Scientific notes. Electronic scientific journal of Kursk State University. 2018. №3(7), p.59-66.

102. Pelykh A.S. Features of modern personnel management at domestic enterprises. Innovative economy. 2010. №15, p.163-166. URL: http://www.nbuv.gov.ua/portal/Soc_Gum/inek/2010_1/163.pdf

103. Linenko A.V. The essence and analysis of the personnel of the enterprise in terms of its efficiency. State and regions. Series: Economics and Entrepreneurship. 2008. № 4, p.111-116.

104. Antoshina O.A. Analysis of labor indicators. Audit sheets. 2007. № 7, p.3541. 


\section{ECONOMIC STRATEGIES FOR THE DEVELOPMENT OF SOCIETY}

105. Bukhonova S.M. Doroshenko Yu.A. Theoretical and methodological bases of economic assessment of labor potential. Russian entrepreneurship. 2006. № 6, p.5660 .

106. Bykova L.A. Model of adaptation in the personnel management system. Personnel directory. 2018. № 4, p.113-121.107. Воронецька I. С., Кравчук О. О., Корнійчук Г. В. Науково-практичні засади функціонування ринку кормів. Агросвіт. 2016. № 20. С. 3-11.

108. Концепція розвитку кормовиробництва в Україні на період до 2025 року. / За ред. В.Ф. Петриченко. Інститут кормів та сільського господарства Поділля НAAH. URL: http://fri.vin.ua/download_materials/Концепція2025.pdf

109. James E. Boyle. Marketing of Agricultural Products. The American Economic Review , Jun., 1921, Vol. 11, No. 2 (Jun., 1921), pp. 207-213. URL: https://www.jstor.org/stable/1808656

110. Baker Michael J. Marketing Strategy and Management / Michael J. Baker. - Palgrave Macmillan, 2007. - 542 p.

111. Воронецька I. С., Спринчук Н. А., Кравчук О. О. Перспективи розвитку товарного кормовиробництва в Україні. Агросвіт. 2018. № 3. С. 12-18.

112. Офіційний сайт Державної служби статистики України. Економічна статистика. Економічна діяльність. Промисловість. URL: http://www.ukrstat.gov.ua/ (дата звернення 20.11.2020)

113. Кревенс Д. Стратегический маркетинг / Д. Кревенс; пер. с англ. - 6е изд., доп. - М.: Вильямс, 2003. - 752 с.

114. Зозулев А.В. Маркетинговые исследования: теория, методология, статистика: учеб. пособие / А.В. Зозулев, С.А. Солнцев. - К.: Знання, 2008. $643 \mathrm{c}$.

115. Эванс Дж.Р. Маркетинг / Дж.Р. Эванс, Б. Берман; пер. с англ. - М.: Сирин, 2002. - 308 с.

116. Офіційний сайт Верховної ради України. Законодавство України. URL: https://zakon.rada.gov.ua/ (дата звернення 21.11.2020)

117. Войчак А. Шумейко. Дослідження сучасних концепцій маркетингу 
ECONOMIC STRATEGIES FOR THE DEVELOPMENT OF SOCIETY та маркетингового менеджменту . Маркетинг в Україні. 2009. № 4. С. 52-55.

118. Алаев Э. Б. Федерализм: Энциклопедический словарь / Э. Б. Алаев. - М.: ИНФРА-М, 1997. - 288 c.

119. Шатіло В.А. Централізація і децентралізація в механізмі державної влади: до постановки проблеми / В.А. Шатіло // Адміністративне право і процес. - 2015. - № 1(11)..

120. Децентралізація

в $\quad$ Україні

URL: https://uk.wikipedia.org/wiki/Децентралізація_в_Україні.

121. Децентралізація: коротко про головне URL: http://cost.ua/news/698detsentralizatsiya-korotko-pro-holovne.

122. Динаміка створення об’єднаних громад позитивна, однак попереду ще багато роботи - нові дані моніторингу Мінрегіону. https://decentralization.gov.ua

123. Власні доходи місцевих бюджетів України зросли на 124 мільярди. www.ukrinform.ua

124. Моніторинг процесу децентралізації станом на липень 2018 року. https://decentralization.gov.ua

125. Уряд визначив новий порядок діяльності освітніх округів та опорних загальноосвітніх навчальних закладів // Урядовий портал Єдиний веб-портал органів виконавчої влади України. - 2016. - URL: https://www.kmu.gov.ua/news/248776954.

126. Яким бути українському префекту - URL: https://decentralization.gov.ua/news/1200.

127. Префекти уроки Франції для України URL: http://www.slgcoe.org.ua/wp-content/uploads/2016/09/брошура_Префекти_уроки-Франції-дляУкраїни.pdf

128. Порівняння реформи децентралізації в Польщі і Україні URL: http://dialog.lviv.ua/wp-content/uploads/2017/10/Porivnyalniy-analiz-protsesudetsentralizatsiyi-Ukrayini-ta-Polshhi.pdf 


\section{ECONOMIC STRATEGIES FOR THE DEVELOPMENT OF SOCIETY}

129. Official website of the State Statistics Service of Ukraine / Electronic resource. - Access mode: http://www.ukrstat.gov.ua.

130. Dikan, V.L. Complex approach to management of the engineering enterprises steady development / V.L. Dikan // Economics of transport and industry bulletin. 2015 № 49. C. 11-18.

131. Бойетт Дж.Г., Бойетт Дж.Т. Путиводитель по царству мудрости: лучшие советы мастеров управления. Пер. с англ. - 2-е изд., стер. - М.:ЗАО «Олимп-Бизнес», 2002. - 416с.

132. Богацька Н.M., Козир А.I. Якість як основний фактор конкурентоспроможності підприємства (Електронний ресурс). URL : http://www.rusnauka.com/30_NNM_2010/Economics/72321.doc.htm звернення: 13.10 .2020$)$.

133. Корнійчук А.А., Загоровська В. В. Фактори, що впливають на якість продукції підприємства (Електронний ресурс). URL : https:/conf.ztu.edu.ua/wpcontent/uploads/2018/12/505.pdf (дата звернення: 13.10.2020).

134. Кросби Ф.Б. Качество и Я / Ф.Б. Кросби; пер. с. англ. А. Денисова. - М.: Стандарты и качество, 2008. - 263 с.

135. Косянчук Т.Ф., Майорова H.I. Забезпечення якості та конкурентоспроможності продукції на засадах сучасних принципів управління якістю (Електронний pecypc). URL http://journals.khnu.km.ua/vestnik/pdf/ekon/2010_3_3/051-054.pdf (дата звернення: 13.10.2020).

136. Іванов Ю.Б., Кизим М.О., Тищенко О.М., Іванова О.Ю., Ревенко О.В., Чечетова-Терашвілі Т.М. Підручник - Х.: ВД «ІНЖЕК», 2010. - 320 с.

137. Бойко I.М. Вплив інноваційної діяльності підприємства на рівень його конкурентоспроможності (Електронний ресурс). URL : http://www.ej.kherson.ua/journal/economic_06/91.pdf (дата звернення: 13.10.2020).

138. Середюк Ю.І., Шматковська Т.О. Особливості інновацій в сільському господарстві (Електронний pecypc). URL 
ECONOMIC STRATEGIES FOR THE DEVELOPMENT OF SOCIETY http://ena.lp.edu.ua/bitstream/ntb/32132/1/169-304-305.pdf (дата звернення: 13.10.2020).

139. Рейтинг інноваційних компаній: ТОП-5 лідерів агробізнесу (Електронний ресурс). URL : https://landlord.ua/news/reitynh-innovatsiinykhkompanii-top-5-lideriv-ahrobiznesu/ (дата звернення: 13.10.2020).

140. Данько М. Інноваційний потенціал у промисловості України// Економіст. - 1999. - № 10. - С. 26-32.

141. A Guide to the Project Management Body of Knowledge (PMBOK® Guide) (Електронний ресурс) / Project Management Institute, 2008. - 459 р. Режим доступу : http://www.cs.bilkent.edu.tr/ cagatay/cs413/PMBOK.pdf.

142. Berezin, V. (2009) Upravleniye proektami v mire i Ukraine [Project Management in the world and Ukraine]. Computernoe obozrenie - Computer Review, 36. Retrieved from http://ko.com.ua/ [in Ukrainian].

143. Innovations in Public Expenditure Management: Country Cases from the Commonwealth / Edited by Andrew Graham. - London, U.K.: Commonwealth Secretariat and Institute of Public Administration of Canada, 2011. - $108 \mathrm{p}$.

144. ISO 21500:2012 Guidance on project management (Електронний ресурс) / Міжнародна організація зі стандартизації. - Режим доступу: http:/www.iso.org /iso/catalogue_detail?csnumber $=50003$

145. Бірдус Л.В. Стратегічне управління аграрним сектором економіки України/ Л. В. Бірдус, М. А. Бірдус //Економіка та держава.- 2015. - № 11. - С. $92-$ 94

146. Вітлінський В. В. Ризикологія в економіці та підприємництві : [монографія] / В. В. Вітлінський, Г. І. Великоіваненко. - К. : КНЕУ, 2004. - 480 c.

147. Вітлінський В.В. Ризикологія в зовнішньоекономічній діяльності: Навчальний посібник/ В. В. Вітлінський, Л. Л. Маханець. - К.: КНЕУ, 2008. - 432 c.)

148. Готра В.В. Сучасний стан та проблеми інноваційного розвитку аграрного сектору України/ В. В. Готра //Актуальні Проблеми Економіки.- 2014. 
ECONOMIC STRATEGIES FOR THE DEVELOPMENT OF SOCIETY

- № 6. - C. 79-85

149. Гудима О.В. Основні стратегії розвитку аграрного сектору України/ О. В. Гудима, Ю. Г. Левченко //Формування ринкових відносин в Україні: Збірник наукових праць.-2016. - № 5. - С. 12-15

150. Кігель В.Р. Ризикологія: теоретичні основи та прикладні задачі, моделі i методи: навчальний посібник для студентів економічних спеціальностей/ В. Р. Кігель. - К.: Міленіум, 2017. - 230 с.

151. Селюченко Н. Є. Ризики та загрози підприємства: підходи до трактування та уточнення їхньої суті (Електронний ресурс) / Н. С. Селюченко,Климаш.Режимдоступу:http://www.nbuv.gov.ua/portal/natural/Vnulp/Menegment/2011 720/35.pdf. - Заголовок з екрана.

152. Лопатовський В. Г. Альтернативні підходи до поняття ризик / В. Г. Лопатовський // Вісник Технологічного університету Поділля. Економічні науки. - 2004. - №6. - С. 193-198.

153. Коломієць Г. М. Небезпеки і ризики сучасної економіки (Електронний ресурс) / Г. М. Коломієць, Ю. Г. Гузненков. - Режим доступу:http://dspace.univer.kharkov.ua/bitstream/123456789/6849/2/Kolomiets Gu zenko v.pdf. - Заголовок з екрана.

154. Сучасний тлумачний словник української мови : 65000 слів / за заг. ред. д-ра філол. наук, проф. В. В. Дубічинського. - Харків : ВД -Школа, 2006. $-1008 \mathrm{c}$.

155. Гутко Л. М. Досвід державної підтримки страхування ризиків / Л. М. Гутко // Економіка АПК. - 2009. - №10. - С.147-152.

156. Маханець Л. Л. Моделювання ризику в зовнішньоекономічній діяльності : автореф. дис. на здобуття наук. ступеня канд. екон. наук : спец.08.03.02-Економіко-математичне моделювання"//юбов Леонідівна Маханець. - К., 2002. - 20 с.

157. Hopkin P. Fundamentals of risk management: understanding, evaluating, and implementing effective risk management [Electronic resource] / P. Hopkin.Mode of access: http://www.nashaucheba.ru/v40360/?download=1. - Title from the 


\section{ECONOMIC STRATEGIES FOR THE DEVELOPMENT OF SOCIETY}

screen.

158. Тибінь А. Сутність i класифікація економічного ризику в зовнішньоекономічній діяльності підприємств / А. Тибінь, І. Вербицька // Економіка АПК. - 2010. - №1. - С. 138-142.

159. Тюріна Н. М. Зовнішньоекономічна діяльність підприємства [текст] Т 98 навчальний посібник / Н. М. Тюріна, Н. С. Карвацка. - К.: "Центр учбової літератури", 2013. - 408 с

160. Грушко B.I. Національні фінанси: підручник / B.I. Грушко, О.С. Наконечна, О.Г. Чумаченко; за ред. д.ек.н., проф. В.І. Грушка - К.: Університет економіки та права "КРОК", 2017. - 660 с

161. Амеліна I. В. Принципи управління ризиками підприємств у зовнішньоекономічній діяльності [Електронний ресурс] / I. В. Амеліна, Л. Б. Дьяченко.

Режим доступу:http://www.rusnauka.com/34_NIEK_2010/Economics/75476.doc.htm. - Назва з екрана.

162. Байда Н. Ризики зовнішньоторговельної діяльності / Н. Байда // Фінанси України. - 2002. - № 11. - С. 44-48.

163. Абдуллаев Р. Особенности финансовых рисков в сфере международных экономических отношений и внешнеэкономической деятельности [Электронный ресурс] / Р. Абдуллаев. - Режим доступа: http://webcityhost.net/vergiler/upload/File/art-87.pdf. - Загл. с экрана.

164. Шевченко В. С. Визначення впливу корпоративної культури на діяльність підприємства / В.С. Шевченко // Комунальне господарство міст. 2014. №114. C. $157-161$.

165. Спивак В. А. Корпоративная культура. СПб. : Питер, 2001. 352 с.

166. Чернишова Т.О. Деякі аспекти корпоративної культури організації / Т. О.Чернишова, Т. А. Немченко //Наукові праці КНТУ. Економічні науки. 2010. Вип. 17. 


\section{ECONOMIC STRATEGIES FOR THE DEVELOPMENT OF SOCIETY}

167. Роббинс С. П. Менеджмент / С. П. Роббинс, М. Коултер ; пер. с англ. О. В. Медведь ; 8-е изд. М. : Издат. дом «Вильямс», 2007. 1056 с.

168. Дяків О.П. Основні складові формування корпоративної культури в організації / О. Дяків // Міжн. наук.-практ. конференція "Соціально-трудові відносини: теорія та практика. К. : КНЕУ, 2010. т.3 с. 94-100.

169. Кричевский Р.Л. Если вы руководитель. Элементы психологии менеджмента в повседневной работе / Р.Л. Кричевский. М. : Дело, 2003. 115 с.

170. Електронний ресурс. Доступно за адресою: https://www.careeraddict.com/ best-company-culture. (Дата звернення 20 вересня 2020).

171. F Galgano, R Tolve, MA Colangelo, T Scarpa Conventional and organic foods: A comparison focused on animal products - Cogent Food \& Agriculture, 2016 DOI: http://dx.doi.org/10.18203/2394-6040.ijcmph20175319

172. . Marketing Organic Products: Exploring Some of the Pervasive Issues David Pearson \& Joanna Henryks Pages 95-108 | Published online: 08 Sep 2008 Journal of Food Products Marketing, 11: 63-76. doi:10.1300/J038v11n04_05 ... Canberra, , Australia: Department of Agriculture, Fisheries, and Forestry. Download citation https://doi.org/10.1080/10454440801986421

173. Food crises, food regimes and food movements: rumblings of reform or tides of transformation? Eric Holt Giménez \& Annie Shattuck Pages 109-144 | Published online: $\quad 13$ Jan 2011. Download citation https://doi.org/10.1080/03066150.2010.538578

174. Food Choice Motives When Purchasing in Organic and Conventional Consumer Clusters: Focus on Sustainable Concerns (The NutriNet-Santé Cohort Study) Nutrients. 2017 Feb; 9(2): 88. Published online 2017 Jan 24. doi: $\underline{10.3390 / \text { nu } 9020088}$

175. Перспективи використання технології блокчейн у мережі інтернет речей N.G. Yatskiv, S.V. Yatskiv 381-387 DOI https://doi.org/10.15421/40260857 
ECONOMIC STRATEGIES FOR THE DEVELOPMENT OF SOCIETY

176. Технологія блокчейн і ऑї вплив на фінансові послуги та послуги морських перевезень Viktor Diordiiev 51-63 DOI https://doi.org/10.31520/2616$\underline{7107 / 2018.2 .1-5}$

177. UI GreenMetric World University Ranking 2019. UI GreenMetric, 2020. Retrieved from http:/greenmetric.ui.ac.id/overall-rankings-2019/.

178. Zhao J. Learning from the international low-carbon campuses. International Urban Planning, 2010, 25. P.106-110.

179. Ying Han, Xuejie Zhou, Ruijiang Luo. Analysis on campus energy consumption and energy saving measures in cold region of China. Procedia Engineering, 2015, 121. P. 801-808.

180. Sun L. Content and low-carbon path in university campus. Business and Economy 2011, 11. P. 15-17.

181. Wageningen University \& Research. Sustainability, 2020. Retrieved from https://www.wur.nl/en/About-Wageningen/Sustainability.htm.

182. 10 of the Greenest Universities in the UK. QS Top Universities, 2019. Retrieved from https://www.topuniversities.com/blog/10-greenest-universities-uk.

183. Maistry N., McKay T. M. Promoting energy efficiency in a South African university. Journal of Energy in Southern Africa, 2016, 27 (3). Retrieved from http://www.scielo.org.za/pdf/jesa/v27n3/01.pdf.

184. Sineviciene L., Sotnyk I., Lakstutiene A., Kubatko O. What makes countries to be energy efficient: case of Lithuania and Ukraine? Proceedings of the 2017 International Conference "Economic Science for Rural Development", No 45. Jelgava, LLU ESAF, 27-28 April 2017. P. 213-220.

185. Sotnyk I., Dehtyarova I., Kovalenko Y. Current threats to energy and resource efficient development of Ukrainian economy. Actual Problems of Economics, 2015, 11. P. 137-145.

186. Kurbatova T. Economic benefits for producers of biogas from cattle manure within energy co-operatives in Ukraine. International Journal of Sustainable Energy Planning and Management, 2018, 18. P. 69-80. https://doi.org/10.5278/ijsepm.2018.18.5. 


\section{ECONOMIC STRATEGIES FOR THE DEVELOPMENT OF SOCIETY}

187. Енергоефективність та відновлювальна енергетика в Україні: проблеми управління : монографія / за заг. ред. І. М. Сотник. Суми: ПФ «Видавництво «Університетська книга», 2019. 247 с.

188. Mohammadalizadehkorde M., Weaver R. Universities as models of sustainable energy-consuming communities? Review of selected literature. Sustainability, 2018, 10. P. 3250. doi:10.3390/su10093250.

189. Maiorano J., Savan B. Barriers to energy efficiency and the uptake of green revolving funds in Canadian universities. International Journal of Sustainability in Higher Education, 2015, 16. P. 200-216.

190. Myskevych T. On the issue of state regulation of the stock market in Ukraine (Electronic resource) / T. Myskevych // Public opinion on lawmaking. 2019. № 8 (173) - Access mode: http://nbuviap.gov.ua/images/dumka/2019/8.pdf.

191. Peresada AA Investment analysis: teaching method. manual for self. studied dist. / Peresada AA, Onikienko SV, Kovalenko Yu. M. - K .: KNEU, 2003. 134 p.

192. Kvasnytska RS The essence and composition of institutional investors in the financial market / RS Kvasnytska. // Economist. 2015. №5. Pp. 48-50.

193. Kovalenko Yu. M. Levels of regulation of the financial sector in Ukraine / Yu. M. Kovalenko // Economic Bulletin (series: finance, accounting, taxation). - Irpin: UDFSU Publishing House, 2017. № 1.C. 68-77.

194. Gadzhimuradova L.A. The role and structure of the securities market. Evolution of modern science, 2017. P. 50-52.

195. Kilyachkov A.A, Chaldaeva L.A. Securities market: textbook. for universities. 3rd ed., Moscow, 2012.p. 169.

196. Kuzmenko N.F. The essence and functions of the securities market. Intellectual potential of the XXI century: stages of knowledge, 2016. № 33. S. 151-155.

197. Patrakeeva D.A. Study of the essence and principles of functioning of the securities market. Current issues of law, economics and management, 2016. P. 65-70. 


\section{ECONOMIC STRATEGIES FOR THE DEVELOPMENT OF SOCIETY}

198. Makovetsky M.Yu., Fedorova V.A. The role of the securities market in the investment process in modern conditions. Omsk Scientific Bulletin, 2015. № 3 (139). Pp. 233-236.

199. Patrakeeva D. A. Study of the essence and principles of the securities market. Current issues of law, economics and management, 2016. P. 65-70.

200. Popova E. M. Regulation of the stock market: a textbook / EM Popova, Yu. N. Lvova, SPb. : Izd-vo SPbGEU, 2016. - 141 p.

201. Khutaev R. I., Mansurov R. M. The place of the securities market in the financial markets of the Russian Federation. Questions of education and science: theoretical and methodological aspects, 2015. S. 144-145.

202. Chokhatarova O. P. The role of the securities market in the modern economy. Proceedings of international scientific conferences, 2016. S. 385-387.

203. Schegleva N.G. Currency market and currency transactions. Moscow: MFPA, 2014. S. 453.

204. Коваленко Л.П. Особливості кредитування сільськогосподарських підприємств комерційними банками / Л.П. Коваленко // Держава та регіони. Серія: Економіка та підприємництво: [науково-виробничий журнал] / [гол. ред.: Л.Ю. Мельник]. Запоріжжя : ГУ “ЗІДМУ”, 2005. № 4. С. 125-129.

205. Кушнір Л.П. Створення системи кредитування сільськогосподарських підприємств шляхом заснування аграрної кредитної корпорації / Л.П.Кушнір // Вісник Львівської комерційної академії. Серія економічна: [збірник наукових праць] / [ред. кол.: Г.І. Башнянин, В.В. Апопій, О.Д.Вовчак]. Львів: Вид-во ЛКА, 2009. Вип. 30. С. 73-75.

206. Jansson K.H., Huisma, C.J, Lagerkvis, C.J, Rabinowicz E. Agricultural Credit Market Institutions. A Comparison of Selected European Countries // Factor Markets Working Paper, 2013. № 33.30 p.

207. Алескерова Ю.В. Кредитні аспекти державної підтримки розвитку аграрного сектору України / Ю.В. Алескерова, О.Д. Радченко, В.Л. Тодосійчук // Економіка. Фінанси. Менеджмент: актуальні питання науки і практики, 2018, № 11. c. 84-94. 


\section{ECONOMIC STRATEGIES FOR THE DEVELOPMENT OF SOCIETY}

208.

209. Про цінні папери та фондовий ринок: Закон України від 23 лютого 2006 p. № 3480-IV / Верховна Рада України. URL: https://zakon.rada.gov.ua/laws/show/3480-15\#Text (дата звернення: 22.11.2020)

210. Герасименко Ю.В. Суть інвестиційного процесу як економічної категорії. Вісник аграрної науки Причорномор'я. 2007. Вип.1. С.76-82

211. Гулей А.І. Сутність і економічна природа інвестицій та інвестиційного процесу. Інвестииії: практика та досвід. 2013. № 16. С. 15-17

212. Квасницька Р.С. Інвестиційний потенціал інститутів фінансового ринку України : монографія. Хмельницький: ПП «Монускрипт», 2015. 314 с.

213. Інформаційні довідки щодо розвитку фондового ринку України протягом за 2015-2019 p.p./ Національна комісія з цінних паперів і фондового ринку. URL: https://www.nssmc.gov.ua/news/insights/ (дата звернення: 22.11.2020).

214. Добринь С. В. Організація системи управління фінансовими ресурсами підприємства. Інвестииії: практика та досвід. 2015. № 10. С. 37-40.

215. Коваленко Л. О., Ремньова Л. М. Фінансовий менеджмент: навч. посіб. Київ: Знання. 2008. 483 с.

216. Попов В. М. Сучасні особливості фінансового забезпечення сільського господарства.

URL:

http://kntu.kr.ua/doc/zb_22(2)_ekon/stat 20 1/27.pdf

217. Рубай О.В. Оцінка стану фінансового забезпечення сільськогосподарських підприємств. Аграрна економіка. 2019. Т. 12. № 1-2. С. $38-43$.

218. Стецюк П.А. Модернізація механізмів фінансового забезпечення аграрного виробництва. Облік і фінанси. 2016. № 1 (71). С.132-136.

219. Ткаченко I. П. Фінансові ресурси підприємств: управління ефективністю формування та використання. Інвестиції: практика та досвід. 2013. № 19. C. 46-52. 


\section{ECONOMIC STRATEGIES FOR THE DEVELOPMENT OF SOCIETY}

220. Чернявський С.С. Фінансове шахрайство: методологічні засади розслідуванн: монографія. Київ. «Хай-ТекПрес». 2010. 57с.

221. Cressey D. R. Other People's money. Montclair. NJ: Patterson Smith, $1973.30 \mathrm{p}$.

222. Мельник С.С. Виявлення та запобігання фінансовому шахрайству у забезпеченні фінансової безпеки комерційних банків. Дисертація на здобуття наук.ступ. к.е.н. Київ. 2019. 252 с.

223. Драпак Г., Скиба М. Основи інтелектуальної власності : навч. посіб. / Г. Драпак, М. Скиба. - Київ : Кондор, 2017. - 156 с.

224. Цибульов П. М. Основи інтелектуальної власності : навч. посіб. / П. М. Цибульов. - Київ : «ІІВП», 2005. - 108 с.

225. Про наукову і науково-технічну діяльність (Електронний ресурс): Закон України (із змінами і доповненнями) від 26.11.2015 № 848-VIII. - Режим доступу : http://zakon.rada.gov.ua/laws/show/848-19

226.Патентознавство : навч. посіб. для студ. вищ. фар мац. навч. закл. / В. Ф. Москаленко, Д. С. Волох, Л. А. Бутко [та ін.] ; за ред.. проф. В. Ф. Москаленка. - Вінниця : Нова книга, 2017. - 360 с.

227. Інтелектуальна власність. Теорія і практика інноваційної діяльності : підруч. для вищ. навч. закладів / М. В. Вачевський, В. Г. Кремень, В. М. Мадзігон та ін.; Дрогобицький держ. пед. ун-т ім. і. Франка. - К. : ВД "Професіонал", 2015. $-448 \mathrm{c}$.

228. Андрощук Г. Раціоналізаторська пропозиція як об’єкт промислової власності: проблеми регулювання / Г. Андрощук // Інтелектуальна власність. 2016. - № 4.

229. Крайнєв П. П. Інтелектуальна економіка: управління промисловою власністю : [моногр.] / П. П. Крайнєв. - Київ : Ін Юре, 2014. - 448 с.

230. Солнцева Н. В. Аналіз сучасного стану винахідницької та інноваційної діяльності в Україні / Н.В.Солнцева // Глобальні та національні проблеми економіки. - 2015. - № 7. - С. 482-486.

231. Цибульов П. М. Управління інтелектуальною власністю 
ECONOMIC STRATEGIES FOR THE DEVELOPMENT OF SOCIETY

П. М. Цибульов. - К. : Держ. ін.-т інтел. власн., 2009. - 312 с.

232. Промислова власність у цифрах. Показники діяльності у сфері промислової власності за 9 місяців 2019 р. - Режим доступу : https://ukrpatent.org/atachs/promvlasnist-9m-2019.pdf

233. Garvy G. Kondratieff's Theory of Long Cycles. The Review of Economics and Statistics, vol. 25, no. 4, 1943. pp. 203-220. Available at: www.jstor.org/stable/1927337

234. Kondratieff N.D. Big Cycles of Conjuncture and the Theory of Forecasting [in Russian]. M .: Economics, 2002.

235. Pantin V.I., Aivazov A.E. Kondratieff Cycles and Evolutionary Cycles of the World System: Substantiation and Prognostic Potential [in Russian]. Kondratieff Waves Aspects and Prospects, 2012. pp. 136-155.

236. Akaev A.A. The modern financial and economic crisis in the light of the theory of innovation and technological development of the economy and management of the innovation process [in Russian]. System monitoring. Global and Regional Development, 2009. pp. 141-162.

237. Grinin L., Korotayev A. Interaction between Kondratieff Waves and Juglar Cycles. In L. Grinin, T. C. Devezas, \& A. Korotayev (Eds.), Kondratieff Waves: Juglar - Kuznets - Kondratieff; Yearbook. Volgograd: Uchitel Publishing House, 2014. pp. 25-95. Available at: https://nbn-resolving.org/urn:nbn:de:0168$\underline{\text { ssoar-58889-7 }}$

238. Akaev A. A. Large business cycles and the innovation-cyclical theory of economic development of Schumpeter-Kondratieff [in Russian]. ENSR, № 2 (61), 2013. pp. 7-29.

239. Kravchuk A.V. Analysis of the existing methods of an economic evaluation of the efficiency of industrial innovations [in Ukrainian]. Transactions of Kremenchuk Mykhailo Ostrohradskyi National University, №2, 2019. pp. 69-78. doi: 10.30929/1995-0519.2019.2.69-78.

240. Goncharova N.P., Pererva P.G., Yakovlev A.I. Marketing of the innovation process [in Russian]. Kyiv: VIRA-R, 1998. 267 p. 


\section{ECONOMIC STRATEGIES FOR THE DEVELOPMENT OF SOCIETY}

241. Koch, T., \& Windsperger, J. (2017). Seeing through the network: Competitive advantage in the digital economy. Journal of Organization Design, 6(1), 6.

242. Aarikka-Stenroos, L., \& Ritala, P. (2017). Network management in the era of ecosystems: Systematic review and management framework. Industrial Marketing Management, 67, 23-36. https://doi.org/10.1016/j.indmarman.2017.08.010.

243. Ades, C., Figlioli, A., Sbragia, R., Porto, G., Plonski, G. A., \& Celadon, K. (2013). Implementing open innovation: The case of natura, IBM and Siemens. Journal of Technology Management \& Innovation, 8, 12-25.

244. Laloux, F. (2014). Reinventing Organizations: A Guide to Creating Organizations Inspired by the Next Stage of Human Consciousness. Nelson Parker.

245. Examples of open innovations // https://www.viima.com/blog/16examples-of-open-innovation-what-can-we-learn-from-them

246. Tidd, J., Bessant, J. and Pavitt, K. (2005). Managing innovation: Integrating technological, market and organizational change, 3rd edition. John Wiley $\&$ Sons.

247. Afuah, A. (2014). Business model innovation : Concepts, analysis, and cases. New York: Routledge.

248. Dmytriv I. «U Ratushu Kamyanczya-Podils`kogo zanesly 223 zayavy pro vid 'omstvo...». U misti, vidomomu istorichnoyu forteczeyu, mozhna vidvidaty nichnu ekskursiyu «Polyuvannya na vid`om» [«At Kamyanets-Podilskyi Town Hall, 223 allegations of witchcraft were made...». In the city of the famous historic fortress you can visit the night trip "Witch Hunt"]. Vysoky zamok. 31.10-06.11.2019. P. 10.

249. Kamieniec w latach 1919-1920 [Kamyanets in 1919-1920]. Retrieved from http://slowopolskie.org/kamieniec-w-latach-1919-1920/.I

250. Karelov K.Poddel 'nye dostoprimechatel'nosti [Fake sights]. Tajny XX veka.2020. \#4, 26-27.

251. Liniya Arpada - grandiozna oboronna sporuda v Karpatax. URL: Prokarpaty-tour.info/uk/liniya-arpada. 


\section{ECONOMIC STRATEGIES FOR THE DEVELOPMENT OF SOCIETY}

252. Liniya Molotova. URL: https://uk.wikipedia.org/wiki/

253. Linia Molotowa. URL: https://pl.wikipedia.org/wiki/Linia

254. Linia Molotowa. URL: https://www.biebrza24.pl/oferta/wycieczkipiesze/linia-molotowa.

255. Kasyanova I. The secret lair of power. Vesti. 2020. 6 August. P.14.

256. Magiczne Roztoce. Magazyn turystyczny.2017. Zamosc: Drukarnia FastGraw, 2017. 54 s.

257. Malkowicz A. Wspolpraca organizacyjna wladz polskich i ukrainskich w okresie wojny 1920 r. we wspomnieniach gen.Jana Romera [Organizational cooperation of Polish and Ukrainian authorities during the 1920 war in the memoirs of General Jan Romer]. Regional 'na polityka: polityko-pravovi zasady, urbanistyka, prostorove planuvannya, arkhitektura. [Zb.nauk.pr.]. Vyp.5. Materialy mizhn.nauk.prakt. konf.Min-vo osviyi Ukrainy, Min-vo rozvitku gromad ta teritorij Ukrainy, Kyivsk.nacz. un-t budivnycztva i arkhitektury. Kyiv - Ternopil’: Beskidy, 2019. V 2 ch. Ch.1. P.79-84.

258. Michkovskaya N. In quarantine-time cafes and restaurants have become convenient "scapegoats". KP in Ukraine. 2020. 6-13 August. P.7.

259. Milinevsky N. Soon we will see the shaft of restaurant closures. Vesti. 2020. 28 July. P.10.

260. Olijnyk S. Bojova spivpraczya naddnistryancziv ta naddnipryanczyv u 1919-1920 rokakh [Combat Cooperation between the Dnister Army and the Dnieper Army in 1919-1920]. 100-richchya zluki UPR ta ZUPR: Zbirnyk materialiv naukovogo kruglogo stolu [100th Anniversary of UPR and ZUPR Union: Collection of Scientific Round Table Materials]. Kamyanecz-Podilskyj: K - P NU after Ivan Ogiyenko. 2019. P.27-36.

261. «Ostannya stoliczya», abo yak Kamyanetz na tri dni povernuvsya v minule ["The last capital" or as Kamenetz for three days returned to the past]. Retrieved from https:/www.istpravda.com.ua/articles/2019/08/27/ 156149/ [in Ukrainan]

262. Petrov V. Odynokyj volk. Sekretnye arhivy. 2020.№8. S.16-17. 
ECONOMIC STRATEGIES FOR THE DEVELOPMENT OF SOCIETY

263. Pustinnikova I. Ostannya stoliczya UNR [The UPR last capital ]. Retrieved from http://incognita.day.kyiv.ua/ostannya-stoliczya- unr.html [in Ukrainan].

264. Smyrnov I.G. Logistyka turyzmu: navch.pos.[Tourism logistics: textbook]. K.: Znannya, 2009. 444 p.

265. Steczyuk V. Naddnipryans`ki ta galicz'ki struktury v KamyancziPodils 'komu v chervni - listopadi 1919 roku [The Dnieper and Galician structures in Kamianets-Podilskyi in June-November 1919]. Zbirnik materialiv naukovogo kruglogo stolu [100th Anniversary of UPR and ZUPR Union: Collection of Scientific Round Table Materials].Kamyanecz-Podilskyj: K - P NU after Ivan Ogiyenko. 2019. P.37-42.

266. Yurkova G., Pustinnikova I., Moshak M. Kamyanecz - ostannya stoliczya UNR [ Kamyanets - the UPR last capital ]. Putivnyk [Guide-book]. KamyaneczPodilskyj: Medobory, 2011. 80 p.

267. Bill Drayton and Social Entrepreneurship: How a Social Movement is Changing the World...and Launching Another: EVERYONE A CHANGEMAKER. Електронний pecypc.

Режим

доступу: https://www.forbes.com/sites/williammeehan/2019/11/22/bill-drayton-and-socialentrepreneurship-how-a-social-movement-is-changing-the-worldand-launchinganother-everyone-a-changemaker/?sh=c70655645ded

268. North D.C. Institutions, Institutional Change, and Economic Performance / D.C. North. - New York: Cambridge University Press. - 1990.

269. Emerson J. The blended value map: Tracking the Intersects and Opportunities of Economic, Social and Environmental Value Creation / J. Emerson, S. Bonini, K. Brehm. - 2003. - 182 p.

270. Фрір Спреклі. Посібник з Планування Соціального Підприємництва// Перше видання 2011 р. Опубліковано: Британська Рада www.britishcouncil.org (Електронний ресурс) - Режим доступу : http://www.sii.org.ua/wpcontent/uploads/2016/07/posibnik_z_planuvannya_socialnogo_pidpriiemstva.pdf 


\section{ECONOMIC STRATEGIES FOR THE DEVELOPMENT OF SOCIETY}

271. Dees J. Gregory. The Meaning of Social Entrepreneurship. Original Draft: October 31, 1998 Reformatted and revised: May 30, 2001- Електронний ресурс Режим доступу : http://www.caseatduke.org/documents/dees_sedef.pdf

272. Murray, Caulier-Grice \& Mulgan The open book of social innovation / The young foundation 2010. - 220 р. - Електронний ресурс - Режим доступу : http://temp.uefiscdi.ro/edigiregion_v2/the_open_book_of_social_innovationNESTA. pdf

273. Is social enterprise growing? Five interesting facts. - Електронний ресурс - Режим доступу : https://info.sapphirecapitalpartners.co.uk/blog/five-interestingfacts-about-social-enterprises

274. Capitalism in Crisis?: State of Social Enterprise Survey 2019. Електронний ресурс - Режим доступу : https://www.socialenterprise.org.uk/wpcontent/uploads/2019/11/Capitalism-in-Crisis.pdf

275. The Social Innovation Trends 2020-2030. - Електронний ресурс - Режим доступу : https://mcusercontent.com/60c32dfe371e9913cb2e8eec5/files/8e34dd51efld-41f4-98f1-0affe065fcf9/The_Social_Innovation_Trends_2020_2030_Report.pdf

276. Соціальне підприємництво - міф чи тренд? - Електронний ресурс Режим доступу : https://www.prostir.ua/?library=sotsialne-pidpryjemnytstvo-mifchy-trend

277. Archibugi D., Iammarino S. The Globalization of Technological Innovation: Definition and Evidence // Review of International Political Economy. 9:1. March 2002. Pp. 98-99.

278. Dovgal O., Dovgal G. Innovation as a dominant feature of global competitive leadership in the age of techno-globalism. Innovative scientific researches: European development trends and regional aspects: collective monograph. 2nd ed. Riga, Latvia : "Baltija Publishing", 2020, pp. 45-64. Available at: http://baltijapublishing.lv/omp/index.php/bp/catalog/view/5/27/73-1

279. Bellman L., Webster J., Jeanes A. Knowledge Transfer and the Integration of Research, Policy and Practice // Journal of Research in Nursing. № 16. 2010. Pp. 254 270. 
ECONOMIC STRATEGIES FOR THE DEVELOPMENT OF SOCIETY

280. Bosin A., Dessì N., Fugini M., Liberati D., Pes B. Applying Enterprise Models to Design Cooperative Scientific Environments // Lecture Notes in Computer Science. Vol. 3812. 2006.

281. Oliveira J. A Knowledge Management Environment for Research Centers and Universities // Lecture Notes in Computer Science. Vol. 3841. 2006.

282. Kasper H., Lehrer M., Müller B. Integration-Responsiveness and Knowledge-Management Perspectives on the MNC // Journal of Leadership \& Organizational Studies. Vol. 15, № 3, 2009. Pp. 287-303.

283. Cooke P. The New Wave of Regional Innovation Networks: Analysis, Characteristics and Strategy // Small Business Economics. Vol. 8, № 2. 1996. Pp. 159171.

284. Pennings J., Harianto F. Technological networking and innovation implementation // Organization Science. Vol. 3, № 3. 1992. Pp. 356-382.

285. Kim K., Park J.-H., Prescott J. The Global Integration of Business Functions: a Study of Multinational Businesses in Integrated Global Industries // Journal of International Business Studies. № 34. 2003. Pp. 327-344.

286. Mytelka L. Local Systems of Innovation in a Globalized World Economy // Industry and Innovation. Vol.7, № 1. 2000. Pp. 15-32.

287. Powell W., Koput K., Smith-Doerr L. Interorganizational Collaboration and the Locus of Innovation: Networks of Learning in Biotechnology // Administrative Science Quarterly. Vol. 41, № 1. 1996. Pp. 116-145.

288. Frost T., Zhou C. R\&D Co-Practice and 'Reverse' Knowledge Integration in Multinational Firms // Journal of International Business Studies. Vol. 36, № 6. 2005. Pp. 676-687.

289. Swan J., Scarbrough H. The Politics of Networked Innovation // Human Relations. Vol. 58. 2005.

290. Krysanov D.F. (2013) Innovatsiinyi potentsial pererobno-kharchovykh pidpryiemstv: otsiniuvannia ta realizatsiia. [Innovative potential of food processing enterprises: evaluation and implementation.] Ekonomika i prohnozuvannia Economics and forecasting, 2, 804-105. [in Ukrainian]. 


\section{ECONOMIC STRATEGIES FOR THE DEVELOPMENT OF SOCIETY}

291. Sabluk P.T. (2017) Naukovi ahroekonomichni doslidzhennia v interesakh aktyvizatsii rostu APV i silskykh terytorii. [Scientific agroeconomic research in the interests of intensifying the growth of APV and rural areas]. Ekonomika APK Economics of agro-industrial complex, 5, 19-23. [in Ukrainian].

292. Shubravska O.V., Moldavan L.V. \& Paskhaver B.I. (2014) Ahroprodovolchyi rozvytok Ukrainy v konteksti zabezpechennia prodovolchoi bezpeky: monohrafiia [Agro-food development of Ukraine in the context of food security: monograph]. Kyiv, DU «Instytut ekonomiky ta prohnozuvannia NAN Ukrainy», 456 p. [in Ukrainian].

293. Shpykuliak O.H., Hrytsaienko M.I. (2016) Rozvytok innovatsiinoi diialnosti $v$ ahrarnii sferi: menedzhment ta efektyvnist: Monohrafiia [Development of innovation in the agricultural sector: management and efficiency: Monograph] Kherson: OLDIPLIuS, 424 p. [in Ukrainian].

294. Shlenova V. Yu., Kharyn A. A. \& Kolensky Y. L. (2003) Upravlenye ynnovatsyiamy: uchebnoe posobye [Innovation management: textbook] M.: Vыsshaia shkola, 252 p. [in Ukrainian].

295. Derevianko T.O. (2014) Metodyka otsinky innovatsiinoho rozvytku tvarynnytstva u silskohospodarskykh pidpryiemstvakh. [Methods for assessing the innovative development of animal husbandry in agricultural enterprises.] Efektyvna ekonomika - Efficient economy, 9, 84-95. [in Ukrainian].

296. Maksymov Yu. (2016) Ynnovatsyonnoe razvytye эkonomycheskoi systemы: otsenka ynnovatsyonnoho potentsyala. [Innovative development of the economic system: assessment of innovation potential.] Ynnovatsyy - Innovations, 6, 53-56. [in Ukrainian].

297. Hokhberh L. M. (2014) Analyz y perspektyvы statystycheskoho yssledovanyia ynnovatsyonnoi deiatelnosty $\mathrm{v}$ эkonomyke Rossyy. [Analysis and prospects of statistical research of innovative activity in the Russian economy.] Voprosbl statystyky - Questions of statistics, 9, 3-15. [in Ukrainian].

298. Bukhonova S. M. (2015) Metodyka otsenky ynnovatsyonnoi aktyvnosty orhanyzatsyy. [Methods for assessing the innovative activity of the organization.] 
ECONOMIC STRATEGIES FOR THE DEVELOPMENT OF SOCIETY

Эkonomycheskyi analyz: teoryia y praktyka

Economic analysis: theory and practice, 1, 2-8. [in Ukrainian].

299. Tryfylova A. A. (2015) Otsenka эffektyvnosty ynnovatsyonnoho razvytyia predpryiatyia. [Evaluation of the effectiveness of innovative development of the enterprise.] Fynansbl $\quad y \quad$ statystyka

Finance and statistics, 2, 304-309. [in Ukrainian].

300. Chernov V. A. (2014) Analyz ynnovatsyonnoi deiatelnosty v torhovle. [Analysis of innovation in trade.] Audyt y fynansovbii analyz Audit and financial analysis, 1, 46-49. [in Ukrainian].

301. Ishcheikin T.I. (2011) Metodychni pidkhody do otsinky innovatsiinoho rozvytku torhovelnykh pidpryiemstv. [Methodical approaches to the assessment of innovative development of trade enterprises.] Naukovyi visnyk Poltavskoho universytetu ekonomiky $i$ torhivli - Scientific Bulletin of Poltava University of Economics and Trade, 5 (50), 259-267. [in Ukrainian].

302. Rennings, K. and Zwick, T. Employment Impacts of Cleaner Production: New York: ZEW Economic Studies 21. 2003. 322 p.

303. Прокопенко О. В. Екологізація інноваційної діяльності: мотиваційний підхід : монографія. Суми : ВТД «Університетська книга», 2008. 392 c.

304. Федулова Л. І., Забарна Е. М., Філиппова С. В. Інноваційний розвиток підприємства : підручник / Л. І. Федулова та ін. Одеса : ОНПУ, 2016. $700 \mathrm{c}$.

305. Міністерство розвитку економіки, торгівлі та сільського господарства України. URL: https://www.me.gov.ua/Documents/List?lang=ukUA\&tag=\%D0\%A1\%D1\%82\%D0\%B0\%D0\%BD\%20\%D1\%96\%D0\%BD\%D0\%B2 \%D0\%B5\%D1\%81\%D1\%82\%D0\%B8\%D1\%86\%D1\%96\%D0\%B9\%D0\%BD\%D0 \%BE\%D1\%97\%20\%D0\%B4\%D1\%96\%D1\%8F\%D0\%BB\%D1\%8C\%D0\%BD\%D0 \%BE\%D1\%81\%D1\%82\%D1\%96\%20\%D0\%B2\%20\%D0\%A3\%D0\%BA\%D1\%80 \%D0\%B0\%D1\%97\%D0\%BD\%D1\%96 (дата звернення: 10.11.2020). 


\section{ECONOMIC STRATEGIES FOR THE DEVELOPMENT OF SOCIETY}

306. Кондратьев Н. Д. Большие циклы конъюнктуры и теория предвидения. Москва, 2002. 383 с.

307. Скороход I. С., Ребрина Н. Г. Дослідження факторів еко-інноваційної діяльності підприємств в умовах транскордонного співробітництва. Соц.-ек. проблеми сучас. періоду України. 2014. Вип. 2(106). С. 264 - 273.

308. Передало Х. С., Присяжна К. В. Чинники впливу на розвиток інновацій в сфері екологічного менеджменту. Проблеми формування та розвитку інноваційної інфраструктури: матеріали міжнар. наук.-практ. конф. (м. Львів, 19 -21 травня 2011 р.). - Львів, 2011. С. 340-342.

309. Теряник А. О. Оцінювання сталого екологічного розвитку регіону. Ефективна економіка. 2015. № 5 URL: http://www.economy.nayka.com.ua/?op=1\&z=4103 (дата звернення: 07.11.2020).

310. Алексерова Ю.В. Розвиток сільськогосподарського страхування: теорія, методологія практика: монографія. Вінниця : ТОВ “Видавництво друкарня Діло", 2015. 368 с.

311. Бондарчук М. К., Кондрат I. Ю. Особливості розвитку сільськогосподарського страхування в Україні на засадах державно-приватного партнерства. Науковий вісник НЛТУ України. 2014. Вип. 24. С. $182-188$.

312. Гайдук В.С., Луцько В.С. Стан і проблеми обов'язкового страхування посівів зернових культур. Економіка АПК. 2004. № 2. С. 42.

313. Громоздова Л.В., Писаренко Н.В. Проблеми страхування майна сільськогосподарських товаровиробників та шляхи їх вирішення. Економіка та підприємництво. 2017. № 39. С. 278-290.

314. Дослідження ринку агрострахування в Україні : Шляхи підвищення зацікавленості сільгоспвиробників у використанні послуг агрострахування в Україні: думка споживача : Звіт Міжнародної фінансової корпорації (IFC та Світового банку). URL: http://www.ifc.org

315. Зоря О. Розвиток аграрного страхування в Україні. Economics. 2009. № 33. URL: http:// www.rusnauka.com/33 NIO 2009/Economics/54572.doc.htm.

316. Зуб Г.І. Державна політика щодо розвитку страхування 
ECONOMIC STRATEGIES FOR THE DEVELOPMENT OF SOCIETY сільськогосподарських ризиків. Облік і фінанси АПК. 2006. №6. С.83-88.

317. Кравчук О.В. Становлення аграрного страхування: світовий та вітчизняний досвід. Вісник Сумського нащіонального аграрного університету. Сер. Фінанси і кредит. 2011. № 2. С. 85-91.

318. Орлов I.В., Александрова М.М. Становлення та розвиток страхування сільськогосподарських культур в Україні. Вісник Сумського національноготаграрного університету. Сер. Фінанси і кредит. 2011. №2.

319. Писаренко Н.В. Застосування економіко-математичних моделей у страхуванні сільськогосподарських культур. Інтернаука. Сер. Економічні науки. 2018. № 7(15). С. 140-144. (0,5 д.а.).

320. Писаренко Н.В. Міжнародний досвід здійснення державної політики страхування сільськогосподарських культур. Економіка та підприємництво. 2018. №40. С. 279-294. (0,7 д.а.).

321. Писаренко Н. В. Місце страхування сільськогосподарських культур у загальній системі страхування. Економіка, фінанси, облік, менеджмент і право : зб. тез доп. Міжнар. наук.-практ. конф., 22 черв. 2019 р. Полтава, 2019. Ч. 4. С.40-42. (0,2 д.а.).

322. Писаренко Н.В. Необхідність та перспективи розвитку актуарних розрахунків в аграрному страхуванні. Фінансова система Украйни в умовах економічної та фінансової глобалізації світу : зб. матеріалів Всеукр. наук.-практ. конф., 23 травня 2018 р. Київ, 2018. Т. 2. С. 138-142. (0,2 д.а.).

323. Писаренко Н.В. Страхування сільськогосподарських культур: становлення та шляхи розвитку в Україні : дис... канд. наук : 08.00.08. Київ. 2019.URL:

https://drive.google.com/file/d/1hvwXWnximVoR48ISEBDH4j3CNXOaU4wH/view

324. Писаренко Н.В. Сучасний стан та перспективи розвитку актуарних розрахунків в аграрному страхуванні. Проблеми інноваційно-інвестищійного розвитку (Google Scholar; РИНЦ; Index Copernicus; Ulrichsweb Global Serials Directory). 2018. № 15. C. 107-120. (0,7 д.а.).

325. Про державну підтримку сільського господарства України : Закон 
ECONOMIC STRATEGIES FOR THE DEVELOPMENT OF SOCIETY

України від 15 серпня 2018 p. №1877-IV. URL: http://zakon2.rada.gov.ua/laws/show/1877-15

326. Про особливості страхування сільськогосподарської продукції 3 державною підтримкою : Закон України від 09 лютого 2012 p. №4391-IV. URL: http://zakon.rada.gov.ua/laws/show/4391-17/ed20120209

327. Рудич О.О. Економічна сутність ризику та особливості його прояву у діяльності аграрних підприємств. Економіка та управління АПК : збірник наукових праџь Білочерківського начіонального аграрного університету. 2012. Вип. № 7(93). С. 59-63.

328. Шинкаренко Р. Международная практика государственного регулирования и лицензирования рынка агрострахования. URL: http://www.agroinsurance.com/ru/analy tics?pid=18801

329. Яцух О.О. Ринок агрострахування в Україні: стан та перспективи розвитку. Економіка $i$ суспільство. 2016. Вип. №7. URL: http://www.economyandsociety.in.ua/journal/7 ukr/145.pdf

330. Gromozdova L., Pysarenko N. Key features of agrarian risks insurance. Проблеми інновачійно-інвестиційного розвитку. 2017. №13. С. 103-110.

331. Iturrioz R. Agricultural Insurance. Primer series on insurance: global capital markets development department. 2009. № 12.35 c.

332.Ohmae K. (1990) The bordless World: Power and Strategy in the Interlinked Economy. Fontatna. Harper Business, New York, pp.xv +223.

333.Інститути спільного інвестування в умовах глобалізації світових фінансових ринків: монографія / В. А. Вергун, О. І. Ступницький, В. М. Коверда, Т. В. Волковинська ; Київ. нац. ун-т ім. Т. Шевченка. - К. : Київський університет, 2009. - C.3.

334.Шаравара Р. I. (2016) Глобалізація фінансових ринків:асиметричність розвитку та державного впливу. Причорноморські економічні студіі. Вип. 9-2. С. $28-31$. 


\section{ECONOMIC STRATEGIES FOR THE DEVELOPMENT OF SOCIETY}

335.George J. Benston \& Clifford W. Smith, Jr. (1976) A transaction cost approach to the theory of financial intermediation // The Journal of Finance, Vol. 31, No. 2, pp. 215-231.

336.Allen, F. (1990) The Market for Information and the Origin of Financial Intermediation // Journal of Financial Intermediation, № 1, pp. 3-30.

337.Global Monitoring Report on Non-Bank Financial Intermediation 2019 Available at: https://www.fsb.org/wp-content/uploads/P190120.pdf

338. Іщенко А.В. Інноваційний компонент розвитку конкурентоспроможності експорту України // Науковий вісник Ужгородського національного університету, 2016. - Вип. 7 (Ч. 1). - С. 150-153. - Режим доступу: https://dspace.uzhnu.edu.ua/jspui/bitstream/lib/12516/1/I.pdf

339. Булатова О.В. Регіональна складова глобальних інтеграційних процесів: монографія. - Донецьк: ДонНУ, 2012. - 386 с.

340. Іщенко А. В. Маркетингові технології розвитку конкурентоспроможності товарного експорту: дисертація (Електронний ресурс). - Режим доступу: https://kneu.edu.ua/userfiles/d26.006.02/2017/Ishchenko_diss.PDF

341. Тенденції розвитку зовнішньої торгівлі України. Міністерство економічного розвитку і торгівлі України (Електронний ресурс). - Режим доступу: www.me.gov.ua/Documents/Download?id=dacb14b1-6f6b-4e14-8f30

342. Загальна інформація про УСПТ (Електронний ресурс). - Режим доступу:http://www.me.gov.ua/Tags/DocumentsByTag?lang=ukUA\&tag=SpivrobitnitstvoZSvitovoiuOrganizatsiieiuTorgivli

343. Кузьменко Л.Г. Світовий досвід регулювання діяльності суб'єктів природних монополій та основні напрями вдосконалення їх регулювання в Україні // Наукові записки, 2007. - Т. 68. Економічні науки. - С. 40-46.

344. Як отримати попереднє рішення про країну походження товару? (Електронний pecypc).

Режим доступу:http://www.me.gov.ua/Documents/Detail?lang=uk-UA\&id=fd7e4633-83d7$44 c c-94 c f-3 d f c 6 a f 5 b 348 \&$ title=Stattia3-Uspt] 


\section{ECONOMIC STRATEGIES FOR THE DEVELOPMENT OF SOCIETY}

345. Севрук I.M. Міжнародний досвід інституційно-правового регулювання діяльності торговельних мереж // Ефективна економіка, 2014. - № 4. (Електронний pecypc).

Режим доступу:http://www.economy.nayka.com.ua/?op=1\&z=2957

346. Маштабей В. Made in the World, або Еволюція світової торгівлі (Електронний pecypc).

Режим доступу:/https://apostrophe.ua/article/economy/foreign-trade/2015-03-31/made-inthe-world-abo-evolyutsya-svtovo-torgv1/1511

347. Азоев Г. Л. С кем и как вы конкурируете. С кем и как делать бизнес / Г. Л. Азоев. - М. : Гиперокс, 2000. - 400 с.

348. Чэндлер А. Стратегия и структура / А. Чэндлер. - М. : Мир, 1988. - 464 c.

349. Кемпбелл Э. Стратегический синергізм / Э. Кемпбелл. Лачс К. Саммерс. - 2-е изд. - СПб. : Питер, 2004. - 416с.

350. Бухалков М. И. Внутрифирменное планирование / М. И. Бухалков. - М. : ИНФРА-М, 2000. - 400 c.

351. Самочкин В. Н. Гибкое развитие предприятия. Анализ и планирование / В. Н. Самочкин. - М. : Дело, 1999. - 336 с.

352. Загрива Ю. О. Формування корпоративної стратегії соціального та економічного розвитку акціонерного товариства : дис. на здобуття наук. ступеня канд. економ. наук : спец. 08.09.01 / Ю. О. Загрива, 2008. - 224 с.

353. Ілляшенко С. М. Управління інноваційним розвитком: проблеми, концепції, методи : навчальний посібник / С. М. Ілляшенко. - Суми : ВТД Університетська книга, 2003. - 278 с.

354. Поповенко Н. Оценка инновационного потенциала хозяйственной системы / Н. Поповенко, Н. Заварная // Бизнес-Информ. - 1998. - № 3. - С. 51-52.

355. Зайцева О. А. Основы менеджмента / О. А. Зайцева, А. А. Радугин, К. А. Радугин, Н. И. Рогачева. - М. : Центр, 1998. - 432 с.

356. Котлер Ф. Маркетинг менеджмент /Ф. Котлер; [пер. с англ.]. - Спб. : Питер, 1999. - 600 с. 


\section{ECONOMIC STRATEGIES FOR THE DEVELOPMENT OF SOCIETY}

357. Lytvynenko O. D. World Trends Managing Innovations / O. D. Lytvynenko // Modern Tendencies in Business and Public Sector: Monograph. - Opole : Publishing house WSZiA, 2018. - 216 p. - pp. 109-114.

358. Сгоркіна Т. О. Роль функції мотивації в управлінні витратами підприємства / Т. О. Єгоркіна // Економіка будівництва і міського господарства. - 2006. - T. 2. - № 3. - C. 159-165.

359. Толстікова О. В. Особливості впливу мотиваційного механізму на соціальний розвиток підприємства / О. В. Толстікова // Економіка : проблеми теорії та практики : збірник наукових праць. - Вип. 203. - Дніпропетровськ : ДНУ, 2005. - Том 3. - С. 872-877.

360. Пилипенко А. А. Організація управління розвитком матеріальнотехнічної бази підприємства : м о н о г р а фія / A. А. Пи ли п енко, А. О. Ли тв ин енко ФОП З д о р о в и й Я. А., 2015. - 236 с.

361. Том Н. Управление изменениями (Електронний ресурс) / Н. Том. Режим доступу : http://www.cfin.ru/management/ change_management.shtml.

362. Barney J. Strategie Factor Markets : Expectations, Luck, and Business Strategy / J. Barney // Management Science. - 1986. - V. 32. - N 10. - P. 1231-1241.

363. Hamei G. Competing for Future / G. Hamei, K. Prahalad // Boston : MA Harvard Business School Press, 1994.

364. Стан та перспективи соціальної безпеки в Україні: експертні оцінки [Текст] : монографія / О. Ф. Новікова, О. Г. Сидорчук, О. В. Панькова [та ін.] / Львівський регіональний інститут державного управління НАДУ; НАН України, Інститут економіки промисловості . К. Львів : ЛРІДУ НАДУ. 2018. 184 с.

365. Третяк В. В., Гордієнко Т. М., Економічна безпека: сутність та умови формування. Економіка та держава. № 1. 2010. С. 6-8.

366. Журнал «Вестник Санкт-Петербургского университета ГПС МЧС России» (2013). URL: https://vestnik.igps.ru/wpcontent/uploads/ 


\section{ECONOMIC STRATEGIES FOR THE DEVELOPMENT OF SOCIETY}

367. Користін О. С., Барановський О. І., Герасименко Л. В. Економічна безпека: навч. посіб.; за ред. О.М. Джужі. К. 2010. 368 с.

368. Дмитренко В. I. Імплементація міжнародного досвіду державного аудиту для забезпечення економічної безпеки України. Агросвіт. № 10. 2020. С. 65 - 70. URL: http://www.agrosvit.info/index.php?op=1\&z=3200\&i=9

369. Офіційний сайт OOH. URL: https://www.un.org/ru/ga/40/docs/40res.shtml

370. Акімова Л. М. Механізми державного управління економічною безпекою України: аналіз чинників впливу, систематизованих за окремими сферами їі розвитку. Аспекти публічного правління. Том 6 № 6-7. 2018. С.5-13.

371. Стратегія національної безпеки України «Безпека людини - безпека країни» URL: https://zakon.rada.gov.ua/laws/show/392/2020\#n12

372. Офіційний сайт Державної служби статистики України // Електронний ресурс: http://www.ukrstat.gov.ua/

373. Пандемія COVID-19 та iї наслідки у сфері туризму в Україні // Електронний ресурс. Режим доступу: http://www.ntoukraine.org/assets/files/EBRD-COVID19-Report-UKR.pdf

374. Теребух А.А. Проблеми розвитку міжнародного туризму в Україні / А.А. Теребух, О.П. Макар, Г.Я.Ільницька // Молодий вчений. 2015. № 11(2). С. 126-129.

375. Гірськолижні курорти поблизу Львова: // Електронний ресурс. Режим доступу: https://lviv-online.com/ua/articles/hirskolyzhni-kurorty-poblyzulvova/

376. Туристичний комплекс "Захар Беркут" с. Волосянка // Електронний pecypc. Режим доступу: https://zaharberkut.ua/ru/winter-holidays-ski-slopes/

377. Географія туризму: опор. конспект лекцій; уклад.: Коцупей В.М., Миронов Ю.Б.. - Львів : Вид-во Львів. торг.-екон. ун-ту, 2017. 107 с.

378. Кушнір Л.П. Послуги туризму спеціального інтересу (SIT) на міжнародному туристичному ринку / Л.П. Кушнір, Р.М. Лозинський // 


\section{ECONOMIC STRATEGIES FOR THE DEVELOPMENT OF SOCIETY}

Туристичні послуги на світовому ринку як фактор розвитку міжнародного туризму: Вісник ЛІЕТ. Львів, 2018.

379. Кушнір Л.П. Концепція серйозного дозвілля і туризм спеціального інтересу, або як виникають і розвиваються інноваційні види туризму / Р.М. Лозинський, Л.П. Кушнір // Колективна монографія «Функціонування та перспективи розвитку туристичної галузі України»: за заг.ред. д.е.н. Барна М.Ю. Львів: ЛТЕУ, 2018. 320 с. (ISBN 978-617-602-234-3).

380. Кушнір Л.П. Перспективи розвитку туризму в межах міст / О.В. Терлецька, Л.П. Кушнір // Географія та туризм: наук. зб. Ред. кол.: Любіцева О.О. (гол. ред.) та ін. К.: Альфа-ПІК, 2019. Вип. 48. 142 с.

381. Увесь світ у цифрах і фактах: Довідник. 4-е вид., випр. та допов. К. Мапа, 2015. 217 c.

382. Рудницький В. С. Аудит / Я. А. Гончарук, В. С. Рудницький. Львів: Оріяна Нова, 2004.292 с.

383. Булат Г.В. Організаційно-методичне забезпечення обліку і аудиту оборотних активів (на прикладі автотранспортних підприємств): дис....канд. екон. наук: 08.00.09 / Одес. нац. унів. Одеса, 2013, 267c.

384. Christian Cordes, Stephan Müller, Georg Schwesinger, Sarianna M. Lundan Governance Structures, Cultural Distance, and Socialization Dynamics: Further Challenges for the Modern Corporation https://media.suub.unibremen.de/bitstream/elib/4268/4/Cultural\%20Distance_2020.pdf

385. Levine, John M., \& Moreland, Richard L. 1998. Small Groups. In: Gilbert, D. T. and Fiske, S.T. and Lindzey, G. (eds.), The Handbook of Social Psychology, Boston: McGraw-Hill, 415-469

386. Schein, Edgar H. 1992. Organizational Culture and Leadership. San Francisco: Jossey-Bass Publishers.

387. Karen Sobel Lojeski, Richard R. Reilly Understanding Effective ECollaboration Through Virtual Distance, 2008 Encyclopedia of E-Collaboration, 607 p. 


\section{ECONOMIC STRATEGIES FOR THE DEVELOPMENT OF SOCIETY}

388. Teo Poh Chuin 2019. Belt and Road Initiative: The Case of Malaysia. The Belt and Road Strategy in International Business and Administration

389. Bessie Rean Bows. Banding Organization, Management, and Leadership Theories to Identify Managerial Strategies. Handbook of Research on Emerging Business Models and Managerial Strategies in the Nonprofit Sector

390. Schwesinger, Georg \& Müller, Stephan \& Lundan, Sarianna M., 2016. "Governance Structures, Cultural Distance, and Socialization Dynamics: Further Challenges for the Modern Corporation," Annual Conference 2016 (Augsburg): Demographic Change 145907, Verein für Socialpolitik / German Economic Association

391. Eden, L., \& Miller, S. R. 2004. Distance matters: Liability of foreignness, institutional distance and ownership strategy. In M. Hitt \& J. Cheng (Eds.), Advances in international management: Vol. 16. Theories of the multinational enterprise: 187221. Amsterdam: Elsevier.

392. Ghemawat, P. 2001. Distance still matters. Harvard Business Review, 79: 137-147.

393. Kostova, T., \& Roth, K. 2002. Adoption of an organizational practice by subsidiaries of multinational corporations: Institutional and relational effects. Academy of Management Journal, 45: 215-233.

394. Dow, D., \& Karunaratna, A. 2006. Developing a multidimensional instrument to measure psychic distance stimuli. Journal of International Business Studies, 37: 578-602.

395. Hofstede G.H. Cultures and organizations: software of the mind. Mc Graw Hill. 1997.

396. Hofstede, G., Hofstede, G. J.,Minkov, M. (2010). Cultures and Organizations: Software of the Mind. Revised and expanded third edition. New York: McGraw-Hill

397. Ткаченко В.В. Формування ефективної регіональної політики на засадах цифровізації / В.В. Ткаченко, М.М. Климчук, А.А. Клочко // Регіональна політика: політико-правові засади, урбаністика, просторове планування, 
ECONOMIC STRATEGIES FOR THE DEVELOPMENT OF SOCIETY архітектура [зб. наук. пр.]. Київ-Тернопіль : «Бескиди», 2019. Ч. 1. С.29-33.

398. Armstrong H., Taylor J. Regional Economics and Policy. New York: Harvester Wheatsheaf, 1993.

399. Directive 2012/27/EU of the European Parliament and of the Council of 25 October 2012 on energy efficiency, amending Directives 2009/125/EC and 2010/30/EU and repealing Directives 2004/8/EC and 2006/32/EC Text with EEA relevance.- Special edition in Croatian: Chapter 12 Volume 004 P. $202-257$

400. Doyle F.(1989), Regional policy and European integration, op. cit.

401. Klymchuk M. Concept of Innovative Marketing in Management of Enterprise / Fedun Igor, Novikova Innola, Vildman Igor, Klymchuk Marina, Goryn Marta // Jour of Adv Research in Dynamical \& Control Systems, Vol. 12, 07. 2020.

402. Klymchuk M. The determinants forming the methodology of managing the investments for enterprise digitalization / M. Klymchuk, V. Tkachenko // V International snterdasciplinary scientific conference «Social development towards values ethics -technology- society», 2019 - p. 147.

403. Projects and documents / [Electronic resource]https://keep.eu/projects/

404. Temple M.(1994), Regional Economics, MacMillan Press, Basingstoke.

405. Vanhove N. Regional policy: A European approach. Aldershote etc.: Ashgate, 1999.

406. Agriculture of Ukraine - 2019. State Statistics Service of Ukraine. URL: http://www.ukrstat.gov.ua

407. Carver, B. F. (2009). Wheat: Science and Trade. Hoboken: Wiley-Blackwell, $616 \mathrm{p}$.

408. Elfson, S. B. (2011). Barley: Production, Cultivation and Uses. Hauppauge: Nova Science Publishers, Inc., 341 p.

409. Danforth, A. T. (2009). Corn Crop Production: Growth, Fertilization and Yield. Hauppauge: Nova Science Publishers, Inc., 377 p.

410. Schroeder, K. G., Meyers, W. H. (2015). Policy Issues and Prospects for Ukraine Grain Exports. Transition to Agricultural Market Economies: The Future of Kazakhstan, Russia and Ukraine. Wallingford: CABI, pp. 39-50. 
ECONOMIC STRATEGIES FOR THE DEVELOPMENT OF SOCIETY

411. Petrenko, O. (2019) Financial and Economic Analysis of the Grain Market as a Precondition for Ukrainian Food Security. Modern Economics, 13, 207-212.

412. Vasylieva, N. (2018). Ukrainian Agricultural Contribution to the World Food Security: Economic Problems and Prospects. Montenegrin Journal of Economics, $14(4), 215-224$.

413. Moroz, S., Karamushka, O., Shramko, I. (2018). Application of net technologies in agribusiness. Effective Economy, 11. URL: https://doi.org/10.32702/2307-2105-2018.11.89

414. Bessler, D. A., Doefman, J. H., Holt, M. T., LaFrance, J. T. (2010). Econometric Developments in Agricultural and Resource Economics: The First 100 Years. American Journal of Agricultural Economics, 92(2), 571-589.

415. Dmitriyeva, V. (2018). Trends in dynamics of Ukrainian crop production: effects of smoothing data series. Effective Economy, 12. URL: https://doi.org/10.32702/2307-2105-2018.12.87

416. Samarets, N., Nuzhna, S. (2018). The Modern Contribution of the Basic Categories of Producers to Ukrainian Agrarian Production. Agricultural and Resource Economics: International Scientific E-Journal, 4(4), 52-71. URL: http://arejournal.com

417. Domar E. Essays in the Theory of Economic Growth. New York, 1967. 2. Denisenko MP Provisioning of innovations: textbook / Denisenko MP, Grechan AP, MV Haman and others. - K .: Publishing House "Professional", 2008.- 448 p.

3. Scientific notes of Lviv University of Business and Law: [collection of scientific works / editor in chief. LA Yankovskaya]. Issue 16 - Lviv, Galician Publishing Union, 2016.- 184p.

418. Zykhor O.B. Innovative policy of regional development: theory and practice of formation, mechanisms of implementation: [monograph] - Lviv: Institute of Regional Studies of the National Academy of Sciences of Ukraine, 2009. -544 p.

419. Kirichenko OA Investing: a textbook./ OAKyrychenko, SAErokhin.-K .: Knowledge, 2009.-573p. 


\section{ECONOMIC STRATEGIES FOR THE DEVELOPMENT OF SOCIETY}

420. The Economic Journal, Volume 129, Issue 620, May 2019, Pages 17311781, https://doi.org/10.1111/ecoj.12588 